\title{
Nederland en het Nabije Oosten : de Nederlandse rol in de internationale politiek ten aanzien van het Arabisch-Israelisch conflict 1973-1982
}

Citation for published version (APA):

Grünfeld, F. (1991). Nederland en het Nabije Oosten : de Nederlandse rol in de internationale politiek ten aanzien van het Arabisch-Israelisch conflict 1973-1982. [Doctoral Thesis, Maastricht University]. Rijksuniversiteit Limburg. https://doi.org/10.26481/dis.19910405fg

Document status and date:

Published: 01/01/1991

DOI:

10.26481/dis.19910405fg

Document Version:

Publisher's PDF, also known as Version of record

Please check the document version of this publication:

- A submitted manuscript is the version of the article upon submission and before peer-review. There can be important differences between the submitted version and the official published version of record.

People interested in the research are advised to contact the author for the final version of the publication, or visit the DOI to the publisher's website.

- The final author version and the galley proof are versions of the publication after peer review.

- The final published version features the final layout of the paper including the volume, issue and page numbers.

Link to publication

\footnotetext{
General rights rights.

- You may freely distribute the URL identifying the publication in the public portal. please follow below link for the End User Agreement:

www.umlib.nl/taverne-license

Take down policy

If you believe that this document breaches copyright please contact us at:

repository@maastrichtuniversity.nl

providing details and we will investigate your claim.
}

Copyright and moral rights for the publications made accessible in the public portal are retained by the authors and/or other copyright owners and it is a condition of accessing publications that users recognise and abide by the legal requirements associated with these

- Users may download and print one copy of any publication from the public portal for the purpose of private study or research.

- You may not further distribute the material or use it for any profit-making activity or commercial gain

If the publication is distributed under the terms of Article $25 \mathrm{fa}$ of the Dutch Copyright Act, indicated by the "Taverne" license above, 
NEDERLAND EN HET NABIJE OOSTEN 


\section{.}




\section{NEDERLAND EN HET NABIJE OOSTEN}

De Nederlandse rol in de internationale politiek ten aanzien van het Arabisch-Israëlisch conflict 1973-1982

\section{PROEFSCHRIFT}

ter verkrijging van de graad van doctor aan de Rijksuniversiteit Limburg te Maastricht, op gezag van de Rector Magnificus, Prof. Mr. M.J. Cohen, volgens het besluit van het College van Dekanen, in het openbaar te verdedigen op vrijdag, 5 april 1991 om 16.00 uur

door

Frederik Grünfeld 


\section{Beoordelingscommissie: Prof. mr. M.J. Cohen (voorzitter) Prof. dr. J.E. Ellemers (RUG) Prof. dr. A. van Staden (RUL)}

Alle rechten vcorbehouden. Niets uit deze uitgave mag worden verveelvoudigd, opgeslagen in een geautomatiseerd gegevensbestand, of openbaar gemaakt, in enige vorm of op enige wijze, hetzij elektronisch, mechanisch, door fotocopieën, opnamen, of enige andere manier, zonder voorafgaande schriftelijke toestemming van de uitgever.

Voor zover het maken wan kc pieèn uit deze uitgave is toegestaan op grond van artikel 16b Auteurswet $1920 \mathrm{j}^{\circ}$, het Besluit van 20 juni 1974, Stb. 351, zoals gewijzigd bij het Besluit van 23 augustus 1985, Stb. 471 en artikel 17 Auteurswet 1912, dient men de daarvoor wettelijk verschuldigde vergoedingen te voldoen aan de Stichting Reprorecht (Postbus 882, 1180 AW Amstelveen). Voor het overnemen van gedeelte(n) uit deze uitgave in bluemlezingen, readers en andere compilatiewerken (artikel 16 Auteurswet 1912) dient men zich tot de uitgever te wenden. 


\section{INHOUDSOPGAVE}

Voorwoord

IX

Hoofdstuk 1 Buitenlandse politiek en internationale politiek ten aanzien van het Arabisch-Israëlisch conflict

1.1

1.2 .1

Inleiding

1.2 .2

1.2 .3

1.2 .4

1.3

1.3.1

1.3 .2

Binnenlandse en buitenlandse politiek

Buitenlandse en internationale politiek

Binnenlandse actoren

Nederland in de internationale politiek 19

Internationale organisaties $\quad 21$

Nieuwe internationale organisaties $\quad 24$

Europese Politieke Samenwerking 26

1.4

1.4 .1

Europese Politieke Samenwerking en het Arabisch-

Israëlisch conflict

De relatie Nederland-Israël 31

1.4.1.1

Massapubliek

Antizionisme - antisemitisme $\quad 37$

1.4 .2

1.4.2.1

De niet-formele politieke elite

De kerken en de Joodse gemeenschap 39

1.4 .2 .2

Actiegroepen

1.4 .2 .3

1.4 .2 .4

Het bedrijfsleven

Politieke partijen

1.4 .2 .5

De media

Hoofdstuk 2 Olie-embargo 1973

Oktoberoorlog in het Midden-Oosten en resolutie

242

Buitenlands beleid

De regering

Militaire steun aan Israël

Verbale steun aan Israël

2.2.1.3

Nederlands veto met betrekking tot Brits-Franse rol

Binnenlandse olieverbruik-beperkende maatregelen 
Bedrijfsleven, vakbeweging en oliemaatschappijen

Publieke opinie

November 1973

December 1973

Hoofdstuk 3 Schuivende stellingen 1974-1980

Nederlandse bijdrage aan de besluitvorming in de EPS

\section{2}

3.2 .1

Buitenlandse politiek

De niet-formele politieke elite $\quad 189$

3.2.3.2

Actiegroepen 
4.1.2.2 Participatie in de MFO 220

4.1.2.3 De vier Europese participanten in de MFO 222

4.1.2.4 Besluiten inzake Europese participatie 226

4.1.2.5 Nederlandse inbreng bij Europese participatie 230

$\begin{array}{lll}4.2 & \text { Buiterlandse politiek } & 237\end{array}$

4.2.1 Parlement 237

4.2.2 Groepen in de samenleving 238

$4.3 \quad$ Conclusie over Nederland en de MFO 240

4.4 Conclusies en slotopmerkingen 245

$\begin{array}{lll}\text { Hoofdstuk } 5 & \text { Conclusies } & 247\end{array}$

5.1 Het buitenlands politiek proces $\quad 249$

$5.2 \quad$ Het internationaal politieke proces $\quad 252$

5.3 Relatie buitenlands politieke en internationaal $\begin{array}{ll}\text { politieke proces } & 256\end{array}$

$\begin{array}{ll}\text { Samenvatting } & 261\end{array}$

$\begin{array}{ll}\text { Summary } & 265\end{array}$

Bijlagen:

1. Schema van Rosenau"s pretheorie $\quad 269$

2. Schema van Rosenau's theorie van aanpassing 270

3. Nederlandse export naar het Midden-Oosten 271

4. Publieke opinile onderzoeksgegevens $\quad 272$

5. De verklaring van zes november $1973 \quad 274$

6. Overzicht Arabische maatregelen ter beperking van de olie-export 276

7. Algemene Vergadering der Verenigde Naties, stemgedrag van de EG 278

8. Werkdocument, 31 januari 1977 (Londen) 279

9. Verklaring over het Midden-Oosten van 29 en 30 junỉ 1977 (Londen) (Europese Raad) $\quad 280$

10. Toespraak O'Kennedy voor de algemene vergadering van de VN op 25 september 1979

11. . Verklaring van Venetië van 13 juni 1980 (Europese Raad) 284

12. Aandacht in de media voor enkele uitspraken van Nederlandse politici in 1979

13. Staten die in 1981 diplomatieke betrekkingen met Israël onderhielden en gevraagd zijn voor deelname aan de MFO

14. Gemeenschappelijke verklaring van de vier inzake participatie MFO 288

15. De nationale verklaring inzake participatie $\mathrm{MFO} \quad 289$

16. Overleg regering-parlement over participatie in MFO 290

17. Samenstelling kabinet in Nederland, Duitsland, Verenigd Koninkrijk, Frankrijk, Italië, België, Ierland, Denemarken, Luxemburg, Griekenland, Egypte, Israël en Verenigde Staten. 
18. Samenstelling van het parlement (\%) in Nederland, Bondsrepubliek Duitsland, Verenigd Koninkrijk, Frankrijk, Italië, België, Denemarken, Ierland, Luxemburg

19. Overzicht van data gebeurtenissen 313

20. Olie-embargo 318

21. Verklaring van Venetië 320

22. MFO 321

Bronnen

1. Lijst van archieven en persdocumentatie $\quad 323$

2. Lijst van geïnterviewden met functie en datum 325

$\begin{array}{ll}\text { Aangehaalde literatuur } & 329\end{array}$

$\begin{array}{ll}\text { Personenregister } & 349\end{array}$

$\begin{array}{ll}\text { Zakenregister } & 353\end{array}$

$\begin{array}{ll}\text { Curriculum vitae } & 360\end{array}$ 


\section{VOORWOORD}

Deze publikatie is de afronding van een studie over Nederland en het Nabije Oosten ${ }^{1}$ In $1980 \mathrm{trad} \mathrm{ik}$ in dienst bij de Nederlandse organisatie voor zuiver-wetenschappelijk Onderzoek (ZWO) en verrichtte ik aan de Rijksuniversiteit Leiden onderzoek naar de binnenlandse beïnvloeding van het Nederlandse Midden-Oostenbeleid ${ }^{2}$. Aan de Rijksuniversiteit Limburg onderzocht ik vervolgens de Nederlandse rol in de internationale politiek ten aanzien van het Midden-Oosten ${ }^{3}$. Sedert 1988 heb ik aan dit proefschrift gewerkt waarbij ik gebruik maakte van de resultaten uit de twee eerdere onderzoeken. In deze studie wordt de vraag gesteld of Nederland in staat is geweest buitenlandse en binnenlandse verlangens met elkaar te verzoenen. Voor de beantwoording wordt in deze studie het Nederlands beleid ten aanzien van het Arabisch-Israëlisch conflict over de periode 1973-1982 onderzocht.

In deze studie is het tijdvak 1973-1982 als onderzoeksperiode gekozen. In 1973 werd de eerste gemeenschappelijke verklaring door de deelnemers van de Europese Politieke Samenwerking over het conflict in het Midden-Oosten aanvaard. Deze samenwerking bereikte zijn hoogtepunt in 1981. Aan het begin van de Oktoberoorlog, die op 6 oktober 1973 uitbrak, stond Israëls voortbestaan op het spel. Nederland was toen bereid Israël daadwerkelijk te steunen. Het Israëlisch-Egyptisch vredesverdrag verschafte Israël meer veiligheid dan het tot dusverre had gekend. Nederland was niet betrokken bij de totstandkoming van het vredesverdrag, maar het heeft een belangrijke rol gespeeld in de beslissing tot Europese deelname in de vredesmacht ter handhaving van deze vrede. $\mathrm{Na}$ de Israëlische terugtrekking uit de Sinaï begon deze vredesmacht MFO (Multinational Force and Observers) op 25 april 1982 aan haar taak. Deze studie start met de gedwongen terugtrekking van Israël uit Egypte - aan het Suezkanaal - in 1973 en eindigt met de vrijwillige terugtrekking van Israell uit Egypte in 1982. Het Nederlands beleid ten aanzien van het Arabisch-Isralisch conflict in de tussenliggende periode is onderzocht.

In de eerste plaats wil $\mathrm{ik}$ degenen danken die mij een interview toestonden ${ }^{4}$. Hun informatie was van wezenlijk belang voor deze studie. De medewerking van de bij de besluitvorming betrokken Nederlanders was groot, hetgeen niet van de besluitvormers uit het buitenland gesteld kan worden ${ }^{5}$.

1. De term 'Midden-Oosten' werd na de Tweede Wereldoorlog gebruikt. Voordien was de term 'Nabije Oosten' meer gebruikelijk. Beide benamingen weerspiegelen de Europese oriểntatie. Zo wordt bijwoorbeeld in India de term "West-Axië" gebruikt; maar dan vallen Egypte en de rest van Noord-Oost Afrika er buiten (Shimoni and Levine 1974, pp. 252-253). In deze studie wordt meestal de term Midden-Oosten gehanteerd, maar ook well eens de term Nabije Oosten, om daarmee de social-psychologische 'nabijheid' aan te geven.

2. Grünfeld, 1983.

3. Grünfeld and Knegtmans, 1989.

4. Zie lijst van geinterwiewden.

5. Een interview werd geweigerd door A. wan Agt, Lord Carringtom, A. Haig, E. Heath, D. Hurd, V. Giscard d'Estaing, J. François-Poncet, M. Jobert, W. Scheel, W. Brandt en enkele lioge Britse en Westduitse ambtenaren. Frequent contact met de heer $\mathbb{R}$.. van $\mathbb{E}$ lslande gedurende vier jaar (19861990, 13 brieven en 8 telefoongesprekken) ower de Belgische opstellüng in 1973, bleef zonder 
Veel archieven bleven helaas gesloten ${ }^{6}$. In hoeverre mijn bevindingen door archiefonderzoek zullen worden bevestigd, is voorbehouden aan de historici.

Veel dank ben ik verschuldigd aan de drie promotores, Theo van Boven, Peter Baehr en Kees Flinterman. Zij hebben mij gestimuleerd bij het schrijven van deze dissertatie, die zij zeer nauwgezet hebben doorgenomen. Van hun waardevolle opmerkingen en aarmerkingen heb ik veel geleerd. Ook de leden van de beoordelingscommissie Job Cohen, Joop Ellemers en Fred van Staden wil ik graag bedanken. Enkele student-assistenten hebben mij geholpen waarvan ik met name Mieke Vervoort, Artemis Schils, Petra Faasen en Anette Brouwer wil noemen. In het bijzonder wil ik Pêjé Knegtmans bedanken, die mij gedurende een jaar bij dit onderzoek assisteerde en veel primaire bronnen bestudeerde. Hij heeft bovendien in de eindfase het manuscript becommentarieerd.

Voor de Engelse samenvatting wil ik graag Caroline Forder en Rob Bakker bedanken. De verwerking van de tekst werd verzorgd door Lisette Damen en Laura Winkelman. Met name Laura Winkelman heeft de eindversie voor publikatie gereedgemaakt waarvoor ik haar wil bedanken. Ingrid Westendorp heeft vervolgens de eindversie gecontroleerd.

Het 'camera-ready' omzetten van de tekst geschiedde door Jean-Pierre Raas, Joof Schöpping en Rejean Pinckaers. Graag wil ik Oene Bouma voor de omslag bedanken. Hij bood spontaan aan deze kartografie te verzorgen. Voor deze publikatie ontving ik een subsidie van het Fronika Sandersfonds.

Veel collega's binnen de faculteit der Rechtsgeleerdheid van de Rijksuniversiteit Limburg stimuleerden mij door het uiten van hun belangstelling. Een stimulerende impuls ging ook uit van mijn collega's uit de interuniversitaire werkgroep 'buitenlands beleid van Nederland'.

De grote belangstelling van mijn familie was hartverwarmend. De intellectuele inspiratie van mijn vader, die in 1985 overleed, heeft mij sterk beïnvloed,

Marij, Joram en Samme willen niet op deze plaats bedankt worden. De turbulentie in de internationale betrekkingen weerspiegelde zich thuis. Het samenleven met hen is een uitdaging.

$5 . \rightarrow$ resultaat omdat de betreffende archiefstukken hem niet ter beschikking werden gesteld Het toegezegde interview met $\mathrm{C}$. Cheysson vond niet platats.

6. Zis lijst van archieven en persdocumentatie. Geen toegang werd verleend tot de archieven van het VVD-bestuur, de VVD-Tweede Kamer-fractie, CDA Tweede Kamer-fractie, het ministerie van Buitenlandse Zaken, het ministerie van Algemene Zaken. 


\section{Hoofdstuk 1. Buitenlandse politiek en internationale politiek ten aan- zien van het Arabisch-Israëlisch conflict}

\subsection{Inleiding}

In deze studie wordt het Nederlands beleid ten aanzien van het Arabisch-Israëlisch conflict over de periode 1973-1982 onderzocht.

Tijdens en na de Oktoberoorlog van 1973 raakte Nederland betrokken bij het ArabischIsraëlisch conflict. In de laatste week van de oorlog in het Midden-Oosten - eind oktober 1973 - werd Nederland getroffen door het Arabisch olie-embargo. Het embargo zou pas worden opgeheven als het Nederlands buitenlands beleid ten aanzien van het Arabisch-Israëlisch conflict zou worden gewijzigd in een pro-Arabische richting. Ditmaal werd niet slechts gedreigd, er werden economische sancties op Nederland toegepast met het doel een wijziging in het Nederlands buitenlands beleid te bewerkstelligen. Het door Nederland gevoerde pro-Israëlisch beleid moest worden beëindigd.

Niet alleen de Arabische wereld maar ook de partners van Nederland in de Europese Gemeenschap beoogden het Nederlands buitenlands beleid ten aanzien wan het ArabischIsraëlisch conflict in meer pro-Arabische zin te veranderen. De buitenlandse druk was zeer groot. De economische sancties door de Arabische olieproducerende staten werden in feite versterkt door het uitblijven van steun voor de Nederlandse positie van de andere lidstaten van de Europese Gemeenschap.

De consequentie van het partij kiezen door Nederland in het Arabisch-Israëlisch conflict was groot. Zo verwachtte het kabinet indertijd dat hierdoor het aantal werklozen van 55.000 op dat moment tot 100.000 à 200.000 zou toenemen. Een wijziging van het Nederlandse standpunt in pro-Arabische richting lag dan ook voor de hand, zo zou men kunnen veronderstellen. Het resultaat van het besluittvormingsproces was echter anders want het Nederlands buitenlands beleid ten aanzien van het Arabisch-Israëlisch conflict in de periode 1973-1974 werd niet of natuwelijks gewijzigd; in ieder geval niet voldoende in de visie van de Arabische olieproducenten om het selectieve embargo tegen Nederland te beëindigen. Dit is te verklaren door de opvattingen binnen Nederland over het conflict in het Midden-Oosten bij de analyse te betrekken. Een binnenlandse proIsraell consensus bleef voortbestaan en de besluitvormers hebben claar bij hun beleidskeuze steeds rekening mee gehouden. Dat was overigens zeker niet contre-coeur. Ook hen lag het voortbestaan van Israël na aan het hart. Wat betreft het Nabije Oosten speelde voor veel Nederlanders de "nabijheid" van Israël een belangrijke rol. Aldus ontstond een spanning tussen de tegengestelde opvattingen vanuit het buitenland en vanuit het binnenland over het gewenste Nederlands buitenlands beleid ten aanzien van het Midden-Oosten.

Het door Nederland gevoerde buitenlands beleid kwam daarmee onder druk te staan, zowel vanuit het buitenland als vanuit het binnenland. De eerste vorm zal hier externe druk en de tweede interne druk worden genoemd. Er bestaat echter niet zoiets als én externe of interne druk en de vraag deed zich voor of en - zo ja - in welke richting het beleid gewijzigd zou worden. 
De vraag is niet alleen hoe een buitenlands beleid, rekening houdend met verschillende belangen en - overigens niet altijd conflicterende - doelstellingen, tot stand komt, maar tevens hoe dat beleid vervolgens gerealiseerd wordt. De vraag is dan welke rol Nederland in de internationale politiek en in het bijzonder binnen internationale gouvernementele organisaties heeft vervuld en in hoeverre Nederland erin is geslaagd zijn opvattingen in het internationale politieke standpunt tot uiting te brengen.

De invloed van Nederland in de internationale politiek is niet alleen afhankelijk van min of meer vaste factoren (de machtsbasis ${ }^{\mathrm{t}}$ ) maar ook van inzichten van andere deelnemers aan het internationale politieke proces. Voor deze studie zijn dat vooral de lidstaten van de Europese Gemeenschap, omdat Nederland zich vanaf 1973 in zijn beleid ten aanzien van het Midden-Oosten gebonden achtte, vanwege de eigen kwetsbaarheid, aan de besluitvorming ter zake in de Europese Politieke Samenwerking. De Nederlandse regering wilde na het olie-embargo voorkomen in de toekomst opnieuw in een kwetsbare positie te geraken. Dat werd na 1973 een van de doelstellingen van het beleid. De Europese Politieke Samenwerking (EPS) werd het internationale politieke forum bij uitstek waarin Nederland zijn opvattingen inbracht ${ }^{2}$. De Nederlandse vrijheid van handelen werd hiermee beperkt.

De vraagstelling is:

1. Hoe kwam het Nederlands buitenlands beleid ten aanzien wan het ArabischIsraëlisch conflict tot stand?

2. Welke rol heeft Nederland in de internationale politiek ten aanzien van thet Arabisch-Israëlisch conflict vervuld?

3. Bestond er een relatie tussen Nederlands buitenlands beleid en de Nederlandse inbreng in de internationale politiek ten aanzien wan het Arabisch-Israëlisch conflict?

De relevantie van deze vraagstelling schuilt in de vaststelling dat het besluitvormingsproces ten aanzien van het conflict in het Midden-Oosten is gekenmerkt door zowel externe druk - vanuit het buitenland - als interne druk - vanuit de Nederlandse samenleving - op de Nederlandse regering. De externe druk komt vooral tot uiting in thet internationaal politieke overleg. De interne druk is van invloed op de totstandkoming van het Nederlands buitenlands beleid. Dit leidt tot de vraagstelling of Nederland in staat is geweest buitenlandse en binnenlandse verlangens met elkaar te verzoenen. In deze studie wordt aangetoond dat er een tegenstelling tussen beide soorten druk bestond.

1. Onder machtsbasis wordt onder meer werstaan de omvang van het grondgebied, de grootte van de bevolking, het bruto national produkt, de militaire sterkte. Zie verder Deutsch, 1969, pp. 21-39; Russett and Starr, 1981, pp. 136-153.

2. Aangezien deze studie de Europese Politieke Samenwerking behandell, wordt onder Europa in deze studie niet de geografische maar de politieke dimensie bedoeld. De politieke dimensie wordt beperkt tot de staten die behonen tot de Europese Gemeenschap. Van 1973 tot 1981 waren dat de Negen en vanaf 1981 tot 1983 de Tien die tezamen de partners vormden van de Europese Politieke Samenwerking warbinnen getracht werd aan de buitenlandse politieke dimensie van dit Europa vorm te geven. 
Het verschil tussen het besluitvormingsproces inzake het buitenlands beleid, dat binnen de nationale samenleving plaatsvindt, en inzake de internationale politiek, dat buiten de nationale samenleving tussen twee of meer staten plaatswindt, wordt in de volgende paragrafen behandeld (zie 1.2.1 en 1.2.2). Vervolgens wordt inzicht gegeven in vier vormen van aanpassing door een regering in haar beleid met betrekking tot de externe en interne verlangens. Dit theoretisch raamwerk wordt in deze studie toegepast in de hoofdstukken twee, drie en vier. In de conclusie worden de drie vragen beantwoord (respectievelijk 5.1, 5.2 en 5.3).

De twee thesen in deze studie zijn:

1. Nederland heeft ten aanzien van het Arabisch-Israëlisch conflict geen eigen buitenlands beleid meer, maar alleen een aanpassing aan een internationaal politiek standpunt.

2. Succesvolle binnenlandse beïnvloeding van het buitenlands beleid is een noodzakelijke voorwaarde voor invloed in de internationale politiek ${ }^{3}$.

De eerste stelling wordt in deze studie verworpen; de tweede niet.

Eén van de gevolgen van het belieid ten tijde van het olie-embargo uit 1973 was echter dat eerst binnen het internationaal politieke forum van de EPS een standpunt werd bereikt. Het nationale parlement werd er pas achteraf bij betrokken. Na 1973 ging het internationaal politieke proces vooraf aan het buitenlands politieke proces, gezien vanuit het oogpunt van parlementaire betrokkenheid $d^{4}$.

Vóór 1973 had Nederland een grotere vrijheid van handelen in een meer onafhankelijk optreden in de Verenigde Naties. Na 1973 werd ook Nederlands optreden aldaar afhankelijk van het bereikte compromis in de EPS en werd het standpunt voor de Nederlandse vertegenwoordiger in New York vanuit de EPS voorgekookt. Het Nederlandse openbare optreden in de Algemene Vergadering van de Verenigde Naties is een resultante van het vertrouwelijke besluitvormingsproces in de EPS, waarin met name de ambtelijke top van het departement van Buitenlandse Zaken een hoofdrol vervult.

Dat betekent dat een deel van het buitenlands beleid zich hoe langer hoe meer aan democratische controle door het parlement en binnenlandse beinvloeding onttrekt. Als these voor deze studie werd enigszins gechargeerd gesteld dat Nederland geen eigen buitenlands beleid ten aanzien van het Midden-Oosten meer heeft maar alleen een internationaal politiek standpunt kent dat voortvloeit uit het EPS-beraad.

Gekozen is voor een chronologische aanpak. Door Baehr en ook door Sondermann is verondersteld dat de totstandkoming van de buitenlandse politiek in de tijd aan de totstandkoming van de internationale politiek vooraf gaat ${ }^{5}$. Dit heeft tot gevolg dat het parlement invloed kan hebben op het resultaat, omdat het betrokken is bij de besluitvorming over het buitenlands beleid. Deze volgorde gold grotendeels voor de in hoofdstuk

3. Onder succesvolle binnenlandse beînloeding wordt verstaan dat opvattingen uit het binnenland in het feitelijk gevoerde beleid tot uiting komen. Aangezien anticiperende invloed in deze studie van belang is, wordt niet als maatwtaf voor 'succes' genomen dat het feitelijk regeringsbeleid afwijkt van wal bij afwezigheid wan de beinvloedingspogingen verwacht had mogen worden.

4. Voor het verschil tussen het internationaal politieke proces en buitenlands politieke proces zie 1.2.2.

5. Zie 1.2.1 
twee te behandelen kwestie van het olie-embargo. Zoals gesteld ging na 1973 het buitenlands politieke proces niet steeds vooraf aan het internationaal politieke proces.

In de hoofdstukken drie en vier wordt om die reden eerst de internationale politiek en vervolgens de buitenlandse politiek behandeld. De afnemende betekenis van het buitenlands politieke besluitvormingsproces voor de uitkomst van het internationaal politieke overleg komt ook tot uiting in de aandacht die daaraan in deze studie wordt besteed. Deze constatering omtrent het verloop van de besluitvormingsprocessen houdt echter nog geen oordeel in over de betekenis van de activiteiten van binnenlandse groeperingen voor het uiteindelijk door de regering in te nemen standpunt. Dat laatste is onderwerp van deze studie.

In het vervolg van deze inleiding wordt het plan van behandeling van deze studie geschetst.

In het tweede hoofdstuk wordt de kwestie van het olie-embargo uit 1973 behandeld. Toen werd het eerste gemeenschappelijke standpunt van de Negen dat betrekking had op het Midden-Oosten gepubliceerd. De totstandkoming van deze verklaring van 6 november 1973 geeft inzicht in de beleidsverandering van de Nederlandse regering. Aan het begin van de Oktoberoorlog had Nederland een eigen standpunt ingenomen dat als pro-Isrälisch kan worden gekenschetst. Bovendien was Nederland bereid Israël daadwerkelijk te thelpen in de vorm van logistieke militaire ondersteuning. Dit beleid kon rekenen op binnenlandse steun. De binnenlandse consensus over steun aan Israël begrensde ook het Nederlands optreden in EPS-verband waardoor het Nederlandse beleid ten aanzien van het Israëlisch-Arabisch conflict zich nauwelijks wijzigde. De wijziging betrof de aanvaarding van de EPS als forum voor politieke besluitvorming ten aanzien van het Arabisch-Israëlisch conflict. Steun van de Europese partners voor de Nederlandse olievoorziening - als enige van de EG-leden getroffen door het olie-embargo - bleef echter uit. Aanvankelijk verkeerde Nederland in een geïsoleerde positie binnen de EG, maar gaandeweg wist Nederland de steun van enkele partners te winnen en tenslotte kwam Frankrijk in een geissoleerde positie terecht. Dit internationale politieke proces van oktober 1973 tot februari 1974 wordt in 2.3 beschreven. De EG was echter niet in staat een beleid van onderlinge solidariteit in de energievoorziening te ontwikkelen. Een nieuwe internationale organisatie werd in 1974 opgericht om in deze leemte te voorzien. Dit Internationale Energie Agentschap, dat op initiatief van de VS tot stand kwam, stelde een crisismechanisme op waarmee werd beoogd ook voor Nederland een al te kwetsbare positie ten aanzien van zijn olie-behoefte in de toekomst te voorkomen.

Pas in juni 1977 bereikten de staatshoofden en regeringsleiders van de EG overeenstemming over een nieuwe verklaring. Daarin stond dat voor een oplossing van het conflict 'rekening zou moeten worden gehouden met de behoefte aan een eigen land voor het Palestijnse volk'. Onder de regeringsleiders in 1977 bevonden zich vier socialisten. Zij lieten nu hun reserves varen omdat een maand tevoren de socialisten in Israël de verkiezingen hadden verloren en daardoor voor het eerst niet langer deel uitmaakten van de regering. De term 'homeland' (eigen land) in bovenstaande verklaring, was in 1917 ook gebruikt in de Balfourverklaring. Deze verklaring wordt beschouwd als een doorbraak op de weg naar een Joodse staat. Voor Israël was de creatie van een Palestijnse staat in 1977 anathema. 
Deze verklaring week overigens niet af van de lijn die de Verenigde Staten op dat moment volgden. President Carter drong namelijk aan op een doorbraak in de Palestijnse kwestie. Hij had zich in maart 1977 uitgesproken voor een 'homeland" voor de Palestijnse vluchtelingen ${ }^{6}$.

De overeenstemming in standpunten tussen de VS en de EPS-deelnemers werd vervolgens minder en nadat aanvankelijk in 1978 door laatstgenoemden nog enig enthousiasme voor het Camp Davidproces was getoond, werd later gereserveerd gereageerd op deze Amerikaanse bemiddeling tussen Israël en Egypte.

De Nederlandse regering zag deze verwijdering ten opzichte van de VS met lede ogen aan en trachtte de EPS ertoe te bewegen de rol van de VS in het Midden-Oosten zo min mogelijk te dwarsbomen. Daarnaast probeerde Nederland de verzekering van Israëls bestaansrecht zo krachtig mogelijk in de EPS-verklaringen naar voren te laten komen. De Nederlandse inbreng in de EPS op deze twee punten bij de totstandkoming van het gemeenschappelijke standpunt, zal in 3.1.2.4 gedetailleerd worden beschreven. Het Nederlandse beleid werd naderhand grotendeels door het parlement ondersteund.

In juni 1980 kwam de verklaring van Venetiè tot stand waarin naast een gemeenschappelijk standpunt van de Negen het voornemen van een Europese vredesmissie naar de regio werd aangekondigd. Beoogd werd een verbaal beleid om te zetten in een daadwerkelijk beleid. Een plan werd in december 1980 uitgewerkt woor een oplossing van het Israëlisch-Arabisch conflict maar dit werd niet openbaar gemaakt.

In deze studie zal in 4.1.1.2. worden aangetoond dat Nederland een rol vervulde in het mislukken van dit Europees vredesinitiatief. Dit Europees initiatief verzandde ook omdat de betrokken partijen het verwierpen en bovendien de Fransen - na de presidentswerkiezing van Mitterrand - meer voelden voor de Amerikaanse benadering. Het Europees initiatief zette zich namelijk af tegen de Camp Davidbenadering. Het Israelisch-Egyptisch vredesverdrag werd als onvoldoende beschouwd ondat de EPS voor een allesomvattende vredesregelling opteerde. Een keuze moest worden gemaakt tussen voortgaan op de weg naar een allesomvattende vredesregeling uit de verklaring van Venetië en steun verlenen aan het Israëlisch-Egyptisch vredesverdrag. Een beslissing moest worden genomen, toen aan enkele Europese staten in 1981 werd gevraagd een militaire bijdrage te leveren aan de multilaterale vredesmacht in de Sinaï (MFO). Deze vredesmacht vloeide voort uit het Israëlisch-Egyptisch vredesverdrag; dat verdrag kon voor de Israëli's de enige basis voor deelname zijn. Elke verwijzing naar de verklaring van Venetië was voor Israël onaanvaardbaar en zou een Israëlisch veto ten aanzien van deelname tot gevolg hebben.

De Nederlandse minister van Buitenlandse Zaken Van der Stoel bood na de moord op president Sadat in oktober 1981, op eigen initiatief, een Nederlandse millitaire bijdrage aan. Met het oog op Nederlands kwetsbare positie uit 1973 was cén van de Nederlandse voorwaarden dat de Nederlandse deelname door de overige Europese partners werd gesteund. De Grieken en in mindere mate de Britten hebben zich lang verzet tegen deze akkoordbevinding. Nederland bevond zich, als één van de vier potentiële deelnemers vanuit de $E G$, in het centrum wan de besluitvorming van de internationaal politieke beraadslagingen en speelde een rol in de contacten met de VS. Een verbetering in de

6. Zie verder 3.1.2.1. 
werstandhouding met de VS was ook een zeer belangrijke Nederlandse beweegreden voor deelname aan de MFO. Dit internationale politieke proces zal in deze studie in 4.1.2 uitgebreid worden beschreven.

Met het sturen van Franse, Britse, Italiaanse en Nederlandse militairen naar de Sinaï werd het Egyptisch-Israëlisch vredesverdrag daadwerkelijk ondersteund, terwijl de verklaring wan Venetie nooit het verbale stadium heeft overschreden. Aan het parlement werd medegedeeld dat deelname aan de MFO voortvloeide uit het beleid in de verklaring van Venetiè, daarmee werd de parlementaire steun voor de beslissing van de regering verkregen. Ook de tien EG-lidstaten stemden in met participatie van de vier omdat deelname beantwoordde aan beginselen uit de verklaring van Venetië als het recht op zelfbeschikking van de Palestijnen en een allesomvattende vredesregeling. Aan Israël en de VS werd daarentegen duidelijk gemaakt dat aan deelname geen enkele politieke voorwaarde - vanuit de verklaring van Venetië - werd verbonden. Door de bijdrage aan de MFO met goedkeuring van de EPS werd in feite de Amerikaanse benadering gesteund.

De Nederlandse regering was gelukkig met deze wending; zij heeft ertoe bijgedragen dat een verwijdering tot de VS ten aanzien van het Midden-Oosten zich niet heeft doorgezet, zoals in deze studie zal worden aangetoond. Er werd vervolgens geen nieuw Europees vredesinitiatief ten aanzien van het Midden-Oosten ontplooid.

Deze studie concentreert zich op Israëls voortbestaan binnen veilige en erkende grenzen. Dat was mede een uitgangspunt voor de keuze van de periode 1973-1982 voor dit onderzoek. Sedert de Onafhankelijkheidsoorlog van 1948 was Israẽls veiligheid niet meer zo sterk in gevaar geweest als bij het begin van de Oktoberoorlog in $1973^{7}$. Deze situatie markeert het begin van deze studie die eindigt op het moment dat Israels veiligheid meer dan ooit te woren werd verzekerd. De bedreiging van Israëls voortbestaan nam in april 1982 aanzienlijk af toen, met de teruggave door Israël van het laatste deel van de Sinaï, het Israëlisch-Egyptische vredesverdrag werd voltooid. Deze erkenning van Israel door Egypte - het zowel politiek als militair sterkste Arabisch buurland van Israël ${ }^{8}$ - is een mijlpaal in een periode van bijna 35 jaar Arabisch-Israëlisch conflict. De periode 1973-1982 markeert tevens de ontwikkeling van onderlinge afstemming en convergentie van standpunten in de EPS naar gemeenschappelijk optreden. Het gemeen-

7. Brecher toonde overtuigend aan dat bij het begin van de Zesdaagse oorlog de spanning aan Israelische zijde voorbij was, terwijl de sparning en daarmee de crisis binnen de Israëlusche besluitvormers in 1973 juist begon bij het starten van de oorlogshamdelingen, Brecher 1980 . 8.

$\begin{array}{lrrrr} & \text { Grondgebied } & \text { bewolking } & \text { BNP in dlol. } & \text { milit. sterkte } \\ \text { Israël } & 20.770 \mathrm{~km} 2 & 4,00 \mathrm{mil} . & 23,00 \mathrm{bn} . & 172.000 \\ \text { Egypt } & 1.001 .449 \mathrm{~km} 2 & 43,19 \mathrm{mil} . & 17,80 \mathrm{bn} . & 376.000 \\ \text { Syrie } & 185.680 \mathrm{~km} 2 & 9,50 \mathrm{mil} . & 9,20 \mathrm{bn} . & 222.500 \\ \text { Jordan. } & 91.000 \mathrm{~km} 2 & 3,32 \mathrm{mil} . & 2,69 \mathrm{bn} . & 67.500 \\ \text { S-Arab. } & 2.400 .000 \mathrm{~km} 2 & 10,40 \mathrm{mil} . & 94,60 \mathrm{bn} . & 51.700 \\ \text { Irak } & 438.446 \mathrm{~km} 2 & 13,84 \mathrm{mil} . & 35,20 \mathrm{bn} . & 252.250 \\ \text { Libanon } & 10.400 \mathrm{~km} 2 & 3,09 \text { mil. } & 2,90 \mathrm{bn} . & 23.750\end{array}$

Uit: Military Balance 1981/1982. London IISS, 1981.

The Statesmen's Year-book 1980/1981, London, Macmillan Press 1980. 
schappelijk optreden bereikte zijn hoogtepunt in 1981; de betekenis van de EPS voor derde partijen stelde weinig voor.

Na die tijd treedt het Israellisch-Palestijns conflict op de voorgrond, met de oorlog in Libanon en de Intifadah; een conflict dat met name na december 1988 een grote wijziging onderging door een fundamentele andere Palestijnse opstelling ten aanzien van Israël.

Met de fundamenteel andere Palestijnse opstelling ten aanzien van Israel wordt de aanvaarding door de Palestijnse Nationale Raad van het VN-delingsplan wit 1947 bedoeld. Daardoor behoort een territoriale oplossing met uitzicht op een 'twee-staten' model tot de mogelijkheden. Natuurlijk is dit slechts een eerste stap op weg naar een oplossing; voor belangrijke kwesties als erkenning van Israël, recht op terugkeer van de Palestijnen, positie van Jeruzalem e.d. is nog geen oplossing naderbij gekomen. Het betekent echter wel een wezenlijke verandering in vergelijking met de standpunten uit de periode 1973-1982. De in deze studie gebezigde begrippen als pro-Palestijns, proArabisch en pro-Israëlisch zijn gerelateerd aan de periode 1973-1982.

Onder 'pro-Palestijns' worden verstaan die standpunten en gezichtspunten die gericht zijn op het steun verlenen aan de Palestijnse Bevrijdingsorganisatie (PLO) als de belangrijkste overkoepelende politieke beweging onder de Palestijnen. Bijvoorbeeld een proPalestijnse houding betekent voor de periode van 1973-1982 een erkenning van de PLO als de enige vertegenwoordiging van de Palestijnen en een afwijzen van het 'tweestaten" model, dat wil zeggen een Palestijnse staat behoort niet naast maar in de plaats van Israël te worden gecreëerd.

Onder 'pro-Arabisch" worden die standpunten en gezichtspunten verstaan die gericht zijn op het steunen van de overheersende visie in de Arabische wereld inzake het Arabisch-Israëlisch conflict. Bijvoorbeeld bij een pro-Arabische visie zou het EgyptischIsraëlisch vredesverdrag worden afgewezen.

Onder 'pro-Israëlisch' worden verstaan die standpunten en gezichtspunten die gericht waren op steun aan het bestaan en voortbestaan van de staat Israël. Het begrip proIsraëlisch strekt zich in deze betekenis niet uit tot het steunen van elke Israëlische regeringsbeslissing. Bijvoorbeeld men kan pro-Israëlisch zijn en toch de annexatie van de Golan door Israël afwijzen".

Het Israëlisch-Palestijns conflict heeft nooit enige bedreiging voor Israëls fysieke voortbestaan gevormd; het Arabisch-Israëlisch conflict wel. In de - vanuit dat uitgangspunt belangrijke jaren 1973 en 1982 heeft Nederland een eigen en zelfstandige rol vervuld. Alvorens in de hoofdstukken twee, drie en vier dit buitenlands politieke en internationaal politieke proces te beschrijven, zal in het eerste hoofdstuk worden ingegaan op het onderscheid tussen buitenlandse politiek en internationale politiek. De besluitvorming inzake het buitenlands beleid en de bij deze besluitvorming betrokken actoren komen daarin naar voren. Daarmee komen we op het terrein van de binnenlandse beïnvloeding van het buitenlands beleid. De betekenis van het Midden-Oostenconflict voor zowel

9. Het nadeel van deze zeer ruime omschrijving is dat bijna iedereen eronder valt. Een beperking tot steun aan het lsraëlisch regeringsbeleid zou echter betekenen dat groeperingen als het CIDI, WI, Vrede Nu niet als pro-Israëlisch worden gekenschetst. In een artikel over de visie op Israël na de inval in Libanon in 1982 stelt Rozemond, 1983, p. 149: "Het is moeilijk voor iemand vast te stellen in hoeverre hij achter Israël kan staan, zolang dat land niet zelf aangeeft wat het wil". 
binnenlandse actoren als voor het Nederlands buitenlands beleid wordt beschreven. Onderzocht zal worden of er een relatie bestaat tussen enerzijds succesvolle binnenlandse beïnvloeding van het buitenlands beleid en anderzijds effectief optreden in de internationale politiek. De vraag is dlaarbij aan de orde of een land als Nederland de mogelijkheid heeft een beleid te voeren waarin zowel de opvattingen vanuit het eigen land als de opvattingen vanuit de externe omgeving zijn te verenigen of dat Nederland zich louter heeft aan te passen aan zijn externe omgeving. De besluitvorming in de internationale politiek vond voor het onderwerp van deze studie voornamelijk plaats in het kader van de Europese Politieke Samenwerking, een intergouvernementeel samenwerkingswerband dat in 1.3.2 wordt omschrewen.

In deze studie komt tweemaal voor dat een internationale organisatie (EG en VN) een taak niet vervulde waarvoor zij was toegerust. Beide malen werd een nieuwe internationale organisatie opgericht (IEA en MFO). Aan dit verschijnsel zal aandacht worden geschonken. Het hoofdonderwerp van deze studie is echter de totstandkoming van het buitenlands beleid van Nederland en de Nederlandse rol in de internationale politiek ten aanzien van het Arabisch-Israëlisch conflict.

\subsubsection{Binnenlandse en buitenlandse politiek}

De binnenlandse politiek van een staat richt zich op het bereiken van bepaalde doeleinden binnen de geografische ruimte van een samenleving. De buitenlandse politiek daarentegen richt zich op het bereiken van bepaalde doeleinden buiten de geografische ruimte van een samenleving. In dat geval is de externe omgeving het object ${ }^{10}$.

Het onderscheid tussen binnenlandse en buitenlandse politiek heeft betekenis wanneer de effectuering van het voorgestane beleid aan de orde komt, aangezien de gestelle doeleinden op binnenlands politiek terrein in principe door eigen handelen gerealiseerd kunnen worden; bijvoorbeeld de aansluiting van Lelystad op het spoorwegnet of de met militair geweld gepaard gaande ontruiming van een kraakpand aan de Vondelstraat in Amsterdam. De realisering van doeleinden op buitenlands politiek terrein is daarentegen mede afhankelijk van het handelen van anderen uit de externe omgeving; bijvoorbeeld de afschaffing van de Apartheid in Zuid-Afrika.

Een dergelijk onderscheid is niet meer zinwol wanneer de aandacht zich richt op het beleidsproces oftewel het besluitvormingsproces. Voor de totstandkoming van het beleid binnen een samenleving maakt het geen werschil of een dergelijk beleid gericht is op de interne of externe omgeving. Ook de besluitworming over de buitenlandse politiek vindt plaats binnen de eigen geografische ruimte - in Den Haag - van een staat. Het zelfstan-

10. De externe omgeving van een national politikk systeem bestaat volgens Rosenau uit verschijnselen buiten de geografische ruimte van de samenleving, warvan het politiek systeem deel uitmaakt. Rosenau, 1969 , p. 45 . Wanneer in navolging van Easton onder politiek systeem "het geheel van interacties, waardoor de gezaghebbende toedeling van waarden voor een samenleving plaats hoeft" wordt verstaan, richt de aandacht zich op het nationaal politiek systeem. Easton 1979, p.50. Daarmasit gaf Easton ook al aandacht aan de systemen die buiten de gegeven samenleving liggen, de zogenamde 'extra-societal environment' en onder meer het internationale politieke systeem omvatten. Easton 1979, pp. 73-75. 
dig kunnen onderhouden van buitenlandse betrekkingen wordt zelfs als eén van de voorwaarden voor volkenrechtelijke erkenning van een staat beschouwd ${ }^{11}$.

Ook de actoren die bij het besluitvormingsproces kunnen worden betrokken, behoeven in principe niet te verschillen wanneer het om buitenlandse dan wel binnenlandse politiek gaat. Weliswaar za: de zeggenschap van bepaalde actoren op het ene terrein eerder worden erkend dan op het andere terrein, maar dat geldt eveneens voor verschillende terreinen binnen de binnenlandse politiek. De betrokkenheid en invloed van aan vaarwater gelegen bedrijven op het terrein van de waterstaat ${ }^{12}$ is groter dan hun zeggenschap op het toneelbeleid van de overheid. De tijd dat het buitenlands beleid nog als het 'domaine réservé' van de uitvoerende macht werd beschouwd, met uitsluiting van het parlement en groepen uit de samenleving, is inmiddels achterhaald ${ }^{13}$. Van de uitvoerende macht is bovendien niet meer slechts éen of enkele departementen bij de totstandkoming van het buitenlands beleid betrokken. Het departement van Buitenlandse Zaken heeft geen monopoliepositie meer en is zelfs in feite niet meer verzekerd van de rol van primus inter pares op het terrein van de buitenlandse politiek ${ }^{14}$.

Alle Nederlandse departementen - ook Binnenlandse Zaken - beschikken inmiddels over een afdeling internationale betrekkingen. Hun bemoeienis betreft veelal een deelterrein van het buitenlands beleid die voortvloeit uit de behartiging van de aan hen toevertrouwde taken. Maar dat wil niet zeggen dat hun invloed daardoor geringer zou zijn en dat zij het meer algemene beleid niet zouden kunnen doorkruisen. Zo werd bijvoorbeeld het traditionele Nederlandse 'éen China-beleid' doorkruist met de beslissing tot levering van onderzeeërs aan Taiwan in 1980. Dat een tweede levering van duikboten aan Taiwan in 1983 werd afgewezen, nuanceert het voorbeeld wel maar wijzigt het niet ${ }^{15}$. Zowel de binnenlandse als de buitenlandse politiek wordt binnen een staat gevormd. De internationale politiek wordt daarentegen niet binnen een staat gevormd maar tussen twee of meer staten door vertegenwoordigers van die staten in bilateraal of multilateraal verband. De buitenlandse politiek vormt - volgens Sondermann - de overgangsfase van de nationale naar de internationale politieke processen ${ }^{16}$. Het resultaat - de output - van de buitenlandse politiek vormt de inbreng - de input - in de internationale politiek. Dit wordt schematisch aangeduid op p. 17. Door Baehr werd de studie van de buitenlandse politiek gezien als de toegang tot de internationale politiek ${ }^{17}$. De samenhang en wederzijdse doordringing van buitenlandse en internationale politiek maakt het niet goed mogelijk nog van een éénrichtingverkeer te spreken, in de zin dat alleen de "output" van het nationaal systeem de 'input' vormt voor het internationaal politiek systeem. Deze problematiek zal ik hieronder nader uitwerken. Het is vanwege de samenhang en weder-

11. Kuyper, 1974 , p. 587 'onafhankelijkheid tot uiting komend in de capaciteit zelfstandige betrekkingen met andere staten te onderhouden'; Akehurst, 1987, p. 53.

12. Zie onderzoek van Braam, 1973: Invloed van bedrijven op de overheid, Boom, Meppel, 1973.

13. Everts 1983, pp. 12-13.

14. Bijvoorbeeld in 1980 bij de beslissing tot de eerste levering van duikboten aan Taiwan; Colijn en Rusman, 1984.

15. Colijn en Rusman, 1984.

16. Sondermann in Rosenau, 1961, pp. 14-15. Holsti, 1972, p. 21.

17. Niet elke toegang tot de internationale politiek verloopt via de buitenlandse politiek; bijvoorbeeld over het landbouwbeleid wordt door de EEG beslist en onttrekt zich steeds meer aan de besluitvorming in het nationale parlement. Zie Vermeullen, 1984. 
ziijdse beïnvloeding van buitenlandse politieke processen en internationale politieke processen interessant te bezien of de nationale inbreng in de internationale politiek van een staat mede wordt veroorzaakt door het buitenlandse politieke proces in die staat. Bijvoorbeeld, een sterke bimnenlandse consensus over de modernisering van kernwapens voor de middellange afstand ('kruisraketten-kwestie') heeft niet alleen gevolgen voor het totstandgekomen buitenlands beleid, maar ook voor de invloed van de desbetreffende staat in de internationale politiek.

Via de buitenlandse politiek krijgt men greep op de analyse van de internationale politiek $^{18}$. Dat hoeft mijns inziens echter niet tot gevolg te hebben dat het daardoor nog steeds zinvol is de buitenlandse politiek van andere vormen van beleid te onderscheiden $^{19}$. Immers het besluitvormingsproces tussen binnenlandse en buitenlandse politiek verschilt niet.

Hierdoor is geen grond meer aanwezig om nog verschil te maken tussen de analyse van enerzijds het buitenlands beleid en anderzijds ander overheidsbeleid. Het analyse-niveau is de nationale staat. Het bepaall het besluitvormingsproces ongeacht of het beleidsterrein landbouw, onderwijs of het buitenland betreft. Wellicht waren in het verleden de buitenlandse invloeden op de totstandkoming van het buitenlands beleid van Nederland sterker dan op andere terreinen van het Nederlandse overheidsbeleid. Vanwege de toenemende interdependentie en voortgaande Europese integratie ${ }^{20}$ is echter de beleidsruimte van de Nederlandse overheid niet langer veel beperkter op het terrein van het buitenlands beleid dan op het terrein van het binnenlands beleid. Het verschil lijkt geringer te zijn geworden. Door Voorhoeve werd de beleidsruimte voor Nederland in kaart gebracht waarbij hij de exogene en de endogene beperkingen voor het binnenlands en buitenlands beleid weergaf. Zijn indruk is weergegeven in een figuur waaruit niet blijkt dat de exogene beperkingen veel sterker drukken op de beleidsruimte van de regering inzake het buitenlands beleid dan het binnenlands beleid ${ }^{21}$.

18. Baehr, 1970, pp. 12-13.

19. Baehr, 1970, p. 9.

20. Zo stellen Allen and Byrne, in: Smith and Clark, 1985. p. 125: "any discussion of the foreign policy process must incorporate an acknowledgement of the diminishing validity of a clear-cut distinction between domestic and foreign policy, and this is especially the case in the context of the European Community".

21. Het kan niet meer dan een indruk zijn daar er geen objectieve en nauwkeurige maatstaven zijn deze beperkingen vast te stellen. Voorhoeve $1978, \mathrm{pp}$. 43-44.

Het benadrukken van de toegenomen exogene beperkingen op het totale overheidsheleid houdt verband met het vanuit de interdependentie-leer versehafte inzicht in de mondiale en transnationale politieke processen. Bij dit door Leurdijk omschreven wereld politieke paradigma van Keohane en Nye staat miet langer de nationale soevereiniteit maar de kwetsbaarheid en gevoeligheid van staten voor gebeurtenissen elders voorop. Karns en Mingst wezen op de bruikbatrheid van het begrippen paar - gevoeligheid en kwetsbararheid - voor de mate van aanpassing van een staat aan zijn externe omgeving. Hoe kwetsbaarder een staat is des te meer hij zich moet aanpassen. Karns en Mingst, 1987 , p. 459. 


\subsubsection{Buitenlandse en internationale politiek}

Een onderscheid tussen buitenlandse politiek en internationale politiek is op analytische gronden zinvol. De actoren en de besluitvormingsprocessen zijn verschillend. Het handhaven van dit onderscheid berust grotendeels op de notie dat staten de belangrijkste actoren in de internationale politiek zijn; het is een 'state centered view' op de internationale politiek die hier gebezigd wordt. De inbreng van non-gouvernementele en interstatelijke organisaties in de internationale politiek worden op deze wijze aan het oog onttrokken. Dit uitgangspunt past bij deze studie die voor het internationaal-politieke onderdeel is gericht op een bij uitstek inter-gouvernementeel overlegorgaan als de Europese Politieke Samenwerking waarin slechts staten deel uitmakend van de EG bij de besluitvorming zijn betrokken.

De actoren in het internationaal politieke besluitvormingsproces in deze studie zijn de vertegenwoordigers van staten. De actoren in het buitenlands beleidsproces vormen een heterogeen gezelschap. Singer besteedde aandacht aan de nationale staat als anaylseniveau in de leer der internationale betrekkingen. Hij wees reeds in 1962 op zowel de binnenlandse als de buitenlandse invloeden bij de totstandkoming van het beleid ${ }^{22}$. Anderen werkten dat verder uit ${ }^{23}$; vooral Rosenau leverde baanbrekend werk met de bestudering van de binnenlandse bronnen van de buitenlandse politiek ${ }^{24}$. Daarmee werd een belangrijke bijdrage geleverd aan de analyse van de totstandkoming van het buitenlands beleid van een staat ${ }^{25}$.

Het primaire onderscheid tussen het internationale systeem enerzijds en de nationale staat anderzijds als niveau van analyse is het uitgangspunt voor deze studie. Dit onderscheid wordt gekoppeld aan het onderscheid tussen internationale politiek, waarover de besluitvorming in het internationale systeem plaatsvindt, en buitenlands beleid, waarover de besluitvorming binnen de nationale staat plaatsvindt ${ }^{26}$.

Dit onderscheid is van belang omdat we naast de buitenlandse druk ook geïnteresseerd zijn in de binnenlandse druk op het regeringsbeleid. Wanneer alleen het internationaal

22. Singer in" Rosenau, 1969a, p. 25-28. Singer in Rosenau, 1969, p. 28; "We may utilize one level here and another there, but we cannot afford to shift over orientation in the midst of a study".

23. Lijphart, 1969; Kissinger, 1969; Rosenau, 1969; Hoadley and Hasegawa, 1971; Rosenau, 1973.

24. Rosenau, 1966.

25. Zie voor een kritische beschouwing Pijpers, 1979, pp. 379-404.

26. Holsti stelt: 'Distinction between the terms may be more academic than real, but it is roughly the difference between the objectives and actions (decisions and policies) of a state or states, and the interactions between two or more states ${ }^{*}$, Holsti, 1972, p. 21. Holsti baseert zich op Sondermann die echter wel de plaats van de besluitvorming in zijn definiëring betrekt: 'foreign policy ... as the study of activities of individuals and groups within states and inwolving the governmental machinery of states, which are designed to have an impact on the policies of other istates or on individuals and groups within them" en 'the study of international pollitics centers on the process and effects of inter'actions between foreign policy decisions, made by individuals and groups, and involving governmental institutions, in two or more states and on the enviromment within which such inter-actionsi takes place" Sondermann in Rosenau, 1961, pp. 14-15. De Sprouts zien darentegen buitenlands: beleid als een sub-categorie wan internationale politiek omdat zij het buitenlands beleid binnen de staat en de internationale politiek zowel tussen als binnen staten plastsen. Harold and Margaret Sprout: 1956, p. 6, aangehaald door Sondermann in: Rosenau 1961, p. 17. 
politiek systeem vanuit de traditionele benadering uitgangspunt zou zijn, wordt aan de binnenlandse druk voorbijgegaan ${ }^{27}$. De vraag is vervolgens of aan de binnenlandse dan wel de buitenlandse druk in het beleid tegemoet wordt gekomen. Rosenau onderscheidde vier vormen van aanpassing ${ }^{28}$. Deze zijn:

1. de inschikkelijke aanpassing ('acquiescent adaptation'); aanpassing van het beleid aan de externe omgeving;

2. de onverzoenlijke aanpassing ('intransigent adaptation"); aanpassing van het beleid aan de interne omgeving;

3. de bevorderlijke aanpassing ('promotive adaptation'); geen aanpassing van het beleild;

4. de bewarende aanpassing ('preservative adaptation'); aanpassing van het beleid aan zowel de externe als de interne omgeving.

Schematisch wordt de relatie tussen de beïnvloeding en de vier patronen van aanpassing als volgt gepresenteerd:

Schema 1. 1

\begin{tabular}{|c|c|c|}
\hline \multicolumn{3}{|l|}{ Aanpassingsbenadering } \\
\hline & $\begin{array}{l}\text { eisen en verande- } \\
\text { ringen uit de exter- } \\
\text { ne omgeving }\end{array}$ & $\begin{array}{l}\text { eisen en verande- } \\
\text { ringen uit de inter- } \\
\text { ne omgeving }\end{array}$ \\
\hline 1. inschikkelijke aanpassing & + & - \\
\hline 2. onverzoenlijke aanpassing & - & + \\
\hline 3. bevorderlijke aanpassing & - & - \\
\hline 4. bewarende aanpassing & + & + \\
\hline
\end{tabular}

In deze studie wordt onderzocht welke vorm van aanpassing voor het Nederlands beleid ten aanzien van het Midden-Oostenconflict gold. Zowel in de conclusies aan het slot van elk hoofdstuk als in 5.3, zal deze vraag worden beantwoord.

27. In de traditionele benadering werden de internationale betrekkingen bestudeerd wanuit het international systeem. Met de bestudering van het international systeem als én geheel werd voorbijgegaan an de verschillen van de onderdelen; te weten de nationale actoren. Singer 1969, p. 23.

Zo werd verondersteld dat statslieden denken en handelen in termen wan het nationaal belang en dat was macht Morgenthau 1973, p. 5 .

Niet alleen verschillen do mationale actoren van mening over wat zij als het nationaal belang beschouwen, maar ook onttrekt deze benadering de binnenlandse verschillen binnen de staten aan het oog. Statem reageren - in de veronderstelling wan de traditionele benadering - slechts op elkaar en dat concept wan nationale actoren vertoont enige gelijkenis met het biljartspel. Wolfers en Fox 1959 , aangehaald door Singer, 1969, p. 23, Lijphart, 1969, p. 17 en Van Benthem wan den Bergh 1972, p. $50-51$.

28. Rosenau, 1980, pp. 501-534. 
Op grond van een aantal overwegingen die ten grondslag liggen aan dit raamwerk, zou voor Nederland de inschikkelijke aanpassing moeten gelden. De inschikkelijke aanpassing zou voor Nederland gelden omdat het klein en economisch ontwikkeld is en een open politiek systeem heeft ${ }^{29}$. De grotere EG-lidstaten - met een bevolking van meer dan 23 miljoen inwoners ${ }^{30}$ zoals het Verenigd Koninkrijk, West-Duitsland, Frankrijk en Italië - zouden een beleid van onverzoenlijke aanpassing voeren. Dat wil zeggen dat hun beleid gericht is op het aampassen van de externe omgeving aan de binnenlandse krachten. Aldus ontstaat een beeld waarin de externe omgeving wordt gemodelleerd naar de wensen van de grote staten waaraan de kleinere staten zich hebben aan te passen. In deze studie zal dit beeld noch worden verworpen noch worden bevestigd. Immers, de binnenlandse actoren verschillen van mening en het hangt er maar van af hoe de onderlinge krachtsverhouding tussen de binnenlandse actoren is en thoe eensgezind of verschillend de visies van deze binnenlandse actoren ten aanzien van een bepaalde kwestie zijn. Bovendien verschillen de 'grote staten' van mening over bijvoorbeeld de meest wenselijke oplossing van het Israelisch-Arabisch conflict. Het is met name vanwege de laatste omstandigheid dat een klein land als Nederland wèl invloed in de internationale politiek kan uitoefenen als het eén of meer van de grote lidstaten aan zijn zijde vindt. In de drie te behandelen kwesties verschilde deze configuratie - onderlinge verhouding tussen de grotere lidstaten - en was deze tevens bepalend voor de Nederlandse invloed. In het geval van een 'inschikkelijke aanpassing', is mijns inziens geen sprake meer van invloedsuitoefening, omdat de anderen dan het beleid bepalen. Hoewell het hier strikt genomen gaat om de totstandkoming van het buitenlands beleid, wordt tevens de overgang naar het internationaal politiek proces gemaakt. Ik wil hiermee zeggen dat, wanneer de buitenlandse invloeden bij de totstandkoming van het buitenlands beleid zo overheersend zijn geworden dat dit leidt tot een op aanpassing aan de externe omgeving gericht beleid, welhaast per definitie geen eigen Nederlandse invloed in de internationale politiek te verwachten is. Het louter 'in de pas lopen' betekent dat een eigen inbreng achterwege blijft.

Daarmee kom ik tot mijn stelling dat succesvolle binnenlandse betnvloeding van het buitenlands beleid een noodzakelijke voorwaarde is voor invloed in de internationale politiek. Het is een stelling die ingaat tegen de veelal aangehangen opvatting dat juist vanwege de binnenlandse beïnloeding de Nederlandse rol en invloed in de internationale politiek is geslonken ${ }^{31}$.

Voor de rijkere staten met een democratische structuur (open politiek systeem) zou ook de bewarende aanpassing van toepassing kunnen zijn. Rosenau verwachtte voor de toekomst een verschuiving naar de bewarende aanpassing. Voor Nederland zouden dan zowel een beleid van inschikkelijke aanpassing als een beleid van bewarende aanpassing

29. Smith, 1981, pp. 44, 53 en 54 .

30. Dit gegeven werd door Rosenau voor zijn indeling gehanteerd.

31. Voorhoeve, 1981, pp. 69-78. 
tot de mogelijkheden behoren ${ }^{32}$. De keuze daartussen hangt af van de mate van druk uit de externe omgeving en de tegendruk vanuit de interne omgeving. Is deze laatste niet aanwezig of niet meer in de beleidsuitkomsten terug te vinden, dan geldt een inschikkelijke aanpassing. Dat is in feite de centrale vraag in deze studie die als volgt onder woorden kan worden gebracht: 'Is Nederland in staat een beleid van bewarende aanpassing te voeren?' Voor de beantwoording van die vraag moet zowel het buitenlands politiek proces als het internationale politieke proces worden onderzocht.

Zojuist heb ik betoogd dat, wanneer een staat zich louter aampast aan zijn externe omgeving, er van invloedsuitoefening of een zelfstandige inbreng in de internationale politiek geen sprake is. De vraag doet zich voor of er sprake is van het uitoefenen van invloed wanneer een staat in de internationalle politiek de rol van bemiddelaar of bruggenbouwer vervult. De externe omgeving en de daaruit voortvloeiende veelal conflicterende krachten vormen dan het uitgangspunt. Volgens de Belgische oud-minister van Buitenlandse Zaken, Simonet, is dan van een eigen inbreng geen sprake: 'Vroeger liep men hier nogal eens te pronken met de zogenoemde verzoeningspendel van de Belgische diplomatie. Ik verwacht daar niet zoveel heil van. Het oppeppen van de dynamiek van het handjes-schudden kan ook een voorwendsel zijn om geen eigen politiek te moeten opbouwen. Wie zich alleen maar toespitst op een bemiddelingsrol moet nooit een standpunt innemen en dit soort gemakzucht verwerp $\mathrm{ik}^{333}$. Aan de andere kant kan bij de vervulling van de rol van bemiddelaar of bruggenbouwer wel een eigen inbreng gevergd worden. De na te streven oplossing zal niet alleen voor de bemiddelende partijen aanvaardbaar moeten zijn, maar tevens zoveel mogelijk aansluiten bij het eigen beoogde doel. Bij het onderwerp van deze studie was voor Nederland de rol van bruggenbouwer niet alleen een middel om zijn doeleinden ten aanzien van het Arabisch-Israëlisch conflict te verwezenlijken, maar tevens een doel op zichzelf geworden. Het Europese eenwordingsproces mocht immers niet gepaard gaan met Atlantische vervreemding. In de drie volgende hoofdstukken zal blijken dat de Nederlandse inbreng in de Europese Politieke Samenwerking mede gericht was op het verkrijgen van een positieve Amerikaanse reactie. Deze Nederlandse beleidskeuze kon rekenen op steun van de binnenlandse actoren. Het Nederlands optreden om dat doel te bereiken wordt hier beschouwd als een poging tot eigen invloedsuitoefening; het duidt op een "bewarende aanpassing".

In deze paragraaf is een aantal malen de term 'invloed', 'invloedsuitoefening' en 'beinvloeding' gebruikt. Nu zal een korte omschrijving worden gepresenteerd over de hantering van deze termen in deze studie.

32. Smith komt tot de conclusie dat het Nederlands beleid inzake de Europese integratie en het veiligheidsbeleid na 1949 gekenmerkt werd door bewarende aanpassing, terwijl in de kwestie Indonesië aanvankelijk een onverzoenlijke aanpassing en tenslotte een inschikkelijke aanpassing werd gevolgd. Snith, 1981, Pp. 117-130. Ook McGowan komt tot de conclusie dat woor een klein, rijk en open land het meest waarschijnlijk is dat een inschikkelijke aanpassing of een bewarende aanpassing wordt genoend en dat een onverzoenlijke aanpassing minder waarschijnlijk is en tenslotte eem bevorderlijke anpassing onwarschijnlijk is, in: Smith, 1981, p. 44 .

33. Interview in "Het Belang van Limburg" van 7 april 1979, aangehaald in Paul Van De Meerssche: Bilan Belgisch buitenlands beleid 1979 in Res Publics, 1979, pp. 468-469. 
Macht en invloed zijn beide gericht op het bewerkstelligen van een houding of gedrag bij een ander overeenkomstig de wensen van degene die de macht of invloed over de ander uitoefent. Kortom: je zin krijgen. Macht is dan het beschikbare vermogen - dat kan worden uitgedrukt in machtsbases - en invloed is dan de aanwending van dat vermogen. De beoogde effecten zi.jn gericht op het doen en denken van anderen ${ }^{34}$. Het omstreden en vage onderscheid tussen macht en invloed laat ik verder rusten maar ik wil kort aangeven op welke wijze getracht kan worden de beoogde effecten te realiseren. Dit wordt meestal als 'invloedsuitoefening" gezien en deze ruime omschrijving volg ik hier ${ }^{3.5}$. De drie vormen van invloedsuitoefening zijn:

1. positieve imvloed, dat is het bewerkstelligen van een verandering bij anderen, de invloed is gericht op verandering;

2. negatieve invloed, dat is het tegenhouden van een verandering bij anderen, de invloed is gericht tegen verandering;

3. potentiele of anticiperende invloed.

De eerste vorm is het meest bekend en is in principe, bij uitsluiting van andere invloeden, aantoonbaar aangezien in dat geval actor $\mathrm{A}$ de gedragsverandering bij actor $\mathrm{B}$ veroorzaakt die anders niet zou hebben plaatsgevonden. De tweede vorm is moeilijker aantoonbaar daar deze invloed meestal gemaskeerd is en slechts in uitzonderlijke gevallen, bijvoorbeeld bij gebruikmaking van het vetorecht, zichtbaar wordt. Het afschrikkingsdenken is op deze tweede vorm van invloed gebaseerd en deze invloedsuitoefening heeft gefaald wanneer wel geweld wordt aangewend. De derde vorm is nauwelijks aantoonbaar omdat dan wordt geanticipeerd op de verwachtingen en om die reden blijft een bepaald gedrag achterwege ${ }^{36}$. Dat maakt het meten van invloed zo moeilijk terwijl Russett en Starr terecht stellen dat invloed waarschijnlijk het grootst is als die niet behoeft te worden aangewend ${ }^{37}$. In deze studie zullen deze drie vormen van invloed aan de hand van de concrete gevallen in de volgende hoofdstukken worden behandeld.

\subsubsection{Binnenlandse actoren}

In de vorige paragraaf werd gesteld dat de binnenlandse actoren een heterogeen gezelschap vormen. Onder een 'actor' wordt verstaan een kiezendle of handelende persoon

34. Frankel stelt in dat verband: 'the capacity to produce intended effects over the minds and actions of other men", Frankell 1979, p. 101. Frankel 1988, p. 112.

35. Het anwenden van geweld is dan ook invloedsuitoefening. Frankel 1988, p. 113; zie voor de hier gevolgde indeling onder meer Holsti 1972, pp. 154-158, Russett and Starr 1981, pp. 127-130. Ellemers beschouwt macht alls een specifieke vorm van invloed, namelijk die welke ondersteund wordt door negatieve sancties. Macht is bindend omdat zodanig dwangmiddelen ter beschikking staan, waarmee kan worden gedreigd of die kunnen worden gebruikt. Ellemers, 1981, p. 278 en 283.

36. Zie ook Baehr in Meijers, Vierdag (ed. $)$, 1977, pp. 1-5.

37. Dat is de potentiële of anticiperende invloed. Russett en Starr 1981, p. 129 'Influence is likely to be greatest when its instruments do not have to be utilized openly or even in veiled threats. One may anticipate another's reactions, know what the other wants, and do it without any request being made". 
of georganiseerde groepering ${ }^{38}$. In navolging van Everts wil ik voor de Nederlandse situatie een onderscheid maken tussen verschillende groepen actoren ${ }^{39}$ :

1) de directe besluitvormers (kabinet en ministers);

2) de op formele gronden bij het besluitvormingsproces betrokken actoren (parlement en ambtenaren): de formele politieke elite;

3) degenen die niet bij het besluitvormingsproces worden betrokken op grond van hun rol maar wel het buitenlands beleid willen beïnvloeden en trachten de actoren uit de eerste twee categorieën voor hun wensen te winnen (politieke partijen, kerken, actiegroepen, bedrijfsleven, e.d.): de niet-formele politieke elite;

4) degenen die geen beinvloedingspogingen op het terrein van het buitenlands beleid ondernemen en over het algemeen weinig of geen buitenlands politieke interesse hebben maar wel de algemene opinie mede vorm geven: het massa-publiek.

Schematisch kan deze indeling als volgt worden weergegeven:

Schema 1.2

Binnenlandse actoren

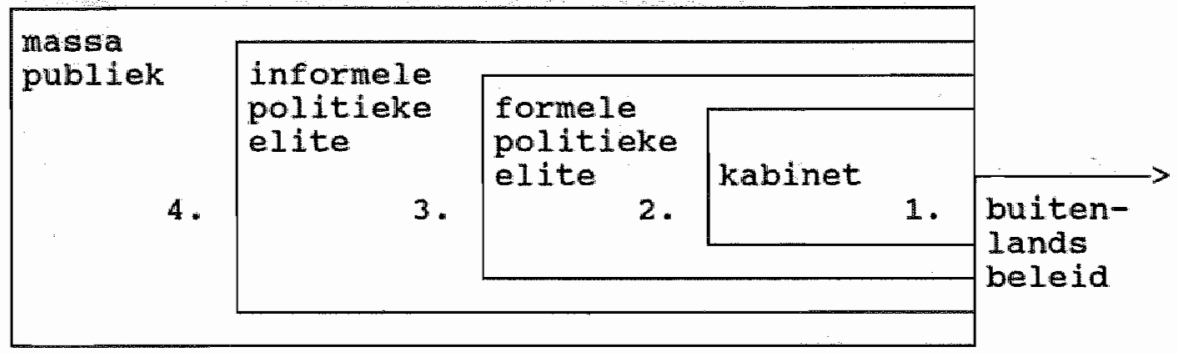

Met dit eenvoudige schema worden de actoren in kaart gebracht die het kabinetsbeleid kunnen beïnloeden.

Op basis van bovenstaand schema is beïnvloeding van het kabinet pas mogelijk indien de formele politieke elite - parlement en ambtenaren - de wensen van de niet-formele politieke elite en het massapubliek steunen. Het schema geeft de fasen in thet besluitvormingsproces weer. De sleutelpositie van het parlement is vanuit democratisch oogpunt aantrekkelijk omdat de volksvertegenwoordigers als een schakel tussen de binnenlandse opinie en het buitenland beleid ten tonele worden gevoerd. In het Nederlandse interuniversitaire onderzoek naar binnenlandse beînvloeding van het buitenlands beleid werd de hypothese opgenomen dat ondersteuning door of vanuit het parlement een noodzakelijke

38. Definitie van Kuypers, 1973, p. 19.

39. Voor het onderscheid tussen formele en informele politieke elite zie Everts in Baehr (e.a. ), 1978, pp. 12-13.

Voor het onderscheid tussen 'goverimental' en 'non-governmental' actoren en de daarop gebaseerde interacties zie Everts, 1983, pp. 56-57. 
voorwaarde is voor het succes van de ondemomen beïnvloedingspogingen vanuit de samenleving ${ }^{40}$. Deze hypothese werd niet werworpen ${ }^{41}$.

Het is echter ook mogelijk dat het parlement wordt gepasseerd. Zo kan een ondernemer (massapubliek) zich met zijn wensen al dan niet via de werkgeversorganisatie (informele politieke elite) tot ambtenaren van het departement van Economische Zaken (formele politieke elite) richten. Deze ambtenaren kunnen dat voorleggen aan hun minister die vervolgens - al dan niet na overleg in het kabinet - een beslissing neemt of niet neemt. Vanwege de grote toegankelijkheid in Nederland van ministers is het ook mogelijk dat de informele politieke elite rechtstreeks in contact treedt met de minister. Een voorbeeld daarvan in deze studie betreft de mogelijke 'opwaardering' van contacten met de PLO. Dit voormemen leidde in 1979 tot verontrusting bij de Joodse gemeenschap (massapubliek). De drie joodse kerkgenootschappen en de Nederlandse Zionisten Bond (informele politieke elite) voerden vervolgens op 18 december 1979 en 12 mei 1980 een gesprek met de minister van Buitenlandse Zaken (direkte besluitvormer) die werd vergezeld door ambtenaren van zijn departement (formele politieke elite) ${ }^{42}$.

In de vorige paragraaf werd buitenlandse politiek van internationale politiek onderscheiden. In deze paragraaf hebben we een invulling gegeven aan wat onder de actoren kan worden verstaan die bij het buitenlands beleidsproces zijn betrokken. Beide indelingen worden in het volgende schema gecombineerd. Dit schema dient als uitgangspunt voor deze studie.

Schema 1.3

Internationaal politiek proces

Internationale Organisatie, bij-

Staat A voorbeeld EG

Staat B

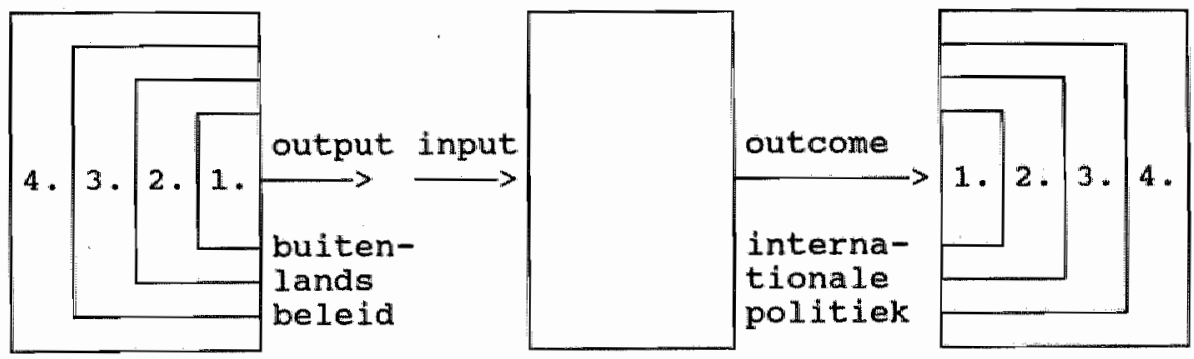

De output van politiek systeem A is het binnen die staat tot stand gekomen buitenlands beleid. Dit vastgestelde buitenlands beleid vormt de input (inbreng) van die staat in de

40. Everts, 1985, p. 17.

41. Everts, 1985, pp. 337-338.

42. Zie 3.2.3.2. 
internationale organisatie. Binnen die internationale organisatie vindt de besluitvorming ten aanzien van het in te nemen standpunt tussen de vertegenwoordigers van de lidstaten plaats. De aldaar tot stand gekomen beslissing in de internationale politieke context en gericht op derde staten (i.c. Staat B) wordt de 'outcome' genoemd. Deze wordt in de Europese Politieke Samenwerking het gemeenschappelijk buitenlands beleid genoemd maar vanwege het intergouvernementele karakter van deze samenwerking en de positie van de actoren in dit besluitvormingsproces lijkt me de term 'gemeenschappelijke internationale politiek' of 'gemeenschappelijk standpunt in de internationale politiek' juister.

Aldus voorgesteld is het een gefaseerd proces en past het bij de in 1.2.1 vermelde omschrijwing van Sondermann en Baehr waarbij de buitenlandse politiek als 'de overgangsfase naar' en 'toegang tot' de internationale politiek naar woren werd gebracht. In de praktijk wordt echter niet altijd eerst een buitenlands politiek standpunt geformuleerd om vervolgens tot een internationaal politiek standpunt te komen. Dit geldt in het bijzonder voor de met veel geheimhouding omgeven Europese Politieke Samenwerking. Een EPS-standpunt gaat dan deel uitmaken van het 'nationale' buitenlands beleid en niet omgekeerd. Kortom: eerst wordt een internationaal politiek standpunt ingenomen en pas daarna als buitenlands beleid door het parlement van een staat aanvaard. De EPS-standpunten over het Midden-Oosten die in dit onderzoek behandeld zullen worden - bijv. de verklaring van 6 november 1973 , de verklaring van Venetië en deelname aan de MFO - zijn daarvan duidelijke voorbeelden. Met andere woorden: met deze verklaringen wordt niet alleen een gemeenschappelijk standpunt ten aanzien van derden ingenomen, maar wordt ook het buitenlands beleid van de deelnemende staten gevormd.

Schema 1.4

Variant internationaal politiek proces

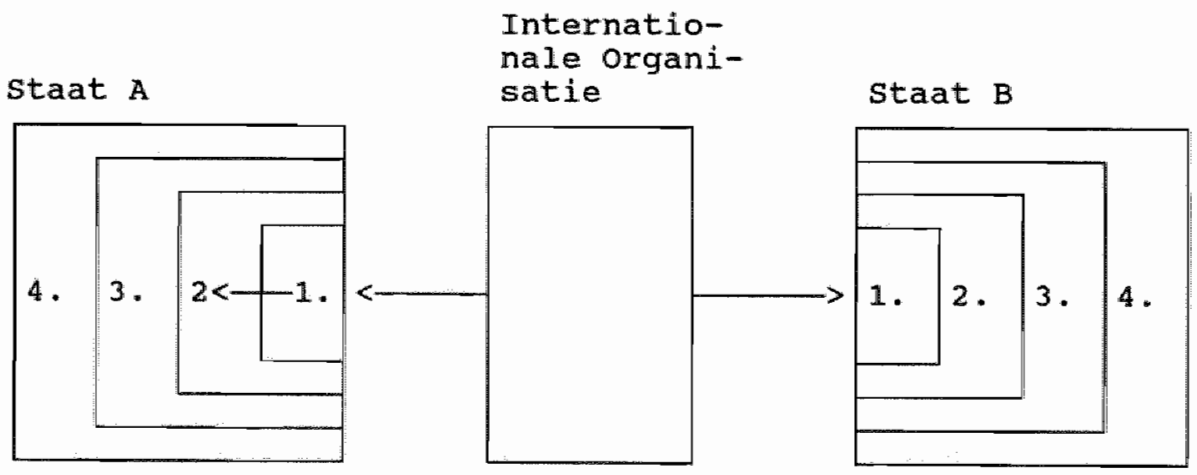

Deze 'modellen' zullen in deze studie worden toegepast voor de analyse van de besluitvormingsprocessen met betrekking tot het olie-embargo (2.4), de verklaring van Venetië (3.3) en de multinationale vredesmacht in de Sinaï (4.3). 


\subsubsection{Nederland in de internationale politiek}

De interuniversitaire werkgroep 'Buitenlands beleid van Nederland' heeft de rol van Nederland in de internationale politiek onderzocht. De onderzoeksresultaten werden in 1989 gepubliceerd ${ }^{43}$. Twee tijdsperioden werden onderzocht namelijk 1955-1970 en 1970-1985. De onderzochte gevallen over de periode 1970-1985 omvatten onder meer de drie Midden-Oostenkwesties - olie-embargo, verklaring van Venetiē en deelname aan de MFO - uit deze studie. Voor deze drie kwesties werden zeven deelbeslissingen onderscheiden. Verder omvatte deze periode 21 andere deelbeslissingen.

Twee conclusies uit dit onderzoek waren:

1. de kans op succes van Nederland is groter indien een op verandering gericht beleid (positieve invloed) wordt voorgesteld door Nederland dan wanneer getracht wordt veranderingen in de internationale politiek tegen te houden (negatieve invloed);

2. de kans op succes van Nederland is groter wanneer de Nederlandse voorstellen kunnen rekenen op binnenlandse consensus.

Deze twee conclusies werden getrokken op grond van onderstaande tabellen voor de periode 1970-1985 waarbij de resultaten van respectievelijk de 28 deelbeslissingen, de 21 deelbeslissingen zonder de Midden-Oostenkwesties en de 7 deelbeslissingen over het Midden-Oosten worden gepresenteerd.

Tabel 1.1

\begin{tabular}{|l|l|l|l|l|l|l|}
\hline \multicolumn{2}{|l|}{ Relatie soort invloed met succes } \\
\hline & alle gevallen (28) & \multicolumn{2}{|l|}{ zonder M.O. (21) } & \multicolumn{2}{l|}{ alleen M.O. (7) } \\
\cline { 2 - 7 } & succes & $\begin{array}{l}\text { geen } \\
\text { succes }\end{array}$ & succes & $\begin{array}{l}\text { geen } \\
\text { succes }\end{array}$ & succes & $\begin{array}{l}\text { geen } \\
\text { succes }\end{array}$ \\
\hline $\begin{array}{l}\text { positieve } \\
\text { invloed }\end{array}$ & $71 \%(15)$ & $29 \%(6)$ & $71 \%(12)$ & $29 \%(5)$ & $75 \%(3)$ & $25 \%(1)$ \\
\hline $\begin{array}{l}\text { negatieve } \\
\text { invloed }\end{array}$ & $57 \%(4)$ & $43 \%(3)$ & $50 \%(2)$ & $50 \%(2)$ & $67 \%(2)$ & $32 \%(1)$ \\
\hline totaal & $68 \%(19)$ & $32 \%(9)$ & $67 \%(14)$ & $33 \%(7)$ & $71 \%(5)$ & $29 \%(2)$ \\
\hline
\end{tabular}

43. Everts and Walraven (eds.), 1989, Voorzichtigheid met deze statistieken, die gebaseerd zijn op cen beperkt aantal kwantitatieve gegevens, is geboden. 
Tabel 1.2

\begin{tabular}{|c|c|c|c|c|c|c|}
\hline \multicolumn{7}{|c|}{ Relatie consensus met succes } \\
\hline & \multicolumn{2}{|c|}{ alle gevallen (28) } & \multicolumn{2}{|c|}{ zonder M.O. (21) } & \multicolumn{2}{|c|}{ alleen M.O. (7) } \\
\hline & succes & $\begin{array}{l}\text { geen } \\
\text { succes }\end{array}$ & succes & $\begin{array}{l}\text { geen } \\
\text { succes }\end{array}$ & succes & $\begin{array}{l}\text { geen } \\
\text { succes }\end{array}$ \\
\hline $\begin{array}{l}\text { wel bin- } \\
\text { nenl. } \\
\text { consensus }\end{array}$ & $73 \%(16)$ & $27 \%(6)$ & $73 \%(11)$ & $27 \%(4)$ & $71 \%(5)$ & $29 \%(2)$ \\
\hline $\begin{array}{l}\text { geen } \\
\text { binnenl. } \\
\text { consensus }\end{array}$ & $50 \%(3)$ & $50 \%(3)$ & $50 \%(3)$ & $50 \%(3)$ & $0 \%(0)$ & $0 \%(0)$ \\
\hline totaal & $68 \%(19)$ & $32 \%(9)$ & $67 \%(14)$ & $33 \%(7)$ & $71 \%(5)$ & $29 \%(2)$ \\
\hline
\end{tabular}

Bron: Bewerking van Everts ton Walraven 1989, p. 326-327.

Uit bovenstaande tabellen blijkt dat de drie Midden-Oostenkwesties passen binnen de geformuleerde conclusies over het Nederlands buitenlands beleid in het algemeen. De zeven beslissingen over de drie Midden-Oostenkwesties wijken niet statistisch significant af van de andere deelbeslissingen over andere kwesties van het Nederlands buitenlands beleid wat betreft de relatie tussen enerzijds succes en anderzijds de op verandering gerichte invloed en binnenlandse consensus ${ }^{44}$. Een opvallend verschil is dat de Nederlandse inbreng in de internationale politiek over de Midden-Oostenkwestie steeds kon rekenen op binnenlandse consensus. Deze binnenlandse consensus had zowel betrekking op Nederlandse voorstellen die beoogden een verandering teweeg te brengen als op voorstellen die een verandering beoogden tegen te houden. Dat laatste is bijzonder omdat de Nederlandse voorstellen inzake andere deelterreinen van het buitenlands beleid die gericht waren op het tegenhouden van veranderingen in de internationale politiek (verzet modernisering kernwapens en totstandkoming Nieuwe Internationale Informatie Orde), niet konden rekenen op binnenlandse consensus.

44. De verdelingen zijn met behulp van de l-toets met elkaar vergeleken. In tabel 1.1. : $1=1.706, \mathrm{df}=3$, $a=0,05$ eenzijdig getoetst, de kritieke grens $=0,352$. In tabel $1.2 .: 1=3.978, \mathrm{df}=3, a=0.05$ eenzijdig getoetst, de kritieke grens $=0,352$. 
Tabel 1.3

\begin{tabular}{|l|l|l|l|l|}
\hline \multicolumn{2}{|l|}{ Relatie soort invloed met consensus } \\
\hline & \multicolumn{2}{|l|}{ alle gevallen(28) } & \multicolumn{2}{l|}{ zonder M.O.(21) } \\
\cline { 2 - 5 } & $\begin{array}{l}\text { wel binnenl. } \\
\text { consensus }\end{array}$ & $\begin{array}{l}\text { geen binnenl. } \\
\text { consensus }\end{array}$ & $\begin{array}{l}\text { wel binnenl. } \\
\text { consensus }\end{array}$ & $\begin{array}{l}\text { geen binnenl. } \\
\text { consensus }\end{array}$ \\
\hline $\begin{array}{l}\text { positieve } \\
\text { invloed }\end{array}$ & $90 \%(19)$ & $10 \%(2)$ & $88 \%(15)$ & $12 \%(2)$ \\
\hline $\begin{array}{l}\text { negatieve } \\
\text { invloed }\end{array}$ & $43 \%(3)$ & $57 \%(4)$ & $0 \%(0)$ & $100 \%(4)$ \\
\hline totaal & $79 \%(22)$ & $21 \%(6)$ & $71 \%(15)$ & $29 \%(6)$ \\
\hline
\end{tabular}

Over dit verschil in de bevindingen worden in hoofdstuk 5 conclusies getrokken. Op dit moment kan volstaan worden met de constatering dat binnenlandse consensus niet alleen relevant is voor de totstandkoming van het Nederlands buitenlands beleid over het Midden-Oosten maar ook dat de Nederlandse inbreng in de internationale politiek kon rekenen op binnenlandse consensus. Het gekozen theoretisch kader voor deze studie met aandacht voor de binnenlandse bronnen en met de nadruk op de interne versus externe invloeden op het Nederlands buitenlands beleid, is geschikt voor het onderwerp van deze studie.

\subsection{Internationale Organisaties}

De afgelopen decennia traden twee tendenties sterker op de voorgrond. Dat zijn interdependentie en decentralisatie. De invloed van de centrale overheid zou als gevolg daarvan zijn afgenomen. Enige overheveling van zeggenschap van de nationale overheid naar hoger niveau (internationale organisaties) en lager niveau (lokale overheden) zou hebben plaatsgevonden.

De eerste tendentie betreft de unterdependentie waarmee de groei van het aantal internationale organisaties gepaard gaat. De natie-staat heeft deze internationale organisaties nodig om de complexe hedendaagse problemen te kunnen oplossen. In de woorden van Jacobson: "More and more states are bound in webs of networks of international organizations, and in more and more functional areas the freedom of states to make unilateral decisions is restricted'45 en 'Nation-states retain sovereignty and consequently remain the principal actors in international politics. But all states are enmeshed in complex webs of international organizations, both governmental and nongovernmental, and their societies rather than being sealed from one another, are linked by growing transnational connections ${ }^{46}$. De onderlinge verbondenheid van samenlevingen en staten, nog afgezien van de vraag of onderlinge verbondenheid ook tot onderlinge afhankelijkheid zal leiden, heeft de groei van internationale organisaties in de hand gewerkt. Staten hadden

45. Jacobson, 1984, p. 386 .

46. Jacobson, 1984, p. 387 . 
internationale organisaties als communicatienetwerken nodig voor het oplossen van de problemen waarmee ze geconfronteerd werden, daar elke staat afzonderlijk daar steeds minder toe in staat was.

Daarnaast valt een tweede tendentie waar te nemen die juist is gericht op meer zeggenschap van leden binnen die samenleving. Jacobson stelde: 'At the same time, the deepening desire for participation in political decisions means that for many problems some nation-states are simply too large to be satisfactory units. Decentralization has been essential to satisfy the desire for participation and also to deal more adequately with complexity ${ }^{47}$. Erosie van de centrale autoriteit zou door beide tendenties in de hand kunnen worden gewerkt. Een voorbeeld van het eerste is het 'Europa na 1992' met het wegvallen van de binnengrenzen in de Europese Gemeenschap; een voorbeeld van de tweede tendentie is de binnengemeentelijke decentralisatie in de als te groot ervaren stad Amsterdam.

Voor deze studie heeft de tweede tendentie weinig betekenis omdat het voeren van een buitenlands beleid bij de regering ligt ${ }^{48}$. Doorkruising van deze zeggenschap door gemeenten en andere lagere overheden werd ongedaan gemaak $t^{49}$. Zoals gesteld kwam decentralisatie voort uit de wens tot politieke participatie. In deze studie zal de toegenomen wens tot deelname aan de besluitvorming en pogingen tot beïnvloeding van het buitenlands beleidsproces door leden van de samenleving worden behandeld. Deze activiteiten worden veelal gedragen door tal van actiegroepen in de samenleving en zijn gericht op beinvloeding van het overheidsbeleid. Met name in de jaren zeventig kreeg hierdoor het buitenlands beleidsproces in Nederland een ander karakter dan in de periode daarvóór toen dergelijke bewegingen minder manifest aanwezig waren. In de tweede helft van de jaren tachtig werd daarvan weer enigszins afstand genomen en ontstond kritiek op de rol van enkele politieke partijen die zich in die periode te zeer op sleeptouw hadden laten nemen door de activiteiten van actiegroepen ${ }^{50}$. Voor de periode van deze studie, 1973-1982, is een onderzoek naar de binnenlandse beïnvloeding van het buitenlands beleid relevant. Op zichzelf hoeft de wens tot beïnvloeding van het buitenlands beleid niet te leiden tot een afkalving van de rol van de centrale overheid in het buitenlands beleidsproces. De beïnvloedingspogingen bleven immers gericht op de 'eigen' overheid. Wel zou de vrijheid van handelen door de overheid op grond van de

47. Jacobson, 1984, p. 386 .

48. Artikel 90 Grondwet: 'De regering bevordert de ontwikkeling van de internationale rechtsorde'.

49. Statsblad 1988, 675; Administratiefrechtelijke Beslissingen/NI 1989, nr. 490, pp. 1443-1445. Het Hilversumse besluit -geen offerte van Shell te behandelen omdat Shell handel dreef met ZuidAfrika - was op 15 januari 1988 - Staatsblad 1988, 12 - al geschorst. Administratiefrechtelijke Beslissing NJ 1989, p. 1444.

De uitzondering is het geven van ontwikkelingshulp bij jumelage. Besluiten van gemeenten die indirect op een boycot van Zuid-Afrika waren gericht, werden geschorst en vernietigd.

50. Bijvoorbeeld het CDA richtte dit verwijt tot de PvdA op het terrein van het veiligheidsbeleid en meende dat de daardoor ontstame polarisatie regeringsdeelname van de PvdA verhinderde, J. De Koning in Het Capitool (NOS-TV) op 5 november 1989. Op een eerdere datum in hetzelfde programma venweet dezelfde - toen nog minister - J. de Koning de PvdA in het verleden vooral doorgeefluik voor actiegroepen te zijn geweest. Volgens hem - tevens oud-informateur - was coalitievorming met de PvdA indertijd vooral onmagelijk door de standpunten van deze partij over buitenlandse politiek; Het Capitool - NOS-TV - 12 juni 1988. 
binnenlandse beïnvloedingen beperkt kunnen worden. In hoeverre dat het geval is geweest zal hier onderzocht worden.

Eveneens kan ten aanzien van de relatie tussen de nationale staat en internationale organisaties worden gesteld dat deze laatste de vrijheid van handelen van de afzonderlijke staten kunnen beperken. Internationale organisaties kunnen echter zelden door dwang de staten tot inwilliging nopen ${ }^{51}$.

De mate van gevoeligheid en kwetsbaarheid voor deze invloeden verschilt per land en zou in principe voor een land als Nederland, waarvan het nationaal inkomen voor ongeveer $60 \%$ afhankelijk is van de export, aanzienlijk kunnen zijn ${ }^{52}$. Internationale organisaties zouden een functie ter bescherming van die positie kunnen bieden. Juist omdat internationale organisaties veelal niet over het vermogen tot dwang beschikken, in tegenstelling tot nationale staten, is een land als Nederland gebaat bij een lidmaatschap van internationale organisaties waarin het, althans formeel, veelal een gelijke stem heeft als machtiger state ${ }^{53}$. Het Nederlands buitenlands beleid was ook vaak gericht op gelijkberechtiging in internationale organisaties ${ }^{\mathrm{s}}$. Het hoeft ook geen verwondering te wekken dat Nederland op de wereldranglijst de vierde plaats inneemt qua

51. Zie ook Jacobson, 1984 , p. 388 .

52. Uit: CBS Nationalle rekeningen.

'Totale uitvoer van goederen en diensten' delen door 'nationaal inkomen' (marktprijzen) x $100=$ percentage van het nationaal inkomen dat in Nederland wordt gevormd door de expont (nationaal inkomen en totale uitvoer in miljoenen guldens).

TABEL

Aandeel wan de Nederlandse export woor het nationale inkomen wan Nederland

\begin{tabular}{|l|r|r|r|}
\hline jaar & $\begin{array}{l}\text { nationaal } \\
\text { inkomen }\end{array}$ & $\begin{array}{l}\text { totale uitvoer van } \\
\text { goederen en diensten }\end{array}$ & $\begin{array}{l}\text { percentage export } \\
\text { v.h. nat.inkomen }\end{array}$ \\
\hline 1973 & 153.290 & 82.670 & 53,930 \\
\hline 1974 & 170.890 & 106.600 & 62,379 \\
\hline 1975 & 184.530 & 109.240 & 59,199 \\
\hline 1976 & 214.450 & 128.520 & 59,930 \\
\hline 1977 & 237.550 & 130.780 & 55,054 \\
\hline 1978 & 256.580 & 133.700 & 52,109 \\
\hline 1979 & 269.280 & 154.810 & 57,490 \\
\hline 1980 & 299.720 & 176.840 & 59,002 \\
\hline 1981 & 313.600 & 204.480 & 65,204 \\
\hline 1982 & 328.540 & 211.120 & 65,260 \\
\hline
\end{tabular}

53. Jacobson, 1984, pp. 126-127.

54. Walraven, in: Everts and Walraven (eds.), 1989, pp. 103-117. 
aantal lidmaatschappen van internationale organisatiess ${ }^{55}$. In deze studie komt zowel aan de orde in hoeverre de yrijheid van handelen van de Nederlandse overheid werd beperkt door internationale organisaties als in hoeverre internationale organisaties een "beschermfunctie' over Nederland hebben kunnen uitoefenen.

\subsubsection{Nieuwe internationale organisaties}

Wanneer staten ontevreden zijn over het functioneren van een bestaande internationale gouvernementele organisatie warvan zij lid zijn, kunnen zij trachten die organisatie te wijzigen. Indien dat niet leidt tot de beoogde verandering in die organisatie en bovendien door die staten aan de uit te voeren taken en functies wel veel belang wordt gehecht, kan getracht worden deze taken en functies door een of meer andere internationale organisaties te laten uitvoeren. Ribbelink stelt de vraag: 'of misschien sprake is van een gemeenschappelijke factor die verklaart waarom juist bij internationale economische organisaties gekozen wordt voor opvolging in plaats van, desnoods zeer verstrekkende amendering, of dat dit een toevallige samenloop van omstandigheden is ${ }^{\$ 56}$. In deze studie zal blijken dat twee bestaande internationale organisaties een bepaalde taak niet konden uitvoeren, terwijl die taken wel tot de functie van die organisaties gerekend konden worden. Op politieke gronden werd het de bestaande organisaties onmogelijk gemaakt deze taken op zich te nemen. Frankrijk verzette zich zodanig dat de EG er niet in slaagde een schema tot evenredige verdeling van de olieaanvoer en een 'crisisschema' op te stellen. Een nieuwe internationale gouvernementele organisatie - zie 2.4 - werd in 1974 opgericht: Het Internationale Energie Agentschap (IEA), dat administratief werd ondergebracht bij een bestaande internationale organisatie: de OESO. Het andere voorbeeld uit deze studie gaat over het verzet van de Sovjetunie binnen de Veiligheidsraad van de Verenigde Naties tegen de oprichting van een vredesmacht. De Sovjetunie stond niet toe dat de Verenigde Naties met een vredesmacht ('peace-keeping force') in de Sinaï het Egyptisch-Israëlisch vredesverdrag zou ondersteunen. Een nieuwe

55. Jacobson, 1984, p. 50, in 1977 was Nederland lid van 84 intergoevernementele organisaties en alleen Frankrijk, het Verenigd Koninkrijk en de Duitse Bondsrepubliek nemen op deze lijst een hogere plaats in.

56. Ribbelink, 1988, p. 2. Dexe vraag werd niet beantwoord. Desgewraagd deelde hij me telefonisch mee dat een plausibele verklaring zou kunnen zijn dat economische organisaties gericht zijn op bepaalde situaties op een bepaald moment en wanneer daar niet meer aan voldaan wordt het makkelijker is een nieuwe organisatie op te richten. Hij beperkt zijn proefischrift tot het aangeven van wellke regels van volkenrecht van toepassing zijn bij opvolging wan internationale organisatie (Tb idem p. 7). Onderscheid kan worden genatkt tussen situaties warbij:
a. taken en functies wan eén organisatie over meerdere andere internationale organisaties worden vercleeld;
b. taken en functies van meerdere organisaties gaan op in eín nieuwe internationale organisatie;
c. Én organisatie wordt opgevolgd door én nieuwe organisatie;
d. ećn organisatie gaat op een later tijdstip op in een bestaande organisatie.

Zie: Ribbelink, 1988 op pp. 2, 116, 117, 121, 122, en Hahn 1962, pp. 171-172, 175, 187, 192. 
internationale organisatie, de Multinational Force and Observers (MFO), - zie 4.1.2 werd vervolgens in 1981 opgericht $^{57}$.

Het IEA en de MFO hebben geen internationale organisaties opgevolgd. In beide gevallen bleven de bestaande internationale organisaties bestaan. $\mathrm{Zij}$ wisten zelfs hun taken op het betreffende terrein uit te breiden - energiesector binnen de EG en vredeshandhaving binnen de VN - zonder, tot op heden, de specifieke taken, waarvoor beide nieuwe internationale organisaties waren opgericht, ook te gaan behartigen. De groei van internationale organisaties die door Jacobson zojuist treffend werd beschreven, had steeds tot doel aan de vervlechting op wereldschaal een functionele inhoud te geven door middel van oprichting van voor deze functie geschikte internationale organisaties. Voor de taken van IEA en MFO bestonden reeds voor deze functie toegeruste internationale organisaties, namelijk de EG en de VN; van een nieuwe functie voor deze twee nieuwe internationale organisaties is geen sprake. Maar het bleek niet mogelijk voor een deel van de staten die deel uitmaakten van de bestaande organisaties, die organisaties tot een wijziging dan wel aanvulling in hun taakuitoefening te bewegen. De Verenigde Staten bleek tenslotte bij machte het initiatief te nemen tot oprichting van beide nieuwe internationale gouvernementele organisaties. De specifieke taakuitoefening kon daardoor gestalte krijgen, maar voor de bestaande internationale organisaties als EG en VN kon het als een verzwakking en wellicht als gebrek aan aanpassingsvermogen aan een nieuwe situatie worden beschouwd. Zij beantwoordden niet aan de nieuwe uitdaging.

Het beeld wordt daardoor versterkt dat internationale organisaties meer gericht zijn op situaties die golden voordat zij werden opgericht en nieuwe situaties niet kunnen beheersen.

Zo schreef Claude: 'It is significant that the great organizational endeavors of the modern world have been parts of the aftermath of great wars, and it is possible to argue that they have tended to produce instruments better adapted to preventing the recently concluded tragedy than to dealing with the momentous issues for the future ${ }^{58}$. De Volkenbond was gericht op het voorkomen van de Eerste Wereldoorlog, maar was niet in staat het uitbreken van de doelbewuste Tweede Wereldoorlog te verhinderen. Terwijl de oprichting van de Verenigde Naties een antwoord was op de Tweede Wereldoorlog en bedoeld ter voorkoming van een nieuwe wereldoorlog, is het de vraag of deze organisatie een oorlog in het nucleaire tijdperk kan verhinderen. Met andere woorden: 'There is a real danger that newly created international organizations may not be simply too little and too late, but also already out of date ${ }^{159}$.

De oprichting van het IEA en de MFO zal in 2.4 en 4.1 .2 worden behandeld. In de volgende paragraaf zal de oprichting en betekenis van een internationaal gouvernementeel overlegorgaan, de Europese Politieke Samenwerking (EPS) worden behandeld. Dit samenwerkingsverband neemt in dit onderzoek een centrale plaats in.

57. De MFO is een internationale organisatie, zie Siekmann 1988, pp. 11 en 240 ; Tweede Kamer, zitting 1981-1982, 17691 , nr. 1, p. 6.

58. Claude, 1971 , p. 46.

59. Claude, 1971, p. 46. De actieve rol van de Veiligheidsraad na de Iraakse inval in Koeweit vam 2 augustus 1990 is daarentegen een zeer hoopvol teken. 


\subsubsection{Europese Politieke Samenwerking}

De Europese Politieke Samenwerking (EPS) kwam in $\mathbb{1 9 7 0}$ tot stand. Het betreft de intergouwernementele samenwerking van de lidstaten van de Europese Gemeenschap op het terrein van de buitenlandse politiek. Enkele jaren voor de oprichting van de EPS stelde de Belgische minister Harmel voor in de West-Europese Unie de mogelijkheden tot samenwerking op onder meer het terrein van de buitenlandse politiek te bestuderen. De ministerraad van de WEU heeft dit voorstel in oktober 1968 echter niet aanvaard vanwege Frans verzet ${ }^{60}$. In februari 1969 bracht de Italiaanse minister Nenni het Harmel-plan opnieuw naar voren. De zeven leden van de WEU zouden zich verplichten elkaar te raadplegen voor iedere belangrijke beslissing op het terrein van de buitenlandse politiek. Een Duits compromis van vrijwillige belofte tot consultatie werd, onder voorbehoud van de Fransen, op 7 februari 1969 wel aanvaard ${ }^{61}$. Op 14 februari 1969 kwamen zes van de zeven - zonder de Fransen - te Londen bijeen om over buitenlandse politiek te spreken; als onderwerp werd het Midden-Oostenprobleem gekozen. De Fransen waren daarover zo verontwaardigd dat ze prompt lieten weten verder aan geen enkele aktiviteit van de WEU te zullen deelnemen ${ }^{62}$. Nadat de Franse president De Gaulle door Pompidou was opgevolgd en de Haagse topconferentie van december 1969 had plaatsgevonden - waarin een aanzet tot zowel uitbreiding van de Gemeenschap als politieke samenwerking werd gegeven - beëindigde Frankrijk op 5 juni 1970 zijn boycot van de $\mathrm{WEU}^{63}$.

Ook de herleving van de WEU kwam voort uit de onstane impasse in de EG over het Genscher-Colombo plan ${ }^{64}$. Voor deze studie is dit voorbeeld geschikt om aan te tonen dat juist het Midden-Oostenprobleem werd aangepakt voor deze politieke samenwerking. Over dit probleem dachten in 1969 de Fransen wel heel anders dan de overige leden van de WEU.

Ook voor de politieke samenwerking binnen de EPS werden het Midden-Oostenprobleem met de CVSE (Conferentie over Veiligheid en Samenwerking in Europa) de eerste onderwerpen van de agenda. De EPS werd omschreven in het Rapport van Luxemburg van 27 oktober 1970 (ook wel 'plan-Davignon' genoemd naar de Belgische voorzitter van het 'comité politique'), het Rapport van Kopenhagen van 23 juli 1973, het Rapport van Londen van 13 oktober 1981 en tenslotte in de Europese Akte van februari $1986^{65}$. De Europese Akte gaf aan deze samenwerking een juridische basis in de vorm van een verdrag, maar dat betekende niet meer dan een formalisering van hetgeen al in de EPS-praktijk bestond; nieuw was de oprichting van een secretariaat te

60. Siegler, 1973 , p. 23 .

61. Siegler, 1973, p. 37-38; Schreiner, 1978, p. 15.

62. Siegler, 1973, pp $40-41$.

63. Siegler, 1973, p. 106; Schreiner, 1978, p. 16; Hommes, 1980, pp. 279-280.

64. Lezing W.F. van Eekelen - secretaris-generaal van de WEU - op 4 september 1989 te Eindhoven. Het Genscher-Colombo plan uit 1981 beoogde de politieke samenwerking te versterken en repte ook: over eem gemeenschappelijk beleid op thet terrein van de veiligheid. Zie De Schoutheete, 1986, p. 32.

65. Denemarken, lerland en Griekenland ondertekenden op 26 februari 1986; de overige Negen op 17 februari 1986, Kapteyn, VerLoren vam Themaat, 1987, p. 21. 
Brussel ${ }^{66}$. De EPS heeft als doel om met betrekking tot belangrijke kwesties in de internationale politiek te komen tot:

1. beter wederzijds begrip door onderlinge uitwisseling van informatie: de 'communauté d'information";

2. harmonisatie van standpunten en coördinatie van gedragslijnen: de 'communauté des vues";

3. gemeenschappelijk optreden: de 'communauté d'action'.

Deze drie doeleinden werden reeds vermeld in het rapport van Luxemburg. De drie doeleinden behelzen een opklimmende mate van bemoeienis met het buitenlands beleid der lidstaten. In hoofdstuk 3 zal ruim aandacht worden besteed aan de beoogde overgang van een 'communauté des vues' naar een 'communauté d'action'. Dan zal worden geanalyseerd waarom een gemeenschappelijk optreden inzake het Arabisch-Israëlisch conflict mislukte en welke rol Nederland daarin speelde.

Aan de uitwisseling van informatie is uitgebreid vorm gegeven in de vorm van een telex-netwerk, aanstelling van 'Europese correspondenten' op de departementen, overleg tussen ambassadeurs die bij derde landen zijn geaccrediteerd, frequent overleg op het niveau van ambtenaren - het werkgroepen overleg -, van de directeuren-generaal politieke zaken van de departementen van Buitenlandse Zaken in 'het comité politique' en van de ministers van Buitenlandse Zaken zowel afzonderlijk als tezamen met de regeringsleiders. Deze EPS-werkzaamheden werden aanvankelijk strikt gescheiden van het overige werk in de Gemeenschap. Zo vergaderden de ministers van Buitenlandse Zaken op 23 juli 1973 in het kader van de EPS 's morgens in Kopenhagen bij de Deense voorzitter en vlogen vervolgens 's middags naar Brussel om hun vergadering als Raad van Ministers voort te zetten. 's Ochtends werd over de politieke rellatie met de VS vergaderd en 's middags over de economische relatie met de VS. Aan deze enigszins krampachtige scheiding is een einde gekomen en bovendien worden de Europese Commissie en het Europees Parlement nu bij de EPS-werkzaamheden betrokken. Het is zelfs de vraag of aan het doel van een gezamenlijk optreden voor doeltreffende gezamenlijke invloed wel inhoud kan worden gegeven zonder de economische machtsmiddelen waarover de Gemeenschap beschikt aan te wenden. Inmiddels is dat laatste geschied, bijvoorbeeld bij het exportverbod naar Argentinië in de Falklandoorlog in $1982^{67}$, de opschorting van ondertekening van het financiële protocol met Israël in 1982 na de Israëlische inval in Libanon en de bepaling in de overeenkomst met de ACP-landen uit 1989 (Lomé IV) dat bij schendingen van de rechten van de mens de hulp kan worden gestopt ${ }^{68}$. Hoewel de aarzeling voor het aanwenden van economische sancties voor politieke doeleinden iets minder lijkt te zijn geworden en onder meer daardoor de instellingen van de EG eerder worden betrokken bij de EPS, blijft de besluitvorming in de EPS een intergouvernementeel karakter dragen. De voorbereidingen vinden plaats op de nationale departementen waarbij de halfjaarlijkse voorzitter een centrale rol

66. Regelsberger, 1988 , p. 29 .

67. Zie ook Regelsberger 1988, p. 23 en Bonvicini 1988 pp $66-67$ die stelt dat deze economische sancties op basis van art. 11.3 EG-verdrag ook leidde tot een meer effectieve relatie tussen de Gemeenschapsinstellingen en de EPS.

68. NRC-Handelsblad 30-10-1989. 
vervult; deze wordt bijgestaan door de vorige en toekomstige voorzitter, de zogenaamde 'troika'. De directeuren-generaal politieke zaken, de ministers van Buitenlandse Zaken en in mindere mate de regeringsleiders vormen de spil van de Europese Politieke Samenwerking. De zeggenschap van het Europees Parlement is nog geringer op het terrein van de EPS dan op het communautaire gebied. De mogelijkheden van nationale parlementen tot invloedsuitoefening vooraf is zeer gering gezien het vertrouwelijke karakter van het EPS-beraad en achteraf van beperkte betekenis, daar de inhoud dan reeds is vastgesteld. De democratische controle van de volksvertegenwoordiging die inzake het buitenlands beleid van Nederland gedurende de afgelopen twee decennia enigszins zou zijn toegenomen, zal bij verdere ontplooiing van de EPS en bij handhaving van de huidige procedures weer worden teruggedraaid.

Terugkerendl naar de doelstellingen van de EPS zullen we in deze studie naar voren brengen dat een 'communauté des vues' in 1973 in gang is gezet met een gezamenlijke standpuntbepaling ten aanzien van het Midden-Oostenprobleem. Toen werd de eerste officiële verklaring uitgegeven (zie 2.2.1.3) en werd voor het eerst een gemeenschappelijk uitgewerkt standpunt (zie 2.2.1.7) gepubliceerd. Regelsberger stelt: 'The Fourth Middle East war in 1973 worked almost as an external federator ${ }^{369}$ en een Egyptische diplomaat zei indertijd tegen Van der Klaauw (toen werkzaam op de permanente vertegenwoordiging bij de Verenigde Naties te New York): 'Weet je, in het Midden-Oosten maken wij Europa" ${ }^{470}$. Zo bezien was het Midden-Oostenprobleem een geschikte kapstok om tot harmonisatie van standpunten te komen. Bovendien werden met de EPSbemoeienis inzake het conflict in het Midden-Oosten twee andere belangrijke doeleinden gediend. Deze zijn het veilig stellen van de eigen economische belangen en het uitdragen van een standpunt dat niet met dat van de. VS overeenkwam waardoor de EPS zich kon onderscheiden en een eigen politieke rol in de internationale politiek kon etaleren. Wellicht was dat onderscheidend element belangrijker dan het ook daadwerkelijk uitvoeren van die rol waar de derde doelstelling van 'communauté d'action' op was gericht. De activiteiten van de EPS in 1980 en 1981 in het Midden-Oosten waren gericht op verwezenlijking van dit derde en verstrekkende doel. In hoeverre de EPS daar ook in slaagde vormt één van de centrale thema's van deze studie.

\subsubsection{Europese Politieke Samenwerking en het Arabisch-Israëlisch conflict}

Niet alleen werd het Midden-Oostenvraagstuk één van de eerste onderwerpen van beraad in het kader van de Europese Politieke Samenwerking, het zou ook nog jarenlang op de agenda blijven staan. Uit een overzicht van de onderwerpen waarover in het kader van de EPS een verklaring werd afgelegd, blijkt dat over het Midden-Oosten verreweg de meeste verklaringen zijn uitgegeven. In de periode 1970-1986 ging van de door de EPS aangenomen verklaringen $24,4 \%$ over het Midden-Oosten, $18,1 \%$ over Afrika, $14,4 \%$ over Azie en 13\% over zowel Latijns-Amerika als CVSE (Conferentie over Veiligheid en Samenwerking in Europa) ${ }^{71}$. Het lijkt een paradox dat op het gebied

69. Regelsberger, 1988, p. 14 .

70. Interview met Van der Klanuw op 31 augustus 1989.

71. A. Pijpers, 1988 , p. 154 . 
waar zoveel energie in werd gestoken om de doeleinden te bereiken, de twijfel overheerst wanneer naar tastbare resultaten wordt gezocht ${ }^{72}$. Omtrent de drang tot al deze verklaringen merkten Greilsammer en Weiler enigszins cynisch op: 'It would seem that each time a European summit conference ends with failure concerning internal issues, the participants feel the need to publish a new text on the Middle East, as if to give the impression of having achieved some sort of result ${ }^{73}$.

In die zin zouden de Midden-Oostenverklaringen een functie kunnen hebben voor de interne cohesie tussen de lidstaten, juist op die momenten dat de Europese integratie geen vooruitgang boekte ${ }^{74}$. Een jaar later benaderen Greilsammer en Weiler de vraag naar het succes van de EPS ten aanzien van het Midden-Oosten vanuit een andere optiek: 'Europe may not have been effective in influencing events in the Middle East, but has been highly successful in attaining her interests which have been to maintain her tradelinks with all parties at no political $\operatorname{cost}^{75}$. Door de EPS-bemoeienis met het Midden-Oosten hebben de lidstaten intern de banden versterkt, maar ook extern werden de banden met de partijen in het conflict niet geschaad. We kunnen dit de 'beschermfunctie' van de EPS activiteiten noemen. Op deze wijze hebben de politieke handelingen gediend ten gunste van de economische belangen van de Europese Gemeenschap, zonder dat op politiek gebied schade werd opgelopen. De partijen in het conflict werden weliswaar niet nader tot elkaar gebracht door de initiatieven en verklaringen aan Europese zijde maar een dergelijk 'verheven doel' heeft misschien helemaal niet ten grondslag gelegen aan de EPS-activiteiten inzake het Midden-Oosten sinds de oliecrisis van 1973. Tot slot kan de EPS ten aanzien van het Midden-Oosten een functie hebben gehad in het zich profilleren ten opzichte van de Verenigde Staten. Met een eigen van de VS afwijkend geluid heeft de EPS zich doen horen in de internationale politiek en dat geluid werd in het overgrote deel van de wereld met instemming begroet. Tegelijkertijd heeft het niet tot zodanige spanningen met de VS geleid dat de Europese lidstaten bezorgd hoefden te worden over de eigen militaire veiligheid, die grotendeels door de VS bleef gegarandeerd. De EPS heeft zich ook het best kunnen uiten binnen een periode van détente waarin het Amerikaans beleid ten aanzien van het Midden-Oosten het minst gestalte kreeg. Afwezigheid van de VS op het politieke toneel van het Midden-Oosten kan de Europese rol meer gewicht geven en de kans vergroten op een bemiddelaarsrol tussen de partijen dan wel een bemiddelaarsrol tussen de VS en de betrokken partijen. Met name het centraal stellen van een oplossing voor de Palestijnen aan Europese zijde is daarvan een voorbeeld.

De oorzaak voor een al dan niet actieve Amerikaanse rol in het Midden-Oosten brengt Quandt in verband met de 'presidentiële cyclus'. Hij gaat ervan uit dat gedurende het tweede en derde regeringsjaar van een nieuwe president en gedurende de eerste anderhalf jaar van een herkozen president, de kans op succes van Amerikaanse initiatieven

72. Greilsammer and Weiler, 1987, p. 99.

73. Greilsammer and Weiler, 1987, p. 107.

74. Daarentegen zei minister Van den Broek in 1989 als het renwordingsproces in Europa stagneert kan je geen geloofwaardige signalen aan derden geven (Radio-NCRV, Hier en $\mathbb{N u}, 10$ december 1989).

75. Greilsammer and Weiler, 1988, p. 3. 
het grootst is ${ }^{76}$. Deze regelmaat kan slechts gelden als aan een aantal voorwaarden is voldaan. In de VS moet - ten eerste - een uitgesproken binnenlandse publieke opinie over het Arabisch-Israelisch conflict bestaan. Ten tweede moet deze publieke opinie niet stroken met de voorstellen van de Amerikaanse regering voor een oplossing van het Arabisch-Israëlisch conflict. Ten derde moet een verschil in opvattingen bestaan ten aanzien van de oplossing van het Arabisch-Israëlisch conflict tussen de VS en de EPSpartners.

Voor de periode 1973-1982 gaat dit schema tamelijk goed op. Het tweede en meest succesvolle jaar van iedere presidentiële periode leidde tot Amerikaanse initiatieven als troepenscheidingsakkoorden tussen enerzijds Israël en anderzijds Egypte en Syrië (1974), de Camp Davidakkoorden (1978) en het Reagan plan (1982). Het derde jaar leidde tot beperkte oplossingen met een hoge prijs voor de VS als het Sinaï-II akkoord (1975) en het Israëlisch-Egyptisch vredesverdrag (1979). In het vierde jaar 1976 en 1980 werden geen Amerikaanse initiatieven ontplooid. Het eerste jaar leidde tot het mislukte Amerikaans-Russische gezamenlijke communiqué (1977) en het strategisch samenwerkíngsconcept (1981) en bij de herkozen Nixon tot enig succes tot en na de afloop van van Oktoberoorlog (1973). De beste kansen voor Europa zouden dan liggen in $1973^{77}, 1976,1977,1980$ en 1981 . Een bevestiging daarvan wordt in deze studie gegeven; in de volgende hoofdstukken komt naar voren dat vanuit de EPS vooral activiteiten ten aanzien van het Midden-Oosten werden tentoongespreid in $1973^{78}$, $1976^{79}, 1977^{80}, 1980^{81}$, en $1981^{82}$. De jaren waarin de VS het meest succes had - dat wil zeggen tweede en derde jaren van iedere presidentiële periode - werd vanuit de EPS geen enkele Midden-Oostenverklaring uitgegeven - 1974 en 1975 - of slechts wat mokkend en tegenstribbelend op het Amerikaanse succes gereageerd zonder met eigen initiatieven te komen - 1978 en 1979 - of de positie van de VS min of meer gevolgd (1982).

De EPS bemoeienis met het Arabisch-Israëlisch conflict heeft zo bezien vooral te maken met andere oogmerken dan het zoeken naar een oplossing van het Arabisch-Israëlisch conflict.

76. Een nieuwe president heeft het eerst jaar onvoldoende kennis vam zowel de complexe MiddenOosten problematiek als de binnenlandse politieke verhoudingen over het conflict; het tweede jaar worden beide verzoend en leiden tot minder ideologisch gekleurde en bescheiden, halalbare voorstellen; het derde jaar wordt naarstig naar succes gestreefd met het oog op de verkiezingen en de oplossingen vergen vaak veel van de Amerikaanse schatkist en blijwen valk oppervlakkig, daar controversiële oplossingen worden gemeden; in het vierde jaar tenslotte is de president zo sterk op bimnenlandse steun gericht dat geen initjatieven te venwachten zijn; Quand, 1986, pp. 6-29.

77. 1973 is een twijfelgeval omdat Nixon was herkozen en daarom volgens Quandt's schema wel succes zou moeten hebben, hetgeen in het laatste kwartaal ook enigszins het geval was. De actieve opstelling vanuit Europa leidde in 1973 dan ook tot grotere spanning met de VS dan in de andere perioden het geval was. De periode 1973-1976 met de presidenten Nixon en Ford wordt als én periode opgevat.

78. Zie met name 2.3.2 en 2.3.3.

79. Zie met name 3.1.1

80. Zie met name 3.1.2.1

81. Zie met name 3.1.2.3

82. Zie met name 4.1.1.2. 
De relatie Nederland-Israël wordt op verschillende manieren omschreven. Gemeenschappelijk daaraan is dat die relatie als 'gevoelig" en 'niet-normaal' wordt aangeduid. De 'gevoeligheid' geeft aan dat men in Nederland niet onverschillig staat ten aanzien van de positie van Israël. Het betekent een grote mate van betrokkenheid, die voortkomt uit verschillende invalshoeken, die weer verschillen per binnenlandse groepering. Daar vloeit uit voort dat het begrip 'gevoeligheid' op het niveau van beleidsmakers ook betrekking heeft op het gevoelig zijn voor houdingen en beïnvloedingspogingen van binnenlandse groeperingen ten aanzien van de relatie Nederland-Israel. I $\mathrm{k}$ zal in deze paragraaf op deze binnenlandse groeperingen ingaan en voor zover deze groeperingen activiteiten hebben ontplooid in de hier te onderzoeken gevallen, komen zij in de volgende hoofdstukken uitgebreider aan de orde.

Het 'niet-normale' van de relatie duidt op het vriendschappelijke, hechte, nauwe, bijzondere etc. daarvan; met andere woorden het 'niet-normale' heeft een positieve connotatie en wanneer deze relatie als "normaal" zou worden omschreven betekent dat een verslechtering in vergelijking met de voorafgaande periode. De aard van de relatie en het te voeren beleid kunnen wel verschillen. Zo hoeft een evenwichtig beleid niet ten koste te gaan van de aard van de relatie en kunnen zelfs vanuit het oogpunt van Israëls positie negatieve sancties worden voorgesteld. Minister Van der Stoel bijvoorbeeld omschreef in 1973 het Nederlands standpunt in een brief aan de Kamer na de instelling van het olie-embargo als evenwichtig waaronder hij verstond: 'recht te doen wedervaren aan de legitieme belarigen van alle betrokken partijen" ${ }^{83}$. Terwijl het Kamerlid Den Uyl, toen hij onder meer voorstelde de Nederlandse ambassadeur uit Israël terug te roepen na de gebeurtenissen in Sabra en Shatilla, verklaarde 'deze daad te stellen, mede terwille van Israël zelf ${ }^{84}$. Uiteraard moet op den duur wel een verband bestaan tussen het beleid en de typering van de relatie Nederland-Israël.

Soetendorp trekt aan het slot van zijn dissertatie over het Nederlands beleid ten aanzien van het Arabisch-Israëlisch conflict over de periode 1947-1977 de stellige conclusie dat de Jodenvervolging in de Tweede Wereldoorlog geen richtsnoer was voor het handelen van de Nederlandse regering. Uitsluitend nationale belangen zouden het beleid hebben bepaald ${ }^{85}$. Elders heb ik kritiek geleverd op deze conclusie waarin 'het nationaal belang" uitsluitend als grondslag voor het beleid heeft gediend ${ }^{86}$.

Waar het mij nu om gaat is dat een pro-Israëlische houding ook haar voedingsbodem heeft in de visie op de 'Shoa' (in het Hebreeuws letterlijk catastrofe of vernietiging is het de benaming voor 'Holocaust', 'Endlösung' of in de termen van Presser 'Verdelging

83. Zitting Tweede Kamer $1973-1974,12600 \mathrm{~V} 14$, p. 3.

84. Tweede Kamer, zitting 1982-1983, 21 september 1982, 17.600, Hoofdstuk V, nr. 7, p. 6.

85. Soetendorp, 1982 en 1983, pp. 205-206: "Het gevoerde beleid was geen kwestie van een pro- of anti-Israelisch of van een pro- of anti-Arabisch sentiment. Evenmin vormde de morele schuldenlast ten aanzien van het in de Tweede Wereldoorlog grotendeels uitgeroeide Nederlandse Joderidom een leidraad voor de handelswijze vam de Nederlandse regering. Deze leidrasd werd slechts gevormd door het bevorderen en zeker stellen van die belangen die als nationale belangen werden opgevat of daarmee samenhingen."

86. Transaktie, jaargang 12,1983 , no. 2 , pp. $214-217$. 
der Joden'). Door menig politicus werd dit naar voren gebracht en hier vollsta ik met een verwijzing naar de tafelrede van premier Lubbers in Jeruzalem toen hij zijn proIsraëlische gevoelens onder meer daarop baseerde ${ }^{87}$.

Een pro-Israëlische houding onder de bevolking kan bovendien de vrijheid van handelen van de regering begrenzen, temeer als een regering ook gevoelig is voor de binnenlandse publieke opinie $e^{88}$.

In deze studie wordt daar verder op ingegaan. Eerst zullen nu de binnenlandse, niet direct bij het besluitvomingsproces betrokken actoren in kaart worden gebracht. Ik ga daarbij uit van het schema in 1.2.3. Achtereenvolgens worden nu het massapubliek en de niet-formele politieke elite behandeld.

\subsubsection{Massapubliek}

Kenmerkend voor de houding van Nederlanders ten opzichte van Israël is de betrokkenheid bij en het niet onverschillig staan ten aanzien van Israël. Het gaat daarbij eerder om een soort grondhouding dan dat daaruit direkt een positieve of negatieve houding ten aanzien van het Israëlische beleid kan worden afgeleid. Dat beeld komt bijvoorbeeld naar voren uit een enquête in mei 1983 waarin de respondenten naar hun houding ten opzichte van achttien landen werden gevraagd. Gevraagd naar 'gevoelens van bewondering' wordt Israël op de eerste plaats gerangschikt en bij een combinatie van deze vraag naar 'gevoelens van bewondering' met 'positief staan tegenover' komt Israël op de tweede plaats (na de VS) te staan. Tegelijkertijd vinden weinigen de buitenlandse politiek van Israël 'goed' (elfde plaats) en velen de buitenlandse politiek van Israël 'slecht" (vijfde plaats). Deze gegevens geven meer inzicht dan de vervolgens gestelde vraag of men pro-Israël $(27,1 \%)$, anti-Israël $(7,8 \%)$, neutraal $(61,5 \%)$ is of het niet weet $(3,6 \%)^{89}$. Ook bij een vraag of de Nederlandse krijgsmacht moet worden ingezet bij een bezetting van Joegoslavië (wel: $28 \%$, niet: $62 \%$, weet niet: $11 \%$ ), Zwitserland en Oostenrijk (wel: $42 \%$, niet: $47 \%$, weet niet: $11 \%$ ) of Israël (wel: $45 \%$, niet: $43 \%$, weet niet: $12 \%$ ) scoort Israël hoog, waarbij moet worden opgemerkt dat de vraagstelling ten aanzien van Israël suggestief ('onder de voet zou worden gelopen') was, hetgeen de beantwoording beïnvloed kan hebben ${ }^{90}$.

87. Hij verhaalde dat zijn moeder hem tijdens de Tweede Wereldoorlog op aanraden wan wrienden regelmatig had binnengeroepen omdat de donkere Lubbers er in Duitse ogen nogal Joods uitzag en vertelde over de diepe indruk - 'een van de gedenkwaardigste uit mijn leven" - die hij als negentienjarige aan een bezoek aan Dachau overhield; NRC Handelsblad 19-7-1988.

88. Bank verweet in dit verband Soetendorp een dedain ten aanzien van het binnenland terwijl de wijze van besluitvorming niet werd onderzocht, Bank 1984, pp. 283-284; Schöffer kritiseerde dat de achtergronden van binnenllandse verhoudingen, pressie en actiegroepen evenals wisselingen in de publieke opinie in Nederland geheel buiten beschouwing bleven, Schöffer 1984, pp. 658-659.

89. Nipo onderzoek: pro of anti-Amerikanisme, mei 1983, $N=1204$ uit: Vaneker en Everts, 1984, pp. 165-166

90. Nipo onderzoek: Defensie 1976, juli 1976, $\mathrm{N}=941$. uit: Vaneker en Everts, 1984, pp. 105-106. De vraagstelling over hulp aan Zuid-Afrika was nog suggestiever 'de gehele blanke bevolking er met uitmoording bedreigd zou worden door militairen uit andere Afrikaanse landen' met als antwoorden: wel: $32 \%$, niet: $57 \%$, weet niet: $12 \%$. 
Aan de andere kant dient de betrokkenheid bij Israël niet overdreven te worden. We constateerden hierboven dat bijna tweederde van de Nederlanders bij de vraag naar proof anti-Israël zich neutraal opstelde of het antwoord schuldig bleef. Het is een inmiddels wel bekend gegeven dat slechts een klein deell van de bevolking zich interesseert voor de buitenlandse politiek ${ }^{91}$. Voor Nederland wordt de buitenlandse politieke elite op 700 à 1000 personen, de opinieleiders op $1 \%$ en het aandachtige publiek op 5 a $10 \%$ geschat ${ }^{92}$. Ook de interesse in de buitenlandse politiek is geen vast gegeven en kan verschillen naar onderwerp en tijd.

Verondersteld kan worden dat in Nederland de interesse voor het Midden-Oostenconflict groter is - vanwege de eerder naar woren gebrachte betrokkenheid - dan voor andere regionale conflicten of buitenlandse politieke onderwerpen.

Uit een enquete uit 1977 blijkt dat van alle respondenten $34 \%$ tot de geïnteresseerden, waarvan $7 \%$ tot de geïnformeerden, inzake het Midden-Oostenconflict gerekend kunnen worden ${ }^{93}$. De eerste veronderstelling wordt op grond hiervan niet verworpen, al is een bevestiging evenmin mogelijk daar aan dezelfde groep respondenten niet gelijktijdig naar andere buitenlandse politieke onderwerpen werd gevraagd.

Daarnaast kan verondersteld worden dat de niet-geĩnteresseerden zich bij de enquêtevragen eerder neutraal opstellen of het antwoord schuldig blijven in vergelijking met de groep geïnteresseerden.

Deze veronderstelling werd deels verworpen daar bij de vraag naar sympathie voor de verschillende partijen de geïnteresseerden weliswaar eerder kozen voor Isrä̈l en Palestijnen maar tevens eerder kozen voor alle partijen dan de niet-geïnteresserden, die iets meer een voorkeur hadden voor Arabische landen of voor geen enkele partij. Met andere woorden de groep 'neutralen' is niet sterker vertegenwoordigd onder de nietgeînteresseerden. Een zeer duidelijke bevestiging werd well gevonden uit de antwoordcategorie 'geen oordeel'; deze werd in alle gevallen veel sterker gerepresenteerd door de niet-geïnteresseerden dan door de geïnteresseerden (zie tabellen 1.4 en 1.5).

91. In 1950 makkte Almond het onderscheid tussen 'the attentive and general publics' waarbij de cerste "het aandachtige publiek" het gehoor uitmaakte wan de diseussie tussen de elites over buitenlandse politiek daar ziji geinteresseerd (en geïnformeerd) zijn in buitenlandse politieke problemen. G.A. Almond, in: Rosenau 1967 p. 269.

92. Everts, $1983, \mathrm{pp} .86,87$ en 89.

93. Nipo onderzoek over Israël en het Midden-Oosten, april 1977, $\mathrm{N}=1127$. Op de vraag of de ontwikkelingen van hel conflict al dan niet werd gevolgd antwoordde: $7 \%$ nawwgezet, $27 \%$ in grote lijnen, $25 \%$ oppervlakkig, $14 \%$ nauwelijks, $21 \%$ in het geheel niet, $7 \%$ geen antwoord. Het aantal geïnteresseerden steeg naarmate het genoten opleidingsniveau hoger lag van degenen met lager onderwijs behoorde $18 \%$, hoger beroepsondenwijs $25 \%$, MAVO $43 \%$, VWO $47 \%$, HBO $53 \%$ en universiteit en hogeschool $68 \%$ tot de geïnteresseerden. 
Tabel 1.4

\begin{tabular}{|c|c|c|c|c|c|}
\hline & $\begin{array}{l}\text { Volgt het } \\
\text { nauwgezet } \\
\text { /in grote } \\
\text { lijnen } \\
N=373\end{array}$ & $\begin{array}{l}\text { Volgt het } \\
\text { opper- } \\
\text { vlakkig } \\
N=277\end{array}$ & $\begin{array}{l}\text { Volgt het } \\
\text { nauwelijks/ } \\
\text { in het } \\
\text { geheel niet } \\
N=394\end{array}$ & $\begin{array}{l}\text { Geen } \\
\text { antwoord } \\
N=83\end{array}$ & $\begin{array}{l}\text { Totaal } \\
\mathrm{N}=1127\end{array}$ \\
\hline sympathie voor: & $\%$ & $\%$ & $\%$ & $\%$ & $\%$ \\
\hline Israël & 61 & 57 & 40 & 11 & 49 \\
\hline Arab $_{\text {. landen }}$ & 1 & 3 & 1 & 1 & 2 \\
\hline Palestijnen & 7 & 3 & 2 & - & 4 \\
\hline Alle partij & 15 & 9 & 5 & 2 & 9 \\
\hline Geen oordeel & 10 & 14 & 36 & 77 & 25 \\
\hline Totaal & 100 & 100 & 100 & 100 & 100 \\
\hline
\end{tabular}

Bron NTPO onderzoek ower Israël en het Midden-Oaster, april $1977, \mathbb{N}=1127$.

Tabel 1.5

\begin{tabular}{|l|r|r|r|r|}
\hline \multicolumn{2}{|l|}{ Relatie categorie geen oordeel met politieke interesse M.0. 1977 } \\
\hline & $\begin{array}{l}\text { volgt het } \\
\text { nauwelijks } \\
\text { /in grote } \\
\text { lijnen }\end{array}$ & $\begin{array}{l}\text { volgt het } \\
\text { oppervlak- } \\
\text { kig }\end{array}$ & $\begin{array}{l}\text { volgt het } \\
\text { nauwelijks } \\
\text { in het } \\
\text { geheel niet }\end{array}$ & $\begin{array}{l}\text { geen } \\
\text { antwoord }\end{array}$ \\
\hline $\begin{array}{l}\text { Geen oordeel inzake ge- } \\
\text { wenste beleid veroverde } \\
\text { gebieden }\end{array}$ & $8 \%$ & $23 \%$ & $56 \%$ & $86 \%$ \\
\hline $\begin{array}{l}\text { Geen oordeel inzake ge- } \\
\text { wenste oplossing voor } \\
\text { Palestijnen }\end{array}$ & $14 \%$ & $28 \%$ & $59 \%$ & $8 \%$ \\
\hline $\begin{array}{l}\text { Geen oordeel inzake vre- } \\
\text { deswil Arabische leiders }\end{array}$ & $18 \%$ & $33 \%$ & $57 \%$ & $89 \%$ \\
\hline
\end{tabular}

Bron NIPO onderzoek over Israël en het Midden-Oosten, aprill $1977, \mathbb{N}=1127$.

$\mathrm{Na} 1977$ kwam er verandering in de houding ten aanzien van Israëll mede als gevolg van het aantreden van het kabinet-Begin. Het voortgezette nederzettingenbeleid, het optreden in de bezette gebieden en de invasie in Libanon werden zowel door de lidstaten van de Europese Gemeenschap als door de Nederlandse publieke opinie afgewezen. Tegelijker- 
tijd bleef echter de basis van sympathie en bewondering voor Israël bestaan. De hoge score in de categorie 'geen mening' bij een opinie-onderzoek uit april 1983 werd door de onderzoekers verklaard uit een ambivalente houding van Nederlanders tegenover Israël. Een ambivalente houding die voortkwam uit enerzijds sympathie en begrip voor Israël en anderzijds een verwerping van de politiek die Israël voerde ${ }^{94}$. Een andere mogelijkheid is dat Nederlanders zich bewust zouden zijn van de gecompliceerdheid van het Midden-Oostenconflict waardoor ze de gesimplificeerde antwoordalternatieven verwierpen en wijselijk voor 'geen mening' kozen. Vijf jaar later, in 1988, kort na het begin van de Intifadah, werd gevraagd of de respondent 'als hij alles afweegt achter Israël of achter de Palestijnen staat" waarop $29,9 \%$ voor Israël en $23,3 \%$ voor de Palestijnen koos, terwijl $46,8 \%$ geen mening had.

Het dagblad - het Algemeen Dagblad - dat dit onderzoek betaalde, maakte er voorpaginanieuws van onder de kop 'Israël uit de gratie' wijdde er een hoofdredactioneel commentaar aan en vroeg reacties aan politici van CDA, PvdA, VVD en woordvoerders van Israël en de PLO ${ }^{95}$. Ook bij de opiniepeilers is de aandacht verschoven van het Israëlisch-Arabisch conflict naar het Israëlisch-Palestijns conflict. Deze enquete is wooral interessant omdat - voor zover ik weet - voor het eerst gevraagd werd (in tabel 1.6) naar de kerkelijke gezindte van de respondenten bij een Nederlands opinieonderzoek naar het Midden-Oostenbeleid. Het resultaat vertoont significante verschillen.

Tabel 1.6

\begin{tabular}{|l|r|r|r|r|r|c|}
\hline \multicolumn{2}{|l|}{ Relatie met kerkelijke gezindte februari 1988} \\
\hline & Allen & RK & $\begin{array}{c}\text { Ned. } \\
\text { Herv. }\end{array}$ & $\begin{array}{c}\text { Geref. } \\
\text { Syn. }\end{array}$ & $\begin{array}{c}\text { Geref. } \\
\text { ander }\end{array}$ & $\begin{array}{c}\text { Geen } \\
\text { kerk }\end{array}$ \\
\hline staat achter Israël & $29,9 \%$ & $22,0 \%$ & $36,7 \%$ & $60,9 \%$ & $60,0 \%$ & $27,9 \%$ \\
\hline $\begin{array}{l}\text { staat achter Pale- } \\
\text { stijnen }\end{array}$ & $23,3 \%$ & $22,0 \%$ & $21,7 \%$ & $4,3 \%$ & $3,3 \%$ & $27,9 \%$ \\
\hline $\begin{array}{l}\text { weet niet/geen } \\
\text { mening }\end{array}$ & $46,8 \%$ & $56,0 \%$ & $41,7 \%$ & $34,8 \%$ & $36,7 \%$ & $44,1 \%$ \\
\hline
\end{tabular}

Bron: Burke/Interview BV: onderzoek situatie in Israël, februari $1988, \mathrm{~N}=609$

94. NSS opinie-onderzoek De Nederlanders, Israël en de Palestijnen, april 1983, $\mathrm{N}=870$. De 'weetniet' categorie betreft $22 \%$ over de inval in Libanon, $30 \%$ over het nederzettingenbeleid en $38 \%$ over daden van regering Begin en "lijkt" wolgens de opinie-onderzoekers belangrijk hoger dan bij eerder door hen afgenomen opinie-onderzoek over de buitenlandse politiek. Vergelijkbalarheid wordt bemoeilijkt door het soms wel en soms niet het antwoordalternatief "weel-niet" door de enquetteur an de respondent wordt gepresenteerd. Bij het onderzoek van Burke-Interview BV ower reacties op onnust bezette gebieden, uit januari $1988(\mathrm{~N}=506)$ werd de ondervrager uitdrukkelijk geïnstructeerd bij het mogelijk antwoond 'geen mening" dat niet voor te lezen.

95. Algemeen Dagblad, 20-2-1988. 
Het verschil van 38 a $39 \%$ in tabel 1.6 tussen gereformeerden en rooms-katholieken bij de vraag naar voorkeur voor Israël is niet gering. In de tijd van vór het CDA kon ik dit verschil in tabel 1.7 nog op indirekte wijze naar voren brengen door te wijzen op het verschil tussen ARP- en KVP-kiezers. Dat verschil bedroeg toen $36 \%$.

Tabel 1.7

\begin{tabular}{|l|r|r|r|r|r|r|r|}
\hline Relatie sympathie met partijwoorkeur november 1974 \\
\hline & Allen & ARP & CHU & PvdA & VVD & PPR & KVP \\
\hline Pro Israël & $37 \%$ & $65 \%$ & $63 \%$ & $33 \%$ & $50 \%$ & $26 \%$ & $29 \%$ \\
\hline Pro Arab. staten & $3 \%$ & - & $3 \%$ & $4 \%$ & $1 \%$ & $5 \%$ & $3 \%$ \\
\hline Neutraal & $56 \%$ & $35 \%$ & $33 \%$ & $60 \%$ & $44 \%$ & $68 \%$ & $68 \%$ \\
\hline Geen antwoord & $4 \%$ & - & $1 \%$ & $3 \%$ & $5 \%$ & - & $1 \%$ \\
\hline
\end{tabular}

Bron: NIPO, bericht no. 1679 van 17 december $1974, \mathrm{~N}=834$

In 1972 was $98 \%$ van de KVP stemmers katholiek, terwij1 $38 \%$ van alle rooms-katholieken op de KVP stemde. De ARP-kiezers bestonden voor $66 \%$ uit gereformeerden en $20 \%$ uit hervormden. De CHU-kiezers bestonden voor $85 \%$ uit hervormden en $5 \%$ uit gereformeerden. Van alle gereformeerden stemde $56 \%$ op de ARP en van alle hervormden stemde $18 \%$ op de CHU. De SGP-aanhang bestond voor $58 \%$ uit gereformeerden en $34 \%$ hervormden. De GPV-aanhang voor $28 \%$ uit hervormden en $72 \%$ gereformeerden ${ }^{96}$.

Vanwege de indirekte rekenmethode moest ik in een eerdere publikatie met mijn conclusie voorzichtig zijn ${ }^{97}$. Deze woorzichtigheid kan ik nu laten varen. Kortom: de Nederlandse rooms-katholieken kozen het minst partij voor Israël, de Nederlandse gereformeerden daarentegen vertoonden het sterkst sympathie met Israël. Opvallend is dat de verschillen in 1988 nog zo groot waren en verondersteld zou kunnen worden dat een dergelijk verschil in visie wel tot spanningen binnen het CDA zou hebben geleid. Dat was echter nauwelijks het geval. In deze studie zal naar voren worden gebracht ${ }^{98}$, dat binnen het CDA een standpunt in de partijprogramma's werd neergelegd dat veel meer gelijkenis vertoond met het vroegere ARP-standpunt dan met het vroegere KVP-standpunt. Bovendien walt een verschil in houding te constateren tussen KVP-politici en hun achterban ${ }^{99}$. Anderzijds komt uit het archief-onderzoek van Soetendorp en anderen inzake de deling van Palestina en de erkenning van Israël naar voren dat KVP-politici

96. De Bruyn, Foppen en Hoogerwerf, 1973, pp. 30-35.

97. Grünfeld, 1984, pp. 14-15.

98. Zie 3.2.1.1.

99. Bekende KVP politici als Mommersteeg, Klompe, Luns, Van Agt, Lubbers, Van den Broek hebben vaak een houding ingenomen die als pro-Israëlisch kan worden omschreven. 
en KVP-bewindslieden minder geporteerd waren voor aanvaarding van het delingsplan of erkenning van Israel dan andere politici indertijd binnen en buiten het kabinet ${ }^{i \infty}$ "

Op 'massaniveau' is godsdienstige gezindte het onderscheidend criterium in de houding ten aanzien van het Israëlisch-Arabisch conflict. Andere variabelen als leeftijd, opleidingsniveau, sexe, urbanisatiegraad van de woonplaats geven onder de respondenten geen significante verschillen in hun oordeel over het Israëlisch-Arabisch conflict. Bij kiesgedrag is dat wel het geval, maar kiesgedrag is in Nederland voor een deel een resultante van godsdienstige gezindte en weerspiegelt de reeds ingenomen positie van de politieke partijen. Zo is in de periode 1973-1982 bijvoorbeeld de PvdA kritischer geworden over het Israëlisch beleid en wordt door de VVD en 'klein rechts' in het parlement en in hun partijprogramma's het meest steun gegeven aan de positie van Israël. In onderstaande tabel 1.8 wordt het verschil in houding ten aanzien van Israël tussen de kiezers van de VVD en de PvdA weergegeven. Kortom, zowel godsdienstige gezindte als kiesgedrag zijn van invloed op de houding ten aanzien van het ArabischIsraëlisch conflict.

Tabel 1.8

\begin{tabular}{|l|r|r|r|r|r|}
\hline \multicolumn{6}{|l|}{ Pro-Israëlische voorkeur onder VVD en PvdA kiezers 1969-1988 } \\
\hline Pro Israël: & 1969 & 1973 & 1974 & 1977 & 1988 \\
\hline VVD & $66 \%$ & $41 \%$ & $50 \%$ & $54 \%$ & $44 \%$ \\
\hline PvdA & $56 \%$ & $39 \%$ & $33 \%$ & $47 \%$ & $25 \%$ \\
\hline Allen & $51 \%$ & $36 \%$ & $37 \%$ & $49 \%$ & $30 \%$ \\
\hline
\end{tabular}

Bron NIPO: voor 1969 no. 1330 van 28 januari 1970, voor 1973 bericht no. 1546 van 15 februari 1973 , voor 1974 bericht no. 1679 van 17 december 1974, voor 1977 opinie-onderzoek over Israèl en het Midden-Oosten van 19 april 1977 en woor 1988 Burke-Interview BV onderzoek situatie Israël van 1988.

\subsubsection{Antizionisme - antisemitisme}

In de discussie over de houding ten opzichte van Israël spelen de begrippen antizionisme en antisemitisme een rol.

De grens tussen antizionisme en antisemitisme is moeilijk te trekken. De vraag waar men meent de grens te moeten leggen is omstreden ${ }^{101}$. Bovendien doet zich het merkwaardige verschijnsel voor dat bestrijders van het antisemitisme vaak felle antizionisten blijken te zijn, terwijl personen met een antisemitisch verleden zich soms opwerpen als vrienden van de staat Israël ${ }^{102}$. Ook in Nederland weten we inmiddels dat twee leden

100. Soetendorp, 1983, pp. 35-39, 50 en 56-57; zie ook het artikel van P. Koedijk en M. van Weezel in Vrij Nederland van 23 april 1988 waruit met name blijkt dat KVP-bewindslieden als van Boetzellaer-van Oosterhout, Stassen, Fiévez, Van den Brink zich un het kabinet verzet hebben tegen aanvaarding wan thet delingsplan en erkenning van de staat Israël.

101. Van Andel, 1984, p. 148.

102. Van Praag, ZWi Werblokwsklly, 1969, p. 7. 
van het 'Zwarte Front ${ }^{\text {s103 }}$ in de Tweede Wereldoorlog heel verschillend ten opzichte van Israël kunnen staan. Zo behoorde Delfgaauw tot de initiatiefnemers van het Nederlands Palestina Komitee ${ }^{104}$ en heeft Mommersteeg deel uitgemaakt van de Euro-Israelische dialoog ${ }^{105}$. Het Tweede Kamerlid Aantjes heeft in en buiten het parlement steeds Israël gesteund terwijl hij in de Tweede Wereldoorlog lid van de Germaanse SS was. Andersom bleek de virulent antisemitische gezindte van de Argentijnse junta voor de Isrälische regering geen beletsel te zijn Argentinië van wapens te voorzien.

Antisemitisme is een schending van de rechten van de mens - zie in de volgende paragraaf de preambule van de Universele Verklaring -; antizionisme is dat niet. Wanneer de haat tegen de Joden als haat tegen zionisten wordt voorgesteld, is wel sprake van antisemitisme. Wanneer zionisme als een vorm van racisme wordt gekenschetst, zoals in $\mathrm{VN}$ resolutie 3379 uit 1975 , kan dat als een vorm van antisemitisme worden ervaren. De verbondenheid van Joden met het voortbestaan van Israël veroorzaakt dan dat een dergelijke resolutie niet als louter anti-Israël wordt opgevat. In de 'propaganda-oorlog' over het Midden-Oostenconflict wordt de Shoa well cens misbruikt. Het doel is dan een wijziging te brengen in de beeldvorming in de westerse publieke opinie. In dat geval wordt het gedrag van de Israëli's vereenzelvigd met het gedrag van de Nazi's. Bleich stelde daarover: "terwijl men met historische vergelijkingen in het algemeen al voorzichtig moet zijn, is er niets smakelozers denkbaar dan het lastig vallen van de slachtoffers van gisteren met het etiket van hun beulen ${ }^{106}$.

Antizionisme in de zin van de ontkenning van het zelfbeschikkingsrecht van het Joodse volk is evenmin per definitie antisemitisch te noemen. Weliswaar wordt dan wel de vraag opgeworpen waar deze mening op is gebaseerd indien tegelijkertijd wel voor het zelfbeschikkingsrecht van andere volkeren wordt geijverd. De 'waarborgfunctie' van Israëls voortbestaan speelt in deze bij veel Joden ook buiten Israël een rol. Het is een complexe en gevoelige kwestie waarbij het niet goed mogelijk is scherp onderscheid te maken tussen antizionisme en antisemitisme. Dat laatste wil niet zeggen dat met kritiek op Israël terughoudender zou moeten worden omgesprongen dan met kritiek op andere staten. Immers ook filosemitisme is eigenlijk een vorm van antisemitisme, hoe paradoxaal dat ook klinkt ${ }^{107}$.

\subsubsection{De niet-formele politieke elite}

Na de presentatie van de publieke opiniecijfers - het massapubliek - zullen nu de groeperingen behandeld worden die het Nederlands buitenlands beleid ten aanzien van het

103. Het $Z$ warte Front werd in april 1940 omgezet in Nationaal Front; over beider lidmaatschap NRCHandelsblad 7-2-1990.

104. Het Parool, 30-5-1969 en Nieuwsbrief Palestina Komitee, (7e) augustus 1979, no. 4/5,p. 7, evenals P. Nak die mede de februaristaking van 1941 organiseerde. P. Nak trad in 1970 weer uit thet Palestina Komitee.

105. Brief van Mommersteeg han auteur van 17 augustus 1983.

106. Bleich, 1988, p. 12.

107. Van Andel, 1984, p. 187. 
Midden-Oosten willen beïnvloeden. Deze niet-formele politieke elite wordt gevormd door actiegroepen, kerken, politieke partijen en het bedrijfsleven ${ }^{108}$.

\subsubsection{De kerken en de Joodse gemeenschap}

Uit publieke opinie-onderzoek kwam een verschil in houding ten opzichte van Israël tussen met name rooms-katholieken en gereformeerden naar voren. In deze paragraaf zal onderzocht worden in hoeverre het geconstateerde verschil onder de achterban ook van invloed is geweest op de opstelling van de kerken en kerkelijke groeperingen in het Arabisch-Israëlisch conflict. Vervolgens wordt aandacht besteed aan de Joodse gemeenschap in Nederland. Nagegaan wordt in hoeverre door de Nederlandse regering in het beleid ten aanzien van het Arabisch-Israëlisch conflict met de wensen vanuit deze Joodse gemeenschap rekening werd gehouden. Onder de Joodse gemeenschap worden de 30.000 Nederlandse Joden verstaan. In deze studie zal wanneer louter de godsdienst en de godsdienstige gezindte wordt bedoeld een kleine letter - jood, joods - worden gebruikt en in de overige gevallen met de hoofdletter - Jood, Joods - worden geschreven ${ }^{109}$.

De bespreking van binnenlandse actoren heeft tot doel inzicht te verschaffen in de beperkingen die zij aan de vrijheid van handelen van de Nederlandse regering hebben. opgelegd.

\section{De kerken}

Het verschil in opstelling tussen rooms-katholieken en protestanten, waaronder in het bijzonder gereformeerden, dat op het niveau van 'massa-publiek' werd geconstateerd, wordt eveneens op het niveau van 'kerkleiders' aangetroffen. Het Vaticaan heeft de staat Israël nog steeds niet erkend en worstelt nog met de positie van het Joodse volk; dat laatste mede vanwege de inmiddels achterhaalde substitutietheologie ${ }^{110}$. Opheldering omtrent de rol van de rooms-katholieke kerk tijdens de Tweede Wereldoorlog en haar bemoeienis met de ontsnapping van oorlogsmisdadigers naar Zuid-Amerika werd niet gegeven en ook activiteiten als de plaatsing van een klooster bij Auschwitz in 1984 of de heiligverklaring van een 'Joodse non' versterken de negatieve beeldvorming in

108. Zie 1.2.3.

109. Renkema, 1989, p. 146: "Als we am de godsdienst denken moet het "jood" zijn. Vergelijk: 'de christelijke godsdienist'. Voor het begrip Joodse indentiteil zie p. 44.

Voor alle duidelijkheid wijs ik erop dat een burger van de staat Israël cen Israëliër of Israẻli is, met als meervoudsvorm Israëliërs of Israēli's. Een Israëliet is daarentegen een synoniem voor Jood met als bijwoeglijk naamwoord Israëlitisch voor Joods.

110. Volgens de substitutietheologie zou het Jadendom zijn opgevolgd door het Christendom en is er geen plaats voor het Joodse volk. In de verklaring 'Nastra actate' tijdens het Tweede Vaticaanse Concilie wordt ook eerder gekozen voor dialoog dan voor bekering van de joden. Toch is dat binnen de Rooms-Katholieke kerk nog niet algemeen aanvaard. Ook moeten terzake bij de gereformeende kerken en de Nederlands Hervormde Kerk nog de 'kerkorden' gewijzigd worden. Dat geeft problemen, alhoewel van een 'actieve bekeringsdrift' volgens de voorzitter van het OJEC geen sprake is. NRC-Handelsblad 8-8-1989. 
Israël en bìj Joodse groeperingen omtrent de rooms-katholieke kerk ${ }^{111}$. De katholieke vredesbeweging Pax Christi koos sinds 1970 de zijde van de PLO door een voorkeur uit te spreken woor een democratisch seculiere staat, waarbij bovendien de wet op de terugkeer - in feite is immigratie van Joden de 'raison d'être' van de staat Israël diende te vervallen ${ }^{12}$. Binnen de rooms-katholieke kerk werd de visie van Pax Christi bestreden door de Katholieke Raad voor Israël die zich toelegt op het verbeteren van de relatie tussen joden en katholieken in Nederland en daarnaast Israël steunt. De invloed van Pax Christi binnen de rooms-katholieke kerk en op de bisschoppen werd als groter gezien dan die van de Katholieke Raad voor Israell. Er bestaan contacten en ook personele relaties met gelijkgerichte actiegroepen ${ }^{113}$.

In calvinistische kring heeft de band met 'het oude verbondsvolk' een rol gespeeld in zijin houding ten aanzien van het moderne Israël. De verbondenheid met het Joodse volk kwam ook tot uiting in het verzet vanuit gereformeerde zijde in de Tweede Wereldoorlog. Ook binnen de CDA-fractie hebben met name de 'orthodox-protestanten' vaak druk uitgeoefend ten gunste van Israël ${ }^{14}$. Binnen de protestantse kerken bestaan vier Israëldeputaatschappen vanuit de Nederlands hervormde, de gereformeerde, de christelijk gereformeerde en vrij evangelische kerken die zijn verenigd in de Moderamina der Israël-organen. Deze hebben weer kontakten onderhouden met de Katholieke Raad voor Israël en pro-Israël actiegroepen als het Centrum voor Informatie en Documentatie Israël (CIDI) en de Werkgroep Israël.

In de Raad van Kerken zijn de christelijke kerkgenootschappen vertegenwoordigd. Niet alleen de Raad zelf maar ook drie groepen binnen deze Raad hebben zich met de Midden-Oostenproblematiek bezig gehouden. Dat zijn de werkgroep 'De Kerk en het Joodse Volk' (die ressorteert onder de sectie Geloofsvraagstukken en als pro-Israëlisch kan worden beschouwd met verbindingen naar de Katholieke Raad voor Israël en de IsraëlModeramina), de werkgroep 'Kerk en Ontwikkelingssamenwerking" (die als pro-Palestijns kan worden beschouwd met verbindingen naar Pax Christi) en de sectie Intermationale Zaken (die tussen beide groeperingen een middenpositie innam). Deze drie groeperingen waren betrokken bij de voorbereidingen van de beslissingen van de Raad.

111. Zie voor een overzicht ower bet klooster bij Auschwitz: F. Alting van Geusau: "Nieuwe Polen maakt einde aan Auschwitzconflict in NRC-Handelsblad van 20-3-1990. Uit de omschrijving van het begrip "Jood" in de volgende paragraaf volgt dat iemand die vrijwillig tot een andene godsdienst is owergegaan, niet langer als Jood of Jodin is te beschouwen. De non - Edith Stein - kwam in Auschwitz on het leven. De Israëlische oud-ambassadeur bij de EG, S. Minerbi, beschouwt de zaligverklaring van zuster Teresa Benedetta, alias Edith Stein, als een stap van do paus ter 'verchristelijking" van de holocaust. Hij komt darartoe op grond van de toespraak van de paus in mei 1987 ter gelegenheild wan deze zaligverklaring, De Volkskrant 2-9-1989.

112. Ook het Palestina Komitee erkende de nauwe verbinding met Pax Christi, zie Nieuwsbrief Palestina Komitee, (9e) decenber 1980/januari 1981, no. 1,p. 11: 'Pax Christi heeft zich sinds 1970 verdienstelijk gemalkt door een Midden-Oosten perspectief dat programmatisch nogal wat overeenkonst. vertoont met dat van het Komitee".

113. Bijw. Pax Christi met het Nederlands Palestina Kommitee en Katholieke Raad voor Israẽl met het Genootschap Nederland-Isräl.

114. Interview met Gualtherie van Weesel op 6 april 1983. 
Daarnaast bestaat sedert 1981 het 'Overlegorgaan tussen Joden en Christenen' (het OJEC) en daarin hebben zitting het CIDI, het Verbond van Liberaal-Religieuze joden in Nederland, het Nederlands-Israëlietisch Kerkgenootschap, het Portugees-Israëlietisch Kerkgenootschap, de Folkertsma Stichting, de Nes-Amin Vereniging Nederland, de Hervormde Raad voor Kerk en Israël, het christelijk Gereformeerd deputaatschap, de Evangelisch-Lutherse kerk, het Gereformeerd deputaatschap voor Kerk en Israël en de Katholieke Raad voor Israël ${ }^{115}$. Dit OJEC komt veelvuldig in de publiciteit en is proIsraël gericht. Vaak komt het OJEC met zijn steun aan Israël in botsing met onder meer de Raad van Kerken en de rooms-katholieke kerk. Zo werd door het OJEC het overleg met de Raad van Kerken opgeschort nadat de voorzitter van de Raad op 23 november 1989 op een bijeenkomst die door PLO-vertegenwoordiging in Nederland was georganiseerd, een toespraak hield. De voorzitter van de Raad van Kerken meende dat er in Nederland een taboe bestond op het uiten van solidariteit met de Palestijnen ${ }^{116}$. In 1990 werd een overeenkomst, krachtens welke het OJEC altijd door de Raad van Kerken zou worden geraadpleegd in voor Joden gevoelige kwesties, opgeheven ${ }^{117}$. Bovendien zijn nog vele groepen gericht op een dialoog tussen joden en christenen zoals de hierboven vermelde Folkertsma Stichting, de vele leerhuizen in het land en het tijdschrift Ter Herkenning.

\section{De Joodse gemeenschap}

'Alle mensen worden vrij en gelijk in waardigheid en rechten geboren. Zij zijn begiftigd met verstand en geweten, en behoren zich jegens elkander in een geest van broederschap te gedragen" zo luidt artikel 1 van de Universele Verklaring van de Rechten van de Mens uit 1948. Dat was het internationale antwoord op de volkerenmoord van de Tweede Wereldoorlog. De barbaarse handelingen indertijd hebben het geweten van de mensheid geweld aangedaan, zo werd in de preambule van deze Universele Verklaring naar voren gebracht. Het was niet alleen een herinnering uit het verleden doch het heeft het denken in het heden bepaald. Door Elie Wiesel werd dit als volgt verwoord: 'Auschwitz behoort tot het verleden, maar de herinnering aan Auschwitz maakt deel uit van het heden'118. Hij schreef dit in de vorm van een brief aan een jonge Duitser uit de 'Rote Armee Fraktion' die bij de Palestijnse kaping van een vliegtuig in Entebbe onder de passagiers de selectie tussen Joden en niet-Joden uitvoerde. Deze jongere zette zich daarmee niet af tegen de nazi's uit de vorige generatie maar trad in hun voetspoor, zo constateerde Wiesel. De passagiers werden in Oeganda bevrijd door een reddingsactie van het Israëlische leger. De Joodse staat beoogt niet alleen de burgers van Israël te beschermen maar ook de Joden in de hele wereld. Het incident van de kaping bij Entebbe geeft kort de wanhoop (i.c. selectie van passagiers) en hoop (i.c. Israëlische bevrijdingsactie) weer die onder veel Joden van na de Tweede Wereldoorlog bestond

115. Pershericht van 2 december 1981 .

116. Israël Nieuwsbrief, (4e), van 16 nowember 1989 no. 18, NRC-Hlandelsblad 22-11-1989, NCRVRadio Kerk Vandaag van 24 november 1989.

117. NRC-Handelsblad 1-3-1990

118. Wiesel, 1978 , p. 102. 
en bestaat"19. Een hoop en wanhoop die kenmerkend zijn voor de Joodse geschiedenis. De hoop was gericht op het uitbannen van ongelijkheid en daarmee ook van Jodenhaat in de wereld. Veel Joden waren actief in socialistische en revolutionaire bewegingen en zetten zich juist af tegen de zionistische beweging. Het universalisme botste met het - zionistisch - particularisme. Universele idealen werden geen werkelijkheid en de Shoa vond plaats.

De waarborgfunktie van de Joodse staat Israël werd door het overgrote deel der Joden niet langer in twijfel getrokken. Jodenhaat bleef bestaan ongeacht het handelen van Joden of de aanwezigheid van Joden.

Jodenhaat als een natuurverschijnsel - van welke oorsprong dan ook - zou als zodanig, gezien de onveranderbaarheid, nauwelijks de preoccupatie van Joden behoeven. Herzberg stelle kernachtig: 'De Joden lijden eronder, de niet-Joden lijden eraan'120.

Door Sartre werd Jodenhaat ook niet als een probleem voor de Joden, maar als een probleem voor de niet-Joden gezien ${ }^{121}$. Zijn definitie sloot daarop aan: 'De Jood is een mens, die de andere mensen voor een Jood houden: dat is de eenvoudige waarheid en het uitgangspunt ${ }^{122}$. Enerzijds is dat een negatieve definitie daar voor het bezitten van een Joodse idlentiteit geen plaats is ingeruimd. Anderzijds geeft het de gerichtheid van Joden op hoe anderen over hen denken - als bepalend in die definitie - treffend weer. De kwetsbaarheid werd door Anne Frank als volgt beschreven: ' $O$ het is treurig, heel erg treurig, dlat weer voor de zoveelste maal de oude wijsheid bevestigd is: wat én Christen doet moet hij zelf verantwoorden, wat één Jood doet, valt op alle Joden terug' $(22 \text { mei 1944) })^{123}$.

De vrees voor Jodenhaat vormt een wezenlijk bestanddeel in het denken van veel Joden. De politieke handelingen van de staat Israël worden met argusogen gevolgd, onder meer uit angst dat een negatief oordeel daarover gevolgen kan hebben voor de positie van Joden buiten Israël. Ook in Nederland kwamen na de Israëlische invasie in Libanon uitingen van Jodenhaat naar boven, die door regering en parlement werden veroordeeld ${ }^{124}$. Zo ontstaat een zeer gecompliceerde situatie: enerzijds vormt Israël de waarborg en het eventuele toevluchtsoord voor Joden, anderzijds kan de angst bestaan dat door Israëls handelen de positie van Joden buiten Israël zal worden ondermijnd. Abba Eban beschreef dit laatste als volgt: 'In the American-Jewish community I always found a warm welcome but I often felt that while they listened to me, American Jews had one eye directed to the gentile audience whom I was trying to convince. Their pride was often a function of Israel's capacity to impress non-Jewish Americans"125. Hij schrijft vervolgens dat een positieve beeldvorming over Israël niet alleen voor Joden buiten

119. In dit geval de wanhoop dat in een Frans verkeersvliegtuig in Oeganda in 1976 de selectie tussen Joden en niet-Joden onder de passagiers plaatsvond en de hoop op het Israèlisch ingrijpen.

120. Van Andel, 1984, p. 182; uit De Nieuwe Linie van 11 februari 1981.

121. Vergelijk Sartre: "anti-semitism is not a Jewish problem: it is our problem", Sartre 1965, p. 152, oorspronkelijk Réflexions sur la question Juive, 1946.

122. Geciteerd in Kleerekoper, 1970, p. 82.

123. Uit: Antisemitisme, een geschiedenis in beeld, Anne Frank Stichting, SDU Uitgeveriji, 's-Gravenhage 1989 .

124. Handelingen Tweede Kamer, zitting 1982-1983, 14 oktober 1982, pp. 273-306.

125. Eban, 1977, p. 600 . 
Israël belangrijk is maar tevens een Israëlisch belang voor noodzakelijke internationale steun. Maar aan de andere kant strijdt de wens naar positieve beeldworming met een hardnekkige houding aan de onderhandelingstafel. Dat laatste kan prioriteit krijgen: 'It is important to be popular - but even more important to be alive ${ }^{126}$. Kortom, het voortbestaan van de staat kan een onvermurwbare houding vereisen. Daarentegen was in het verleden de vraag hoe anderen over Joden dachten vaak een kwestie van leven en dood. Daaruit verklaart Eban de nadruk die Joden buiten Israell op de beeldvorming leggen ${ }^{127}$. Het verklaren, begrip kweken en steeds maar weer de discussie aangaan over Israël is een belangrijke activiteit van vele met Israël verbonden groeperingen. Het is niet louter een steunen van Israël - zoals de stelling dat Israël de diaspora evenzeer nodig heeft als de diaspora Israël nodig heeft - maar deze aktiviteit heeft ook een functie voor de versterking van de eigen positie. Zo toonde Gilboa aan dat de Amerikaanse niet-Joden op momenten van spanning in de Amerikaans-Israëlische relatie aan Joden eerder een 'dubbele loyaliteit' toeschreven (37\% in april 1974 en begin 1983) dan wanneer de VS en Israël een eensgezinde opvatting hadden (25\% in augustus $1979 \mathrm{en}$ januari 1984). Het toedichten van 'dubbele loyaliteit' kan een uitingsvorm zijn van antisemitisme ${ }^{128}$, met name indien dat gepaard gaat met de beschuldiging van gebrek aan vaderlandsliefde of antipatriotisme $\mathrm{e}^{129}$. De vrees dat Israëls handelen de positie van Joden buiten Israël zou kunnen ondermijnen is de andere kant van de medaille van de bekende opvatting van Israël als waarborg en toevluchtsoord van Joden. De visie op Israël als waarborg en toevluchtsoord van Joden staat voorop in publikaties met interviews of artikelen van bekende Nederlandse Joden over Israël ${ }^{130}$. Na de Israëlische inval in Libanon in 1982 nemen niet alleen de verschillen in opvattingen over het beleid

126. Eban, 1977, p. 607.

127. Eban 1977, p. 607: 'At the same time I was disturbed by the excessive emphasis that Diaspora Jewry places on the question of 'image". "This obsessive concern arises out of a special Jewish experience. What other people have thought about Jews has often been an issue of life and death. But in Israel"s context there is an inherent conflict between the negotiating interest and the interest of image-making, it is better to be always flexible. But then there is damage to the concrete interests defended at the negotiating table. Other nations consistently subordinite transient poptularity to concrete interests; never the other way around. In Israel's case the situation is more complex, since a degree of international support for our image is itself a 'concrete' interest. Israel, on the whole, appeals more to the conscience and values of the world community than to its utilitarian interests'.

128. Le Pen van het Front National bejegende met smaad de Franse staatssecretaris van planning, Stoléru voor de Franse televisie. De Joodse staatssecretaris werd dubbele nationaliteit verweten. Uit zijn evenwicht gebracht antwoordde Stoleru "Jood zijn? Dat is geen mationaliteit', NRC-Ffandelsblad, 6-12-1989.

129. Van Andel, 1984, p. 182.

130. W.F. Kleim en M. Kopuit: De Joden in Nederland, Assen, Van Gorcum \& Comp., 1969; D. Houwart e.a: Mijn Jodendom, Den Haag, J.N. Voorhoeve 1980; M. Kopuit e.a: : Mijn Israêl, Den Haag, J.N. Voorhoeve 1982; S. Leydesdorff, M. Mock en M. var Weezel (red): Israël: een blanco cheque? Amstelveen, Amphora Books en Amsterdam, Van Gennep, 1983; Y. Koren en C. Vecht: Verzonken Heimwee. Joods hier, Israëlisch daar, Balans, 1988; G. van der Wal (red): Isrä̈l 40 jaar, Amsterdam, Sijthoff, 1988. 
van Israël in Israell toe maar ook binnen de Joodse gemeenschappen buiten Israël ${ }^{131}$. Voor de periode van dit onderzoek 1973-1982 kan worden gesteld dat, hoewel slechts een kleine minderheid van de Nederlandse Joden zich aansloot bij een zionistische organisatie, het overgrote deel als 'pro-Israell' kan worden beschouwd. Bij gebrek aan empirisch onderzoek kunnen geen kwantitatieve gegevens worden gepresenteerd ${ }^{132}$.

Het bestaan en voortbestaan van Israël is voor veel Nederlandse Joden heel belangrijk. Ik kan de stelling van Agsteribbe echter niet onderschrijven dat het bestaan en voortbestaan vañ de staat Israël door vrijwel alle Joden wordt gezien als de essentie en voorwaarde voor hun Joodse identiteit ${ }^{133}$. Voor $z 0^{\prime} n$ generalisatie bestaan geen onderzoeksgegevens. Abram waagt zich niet aan een schatting van de relevantie van de segmenten waaruit zijns inziens de Joodse identiteit kan bestaan. Deze zijn: 1 . Joodse religie, cultuur en traditie. 2 . Shoa en antisemitisme. 3. Israël en zionisme. 4. De nietJoodse cultuur en omgeving. 5. Persoonlijke levensgeschiedenis ${ }^{134}$. De doorwerking van elk van deze vijf segmenten verschillt per individu. Het aardige van deze indeling is dat daarmee het misverstand wordt weggenomen dat alleen een religieuze jood een Joodse identiteit zou kunnen hebben. 'Ook niet-religieuze joden (segment $1 \mathrm{smal}$ ), geassimileerde Joden (segment 4 groot), a-politieke Joden (segment 3 smal), anti-fascistische Joden (segment 2 groot) en andere Joden hebben een Joodse identiteit die in de ervaringsgebieden 1 tot en met 5 geworteld is ${ }^{1,35}$. Voor deze studie is het derde segment - de politieke Joden - van belang. Ik heb de indruk dat in de periode van de Zesdaagse oorlog uit 1967 tot aan de oorlog in Libananon in 1982 in het bewustzijn van veel Joden de zorg om het voortbestaan van Israël belangrijk is geweest. De militair superieure positie van Israël nadien en de herleving van de herinnering aan de Shoa in de jaren tachtig zouden de betrokkenheid met Israël hebben kunnen verflauwen ${ }^{136}$.

131. Gilboa, 1987, kan dat met enquêtecijfers voor de VS aantonen. Voor de VS zie ook: C. Bernstein: The agony over Israel; American Jews face a dilemma: how to criticize the Jewish state without. seeming disloyal, Time 7-5-1990, pp. 24-26. Voor Nederland bestaan daar aamwijzingen voor uit onder meer de publikaties van na 1982 en de gevoerde discussie in het Nieuw Israelietisch Weekblad evenals uit de oprichting van bijvoorbeeld de Vrienden van Vrede Nu en Joods-Palestijnse dialooggroepen.

132. Voor de VS stelde Gilboa, 1987 , pp. 242-248, dat 39 \% zich zionist beschouwt, 12 \% vond dat emigratie natar Israël overwogen zou moeten worden, $88 \AA 96 \%$ was pro-Israël en $80 \%$ zou de vernietiging van Israell 'als dle grootste persoonlijke tragedie in zijn leven zou beschouwen'. Voor Nederlland beschikken we slechts over enkele inmiddels sterk gedateerde gegevens uit: Vedder, 1961 en de dissertatie van Wijmberg, 1967. Volgens Gans wordt vooral de staat Isräl als symbool van het jodendom door zowel Joden als niet-Joden gezien. Gans, 1976, p* 13. In zijn afscheidsrede zei Aschkenasy: 'Beide onbegrijpelijke gebeurtenissen, dle Sjoa en de Terugkeer, bepalen de existentie van unijn generatie .... De staat Isrä̈l geeft existentiële zekerheid'. Aschkenasy, 1989, p. 11

133. Agsteribbe, 1977 , p. 10.

134. Abram, 1984, p. 79.

135. Abram, 1984, p. 80. Hij gaf de Joodse identiteit grafisch weer in de vorm van een cirkel die uit de vijf segmenten bestant. Groot of smal verwijst dan naar de invulling van deze ervaringsgebieden voor de Joodse identiteit; zoals gesteld zal dat per individu verschillen.

136. Von der Dunk situeert de herleving van de Sjoa eerder, namelijk na 1971 ten tijde van het debat over de vrijlating van de 'Drie van Breda' "NRC-Handelsbliad, S-5-1979. 
Op basis van het voorafgaande kom ik tot de conclusie dat de Joodse Gemeenschap in Nederland, te weten de 30.000 Joodse Nederlanders ${ }^{137}$, als een pro-Israël groep zijn te beschouwen. De beînvloedingspogingen werden veelal uitgevoerd door de politieke actiegroepen als CIDI en NZB en de drie joodse Kerkgenootschappen.

In deze studie zal op een aantal plaatsen worden aangetoond dat de directe besluitvormers rekening hielden met de wensen vanuit de Joodse Gemeenschap. Dat rekeninghouden was niet alleen gebaseerd op de pro-Israël gevoelens onder de Joodse Nederlanders, maar vooral op het zoveel mogelijk ontzien van de gevoelens van Joodse medeburgers $^{138}$. Dat laatste behoort tot de naoorlogse politieke cultuur van Nederland die zijn voedingsbodem vond in de Shoa en waarvan het gevolg de grote mate van ontvankelijkheid bij besluitvormers voor de wensen uit de Joodse gemeenschap was. Kortom vanwege deze politieke cultuur is de mogelijke invloed van Joodse Nederlanders groter dan op grond van het getal of electorale sancties $-0,2 \%$ van het electoraat - zou mogen worden verondersteld.

Het opbouwen van een brede basis van steun kan daarnaast veroorzaakt zijn door de grotere mate van vervlechting van de naoorlogse Joden met de Nederlandse samenleving dan voor de oorlog het geval was. De Nederlandse Joden van na de Tweede Wereldoorlog vormen geen gedecimeerde afspiegeling van de vooroorlogse Joodse gemeenschap. De uitroeiing van Nederlandse Joden trof de lagere socialle klassen namelijk nog sterker dan de hogere klassen. Hogere sociale klassen hadden vaak niet alleen meer geld voor het betalen van een onderduikadres maar ook meer contacten met niet-Joden voor het eerder verkrijgen van een onderduikadres ${ }^{139}$. Bovendien hadden Joden uit de hogere klassen soms meer kans door plaatsing op de Barneveldlijst of door het bezit van Palestina papieren naar een concentratiekamp - Bergen-Belsen, Theresienstadt - gedeporteerd te worden dan naar vernietigingskampen als Auschwitz en Sobibor, waardoor de kans op overleving iets groter was ${ }^{140}$. Zo blijkt dat van de na-oorlogse Joodse popu-

137. Schatting in onder meer Yearbook 1977-1978, Encyclopedia Judaica, Keter Publishing, Jeruzalem, 1979 , p. 317; The Jewish Yearbóok 1976, pp. 186-187. Bij de laatste volkstelling van 28 februari 1971 gaven 4.835 personen op tot het Israëlietisch kerkgenootschap te behoren. In 1960 was dat aantal 14.503. Het CBS veronderstelt dat de discussie over de volkstelling ertoe heeft geleid dat in 1971 veel leden wan de Israelietische kerkgenootschappen zich niet als zodlanig hebben kenbaar gemaakt. CBS, $14^{\circ}$ algemene volkstelling, deel 3, kerkelijke gezindte, 's-Gravenhage, Staatsuitgeverij, 1981 , p. 59 .

138. Zoals steeds in deze studie gaat het om de perceptie wan de besluitworners. Van Thijn, de burgemeester van Amsterdam, zei op 29 januari 1989 bij de Auschwitz-herdenking naar aanleiding van het Kamerdebat over de vrijlating van de twee van Breda: 'Ach, men wist zo goed wat beter voor ons was" ... "Het pijnlijke van de afgelopen dagen was dat onze diepste gevoelenst werden afgewogen tegen de beginselen van de rechtsstaat, terwijl wij dachten ons daaraan nu juist te kunnen vastklampen". Dienst Voorlichting van de Gemeente Amsterdam; De Volkskrant, 30-1-1989.

139. Presser, 1965, deel I, pp. 439-447. De Jong, 1978, deel 8, tweede helft, pp. 674-676.

140. Deportatie naar:

$\begin{array}{rr}\text { Auschwitz } & \text { Sobibor } \\ 60.000 & 34.000 \\ \text { Auschwitz } & \text { Sobibor }\end{array}$

Theresienstadt

4.897

Bergen-Belsen

overlevenden uit:

500

19

Theresienstadt

1.273

Bergen-Belsen

4.000

1.100

Encyclopedia Judaica, deel 12, Keter Publishing, Jerusalem, 1971, pp. 988-989; zie ook De Jong, 1978 , deel 8 , tweede hellft, p. 673. 
pulatie uit het onderzoek van Wijnberg $46 \%$ in de Tweede Wereldoorlog was ondergedoken, $6 \%$ uit een vernietigingskamp was teruggekeerd, $20 \%$ uit een concentratiekamp was teruggekeerd, $21 \%$ niet voor deportatie in aanmerking kwam (voornamelijk 'gemengd gehuwden' en 'half Joden') en 7\% de oorlog buiten bezet gebied heeft doorgebracht $^{14 !}$.

Tot slot, de vraag "Wie is Jood" is minder interessant dan politieke controversen in Israël doen vermoeden. Op grond van de joodse traditie (Halagah) is jood 'hij of zij die uit een joodse moeder is geboren en niet tot een andere godsdienst is overgegaan alsook diegene die tot de joodse godsdienst is overgegaan". De Israëlische wet op de terugkeer hanteert een ruimere omschrijving bij immigratie, namelijk de kinderen en kleinkinderen van een jood evenals de echtgenoot van een jood en de echtgenoot van een kind en kleinkind van een jood die niet vrijwillig tot een andere godsdienst zijn overgegaan ${ }^{142}$ * Deze omschrijving omvat ook de kinderen en kleinkinderen van joodse vaders en sluit beter aan bij de eerder naar voren gebrachte Joodse identiteit, daar in deze studie het politieke en niet het religieuze aspekt daarvan relevant is.

\subsubsection{Actiegroepen}

Het wemelt in Nederland van groepen die, veelall wanuit een 'christelijke gedachte', op enigerlei wijze aan Israël steun verlenen en/of zich met het Midden-Oosten bezighouden. Maar liefst 62 organisaties vallen binnen deze categorie. Een overzicht daarvan heb ik elders gepubliceerd ${ }^{143}$. De meeste van deze groepen zijn na 1973 opgericht en waren niet actief betrokken bij de beïnvloeding van het Nederlands buitenlands beleid ten aanzien van het Midden-Oosten. Van de wel actieve groepen is het Israël Comité Nederland (ICN) het meest op de voorgrond getreden. Het kan als illustratie dienen voor vele kleinere groepen met een voornamelijk protestantse achtergrond. Het comité werd in april 1974 opgericht met het doel de latente solidariteit met Israël in Nederland manifest te maken. Het stelde zich zonder voorbehoud achter Israël op in de geest van 'right or wrong my country'. Het telde 4000 leden en beschikte over een eigen kantoor met vier administratieve medewerkers. Het presenteerde zich breed met een comité van aanbeveling waarin onder meer politici van alle politieke partijen - met uitzondering van klein-links - zitting hadden, maar de leden hadden voor het grootste deel een christelijke en in het bijzonder calvinistische achtergrond en het beval als stemadvies het RPF, de GPV en DS ' 70 aan. In het bijzonder bij het verzet tegen de verplaatsing van de Nederlandse ambassade van Jeruzalem naar Tel Aviv was het ICN de actiefste politieke actiegroep in Nederland ${ }^{144}$.

Naast het ICN waren de meest in het oog springende actiegroepen in de periode 19731982 die gericht waren op beilnvloeding van het Nederland buitenlands beleid ten aanzien van het Midden-Oosten: de Nederlandse Zionisten Bond (sedert 1899), het Nederlands Palestina Komitee (sedert 1969), de Werkgroep Israël (van 1973 tot en met 1982)

141. Wijnberg 1967, p. 7; zie ook Vedder 1961 , p. 9.

142. Amendement no. 2 van 19 maart 1970, Rolef 1987 , p. 350.

143. Grünfeld, 1984, pp: 172-175.

144. Grünfeld, 1984, pp. 147-150. 
en het Centrum voor Informatie en Documentatie Israël (sedert 1974). Geen van deze organisaties was gericht op steun aan Arabische landen. Wanneer we hen op een schaal van begrip voor het Palestijnse standpunt versus begrip voor het Israëlische standpunt - hoe gesimplificeerd dat ook is - plaatsen, krijgen we de volgende indeling.

\section{Schema 1.5}

Indeling vijf actiegroepen

Volledig begrip

Palestijns standpunt

Volledig begrip

Israëlisch standpunt

1

2

3

4

5

NPK

WI

CIDI NZB ICN

De Nederlandse Zionisten Bond (NZB) is een organisatie waarvan uitsluitend Joden lid kunnen worden. Slechts 5\% (1500 van de 30.000 Nederlandse Joden) is aangesloten bij deze organisatie die zich ten doel stelt de zionistische idealen in Joodse kring uit te dragen en daarnaast op te komen voor Israël in brede kring. Vóór de Tweede Wereldoorlog vond de Bond veel aanhang in socialistische kring ${ }^{145}$, na de oorlog werd hij meer behoudend. Aan het eind van de jaren zestig kreeg de Bond te maken met verzet van kritische zionisten die voor de Palestijnen aandacht vroegen. In het midden van de jaren zeventig werden achtereenvolgens drie oud-voorzitters van de Werkgroep Israël tot voorzitter van de NZB gekozen, waardoor deze wat opschoof in zijn standpuntbepaling. Toch is de NZB als behoudend te kenschetsen ${ }^{146}$, blijkens bijvoorbeeld de Nederlandse delegatie naar het congres van de Wereld Zionistische Organisatie. De NZB was de enige pro-Israël actiegroep ten tijde van de Oktoberoorlog. Hij heeft in die periode een actieve en coördinerende rol vervuld ${ }^{147}$. Ook nadien heeft de NZB vooral activiteiten ontplooid gericht op de formele politieke elite, veelal in overleg met of tezamen met de drie Joodse kerkgenootschappen voor welke de NZB vaak de politieke spreekbuis was. Deze rol werd echter hoe langer hoe meer door het CIDI overgenomen, waarmee overigens vaak wordt samengewerkt.

Het Nederlands Palestina Komitee (NPK) stelde zich ten doel een politieke campagne te voeren voor steun aan de Palestijnse revolutie op basis van het politieke programma als gedefinieerd door het Palestijnse volk. Met de verandering in de PLO in 1988 wijzigde ook zijn standpunt ten gunste van een 'twee-staten' oplossing, maar daarvan was in de onderzoeksperiode 1973-1982 nog geen sprake. Met het bewust integraal verdedigen van de 'Palestijnse these' en door niet af te wijken van het PLO standpunt was het NPK zich ervan bewust een marginale groep in de Nederlandse samenleving te

145. Zie verder de dissertatie van Giebels, 1975.

146. Bijvoorbeeld de vier Nederlandse afgevaardigden naar het Wereld Congres van Zionisten waren verdeeld over Mizrachi (109 stemmen), Algemene Zionisten (183 stemmen), Cherut (167 stemmen) en de progressieve lijst Meyers (241 stemmen). Interview Broers op 6 april en 6 juli 1982.

147. Zie 2.2.4.1. 
zullen blijven. Met een van de PLO afwijkend standpunt ${ }^{148}$ zou het NPK enerzijds wel eerder geaccepteerd worden in de Nederlandse samenleving, maar anderzijds zou dat zowel tot werdeeldheid binnen het NPK leiden als problemen in de contacten met de Palestijnen opleveren. Oud-voorzitter Hendriks stelde: 'Je kunt moeilijk iets anders uitdragen dan wat de Palestijnen zeggen. Het is toch al moeilijk Palestina Komitee te $z_{i j n}{ }^{\prime 49}$. De aanhang bestond voornamelijk uit studenten uit Amsterdam en Nijmegen. Met de in Nederland wonende Palestijnen, verenigd in de Vereniging voor Palestijnen in Nederland en de Palestijnse Vrouwenunie, werd nauw samengewerkt. Later ontstond - na de onderzoeksperiode - een dialooggroep tussen Palestijnen en Joden in Nederland. Partijpolitieke contacten had het NPK met de PSP, de PPR en de CPN. Het NPK beoogde een meningsverandering binnen de PvdA tot stand te brengen, waar het in de loop der tijd steeds beter in slaagde. Het NPK meende dat beïnvloeding van de formele politieke elite niet tot resultaat zou leiden; hij richtte zich meer op de 'ontmythologisering' van Israël in de publieke opinie.

Het velle malen afgewezen NPK-verzoek voor overheidssubsidie maakte duidelijk hoe controwersieel over het NPK werd gedacht. Dit verzoek tot de Nationale Commissie voorlichting en bewustwording Ontwikkelingssamenwerking - NCO - werd zelfs onderwerp van beraad in de ministerraad. De aanvraag uit 1976 betrof subsidie voor de aanstelling van een tweede full-time medewerker bij het NPK. De NCO gaf een positief advies. Minister Pronk vroeg vervolgens advies aan het Adviescollege voorlichting en bewustwording Ontwikkelingssamenwerking. Dit adviseerde in meerderheid - zes tegen, twee voor - negatief. Minister Pronk nam in zijn afwijzing van de subsidieaanvraag de argumentatie van dit Adviescollege over. Hij wees erop dat het NPK in Nederland niet aanvaard was. Tevens deelde Pronk mee dat hij de gevoelens van Joodse bevolkingsgroepen in en buiten Nederland zwaar had laten wegen ${ }^{150}$.

In een interview met het Palestina Komitee vertelde Pronk twee jaar later dat hij destijds de subsidieverlening met een positief advies aan het kabinet had voorgelegd. Volgens hem waren echter alle vijftien andere ministers tegen subsidieverlening en heeft hij daarom de aanvraag afgewezen ${ }^{15 !}$.

Nog voor de minister had beslist, werden tot driemaal toe vragen vanuit de PvdA, PSP en VVD fracties in de Tweede Kamer over deze kwestie aan hem en zijn collega van Buitenlandse Zaken gesteld ${ }^{152}$. Hoewell een jaar later het Adviescollege over een nieuwe aanvraag wel positief adviseerde ${ }^{153}$, weigerde minister De Koning aan 'een

148. Interview met Hendriks op 11 februari 1983.

149. Interview met Hendriks op 11 februari 1983.

150. Internationale Samenwerking, 4 maart 1977 , Brief Adviescollege aan minister Pronk van 7 januari 1977; Brief wan minister Pronk aan Adviescollege van 31 januari 1977; Internationale Samenwerking, Informatie DGIS no. 4, 1 februari 1977.

151. Nieuwsbrief Palestina Komitee, (7)april 1979, no. 3, p. 29.

152. Aanhangsel 1976-1977, Kamervraag no. 350, 403/610, 404, vragen van 16 en 18 november 1976 en antwoorden van 2 en 14 december 1976 en 1 februari 1977.

153. Volgens het Adviescollege had het NPK afstand genomen van artikel 6 wan het PLO Handvest, te weten: "Joden die permanent in Palestina woonden voor het begin van de zionistische invasie, worden geacht Palestijn te zijn'. Minister De Koning deelde de mening van het Adviescollege niet. 
club die op de vernietiging van de staat Israël gericht is'154 overheïdssteun te ge$v^{2} n^{155}$. De hernieuwde aanvraag van 1979 gaf een herhaling van zetten te zien; De Koning wees de aanvraag af. Hij stelde dat de oprichting van de staat Israël aan de Joodse medeburgers na de Tweede Wereldoorlog een zekere geborgenheid bood. Hij begreep en respecteerde de gevoelens van verontrusting onder de Joodse 'lotgenoten' indien deze geborgenheid opnieuw ter discussie werd gesteld ${ }^{156}$.

Vanaf 1980 zou bij programsubsidie niet langer de minister maar het NCO de eindbeslissing nemen. Subsidie werd aangevraagd voor een project - 'De Palestijnen in ontwikkelingsperspectief' - waarbij de pro-Palestijnse (NPK, Pax Christi, Kerk en Ontwikkelingssamenwerking) en de pro-Israëlische groepen (Nederlands Israëlietisch Kerkgenootschap, Werkgroep Israël, de vier Israël-moderamina) betrokken werden. De proIsraël groepen haakten af vanwege de positie van het NPK, twee van de drie geraadpleegde hoogleraren Volkenrecht en ook de minister adviseerden negatief aan het NCO en deze laatste besloot het project niet voor subsidiëring aan de algemene vergadering van het NCO voor te dragen ${ }^{157}$.

Het controversiële karakter van het Palestina Komitee kwam ook naar voren bij de weigering van het College van Burgemeester en Wethouders van Amsterdam het een vergunning te verlenen om te collecteren. De aanvraag werd gedaan door het Medisch Komitee Palestina waarmee het Palestina Komitee nauw verbonden was. De collecte was bedoeld voor 1975, 1976 en 1977 ten behoeve van de Palestijnse Rode Halve Maan. Steunverlening daaraan was ook een van de doelstellingen van het Palestina Komitee. Tegen de weigering uit 1976 werd beroep aangetekend bij de Afdeling Rechtspraak van de Raad van State die het beroep op 19 oktober 1978 verwierp ${ }^{158}$. Indertijd schonk de regering niet rechtstreeks geld aan de Palestijnse Rode Halve Maan ${ }^{159}$. Naar aanleiding van de aanvraag van het Medisch Komitee Palestina voor een collectevergunning in 1979 - ditmaal niet voor de Palestijne Rode Halve Maan maar voor de culturele Ghassan Kanafani stichting - ontstond een uitgebreid debat in de Amsterdamse gemeenteraad. De aanvraag werd door het College opnieuw afgewezen daar het streven van de organisatie rechtstreeks was gericht tegen het bestaan van de staat Israël, waar-

154. Interview in NIW van 7-7-1978.

155. NRC-Handelsblad van 26-6-1978 en 4-7-1978, Het Parool van 26-6-1978 en 4-7-1978, Trouw van 27-6-1978, Algemeen Dagblad van 27-6-1978, NIW van 30-6-1978, De Volkskrant van 15-7-1978, De Waarheid van 4-7-1978; Brief van mimister de Koning van 21 juni 1978 aan NCO uit IS Informatie DGIS van 8 januari 1980; Kamervraag no. 1257 in Aanhangsel 1977-1978 vraag van 18 mei 1979 en antwoord van 9 juni 1978.

156. Brief van 9 november 1979 en 8 februari 1980 van minister De Koning alan NCO en van 3 januari 1980 van NCO aan minister De Koning, uit IS Informatie DGIS, no. 4, 8 februari 1980.

157. Brief van 3 januari 1980 aan de NCO aan minister De Koning; gesprekken vonden onder meer plaats op 26 juni 1979 en 5 juni en 18 nowember 1980 . Daarvan werden verslagen gemualkt door de NCO. Brieven van de hoogleraren Kooijmans (4 november 1980, Röling (7 november 1980) en De Waart (2 november 1980) aan de NCO. Brief van 13 februari 1981 van minister De Koning aan de NCO. Brief van 20 februari 1981 van de NCO aan Pax Christi en de Werkgroep Kerk en Ontwikkelingssamenwerking. Zie ook het artikel van Siekmann, 1982, pp. 336-338 en 340.

158. Administratieve Rechtspraak Overheidsbeschikkingen; Alphen aan de Rijn, Samson Uitgeverij 1976, deel 4 , pp. 517-524.

159. Antwoord wan de regering op 13 oktober 1976 op een wrag van bet kamerlid Van der Spek. 
door alleen al het collecteren tot een 'aantasting van heel diepe gevoelens' voor een groot aantal stadgenoten zou leïden. Door de gemeenteraad werden ook voorstellen een eventuele collecte-aanvraag in de toekomst te honoreren, verworpen ${ }^{160}$. Deze beschrijving heb ik hier naar voren gebracht omdat ermee wordt geillustreerd dat zelfs een aanvraag tot collecteren op hevig verzet stuitte, een tegenwerking die andere actiegroepen niet ondervonden ${ }^{161}$. Tevens werd hierboven een tijdsbeeld geschetst dat na de veranderingen binnen de PLO wit 1988 ook tot een ander Nederlands beleid leidde. Find september 1989 heeft het ministerie van Buitenlandse Zaken 1,2 miljoen gulden aan de Palestijnse Rode Halve Maan geschonken ${ }^{162}$. Alleen de VVD-fractie uitte hierop nog enige kritiek ${ }^{163}$.

De Werkgroep Israël (WI) werd in december 1973 opgericht door voornamelijk linkse jongeren; de aanhang bestond ook grotendeels uit studenten. Binnen de pro-Israël groepen stond de WI het meest kritisch ten opzichte van het Israëlische beleid. De WI koos van meet af aan voor een 'twee-staten' model en ging daarbij uit van zowel het bestaansrecht van de staat Israël als het recht op nationale zelfbeschikking van de Palestijnen. Dat was in 1973 nog een omstreden uitgangspunt maar in 1982 bij de opheffing van de WI algemeen aanvaard in politiek Nederland. Dat lijkt een succesvol resultaat voor een actiegroep maar is veeleer het resultaat van een - niet primair beoogde - kritischer houding ten aanzien van Israë $1^{164}$. De WI legde zich toe op het handhaven van de solidariteit met Israël onder behoud van het opkomen voor de rechten van de Palestijnen. De twee behoorden in haar visie geen tegenstelling te zijn; bovendien moest worden voorkomen dat alleen 'politiek-rechts' nog steun aan Israël zou geven. De beoogde brugfunctie tussen pro-Israël groeperingen en de linkse beweging in Nederland kwam echter niet tot stand. Onvrede met het beleid van de regering-Begin bewerkstelligde de opheffing van de Werkgroep Israël eind 1982. De steun aan de Israëlische vredesbeweging Shalom Achshav werd in Nederland voortgezet door de Stichting 'Vrienden van Vrede $\mathrm{Nu}$ '.

In de periode 1973-1982 verschilden de WI en NPK van opvatting over het principiële punt van het bestaansrecht van Israël. De eerste beschouwde het zionisme als de nationale bevrijdingsbeweging van het Joodse volk en de tweede streefde naar vervanging van het zionistische staatsbestel. De twee actiegroepen werkten elkaar tegen. Zo werd mede door toedoen van de WI de subsidie-aanvraag van het NPK voor 1980 bij het NCO niet gehonoreerd, zoals we zojuist constateerden. Het miet toelaten van de WI tot de Bedrijfs- en Schooljeugd (BSJ) - een op educatie gericht samenwerkingsverband van enkele actiegroepen waar onder meer het NPK deel van uitmaakte - leidde onder andere

160. Gemeenteblad, Afdeling 1, 1979, nr. 252 pp. 379-382; Gemeenteblad, Afdeling I, 1979, nr. 270, pp. 416-417; Gemeenteblad, Afdeling II, 1979, nr. 49, pp. 473-501; Brief van Burgemeester en Wethouders axn Medisch Komitee Palestina van 23 juli 1982.

161. Zo werd aan de Werkgroep Israël in 1979 door de gemeente Amsterdam toegestaan om zelfs op de Dam een demonstratieve bijeenkomst te houden ter viering van de ondertekening van het IsraëlischEgyptisch vredesverdrag.

162. NRC-Handelsblad van 23-9-1989.

163. ANP, radio, 25-9-1989.

164. De Volkskrant, 6-8-1982; Jaarverslag Werkgroep Israël over 1981 van juli 1982, pp. 1-2. 
tot beëindiging van de subsidie aan de BSJ door de Centrale Kerkeraad van de Hervormde Gemeente te Amsterdam en de afwijzing door de minister van een door de BSJ aangevraagde NCO-subsidie. De argumentatie van de minister was nagenoeg gelijk aan die welke hij bij zijn afwijzing voor subsidie aan het NPK in 1979 gebruikte. Ook deze kwestie heeft veel stof doen opwaaien en zowel Kamerleden als Amsterdamse gemeenteraadsleden bemoeiden zich ermee. Naast de minister van Ontwikkelingssamenwerking werden ook zijn topambtenaar - de directeur-generaal internationale samenwerking - en de Raad van State erbij betrokken ${ }^{165}$.

Het Centrum voor Informatie en Documentatie Israël (CIDI) werd in april 1974 opgericht. De primaire taak van het CIDI is het geven van voorlichting aan het Nederlandse publiek. Daarbij richtte het zich op beïnvloeding van de publieke opinie en van politici, waardoor het als een pro-Israël actiegroep beschouwd kan worden. Door sommigen werd het CIDI gezien als een spreekbuis van de Israëlische ambassade. Daarbij werd evenwel over het hoofd gezien dat het CIDI ook in openbare verklaringen het Israëlische beleid een aantal malen kritiseerde zoals bij de annexatie van de Golanhoogvlakte, de uitzetting van Palestijnse burgemeesters en de inval in Beiroet. Vanuit de rechterzijde in de Joodse gemeenschap en zionistische beweging kwam in zulke gevallen juist kritiek op de opstelling van het CIDI. De huidige directeur, Naftaniel, en de stafmedewerkers zijn afkomstig uit de meer kritische pro-Israël actiegroepen als de 'Werkgroep Israël' en 'Vrienden van Vrede Nu'. De kritiek neemt niet weg dat het CIDI als de belangrijkste woordvoerder over Israël namens de Joodse en pro-Israël organisaties wordt gezien. Het coördineert vaak de activiteiten op dit gebied. Zo was het bijvoorbeeld betrokken bij de oprichting van het OJEC. Door de media wordt het vaak voor commentaar benaderd. Invloed is altijd moeilijk aan te tonen maar in vergelijking met de hiervoor genoemde groepen kan gesteld worden dat de invloed van het CIDI ten aanzien van het Nederlandse Midden-Oostenbeleid het grootst is. De invloed bleek onder meer toen op grond van het door het CIDI gepubliceerde "Zwartboek over de Arabische boycot' een parlementaire onderzoekscommissie werd ingesteid ${ }^{166}$. De vergelijking van partijprogramma's door het CIDI voor de Kamerverkiezingen wordt nauwlettend gevolgd en politici trachten zich tijdens verkiezingsbijeenkomsten zoveel mogelijk pro-Israël voor te doen ${ }^{167}$. De druk van de partijbesturen van CDA en D'66 op hun partijgenoten af te zien van een bijdrage voor een door de PLO-vertegenwoordiger te houden bijeenkomst, vond plaats nadat deze besturen een brief van het CIDI hadden ontvangen ${ }^{168}$. Bij mijn onderzoek bleek dat alle geinterviewde politici bekend waren met de activiteiten van het CIDI. Van der Klaauw zei bijvoorbeeld: 'Je wist dat Naftaniel een bepaald standpunt had en als je maar het woord PLO in de mond nam dan

165. Zie voor een meer gedetailleerde behandleling Grünfeld 1984, pp. 26-28.

166. Ook na instelling van de bijzondere Kamercommissie onder leiding van Van den Bergh werd het beleid ter zake gevolgd en actie ondernomen; een interessant onderwierp dat voldoende stof biedt voor een aparte dissertatie.

167. Zie verslag in De Volkskrant van 29-8-1989.

168. De brief aan de Raad van Kerken zou door het OJEC geschreven zijn; NRC-Handelsblad 7 en 8 novernber 1989; het krantebericht malkt geen melding of het bestuur van de PvdA werd benaderd. 
stond hij al aan de bel te trekken, dat is logisch'169. Op zijn minst zal daar enige anticiperende invloed van zijn uitgegaan.

\subsubsection{Het bedrijfsleven}

De groei van de Nederlandse export naar de Arabische wereld steeg in de periode 19731982 met $712 \%$ terwijl de totale Nederlandse export in die periode met $265 \%$ steeg. De Nederlandse export naar Israël steeg met $150 \%$ hetgeen een relatieve achteruitgang betekent. De cijfers zijn in Bijlage 3 opgenomen; daaruit blijkt eveneens dat, hoewel de export naar bepaalde landen - bijvoorbeeld Saoedi-Arabië van ruim honderdzestig milloen naar ruim twee en een half miljard gulden - gigantisch steeg, het aandeel van het Midden-Oosten in het totale Nederlandse exportpakket beperkt bleef tot $5,3 \%$. Ofschoon een beperkt aandeel, was wel sprake van een verdubbeling in de groei. De periode $1973-1982$ gaf een relatieve groei van $2,6 \%$ tot $5,3 \%$ te zien. Bepaalde takken van de industrie - de bouw, de baggersector en telecommunicatie - waren sterk gericht op export en investeringen in de Arabische wereld die beschikte over de zogenaamde petro-dollars, maar de gevoeligheid voor de Nederlandse samenleving voor deze export was beperkt en van kwetsbaarheid was geen sprake. In de volgende hoofdstukken zal daarop worden teruggekomen en zal de rol van de werkgevers worden behandeld. Anders lag de situatie ten aanzien van de import uit het Midden-Oosten. Deze bestond grotendeels uit olie. Als gevolg van het olie-embargo kwam Nederland wel in een kwetsbare positie. De ingevoerde olie was, deels direct en deels na raffinage, bovendien een zeer belangrijk exportartikel voor Nederland. Van de ingevoerde olie werd namelijk weer meer dan $80 \%$ geëxporteerd ${ }^{170}$. De Nederlandse samenleving was niet alleen gevoelig voor de prijsverhoging van de olie maar bovenal kwetsbaar bij het langdurig uitblijven van de olietoevoer. In het volgende hoofdstuk over het olie-embargo zal op deze kwestie uitgebreid worden ingegaan. Dan zal tevens de vraag worden beantwoord in hoeverre de kwetsbare positie van Nederland heeft geleid tot een wijziging in de Néderlandse opstelling ten aanzien van het Arabisch-Israëlisch conflict.

De Nederlandse vakbeweging stond in internationaal verband aan de kant van Israël en heeft Israël ook steeds gesteund in internationaal - ILO (International Labour Organization) - verband. Er bestonden nauwe kontakten tussen de Israëlische en Nederlandse vakbeweging en die kontakten waren er niet met de Arabische vakverenigingen die - met uitzondering van Tunesie en Libananon - niet waren aangesloten bij het Internationaal Verbond van Vrije Vakverenigingen. In 1973 werd door de drie Nederlandse vakcentrales nog een pro-Israël verklaring uitgegeven, maar verder hebben zij zich niet met het Midden-Oostenconflict beziggehouden. Alleen daar waar vakbondsrechten in het geding kwamen, zoals bij de Arabische boycotbepalingen inzake de 'niet-jood'-verklaring en de 'negatief-goederen'-verklaring hebben zij gestreefd naar een verbod op de toepassing van deze boycotbepalingen in Nederland. Zij steunden daarin het CIDI en stonden daarbij - volgens hen - tegenover de werkgeversorganisaties ${ }^{171}$.

169. Interview met Van der Klaauw op 31 augustus 1989.

170. Gegevens op basis van 1972.

171. Interview met Etty op 26 april 1982; brief van de FNV van 11 januari 1983 en 31 ste jaarverslag. NVV, 1973, pp. 98-99. 


\subsubsection{Politieke partijen}

De inhoud van de standpunten van de politieke partijen en de veranderingen in hun partijprogramma's over de periode 1973-1982 ten aanzien van het Midden-Oosten zullen in de volgende hoofdstukken worden behandeld. Hier wordt enige achtergrondinformatie omtrent de betekenis van de Midden-Oostenkwestie voor de politieke partijen verschaft. De Midden-Oostenkwestie heeft nooit eenzelfde rol gespeeld in de verkiezingstijd als bijvoorbeeld de kruisrakettenkwestie die tot polarisatie in de Nederlandse politieke partijverhoudingen leidde. Zo stelde het Tweede Kamerlid Brinkhorst:" 'Het MiddenOostenbelleid is in Nederland nooit een gepolariseerd beleid geweest, gelukkig niet ${ }^{\text {172 }}$. De toewoeging - 'gelukkig niet' - geeft aan dat een polarisatie over het Nederlandse Midden-Oostenbeleid door hem als ongewenst werd gezien. Enkele politieke partijen waren intern nogal verdeeld over het Midden-Oostenconflict. Een polarisatie tussen politieke partijen is dan ook minder goed mogelijk. Naar de mening van Van der Klaauw was het voor de PvdA in de oppositie vanwege de interne verdeeldheid ook moeilijker met uitgesproken standpunten te komen en beperkte de PvdA-fractie zich tot algemeenheden ${ }^{173}$. De verdeeldheid over het Midden-Oosten binnen de politieke partijen was overigens geen Nederlands verschijnsel maar deed zich ook elders in Europa voor $^{174}$.

172. Handelingen Tweede Kamer, zitting 28 augustus 1980, p. 5965.

173. Interview met Van der Klaauw op 31 augustus 1989.

174. Interview met Patijn op 7 december 1981 .

Binnen de Britse Labourpartij bijvoorbeeld bevonden zich ook verschillende stromingen met tegenover elkaar staandle opvattingen ten aanzien van het conflict. Ook bestond er verschil in opvattingen onder de kjezers van Labour en Conservatives waardoor hef electoraat van beide partijen nauwelijks verschilde in voorkeur woor een van de partijen in het conflict, hetgeen eveneens in West-Duitsland het geval was.

Opinie-onderzoek van november 1973 in het Verenigd Koninkrijk en de Duitse Bondsrepubliek in percentages naar voorkeur voor:

$\begin{array}{lllll} & \text { Arabieren } & \text { Isrä̈liërs } & \text { Geen van beide } & \text { G } \\ \text { Conservatives } & 5 & 56 & 29 & 11 \\ \text { Labour } & 4 & 44 & 33 & 19 \\ \text { Liberal } & 5 & 48 & 33 & 13 \\ \text { CDU en CSU } & 4 & 43 & 44 & 8 \\ \text { SPD } & 6 & 39 & 47 & 7 \\ \text { FDP } & 8 & 51 & 35 & \end{array}$

Bron: De Boer, 1987, pp. 93 em 111.

Anderzijds was het beleid van de Labourregering onder Wilson en Callaghan veel sterker pro-Israël dan van de conservatieve regering onder Heath. Enige onderlinge solidariteit tussen socialisten - tot 1977 werden de Israëlische kabinetten gedomineerd door socialisten - geeft enige verklaring. Daarnaast bleek dat met het aan de macht komen van een socialistische president in 1981 in Frankrijk het Franse beleid in een meer pro-Israelische richting veranderde. 
De verdeeldheid binnen politieke partijen zou de continuïteit in het buitenlands beleid ten aanzien van het Midden-Oosten bevorderd kunnen hebben. Verdeeldheid binnen een politieke partij kan leiden tot een minder uitgesproken partijstandpunt waardoor die partij zich over dat onderwerp niet kan profileren ten opzichte van andere partijen. Niet alleen ligt daarom beleidswijziging bij veranderde samenstelling van het kabinet minder voor de hand; verdeeldheid kan tevens leiden tot een eerder op aanpassing aan de externe omgeving gericht buitenlands beleid (de inschikkelijke aanpassing). Bij een verdeeld binnenland zal eerder een wijziging in het beleild op grond van invloeden uit de externe omgeving worden aanvaard dan in een situatie waarin een hecht verzet in het binnenland tegen de beoogde beleidswijziging bestaat. In hoeverre deze veronderstelling voor Nederland opgaat, zal in deze studie aan de hand van het Nederlandse beleid ten aanzien van het Midden-Oosten over de periode 1973-1982 worden onderzocht.

In deze studie zal naar voren worden gebracht dat na 1977 minder sprake is geweest van verdeeldheid binnen politieke partijen en dat de 'links-rechts dimensie' ook inzake standpunten over het Arabisch-Israëlisch conflict is gaan gelden. Dat zal tot gevolg kunnen hebben dat een kabinetswisseling - eerder dan in het verleden - tot een wijziging in het beleid ten aanzien van het Arabisch-Israelisch conflict leidde. Ook in dat geval kan de bimnenlandse verdeeldheid voortbestaan - niet langer binnen maar tussen politieke partijen - waardoor een op aanpassing aan de externe omgeving gericht buitenlands beleid in het binnenland aanvaard wordt. Kortom, de houding van binnenlandse actoren is niet alleen van invloed op de totstandkoming van het buitenlands beleid, maar bepaalt tevens de vrijheid van handelen van de regering in internationaal verband. Op grond van het in deze paragraaf naar voren gebrachte zou de vrijheid van handelen voor de Nederlandse regering in internationaal verband ten aanzien van het Arabisch conflict in de bestudeerde periode moeten zijn toegenomen.

\subsubsection{De media}

De Nederlandse massamedia hebben veel aandacht besteed aan het Arabisch-Israëlisch conflict. Uit een onderzoek over de periode april-juni 1977 kwam naar voren dat inzake het buitenland de berichtgeving in Nederland over het Midden-Oosten op de tweede plaats kwam; slechts voorafgegaan door informatie uit andere landen in West-Euro$\mathrm{pa}^{175}$. Slechts weinig Nederlandse correspondenten bevonden zich in de Arabische wereld, al is daar na 1979 enige verbetering in ontstaan. Daarentegen heeft nagenoeg elke omroep en krant een correspondent in Israël. Zo beschikt Het Parool na de inkrimping in 1989 nog slechts over éen vaste correspondent in het buitenland, namelijk in Israell ${ }^{176}$. Dat is wellicht een wat vreemde prioriteit maar het geeft aan hoezeer deze redactie waarde hecht aan berichtgeving uit Israël. Het Nederlandse publiek wordt uitgebreid vanuit Israël geïnformeerd. Daarbij is echter nog weinig gezegd over de

175. Dit werd gemeten naar auntal items, tijdsduur van radio en televisie en kolombreedte van drie kranten, waarbij buitenlandse persbureaus voor $50 \%$ de bron van de berichtgeving vormden. Een wereld vol mieuws - inhoudsanalyses wan de buitenlandse berichtgeving in een aantal kranten over de jaren $1979,1969,1959$ en 1949, Werkgroep Massacommunicatie RUU, Utrecht, september 1981, pp. 146-149.

176. Interview hoofdredacteur Van der Zee van Flet Parool in De Volkskrant van 2-9-1989. 
inhoud van de geboden informatie. De informatie kan namelijk ook zeer kritisch over het Israëlisch beleid zijn. De vele informatie betekent enerzijds dat de lezer enigszins vertrouwd raakt met hetgeen zich in Israël afspeelt, maar kan anderzijds ook tot een vertekening leiden. Een vertekening kan voortkomen uit een discrepantie tussen norm en gedrag. Enerzijds wordt san Israël verwacht zich naar westerse normen te gedragen. Anderzijds stelt Israël dat zijn gedrag beantwoordt aan een actie-reactie patroon zoals dat in het Midden-Oosten zou gelden. De Israëlische schrijver Amos $\mathrm{Oz}$ was het niet met deze laatste opvatting eens. Hij vond het huichelachtig wanneer Israëli's klaagden over kritiek van anderen op hun optreden als een 'wildeman' en tegelijkertijd zelf met hoogdravende morele argumenten wapperden ${ }^{17}$. De hogere verwachtingen ten aanzien van het gedrag van Israël bestonden niet alleen bij derden, maar werden ook door Israël zelf in het leven geroepen.

De enige Joodse staat in de wereld heeft alleen al om die reden een aantal unieke rolopvattingen die verder gaan dan het behartigen en beschermen van de Israëlische burgers. Bekende voorbeelden daarvan waren het Eichmannproces in Jeruzalem en de bevrijding van het Franse verkeersvliegtuig in Entebbe ${ }^{178}$. Ik ben het dan ook niet eens met de bewering dat het aanleggen van andere maatstaven voor Israël dan voor andere staten als een uitingsvorm van antisemitisme moet worden beschouwd ${ }^{179}$. In de discussie over de - kritische - berichtgeving door de media over Israël werd kritiek op Israël wel eens - zie 2.1.4.5 - als een vorm van antisemitisme opgevat. Eerder in deze studie werd aandacht besteed aan het onderscheid tussen antisemitisme en antizionisme. In ieder geval heerst in Nederland geen taboe meer op kritiek op Israël zoals vóór 1973. Kritiek op Israël wordt dan ook niet langer als een vorm van antisemitisme bestempeld en in de kiem gesmoord. Een inhoudsanalyse omtrent de berichtgeving over Israël en het beeld dat daaruit zou voortvloeien ontbreekt in Nederland. Een dergelijk onderzoek zou een antwoord kunnen geven op de vraag of over Israël een stereotype beeld door Nederlandse media wordt gegeven en of die beeldvorming op een antisemitische houding zou zijn gebaseerd. In de volgende hoofdstukken zal ik wel de berichtgeving over de bestudeerde onderwerpen aan de orde laten komen en ingaan op de vraag in hoeverre de media van invloed zijn geweest op het gevoerde beleid. Tot slot valt te wijzen op de bijzondere plaats binnen de media van het Nieuw Israëlietisch Weekblad (NIW). Dit weekblad heeft pas na de Tweede Wereldoorllog het zionisme gesteund en kon na 1945 volgens Lipschits zelfs gezien worden als 'een strijjorgaan voor het zionisme" ${ }^{180}$. Het Nederlandse beleid ten aanzien van het Midden-Oosten wordt in dit weekblad nauwlettend gevolgd en van commentaar voorzien. In 1980 werd bijvoorbeeld in het NIW het Nederlandse besluit de ambassade in 1980 van Jeruzalem

177. Amos Oz, 1984, p. 118.

178. Eichmann werd veroordeeld voor daden die werden begaan toen de staat Israël nog niet bestond. Zie voor de Israëlische actie in Entebbe 1.4.2.1.

179. Zie recensie Van Amerongen, 1989 pp. 405: 'Sommige "progressieven' beoordelen Israëls daden en beleidsmaatregelen anders dan die van welke andere staat dlan ook omdat het een Joodse staat is. Dit stellen van hogere eisen aan Israël is volgens Seidel ook een vorm van anti-semitisme. Ik ben het met haar eens.'

180. Lipschits, 1966, p. 253, zie hoofdstuk X: Het NIW en het zionisme, van felste bestrijder tot grootste verspreider pp. 228-253. 
naar Tel Aviv te verplaatsen fel veroordeeld ${ }^{131}$. De regering maakte bij haar beslissing gewag van de aanhoudende druk op Nederland, "ten dele met een ultimatief karakter" vanuit islamitische landen vanwege de plats van de ambassade in West-Jeruzalem ${ }^{182}$. Het commentaar van het NIW luidde "Het besluit van de regering is schokkend, schokkender nog is haar motivering: ${ }^{383}$. Deze motivering werd evenwel opgenomen op advies van de Israellische regering. Minister Van der Klaauw vroeg indertijd de Israëlische ambassadeur, na duidelijk te hebben gemaakt dat de ambassade verplaatst moest worden, "hoe doen we dat nou op de beste manier voor onze relaties". Na overleg met Jeruzalem zei deze 'onze voorkeur is dat je zegt onder druk van de Arabieren te staan want dan kunnen wij een verklaring uitgeven dat zelfs zo'n goede vriend als Nederland daarvoor moet wijken'. De Israellische voorkeur werd overgenomen en daarop werd de beslissing van Nederland in Israël rustig opgevat; "ik ben wel een beetje diplomaat" voegde Van der Klaauw er aan toe ${ }^{184}$. In het parlement was kritiek op de motivering en in een motie brachten Van der Stoel en Brinkhorst dit naar voren ${ }^{185}$. Die motie werd evenwel werworpen ${ }^{186}$ : Ook in het periodiek wan de pro-Israëlische groep NZB werd de regering deze motivering verweten ${ }^{187}$, maar andere pro-Israellische groeperingen als het ICN en het CIDI steunden de regering op dat punt ${ }^{1888}$.

Dit voorbeeld geeft aan dat een op instigatie van Israël opgenomen passage - hetgeen niet bekend was noch in het parlement bekend werd gemaakt - door groeperingen die het voor Israël opnamen niet werd verwelkomd. Tevens blijkt hieruit dat bij een voor Israël ongunstige beslissing, Israêl door de Nederlandse regering werd geraadpleegd over de bekendmaking van dat besluit. Het handhaven van goede relaties tussen Nederland en Israel stond daarbij aan de zijde van de Nederlandse besluitvormers voorop.

In dit hoofdstuk is een uiteenzetting gegeven van het doel en van de probleemstelling van de studie.

Het theoretisch kader voor deze studie is ontvouwd. In de volgende hoofdstukken zal de toepassing plaatsvinden. Het onderscheid tussen buitenlandse politiek en internationale politiek leidt ertoe dat de chronologische ontwikkeling niet steeds gevolgd zal worden. Soms wordt op ontwikkelingen vooruitgelopen en soms vindt een herhaling plaats. De standpunten wan binnenlandse groeperingen over het Arabisch-Israëlisch conflict zijn in het laatste deel -1.4. - van dit hoofdstuk behandeld.

In de volgende hoofdstukken zal worden onderzocht of zij op de totstandkoming van het Nederlands belleid ten aanzien van het Arabisch-Israelisch conflict in de periode 19731982 invloed uitoefenden.

181. NIW van 22-8-1980, 29-8-1980 en 5-9-1980.

182. Tweede. Kamer, zitting $1970-1980,16.300$ no. 1.

183. NIW van 29-8-1980.

184. Interview met Van der Klauaw op 31 augustus 1989.

185. Tweede Kamer, zitting 1979-1980, 16300 no, 4.

186. PvdA, D'66, PSP, CPN, BP, GVP, SGP stemden voor.

187. Joodse Wachter, oktober 1980 , pp. 6-7.

188. Speciale uitgave over Jenuzalem van het Contactbllad van het ICN van 25 september 1980 pp. 31-32 over brief aan de regering van 1 september 1980 ; Interview met Naftaniel op 21 september 1982. 


\subsection{Oktoberoorlog in het Midden-Oosten en resolutie 242}

Op zaterdag 6 oktober 1973 overschreden Egyptische en Syrische legereenheden de bestandslijnen met Israël. Hiermee werd de Oktoberoorlog ingezet. Aan Israëlische zijde wordt deze oorlog ook wel de Yom-Kippoer (Grote Verzoendag)-oorlog en aan Arabische zijde de Ramadan-oorlog genoemd op grond van het tijdstip van het begin van de gevechtshandelingen. Israël werd door deze aanval volledig verrast en in het defensief gedrongen. De opmars aan Egyptische zijde - oversteek van het Suezkanaal en doorbraak van de Israëlische verdedigingslinie (Bar-Lev linie) aldaar - en aan Syrische zijde - doorstoten tot op tien kilometer van het meer van Tiberias - verliep voorspoedig. Pas na tien dagen kon Isräl zich wan de eerste klap herstellen en de aanval een halt toeroepen. $\mathrm{Na} 19$ oktober gingen de Israëli's zelfs tot de tegenaanval over en werden de Egyptische en Syrische strijdkrachten teruggedrongen. Een door de Verenigde Staten en Sovjetunie ontworpen resolutie voor de Veiligheidsraad op 25 oktober 1973 waarmee de beide partijen instemden, maakte een einde aan de hevige gevechten waarbij aan beide zijden zware verliezen waren geleden. Aan Egyptische, Syrische en Israëlische zijde sneuvelden respectievelijk $15.000,3.500$ en 2.700 mensen ${ }^{1}$.

Om de strijd te kunnen voortzetten en in hun voordeel te beslechten hadden beide partijen dringend behoefte aan wapenleveranties tijdens de oorlog. De wapenluchtbrug vanuit de Sovjetunie naar Egypte en Syrië kwam al 9 oktober op gang ${ }^{2}$; de wapenluchtbrug vanuit de Verenigde Staten naar Israël liet aanvankelijk op zich wachten ${ }^{3}$. Volgens Sheehan wilde Kissinger namelijk vanuit een staakt-het-vuren ter plaatse goede kansen voor de Amerikaanse diplomatie scheppen. Kissinger gaf echter de schuld aan het Pentagon om zodoende te voorkomen dat de Israëlische ambassadeur in de VS de Amerikaanse Joden tegen het talmen van de regering kon mobiliseren. Kissinger was van mening dat geen van de partijen dominant mocht zijn teneinde tot een akkoord te komen. Slechts vanuit een positie van evenwicht konden de partijen tot elkaar worden gebracht ${ }^{4}$.

In de boezem van de Nederlandse regering werd de Israëlische positie in het begin wan de oorlog als benard gezien en werd overwogen Israël materieel bij te staan ${ }^{5}$. Degenen in het centrum van de besluitvorming in Nederland vreesden voor Israëls voortbestaan. Daarnaast kwam ook Nederlands verbale beleid al snel onder druk te staan, toen bleek

1. Rolef, 1987, p. 342; Volgens Strategic Surwey 1973 respectievelijk $15.000,7.000$ en 2.812 gesneuvelden, p. 26.

2. Laqueur, 1974 , p. 1.45 .

3. Over de mogelijke oorzaken en besluitworming aan Amerikaanse zijde zie onder meer Kissinger 1982, pp. 478-515, Golan, 1976, pp. 32-58, Maghroori and Gorman, 1981, p 17-30; Sheehan 1976, pp. 32-34.

4. Lezing Kissinger op 15 november 1988 te Amsterdam.

5. Gebaseerd op informatie van Den Uyl, Van der Stoel en Vredeling uit respectievelijk interwiew op 26 februari 1987, brief van 7 januari 1988 en imterview in Vrij Nederland wan 8-10-1983; zie werder 2.2.1. 
dat de partijen aan Arabische zijde zich niet beperkten tot oorlogvoering in het MiddenOosten, maar met politiek-economische middelen de rest van de wereld bij deze strijd betrokken. De aanwending van de hulpbron olie voor politieke doeleinden was reeds vóór de oorlogshandelingen overeengekomen en kon tijdens de Oktoberoorlog kenbaar worden gemaakt. Met name West-Europa en Japan waren voor hun economische ontwikkeling in toenemende mate afhankelijk geworden van de import van Arabische olie en waren dan ook kwetsbaar voor elke mogelijke reductie in de aanwoer.

Tegelijkertijd werden de prijzen voor olie van Arabische zijde direct llink verhoogd - een toename van meer dan $400 \%$ in het laatste kwartaall van $1973^{6}$ - waardoor hun inkomsten, ondanks de reductie in de export, niet zouden teruglopen en zij het 'oliewapen' konden contimueren ${ }^{7}$. Politieke uitspraken en handelingen van de regeringen in de wereld werden nauwlettend in het oog gehouden en onder leiding van de olieministers van Algerije (Abdul al Salam) en Saoedi-Arabië (Ahmed Zahi Ya'amani) werd daarop flexibel geantwoord. Zo werden de olieconsumerende staten ingedeeld in de categorie bevoorrechte, bevriende, neutrale of de vijand steunende landen en vond tussentijdse bijstelling plaats. België en Japan bijvoorbeeld klommen eind december op van neutraal naar bevriend ${ }^{8}$. De meeste Afrikaanse landen verbraken als eerste - en meest kwetsbare naties - de diplomatieke betrekkingen met Israël en hoopten zo in een betere positie te komen". Ook in Europa werd getracht de olievoorziening zo veel mogelijk veilig te stellen door de Arabische partij in het conflict gunstig te stemmen. Een dergelijke houding werd door Nederland feitelijk op de proef gesteld met het verzoek de gemeenschappelijke markt voor de lidstaten van de EG in stand te houden nadat het zelf door een doelgericht Arabisch olie-embargo was getroffen. De bevoorrechte landen, waaronder Frankrijk en het Verenigd Koninkrijk, zouden deze status namelijk verliezen indien zij de geleverde olie opnieuw zouden uitvoeren.

Dankzij de publikatie van autobiografieën van de direct betrokken politieke leiders als Mohammed Heykal, Anwar el-Sadat, Golda Meïr, Moshe Dayan en Abba Eban kan worden nagegaan welk belang aan de Europese opstelling ten aanzien van het MiddenOosten in hun gedachtenvorming werd toegekend ${ }^{10}$. Dat blijkt nihil te zijn. Weliswaar werd van Israëlische zijde, met name door Eban en Dayan, kritiek geuit op de Europese opstelling, maar in de besluitvorming zelve heeft deze nauwelijks een rol gespeeld, hetgeen ook uit de diepgaande analyse van Michael Brecher blijkt ${ }^{11}$. De oorlogvoering, wapenluchtbrug, statat-het-vuren resoluties, troepenscheidingsakkoorden waren de

6. Shwadran, 1977, p. 73; op 1 oktober 1973 was de prijs voor een vat ruwe olie - Arabian Light 2.59 dollar en op 23 december 1973 werd die op 11.65 dollar vastgesteld. Zie ook Quandt, 1977 , pp. 176-186; Strategic Survey 1973, p. 35 .

7. In 1979-1981 zou de prijs weer enorm stijgen. De prijs per vat bedroeg in november 198134 dollar. Chan, 1984, pp. 285-289.

8. Zie ook Shihata, 1974, pp. $591-597$ en Van Ginkel, 1978 pp. 89-90.

9. Do Afriktanse landen die de diplomatieke betrekkingen met Israël hadden verbroken, werden op de conferentie wan Arabische olieministers te Koeweit op 8 december 1973 tot de bewoorrechte landen gerekend en konden zoveel olie krijgen als ze nodig dachten te hebben, Shihata, $1974 \mathrm{p}$. 596, Van Ginkel, 1978 p. 89 . Zie ook Laqueur, 1974, p. 152 voor een overzicht wan Afrikaanse staten die de diplomatieke betrekkingen met Israël verbraken in 1972-1973.

10. Heykal, 1975; el-Sadat, 1978; Meïr, 1976; Dayan, 1976; Eban, 1977.

11. Brecher, 1980 . 
allesoverheersende aandachtspunten voor de besluitvormers van de conflicterende partijen. Europa speelde daarin geen directe rol maar was varwege de mogelijke invloed op het gedrag van de Verenigde Staten wel indirect betrokken. Het gedrag van de VS stond in toenemende mate centraal, zowel om de strijd aan Israëlische zijde te kunnen volhouden (Amerikaanse luchtbrug naar Israël), als om tot een staakt-het-vuren en een vredesregeling te kunnen komen. Bij de eerste troepenscheidingsovereenkomsten van begin november bemiddelden de VS met het doel Moskou's invloed in het Midden-Oosten te beperken en het olie-embargo te laten beëindigen. Dat olie-embargo trof de VS minder sterk dan de oliebeperkende maatregelen die het veel afhankelijker West-Europa en Japan raakten ${ }^{12}$.

Van deze zijdelingse Europese betrokkenheid was bijvoorbeeld Dayan zich bewust toen wij in de onderhandelingen met de VS stelde dat Israël zich niet zou terugtrekken als Egypte de politieke voorwaarden (beëindiging van de staat van oorlog) niet accepteerde; 'I said this even though I knew that it was not only Egypt that was interested in an immediate arrangement. America was too, in order to put an end to the hysteria in Europe over oil' ${ }^{13}$. Niet alleen in 1973 maar in het hele volgende decennium bleek Europa "s rol en invloed op het vredesproces in het Midden-Oosten beperkt te zijn maar was - in de perceptie van de direct betrokken partijen - de Europese invloed op de VS inzake het Midden-Oosten wel van belang. Binnen de Europese Gemeenschap kwam al vanaf 1971 de vraag aan de orde in welke mate Europa een onafhankelijke rol in het Midden-Oosten kon en wilde vervullen.

In de periode van toenemende ontspanning tussen de beide grote mogendheden, sinds het midden van de jaren zestig, had Europa een grotere vrijheid van handelen verworven. Door de Amerikaanse minister van Buitenlandse Zaken, Kissinger, was 1973 uitgeroepen tot 'het jaar van Europa'. Het Amerikaanse beleid zou gericht blijven op steun aan de Europese eenwording en het nakomen van Amerikaanse verplichtingen in Europa, waardoor het Westen als geheel werd versterkt ${ }^{14}$.

Als gevolg van de oorlog in het Midden-Oosten zouden echter de Atlantische verhoudingen onder grote druk komen te staan en het "jaar van Europa' werd een fiasco. Zo zei Kissinger in zijn 'Year of Europe speech' op 23 april 1973: 'We are prepared to work cooperatively on new common problems we face. Energy, for example .... . This could be an area of competition; it should be an area of collaboration' ${ }^{\text {is }}$.

\section{Resolutie 242}

Op 22 oktober 1973 werd door de Veiligheidsraad resolutie 338 aanvaard. In deze resolutie werd naast een staakt-het-vuren ter plaatse de uitvoering van resolutie 242 in al haar onderdelen verlangd. Met succes wisten de Israeli's te bewerkstelligen dat het staakt-het-vuren niet alleen gekoppeld werd aan de oproep tot uitvoering van resolutie 242, maar tevens aan het starten van onderhandelingen tussen de betrokken partijen. Enige kennis ower de totstandkoming en betekenis van resolutie 242 is van belang voor

12. Van Ginkel, 1978, p. 100, tabel 7; Grosser, 1982 , p. 276 , Strategic Survey, 1973 ,p. 36 , tabel 7 .

13. Dayan 1976, p. 553 .

14. Zie Grosser, 1982, pp. 270 e.v.; Kissinger, 1982, pp. 151 e.v.

15. Kissinger, $1982, p, 153$. 
het verkrijgen van inzicht wan de behandeling van het Israëlisch-Arabisch conflict in de internationale politiek.

Over de uitleg van deze resolutie werd door de lidstaten van de EG verschillend gedacht. In de eerste gemeenschappelijke EPS-verklaring over het Midden-Oosten (zie 2.2.1.7) werd een compromisformulering gevonden. Onduidelijkheid bleef voortbestaan waarover in Nederland later (zie ook $2.2 .2,2.2 .3 .1$ en 2.2.4.4) enige beroering ontstond. De controversen gingen over de vraag òf Israël zich uit alle bezette gebieden zou moeten terugtrekken of dat aan Israel grenscorrecties zouden moeten worden toegestaan. In de befaamde resolutie 242 van de Veiligheidsraad van 22 november 1967 , die onder hoofdstuk VI van het Handvest unaniem werd aanvaard, werd een tekst aangenomen die verschillend is vertaald en versehillend kan worden geïnterpreteerd. Volgens de Engelse tekst zoti Israẻl zich dienen terug te trekken uit gebieden die tijdens het jongste conflict zijn bezet ('withdrawal of Israel armed forces from territories occupied in the recent conflict'), volgens de Franse en Spaanse tekst daarentegen moet Israël zich uit de, tijdens het jongste conflict, bezette gebieden terugtrekken ('Retrait des forces armées israéliennes des territoires occupés lors du recent conflit' en 'Retiro de las fuerzas armadas israelies de los territorios que occuparon durante el reciente conflicto').

Uit onderzoek naar de totstandkoming van deze resolutie blijkt dat niet van een simpele vertaalfout kan worden gesproken ${ }^{16}$. Op 7 november 1967 verzocht Egypte de Veiligheidsraad bijeen te komen voor het ontwerpen van een resolutie. Gedurende zeven bijeenkomsten van 9 november tot 22 november werd gedebatteerd en werden enkele ontwerpresoluties ingediend.

Op 7 november werden twee ontwerpresoluties ingediend. De eerste door India, Mali en Nigeria gericht op terugtrekking van Israël uit al de bezette gebieden ('Israel's armed forces should withdraw from all the territories occupied as a result of the recent conflict') en de tweede door de VS die terugtrekking uit bezette gebieden eiste ('withdrawal of armed forces form occupied territories'). In het debat verwierp de Sovjetunie het voorstel van de VS aangezien Israël zich in dat geval niet noodzakellijkerwijs uit alle veroverde Arabische gebieden zou moeten terugtrekken. Op 16 november dienden de Britten een ontwerpresolutie in - de latere 242 - die het Amerikaanse ontwerp volgde maar daaraan de preambule toevoegde over 'the inadmissibility of the acquisition of territory by war'. De Russen wensten een duidelijke paragraaf over de terugtrekking zodat niemand zijn eigen interpretatie zou kunnen geven en kwamen met een eigen ontwerpresolutie, gericht op direkte terugtrekking tot de grenzen van voor 5 juni ('the parties to the conflict should immediately withdraw their forces to the positions they held before 5 June'). Op 22 november zou de stemming over deze vier ontwerpresoluties plaatsvinden. In dit geval was van amendementen geen sprake en zou eerst over de resolutie van India c.s. worden gestemd. De permanente vertegenwoordiger van India deelde tevens namens Mali en Nigeria mee dat zij het Britse ontwerp, gezien de preambule en de verklaringen van de Britse minister van Buitenlandse Zaken, als Israëlische terugtrekking uit alle bezette gebieden opvatten en dat zij het daarom niet nodig vonden dat over hun ontwerp werd gestemd.

16. Zie met name de studie van Bailey, 1985. Zie ook: Pogany 1984, pp. 101-108, Gainsborough, 1986, pp. 139-140 en 154-157; United Nations Yearbook 1967, pp. 245-255. 
De Britse gedelegeerde antwoordde daarop dat de bewoording van zijn resollutie duidelijk was en dat elke delegatie weliswaar haar eigen interpretatie kon hebben, maar dan ook alleen voor zichzelf sprak ('All of us, no doubt, have our own views and interpretations and understandings .... On these matters each delegation rightly speaks only for itself $)^{17}$. De Britse vrijheid van handelen was inmiddels ook beperkt geworden. Achter de schermen hadden zij immers getracht de Israeli's te bewegen de toevoeging van het lidwoord 'the' (from the territories') te aanvaarden. Israël weigerde en daarop probeerde de Britse indiener (Lord Caradon) de VS te beinvloeden de Israeli's te bewegen hun positie te wijzigen. De Amerikanen weigerden dat en maakten de Britten bovendien duidelijk dat zij hun steun aan het Britse ontwerp zouden intrekken indien een enkell woord werd toegevoegd of geschrapt ${ }^{18}$. In het debat drongen de VS ook niet langer aan op stemming over hun ontwerp en na de aanvaarding van het Britse ontwerp insisteerde de Sovjetunie ook niet op stemming over haar ontwerp. Na afloop van de stemming verklaarde Brazilië dat grenscorrecties mogelijk waren, Egypte en Jordanië meenden daarentegen dat Israël zich uit alle gebieden zou moeten terugtrekken, Syrië verwierp de resolutie, Israël hield vast aan de originele Britse tekst waarvan Frankrijk meende een precieze interpretatie te hebben gegeven ${ }^{19}$.

Resolutie 242 in de oorspronkelijke Britse voorstelling - met de mogelijkheid van grenscorrecties - was en bleef het uitgangspunt voor de Nederlandse regering. Ook de Isrälische regering koos in 1973 nog voor terugtrekking met inachtneming van grenscorrecties, maar binnen de Israëlische samenleving nam het aantal tegenstanders van elke teruggave van gebied toe. Deze tweedeling zou het politieke toneel in Israël gaan bepalen ${ }^{20}$.

\section{$2: 2$ Buitenlands beleid}

Op 6 oktober 1973 brak de Oktoberoorlog uit; op 20 oktober stelde Algerije als eerste een olie-embargo tegen Nederland in. Andere Arabische olie-producerende en -exporterende landen volgden. Het embargo werd formeel pas op 10 juli 1974 opgeheven. Onder de term embargo wordt hier verstaan de beslissing van een actor - i.c. olieproducerend land - niet te verkopen aan een of meer andere landen. Onder een boycot wordt de beslissing aangeduid niet van een ander land te kopen ${ }^{21}$. In het spraakgebruik worden beide termen door elkaar gebruikt. De beslissing van de staten van de OAPEC (Organization of Arab Petroleum Exporting Countries) geen olie aan Nederland te

17. Pogany, 1984, p. 106.

18. Gainsborough, 1986, pp. 139-140.

19. U.N. Yearbook 1967, pp. 245-255.

20. Demamt, 1989, p. 56 stelt: 'De ideologische strijd verplaatste zich van én tussen aanhangers van (nagenoeg) volledige terugtrekking en aanhangers van selectieve annexatie naar én thussen voorstanders 'wan substantiële annexatie en tegenstanders van elke teruggave van gebied.' Enkkele Israëlische politieke groeperingen zijn echter nog wel voorstanders van nagenoeg volledige teruggave met uitzondering van Jeruzalem.

21. Licklider, 1988, p. 14; Holsti, 1972, pp. 245-246. 
verkopen, is een duideljk voorbeeld van een embargo ${ }^{22}$. De redenen voor het specifieke olie-embargo tegen Nederland zijn niet ruim bekend gemaakt. Irak en Algerije lijken (zie chronologisch overzicht bijlage 19) de initiatiefnemers te zijn geweest. Desalniettemin weigerde Irak aan enig olle-mbargo mee te werken.

Door Irak werd de beslissing tot naasting van het aandeel van Shell in de Basrah Petroleum Company genomen als strafmaatregel vanwege Nederlands vijandige positie tegenover het Arabische wolk ${ }^{23}$. Het Irakse Nieuwsagentschap stelde dat:

- Nederlands grondgebied als een bruggehoofd werd gebruikt voor hulp aan de vijand;

- olle aan Israel werd gezonden vanuit Nederlandse voorraad;

- huurlingen en hulp aan de vijand met KLM-vluchten werden overgebracht;

- Nederland zich had verzet tegen de uitgifte van een objectief communiqué door EEG-landen;

- de Nederlandse minister van Buitenlandse Zaken tegen Arabische ambassadeurs de steun van zijn land aan Israel had bekend gemaakt;

- de Nederlandse minister van Defensie had deelgenomen aan een manifestatie in Amsterdam voor steun aan Israël;

- Nederlandse instellingen en bedrijven hadden deelgenomen aan inzamelingen voor de Israëlische oorlogsinspanningen ${ }^{24}$.

Van Algerijnse zijde werd gesteld dat het olie-embargo tegen Nederland op politieke gronden was ingesteld. Nederland heeft zich altijd volledig achter Israël opgesteld. Hieronder volgt een opsomming om deze bewering te staven:

In de Algemene Vergadering van de Verenigde Naties heeft Nederland de Engelse versie van resolutie 242 gesteund zodat Israel niet alle bezette gebieden hoefde te ontruimen. Ook in de gespecialiseerde en andere organisaties van de VN als de UNESCO in 1972, WHO in 1973, Commissie van de Rechten van de Mens in $1973^{25}$, ITU in 1973 theeft Nederland Israell niet veroordeeld. Binnen de EG heeft Nederland het eerste Europese initiatief ten aanzien van het Midden-Oosten in 1971 getorpedeerd, dat herhaald op 13 oktober 1973 en daarbij bovendien het gevraagde Brits-Franse mandaat voor de Veiligheidsraad geweigerd. Binnen de EEG heeft Nederland geijverd voor een wrijhandelszone met Israël. Tevens heeft Nederland op Israëlische aanwezigheid in de CVSE aangedrongen. Veel economische en financiële hulp werd aan Isrä̈l gegeven terwijl Nederland profiteerde van de toegenomen export naar de Arabische wereld en van de doorvoer van Arabische olie.

Tijdens de Oktoberoorlog publiceerde de Nederlandse regering op 6 oktober 1973 een pro-Israel verklaring. Daharnaast betuiglen de burgemeester van Amsterdaun, de minister van Defensie en drie oud-premiers openlijk hun steun an Israël. Vrijwilligers werden geworven als huurlingen voor het Israëlische leger en de KLM vervoerde hen. Bovendien hesft de Nederlandse minister van Buitenlandse Zaken bij

22. Vergelijk woor dit onderscheid resolutie 418 van de Veiligheidsraad van 4 november 1977 met resolutie 558 van de Veiligheidsraad wam 14 december 1984 . In het eerste geval werd bindend opgelegd niet langer wapens aan Zuid-Afrika te verkopen - dus een wapenembargo - in het tweede geval werd een niet-bindend invoerverbod van wapens uit Zuid-Afrika - dus een wapenboycot daaraan toegevoegd.

23. Law no. 90 van 21 oktober 1973, Shihata, 1974, p. 594.

24. Shihata, $1974, \mathrm{p} .594$.

25. Zie verder 2.3.1. 
kanselier Kreisky geprotesteerd tegen de sluiting van het Oostenrijkse doorgamgskamp Schönau voor Russische Joiden ${ }^{26}$.

Het was niet duidelijk aan welke eisen Nederland moest voldoen opdat het Arabische olie-embargo zou worden beëindigd. Door Saoedi-Arabië en Algerije werden wel enkele voorwaarden voor opheffing van het olie-embargo tegen Nederland naar voren gebracht. In het ultimatum van Saoedi-Arabië van 26 oktober 1973 werden de volgende drie eisen gesteld:

- Nederland moest van Israël verlangen de bezette gebieden te ontruimen;

- Nederland moest Israël veroordelen wegens agressie;

- Nederland moest het zelfbeschikkingsrecht van de Palestijnen erkennen.

De Algerijnse minister Abdul el Salam zou op 1 december 1973 de volgende drie eisen hebben gesteld:

- Nederland moest de diplomatieke betrekkingen met Israël verbreken;

- Nederland moest de Arabische staten steunen met militaire en andere hulp;

- Nederland diende te verklaren dat Israël alle bezette gebieden moest ontruimen ${ }^{27}$.

Deze laatste eis kwam overeen met de eerdere eis van Saoedi-Arabië; van Nederland werd daarover een aparte verklaring verlangd en er werd geen genoegen genomen met cen verwijzing naar de EG-verklaring van 6 november 1973.

Het is tenslotte wel duidelijk dat Nederland zijn beleid niet voldoende had gewijzigd om tot opheffing van het Arabische olie-embargo te kunnen besluiten. Volgens de Arabische olie-exporterende staten was Nederland blijven vasthouden aan de Israëlische zienswijze en werd het olie-embargo alleen beëindigd terwille van de gewenste betere relatie tussen de Arabische naties en de Europese Gemeenschap als geheel ${ }^{28}$.

Inzake het olie-embargo werd het Nederlands beleid bepaald door de volgende tien beslissingen, die nu worden onderzocht:

1. 8 oktober het in overweging nemen van de mogelijkheid van Nederlandse militaire hulp aan Israël (2.2.1.1).

2. 9 oktober verklaring van de Nederlandse regering over het Midden-Oostenconflict (2.2.1.2)

3. 12 oktober Nederlands veto op EPS-bijeenkomst over Brits-Frans mandaat $(2.2 .1 .3)$

4. 28 oktober Nederlandse diplomatie in de Arabische wereld (2.2.1.4)

26. Balta, 1974, pp. 14-15 baseert zich op Algerijnse bronnen.

27. Trouw, 3-12-1973.

28. The Arabic World, 11 juli 1974, p. 5 en 12 juli 1974, pp. 11-12. 
5. 31. oktober

6. 4 november

7. 6 november

8. 15 november

9. 15 december

10. 11 februari

instemming met gemeenschappelijke EG-verklaring Brussel $(2.2 .1 .7)$

dreiging van afsluiten van aardgas naar EPS-partners (2.2.1.8)

instemming met EG-verklaring Kopenhagen (2.2.1.9)

instemming met verklaring conferentie van Washington $(2.2 .1 .10)$

De doeleinden wan Nederland daarbij waren:

a. solidariteit met Israel handhaven;

b. Europese steun voor Nederlands oliepositie verwerven;

c. de gevolgen van het olie-embargo beperken en een kwetsbare Nederlandse positie voor de toekomst vermijden.

Achteraf kan gesteld worden dat primair met de beslissingen 1, 2 en 3 het bereiken van doel a. werd beoogd, de beslissingen 6,7 , 8 en 9 op doel b. waren gericht en met de beslissingen $4,5,9$ en 10 getracht werd doel $c$. naderbij te brengen.

Hierna zullen de activiteiten van de binnenlandse actoren in het besluitvormingsproces met betrekking tot de bovenstaande tien beslissingen onder de loupe worden genomen. Deze binnenlandse beïnvloedingspogingen op het buitenlands beleid worden onderscheiden van de Nederlandse invloed in de internationale politiek. Aan de vormgeving van deze internationale politiek werd in het besluitwormingsproces van internationale organen gestalte gegeven.

Het internationaal politieke overleg vond plaats binnen het kader van de Europese Politieke Samenwerking en op de ad hoc-conferentie van de olieverbruikende landen te Washington. Dit zal in 2.3 aan de orde komen. Tenslotte zal in 2.4 het olie-embargo, de gevolgen daarvan en met name de vraag op welke wijze dit vraagstuk op het internationale vlak werd opgelost, nader worden beschouwd.

\subsubsection{De regering}

\subsubsection{Militaire steun aan Israël}

Voor minister-president J.M. den Uyl was allesoverheersend de reactie op 'de inval in Israèl". In de partijdiscussie in de voorafgaande jaren nam Den Uyl het standpunt in dat het voortbestaan wan Israell nooit in gevaar mocht komen. 'Wat voor mij - en ook voor Van der Stoel, die iets meer reserves had - van doorslaggevende betekenis was, was dat er in de eerste twee dagen van de oorlog een reëel gevaar leek te bestaan voor het voortbestaan van Israël. Ook uit latere uiteenzettingen die ik daarover gehoord heb van 
Golda en van Rabin ${ }^{29}$, heeft het inderdaad op heel weinig gehangen of er waren thele grote ongelukken gebeurd. Dat was dus niet verkeerd gezien. Het kostte mij weinig moeite om tot de standpuntbepaling te komen dat dat in elk geval niet mocht gebeuren en dat er hulp geboden moest worden' ${ }^{30}$.

Op de tweede dag van de Oktoberoorlog kwam de Israellische ambassadeur met het verzoek om militair-logistieke hulp naar minister van Buitenlandse Zaken, $M$. van der Stoel. Van der Stoel stelde zich op het standpunt dat eerst met de Amerikanen zou moeten worden overlegd ${ }^{31}$. De Amerikanen zochten steunpunten voor tussenlandingen van hun vliegtuigen. 'Van onze kant is toen het aambod gedaan dat ze gebruik zouden kunnen maken van onze vliegvelden. Ik geloof dat besloten was dat Soesterberg het vliegveld zou zijn waar tussenlandingen konden worden gemaakt voor het bijladen van olie. Voorzover mijn herinnering strekt, is goed gevonden dat er reserve munitie vanuit Volkel zou worden vervoerd, maar het heeft in feite niet plaatsgevonden" ${ }^{32}$, aldus Den Uyl.

Volgens Van der Stoel werd een aanbod tot hulp niet gedaan. 'In het geheim werd de mogelijkheid van Nederlandse hulp in overweging genomen. Op Defensie werd gedacht aan de mogelijkheid het militaire vliegveld Soesterberg open te stellen voor tussenlandingen opdat brandstof kon worden getankt voor de Amerikaanse wapentransporten naar Israël. Ook de optie van vervoer van reserve munitie uit Volkel kwam in bespreking, ${ }^{33}$.

De toenmalige minister van Defensie, H. Vredeling, die de Nederlandse bereidheid in deze kwestie na tien jaar in de openbaarheid bracht - 'terwille van de geschiedschrijving mag je na tien jaar wel iets toegeven' - zocht destijds zelf contact met de Israëlische ambassadeur. Hij liet hem toen weten in geval van nood de militaire vliegvelden beschikbaar te stellen voor inscheping van materieel en voor het tanken van brandstof. Volgens Vredeling mocht de Amerikaanse regering er ook op vertrouwen dat de in het kader van de NAVO aan de Nederlandse stijdkrachten ter beschikking staande militaire uitrustingsstukken (wapens en munitie) vrijelijk door de Amerikanen gebruikt konden

29. Golda Meïr was indertijd premier van Israël en Yitzak Rabin was toen ambassadeur in Washington en werd in 1974 premier.

30. Interview met Den Uyl op 26 februari 1987.

31. Interview M. van der Stoel in Achter het Nieuws, VARA, 17 januari 1988 en brief Van der Stoel aan auteur van 7 januari 1988. Letterlijke tekst TV-interview 17 januari 1988, VARA Achter het Nieuws, 21.50 uur.

Van der Stoel:

'In 1973 in de Yom Kippoeroorlog kwam de Isrälische ambassadeur wanhopig bij me om te zeggen dlat het er voor Israell heel slecht voorstond en of Nederland niet het een en ander kon ondernemen." Vraag:

Hij kwam persoonlijk bij u. Een noodkreet.*

Van der Stcel:

'Ja $a_{b}$ noodkreet. Dat heeft in eerste instamtie geleid tot overleg tussen Den Uyl, Vredeling als minister van Defensie en mij. We hebben toen het beleidl gevolgd dat in de eerste platis met Amerika moest worden overlegd, omdat als er een land werkelijk hulp zou kunnen geven, dat Amerika zou zijn. Toen bleek kort daarna dat Amerika een luchtbrug tot stand had gebracht. Rechtstreekse militaire hulp van Nederland aan Israël is er dus niet gekomen."

32. Interview met Den Uyl op 26 februari 1987.

33. Brief Van der Stoel aan de auteur van 7 januari 1988. 
worden. Hiermee zou Amerikaans oorlogsmaterieel uit de algemene Nederlandse NAVo-voorraad worden losgemaakt om naar Israël te worden getransporteerd met medeweten van de Nederlandse minister van Defensie ${ }^{34}$.

De toenmalige Israëlische ambassadeur in Nederland, C. Bar On, bevestigt Vredelings bereidheid om vliegtuigen van de VS te laten landen en gebruik te laten maken van Nederlandse vliegvelden. Hij ontkent echter dat thet laten overvliegen van de in Nederland opgeslagen Amerikaanse NAVO-wapens deel uitmaakte van Vredelings aanbod ${ }^{35}$. Waarschijnlijk is Vredeling in zijn aanbod meer uitgesproken geweest dan Van der Stoel. wenste. Deze laatste had met nadruk gesteld 'wait op Defensie ook mocht zijn overwogen, tot een Nederlands aanbod is het niet gekomen' ${ }^{36}$. Met 'Defensie' moet in dit verband louter aan minister Vredeling worden gedacht, daar het departement van Defensie niet betrokken was bij de beleidsworming ter zake.

De staatssecretaris van Defensie, J.A. Mommersteeg, was niet op de hoogte en heeft ook geen contact met Van der Stoel of diens ministerie hierover gehad. Wel heeft Mommersteeg een keer in een gesprek met Vredeling naar voren gebracht dat, indien Israël om wapenleveranties zou vragen, hij daar een voorstander van zou zijn. Volgens hem was zijn mening echter irrelevant voor de beleidsvorming aangezien hij er volstrekt buiten stond ${ }^{37}$. Een half jaar na mijn interview met Mommersteeg zou deze kwestie pas openbaar worden. Achteraf blijkt Vredelings peiling bij Mommersteeg relevanter te zijn geweest dan Mommersteeg meende omdat indertijd militair logistieke steun aan Israël onderwerp van besluitvorming was. In de afgenomen interviews met ambtenaren van het departement van Buitenlandse Zaken werden de rol en invloed van Vredeling op het besluitvormingsproces nog als vrijwel nihil beoordeeld.

Slechts Den Uyl, Vredeling, Van der Stoel, de drie meest betrokken PvdA-ministers, en enkele militairen van de generale staf waren aan de Nederlandse zijde betrokken bij de besluitworming over de Nederlandse bereidheid militaire hulp aan Israël in overweging te nemen. De Amerikaanse minister van Defensie, J. Schlesinger, en het Israëlische kabinet waren Nederland zeer dankbaar voor deze houding, maar hoefden op het aanbod niet in te gaan toen bleek dat tussenlandingen op de Azoren met Portugese toestemming mogelijk waren. Van Israëlische en Amerikaanse zijde werd dan ook geen officieel verzoek gedaan aan de Nederlandse regering. Zo bleef deze Nederlandse bereidheid lange tijd geheim en werd zij nimmer in het kabinet besproken.

De Nederlandse bereidheid hoefde niet te worden gerealiseerd en de minister van Buttenlandse Zaken kon de schriftelijke vraag van het Tweede Kamerlid Van der Spek (PSP) dan ook naar waarheid beantwoorden met de verzekering dat tijdens de Oktoberoorlog geen vergunningen waren verstrekt voor de uitvoer en doorvoer van wapens naar Israẹl ${ }^{38}$.

Het Nederlandse luchtruim is, zo deelde Van der Stoel mij mee, in 1973 niet gesloten geweest voor wapenleveranties aan Israël ${ }^{39}$. Ook daarin verschilde Nederland van vele

34. Interview Vredeling met Van Tijin, Vrij Nederland 8-10-1983.

35. Interview Bar On met Benima, NIW, 21-10-1983.

36. Brief van Viun der Stoel an auteur van 7 januari 1988.

37. Interview met Mommersteeg op 24 februari 1983.

38. Tweede Kamer, zitting 1973-1974, Aanhangsel p. 671.

39. Telefoongesprek met auteur, 31-8i-1983. 
van zijn Europese partners. Golda Meïr heeft op 10 en 11 november 1973 in Londen op een bijeenkomst van de Socialistische Internationale de Europese sociaal-democraten dat ernstig verweten: 'Not one inch of your territory was put at our disposal for refuelling the planes that saved us from destruction' 40 .

De assistent internationaal secretaris van de PvdA, H. van den Bergh, zeil in een interview: 'Ik zal nooit vergeteil dat Wilson, die voorzat, na haar toespraak moest schorsen omdat de gêne bij ieder die daar zat zo groot was dat niemand een vraag stelde: Absoluut gebeurd. Ik heb erbij gezeten, naast Joop den Uyl'. Hij vervolgt dan: 'Wij waren de enigen die wèl iets gedaan hadden. Reserve-voorraden munitie naar Israël gestuurd. Dat is inmiddels well bekend ${ }^{41}$.

Andere bronnen bevestigen niet dat de reservemunitie daadwerkelijk werd gestuurd, wel dat de bereidheid bestond deze te sturen. In feite heeft het vervoer niet plaatsgevonden ${ }^{42}$.

De direct bij het buitenlands beleid betrokken bewindslieden hebben zich in het begin van de Oktoberoorlog in hun politieke opstelling achter Israël geschaard en waren bereid daarvoor de middelen aan te wenden ter ondersteuning van deze doelstelling. De continuilteit in het Nederlands beleid op dit punt is dan ook veel groter dan wel eens wordt aangenomen wanneer de vergelijking met 1967 wordt getrokken, toen Nederland Israël op zeer ruime schaal van wapens voorzag. H.J. de Koster, in 1967 staatssecretaris op Buitenlandse Zaken, heeft in 1967 met de ministers van Defensie (W. den Toom) en van Buitenlandse Zaken (J.M.A.H. Luns) dag en nacht gewerkt om zoveel mogelijk wapens naar Israël te exporteren en verklaarde hen volop geholpen te hebben met alles wat zij nodig hadden; 'dat kon toen nog' ${ }^{43}$.

Op het moment dat Israëls voortbestaan in gevaar zou kunnen komen, reageerde Nederland niet alleen verbaal maar bleek de regering ook bereid daadwerkelijk te reageren. Met deze eerste beslissing in de kern van de regering werd de eerste doelstelling, gericht op de handhaving van de solidariteit met Israël, ondersteund.

\subsubsection{Verbale steun aan Israël}

De Nederlandse regeringsverklaring van 9 oktober kwam tot stand op aandrang van Kamerleden op 7 oktober ${ }^{44}$. Deze regeringsverklaring werd voorbereid op het departement van Buitenlandse Zaken ${ }^{45}$ en het ontwerp werd op 8 oktober onderschreven door de vaste Kamercommissie voor Buitenlandse Zaken ${ }^{46}$.

40. Meir, 1976, p. 376. Zie ook Brecher, 1980, p. 290.

41. Interview Van den Bergh in Playboy 6-6-1985, het zou gaan om het vliegweld Volkel. Brief wan S. Rozemond van 19 oktober 1985 aan auteur. Van den Bergh gaat akkoord met deze tekst, telefoongesprek op 1 augustus 1990.

42. Interview met Den Uyl op 26 februari 1987 en brief van Van der Stoel 7 januari 1988.

43. Interview met De Koster op 31 decenber 1982.

44. Zie 2.2.4.1.

45. Zie 2.2.3.1.

46. Zie 2.2 .2 . 
In deze verklaring stelde de regering dat Egypte en Syrië, die het initiatief tot de militaire activiteiten hadden genomen, het sinds augustus 1970 gehandhaafde bestand eenzijdig hadden verbroken en vervolgde: "een terugkeer van beide partijen tot de voor zaterdag jongstleden geldende bestandslijnen lijkt de beste basis voor een staakt-hetvuren te bieden. Vanuit die situatie zou dan het zoeken naar een politieke oplossing (op basis van resolutie 242) van het Midden-Oostenconflict kunnen worden hervat' ${ }^{47}$.

Ook de VS spraken zich in de Veiligheidsraad uit voor een staakt-het-vuren op basis van een terugtrekking achter de grenzen van vóór het uitbreken van het jongste conflict ${ }^{48}$, het Verenigd Koninkrijk wenste een staakt-het-vuren ter plaatse en de meeste leden van de Veiligheidsraad, 9 van de 15 waaronder Frankrijk en de Sovjetunie, konden alleen met een oproep voor een staakt-het-vuren instemmen als Israël de bezette gebieden opgaf ${ }^{49}$. Wegens de uiteenlopende standpunten van de leden kwam de Veiligheidsraad niet toe aan het aanvaarden van een resolutie. De pro-Israelische positie van Nederland en de VS tegenover de pro-Arabische positie van Frankrijk kwam zo al in het begin van deze episode naar voren. In de Nederlandse regeringsverklaring van 9 oktober werd tevens aangekondigd dat de regering haar buitenlands politieke standpunt zou inbrengen in de besluitvorming in de internationale politiek ${ }^{50}$.

De regering toonde in deze verklaring geen begrip voor het motief dat Egypte en Syrië ertoe had gebracht deze oorlog tegen Israël te beginnen; namelijk de herovering van de bezette gebieden. De suggestie op dat moment aan de strijdende partijen om terug te keren naar de bestandslijnen van voór de Oktoberoorlog was voor de Arabische zijde zeer ongunstig. Hun initiatief tot en hun resultaten in deze oorlog - zoals eerder beschreven (2.1) hadden de Egyptenaren het Suez-kanaal overgestoken en waren de Syriërs bijna tot aan het meer van Tiberias doorgedrongen - zouden daarmee immers teniet worden gedaan. Deze verklaring werd dan ook als een partij kiezen voor Israël opgevat. Zelfs tien jaar later heeft Van der Stoel moeite met dat waarde-oordeel wanneer hij schrijft dat de formule van 'terugkeer naar de oude bestandslijnen' pas door het verloop van de gevechtshandelingen (de oorspronkelijke Egyptische en Syrische successen) een pro-Israël connotatie kreeg, maar deze niet automatisch hoefde te hebben ${ }^{51}$. De minister-president en de minister van Buitenlandse Zaken verdedigden in de Tweede Kamer deze regeringsverklaring ook met het argument dat vanuit militair oogpunt de vroegere bestandslijnen stabieler waren en daardoor meer geschikt zouden zijn om tot

47. Tweede Kamer, zitting 1973-1974, 12.600, hoofdstuk $V_{\text {, no. 8. p. } 2 .}$

48. B. Person, VARA-radio, 9 oktober 1973.

49. N. van Vhiet, NCRV-radio, 8 oktober 1973.

50. "Nederland zal zijn standpunt uitdragen binnen het overleg wan de Negen en tegenover andere Janden die tot werwezenlijking van dit standpunt kunnen bijdragen", Tweede Kamer, zitting 1973-1974, 12.600 , hoofdstuk V, no. 8 , p. 2.

51. Brief Van der Stoel aan auteur van 1 september 1983. Ook Kissinger verdedigde zijn opvatting van een staakt-het-kuren op de grenzen ex ante met de verwachting van dat moment dat de Israêli"s Kaïro en Damascus zouden gaan veroveren. Kissinger, 1982, pp. 467-491. Gezien het tijdstip van bekendmaking wan zowel het Amerikaanse als het Nederlandse standpunt in relatie tot het verloop wan de oorlogshandelingen is deze verwachting niet op de feiten gebaseerd. Voor een kort overzicht van de oorlogshandelingen zie Strategic Survey 1973, pp. 16-27. 
een politieke oplossing te komen dan de onduidelijke situatie die naderhand was ontstaan ${ }^{52}$.

Uit de vorige paragraaf blijkt dat de Nederlandse regering bevreesd was voor Israëls positie in het begin van de Oktoberoorlog en bereid was uit die vrees consequenties te trekken. Omstreeks dezelfde tijd werd de regeringsverklaring uitgegeven en daaruit komen mijns inziens een zelfde verontrusting en zorg voor Israëls positie naar voren. Ook deze beslissing was ten gunste van de eerste doelstelling, gericht op het handhaven van de solidariteit met Israël. Dit partij kiezen voor Israël kwam overeen met de publieke opinie in het land. In de Franse regeringsverklaringverklaring daarentegen werd de Arabieren het recht toegekend het door hen verloren grondgebied te heroveren ${ }^{53}$. Zo stelde de minister van Buitenlandse Zaken, M. Jobert, de retorische vraag: 'Est-ce que tenter remettre les pieds chez soi constitue forcément une agression imprévue?? ${ }^{54}$.

\subsubsection{Nederlands veto met betrekking tot de Brits-Franse rol}

Voor het afstemmen van de standpunten inzake de buitenlandse politiek van de lidstaten van de Europese Gemeenschap was het kader van de Europese Politieke Samenwerking geschapen ${ }^{55}$.

Op donderdag 11 oktober kwamen de directeuren-generaal politieke zaken (het Comité Politique) in Kopenhagen bijeen voor het formuleren van een standpunt over de Oktober-oorlog. Binnen het Nederlandse departement ${ }^{56}$ van Buitenlandse Zaken bestond verschil van mening over de vraag of vanuit het EPS-kader al dan niet een verklaring over het conflict in het Midden-Oosten zou moeten worden afgelegd ${ }^{57}$. Van der Stoel besliste ten gunste van het afleggen van een verklaring. Hij deelde later mee dat het vreemd zou zijn als Europa over deze oorlog 'in de achtertuin van Europa* had ge-

52. Handelingen Tweede Kamer, zitting 1973-1974, van 9 oktober, 10 oktober en 31 oktober pp. 109, $145,521$.

53. ANP-radio 10 oktober 1973.

54. Laqueur, 1974, p. 153. 'Is de poging je eigen land weer in bezit te nemen een daad van onwoorziene agressie? Vergelijk de Nederlandse vitdrukking: 'zijn bemen onder een anders tafel steken', dat betekent 'geen eigen huis hebben war men de baas is'.

55. Zie 1.3 .

56. Er bestaat staatsrechtelijk geen werschil tussen de benaming departement en ministerie. De Gids over de organisatie wan het ministerie van Buiterlandse Zaken theette vroeger 'Gids van het Departement wan Buitenlandse Zaken". Deze werd omstreeks 1984 veranderd in "Gids van thet Ministerie van Buitemlandse Zaken". Deze naamswijziging kwam tot stand op grond van een circulaire varn de regering dat voortaan naar buiten toe de benaming ministerie moest zijn. Sprake is van een geografische afbakening waarbij onder departement degenen werkzaam in Den Haag wallen en onder ministerie ook zij die in het buitenland op de diplomatieke posten werken, wordt verstaan (Telefonische informatie van $\mathrm{R}$. Groenewoud, Directie Voorlichting van het ministerie van Buitenlandse Zaken op 30 maart 1990 ). Bij departement denk ik iets eerder aan de ambtenaren en overleg van ambtenaren zonder de minister - interdepartementaal overleg - en bij het ministerie iets eerder aan de minister en zijn medewerkers. Zo zal ik bij besluitwormingsprocessen die lijken op het door Allison gepresenteerde 'Organizational Process' en 'Governmental Politics' modlell eerder het woord departement gebruiken en bij het 'Rational Actor' model eerder het woord ministerie; Allison, 1971, pp. 10-39 en pp. 144-184.

57. Zie 2.2.3.1. 
zwegen ${ }^{58}$. Op deze vergadering vroegen de Fransen en Britten van hun Europese partners een mandaat om namens de Negen in de Veiligheidsraad het woord te mogen voeren over het Midden-Oosten. Op zichzelf kan dat verzoek als bijzonder worden beschouwd aangezien deze permanente leden van de Veiligheidsraad in hun optreden aldaar zeer gesteld zijn op vrijheid van handelen en hun soevereiniteit zo sterk bewaken dat voorafgaand overleg in de EPS over zaken in de Veiligheidsraad (dit in tegenstelling tot het wel gezamenlijk optreden in de Algemene Vergadering) meestal wordt afgewezen. Uitzonderlijk was ook het Nederlandse optreden aldaar: het Brits-Frans verzoek werd met een Nederlands veto beantwoord. Dit veto kwam ter sprake in het kabinetsberaad van vrijdag 12 oktober, gedurende welke de Nederlandse vertegenwoordiger naar het Catshuis belde en om een andere instructie vroeg. Den Uyl en de overige leden van het kabinet bleven het Nederlandse veto handhaven ${ }^{59}$. Hoewel zowel het Brits-Frans verzoek als het Nederlandse antwoord bijzonder zijn, wordt de weergave van hetgeen in Kopenhagen geschiedde niet betwist. Bevestiging is in zowel Nederlandse als buitenlandse bronnen te vinden ${ }^{60}$. De Britten en Fransen wezen bijwoorbeeld op 20 november 1973 Nederland erop dat het geen beroep op Europese solidariteit inzake de energievoorziening kon doen, omdat Nederland op 13 oktober zelf niet solidair was geweest toen het een veto uitsprak over het Brits-Frans verzoek ${ }^{61}$.

In een Nederlandse regeringsverklaring van 23 oktober werd de weigering slechts een kwestie van procedure genoemd ${ }^{62}$. De Nederlandse positie in Kopenhagen stuitte op groot verzet van met name de Italianen en in iets mindere mate de Fransen ${ }^{63}$. De Italiaanse directeur-generaal politieke zaken, Ducci, liet zijn woede over de Nederlandse opstelling blijken in het beraad en liet het Nederlands verzet tegen het gevraagde BritsFrans mandaat uitlekken ${ }^{64}$. De Arabische regeringen beschuldigden daarop Nederland van een anti-Arabische houding en betoogden dat Nederland bevreesd was voor een 'objectieve' standpuntbepaling van Frankrijk en het Verenigd Koninkrijk namens de Negen.

58. Interview met Van der Stoel op 17 november 1982.

59. Interviews met Van Lynden, Meijer, Van der Stoel, Den Uyl op respectievelijk 13 september 1982 , 15 oktober 1982,17 november 1982, 26 februari 1987.

60. Balta, 1974 , p. 15

Le Monde, 28-11-1973

NRC-Iandelsblad, 20-11-1973

Shihata, 1974, p. 594

Interviews met Van Lynden, Meijer, Van der Stoel op 13 september 1982, 15 oktober 1982, 17 november 1982 .

Voorhoeve, 1985, p. 239

Ifestos, $1987, p .420$

Sus, 1974, p. 78

Soetendorp, 1982, p. 137.

Zie ook 2.3.

61. NRC-Handelsblad 20-11-1973.

62. Soetendorp, 1982, p. 137. Op 21 november 1973 verklaarde Den Uyl: 'wat toen inderdaad een punt van verschil vormde was een procedurele zaak en niet een zaak van enige verklaring inzake het Midden-Oosten', Handelingen Eerste Kamer, zitting 1973-1974, 21 nowember 1973, p. 112.

63. Interview met Van Lynden op 13 september 1982.

64. Het parool, 7-11-1973. 
Nederland zou bovendien een constructief en uitgewerkt initiatief voor een gemeenschappelijke actie van de Negen hebben tegengehouden ${ }^{65}$. Deze laatste beschuldiging werd door de minister-president in de Eerste Kamer ontkend ${ }^{*}{ }^{6}$. De minister van Buitenlandse Zaken stelde dat aan Frankrijk en het Verenigd Koninkrijk - bij instemming met hun verzoek - een mandaat met een ongelimiteerde vrijheid van handelen zou zijn verschaft. Dat beschouwde hij als 'griezelig' ${ }^{87}$.

Tenslotte kon in Kopenhagen, na twee dagen vergaderen, worden ingestemd met een korte verklaring, zonder de bewuste paragraaf over het mandaat, waarin de strijdende partijen werden opgeroepen tot een 'staakt-het-vuren sur place'. Voor Nederland betekende deze verklaring van 13 oktober een kleine concessie, daar op 9 oktober nog werd gekozen voor een staakt-het-vuren op de grenzen ex ante, dat wil zeggen een terugtrekken van de Egyptische en Syrische troepen op de bestandslijnen van vóör de Oktoberoorlog. Deze verklaring kwam in Kopenhagen tot stand dankzij de bemiddeling van de Belgische directeur-generaal Davignon. De onvrede over de Nederlands politieke opstelling aan Arabische en Europese zijde was daarmee echter niet weggenomen.

\subsubsection{Bilaterale diplomatie naar Arabische staten}

Na de aankondiging door Algerije op 20 oktober en het verzoek van de Arabische Liga op 21 oktober volgden de andere Arabische olie-producerende en -exporterende landen (OAPEC) met een olie-embargo tegen Nederland. Aanvankelijk trachtte Nederland dit gevaar te keren door te wijzen op vermeende misverstanden in de Arabische kritiek op Nederland. Diplomatiek overleg in Den Haag mocht niet baten en de Golfstaten sloten zich ${ }^{6}$ bij het olie-embargo aan. Op 26 oktober dreigde Saoedi-Arabië via een ultimatum ook een olie-embargo te zullen instellen. Saoedi-Arabië was voor Nederland het belangrijkste olie-exporterende land, daar bijna $34 \%$ van de totale aanvoer van ruwe olie daar vandaan kwam.

Tabell 2.1

Procentuele verdeling van de aanvoer in Nederland ruwe aardolie naar landen van herkomst, $1972^{69}$

* Saoedi-Arabië

* Koeweit

Iran

Nigeria

* Libië

* Quatar

* Arabische verdragsstaten

$$
\begin{array}{r}
33,6 \% \\
20,6 \% \\
17,1 \% \\
12,3 \% \\
4,5 \% \\
4,4 \% \\
2,4 \%
\end{array}
$$

65. Balta, 1974, pp. 14-16.

66. Den Uyl, Handelingen Eerste Kamer, zitting 1973-1974, van 21 november 1973, p. 112.

67. Interview met Van der Stoel op 17 november 1982.

68. Koeweit 23-10-1973, Aboe Dhabi en Qatar 24-10-1973, Oman 25-10-1973.

69. Zitting 1973-1974, 12.724 Beperking van de olie-aanvoer en de gevolgen daarvan, Nota, Nr. 2, pp. 1-2. 
* Algerije

* Muskaat

* Libanon

Venezuela

Irak

Gabon

Liberia

Aruba

* Egypte

* Syrië
$1,3 \%$

$1,1 \%$

$1,1 \%$

$0,5 \%$

$0,4 \%$

$0,2 \%$

$0,2 \%$

$0,1 \%$

$0,1 \%$

$0,1 \%$

* Zijn de staten die tegen Nederland een olie-embargo hadden aangekondigd en in totaal ruim tweederde van de olie-aanvoer verzorgden ${ }^{70}$.

Tabel 2.2

\begin{tabular}{|l|r|r|r|r|r|r|}
\hline Import ruwe aardolie in Nederland over periode oktober 1973 tot maart $1974^{71}$ \\
\hline & $\begin{array}{r}\text { okt. } \\
1973\end{array}$ & $\begin{array}{r}\text { nov. } \\
1973\end{array}$ & $\begin{array}{r}\text { dec. } \\
1973\end{array}$ & $\begin{array}{r}\text { jan. } \\
1974\end{array}$ & $\begin{array}{r}\text { feb. } \\
1974\end{array}$ & $\begin{array}{r}\text { mrt. } \\
1974\end{array}$ \\
\hline Saoedi-Arabië & 2278 & 2301 & -44 & 0 & -1 & 2 \\
\hline Koeweit & 1082 & 835 & 392 & 95 & 3 & - \\
\hline Iran & 915 & 1121 & 1857 & 3734 & 3149 & 3873 \\
\hline Quatar & 589 & 737 & - & - & - & - \\
\hline Noord-Afrika & 1264 & 1135 & 1166 & 1328 & 1449 & 1560 \\
\hline Totaal & 6469 & 6437 & 3453 & 5257 & 4686 & 5509 \\
\hline
\end{tabular}

Nederland zou slechts aan het Saoedische olie-embargo kunnen ontkomen indien de regering:

a. Israël zou veroordelen wegens agressie;

b. het zelfbeschikkingsrecht van de Palestijnen zou erkennen;

c. van Israël ontruiming van de bezette gebieden zou verlangen ${ }^{72}$.

70. Tweede Kamer, zitting 1973-1974, no. 12.946, no. 2 pp. 1 en 2, 'Beperking wan de olie-aanvoer en de gevolgen datrvan".

71. Tweede Kamer, zitting 1975-1976, 12.946, nr. 5, p. 2: kwantitatievo beperkingen in de olieasanvoer, bijlage III bij Memorie van Antwoord. Deze tabel is niet volledig maar geeft aan dat in december de totale anvoer fors vermindorde en vervolgens deels kon worden opgevangen door een flinke toename in de aanvoer wan Iraanse ruwe ascdolie.

72. Interviow met Van Lynden op 13-9-1982. 
Nederland wilde daar niet aan voldoen en Van der Stoel gaf de Saoedische ambassadeur een ontwijkend antwoord op 27 oktober. Vervolgens stuurde hij zijn ambassadeur in Iran, P.A.E. Renardel de la Valette, voor een 'goodwill missie' op 28 oktober naar Irak, Koeweit, Quatar en de Verenigde Arabische Emiraten ${ }^{73}$. Op 2 november tenslotte stelde Saoedi-Arabië als laatste Arabisch land het olie-embargo tegen Nederland in. Nederland probeerde nog tevergeefs in een bijzondere "royale" missie van de oudminister van Buitenlandse Zaken en oud-ambassadeur, J.H. van Royen, naar koning Feisal op 17 november met een brief van koningin Juliana en geschenken (de werken van de Nederlandse Islam deskundige Snouck Hurgronje) de Saoedi's gunstig te stemmen. Duidelijk was dat met deze bilaterale diplomatieke activiteiten het olie-embargo niet ongedaan kon worden gemaakt. Nederland zou moeten trachten de gevolgen van het olie-embargo op te vangen door distributie maatregelen in eigen land en diplomatieke activiteiten in multilateraal verband.

\subsubsection{Binnenlandse olieverbruik-beperkende maatregelen}

De Nederlandse regering was zich eind oktober bewust van de economische teruggang die als gevolg van de verminderde aanvoer zou kunnen ontstaan ${ }^{74}$. De eerste economische maatregelen om het olieverbruik te beperken, zoals de invoering van de autoloze zondag, werden op 31 oktober door het parlement aanvaard. Het begin van deze crisisperiode kan op 31 oktober 1973 worden gesteld.

Onder invloed van de sombere vooruitzichten ontstond kritiek bij de media en enkele politieke partijen op de regering (zie 2.2.5.4 en 2.2.2). Het debat in het parlement beperkte zich grotendeels tot de uitwoeringsmaatregelen en mondde uit in het indienen van een motie van Van Dis (SGP) inzake het verlenen van ontheffingen op de autoloze zondagen voor degenen die kerkdiensten wilden bezoeken of leiden. Naast bovengenoemd Kamerlid dat het voor bezoek aan de kerkdiensten op zondag opnam, beval de minister van Economische Zaken, Lubbers, aan de gordijnen 's avonds te sluiten. Hare Majesteit verzocht het kabinet uitdrukkelijk haar geen ontheffing te verlenen voor haar auto's ${ }^{75}$. Later verschenen ook foto"s in de internationale pers met koningin Juliana op de fiets. Dat maakte wel indruk in het buitenland en werd door de Europese partners ook wel opgevat als een soort koketteren. Al was de dreiging ernstig, ondat door de boycot ruim tweederde van de olle-aanvoer zou worden getroffen ${ }^{76}$, Den Uyl verklaarde: 'Wij willen, met handhaving van het standpunt dat dit kabinet bij het uitbreken van het conflict heeft ingenomen, gaarne trachten met het oog op alle in het geding zijnde belangen de gevolgen voor de Nederlandse bevolking; die het zou kunnen hebben, zo goed mogelijk op te vangen' $\pi$.

73. Trouw, 29-11-1973.

74. Brief van de minister van Economische Zaken inzake de oliesituatie, 31 oktober 1973, no. 12670.

75. Handelingen Tweede Kamer, zitting 1973-1974, 31 oktober 1973, p. 529 en p. 543.

76. Handelingen Tweede Kamer, zitting 1973-1974, nota 12.724 no. 2, p. 1 en 2, Beperking van de olie-aanwoer en de gevolgen daarvan.

77. Handelingen Tweede Kamer, zitting 1973-1974, 31 oktober 1973 pp. 525 en 526 . 
In hetzelfde debat verklaarde Van der Stoel "dat door het besluit van de olieboycot tegen Nederland tevens een druk op geheel Europa wordt gelegd' ${ }^{78}$; deze zienswijze zou in de toekomst met meer na druk vanuit Nederland worden herhaald om daarmee Europese solidariteit met en steun voor de Nederlandse positie in EG-verband te verkrijgen.

Op 31 oktober werd nog gemeend dat door het wegnemen van 'misverstanden' in de Arabische wereld de zaak ten goede kon keren ${ }^{79}$. Van der Stoel herhaalde het Nederlandse standpunt gebaseerd op resolutie 242 van de Veiligheidsraad en schonk veel aandlacht aan de integrale uitvoering door ook de preambule van deze resolutie als 'een onmisbaar element bij de interpretatie daarvan' te betrekken ${ }^{80}$. Israèl zou zich volgens Van der Stoel 'dienen terug te trekken uit de bezette gebieden tot een gebied, dat bij benadering even groot is als het territoir van voór de juni-oorlog van 1967. Dat is een formulering, die inhoudt, dat kleine grenscorrecties, in overleg tussen partijen overeen te komen, mogelijk moeten zijn' ${ }^{3 !}$.

\subsubsection{Toestemming tot Europees beraad}

In het debat in de Tweede Kamer van 31 oktober deelde Van der Stoel mee, dat de regering haar Europese partners had voorgesteld dat de ministers van Buitenlandse Zaken zich op de EG-Raad van 5 en 6 november over de situatie zouden beraden. Op 29 oktober had Van der Stoel de ambassadeurs van de partnerlanden ontvangen. Nederland nam ook het initiatief tot een actief beleid van de Europese Commissie. Deze werd verzocht 'de nodige initiatieven te overwegen die met handhaving van de grondregels van de gemeenschappelijke markt een evenwichtige voorziening" waarborgen. De regering stelde zich 'de handhaving van een evenredige olievoorziening van de lidstaten en van het vrije verkeer binnen de gemeenschappelijke markt' ten doel en drong derhalve aan op een gemeenschappelijk beleid ${ }^{82}$.

In Europees verband vond frequent ambtelijk beraad plaats over zowel een gemeenschappelijk beleid inzake de olievoorziening als een gemeenschappelijk beleid over een stellingname ten aanzien van het Arabisch-Israëlisch conflict. Het lag in de bedoeling

78. Handelingen Tweede Kamer, zitting 1973-1974, 31 oktober 1973, p. 526.

79. Aan Nederlandse zijde werd de indruk gewekt dat aan Arabische zijde miswerstanden bestonden over de Nederlandse positio en standpunten in het Arabisch-Israëlisch conflict $\mathrm{Na}$ uitleg zoudlen de bezwaren dan wel verdwijnen. In leder geval bleek dat de bilaterale diplomatieke activiteit geen oplossing bracht. Ook niet alle punten van kritiek op Nederland leken op vaststaande feiten gebaseerd to zijn - onhoffelijke behandeling van Arabische ambassadeurs door de Nederlandse minister van Buitenlandse Zaken, verwer van olie uit Nederland naar Israël, Nederlandse vrijwilligers in Isrällische leger -, of zijn de regering niet te verwijten, zoals particulier geldinzamelingsacties en andere particuliere steunverlening aan Israël. Dat Nederland in de internationale politiek - zowel binnen de VN als binnen de EG - veelal positie koos voor Israël is wel juist en van Arabische zijde werd dit argument ook onderbouwd.

80. Emphasizing the inadmissibility of the acquisition of territory by war and the need to work for a juist and lasting peace in which every State in the area can live in security (Veiligheildraad resolutie 242 wan $22-11-1967,1382$ ste zitting).

81. Handelingen Tweede Kamer, zitting 1973-1974, 31 oktober 1973, pp. 526-527.

82. Handelingen Tweede Kamer, zitting 1973-1974, 31 oktober pp. 527-528. 
dat op beide terreinen in Brussel besluiten zouden worden genomen ${ }^{3}$. Het Comité Politique van de EPS bereidde de gemeenschappelijke verklaring over het ArabischIsraëlisch conflict voor en de Nederlandse vertegenwoordiger Van Lynden vroeg op zondag 4 november aan Van der Stoel de ontwerp-tekst goed te keuren.

De ambtelijke top van het ministerie van Buitenlandse Zaken kwam op deze eerste autoloze zondag bij Van der Stoel thuis bijeen en tenslotte besloot Van der Stoel aan Van Lynden de gevraagde volmacht te verlenen (zie 2.2.4.1 over dit beraad). Deze beslissing van Van der Stoel werd zowel door de directeur-generaal internationale samenwerking, Meijer, als door de directeur-generaal politieke zaken, Van Lynden, als een Nederlandse beleidswijziging opgevat. In paragraaf 2.2.4.1 zal ik hun opvattingen in deze kwestie behandelen. Zonder het kabinet of een van de leden van de regering van de inhoud op de hoogte te hebben gebracht, vertrok Van der Stoel de volgende dag naar Brussel.

\subsubsection{Instemming met Europese verklaring}

Op 5 november was het Comité Politique overeengekomen, met instemming van de Franse deelnemer, om de volgende dag 's ochtens de politieke verklaring over het Arabisch-Israëlisch conflict en 's middags de verklaring over de olievoorziening door de ministers te laten aanvaarden. Zeer uitvoerig heeft de Belgische directeur-generaal politieke zaken, Davignon, de beoogde koppeling van de politieke beslissing 's ochtends en de economische gemeenschapsverklaring 's middags onthuld. 'Het was duidelijk dat het niet samen gedaan kon worden, maar het was duidelijk dat als wij tot een gemeenschappelijke politieke stellingname zouden komen, dat betekende dat wij ook tot een gemeenschappelijke gemeenschapsstellingname zouden komen met solidariteit over een embargo'. Doordat Jobert, minister van Buitenlandse Zaken van Frankrijk, weigerde 's middags met een besluit in te stemmen, werd het evenwicht verbroken. Volgens Davignon ging het om een pakket van algemene politiek. 'Er waren twee problemen - een reactie op Israël en een reactie op de oliemaatregelen van enkele Arabische landen - en er moest op beide gereageerd worden'. 'Eén signaal was een andere boodschap dan twee signalen zouden zijn geweest'. Nu kon de Israëlische regering zeggen dat Europa had toegegeven aan chantage van de OAPEC.

Hoewel Davignon niet van mening is 'dat het (totale pakket) een compromis was tussen de Nederlandse vraag om solidariteit op het gebied van olieleveranties en daarom aan de politieke kant wat concessies had gedaan', was hij er 'niet zeker van dat de 6 novernber verklaring tot stand zou zijn gekomen als die onzekerheid over het tweede deel van het pakket zou hebben bestaan' ${ }^{84}$.

De ontwerp-tekst voor de politieke verklaring van 6 november werd door Van Lynden op maandagavond 5 november aan Van der Stoel in Brussel overhandigd. Van der Stoel was daar niet ontevreden over. Alle directeuren-generaal politieke zaken waren gemachtigd (zie 2.2.1.6) een compromis op te stellen. Zij slaagden daarin en de ministers

83. Interview met Davignon, op 22 juni 1987 en zie 2.2.1.7 en 2.3.2.

84. Interview met Davignon op 22 juni 1987. 
konden hun instructies erin terugvinden. Op 6 november werd de politieke verklaring snel door de ministers aangenomen.

Van der Stoels herinnering van de vijfde november wordt overschaduwd door het Britse dreigement een Koninklijk Besluit (Order in Council) uit te vaardigen, opdat de olie yoor het Verenigd Koninkrijk niet bij anderen terecht zou komen. Enkele malen herhaalde de Britse minister van Buitenlandse Zaken, Douglas-Home, tegenover Van der Stoel de volgende zin 'the supply of crude oil to Britain has to be assured'. Voor Van der Stoel waren dat de 'meest benauwende' ogenblikken in deze kwestie ${ }^{85}$.

De dag tevoren, op 4 november, had de Nederlandse president-directeur van Shell, G.A. Wagner, voor de televisie verklaard dat alle landen in principe hetzelfde percentage olie minder zouden ontvangen, wat mogelijk was door een verschuiving in de aanvoer van olie uit niet-Arabische olieproducerende landen ${ }^{86}$. Deze uitspraak inzake de toepassing van een uniform reductiepercentage voor olie voor alle verbruikslanden, schoot de Britten in het verkeerde keelgat. Premier Heath, in eigen land ook al geplaagd door een staking in de steenkolenmijnen, eiste vervolgens van British Petroleum dat het Verenigd Koninkrijk een voorkeursbehandeling zou krijgen. De maatschappij weigerde waarop Heath een wetsvoorstel wilde indienen, dat de Britse regering de bevoegdheid gaf richtlijnen uit te vaardigen om de vaste contracten ongedaan te maken. Daarbij zou de Britse regering tevens schriftelijk moeten aangeven ten koste van welke landen de bevoorrechte behandeling door BP zou moeten plaatsvinden ${ }^{87}$.

Al heeft de Britse regering dit wetsvoorstel uiteindelijk niet ingediend uit vrees voor haar relaties met de Europese bondgenoten, het is wel duidelijk dat de angst bij de Britten groot was. Het lijkt me dan ook niet juist het mislukken van de economische gemeenschapsverklaring in de middag van 6 november louter aan de Fransen toe te schrijven. Volgens Van der Stoel bestond deze angst ook bij de andere Europese partners. Op dat moment twijfelde Van der Stoel aan de machtspositie van de oliemaatschappijen.

Achteraf gezien is deze twijfel wellicht ten onrechte, maar dat is niet zo relevant voor de perceptie van de besluitvormers indertijd. Zo ervoer Van der Stoel het dreigement van de Britten op 5 november als "een grotere zorg dan de strekking van de verklaring voor de volgende dag'. Deze verklaring zou echter wel de nodige opschudding in Nederland veroorzaken (zie 2.2.5.4).

\section{De zes november verklaring}

De tekst van de verklaring van 6 november 1973 is opgenomen in bijlage 5 .

De Negen wilden een bijdrage leveren tot een oplossing van het probleem. Een eigen Europese vredesbemiddelende rol werd aldus naar voren gebracht. Daarbij werd de voorkeur aan een globale oplossing gegeven; dit in tegenstelling tot het Amerikaanse voornemen op dat moment. Op 6 november zou de Amerikaanse minister van Buiten-

85. Interwiew met Van der Stoel op 7 nowember 1982.

86. Stobaugh, 1975, pp. 189, 191 .

87. Ibidem; Van Ginkel, 1978, pp. 101-102. 


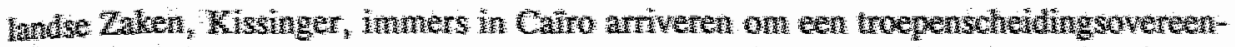

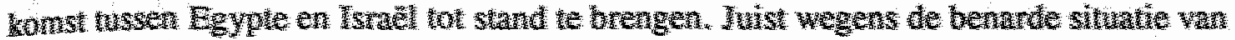
het derde Egyptische Ieger, dat bit de stad Suez aan de westelike zijde van het Suezka-

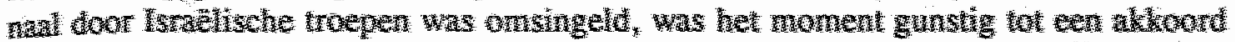

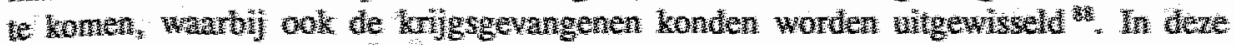

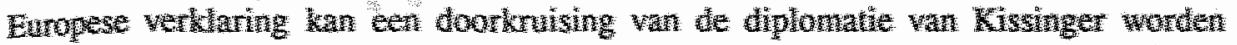
gelezen, ondat - in pun 1 - de strifiende gartijen werden ongeroegen terug te

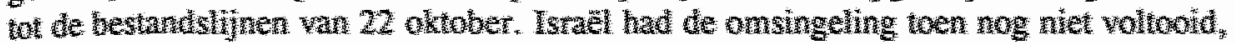

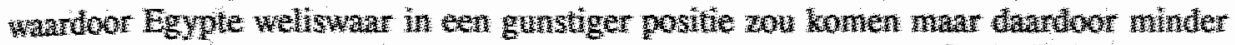
geneigd zou zinn met een politieke overeenkomst in te stemmen. Dammast werd - in punt 2 - gesteld dat onderhandelingen alleen in het kader van de Verenigute Naties moeten worten gevoer. Dat betekent evennin enige steun an het Anerikanse voornemen tot deelakwoorden te komen tussen de partien in het conflict.

Interessant is pun 3 uit deze werklaring warin de Europennen vier punten wax woren

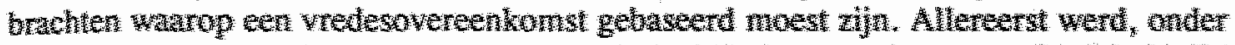

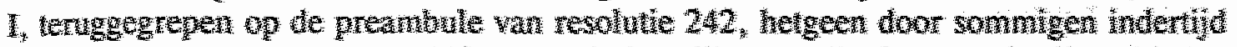

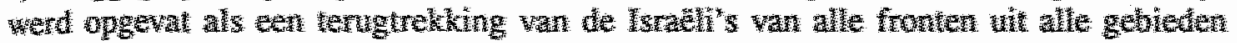

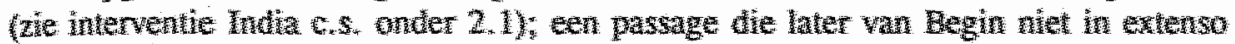
athocht worden ongenome in de Camp Davidakkoorden ${ }^{2}$.

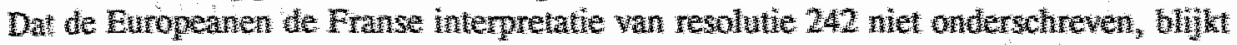

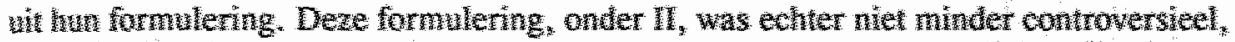

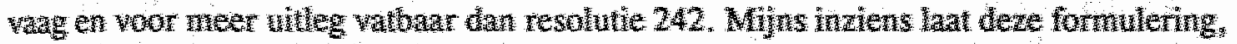
"de territorize bezetting te heerndigen", wel ruimte woor grenscorrecties. Volgens

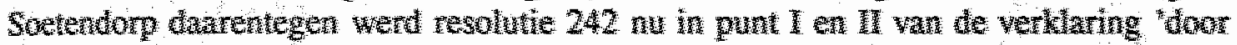

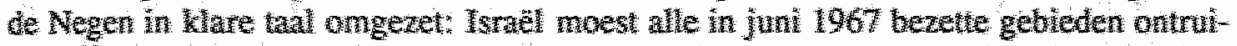

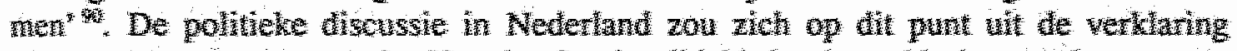
concentreren, we mee ondat Van der Stoel wohield dat de verklaring op deze punten Fiel wershilde van resolutie 242 . Een pretentie die de PviA woordworder, Dan-

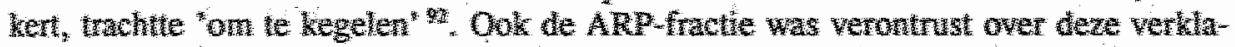

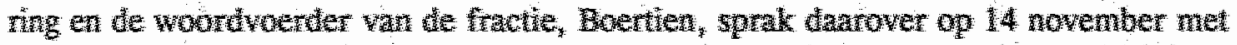
Van der Stoes. In Boetten's verslag staan de volgende interessante zinnen:" Minister Van der Stoel heeft direct na afloop van de EEG-Ministerraad meegedeeld dat Nederland daarover een interpretatieve verklaring heeft gegeven, namelijk dat die passage moet worden opgevat als geheel in overeenstemming met de resolutie 242 d.d. 22 november 1967 en met de passage in de Memorie van Toelichting op de begroting van 1974. Die interpretatieve verklaring is in de notulen der EEG-ministerraad vastge-

88. Strategic Survey 1973, pp. 21-23.

B9. Quandt, 1986, pp. 233.

90. Soetendorp, $1983, \mathrm{p} .146$.

91. Zie ook 2.2.1.8 en 2.2.3.1 over het op non-actief stellen van de woordvoerder van het ministerie van Buntenlandse Zaken, Thurkow, omdat deze meende dat de 6 november-verklaring wèl op een Israëlische terugtrekking uit alle bezette gebieden duidde.

92. Verslagen Tweede Kamer fractie PvdA, F 406, notitie van P. Dankert, 10 januari 1974, zie ook 2.2 .2$, p. 109 . 
legd" 93 . Hieruit blijkt naar mijn mening dat Van der Stoel toch niet zo zeker is geweest dat deze werklaring niet in strijd was met de door Nederland aangehangen versie van resolutie 242. Rozemond wijst erop dat evenals Schmelzer indertijd, die in de VN een operbare stemverklaring aflegde die erop neerkwam dat niet van het eerder gevoerde beleid werd afgeweken, Van der Stoel ditmaal een geheime stemverklaring in dezelfde trant aflegde 94 .

De passage in de Memorie van Toelichting voor de rijksbegroting 1974 was als volgt:

De Nederlandse Regering handhaaft haar standpunt dat een oplossing op basis van VR-resolutie 242/67, in zijn geheel en ondeelbaar, in overleg tussen partijen tot stand gekomen, de beste kansen biedt voor vrede in het Midden-Oosten, dat wil zeggen enerzijds dat Israel zich zal terugtrekken achter overeen te komen veilige grenzen op ten gebied dat bij benadering even groot zal zijn als haar grondgebied vớr de zesdagage oorlog, anderzjjds dat de staat van oorlog in het Midden-Oosten geheel zal worden opgeheven onder respectering en erkenuing van de soevereiniteit en territoriale integriteit en politieke onafhankelijkheid van elke staat in dit gebied. Een rechtwsardige oplossing voor het wragsstuk van de wluchtelingen is naar het oordeel van de Regering even essentieel als een bevredigende oplossing van het territoriale vraiagstuk en daarmede ook onwerbrekelijk verbonden ${ }^{25}$.

Desgevraagd meldde Van der Stoel dat deze interpretatieve verklaring niet op weerstanden stuitte bij de EG-partners. Daarin zag hij een bevestiging van zijn stelling dat de verklaring van 6 november, behoudens het punt over de Palestijnen, niet verder reikte dan resolutie $242^{\circ \%}$ :

Onder punt IV werden de 'legitieme rechten' van de Palestijnen erkend en daarmee werd afgeweken van resolutie 242 waarin de Palestijnse kwestie nog louter als een vluchtelingenprobleem werd beschouwd. Het toekennen van een politieke dimensie aan de Palestijnse kwestie werd ook door de regering als een beleidswijziging beschouwd. Al eerder was ook in de discussie in Nederland echter begrip ontstaan voor het politieke probleem van de Palestijnen. Het was meer dan alleen een humanitaire kwestie. Zo gaf de Nederlandse regering in 1972 ook haar steun aan een resolutie in de Algemene Vergadering wan de Verenigde Naties waarin 'de eerbiediging van de rechten van de Palestijnen als een onmisbaar element voor een rechtvaardige en duurzame vrede in het Midden-Oosten' werd erkend ${ }^{97}$. Twee jaar eerder had Nederland nog tegen een resolutie van gelijke bewoording gestemd.

Minister Schmelzer erkende in 1972 dat Nederlands voorstemmen ditmaal mede werd beinvloed door het standpunt van de overige EG-partners ${ }^{98}$. Overigens had Van der Stoel al in 1971 als voorzitter van de Midden-Oostencommissie van de PvdA de politieke aspiraties van de Palestijnen naar voren gebracht in een nota waarin twee 'nationale strevingen' namelijk van de zionistische beweging en van de Palestijnse Arabieren

93. Verslag ARP-fractievergadering van 15 november 1973 pp. 4-5.

94. Rozemond, 1987, p. 56.

95. Memorie van Toelichting woor de rijkssegroting 1974, p. 14.

96. Brief vin $\mathbb{1}$ september 1983 van Van der Stoel aan auteur.

97. Resolutie 2949 van 8 december 1972 in de Algemene Vergadering der Verenigde Naties; Vragen in de Tweede Kamer van Van der Stoel, Van Thijn en Dankert no. 246, Tweede Kamer zitting 1972-1973, Aanhangsel pp: 495-496a.

98. Soetendorp 1983, pp. 110-112, Schaper, 1975, pp. 236-237. 
werden erkend ${ }^{99}$. Op grond van het eerdere Nederlandse stemgedrag in de Verenigde Naties en de ontwikkeling in de PvdA was de aanvaarding van deze paragraaf door een Nederlands socialistische minister van Buitenlandse Zaken een minder grote beleidsombuiging dan indertijd door de Nederlandse media werd verondersteld. Binnen het partijbestuur van de PvdA stelde Den Uyl indertijd dat de erkenning van de legitieme rechten van de Palestijnen uiteindelijk tot Palestijnse staatsvorming zou moeten leiden ${ }^{100}$.

De hierboven gepresenteerde analyse toont aan dat met de verklaring van zes november slechts in zeer beperkte mate sprake is van een beleidswijziging door de Nederlandse regering. De toonzetting en vooral het moment van uitgifte van dleze verklaring wekte op z'n minst de indruk de Arabieren hiermee gunstig te willen stemmen. Het odium van de 'oliegeur' die aan deze verklaring kleefde, werd versterkt, doordat op 4 november de Arabische olie-exporterende landen besloten de olieproduktie met $25 \%$ - van het niveau van september 1973 - te beperken en vervolgens elke maand een vermindering van $5 \%$ door te voeren. Deze laatste maatregel zou echter niet worden toegepast op die landen die als 'bevriend' beschouwd zouden kunnen worden ${ }^{101}$. In de ogen van de Arabische olieproducerende landen was deze dreiging effectief geweest en zij konden op 18 november bekend maken dat uit dank voor de verklaring van 6 november de reductie van $5 \%$ voor december niet zou gelden voor de EG-lidstaten. Eén land werd daarvan echter uitgezonderd: het olie-embargo tegen Nederland werd gehandhaafd ${ }^{102}$. In dit communiqué van 18 november uit Wenen werd hiervoor geen reden genoemd maar later werd wel duidelijk dat Nederland een eigen gebaar moest maken.

Nederlands hoop op beëindiging van het olie-embargo door in te stemmen met de politieke verklaring van zes november werd daarmee de grond ingeboord. De vraag was vervolgens of Nederland toch op Europese solidariteit zou kunnen rekenen of dat de Europese partners Nederland in de kou zouden laten staan.

\subsubsection{Europese solidariteit blijft uit}

Teruggekeerd uit Brussel lichtte Van der Stoel Den Uyl in over de zes november verklaring die daarop nogal geschrokken reageerde. Pas achteraf werden Den Uyl en de overige leden van het kabinet op de hoogte gebracht van de twee belangrijke beslissingen - toestemming tot en instemming met de verklaring over het Midden-Oostenconflict in EPS-verband - die alleen door Van der Stoel zijn genomen en waarbij aan Nederlandse zijde slechts enkele hoge ambtenaren op het departement van Buitenlandse Zaken betrokken waren geweest.

De regering kwam in een bijzonder moeilijke positie. De critici van de regering volhardden in hun kritiek nu het olie-embargo voortduurde. Degenen die de regering eerder hadden gesteund in haar pro-Israël-beleid, waren daarentegen zeer ontevreden met de zes nowember verklaring. Zo werd Van der Stoel door de eerste groepering verweten door een provocatieve houding - gebaseerd op een vermeende gidslandfunc-

99. Het Midden-Oosten, een brandhaard, Socialisme en Democratie, (28), januari 1971, no. 1.

100. Notulen partijbestuur PvdA, 12 november 1973.

101. Conference of Arab Oil Ministers, the Communique, Kuwait, November 4-11-1973, in: Paust and Blaustein, 1977, pp. 6 en 46.

102. Paust and Blaustein, 1977 , pp. 7 en 12. 
tie - Nederland onnodig in de problemen te hebben gebracht. De tweede groepering verweet Van der Stoel nu Israêl te hebben laten vallen met deze 'knieval voor chantage' (deze laatste term was de kop van het commentaar in het Utrechts Nieuwsblad van 7 november 1973). Ik zal op deze binnenlandse kritiek in de volgende paragrafen uitgebreid terugkomen.

In feite was het voor Van der Stoel vanwege de internationale politieke situatie niet goed mogelijk op deze kritiek te reageren, wilde hij het pro-Israel standpunt van de Nederlandse regering handhaven. Indien hij bijwoorbeeld de interpretatieve verklaring in de openbaarheid zou hebben gebracht, was de kritiek van de tweede groepering wel verstomd maar zou het olie-embargo zeker zijn gecontinueerd. Bovendien zouden de Europeanen dan nog minder geneigd zijn geweest Nederland te helpen. De gemeenschappelijke Europese verklaring vervulde voor Nederland een beschermende 'paraplufunctie', een verklaring waar men zich achter kon verschuilen. Aan de andere kant heeft de regering op grond van haar politieke overtuiging de binnenlandse druk van de eerste groepering weerstaan door geen nieuwe verklaringen uit te geven die iets meer de Arabische kant uitgingen. De woordvoerder van het departement van Buitenlandse Zaken, Thurkow, die de verklaring van zes november op een persconferentie op 4 december interpreteerde als betrekking hebbend op Israëlische terugtrekking uit alle bezelte gebieden werd, na een interpellatie van de Tweede Kamer, vervolgens door de minister op non-actief gesteld ${ }^{103}$. Thurkow zou tegen journalisten gezegd hebben: 'Maar jullie moeten niet vergeten dat de tijd niet stilstaat, er is toch wel iets veranderd, al is het standpunt hetzelfde gebleven" ${ }^{104}$.

Niet zozeer vanwege de kritiek in eigen land maar wegens de slechte economische vooruitzichten en het woortdurend ontbreken van Europese steun kon de positie van de Nederlandse regering op dat moment als 'moeilijk' worden gekwalificeerd. In de ministerraad van 30 november ging het kabinet uit van een vermindering van 40 procent in de aanvoer van olie. De regering verwachtte dat als gevolg daarvan het aantal extra werklozen - op dat moment nog 55.000 - tussen de 100.000 a 200.000 zou komen ${ }^{105}$. Wellicht om paniek te voorkomen werd op de persconferentie na afloop meegedeeld dat een verdubbeling van de werkloosheid niet werd verwacht ${ }^{106}$ "Wel richtte de premier zich in een speciale toespraak op de televisie rechtstreeks tot het Nederlandse volk - een weinig voorkomend gebeuren in Nederland - met de befaamd geworden uitspraak; "Zo bezien, keert de wereld van vóór de oliecrisis niet terug" ${ }^{107}$.

In deze omstandigheden werd de onstane situatie als een economische crisis gepercipieerd ${ }^{108}$. Volgens sommigen is Nederland in 1973 niet in een crisis terechtgekomen

103. Radio Nieuwsdienst ANP 18.00 uur en NOS Journal van 20.00 uur en 23.20 uur op 4 december 1973; Handelingen Tweede Kamer, zitting 1973-1974, 5 december p. 1439; NRC-Handelsblad 8-121973.

104. Uit I. Comelissen: Mr. Thurkow, Van der Stoels tronwste ambtenaar, Vrij Nederland 22-12-1973, pp. 1 en 2.

105. Versllag van Pronk, Notulen partijbestuur PvdA, 3 december 1973.

106. NRC-Handelsblad 1-12-1973.

107. Televisie-toespraak op 1 december 1973; NRC-Handelsblad 3-12-1973.

108. Ook volgens de definitie van het 'Intermational Crisis Behavior Projeet', die zich concentreert op de perceptie en het gedrag van een staat, kan gesteld worden dat Nederland zich toen in een econo- 
omdat de olie-tekorten achteraf gezien meevielen ${ }^{109}$. Dat laatste is juist, maar het is met name de verwachting die bepalend is voor crisisgedrag. Zo lag in een berekening van het departement van Economische Zaken op 23 november 1973 de raming voor de olietoevoer in januari $197460 \%$ lager dan de feitelijke uitkomst later bleek te zijn ${ }^{10}$. De hoogste besluitvormers - leden van het kabinet - hadden in elk geval de perceptie van een dreiging en zochten nu naar het Nederlandse antwoord. Tegen het partijbestuur van de PvdA zeil Pronk over dat antwoord op 3 december 1973: 'Nederland heeft wat betreft de internationale samenwerking de keuze tussen samenwerking met de Verenigde Staten of de EEG. Omdat wij economisch afhankelijk zijn van de EEG, wordt de samenwerking met de VS voorlopig afgehouden; het wachten is op de houding van andere Europese landen tijdens de komende Europese top" ${ }^{\text {"II }}$. Deze top zou op 15 december in Kopenhagen plaatsvinden en wordt in de volgende paragraaf behandeld. Reeds in oktober had Nederland contact gezocht met de Europese Commissie. Op 24 oktober kwam haar voorzitter, Ortoli, naar Den Haag en verklaarde dat bij een Arabische boycot van Nederland de Europese solidariteit op de voorgrond zou dienen te staan ${ }^{12}$. Op 26 oktober stelde de Commissie aan de Raad voor een informatiesysteem op te zetten ten einde gecoördineerde hulp van allen te kunnen bieden bij een crisis in één land ${ }^{113}$.

Eerder werd gesteld (zie 2.2.1.7) dat op 6 november 's middags een economische gemeenschapsverklaring niet werd aangenomen waardoor over de olievoorziening geen positief resultaat werd behaald. Op 7 november 's morgens kwam de Amerikaanse minister van Defensie, Schlesinger, bij Van der Stoel op bezoek en bood Nederland hulp aan in de oliebevoorrading. Later zouden ook de Amerikaanse minister van Buitenlandse Zaken, Kissinger, op 22 november en de Amerikaanse minister voor oliezaken, Donaldson, op 17 december dit aanbod herhalen. Nederland was wel gelukkig met het

108. $(\rightarrow)$

mische crisis bevond. Immers niet de feitelijke situatie is kenmerkend voor het crisisbegrip masir de verwachtingen van de besluitvormers zijn bepalend voor crisisgedrag. Volgens Brecher, "a crisis is a situation with three necessary and sufficient conditions, deriving from a change in its external or internal environment, all three conditions are perceptions held by the highest level decisionmakers;

1. threat to basic values, with a simultaneous or subsequent;

2. high probability of involvement in military hostilities and the awareness of;

3. finite time for response to the external walue threat.'

Met name de tweede voonwarde geldt voor het issue-area van militaire veiligheid en kan voor het economisch gebied worden vervangen. 'An economic crisis requires an expectation of adverse material consequences unless the response were drastic and effective" M. Brecher - India's Devaluation of 1966: Linkage politics and crisis decisionsmaking, British Journal of International Studies, 3 april 1977,1 . Brecher, 1980, p.1.

In dit geval werd de dreiging van basisvoorwaarden in de Nederlandse samenleving weroorzaakt door een verandering in de externe omgeving vaun Nederland waarop binnen beperkte tijd gereageerd moest worden.

109. Soetendorp, 1984 , p. 40.

110. Tweede Kamer, zitting 1973-1974, no. 12.946 , no. 5, p. 1.

111. Notulen Partijbestuur PvdA, 3 december 1973.

112. Europe, 25-10-1973, p. 1386.

113. Europe, 26-10-1973, p. 1387. 
Amerikaanse aanbod waardoor tewens Nederlands onderhandelingspositie werd versterkt. We hebben zojuist echter kunnen constateren dat deze samenwerking met de VS voorlopig werd afgehouden. De Nederlandse hoop op Europese solidariteit werd echter wel zwaar op de proef gesteld. De Europese Commissie, die gemeenschappelijke maatregelen voorstond, kreeg begin november geen gehoor en werd door de Energie-Raad op 3 en 4 december volledig buiten spel gezet bij de voorbereiding van de top, terwijl de haar toegedachte taak - administratieve en organisatorische voorbereidingen voor een gezamenlijke aanpak van de energiecrisis - drie dagen na die topconferentie door een Brits veto zou worden geblokkeerd ${ }^{114}$. Nederland zou - in de woorden van Den Uyl'er verbitterd voor vechten dat de EG zich waarmaakt' ${ }^{115}$. Het Kamerlid Van der Hek meende ook dat Nederland consequenties zou moeten trekken uit de opstelling van de Europese partners ten aanzien van de invoer en uitvoer van olie, olieprodukten en aardgas ${ }^{116}$. De minister van Economische Zaken, Lubbers, gaf daarop als reactie dat de Nederlandse regering niet zou schuwen de aardgasuitvoer te beperken als een gemeenschappelijk energiebeleid met de andere Europese partners niet tot stand zou komen ${ }^{117}$.

De bereidheid deze vergaande maatregel te nemen, hier als de achtste beslissing aangeduid, was gezien de Nederlandse buitenlandse politieke traditie, bijzonder. Wel werd er door Lubbers aan toegevoegd dat dergelijke maatregelen slechts in noodgevallen zouden worden genomen. Deze laatste restrictie lijkt meer op juridische dan op politieke gronden gebaseerd te zijn. De dreiging van het aanwenden van negatieve sancties tegenover de Europese partners was aan Nederlandse zijde geuit. Dit zou op 10 december 1973 in een overleg van premier Den Uyl met de fractieleiders van KVP en ARP, Andriessen en Aantjes, herhaald worden. Op dat moment werden ook binnenlandse maatregelen - omschakeling van olie op aardgas en naast de benzinedistributie ook distributiemaatregelen voor andere grondstoffen - door Den Uyl overwogen ${ }^{118}$.

In de eerste helft van 1973 werd 15,5 miljard kubieke meter aardgas geëxporteerd, ten opzichte van het Nederlands verbruik bedroeg deze export $75 \%$. De export ging naar West-Duitsland ( 7 miljard), België $\left(4,5\right.$ miljard) en Frankrijk (4 miljard) ${ }^{119}$. De afhankelijkheid van deze energiebron was echter niet zo groot voor deze landen: in 1973 was het aandeel van aardgas in het totale energieverbruik voor West-Duitsland $10,1 \%$, voor België/Luxemburg 13,8\% en voor Frankrijk $8,1 \% 120$. De Duitse directeurgeneraal politieke zaken zei miet onder de indruk te zijn gekomen van deze 'dreiging:

114. NRC-Handelsblad novembermdecember 1973.

115. NRC-Handelsblad, 23-11-1973.

116. NRC-Handelsblad, 15-11-1973.

117. NRC-Handelsblad, 16-11-1973; Tweede Kamer, zitting 1973-1974, Aanhangsel, vraag no. 504, p. 1009, Europe, $19 / 20$ november 1973, p. 1402.

118. Verslag ARP-fractie 11 december 1973.

119. Tweede Kamer, zitting 1973, zitting 1973-1974, Aanhangsel p. 1009. Antwoord van minister Lubbers op 30 november 1973 .

120. Grosser, 1982, p. 276. Zijn tabel is gebaseerd op R.J. Lieber, Oil and the Middle East War: Europe in the Energy crisis, Harvard University Press 1976. 
Hij ervoer de Nederlandse uitspraak ook niet als een dreiging en deze heeft in het besluitwormingsproces aan Duitse zijde geen rol gespeeld ${ }^{121}$.

Op de mislukte Energie-Raad zei Van der Stoel eveneens dat de EG-lidstaten het aan den lijve zouden ondervinden, als de Nederlandse economie aan de basis zou worden aangetast: 'Dat is de economische realiteit' 122 .

Nederland hoopte dat het niet zo ver hoefde te komen en trachtte zijn invloed in de bilaterale contacten aan te wenden met het oog op het bereiken van een gunstig resultaat op de top. Zo sprak Den Uyl tijdens de Socialistische Internationale op 10 november in Londen met de Duitse bondskanselier Brandt. De volgende morgen, op zondag 11 november, had Den Uyl een onderhoud met de Britse minister-president Heath. Op 9 november sprak Van der Stoel in Parijs met zijn collega Jobert en president Pompidou. Begin november bleken deze regeringsleiders nog niet van standpunt te zijn veranderd en waren het de oppositiepartijen in eigen land, de Engelse en Franse socialisten en de Duitse christen-democraten, die eerder op een positiever standpunt ten aanzien van Israël en voor de instandhouding van een gemeenschappelijke markt (i.c. ten gunste van Nederland) aandrongen.

Op 19 november verklaarden Pompidou en Heath nog gezamenlijk in een communiqué, zich te zullen verzetten tegen het opstellen van een schema om de beschikbare olie te verdelen. Op 26 november verklaarde Brandt voor het eerst dat Europese solidariteit in de oliecrisis noodzakelijk was en dat Duitsland Nederland ook op de Energie-Raad van 4 december zou steunen ${ }^{123}$. Den Uyl heeft in deze periode ook enkele malen telefonisch contact gehad met Brandt. Diens steun nam enigszins toe maar was toch weinig uitgesproken ${ }^{124}$.

\subsubsection{Instemming met verklaring op Europese top}

Medio december zou de Europese top in Kopenhagen worden gehouden. Daarop had Nederland zijn hoop gevestigd, omdat tot dan toe de Nederlandse diplomatieke activiteiten niet tot resultaat hadden geleid. Deze topconferentie kwam in de daaraan voorafgaande dagen al onder druk te staan, doordat met name de grote mate van onenigheid in de transatlantische verhoudingen zichtbaar werd.

In de Oktoberoorlog was het wederzijdse wantrouwen tussen de VS en de Europese landen gegroeid. De wrevel had aan Amerikaanse zijde vooral betrekking op het gebrek aan begrip en medewerking voor het beleid van de VS (bijvoorbeeld bij het transport. van Amerikaanse wapens via Bremerhaven naar Israël). Vanuit Washington werd de door de Europeanen voorgestane ondeelbaarheid in veiligheidsvraagstukken in twijfel

121. Interview met Van Well op 30 januari 1990 . Het trok wel de aandacht in de buitenlandse pers, bijwoorbeeld op 21 november 1973 luidde de 'kop' in de International Herald Tribune 'The Hague says it may cut North Sea gas exports."

122. NRC-Handelsblad, 5-12-1973.

123. Europe, 28-11-1973, p. 1408.

124. Dit is mijn indruk op basis van cle wat gereserveerde opstelling van zowel Den Uyl als Van der Stoel daarover. De Duitse directeur-generaal politieke zaken uit die tijd Van Well was echter wan mening dat Duitsland Nederland steeds heeft gesteund. Interviews respectievelijk op 26 februari 1987,17 november 1982 en 30 januari 1990. 
getrokken 125 . Aan Europese zijde werd de Amerikanen gebrek aan bondgenootschappelijk overleg verweten vooral naar aanleiding van de beslissing van de VS op 25 oktober alarmfase 3 (nucleair alarm, alle Amerikaanse troepen in staat van paraatheid) af te kondigen. Een confrontatie tussen de Sovjetunie en de VS dreigde. De gevaarlijkste internationaal politieke situatie sedert de Cuba-crisis deed zich voor.

Binnen het NAVO-beraad werden de plooien wel gladgestreken met zelfs een gemeenschappelijk paragraafje over het Midden-Oosten, maar de Frans-Amerikaanse tegenstelling kwam dezelfde dag in dezelfde stad - Brussel - met nagenoeg dezelfde personen ${ }^{126}$, op een andere locatie weer boven ${ }^{127}$. De volgende dag, op 12 december 1973, zei Kissinger dan ook dat 'sommige Europeanen tegenwoordig meenden dat de maatstaf voor de Europese identiteit moest zijn de afstand die Europa scheidde van de VS' ${ }^{128}$.

In de toespraak op 12 december voor de Pilgrims Society te Londen verklaarde Kissinger dat de Amerikaanse wapenluchtbrug naar Israël niet als partij kiezen voor Israël moest worden beschouwd. Reden van de hulp was 'om als Westen enige invloed te behouden bij het tot stand brengen van een politieke toekomst voor een gebied waarvan Europa nog sterker dan de VS afhankelijk is'. Vervolgens ging hij in op de diepere oorzaken van de energiecrisis en zocht hij naar een oplossing voor de langere termijn. Deze lag in een prikkel tot produktieverhoging, rationeler gebruik van energie en het ontwikkelen van alternatieve energiebronnen. 'Dit is een oplossing die de VS met grote moeite alleen kunnen oplossen en die Europa in isolement in het geheel niet kan oplossen. Daarom doen de VS het voorstel dat de naties van Europa, Amerika en Japan een energie-actiegroep instellen" 129 . Ook Den Uyl wees van meet af aan op de diepere oorzaken van de energiecrisis en vanuit Duitsland werd dit later vertaald naar noodzakelijke solidariteit binnen de EG. Daarnaast dreigde de voorzitter van de Commissie, Ortoli, op 7 december te zullen aftreden als de top in gebreke zou blijven. Hij voerde daarbij aan: 'als de energiecrisis voortduurt zal niet alleen Nederland, maar heel de EG verpauperen' ${ }^{130}$.

Kissingers uitdaging ging sommige Europeanen well erg ver.

Vanuit een analyse van het Amerikaanse buitenlands beleid concluderen Maghroori en Gorman dat het Arabische olie-embargo tegen de VS niet effectief was vanwege de directe invloed op het Amerikaanse verbruik, maar dat de beperking van de olie-export wel effectief was door de afhankelijkheid van West-Europa en Japan van de Arabische

125. Keesings Historisch Archief, 11 januari 1974, pp. 21-22.

126. De lerse vertegenwoordiger, wel lid van de EG maar niet van de NAVO, kwam het cerdere gezalschap versterken.

127. De Amerikaanse ministers van Defensie (Schlesinger) en Buitenlandse Zaken (Kissinger) kwamen natar Europa voor berad in de NAVO; Schlesinger op 7 november en Kissinger op 10 en 11 december 1973.

128. Keesings Historisch Archief 11 januari 1974, pp. 20-21; Kissinger, 1982, p. 725.

129. Keesings Historisch Archief 11 januari 1974, p. 21; zie ook Kissinger 1982, pp. 725-727.

130. NRC-Handelsblad 7-12-1973. 
olie. Hun tekorten werden veroorzaakt door het Amerikaanse beleid. Gevolg daarvan was dat hun relaties met de VS gespannen werden ${ }^{131}$.

In oktober en november stonden in het bijzonder het vraagstuk van de olievoorziening en het in te nemen standpunt ten aanzien van het Arabisch-Israëlisch conflict centraal. Beide kwesties speelden op de Europese top, maar daar kwam als derde factor bij de relatie met de VS. Op dat moment bleek alleen Frankrijk bereid te zijn zich van Washington te isoleren door een onafhankelijk Midden-Oostenbeleid ${ }^{132}$.

De top met voor de laatste maal de drie leiders Pompidou, Heath en Brandt bijeen, had een merkwaardig verloop. Pompidou was - al zeer ernstig ziek - in Kopenhagen aanwezig, maar wilde niet over zoiets 'banaals' als olie overleggen. Volgens hem moesten de grote lijnen voor de Europese identiteit en Europese samenwerking worden uitgestippeld. De energieverklaring zou dan ook slechts als bijlage worden uitgegeven. Ook Heath, weliswaar meer dan de Fransen gericht op Atlantische samenwerking, schaarde zich enerzijds graag achter het Franse "grand-design' maar riep te zelfder tijd 'dat geen Engelse olie aan andere EG-landen zal worden afgestaan'. Het waren daar met name Ortoli, Brandt en Den Uyl die zich tegen Frankrijk en het Verenigd Koninkrijk verzetten en enige steun van de andere EG-lidstaten kregen. Tot een doorbraak zou het niet komen en het resultaat was een lange maar weinig zeggende verklaring van de Deense voorzitter waarin echter wel openingen voor de toekomst werden geboden. Evenmin werd de zes novemberverklaring nu aangescherpt ondanks de aanwezigheid van de Arabische minitop in Kopenhagen - de ministers van Buitenlandse Zaken van Algerije, Tunesië, Soedan, de Verenigde Arabische Emiraten verschenen plotseling met de Arabische ambassadeurs uit de Scandinavische landen - die bedoeld was om druk op de EG uit te oefenen ${ }^{133}$.

Den Uyl heeft op deze top hard voor het Nederlandse standpunt gestreden. Dat standpunt omvatte de drie aan het begin van dit hoofdstuk gestelde doeleinden. Volgens Den Uyl zag Pompidou in hem een heuse 'straatvechter' ${ }^{134}$. Van een ommekeer kon nog niet worden gesproken, maar een naar Nederlands inzicht ongewenste ontwikkeling werd nu niet voortgezet. Er werden voor het eerst weer openingen geboden. Zo kwam het initiatief van Kissinger voor een energie-actiegroep ter sprake en werd dat niet publiekelijk afgewezen. Voor een gezamenlijke Europese aanpak zou onder voorzitterschap van de Europese Commissie een crisiscomité worden opgericht. Aan Israël werden in Kopenhagen geen Europese eisen, anders dan die van 6 november, gesteld. In feite waren hiermee de verhoudingen grondig gewijzigd en stond Nederland na twee maanden niet langer geïsoleerd binnen de EG maar raakten Frankrijk en het Verenigd Koninkrijk in een isolement. Dat was voor hen moeilijk te verkroppen en beide landen

131. "And it was the fact that unilateral US politics were responsible for the disruption of oil flows to Western Europe and Japan that strained their relations with Washington, since they were in effect experiencing the repercussion of policies in which they had had no voice.' Maghoori and Gorman, 1981, pp. 66-67.

132. Zie ook Stephens, 1974, p. 19, aangehaald door Dajani, 1982, pp. 221-222.

133. Hun intermezzo maakte wan deze top een "surrealistische, soms aan het absurde grenzende en daarom verbijsterende gebeurtenis'. Hoofdredactioneel commentar NRC-Handessblad wan 17-121973.

134. Interview met Den Uyl op 26 februari 1987. 
lieten na afloop van de top aan de Arabische wereld weten dat de Bondsrepubliek Duitsland en Nederland zich hadden verzet tegen een voor Israël veel scherpere verklaring dan in werkelijkheid werd aangenomen. In de verworpen tekst werd aan Israel gevraagd zich dankbaar te tonen voor de Arabische bereidwilligheid om in Genevve te gaan onderhandelen ${ }^{135}$.

Tijdens de Raad van Ministers op 17 en 18 december, eisten de Britten veel meer geld dan de Commissie (respectievelijk 11 en 8 miljard gulden) aan de Raad had gevraagd voor het fonds voor de ontwikkeling van achtergebleven gebieden in de EG-landen. De Duitsers - als grootste betaler - weigerden en sloten verdere onderhandelingen daarover uit. Daarop spraken de Britten hun veto uit inzake de oprichting van het crisiscomité en werd aldus de eerste aanzet tot een gemeenschappelijke aanpak van de energieproblemen getorpedeerd. De commissievoorzitter, Ortoli, concludeerde: ' $\mathrm{Er}$ is gewoon veel meer communautaire geest nodig" ${ }^{n 136}$.

\subsubsection{Instemming met verklaring conferentie van Washington}

In aansluiting op de toespraak wan Kissinger van 12 december stuurde president Nixom op 9 januari 1974 de vitnodigingen voor de energieconferentie voor 11 februari te Washington.

Voor de conferentie werden Noorwegen, Japan, Canada, de landen van de EG en de voorzilter van de OESO uittgenodigd. Aan de olieproducerende landen werd eveneens een brief gestuurd waarin werd meegedeeld dat de olieconsumerende landen nu werden uitgenodigd voor overleg en gehoopt werd dat dat overleg spoedig tot een gezamenlijke conferentie van consumenten- en producenten-naties zou leiden. Jobert zag de Amerikaanse uitnodiging als een provocatie jegens de Arabische vrienden. De Fransen wilden de energieproblemen buiten de VS regelen door middel van de Euro-Arabische dialoog en bilaterale overeenkomsten. Desondanks besloot de Raad van Ministers dat de EG - in de persoon van de voorzitter van de Raad en de Commissie, Scheel en Ortoli - aan de uitnodiging gehoor zou geven. Veel van de Franse bezwaren kwamen echter wel terug in het mandaat voor de EG-delegatie dat door de Raad van Ministers op 4 en 5 februari werd opgesteld. De EG zou bijwoorbeeld moeten pleiten voor een permanente dialoog met de producentenlanden en zich moeten verzetten tegen de oprichting van een permanent overleginstituut van de consumentenlanden.

Dat laatste was nu precies de bedoeling van de VS, al verving Kissinger nu de term 'actiegroep" door 'coördinatiegroep' voor een veelomvattend actieprogram. De Franse delegatie verzette zich dartegen en stemde tegen de daarop betrekking hebbende passages in het slotcommuniqué. Aan de OESO werd - op bijeenkomsten van de coördinatiegroep waaraan Frankrijk niet meer meedeed - de uitvoering opgedragen ${ }^{137}$.

Later in november 1974 werd binnen de OESO het Internationaal Energie Agentschap opgericht dat aan het slot van dit hoofdstuk (2.4) zal worden behandeld.

135. NRCHandelsblad 19-12-1973.

136. Keesings Historisch Archief, 4 januari 1974, p. 9.

137. Keesings Historisch Archief, 21 juni 1974, pp. 388-391. 


\subsubsection{Het parlement en de politieke partijen}

In de vorige paragraaf werden tien beslissingen wan de Nederlandse regering naar voren gebracht. Bij slechts twee van deze beslissingen was het parlement direct betrokken en heeft het invloed kunnen uitoefenen op de inhoud van de beslissing. Dat waren de eerste regeringsverklaring van 9 oktober (no. 2) en de olie-verbruik-beperkende maatregelen van 31 oktober (no, 5).

Inzake de andere beslissingen is het parlement niet van tevoren geraadpleegdl en kon het de regering pas achteraf ter verantwoording roepen. De uitzonderlijke eerste beslissing (militaire hulp aan Israël) werd voor het parlement geheim gehouden. Zo vernam Van Mierlo, lid van D'66 in de commissie voor Buitenlandse Zaken, deze beslissing pas in 1980 toen hij minister van. Defensie was geworden en het dossier doornam ${ }^{138}$.

De invloed van het parlement op het buitenlands beleid was steeds al zeer beperkt geweest, alhoewel deze sedert het eind van de jaren zestig enigszins was toegenomen ${ }^{139}$. Daar staat tegenover dat we het parlement in het eerste hoofdstuk wel als formele besluitvormer naar voren hebben gebracht en de steun van het parlement voor binnenlandse beïnvloedingspogingen van anderen als een noodzakelijke voorwaarde voor succes hebben verondersteld. Werd de regering als schakel beschouwd tussen de internationale politiek en het buitenlands beleid, zo kunnen de volksvertegenwoordigers als schakel. tussen de binnenlandse opinie en het buitenlands beleid worden gezien.

Bij beslissingen die in internationale politieke organen worden genomen, is de invloed van het parlement welhaast per definitie beperkt. Wanneer het parlement pas achteraf in debat kan treden, wordt die invloed nog geringer. Indien bovendien een parlement ervoor terugschrikt in een crisissituatie kritiek op het regeringsbeleid naar voren te brengen waardoor Nederlands internationale positie zou kunnen verzwakken, resteert er nog slechts weinig van de parlementaire invloed. Dit laatste deed zich voor in de kwestie van het olie-embargo. Ter illustratie van deze moeilijke positie voor het parlement diene het volgende voorbeeld.

Binnen de ARP-fractie stelden enkele leden voor naar aanleiding van de EG-verklaring van 6 november de regering kritische vragen te stellen of te interpelleren. De fractie beslloot uiteindelijk daarvan af te zien om de positie van de minister van Buitenlandse Zaken, zowel extern in de internationale politiek als intern in de partijpolitieke verhoudingen, niet te verzwakken ${ }^{140}$.

Al was de direct waarneembare invloed van het parlement op de regeringsbeslissingen gering, toch was de invloed van het parlement op de vrijheid van handelen van de regering wel aanwezig. Deze vrijheid van handelen werd beperkt door de overwegende pro-Israël consensus in het parlement. In de vorm van anticiperende invloed heeft de regering dan ook steeds rekening gehouden met de voorkeur van het parlement. Zo verklaarde Van der Stoel dat het aanbieden van wezenlijke concessies aan de Arabische

138. Interview met van Mierlo op 2 aprill 1987.

139. Zie onder meer Voorhoeve, 1985, pp. 81-82, die stelt: "Although parliamentary participation in foreign policy has increased, particularly since the late 1960 's, the determination of daily foreign policy has remained largely in the hands of the Foreign Minister'.

140. Verslag ARP-fractie, 13 november 1973. 
gesprekspartners in strijd zou zijn geweest met de zo uitdrukkelijk gebleken will van de overgrote meerderheid van de volksvertegenwoordiging ${ }^{141}$.

De parlementariërs waren zich ervan bewust dat deze kwestie zeer gevoelig lag in de Nederlandse samenleving en drongen er bij de regering op aan de afstand tussen de gevoelens van de mensen en de buitenlandse politieke acties zo klein mogelijk te houden. Bovendien werd de regering aangemoedigd het Midden-Oostenbeleid in deze periode ook continu uit te leggen aan de bevolking ${ }^{142}$. De schakelfunctie kon des te beter worden uitgeoefend vanwege de overeenstemming in het politieke oordeel ten aanzien van het Arabisch-Israellisch conflict tussen zowel de publieke opinie en het parlement als tussen politieke partijen in het parlement ${ }^{143}$. Dat laatste is ook een bijzonder aspect. Over veel buitenlandse politieke vraagstukken verschillen de opvattingen volgens de links-rechtse tegenstelling ${ }^{144}$. Inzake het Midden-Oostenvraagstuk daarentegen waren verschillen in politieke opvattingen indertijd eerder binnen dan tussen de politieke partijen te vinden ${ }^{145}$. Dit verschijnsel deed zich ook in andere Westeuropese landen voor ${ }^{146}$.

Dit betekent echter niet dat binnen het parlement in deze olie-embargo-kwestie geen verschil van mening bestond over het te voeren beleid. Naarmate Nederland sterker door de negatieve sancties werd getroffen, nam de kritiek vanuit de oppositie op het beleid van Van der Stoel en het kabinet-Den Uyl toe. Zij verweten Van der Stoell een onhandig optreden en vooral de zogenaamde voortrekkersrol van Nederland als 'gidsland' werd als oorzaak van het olie-embargo naar voren geschoven. Met andere woorden, het olie-embargo werd aangegrepen om de kritiek op het buitenlands beleid van de regering te uiten. De oppositie had bezwaar tegen de Nederlandse veroordelingen van de dictatoriale regimes in Portugal, Griekenland, Zuid-Afrika en Chili. In de opvattingen van de critici behoorde Nederland zijn buitenlands beleid meer te baseren op zijn nationale economische belangen dain bijvoorbeeld op de naleving van de mensenrechten. In hun opvattingen was de balans onder de socialistische bewindslieden in de buitenlandsector doorgeslagen naar een getuigenispolitiek waarin Nederland andere staten voorschreef hoe zij zich moesten gedragen ${ }^{147}$.

De kritiek van de oppositie op de regering sloeg niet op de inhoudelijke opvattingen van de regering ten aanzien van het Arabisch-Israëlisch conflict. Daarover bestond consensus, waarbij de oppositie in het begin van de Oktoberoorlog de regering nog overtrof in sympathie voor Israël. Zo sprak VVD-fractievoorzitter Wiegel op 9 oktober in het parlement over de 'invasie' in Israël. Bij het begin van de algemene beschouwingen werd de sympathie voor Israël geuit en onderschreven de politieke partijen, met uitzon-

141. Brief van Vian der Stoel an auteur 1 september 1982.

142. Handelingen Tweede Kamer, zitting 1973-1974, 29 november 1973, p. 1348.

143. De opvattingen wan politieke partijen en parlement worden in deze paragraaf behandeld. De resulta. ten van publieke opinie onderzoek over deze kwestie worden in 2.2 .4 .5 behandeld.

144. Everts (ed.), 1985, pp. 339-340.

145. Handelingen Tweede Kamer, zitting 28 augustus 1980, p. 5965. Zie 1.4.2.4. Met instemming van andere parlementariërs werklaarde Brinkhorst bijvoorbeeld in 1980 dat het Nederlandse MiddenOostenbeleid gelukkig nooit een gepolariseerd beleid is geweest.

146. Interview met Patijn op 7 december 1981.

147. Handelingen Tweede Kamer, zitting 1973-1974, van 29 november 1973, p. 1300 over debat De Koster - Van der Stoel. 
dering van de PSP en de CPN, de pro-Israël-verklaring wan de regering. De fractieleiders van de PvdA, de PPR en de ARP brachten daamaast naar voren dat ook een oplossing gevonden moest worden voor de politieke aspiraties van de Palestijnen ${ }^{148}$. De dag tevoren schijnen in de vaste Kamercommissie voor Buitenlandse Zaken met name de oppositionele VVD en CHU zich voor sterke steun aan Israell te hebben uitgesproken; zij zouden zich later in dezelfde vaste Kamercommissie uiterst kritisch hebben opgesteld ten aanzien van deze regeringsverklaring. Volgens Van der Stoel werd hem destijds de schuld van het olie-embargo toegerekend vanwege de inhoud van de eerste regeringsverklaring. De CHU en de VVD werden door een Kamerlid van de PvdA indertijd als 'oliepartijen' beschouwd ${ }^{149}$.

Tien jaar later nog bracht Van der Stoel in een interview zijn afgrijzen naar buiten over de rol van de fractieleider van de CHU, Kruisinga, die zo nodig op de autoloze zondag voor de goede sier naar de honorair consul van Koeweit, Rabbani, moest fietsen ${ }^{150}$. In de euforie van de eerste dagen van de Oktoberoorlog vroegen op 12 oktober de defensiespecialisten van de drie confessionele partijen de regering om Israël niet alleen morele maar ook materiële steun te verlenen ${ }^{151}$.

Het kabinet-Den Uyl werd gesteund door de fracties van PvdA, D'66 en PPR en gedoogd door de fracties van ARP en KVP. Het is interessant de opstelling van de meer regeringsgezinde fracties en de meer oppositionele fracties in de crisissituatie van eind oktober tot medio december nader te onderzoeken.

Achteraf is van PvdA-zijde wel beweerd dat een kabinet van een andere politieke samenstelling onder deze omstandigheden Israël eerder in de steek zou hebben gelaten ${ }^{152}$. De oppositie werd vooral geleid door De Koster (VVD) en Kruisinga (CHU) die in deze periode nauw contact met elkaar onderhielden.

Het standpunt binnen de $\mathrm{CHU}$-fractie werd bepaald door Kruisinga die de redevoering opstelde. Andere leden van de fractie werd de mogelijkheid geboden op het concept te

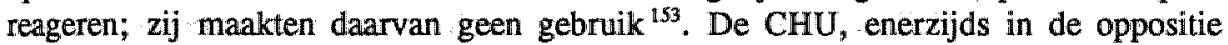
tegenover het kabinet-Den Uyl, anderzijds deelnemer in de fusie-besprekingen voor een CDA, heeft niet samengewerkt met de twee confessionele partijen die het kabinet wel gedoogden. De CHU voerde een felle oppositie waarbij zowell de leider van de Eerste Kamerfractie, Van Hulst, als de fractieleider in de Tweede Kamer, Kruisinga, tegenover Van der Stoel telkenmale het beleid van Luns in 1967 als nastrevenswalardig voorbeeld presenteerden. Deze kritiek op Van der Stoel ondervond enig verzet in de partij waar de buitenlanddeskundige, Bos, die niet meer deel uitmaakte van de fractie, meende dat

148. Handelingen Tweede Kamer, zitting 1973-1974, van 9 oktober 1973, p. 76 (VVD), p. 90 (ARP), p. 98 (PvdA), p. 123 (PPR)).

149. Interview met Patijn op 7 december 1981; van deze vergaderingen van de vaste Kamercommissie bestaan geen verslagen.

150. De Volkskrant, interview met Van der Stoel door Brill en Groen op 30 oktober 1982.

151. Dat waren Van Elsen (KVP), Van Leeuwen (ARP) en Scholten (CHU) in vraag no. 334, Aanhangsel p. 669, Tweede Kamer, zitting 1973-1974.

152. E. van Thijin in een toespraak voor de JOWD eind 1973, volgens interview met Wajsberg op 24 maart 1982.

153. Archief CHU Tweede Kamerfractie bij de Tweede Kamer te Den Haag 1973-1974. 
het volstrekt zinloos was te beweren dat Nederland aan een embargo zou zijn ontkomen indien Luns nog minister van Buitenlandse Zaken was geweest ${ }^{154}$. In het licht van deze discussie is het opvallend dat de secretaris-generaal van de Arabische Liga, M. Riad, de uitspraak van Luns uit medio oktober 1973, dat gebruikmaking van het oliewapen door de Arabieren bijna als een casus belli kon worden beschouwd, aanmerkte als de ware reden van de boycot tegen Nederland en dat de oorzaak niet lag bij de politiek van de Nederlandse regering ${ }^{1.55}$.

De $V V D$ had zich zowel binnen als buiten het parlement zeer uitgesproken ten gunste van Israël opgestell. In de eerste helft wan oktober hebben Kamerleden van deze fractie, Berkhouwer en Keja, op pro-Israël manifestaties het woord gevoerd. Het hoofdbestuur van de partij stuurde een telegram aan de Israëlische ambassadeur en de partijvoorzitster, Van Someren-Downer, ondertekende een advertentie voor solidariteit met Israël. $\mathrm{Na}$ de instelling van het olie-embargo verweet dezelfde voorzitster Den Uyl in deze kwestie onbekwaamheid en zij vond dat de regering meer rekening had moeten houden met de positie van de Rotterdamse haven ${ }^{156}$. Het Kamerlid De Koster schijnt het beleid in de vaste Kamercommissie gehekeld te hebben ${ }^{157}$. Hij verweet in de plenaire Tweede-Kamervergadering de regering 'te pas en te onpas te willen getuigen, waardoor een klimaat ontstaat waarin gemakkelijk misverstanden kunnen ontstaan die zijn ontstaan' ${ }^{158}$. De kritiek van de VVD richtte zich, zoals eerder vermeld, op het 'getuigenissenbeleid' van dit kabinet vooral inzake situaties in Afrika en Latijns-Amerika. Achteraf had het Kamerlid Portheine vooral problemen met Van der Stoels minder goede persoonlijke verstandhouding met Arabische diplomaten en De Koster wees op het gebrek aan eenheid in het beleid. Er bestaat een verschil in waardering over hun optreden zoals de VVD-Kamerleden dat zelf zagen en zoals in het bijzonder de PvdA het percipieerde. De linkse pers nam het beeld van de PvdA over en portretteerde de VVD tezamen met de werkgevers en de oliesjeiks tegenover Den Uyl ${ }^{159}$. Hoewel duidelijk is dat de VVD veel kritiek had op het door het kabinet-Den Uyl voorgestane buitenlands beleid in het algemeen, blijkt geen inhoudelijke kritiek op het MiddenOostenstandpunt van de regering. De stelling dat een VVD-kabinet Israël eerder zou hebben laten vallen, lijkt mij dan ook niet houdbaar.

154. De Nedertander, CH weekblad van 16 november 1973, zie ook de nummers van 9 november, 30 november en 7 december 1973.

155. Archief Fractie PvdA no. F. 530; verslag van een reis naar het Middem-Oosten van $\mathbb{R}$. ter Beek van 27 maart 1974; eveneens naar voren gebracht in R. Valeriani, Travels with Henry. Barkley Books 1980, in De Volkskrant, 10-11-1982.

156. Handelingen Tweede Kamer, zitting 1973-1974, van 28 en 29 november 1973, pp. 1221, 1300, $1311,1312,1336$ en 1337.

157. NRC-Handelsblad 30-10-1973 en het Vrije Volk 31-10-1973. Van deze vergadering bestaan geen verslagen. De uitspraak is gebaseerd op interviews met Patijn en Van der Stoel op respectievelijlk 7 december 1981 en 17 november 1982. De Koster ontkende het niet maar wees vooral op getuigenissenbeleid van Van der Stoel, dat hij hekelde; interview op 31 december 1982.

158. Interviews met Portheine op 25 mart 1983 en De Koster op 31 december 1982.

159. Zie onder meer carricaturen wan Opland in De Groene wan 14-11-1973 en de Volkskramt van 3-111973. 
Het geeft wel een beeld uit die tijd waarin met name de sterke binding in Nederland tussen het democratisch-socialisme en steun aan Israell bleek. Illustratief in dit verband is dat toen Peres in 1981. op de jaarvergadering van de Nederlandse Zionisten Bond zei 'de strijd voor Israël is voor mij alleen maar te verbinden met de strijd voor het socialisme, dat is één en hetzelfde', het liberale Kamerlid Portheine reageerde met de opmerking dat hij zich dan kennelijk te midden van het verkeerde gezelschap bevond ${ }^{160}$. Ook bij hen die aangesloten waren bij het Verbond van Liberaal-Religieuze Joden, bestond volgens Knoop de opvatting dat alleen socialisten achter Israël stonden ${ }^{161}$.

Door Neuman is de relatie tussen de Socialistische Internationale en de staat Israël als een 'idylle' gekenschetst ${ }^{162}$. Wat het veranderende beeld over Israël betreft, kwam Den Uyl dan ook tot de conclusie dat het beeld van een socialistische modelstaat naar de achtergrond verdween ${ }^{163}$.

In geen politieke partij in Nederland is over de Midden-Oostenkwestie zo veelvuldig en hevig gediscussieerd als in de $P v d A$. Dat werd niet alleen veroorzaakt door de internationale oriëntatie van de PvdA, maar ook doordat in het bijzonder binnen de PvdA verschillende opvattingen over het Arabisch-Israëlisch conflict bestonden. De traditionele pro-Israëlische gerichtheid van de PvdA kwam onder vuur te staan zowel vanwege kritische stromingen binnen de partij als ten gevolge van veranderingen in Israël en de politieke situatie in het Midden-Oosten.

De scheidslijnen hiervan binnen de PvdA vielen - wederom in tegenstelling tot vele andere terreinen van de buitenlandse politiek - niet samen met de meer vooruitstrevende en de meer behoudende groeperingen in de PvdA. Weliswaar was een deel van de proIsraël aanhang te vinden bij degenen die zich hadden afgescheiden in DS"70 - Den Uyl maakte hierbij een vergelijking met de PSDI in Italië - maar ook onder de stroming Nieuw Links bevonden zich velen die sterk voor Israël opkwamen ${ }^{164}$. Veel actieve leden in de PvdA waren tevens lid van verschillende buitenparlementaire actiegroepen die zich ten doel stelden het partijstandpunt in hun richting te beïnvloeden. Voor een groot deel vonden deze beïnvloedingspogingen na 1973 plaats; niettemin was de discussie binnen de PvdA al enkele jaren aan de gang en had ze in 1971 geleid tot een rapport waarin de twee 'nationale strevingen' - van zowel de zionistische beweging als de Palestijnse Arabieren - werden erkend en de Jordaanse optie - Palestijnse ambities verwezenlijken binnen Jordanië - overeenkomstig de Israëlische zusterpartij werd geprefereerd.

160. Interview met Portheine op 25 maart 1983.

161. Knoop in: Kopuit, 1982, pp. 63-64.

162. H.J. Neuman in Trouw, 10-9-1982.

163. Letterlijk zei hij: 'de gedachte van een socialistische modelstaat week terug'. In artikel van Brill, 1980 , p. 4 in conferentiebundel 'De PvdA en het Midden-Oosten'.

164. Interview met Den Uyl op 26 februari 1987. Ook in publikaties van Nieuw-Links waarin wel veel aandacht werd besteed aan het buitenlands beleid en een ander Nederlands beleid werd aambevolen ten aamzien van bijwoorbeeld bet lidmaatschap van de NAVO, de erkenning van de DDR en Vietcong en inzake Portugese koloniën in Afrika, ontbraken passages ower het Midden-Oosten. Zie Van den Doel, en Lammers (e.a.), 1966 pp. 57-68. 
Over het beleid in deze kwestie van het olie-embargo 1973 werd gedurende de periode oktober 1973 - maart 1974 in bijna elke vergadering van het partijbestuur gesproken. Opvallend is dat de discussie daarover binnen de Tweede-Kamerfractie werd opgeschort tot na het einde van de crisisperiode en pas in januari 1974 gevoerd werd. Deze opschorting heeft te maken met het eerder ter sprake gebrachte aspect om vanuit de regeringsgezinde fracties de regering in de crisisperiode zo min mogelijk lastig te vallen. Dit betekent weliswaar niet dat het zwaartepunt van de PvdA-inbreng daardoor verschoven zou zijn van fractie naar partij. Het Kamerlid Dankert, de woordvoerder van de PvdA-fractie en voorzitter van de vaste Kamercommissie voor Buitenlandse Zaken, sprak op de bijeenkomst van 7 oktober waarin solidariteit met Israël werd geuit. Hij kondigde aan de Kamercommissie te willen bewegen haar sympathie met Israël uit te spreken en er bij de regering op aan te dringen een verklaring uit te geven ${ }^{165}$. Mede op zijn initiatief werd de tweede regeringsbeslissing genomen. Fractievoorzitter Van Thijn, die deze verklaring op 9 oktober in de Tweede Kamer steunde, had de dag tevoren het partijbestuur over zijn standpunt ingelicht. Verschillende leden van het partijbestuur waren het niet eens met zijn standpunt maar besloten werd deze kritische stemmen nu niet openlijk te uiten ${ }^{166}$. De fractiewoordvoerders hadden een pro-Israelisch standpunt en enige discussie in het partijbestuur lag voor de hand. In het partijbestuur zaten zowel leden met een pro-Palestijns standpunt (mevrouw Van der GaastBakker Schut) als leden met een pro-Israëlisch standpunt (mevrouw Rood-De Boer). Ook binnen het partijbestuur bepaalden met name de leden van de fractie - Van Thijn, Dankert, Ter Beek - het partijstandpunt. Daarbij was Ter Beek zowel lid van de fractie als - in zijn hoedanigheid van internationaal secretaris - lid van het partijbestuur. Bovendien was Van Thijn als fractievoorzitter qualitate qua ook lid van het partijbestuur. De inbreng in de partijdiscussie kwam vooral van de fractie en de bewindslieden Den Uyl, Pronk en Van der Stoel.

Het dagelijks bestuur steunde met een eigen verklaring de rede van Dankert op de bijeenkomst van het Aktie Comité Israël. Deze verklaring, opgesteld door de assistent internationaal secretaris, Van den Bergh, onderschreef in feite het pro-Israël standpunt van de fractie waarbij eveneens de politieke aspiraties van de Palestijnen (uit het partijrapport van 1971) werden vermeld ${ }^{167}$. Enkele leden van het partijbestuur hadden kritiek op deze verklaring. De voorzitter, Van der Louw, verwierp de kritiek aangezien "nuancering nu zal worden uitgelegd als terugkrabbelen voor de olieboycot, zoals wij al zoveel rechtse mensen hebben zien doen' ${ }^{168}$. Ook in het parlement herinnerde de PvdA-fractie eind oktober een andere partij - de KVP - aan het eerder ingenomen proIsraęlisch standpunt toen deze partij zich van dat standpunt wilde verwijderen ${ }^{169}$. De leden van het partijbestuur werden in hun vergaderingen gedurende de maanden november en december door Den Uyl en Pronk geïnformeerd.

165. Nieuw Israëlietisch Weekblad, 12-10-1973.

166. Notulen partijbestuur PvdA van 8 en 29 oktober 1973.

167. Notulen partijbestuur PvdlA van 19 oktober 1973; notulen dagelijks bestuur PvdA van 17 oktober 1973; verslag partijbestuur PvdA 1973-1974, pp. 15-16.

168. Notulen partijbestuur PvdA van 29 oktober 1973.

169. Bijwoorbeeld het debat Ter Beek (PvdA) - Peynenburg (KVP) in Handelingen Tweede Kamer, zitting $1973-1974,31$ oktober 1973 p. 511 . 
Een discussie wond pas plaats toen het dieptepunt van de gepercipieerde crisis voorbij was. Op voorstel van Van den Bergh zou de PvdA initiatieven nemen om de PLO en de Israëli's met elkaar in contact te brengen. Den Uyl verdedigde het, volgens hem, consequente regeringsbeleid van de afgelopen periode. Hij gaf daarbij kort de afweging weer die had plaatsgevonden en zei: 'Er bestaat een enorme druk op de Nederlandse regering om het standpunt te wijzigen in verband met de olie. Op zichzelf is een erkenning van het feit dat je economische belangen hebt juist, maar er zijn grenzen aan de consequentie die dat voor je mening heeft' ${ }^{170}$. Eerder had Den Uyl het partijbestuur erop gewezen dat 'een frontvorming van het kabinet met de grote olieconcerns onvermijdelijk is, omdat het land wat die olievoorziening betreft, afhankelijk is van de oliemaatschappijen" ${ }^{171}$. Later gaf Den Uyl in een persoonlijk schrijven een toelichting op de Nederlandse afhankelijkheid van de houding van de oliemaatschappijen: 'U moet dat zien tegen de achtergrond van de snelle prijsstijgingen die optraden en het wantrouwen dat oliemaatschappijen ook belang hadden bij het optreden van schaarste en daarmee gepaard gaande prijsstijgingen. Daartegenover heb ik gewezen op het belang dat Nederland had bij een toewijzing van de olietoevoer naar evenredigheid' ${ }^{72}$. Dat is dan louter een afhankelijkheid op economisch terrein zonder consequenties voor het in te nemen buitenlandse politieke standpunt. Binnen de fractie werden enkele Kamerleden aangewezen uit zowel de economische - (Van der Hek, Epema-Brugma en Van den Doel) als de buitenlands - politieke hoek (Dankert en Ter Beek). Zij zouden de fractie adviseren inzake acties en standpuntbepalingen ${ }^{173}$. Zij lieten weinig van zich horen. Het stilzwijgen in de fractie over deze kwestie duurde voort in de maanden november en december. Ook bij de voorbereiding van het debat over de begroting van Buitenlandse Zaken in november kwam deze kwestie niet aan de orde. In de fractie onstond slechts enige kritiek op het intergouvernementale karakter van de Europese top te Kopenhagen, die overigens binnenskamers bleef ${ }^{174}$.

Op afstand, in New York, werd het Nederlandse standpunt in de VN door het Kamerlid Voogd, deel uitmakend van de Nederlandse delegatie naar de Algemene Vergadering, kritisch gevolgd. Hij stuurde zijn notities aan de Kamerfractie. Naar zijn mening had Nederland op z'n minst een stemverklaring moeten afleggen bij een resolutie inzake een veroordeling van het Israëlische optreden in de bezette gebieden waarin tot een boycot van Israël werd opgeroepen ${ }^{175}$. Het werd hem te gortig toen Nederland geen tegenstem uitbracht over een anti-Apartheidsresolutie waarin zionisme en Israëlisch imperialisme op éen lijn werden gesteld met Apartheid en Portugees kolonialisme. Hij diende

170. Notulen partijbestuur PvdA wan 7 januari 1974.

171. Notulen partijbestuur PvdA wan 12 november 1973 .

172. Brief van Den Uyl aan auteur van 28 februari 1984.

173. Archief PvdA-fractie, F 310, besluiten fractie-overleg. PvdA, 7 november 1973.

174. Archief PvdA-fractie F 329 en F 330 van Ter Beek en Dankert van 19 november 1973 en F 343 van Van den Bergh van 6 februari 1974.

175. Resolutie 3092 B (XXVII) 7 december 1973; verslag ministerie van Buitenlandse Zaken deel 103, pp. 66-68 en 318-320; archief PvdA-fractie F 356 zesde notitie van J. Voogd, Verenigde Naties, 30 november 1973 . 
met Franssen (PvdA) daarover een Kamervraag in waarover hij Van der Stoel te voren had ingelicht en waaruit de Kamervoorzitter enkele waarde-oordelen schrapte ${ }^{176}$. Interessant werd de discussie in de fractie pas op 15 januari 1974 toen een uitgebreid debat over het Midden-Oosten en de opstelling van de fractie plaatsvond. Ruime documentatie en uitgebreide notities van de Kamerleden Dankert, Drenth, Van der Hek en Roethof dienden ter voorbereiding van dit debat ${ }^{17}$.

Door Drenth werd een frontale aanval op de PvdA woordwoerder Dankert ingezet. Volgens hem dacht Dankert in 'koude-oorlogstermen' en had hij de EG-verklaring van 6 novernber wel positief moeten waarderen daar de Palestijnse rechten daarin werden erkend. Bovendien had Dankert Van der Stoel in de kwestie Thurkow gedwongen te verklaren dat het Nederlands beleid niet was gewijzigd, waardoor Dankert in het debat er alles aan had gedaan om de kansen tot opheffing van het embargo te belemmeren ${ }^{178}$.

Dankerts reactie was dat hij bewust 'Van der Stoels pretentie 242 is gelijk 9' trachtte om te kegelen ${ }^{179}$. Door de onjuistheid van die stelling te erkennen zou Van der Stoel de geloofwaardigheid van het buitenlands beleid hebben gediend.

Bovendien zou - volgens Dankert - een erkenning van beleidsverandering Nederlands positie in de Arabische wereld hebben verbeterd. Naar Israël toe had Nederland kunnen toegeven dat hij het in de Negen ook niet voor het zeggen had en naar de Nederlandse publieke opinie had de betekenis van de 6 november verklaring kunnen worden geminimaliseerd door te verwijzen naar de onder Schmelzer aanvaarde erkenning van de eerbiediging van de rechten van de Palestijnen uit VN-resolutie 2949 van 8 december 1972 (zie 2.2.1.7). Deze interne discussie heeft geen invloed gehad op het PvdA-standpunt naar buiten. Ook in de Eerste Kamer werd de lijn Dankert door zijn partijgenoot aldaar, Nederhorst, bij de debatten over de begroting van Buitenlandse Zaken ge-

176. Resolutie 3151 G (XXVIII) wan 14 december 1973; verslag ministerie van Buitenlandse Zaken deel 103, pp. 60-61 an 305-310; archief Pvd.A-fractie F 411 achtste notitie van J. Voogd, Verenigde Naties 11 januari 1974 en telex van 15 december 1973; Tweede Kamer, zitting 1973-1974, Aanhangsel, vraag no. $728 \mathrm{pp}$. 1457-1458. Het antwoord van de regering was dat door een tegenstem tégén de hele resolutie onvoldoende gestalte zou zijn gegeven aan de Nederlandse principiële afwijzing van hett Apartheidsbeleid.

177. Bartalitis, artikel Intermediair, 28 december 1973.

H. wan den Bergh, Het Middlen-Oosten, in Socialisme en Democratie 1971, januari 1971.

Archief PdvA-fractie:

F 403, P. Langendorff, Het Arabisch-Israëlische conflict, NIVV Informatie, 24 oktober 1973.

F 404, reisverslag delegatie naar Israël van E. van Thijn, 19 januari 1974.

F 409, interview met $E$. van Thijn in Davar, 1 januari 1974.

F 406, notitie van P. Dankert, 10 januari 1974 .

1* 401, notitie van H. Drenth, 7 januani 1974.

F 400, notitie van A. van der Hek, 3 januari 1974.

F 405, notitie van H. Roethof, 5 januari 1974.

178. Archief PudA-fractie F 401, p. 5 .

179. Met Van der Stoels pretentie ' 242 is gelijk aan 9' bedoelde Dankert dat Van der Stoel volhield dat de EG-verklaring van de Negen van 6 november 1973 - behalve inzake de Palestijnse kwestie - niet afweek van VN-resolutie 242 uit 1967. 
volgd ${ }^{180}$. Het geeft slechts aan dat ook binnen de PvdA verschillend werd gedacht over het genoemde beleid en over de wenselijkheid van een tegemoetkomende houding ten aanzien van de Arabische olie-exporterende landen.

Gedurende de crisisperiode zo $\Perp$ in een andere regeringsgezinde partij, D'66, de woordvoerder zich op een zodanig pijnlijke wijze vergalopperen dat deze in het openbaar zou moeten worden teruggefloten. De woordvoerder van $D^{\prime} 66$, Imkamp, verzocht in de Kamer de regering de Franse uitleg van resolutie 242 over te nemen die hij foutief interpreteerde als terugtrekking van Israël naar de grenzen van het delingsplan van de VN uit $1947^{181}$ ! Daarop reageerde de fractieleider, Terlouw, met een verklaring waarin hij zei dat ten onrechte de indruk was ontstaan dat de D'66-fractie haar oordeel over de juistheid van de eerste regeringsverklaring van 9 oktober zou hebben gewijzigd ${ }^{182}$. Volgens Imkamp had hij wel namens de gehele fractie gesproken en in 1981 bracht hij zijn rede uit 1973 opnieuw en zonder rectificatie naar voren ${ }^{183}$.

Als Kamerlid gaf hij de regering de raad niet naar de wensen van het parlement te handelen omdat het parlement amateuristisch te werk ging zonder gevoel voor diplomatieke verhoudingen. Vervolgens stelde hij in een interview dat Van der Stoel als minister van Buitenlandse Zaken moest opstappen omdat hij in internationaal verband zijn gezicht had verloren ${ }^{184}$. Opnieuw moest Imkamp via een fractieverklaring tot de orde worden geroepen aangezien de rest van de fractie het volstrekt oneens was met zijn opvattingen. Volgens Van Mierlo raakte Imkamp plotseling geheel gegrepen voor de Arabische zaak. Het roer moest om want zonder goede betrekkingen met de Arabische wereld dreigde - in de visie van Imkamp - het Westen te verpauperen en zou het zijn betekenis verliezen ${ }^{185}$.

Ook bij de $K V P$ trad als gevolg van deze omstandigheden de woordvoerder eind oktober meer gereserveerd op dan begin oktober: Aanvankelijk werd naar aanleiding van de gevechtshandelingen de noodzaak van bufferzones voor Israël onderstreept, eind oktober sprak de woordvoerder nog slechts over 'grensaanpassingen' ${ }^{186}$. Op grond van een in 1970 door het partijbestuur aanvaard rapport - 'Het conflict in het Midden-Oosten' kon na de instelling van het olie-embargo door het partijbestuur een verklaring worden uitgegeven. Deze verklaring werd opgesteld na overleg van het dagelijks bestuur met de fractie waarin de pro-Israël passage uit het concept - inzake Israëlisch bestuur over geheel Jeruzalem - werd geschrapt. Deze verklaring wan het partijbestuur werd op briefpapier van de Tweede Kamer uitgegeven. De geringe aandacht van de partij voor deze

180. Eerste Kamer, zitting 1973-1974, 19 maart 1974, p. 421.

181. Handelingen Tweede Kamer, zitting 1973-1974, van 31 oktober 1973, p. 517. Volgens het VN delingsplan in resolutie 181 uit 1947 behoorde een groot deel van Galilea, een klein deell van de Negev evenals het gebied ten westen wan Jeruzalem tot de woorgestelde Arabische staat. Daarentegen werd in de Franse, Russische en Spaanse versie van resolutie 242 uit 1967 niet getornd atan de Isrä̈lische grenzem wan voor 1967.

182. NRC-Handelsblad 1-11-1973.

183. NRC-Handelsblad 1-11-1973 en De Tijd 3-4-1981.

184. NRC-Hindelsblad 6-11-1973.,

185. Interview met Van Mierlo op 2 april 1987.

186. Handelingen Tweede Kamer, zitting 1973-1974, wan 9 en 31 oktober 1973, pp. 104 en 511. 
kwestie is ook gebaseerd op archiefonderzoek waaruit blijkt dat het dagelijks bestuur en het partijbestuur zich in hun vergaderingen niet hebben beziggehouden met deze kwestie en dat alle aandacht gericht was op de totstandkoming van het $\mathrm{CDA}^{187}$.

De radicale opstelling wan de PSP kwam indertijd met name tot witing in de bijdrage aan het debat van het Berste Kamerlid Van Wijk ${ }^{188}$. Een door het partijbestuur voorbereide resolutie werd op het congres van eind november aangenomen. Deze resolutie, die onder meer opriep tot totale Israëlische terugtrekking uit de bezette gebieden, kostte de PSP een groot aantal leden waaronder drie leden die de PSP in Provinciale Staten vertegenwoordigden ${ }^{\star}$. In feite was deze resolutie zeer gematigd in vergelijking met het PSP-programma waarin wel het zelfbeschikkingsrecht voor Israelische Joden en Palestijnse Arabieren maar niet de staat Israël werd erkend ${ }^{190}$. Binnen het bestuur van de PSP kwam de Midden-Oostenkwestie wel vaak aan de orde ${ }^{191}$ en in een adviescommissie werd een 'gevecht op de vierkante millimeter' gevoerd over het én versus 'twee-staten' model ${ }^{192}$.

Het partijbestuur van de PPR verschilde in zijn opvattingen in deze kwestie weinig van die van de PSP. In een verklaring werd kritiek geleverd op de eenzijdige opstelling van de regering en werd gesteld dat 'Joden en Arabieren in gelijke mate de mogelijkheid moeten hebben om zich te vestigen in het gebied waarop zij - om verschillende redenen - recht kunnen dón gelden" ${ }^{193}$. De Tweede Kamerfractie nam daarentegen het standpunt in dat naar een veilig voortbestaan van de staat Israël moest worden gestreefd. De woordvoerder en fractievoorzitter van de PPR had bovendien een pro-Israël standpunt en steunde de regering ${ }^{194}$.

'Klein-Rechts' heeft zich traditioneel altijd zeer pro-Israëlisch opgesteld. Hoewel het de bezwaren van de oppositie van de VVD en CHU deelde tegen de zogenaamde 'gidslandfunctie' van Nederland, wond het daarentegen dat het standpunt van de regering te zeer

187. Archief KVP-bestuur 1973-1974.

188. Hundelingen Eerste Kamer, zitting 1973-1974, 20 november 1973, pp. 88-91 en overgenomen üit het partijblad 'Radikaal' (7) van 7 december 1973, no. 24.

189. Radikaal (7) van 7 december 1973, no. 24; Vergadering partijbestuur van 8 december 1973 ; 19 leden bedankten voor hun lidnaatschap vanwege dit Midden-Oostenstandpunt, in het vierde kwartaal van 1973 bedankten bji geen enkele andere gelegenheid zoveell ledent tegelijk met opgaaf van reden voor han partijlidmaatschap, Archief PSP overzicht aantall leden periode 30 september -31 december.

190. Werkprogramma 1971-1975 PSP, pp. 63-64.

191. Partijbestuursvergadering op 27 oktober, 17 en 22 november, 8, 13 en 27 december; vergadering dagelijke bestuur op 17 oktober en 2 januari.

192. Interwiew met Boon op 23 september 1982.

193. Verklaring van 31 oktober 1973 'Hett: Midden-Oosten', PPR AK, december 1973.

194. Handelingen Tweede Kamer, zitting 1973-1974, van 9 oktober 1973, p. 123. 
in pro-Arabische regering verschoof. De SGP maakte daar in de vaste Kamercommissie van Buitenlandse Zaken bezwaar tegen ${ }^{195}$.

In calvinistische kringen speelt de binding met 'het volk van het verbond" een belangrijke rol in hun sympathie voor het moderne Israẻ. Niet alleen de politieke opvatting van de ARP maar ook meer kiezers van de ARP zijn pro-Israël dan die van de andere grote partijen (zie 1.4.1). De gehele fractie wilde duidelijk kleur bekennen en fractievoorzitter Aantjes herhaalde aan het begin van de Oktoberoorlog de uitspraak die hij aan het begin van de Zesdaagse oorlog deed: 'Ons hart is met het volk van Israell' ${ }^{196}$. Gedurende de hele periode zou de ARP haar pro-Israel standpunt handhaven. Een lid van het partijbestuur, D.Th. Kuiper, zei op de solidariteitsmanifestatie van het Actie Comite Israël het als een taak van de politieke partijen in Nederland te beschouwen Israël te steunen ${ }^{197}$. Volgens Aantjes wilde Kruisinga (CHU) hem in het begin steeds de loef afsteken in sympathie voor Israël, maar na de bekendmaking van het olie-embargo ontstond een verwijdering ten opzichte van de CHU. Terugblikkend beschouwde Aantjes deze periode als een geweldig moment in de Nederlandse politiek, omdat Nederland niet heeft gewankeld: 'Dat vind ik het onvergetelijk dappere van het kabinet-Den Uyl, dat ze het verdomd hebben om onze eer op het olie-altaar te offeren; want daar ging het in 1973 toch om' ${ }^{198}$.

De verklaring van 6 november veroorzaakte enige beroering in de fractie en enkele leden van de fractie, Roolvink en Van Leeuwen, meenden in navolging van enkele 'opinieleiders' (L. de Jong, E.H. van der Beugel, P. van 't Veer) dat het Nederlandse standpunt was gewijzigd ${ }^{199}$. Zoals reeds vermeld raadde de woordvoerder, Boertien, af nu initiatieven te nemen vanwege de delicate diplomatieke positie van de minister van Buitenlandse Zaken. Bij de behandeling van de begroting van Buitenlandse Zaken verheelde Boertien geen moeite te hebben gehad met de verklaring van 6 november, omdat deze multi-interpretabel was. In de fractie had mevrouw Van Leeuwen gesteld dat 'de EEG-verklaring d.d. 6 november 1973, geheel anders luidt dan resolutie 242 d.d. 22 november $1967,{ }^{200}$. Dezelfde discussie zou later in de PvdA-fractie plaatsvinden, zoals we hebben geconstateerd. Mevrouw Van Leeuwen bleef geschokt over de 6 november verklaring en wilde haar adhesie betuigen aan een initiatiefcomité tot vriendschap met Israël van het Europees Parlement waar ook andere Kamerleden bij betrokken waren ${ }^{201}$. Eerder hebben we gezien dat op die momenten waarop binnen de ARP bezorgdheid over het regeringsbeleid ontstond, rechtstreeks contact met de regering werd gezocht en het gesprek tussen Boertien en Van der Stoel en het onderhoud van

195. Interwiew met Van Rossum op 16 maart 1982; zie ook rede van H.G. Abma voor Algemene Vergadering van de SGP op 5 maart 1974 'Ons keerpunt heet wederkeer'.

196. Werslag ARP-fractie van 9 oktober 1973; Handelingen Tweede Kamer, buitengewone zitting 1967. van 6 juni 1967, p. 332; Handelingen Tweede Kamer, zithing 1973-1974, wan 9 oktober 1973, p. 90.

197. NIW 19-10-1973.

198. Interview met Aantjes op 28 december 1982.

199. Verslag ARP-fractie 13 november 1973 .

200. Verslag ARP-fractie 27 november 1973 .

201. Keuning, DS'70; Eisma en Goudsmit D'66; Patijn PvdA; Verslag ARP-fractie 11 december 1973. 
Aantjes en Aridiessen met Den Uyl plaatswond (zie 2.2.1.7 en 2.2.1.8). De ARP wide woorhomen het kabinet in het operbaar te noeten kritiseren. Ook Van der Stoel was zich van deze steus bewust en werklaarde achteraf "de ARP heef? tijdens de ollecrisis positief en loyal meegewerkt" ${ }^{202}$.

\subsubsection{Departementen en hum bewindshieden}

Bij de besissingen werband houdend met het olie-embargo en de matregelen ter uitwoering van deze beshissingen waren vele departementen betrokken. Bij het Kamerdebat over bjwowbeld de olie-werbnik-beperkende naatregelen waren Den Uyl (ministerpresident en minister van Algemene Zaken), Van Agt (vice-minister-president en minister van Justitie), Van der Stoel (minster van Buitenlandse Zaken), Lubbers (minister van Economische Zaken), Van der Stee (staatssecretaris wan Financièn) en Van Hutten (staatssecretaris van Verkeer en Waterstati) aanwezig ${ }^{\text {tass. }}$. De betrokkenheid van de meeste departementen beperkte zich echter voormamelik tot de uitvoering van de beslissinger. ZJ hadden wethig invloed op de totstandkoming van het buttenlands beleid in deze kwestete. Met nadruk stelde Van der Stoel dat het primaat van het buitenlands beleid bij zijn departement lag en ook niet door anderen werd aangetast. De Koster dacht daar anders over en zei dat "alle collega's wan minister Van der Stoel - de minister-president voorop - allemaal ministerije van Buitenlandse Zaken spelen en het beleid daardoor ook niet in cen hand bliff ${ }^{30}$. Dat laatste zei De Koster naar aanleiding van de affaire Thurkow. In deze kwestie gaf Den Uyl, in weerwil van hetgen wolgens enkele journalisten deze woordvoerder zou hebben gezegd, de verklaring wit dat het beleid niet was gewijzigd. Volgens Yaniv zou Den Uyl door Van Thin zin aange. spoord deze verklaring snel wit te geven. Den Uyl zorgde er persoonlijk voor dat deze verklaring de redactie van de Nos bereikte nog voor de uitzending van het TV-journad van acht un ${ }^{20 \%}$.

Volgens Van der Stoel had Den Uyl van tevoren van hem de werzekering gekregen dat van beleidswijziging geen sprake was. Formeel was Den Uyl op dat monent minister van Butentandse Zaken ad interim. Blikkbar lag deze kwestie nogal gewelig want Van der Stoel beklemoonde voorts 'aan een aantasting van competenties heeft Den Uyl zich niet schuldig gemaakt!" ${ }^{206}$.

Nu was Den Uyl uit hoofde van zijn functie direkt betrokken bij de Europese top te Kopenhagen en als voorzitter van de ministerraad sterk betrokken bij de repercussies van het beleid op andere terreinen. De gepercipieerde economische crisis overschaduwde andere beleidsterreinen en leidde bijvoorbeeld tot een Machtigingswet inclusief een

202. Interview met Van der Stoel door Van Traa in Gortzak, 1978, p. 92.

203. Handelingen Tweede Kamer, zitting 1973-1974, van 31 oktober 1973 , p. 509.

204. Handelingen Tweede Kamer, zitting 1973-1974, van 5 december 1973, p. 1440.

205. Yaniv, 1977 , p. 53.

206. Brief wan Van der Stoel aan auteur van 1 september 1983. Wat gevoeligheid betreft inzake afbakening van competenties was deze reactie vergelijkbaar met de reactie van Van der Stoel en Pronk over hun posities en bevoegdheden bij de vergaderingen van de Nederlandse delegatie te New York bij de Algemene Vergadering van de Verenigde Naties (Brief van Van der Stoel aan auteur van 7 januari 1988, Brief van Pronk ann anteur van 9 maart 1988). 
loonbeschikking van de centrale overheid. Tegen de achtergrond van de Nederlandse verhoudingen in die tijd speelde Den Uyl een opvallend grote rol. Hij verdedigde het beleid in het parlement, trad veelvuldig naar buiten en richtte zich in een speciale toespraak voor de televisie tot het Nederlandse volk ${ }^{207}$. Hij was misschien ook beter in staat; vanwege zowel de gewoeligheid in de publieke opinie met betrekking tot deze kwestie als de gevolgen voor het totale kabinetsbeleid, zich tot de Nederlandse bevolking te richten dan de minister van Buitenlandse Zaken. Daarnaast was Den Uyl ook geinteresseerd in de buitenlandse politiek en als partijleider bij de Socialistische Internationalle betrokken. De band met de Israëlische zusterpartij en haar leider, Golda Meir, in het bijzonder, was ook van invloed op zijn houding. 'Er was voortdurend enige afstand tussen Van der Stoel en mij. Begrijpelijk wel. Van der Stoel had te maken met een Europees politiek overleg dat in zijn algemeenheid toch kritischer stond tegenover Israel, om niet te zeggen de duimschroeven aanlegde. Een Nederlandse positie die weinig steun ondervond in de Negen" ${ }^{208}$. Zoals gesteld, reageerde Den Uyl nogal geschrokken op de 6 november verklaring, maar trok vervolgens in interne kring de lijn wel door dat legitieme rechten voor de Palestijnen ooit op een Palestijnse staatsvorming moesten uitkomen. Den Uyl, die Van der Stoel al sedert de jaren vijfig kende, toen beiden bij de Wiardi Beckman Stichting (het wetenschappelijk bureau van de PvdA) werkten, heeft het beleid van Van der Stoel in deze kwestie steeds gesteund.

Op grond van diens rol zou verwacht kunnen worden dat de minister van Economische Zaken ook veel invloed zou hebben op het besluitvormingsproces in deze kwestie. De portefeuille van de minister van Economische Zaken, Lubbers, omvatte immers onder meer de buitenlandse handel en energie-vraagstukken. Hij nam op grond van de laatste positie ook deel aan het internationaal overleg in OESO-verband over de energie. In feite werd de rol in beperkte betekenis opgevat bij Economische Zaken en niet uitgebreid naar beinvloeding van het buitenlands beleid. De minister van Economische Zaken heeft geen druk uitgeoefend op zijn collega van Buitenlandse Zaken het beleid te wijzigen ${ }^{209}$. Op de ochtend dat het olie-embargo tegen Nederland werd ingesteld vond op initiatief van Den Uyl een gesprek tussen Den Uyl en Lubbers plaats. Van der Stoel was bij dat gesprek aanwezig. Desgevraagd stelde Lubbers dat er geen concessies gedaan zouden moeten worden. Lubbers kreeg de indruk dat Den Uyl en Van der Stoel enigszins verrast waren đoor zijn opstelling: 'én omdat ik voortkwam uit de KVP, die krachtens traditie ook nogal oog had voor de Arabische kant van de medaille én omdat ik als minister van Economische Zaken wellicht meer voor economische belangen op zou komen. Van mijn kant meende ik echter, dat er sprake was van chantage en dat daarom een ferme houding geboden was' ${ }^{2} 10$. Lubbers wierp in het kabinet slechts de vraag op of het beleid wel voldoende evenwichtig was ${ }^{211}$. De zogenaamde 'evenhanded policy zou nadien wel veelvuldig als benaming voor het Nederlandse MiddenOostenbeleid worden gebezigd. Minister Lubbers was, volgens zijn collega van Buitenlandse Zaken, wel gepreoccupeerd met de omstandigheid dat het bedrijfsleven lam

207. NRC-Handelsblad 3-12-1973.

208. Interview met Den Uyl op 26 februari 1987.

200. Interview met Van der Stoel op 17 november 1982.

210. Brief van Lubbers aan auteur, 15 angustus 1990.

211. Interview mell De Grooth op 24 maart 1983. 
gelegd dreigde te worden ${ }^{212}$. Hij was dan ook de eerste contactpersoon met het bodrijfsleven; dat was altijd al zo vanwege het onder zijn ministerie ressorterende directoraat-generaal van de Buitenlandse Economische Betrekkingen, dat maandelijks overlegde met de werkgeversorganisaties in het Centraal Orgaan voor de Economische betrekkingen met het buitenland. Dat gold nu in het bijzonder doordat de problematiek zich toespitste op de energiesector.

Door het Verbond van Nederlandse Ondernemingen (VNO) werd bijvoorbeeld het VVD-Kamerlid Portheine voor overleg verwezen naar Shell omdat 'onze belangen daar wel bekeken worden' ${ }^{213}$. De heer Portheine richtte zich vervolgens tot de directie van Shell en het directoraat-generaal Energievoorziening van het departement van Economische Zaken. De directeur van Shell Nederland verklaarde ook dat de oliemaatschappijen in Nederland vanaf het uitbreken van de oliecrisis en de instelling van het olieembargo vrijwel dagelijks het nauwste contact hebben gehad met het ministerie van Economische Zaken ${ }^{214}$.

De verweventheid was groot en werd ook geïnstitutionaliseerd in bijvoorbeeld het Rijksbureau voor Aardolieprodukten. Dat was een orgaan dat zich bezighield met de levering en distributie van grondstoffen aan de industrie en ressorteerde onder het ministerie van Economische Zaken maar waarvan het werk deels werd verricht door werknemers van de oliemaatschappijen ${ }^{215}$.

Uit een studie van Rotterdamse onderzoekers blijkt dat het departement "volledig werd opgeslokt door de energiecrisis' en dat alle andere onderwerpen van de agenda waren verdrongen. Weliswakar vertoonde Economische Zaken veel activiteiten naar andere departementen ten behoeve van de uitwoering van oliebeperkende maatregelen, maar een intensivering van de contacten met het departement van Buitenlandse Zaken - en dat is relevant voor dit anderzoek - is daarentegen niet geconstateerd ${ }^{216}$. Lubbers bevestigde dat hij zich geheel op de binnenlandse problematiek heeft geworpen ${ }^{217}$.

De keren dat Lubbers wel op internationaal vlak optrad was dat op initiatief van anderen. Immers, het overleg tussen Lubbers en de olie-ministers van Algerije en SaoediArabië op 1 december 1973 te Brussel, vond plaats op verzoek van Van der Stoel die zelf weigerde hen in Brussel te bezoeken. Volgens hem zou dat teveel 'een gang naar

212. Interview met Van der Stoel op 17 november 1982.

213. Interwiew met Portheine op 25 mant 1982.

214. Directeur Shell Nederland, Vaz Nunez op 29 januari 1974 voor de radio-nubriek van de KRO "Echo", in: Beleid Beschouwd no. 2685, p. 6.

215. Rosemthal en Scholten, 1977, pp. 119,121, 122. Op pagina 121 tabel 3 wordt aangegewen dat in de maanden november en december 1973 van de in total 24 en 35 aldaar werkzame personen respectievelijk 11 en 15 mensen ter beschikking werden gesteld door de oliemaatschappijen. Als de vitzendkrachten buiten beschouwing worden gelaten, zaten in de periode novernber-december 1973 zelfs meer employes van oliemaatschappijen dan anbtenaren bij het Rijksbureau voor Aardolieproclukten.

216. Dat laatste werd de auteur telefonisch op 9 september 1982 door de onderzoeker, Rosenthal, bevestigd.

217. Brief van Lubbers aan auteur, 15 augustus 1990. 
Canossa' zijn geweest ${ }^{218}$. De deelname van Lubbers aan de Washington-conferentie van februari 1974 werd door een toevallig incident veroorzaakt. Lubbers zat namelijk niet in de Nederlandse delegatie, maar de dag voor het vertrek van de delegatie, reed Lubbers onder invloed van te veel alcohol een verkeerspaaltje om. Toen vonden Den Uyl en Van der Stoel het beter hem even uit de publiciteit te halen en hem naar het buitenlland te sturen. Een riedewerker van de Amerikaanse ambassade gaf op zaterdagmorgen het visum en zette bij Van der Stoel thuis nog een stempel in Lubbers' paspoort en zo vloog hij diezelfde dag mee naar de VS ${ }^{219}$.

Dit alles wijst op een geringe invloed van Lubbers op het besluitvormingsproces inzake het buitenlands beleid van dat moment. Dat was ook nauwelijks nodig, omdat hij de politieke opvattingen van Van der Stoel en het kabinet inzake het Arabisch-Israëlisch conflict deelde. Hij verdedigde deze opvattingen ook na afloop van het onderhoud van 1 december met zijn Arabische collega's op de persconferentie. Hij weigerde toen aan het Arabische verzoek te voldoen met een afzonderlijke verklaring nogmaals de verklating van 6 november te onderschrijven, aangezien dat zou kunnen worden uitgelegd 'alsof wij op een zaterdagmorgen olie wilden kopen' ${ }^{220}$. De Israëlische premier Peres, op bezoek in Nederland, kwam daar op 20 januari 1986 in een rede op terug toen hij zei dat Lubbers de enige niet-Joodse minister was die weigerde op zaterdag olie te kopen ${ }^{221}$. Tijdens het gesprek op 1 december werd Lubbers de vraag voorgelegd: 'of het - waar Nederland zelf niet tot politieke concessies bereid was - niet mogelijk was te komen tot een afspraak dat er wel weer olie naar Rotterdam zou stromen ten behoeve van doorvoer naar andere West-Europese landen, waarbij door OPEC-inspectie in Nederland verzekerd zou worden dat deze olie niet in Nederland zou blijven". 'Deze vraagstelling werd mij rauwelings in Brussel voorgelegd. Ik heb dat - met name het element van de OPEC-inspectie in het Rotterdamse - toen zonder ruggespraak carrément afgewezen. Ik heb daar toen aan toegevoegd, dat ik uiteraard geen bezwaar had te bevorderen dat olie voor andere West-Europese landen weer via Rotterdam zou gaan stromen, maar dat men voor wat betreft de zekerheid dat deze olie dan niet in Nederland aangewend zou worden, het maar moest doen met mijn woord’ ${ }^{222}$. Behalve dat de politieke noodzaak voor het uiten van een eigen geluid niet aanwezig was, beschikte Lubbers ook nog niet over een ruime parlementaire ervaring - als ondernemer afkomstig uit kringen buiten de politiek en pas enkele maanden in deze functie -; hij had nog geen positie binnen het kabinet verworven om zich reeds sterk te laten gelden ${ }^{223}$. Daar

218. Interview met Van der Stoel op 17 november 1982. Lubbers wees erop dat hij later op verzoek van Van der Stoel naar Saoedi-Arabiè reisde. Van der Stoel ging in maart 1975 niet nadat aan de Joodse joumalist Van Wesel een visum was geweigerd (zie daarover Beleid Beschouwd, nr. 2957 van 21 maart 1975). De minister van Economische Zaken reist meestal zonder begeleiding van journalisten. Brief van Lubbers aan auteur, 15 augustus 1990.

219. Interview met Meijer op 15 oktober 1982.

220. Trouw 3-12-1973.

221. NRC-Handel sblad 25-1-1986.

222. Brief van Lubbers aan auteur, 15 augustus 1190; volgens Lubbers was zijn antwoord voor de Algerijnse minister weinig bevredigend maar vond de Saoedische minister zijn opstelling nog niet zo onredelijk. Een causaal verband tussem de uitkomst wan dit gesprelk en de toename in de aanvoer van olie in januari 1974 - zie schema $D$ in bijlage 6 - is moeilijk aan te tonen.

223. Interview met Meijer op 15 oktober 1982. 
tegenover kon Van der Stoel wel bogen op een lange politieke en parlementaire ervaring. Hij had inmiddels als staatssecretaris in het kabinet Cals-Vondeling ook enige erwaring opgedaan op het departement van Buitenlandse Zaken. Vanwege deze machtsverdeling kregen de ambtenaren van deze departementen dan ook weinig mogelijkheden 'in te breken" in het buitenlands beleidsvormingsproces.

Al was er weinig van interdepartementale beïnloeding te merken, dat wil nog niet zeggen dat het 'bureaucratic politics' model in deze kwestie niet van toepassing zou zijn. Met 'bureaucratic politics' model wordt bedoeld dat de strijd tussen en binnen departementen veelal het resultaat van het besluitvormingsproces bepaalt. De eigen eenheid wordt dan als onmisbaar voorgesteld en beoogd wordt de belangen van die eigen eenheid veilig te stellen. De oplossing van het probleem wordt dan gezien als afhankelijk van de plaats van de onderhandelaars in de organisatie; kortom 'where you stand depends on where you sit' ${ }^{224}$. Wel was het een eenvoudige vorm van dat model. De meningsversehillen deden zich voor binnen het departement van Buitenlandse Zaken. De minister van Buitenlandse Zaken besliste uiteindelijk. Andere departementen raakten daar niet bij betrokken. Bovenstaand model verwijst naar het belang van de 'rolfactoren', uit Rosenau's pre-theorie (zie bijlage 1).

In de volgende paragraaf zal het besluitvormingsproces binnen het departement van Buitenlandse Zaken worden behandeld. Dan zal worden aangetoond dat vooral de rolopvatting bepalend was voor de zienswijze van de betrokken topambtenaren. Niet zozeer de individuele opvattingen over het Arabisch-Israëlisch conflict - individu factoren - maar de posities binnen het departement - rolfactoren - waren doorslaggevend voor hun optreden.

Tot slot verdient de enigszins andere visie van de minister voor Ontwikkelingssamenwerking, Pronk, hier vermelding. Formeel zou de positie van deze minister zonder portefeuille binnen het departement van Buitenlandse Zaken kunnen worden behandeld, aangezien hij zijn werkzaamheden op dit departement uitoefende. Feitelijk had deze minister wel een eigen verantwoordelijkheid met een eigen stem in het kabinet waardoor een bespreking hier meer op zijn plaats is. Pronk verschilde ook niet van mening met Van der Stoel over het Arabisch-Israëlisch conflict. Afkomstig uit een orthodox-hervormd milieu had hij een sterke affiniteit met Israël. Verschil van mening kwam wel tot uiting bij de besluitvorming over instermming met de Washington-conferentie (zie 2.2.1.10). Dat verschil was gebaseerd op een andere visie op de Noord-Zuid relatie en in het bijzonder inzake de front- en machtsvorming aan de zijde van de OAPEC. In zijn visie was de macht van de westerse geïndustrialiseerde maatschappij gebaseerd op een veel te lage olieprijs. Dat een groep Derde Wereldlanden zich organiseerde om hun schaarse grondstof (de olie) als machtsmiddel in de strijd voor andere economische verhoudingen in te zetten, werd door hem positief gewaardeerd. Hij beschouwde de olieprijsstijgingen en de olieproductievermindering als rechtvaardig.

$\mathrm{Er}$ bestaat een nauwe relatie tussen deze visie en het streven naar een Nieuwe Internationale Economische Orde in de wereld dat indertijd op gang kwam. Pronk wees, in een

224. Zie verder Allison, 1971. Citaat werd door Allison aangehaald op p. 176. Bovenstand model was het derde model van Allison, het "Governmental Politics" model, pp. 144-184; zie ook: Russett and Starr, 1985, pp. 264-293 en Dougherty and Pfaltzgraff, 1981, pp. 468-510. 
toespraak op 22 januari 1974 ter gelegenheid van het tienjarig bestaan van de Nationale Raad van Advies inzake hulpverlening aan minder ontwikkelde landen, ter oplossing van de energiecrisis zowel het sluiten van bilaterale overeenkomsten als een naar binnen gericht beleid van de rijke landen van de hand. Hij stelde: 'De enige verantwoordelijke weg die wij kurnen gaan, is die van wereldwijde afspraken waarbij alle consumenten en producenten zijn betrokken'. Over dergelijke grondstoffen-overeenkomsten zou door regeringen moeten worden onderhandeld waarbij de overheersende positie van het bedrijfsleven op de grondstoffenmarkten ongedaan moet worden gemaakt. Een gedragscode voor ondernemingen vond hij te vrijblijvend. Hij koos voor 'internationale verdragen tussen landen die leiden tot de verplichting deze ondernemingen gezamenlijk te controleren' ${ }^{225}$. De overige leden van het kabinet waren van de inhoud van deze rede niet vooraf op de hoogte gebracht en werden er, volgens Pronk, enigszins door overvallen. Hij confronteerde daar het kabinet mee en iedere keer dat hij zich positief over de OPEC uitliet en de olieprijsstijgingen rechtvaardigde, gaf dat een conflict. Evenals voor de andere leden van het kabinet was er voor Pronk geen enkele rechtvaardigingsgrond voor het specifieke embargo tegen Nederland. Hij verschilde daarentegen wèl van mening over de wenselijkheid van de conferentie van Washington die volgens hem gericht was op het ongedaan maken van de machtspositie van de olieproducerende landen. Met zijn bezwaren vond hij in het kabinet enig begrip bij Den Uyl en de PPRministers Van Doorn en Trip. Daar tegenover werd Van der Stoel gesteund door Gruyters (D'66) en de confessionele ministers. Pronk begreep echter dat vanwege het olieembargo, de keiharde positie van Frankrijk en de omstandigheid dat Nederland in de steek was gelaten, de oprichting van het Internationale Energie Agentschap in het belang van Nederland was en accepteerde daarom de toetreding van Nederland ${ }^{226}$. Pronk wilde well in de delegatie naar de Washington-conferentie opgenomen worden en het kabinet heeft zich daarover beraden. De relatie tussen Pronk en Van der Stoel was toen al slecht en zoals zojuist gesteld, kreeg Pronk weinig steun in het kabinet voor zijn bezwaren tegen de opzet wan de Washington-conferentie. Pronk mocht van het kabinet dan ook niet meegaan. Wel mocht zijn (tevens Van der Stoels) hoogste ambtenaar, de directeur-generaal Internationale Samenwerking, deel uit maken van de delegatie ${ }^{227}$.

\subsubsection{Departement van Buitenlandse Zaken}

De politieke leiding van het departement bestond uit de minister van Buitenlandse Zaken, Van der Stoel (PvdA), de minister zonder portefeuille belast met Ontwikkelingssamenwerking, Pronk (PvdA), de staatssecretaris voor Europese Zaken, Brinkhorst (D'66) en de staatssecretaris voor Ontwapeningsvraagstukken, Kooijmans (ARP).

De ambtelijke top bestond uit de secretaris-generaall, Schiff, de directeur-generaal politieke zaken (DGPZ), Van Lynden, de directeur-generaal Europese samenwerking

225. Deze rede van J. Pronk op 22 januari 1974 in het Haagse Congresgebouw over de gevolgen van de oliecrisis en ontwikkelingssamenwerking werd gepubliceerd in "Nederllandse Staatscourant" no. 18 van 25 januari 1974.

226. Interview met Pronk op 17 maart 1983.

227. Interview met Meijer op 15 oktober 1982. 
(DGES), Italianer, en de directeur-generaal internationale samenwerking (DGIS), Meijer ${ }^{228}$.Van deze topambtenaren had de secretaris-generaal niet zozeer een beleidsfunctie als well een coördinerende functie. De directeur-generaal Europese samenwerking, pas kort in functie, vervulde bij de besluitvorming over deze kwestie ook geen belangrijke rol omdat de Europese Politieke Samenwerking niet onder zijn directoraatgeneraal viel.

De bij de besltuitvorming betrokken ambtelijke top bestond dus vooral uit Van Lynden (DGPZ) en Meijer (DGIS). Beiden hadden de Tweede Wereldoorlog zeer bewust meegemaakt. De eerste in Duitse krijgsgevangenschap en de tweede in het verzet (Paroolgroep). Zij waren na de Tweede Wereldoorlog bij Buitenlandse Zaken in dienst getreden ${ }^{229}$. Van Lynden trad toe tot de Buitenlandse Dienst en bekleedde diplomatieke posten in New York, Londen en Wenen. Van 1970 tot 1974 was hij directeur-generaal. Politieke Zaken en nadien werd hij tot ambassadeur te Bonn benoemd.

Meijer had steeds op het departement in Den Haag gewerkt en was sterk georiënteerd op het parlement, de politieke partijen en de publieke opinie in Nederland. In de jaren vijftig bereidde hij vooral de antwoorden op Kamervragen voor. In de jaren zestig werd met name vanuit het parlement de opbouw van het ontwikkelingsbeleid gestimuleerd. Juist voor de onderdelen van het buitenlands beleid waar hij zich voor inzette als ontwikkelingssamenwerking, rechten van de mens, het vluchtelingenvraagstuk en dergelijke, ontving hij steun vanuit het parlement. Daaruit kwam een gerichtheid naar voren op de opvattingen in de Nederlandse samenleving, met gevoel voor de binnenlandse politieke verhoudingen, maar tegelijkertijd had hij een mondiale oriëntatie. Dat laatste kwam voort uit zijn rolopvatting. Onder zijn directoraat-generaal internationale samenwerking ressorteerde toen nog de directie internationale organisaties die het hele netwerk van de Verenigde Naties behartigde. Zijn oriëntatie op het binnenland, met een pro-Israëlische publieke opinie, en op de Verenigde Naties, waar de Midden-Oostenkwestie werd behandeld en waarbinnen Nederland zich een eigen geluid kon veroorloven, bepaalde de visie en inbreng van Meijer in het besluitvormingsproces. Bepalend was vooral de opvatting voortkomend uit zijn positie als directeur-generaal internationale samenwerking. In de termen zoals door Rosenau omschreven ${ }^{230}$ zijn het veel minder de individu-factoren maar meer de rolfactoren die van invloed waren op zijn gedrag. Datzelfde geldt voor Van Lymden die eerder de Europese Politieke Samenwerking wenste te versterken. Desalniettemin hebben de eigen opvattingen van beide ambtenaren ook een rol kunnen spelen. Zo had Meijer geprononceerde - pro-Isrälische - opvattingen over het Midden-Oosten. Hij vreesde de Engels-Franse druk in de EPS die tot een pro-Arabische wijziging van het beleid zou kunnen leiden. Van Lynden daarentegen wees erop dat hij met succes de sterke pro-Israëlische stemming op het departement had

228. Gids van het Departement van Buitenlandse Zaken 1973, 1974, Staatsuitgeverij, "s-Gravenhage $1973,1974$.

229. Van Lynden had als marineofficier geweigerd een loyaliteitsverklaring jegens de Duitsers af te leggen. Hif werd vervolgens gëntemeerd in en Duits krijgsgevangenkamp waaruit hij ontsnapte. NRC-Handelsblad, 9-2-1990 en 20-2-1990. Meijer werd in de oorlog gearresteerd en werd negen maanden gevangen gehouden. Mij behoorde tot de 'Paroolgroep'. Vrij Nederland 23-12-1,989.

230. Zie bijlage 1 en 2. 
weten om te buigen met de aanvaarding van de EPS-verklaring van 6 november. Meijer heeft zich uitdrukkelijk verzet tegen een karakterisering van de houdingen in pro of contra-Israël. Mochten de eigen opvattingen - de individufactoren - een rol hebben gespeeld, dan sloten deze volledig aan bij de opvattingen die zij op grond van hun positie - de rolfactoren - hadden.

De positie en bevoegdheden van de onder deze twee directeuren-generaal ressorterende afdelingen stonden centraal. Uitbreiding van de eén betekende een beperking aan invloed op het beleild van de ander. Het kan dan ook als een voorbeeld van het bureaucratic politics model worden beschouwd. Ik zal daarop terugkomen na eerst de inzichten en activiteiten van beiden in deze kwestie te hebben behandeld.

Van Lynden had de totstandkoming van de Europese Politieke Samenwerking (EPS) van nabij meegemaakt in het Comité-Davignon en was daarvoor geporteerd. In 1972 publiceerde hij een artikel over perspectieven voor de Europese samenwerking waarin hij stelde dat "de politieke samenwerking gelijke tred (diende) te houden met de toenemende invloed die van de vergrote gemeenschappen op de wereld uitgaat ${ }^{231}$. Op 1 januari 1973 was de EG uitgebreid van zes tot negen lidstaten en nog afgezien van de vraag of daarmee de invloed van de EG op de wereld was toegenomen, bestond de wens de EPS te versterken en in omvang te doen toenemen. Ook minister Schmelzer (KVP) was een voorstander van een versterking van de rol van de EPS. De minister van Defensie, De Koster (VVD), verzette zich daar in de ministerraad indertijd nog tegen. Volgens De Koster was het een christen-democratische wens de Fransen te volgen die de totstandkoming van de EPS wilden stimuleren ${ }^{232}$. De Koster meende achteraf zelfs dat, indien de EPS niet had bestaan, Nederland het olie-embargo had kunnen voorkomen. De afzonderlijke houding van Nederland kwam nu immers op de EPS te Kopenhagen naar buiten. Dat werkte averechts op de Nederlandse verhouding met de Arabische landen en heeft - volgens De Koster - het embargo in de hand gewerkt.

De directeuren-generaal Van Lynden en Meijer verschilden in oktober 1973 van mening over de vraag of de Midden-Oostenkwestie al dan niet binnen de EPS behandeld diende te worden. In 1970 werd in EPS-verband in München over het Midden-Oosten gesproken, maar een gemeenschappelijke verklaring werd niet uitgegeven. Volgens sommige berichten had onder meer Luns zich tegen publikatie van een verklaring verzet ${ }^{233}$. Tot oktober 1973 was de Midden-Oostenkwestie dan ook nog geen onderwerp van gemeenschappelijk EPS- optreden geweest.

Het Nederlandse Midden-Oostenbeleid werd uitgedragen in de Verenigde Naties. Het is dan ook niet verwonderlijk dat de eerste regeringsverklaring van 9 oktober (zie 2.2.1.2) ambtelijk werd voorbereid door het Bureau Politieke Zaken van de Directie Internationale Organisatie (DIO) die onder het directoraat-generaal internationale samen-

231. Van Lynden, 1972, p. 1666.

232. Interview met De Koster op 31 december 1982.

233. NRC-Handelsblad 21-11-1971 en 15-5-1971; Die Welt 14-7-1971 in: Schreiner, 1978. Zie ook Siegler, 1973, pp. 144-145. Deze eerste bijeenkomst van de ministers van Buitenlandse Zaken in het kader van de EPS wond plaats op 19 november 1970 te München: 
werking ressorteerde. De DGIS, Meijer, zond het ontwerp via de secretaris-generaal naar minister Van der Stoel.

De inhoud van de verklaring hield ook in dit geval verband met de positie van de afdeling die de verklaring had voorbereid. Bij DIO richtte men zich op de VN. De Midclen-Oostenkwestie speelde voor Nederland toen in de VN. DIO kreeg daarom de opdracht de Nederlandse verklaring over het Midden-Oosten voor te bereiden.

Uitgangspunt van deze verklaring was het beginsel van het geweldverbod in de VN - artikel 2 (4) Handvest - op grond waarvan de resultaten van wapengeweld niet konden en mochten worden aanvaard.

In deze verklaring wordt eerst geconstateerd - op grond van rapporten van VN-waarnemers - dat Egypte en Syrië eenzijdig het bestand hebben verbroken en vervolgens wordt de voorkeur voor een terugkeer van beide partijen tot de voor zaterdag j.1. (6 oktober) geldende bestandslijnen van een staakt-het-vuren uitgesproken. Het is naar mijn mening een redenering die past bij degenen die in hun werk gericht zijn op de beginselen van de VN. Vanzelfsprekend spreekt de politieke voorkeur daarbij ook een rol want op grond van de beginselen uit het VN-Handvest had ook een andere redenering - bijwoorbeeld over de ontoelaatbaarheid dat Israël gebieden bezet hield - gevolgd kunnen worden.

De preambule van resolutie 242 van 22 november 1967 luidde onder meer: 'Emphasizing the inadmissibility of the acquisition of territory by war and the need to work for a just and lasting peace in which every State in the area can live in security; Emphasizing further that all Member States in their acceptance of the Charter of the United Nations have undertaken a commitment to act in accordance with Article 2 of the Charter'. Deze preambule is gebaseerd op het beginsel uit het Handvest in artikel 2 lid 3 en 4.

In de verklaring van 9 oktober stond tenslotte nog: 'Nederland zal zijn standpunt uitdragen binnen het overleg van de Negen en tegenover andere landen die tot verwezenlijking van dit standpunt kunnen bijdragen, ${ }^{234}$.

Dit was de taak van de DGPZ, Van Lynden, die twee dagen later zijn Europese collega's te Kopenhagen voor de EPS bijeenkomst ontmoette. Van Lynden was - volgens hem - onvoldoende gekend in en betrokken geweest bij de standpuntbepaling over de verklaring van 9 oktober. Hij was het ook niet eens met de inhoud daarvan (de keuze voor de bestandslijnen ex ante voor een staakt-het-vuren). In Kopenhagen ontving Van Lynden een telegram waarin stond dat namens de Negen geen verklaring mocht worden afgegeven. Volgens Van Lynden ${ }^{235}$ was dat telegram afkomstig van Meijer. Hij weigerde een instructie van zijn collega te accepteren en deelde dat de minister mee.

234. Tweede Kamer, zitting 1973:1974, 12600, nr. 8.

235. In de volgende passage worden de benaming de DGPZ - de directeur-generaal politieke zaken (Van Lynden) - en de DGIS - de directeur-generaal internationale samenwerking (Meijer) - gehanteerd, ondat het over beide personen gaat. Bovendien kan niet zonder lidwoord over DGPZ worden gerept daar er geen directoraat-generaal politieke zaken bestaat maar alleen directies en functies die onder de directeur-geaneraal politieke zaken ressorteren. Wel kan de term DGIS worden gebruikt want er bestaat een directorati-generaal internationale samenwerking. Gedurende de onderzoekspentode werden VN-zaken vanuit DGIS behandeld, naderhand door de directie politieke VN-Zaken die onder de directeur-generaal pollitieke zaken ressorteerde. 
Volgens Meijer werden door hem geen telegrammen verstuurd, maar hij kon in bepaalde gevallen gemachtigd worden een telegram van de minister voor 'uit te paraferen. Er is - volgens de DGIS - geen sprake van dat een telegram zou zijn verzonden zonder schriftelijke of mondelinge machtiging van de minister. Er zou alleen sprake kunnen zijn van een telegram met vaststaand beleid. Van elk verzonden telegram kregen de minister en de secretaris-generaal bovendien terstond een afschrift. Afgezien van het verschil van mening over dit telegram en de betrokkenheid van de minister daarbij bestaat er geen verschil van mening over de inhoud van het telegram en evenmin over de reactie van de minister op Van Lyndens boodschap uit Kopenhagen.

Van der Stoel accepteerde een verklaring waarin werd opgeroepen tot een 'staakt-hetvuren sur place', wat een verschuiving van standpunt inhield. Wel verzette hij zich tezamen met de premier tegen het verlenen van een mandaat aan de leden (Verenigd Koninkrijk en Frankrijk) van de Veiligheidsraad. Van Lynden was het daarmee niet eens, maar hij voerde de instructie uit (zie 2.2.1.3). Nederland zou als gevolg daarvan binnen de BG in een geïsoleerde positie terecht komen hetgeen met name de DGPZ raakte die dit isolement in de periode van 13 oktober tot 6 november heeft ervaren. Vanuit de regionale directies die onder de DGPZ ressorteerden, werd druk uitgeoefend met het doel Nederland op eén lijn te brengen met de Europese partners.

De vraag die zich opdringt, is in hoeverre de verschillen binnen het departement te maken hadden met een verschil in visie ten aanzien van:

a. het Arabisch-Israëlisch conflict;

b. het ongedaan maken van het olie-embargo;

c. de Europees-Atlantische tegenstelling;

d. het uitdragen van het Nederlandse standpunt in het Europese, dan wel in het VNkader.

De meningen van de participanten in het besluitvormingsproces verschillen daarover en tevens bestaat verschil van mening over de koppeling van deze dimensies in hun standpunt.

Van Lynden wenste een versterking van de EPS en meende dat Nederland sterker zou staan ten opzichte van het olie-embargo wanneer Nederland een gemeenschappelijk standpunt van de EG zou onderschrijven. Hij koerste daarop aan. Hij was tevens van mening dat er op het departement een sterke pro-Israëlische stroming bestond, die hij in de periode 13 oktober - 6 november met succes had weten om te buigen ${ }^{236}$.

Volgens Meijer had de wijziging van het beleid daarentegen niets te maken met een houding pro of contra-Israël, maar bestond deze uit een aantal beslissingen van minister Van der Stoel om het Nederlandse Midden-Oostenbeleid over te hevelen van de VN naar de besloten discussies van de EPS en te onderwerpen aan de compromissen waarvoor inzichten en belangen van Frankrijk en Engeland doorslaggevend waren ${ }^{237}$.

De directeuren-generaal benaderden de kwestie elk vanuit hun eigen sector: de DGPZ vanuit het Europees politiek overleg en de DGIS vanuit het traditionele Midden-Oostenbeleid dat Nederland in de VN voerde. De DGIS beschreef zijn standpunt als volgt: 'De

236. Interview met Van Lynden op 13 september 1982.

237. Interview met Meijer op 15 oktober 1982. 
verschillende visies die zich in het begin van 1973 toespitsten, hadden niet zozeer te maken met houdingen 'pro-Israel' of 'pro-Arabisch". Het Nederlandse beleid ten aanzien van het Midden-Oosten lag, in nauw en voortdurend overleg met het parlement, al jaren vast. Het werd afgeleid van de zich maar langzaam wijzigende besluitworming in de discussies binnen de Verenigde Naties, waar het krachtenveld voornamelijk werd bepaald door de grote mogendheden (de Verenigde Staten en de Sovjetunie). Nederland kon zich onder die omstandigheden een redelijk genuanceerd eigen geluid veroorloven; overeenkomstig de eigen politieke inzichten en de eigen belangen. Onmiskenbaar was echter de neiging, met name in de periode Schmelzer, zich meer en meer te voegen in de Europese Politieke Samenwerking, waarbinnen vooral Engeland en Frankrijk zich tegen de Verenigde Staten wilden afzetten. Nederland verloor binnen de EPS allengs meer politieke identiteit, waartegenover een winst stond aan Europese identiteit. In de toekomst zou, dat was duidelijk, de EPS in omvang toenemen. Tot oktober 1973 was de Midden-Oostenkwestie echter geen onderwerp van gemeenschappelijk EPS-optreden geweest; dit stond nu well te gebeuren, en dat - zo viel naar de mening van Mejjer te verwachten - tot schade van de Nederlandse standpunten en (onder Engels-Franse druk) tot schade van de Nederlandse belangen. In elk geval zou accepteren, onder zulke gevaarlijke oorlogsomstandigheden, van gezamenlijk EPS-optreden een principiele wijziging betekenen van het tot dan toe door Nederland gevoerde Midden-Oostenbeleid, waarbij steeds ernstig rekening was gehouden met de grote verantwoordelijkheid van de Verenigde Staten voor het behoud en herstel van de vrede in het Midden-Oos$\operatorname{ten}^{* 238}$. Meijer beschouwde zijn standpuntbepaling als een tactisch achterhoedegevecht dat hij wel zou verliezen, waardoor kwesties die vroeger in de Verenigde Naties thuishoorden in Europees verband besproken zouden gaan worden. De situatie in die tijd werd door hem omschreven als "een hellend vlak'.

Op mijn vraag aam Van der Stoel of deze zijn mening in de periode tot 6 november had gewijzigd wan het DGIS-standpunt naar het DGPZ-standpunt, antwoordde hij deze zwenking van het DGIS-standpunt naar het DGPZ-standpunt als zodanig niet te hebben ervaren: 'IK was, in tegenstelling tot DGIS, niet ten principale tegen een Europese verklaring over het Midden-Oosten gekant; ik was, in tegenstelling tot DGPZ, niet bereid in de onbestemde situatie van oktober 1973 Frankrijk en Engeland een onvoldoende omlijnd mandaat te geven mede namens ons in de Veiligheidsraad te spreken" 239 .

Na zo uitvoerig te hebben stilgestaan bij de verschillende visies van de twee betrokken directeuren-generaal, kunnen we de zesde beslissing inzake de toestemming tot een gemeenschappelijke EG-verklaring op 4 november kort behandelen (zie 2.2.1.6). Het Comite Politique had een ontwerptekst opgesteld en Van Lynden legde deze ter goedkeuring voor aan Van der Stoel. Deze zou op 5 en 6 november te Brussel in een verklaring worden omgezet. Op zondagmiddag 4 november werd de ambtelijke top zeer

238. Brief van Mejjer an auteur met bijlagen, september 1983. De visie als hier weergegeven werd door hemzelf opgesteld.

239. Brief van Van der Stoel aan auteur van 1 september 1983. 
onverwachts verzocht bij Van der Stoel thuis te komen. Zo belde Van der Stoel op deze eerste autoloze zondag Meijer op en verzocht hem even langs te komen voor een dringende kwestie. Meijer was verbaasd bij aankomst daar ook Van Lynden (DGPZ), Schiff (secretaris-generaal) en Van der Kun (chef Directie Afrika en Midden-Oosten, die op het niveau van experts betrokken was bij de EPS en ressorteerde onder de DGPZ) aan te treffen. Na een moeilijk en langdurig gesprek waarbij vooral Van Lynden en Meijer verschillende visies naar voren brachten die onverenigbaar bleken te zijn, besloot Van der Stoel tenslotte de gevraagde volmacht aan Van Lynden te verlenen. Deze beslissing werd door zowel Meijer als Van Lynden als een beleidswijziging opgevat. Van Lynden kon nu voortgaan met de activiteiten in de Europese Politieke Samenwerking en aan Nederlands geïsoleerde positie in de EG zou een eind kunnen komen. Volgens Van Lynden betekende deze beslissing van Van der Stoel een waterscheiding in de door Nederland gevoerde pro-Israëlische politiek en hij beschouwde deze gebeurtenis als het belangrijkste moment van zijn carrière ${ }^{240}$.

Het in de toekomst voorkomen dat Nederland opnieuw in een kwetsbare positie terecht zou kunnen komen, werd een belangrijk doel van het Nederlandse beleid tijdens deze kwestie en zou dat ook voor Nederland blijven. De EPS had daartoe een beschermfunctie voor het Nederlandse Midden-Oostenbeleid zoals in het eerste hoofdstuk uiteen werd gezet.

Voor het doel, de gevolgen van het olie-embargo te beperken en zo mogelijk het olieembargo te laten beëindigen, was het departement van Buitenlandse Zaken ook bij andere dan de twee hierboven besproken beslissingen betrokken. De activiteiten van het departement waren erop gericht de Arabische landen gunstig te stemmen. In Nederland ging de DGPZ, vaak in gezelschap van de DGIS als 'co-host', tijdens de crisisperiode eéns in de veertien dagen met de Arabische ambassadeurs lunchen. Eenmaal werd een bezoek van de Arabische ambassadeurs aan de Leidse hoogleraar in de Arabische taalen cultuurgeschiedenis Brugman gearrangeerd, die hen in zijn bibliotheek rondleidde. De consul-honorair van Koeweit werd ook wel eens buiten kantoortijd ontvangen. Dit alles leidde echter niet tot resultaat.

De actieve consul-honorair van Koeweit, Rabbani, had daarentegen de olie-ministers wan Algerije en Saoedi-Arabië op $\mathbb{l}$ december in Brussel ingelicht over de situatie in Nederland en hen een lijstje met acht punten van kritiek op Nederland overhandigd ${ }^{241}$. Toen vervolgens Lubbers vergezeld door Van Lynden met de ministers Abdul el Salam en Ya'amani sprak, maakten de Nederlanders nog weinig indruk op de Arabische olie-ministers ${ }^{242}$. De Nederlanders betoogden dat de Palestijnse kwestie inmiddels wel degelijk als een politiek probleem werd gezien en overhandigden hen de regeringsnota van 16 november en Van der Stoels toespraak in de Tweede Kamer van 29 november. Dat was niet voldoende, want volgens de Algerijnse minister Abdul el Salam werd van Nederland verlangd:

a. de diplomatieke betrekkingen met Israël te verbreken;

b. de Arabische staten te steunen met militaire en andere hulp;

240. Interviews met Van Lynden en Meijer op respectievelijk 13 september en 15 oktober 1982.

241. Interview met Van Lynden op 13 september 1982.

242. Interview met Van Lynden op 13 september 1982. 
c. te verklaren dat Israêl alle bezette gebieden diende te ontruimen ${ }^{243}$.

Lubbers theeft ontkend dat deze drie eisen werden gesteld ${ }^{244}$. De drie eisen die Saoedi-Arabie in het ultimatum van 26 oktober stelde waren ook veel minder vergaand. Nederland zou:

a. Israd moeten veroordelen wegens agressie;

b. het zelfbeschikkingsrecht van de Palestijnen erkennen;

c. ontruiming van de bezette gebieden van Israël moeten verlangen ${ }^{245}$.

Het is in ieder geval weinig reëel te verwachten dat Nederland op de eerste twee eisen van 1 december zou ingaan.

Met de derde eis lag dit anders, daar tal van Europese landen deze reeds eerder hadden aanvaand ${ }^{246}$. Zoals gesteld onderschreef Frankrijk die zienswijze al in 1967. Oolk vanuit het departement werd bij herhaling bij Van der Stoel erop aangedrongen een nieuwe verklaring wit te geven die iets meer de Arabische kant zou uitgaan. Van der Stoel heeft dat steeds geweigerd, omdat hij meende het gewenste resultaat eerder te bereiken door vooral niet de indruk te wekken zwak te staan ${ }^{247}$.

In het verkiezingsprogramma van de Partij van de Arbeid wit 1972, Keerpunt, werd weel aandacht geschonken aan het voeren van een actief buitenlands beleid. Met het aantreden van de eerste socialistische minister op het departement van Buitenlandse Zaken, dat gedurende bijna twintig jaar (1952-1956 als minister zonder portefeuille samen met Beyen en vervolgens van 1956-1971 alleen) was geleid door de conservatieve roomskatholiek Luns die van geen kritiek op Westerse bondgenoten wilde horen en laten blijken, werd binnen het departement gevreesd dat daar verandering in zou kunnen. komen.

Een gesprek dat op 17 oktober plaatswond tussen Van der Stoel en de ambassadeurs van Irak, Saoedi-Arabië, Tunesië en de Egyptische zaakgelastigde (waarbij de Chef van de Directie Afrika en Midden-Oosten, Van der Kun, aanwezig was) werd aangegrepen om kritiek op Van der Stoel te leveren. Volgens een artikell in 'Le Monde' zou Van der Stoel zich bij deze ontmoeting onhoffelijk hebben gedragen en de Arabische ambassadeurs bijna de deur hebben uitgegooid ${ }^{248}$. Het was ook éen van de politieke redenen waarmee het olie-embargo tegen Nederland werd beargumenteerd ${ }^{249}$.

Er werd vanuit de Kamer een vraag gesteld waarop Van der Stoel antwoordde: "Bedloeld artikel kan door mij niet anders worden bestempeld dan als een kwaadwillige en totale verdraaing van de feiten' ${ }^{250}$. Ook de bij deze ontmoeting aanwezige Tunesische ambassadeur, met wie de verhouding steeds goed bleef en die de departementsleiding soms

243. Trouw, 3-12-1973.

244. Trouw, 3-12-1973.

245. Interviow met Van Lynden op 13 september 1982.

246. Bijvoonbeeld Belgie huldigde dat standpunt, zie De Raeymaeker, 1979.

247. Interview met Van der Stoel op 17 november 1982.

248. Lo Monde, 16 november 1973, srtikel was geschreven door Paul Balta.

249. Balta, 1974, pp. 14-16.

250. Tweede Kamer, zitting 1973-1974, Aanhangsel p. 891 , vraag no. 445 van W. Scholten (CHU) en Nootenboom (KVP) op 19 november 1973 met antwoord op 21 november 1973. 
van advies diende, ontkende nadrukkelijk de strekking van dai artikel ${ }^{251}$. De beschuldiging in de buitenlandse pers aan het adres van Van der Stoel werd door sommige politici van de oppositie en sommige hoge ambtenaren overgenomen. Zo gaf bijvoorbeeld de diplomaat Boon aan Van der Stoel, vanwege diens houding bij die ontmoeting, de schuld van het olie-embargo: 'Zonneklaar werd dat de droge zakelijke uiteenzetting van de bewindsman, in tegenstelling tot de meer diplomatieke en soepele wijze van opereren van zijn voorgangers, tot een fatale conclusie aanleiding had gegeven' ${ }^{252}$. Van der Stoel reageerde daarop door Boon onzorgvuldigheid te verwijten ${ }^{253}$.

Van der Stoel schreef mij Boons stelling uiterst curieus te vinden omdat Boon niet bij dat gesprek aanwezig was en omdat juist Boon vanuit Rome had gemeld van een goed geinformeerde bron vernomen te hebben dat al in de maanden voor de Oktoberoorlog in Algiers tot de olie-boycot zou zijn besloten ${ }^{254}$.

Bij de PvdA ging de beschuldigende vinger in de richting van de ambtenaren van het Departement en in het bijzonder naar de afdelingen die ressorteerden onder de directeur-generaal politieke zaken, die de minister zouden tegenwerken ${ }^{255}$. Het EersteKamerlid Van Riel (VVD) vroeg daarop aan de minister of hij inderdaad werd tegengewerkt hetgeen natuurlijk werd ontkend ${ }^{256}$. De kritiek binnen de PvdA werd ook door de fractievoorzitter, Van Thijn, bij het dagelijks bestuur van deze partij naar voren gebracht toen hij stelde dat coaching van Van der Stoel in zijn presentatie wel gewenst was, temeer omdat de afdeling voorlichting bij Buitenlandse Zaken zwak was ${ }^{257}$.

Nadat op 3 december rumoer was ontstaan over de persconferentie van de woordvoerder van Buitenlandse Zaken, Thurkow, nam de PvdA het initiatief tot een debat. Het rumoer betrof de interpretatie van de EG-verklaring van 6 november 1973, waarin zou zijn vastgelegd dat Israël zich uit alle bezette gebieden zou moeten terugtrekken. Dat zou een Nederlandse beleidswijziging ten aanzien van het Arabisch-Israëlisch conflict hebben betekend. In dat debat in de Tweede Kamer verwierp Van der Stoel niet de interpretatie die Thurkow had gegeven, maar zegde wel toe de nodige maatregelen te zullen nemen opdat deze misverstanden niet opnieuw zouden rijzen ${ }^{258}$. In het vertrouwelijk overleg na afloop van dat debat om 17.00 uur heeft Van der Stoel Thurkow volledig gedekt maar de volgende morgen werd hij geschorst. Volgens Portheine (VVD) 'kwam dat omdat de heer Dankert (PvdA) dat wenste, dat was heel kras. Hij was een VVD-er, men wilde hem weg'. Volgens Portheine was dat een zwarte bladzijde en werd Thurkow de zondebok ${ }^{259}$.

Volgens Dankert was aan Van der Stoel al vaak duidelijk gemaakt dat hij iets aan de Directie Pers en Nieuwsvoorziening moest doen. Hij stelde: "Dat de Thurkow-zaak nu door Max' traagheid naast Thurkow ook Van der Stoel geschaad heeft, valt niet te

251. Interviews met Van Lynden en. Van der Stoel op respectievelijk 13 september en 17 november 1982.

252. Boon, 1976, p 285.

253. Het Parool, 4-11-1976.

254. Brief van Van der Stoel aan auteur, 1 september 1983.

255. R. Her Beek in een interwiew met het Vrije Volk van 7-11-1973.

256. Eerste Kamer, zitting 1973-1974, Aanhangsel, vraag no. 26, p. 53.

257. Notulen dagelijks bestuur PvdA, 12 nowember 1973.

258. Handelingen Tweede Kamer, zitting 1973-1974, van 5 december 1973, p. 1439.

259. Interview met Portheine op 25 maart 1982. 
ontkennen. Maar als de minister een onduidelijk beleid voent, moet van de woordvoerder verwacht worden dat hij dat onduidelijke beleid onduidelijk verkoopt' ${ }^{260}$. De hierboven beschreven gebeurtenis was een incident. Uit een groeiende irritatie werd het zo hoog opgenomen ${ }^{261}$. De irritatie had te maken met de onzekerheid of het Nederlands beleid al dan niet gewijzigd was. Dat leverde binnenlandse spanning op aangezien in de publieke opinie steun aan het pro-Israëlisch standpunt bleef bestaan en het departement op de uitgifte van een iets meer pro-Arabische verklaring aandrong.

Later zou het in de yorige paragraaf beschreven verschil van mening tussen de beide ministers op het departement over de opstelling op de Washingtonconferentie volgen. De DGIS die in de delegatie zat, wist nog te bereiken dat Van Gorkom, gevolmachtigd minister in New York, in de delegatie werd opgenomen. Doel daarvan was meer tegenwicht te kunnen bieden aan de visie die vanuit de financieel-economische sector - door de minister van Financiën, Duisenberg, en vanuit Economische Zaken naast de minister door de directeur Energie Zaken en de adjunct-directeur voor de Buitenlandse Economische Betrekkingen - naar voren werd gebracht en van toenemend gewicht was geworden ${ }^{262}$.

Voor de besluitvorming in de toekomst binnen het departement inzake het beleid over het Midden-Oosten werd, als gevolg van de beslissing van 4 november, de positie wan de DGPZ versterkt ten opzichte van de DGIS. Zo zou een situatie kunnen ontstaan die leek op die in België waar degene die VN-zaken behartigde ondergeschikt was aan de directeur-generaal politieke zaken. Inmiddels ressorteert ook in Nederland de directie politieke VN-zaken onder de directeur-generaal politieke zaken. Het aan de gang zijnde proces naar versterking van de Europese Politieke Samenwerking en de dienovereenkomstige afstemming van het Nederlands buitenlands beleid op dat van de partners, werd door het olie-embargo 1973 versneld.

\subsubsection{De niet-formele politieke elite}

Tot dusver zijn de actoren behandeld die op grond van bun positie bij het besluitvormingsproces betrokken zijn. De ambtenaren bereiden het beleid voor, de regering stelt het beleid vast en werkt het uit en het parlement controleert het. De praktijk wijkt daar wel van af, zoals onder meer uit de analyse van de tien beslissingen is gebleken, maar dat neemt niet weg, dat de formele politieke elite bij het beleidswormingsproces vanwege haar functie-uitoefening een rol zou kunnen spelen.

Daarnaast zijn er tal van groepen in de samenleving die weliswaar ook invloed willen uitoefenen, maar op grond van hun positie niet direct betrokken zijn bij het besluitwormingsproces. $\mathrm{Zij}$ worden de niet-formele politieke elite genoemd. $\mathrm{Zij}$ kunnen trachten de directe besluitvormers rechtstreeks te beinvloeden. Daarnaast kunnen zij proberen voor hun wensen gehoor te vinden bij de formele politieke elite, opdat deze vervolgens hun wensen in het besluitvormingsproces inbrengt.

260. F 406, notitie van P. Dankert van 10 januari 1974 , p. 5 .

261. Zie ook het uitwoerige artikel met reconstructie wan de persconferentie in Vrij Nederland van 4-121973 watrin Comelissen van VN het voor Thurkow opnam. Vrij Nederland 22-12-1973.

262. Interview met Mejjer op 13 oktober 1982. 
Hoewel de politieke partijen niet tot de deelnemers aan het formele besluitvormingsproces worden gerekend, heb ik deze groepering hier vanwege de nauwe relatie met de parlementariërs en vooral het overheersende gedrag van de parlementaire fractie op de partijlijn, tezamen met het parlement behandeld. Waar verschil van inzicht tussen fractie en partiji bestaat, zoals bijvoorbeeld bij de PPR, zagen we dat de afwijkende visie van de partij in het besluitvormingsproces niet naar voren werd gebracht. Slechts indien de partij andere actoren - dan de eigen parlementariërs - in zo'n geval voor zijn standpunt zou kunnen winnen, zou nog wel invloed kunnen worden uitgeoefend. Daarnaast bestaat de mogelijkheid dat parlementariërs hun standpunt wijzigen onder invloed van de partij. De kans daarop is afhankelijk van de relatie tussen partij en fractie en wordt groter naarmate het Kamerlid bevreesd is een verkiesbare plaats op de kandidatenlijst in de toekomst mis te lopen. Het dreigen met electorale sancties door groepen uit de samenleving kan de druk van de partij op de fractie of de rechtstreekse druk op de fractie versterken. In feite heeft zich dit verschijnsel in 1973 niet voorgedaan; wel bestond aan de zijde van politici een grote gevoeligheid voor de opinie van het publiek op dit terrein. Ik zal daar later op terugkomen.

De niet-formele politieke elite zal hier worden onderscheiden in:

1. politieke actiegroepen;

2. kerken;

3. bedrijfsleven;

4. media;

5. publieke opinie.

\subsubsection{Pollitieke actiegroepen}

Zeer veel groepen in de Nederlandse samenleving houden zich bezig met het MiddenOosten. Een eerste inventarisatie leverde in 1981 tweeënzestig groepen op. Slechts een klein deel daarvan is betrokken geweest bij pogingen tot beinvloeding van het Nederlandse regeringsbeleid met betrekking tot het Midden-Oosten ${ }^{263}$. De meeste groepen die zich voornamelijk op het politieke aspect van het conflict in het Midden-Oosten toeleggen, zijn na 1973 opgericht. Juist uit vrees dat als gevolg van het olie-embargo de Nederlandse publieke opinie ten nadele van Israël zou kunnen veranderen, werden de pro-Israël actiegroepen opgericht. Vơór die tijd - zo werd gemeend - bestond de noodzaak daartoe niet, omdat het beleid als pro-Israël werd gepercipieerd.

Buiten de Nederlandse Zionisten Bond bestonden er voor 1973 nauwelijks pro-Israëlische actiegroepen wat door Houwaart merkwaardig werd gevonden ${ }^{264}$. Tijdens de Oktoberoorlog werd een ad-hoc comité, het Actie Comité Israël, opgericht. De uitvoering daarvan was in handen van de Nederlandse Zionisten Bond die namens de drie joodse kerkgenootschappen en de zionistische vrouwen-, studenten- en jeugdorganisaties optrad. Dit comité heeft geld ingezameld voor Israël, vrijwilligers voor Israël geregistreerd, media benaderd, een pamflet verspreid en demonstraties georganiseerd. 
Met name de grote demonstratie met vijfduizend mensen in de Koopmansbeurs te Amsterdam op 13 oktober 1973 heeft de aandacht getrokken. Op deze bijeenkomst werd het woord gevoerd door de burgemeester van Amsterdam, Samkalden (PvdA), de ambassadeur van Israël en afgevaardigden namens de PvdA (Dankert), de drie confessionele partijen (Kuiper), de VVD (Keja), D'66 (Goudsmit) en DS'70 (Drees). In de zaall werd de aanwezigheid van de minister van Defensie (Vredeling) opgemerkt en dat wekte de toorn op van de Arabische Staten. Vredeling had Den Uyl wel van tevoren van zijn voomemen, als privé-persoon, naar de demonstratie te gaan ingelicht. Den Uyl wilde hem daar niet van weerhouden ${ }^{26.5}$. Vredelings anwezigheid aldaar zou ook als eén van de redenen voor het Arabisch olie-embargo genoemd worden. Ook de aanwexigheid van Samkalden (die door de Arabische landen als één van de belangrijkste mensen in de PvdA werd beschouwd) werd Nederland verweten bij de instelling van het olie-embargo ${ }^{266}$. Het Actie Comité Israël heeft verder een protest-telegram aan de Franse ambassadeur gestuurd, maar niet getracht het Nederlandse beleid te beïnvloeden en politici, ministers en ambtenaren werden dan ook niet benaderd ${ }^{267}$. Ook na de EG-verklaring van 6 november werd door de Nederlandse Zionisten Bond op 22 november binnenskamers grote tevredenheid over het Nederlandse beleid geuit. Op deze vergadering werd overwogen een speciale actie te ondernemen als dank aan de Nederlandse regering. De voorzitter raadde dit echter af, omdat de Nederlandse regering vanwege het olie-embargo daarmee in verlegenheid zou kunnen worden gebracht ${ }^{268}$, Anders dan L. de Jong (directeur van het Rijksinstituut van Oorlogsdocumentatie), die op 7 november een open brief met kritiek op de EG-verklaring aan Van der Stoel schreef en hem daarin van onoprechtheid beschuldigde, heeft de Zionistenbond in de EG-verklaring van 6 november geen beleidsverandering ten nadele van Israël gezien. Al op de tweede dag van de Oktoberoorlog werd de solidariteit met Israël op een demonstratieve bijeenkomst tot uiting gebracht. Deze was georganiseerd door het Solidariteitscomité voor Joden in de Sovjetunie met de opzet te protesteren tegen het voornemen van de Oostenrijkse regering het opvangkamp Schönau voor Russische Joden te sluiten. Onder de tweeduizend aanwezigen bevond zich ook premier Den Uyl - hetgeen niet naar voren werd gebracht bij de instelling van het olie-embargo. Namens de VVD (Berkhouwer en Keja), de confessionele partijen (van Elzen), de PvdA (Dankert ook uit naam van Van Mierlo van D'66) en DS'70 (De Brauw) spraken toen Tweede Kamerleden hun solidariteit met Israël uit en werd het initiatief tot de eerste regeringsverklaring genomen ${ }^{269}$.

Op initiatief van het Genootschap Nederland-Israël werd op 17 oktober een advertentie gepubliceerd waarin de 'solidariteit met Israèl in zijn strijd voor zelfbehoud' door bekende Nederlanders werd betuigd. Onder deze bekende Nederlanders bevonden zich drie oud-premiers, namelijk Drees (PvdA), De Jong (KVP), Biesheuvel (ARP) en

265. Interview met Den Uyl op 26 februari 1987.

266. Het NIW van 19-10-1973 en 9-11-1973; Vrij Nederland van 10-11-1973; Le Monde van 23-111973; Ven Ginkel, 1978, p. 69; Balta, 1974, pp. 14-16. Zie ook 2.2.

267. Overzicht wan de activiteiten van dit comite in brief wan de NZB aan A. Zwergbaum (Wereld Zionistische Organisatie) van 14 novemher 1973, no. 972.

268. Notulen van de vergadering van het Bondsbestuur van 22 november 1973.

269. NIW 12-10-1973. 
werder de politici Diepenhorst (ARP), Klompé (KVP), Wttewaal van Stoetwegen (CHU), Van Someren-Downer (VVD), Steenkamp (KVP), De Brauw (DS'70) naast Stempels (oud-hoofdredacteur NRC-Handelsblad), Carmiggelt (schrijver) en Kloos (VARA) ${ }^{270}$.

Uit deze activiteiten van de pro-Israël actiegroepen blijkt dat zij de steun voor Israel in de samenleving hebben weten te mobiliseren en daarbij met name de politici betrokken.

Het Palestina Komitee had al voor de Oktoberoorlog gevraagd 'de Nederlandse steun aan de zionistische agressiepolitiek' stop te zetten ${ }^{271}$. Aan het begin van de Oktoberoorlog gaf het Komitee op 9 oktober een verklaring ter ondertekening uit. Daarin werd gesteld: 'Wij zijn solidair met de strijd van het Pallestijnse en Arabische volk tegen onderdrukking door zionisme, imperialisme en Arabische reactie en vón de vestiging van een democratisch Palestina, waarin joden en Arabieren als gelijke burgers kunnen samenleven in vrede met de nabuurlanden'; deze verklaring werd later ondertekend door de. Federatie van Jongeren Groepen in de PvdA ${ }^{272}$.

Het Palestina Komitee richtte zich op 'links" en daarbinnen vooral op de jongeren uit Pvd $A$, vakbeweging en bewogen christenen in bijwoorbeeld de Arjos en Pax Chris$\mathrm{ti}^{273}$. Arjos (de jongeren in de ARP) steunde de pro-Israël lijn van de ARP-fractie. Het Palestina Komitee werd daarentegen wel gesteund door Pax Christi (zie 2.2.4.2), terwijl ook binnen de vakbeweging discussie ontstond over het door de leiding ingenomen pro-Israël standpunt (zie 2.2.4.3).

Het Palestina Komitee heeft de media benaderd, tegen-informatie uitgedeeld tijdens de pro-Israël demonstratie van 13 oktober en op 17 oktober een eigen demonstratieve bijeenkomst georganiseerd ${ }^{274}$. Aan deze bijeenkomst werd door meer mensen dan ooit tevoren (ruim vierhonderdvijftig) deelgenomen. Tijdens deze bijeenkomst werd de eerste regeringsverklaring afgewezen en werden met name Den Uyl en Van der Stoel gekritiseerd $^{275}$. Tijdens de algemene ledenvergadering van het Komitee op 24 november werd de Nederlandse regering gevraagd de 'legitieme rechten' van de Palestijnen uit de EG-verklaring nader te preciseren als de onvoorwaardelijke erkenning van het recht op nationale zelfbeschikking van het Palestijnse volk in eigen land en de PLO te erkennen als de wettige vertegenwoordiger van het Palestijnse volk ${ }^{276}$.

Deze opvatting vond in 1973 nog geen gehoor onder de formele politieke elite, met uitzondering van de PSP-fractie. Een hoge ambtenaar op het ministerie van Buitenlandse Zaken was er zich bijvoorbeeld niet eens van bewust dat het Palestina Komitee in 1973 bestond ${ }^{277}$. Er bestonden ook geen hoge verwachtingen van de zijde van het Palestina Komitee: 'We maakten ons weinig illusies, gezien het controversiële karakter van het

270. NRC-Handelsblad, 18-10-1973; Het Parool 18-10-1973.

271. Nieuwsbrief Palestina Komitee (le), juli-augustus 1973, no. 5, pp. 4-5, verklaring van 14 april 1973.

272. Algemene bestuurswergadering FJG wan 3 november 1973.

273. Interview met Hendriks op 11 februari 1983.

274. Nieuwsbrief Palestima Komitee (2e), november-december 1973, no. 1, p. 21.

275. NRC-Handel sblad, 18-10-1973.

276. Nieuwsbrief Palestina Komitee (2e), januari-februari 1974, no. 2, p. 2.

277. Interview met Meijer op 15 oktober 1.982. 
Palestijns-Israëlisch conflict en gezien de aanhang van het Palestina Komitee, over wat wij konden klaarstomen bij de regering. We hebben veel meer gedacht dat mensen van ons in partijen die kwestie aan de orde konden stellen. Door het olie-embargo gingen de mensen nadenken over het conflict' ${ }^{27 \%}$.

\subsubsection{Kerken}

'Het Midden-Oostenvraagstuk is het meest gevoelige vraagstuk in de Nederlandse samenleving en raakt de christenen heel diep', zo verklaarde het Tweede Kamerlid Gualthérie van Weezel ${ }^{279}$. Bij protestanten en in het bijzonder de gereformeerden staat de verbondenheil met het Joodse volk en de Joodse staat voorop. De roomskatholieken volgen daarentegen het Vatikaan dat het bestaansrecht van de staat Israël nog steeds niet heeft erkend. Ook in de opiniepeilingen ten aanzien van sympathie voor de staat Israell komt dit verschil in opvatting tot uiting. Zo verklaarde in november 1974 $65 \%$ van de ARP-kiezers zich pro-lisraël, terwijl onder de KVP-kiezers slechts $29 \%$ pro-Israël was (zie 1.4).

Ondanks enige verandering binnen de rooms-katholieke kerk sedert paus Johannes XXIII treft men aldaar nog restanten van de substitutie-theologie aan. Volgens deze theologie zou het jodendom zijn opgevolgd door het christendom en is er geen plaats voor het Joodse volk weggelegd ${ }^{280}$. De rooms-katholieke vredesbeweging Pax Christi schreef nog tijdens de Oktoberoorlog een brief aan de Tweede Kamer waarin zij zich achter het PLO-standpunt schaarde voor een democratische, niet exclusieve staatsvorm waaraan werd toegevoegd 'bij een dergelijke staatsworm zou de nu bestaande vanzelfsprekendheid voor vele joden van de 'law of return' voor als joden beschouwde mensem (cursivering van auteur) komen te vervallen' ${ }^{281}$. Eerdar heb ik gewezen op de overeenstemming tussen het Nederlands Palestina Komitee en Pax Christi Nederland. Binnen het overleg tussen de bisschoppen zou de stellingname van Pax Christi weerklank hebben gevonden ${ }^{282}$; de beraadslaging tussen de bisschoppen werd niet openbaar gemaakt. In een brief aan de joodse kerkgenootschappen werd op 9 november wel medeleven betuigd met het volk van Israël en alle anderen die onder geweld te lijden hadden, maar werd gezwegen over het bestaansrecht en het voortbestaan van de staat Isra$\mathrm{el}^{283}$.

De drie joodse kerkgenootschappen vroegen op initiatief van de liberale rabbijn Soetendorp aan de christelijke kerken om een duidelijke standpuntbepaling ${ }^{284}$.

In tegenstelling tot de rooms-katholieke bisschoppen reageerden de gereformeerden en de Nederlands hervormden naar de mening van de joodse kerkgenootschappen wel

278. Interview met Hendriks op 11 februari 1983.

279. Interview met Guallherie van Weezel op 6 april 1983.

280. Interview met De Kruijf in De Tijd van 11-5-1974.

281. Punt 5 van de stellingen van Pax Christi Nederland die door de secretaris op 24 oktober 1973 aan de Tweede Kamer werden gestuurd.

282. Interview met De Meijer op 26 november 1981.

283. NTW van 16-11-1973 en A. Soetendorp in: American Jewish Yearbook, 1976, pp. 320-321.

284. NIW 2-11-1973,9-11-1973, 16-11-1973; NRC-HHandelsblad (Hollands Dagboek van Soetendorp) van $27-10-1973$. 
positief, al was het dan niet spontaan. Zo sprak het breed moderamen van de Hervormde Synode zijn verbondenheid met het Joodse volk uit en beklemtoonde het recht van Israël op veilige en erkende grenzen. Tijdens de grote demonstratieve bijeenkomst van 13 oktober 1973 voerden ook de secretaris van de Hervormde Raad voor Israël en de secretaris van de Katholieke Raad voor Israël het woord en spraken zich uit voor steun aan Israël. De Raad van Kerkern heeft tijdens het olie-embargo geen verklaring uitgegeven over het Midden-Oostenconflict ${ }^{285}$. In 1979 en in 1981 zouden politieke verklaringen volgen waarin respectievelijk het zelfbeschikkingsrecht en een staatkundig bestaan voor de Palestijnen naast een veilig voortbestaan van Israël werden erkend en vervolgens voor terughoudendheid in de kritiek op Israël werd gepleit ${ }^{286}$.

Hoewel verschil van mening tussen de verschillende kerkgenootschappen heeft bestaan, heb ik niet de indruk gekregen dat daarvan invloed is uitgegaan op het beleidsvormingsproces. In 1947-1948 bij het delingsplan en de erkenning van de staat Israël maakte dat nog wel wat uit en bleken vooral KVP-politici zich tegen aanvaarding van het VNdelingsplan en de erkenning van Israël te verzetten ${ }^{287}$. Een verschil van mening tussen ministers op grond van hun godsdienstige achtergrond over het Arabisch-Israelisch confliet heeft naar mijn mening in de periode van deze studie geen rol gespeeld.

\section{2:4.3 Bedrijfsleven, vakbeweging en oliemaatschappijen}

In 1973 was het Midden-Oosten nog geen belangrijk afzetgebied woor het Nederlandse bedrijfsleven. Van de totale export ging in 1973 slechts 2,3\% naar het Midden-Oosten, daarbij bedroeg het aandeel naar de Arabische landen 1,4\%. In 1973 was Israël nog - tevens voor het laatst - Nederlands belangrijkste exportland in deze regio. Als gevolg van de oliecrisis en de stroom van petro-dollars naar de Arabische wereld ontstonden hoge verwachtingen voor exportorders en investeringen. Voor het Nederlands bedrijfsleven waren dat aantrekkelijke perspectieven op de potentieel kansrijke Arabische markt. Eerder werd vermeld - 1.4.2.3 - dat de Nederlandse export in de periode 19731982 naar de Arabische landen met $712 \%$ groeide; dat is aanzienlijk in vergelijking met een groei van $265 \%$ in deze periode van de totale Nederlandse export (zie Bijlage 3 ). De bestaande belangen voor het bedrijfsleven noopten in 1973 dan ook minder tot beinvloeding van het Nederlands buitenlands beleid inzake het Midden-Oosten dan later het geval zou zijn.

In 1980 heeft het bedrijfsleven wel duidelijke beïnvloedingspogingen ondernomen. De export naar Saoedi-Arabië bedroeg toen meer dan twee miljard gulden. Het bedrijfsleven vreesde dat deze export in het geding zou komen, indien indertijd niet aan SaoediArabische wensen tegemoet werd gekomen ${ }^{288}$. In de toen slechter geworden economische situatie in West-Europa waren de exportorders naar de Arabische wereld voor met

285. Telefonische informatie door de Raad van Kerken in Nederland van mevrouw Van der Laar, maart 1983.

286. Verklaring van 17 oktober 1979 en 25 mei 1981; schriftelijke enquête secretaris van de werkgroep "De kerk en het joodse volk" wan 10 maart 1982; interview met Zijerveld op 30 juni 1982.

287. Saetendorp, 1982, pp. 31-51.

288. Het ging daarbij om het vertonen van een film op de televisie - 'de dood van een prinses" - en de verplaatsing van de Nederlandse ambassade uit Jeruzalem. 
name ondernemingen in de telecommunicatie, bagger- en bouwsector van enorm belang. Ik zal daar in het volgende hoofdstuk op terugkomen. In 1973 speelden deze belangen nog niet zo"n grote rol. Hoewel het bedrijfsleven in het algemeen "pro-Arabisch" was georiënteerd ${ }^{239}$, bestonden ook sterke 'pro-Israël' gevoelens onder de werkgevers. Zo veroorzaakte een alls pro-Arabisch beschouwd artikel eind 1973 in het Financieel Dagblad 250 opzeggingen binnen een week na publikatie ${ }^{290}$. Naast de aanwezige proIsraëlische gevoelens in de Nederlandse samenleving en de bestaande gevoeligheid over het Midden-Oostenconflict, werd de terughoudendheid aan de zijde van de werkgevers versterkt doordat Nederland met het olie-embargo onder druk werd gezet met cen actie vanuit het buitenland ${ }^{291}$. Volgens de Raad van Nederlandse Werkgeversverbonden VNO en NCW werden tijdens het olie-embargo van 1973 door de centrale verbonden interne noch externe standpunten ingenomen ${ }^{292}$. Geen werkgeversorganisatie heeft in 1973 openlijk op een Nederlandse beleidswijziging aangedrongen. Dat geschiedde evenmin in de gedachtenwisseling tussen de top van het bedrijfsleven (onder meer KLM, AMRO, ABN, SHV, Shell; Philips; Unilever) en de top van het ministerie van Buitenlandse Zaken (minister, staatssecretaris en drie directeuren-generaal) in het Overlegorgaan met het bedrijfsleven ${ }^{293}$. Ook in het meer geïnstitutionaliseerde overleg van het Verbond van Nederlandse Ondernemingen, het Nederlands Christelijk Werkgeversverbond en andere werkgeversorganisaties door middel van het Centraal Orgaan voor de Economische Betrekkingen met het Buitenland met het ministerie van Economische Zaken (met name het Directoraat-Generaal voor de Buitenlandse Economische Betrekkingen) werd niet aangedrongen op een wijziging in het buitenlands beleid van Nederland ${ }^{294}$. Desondanks maakte Van der Stoel kennis met een ondernemerslobby die zich ten doel stelde door wijziging in de Nederlandse politiek de oliekraan weer open te krijgen ${ }^{295}$.

Al werden de VVD- en CHU-fracties dan door de PvdA als olielobby afgeschilderd, van beïnvloedingspogingen vanuit het bedrijfsleven op deze fracties is bij dit onderzoek niets gebleken. Waarschijnlijk bestond de noodzaak daartoe ook niet, daar Kamerleden uit deze fracties al gericht waren op de wensen uit het bedrijfsleven. Een nogal magere onderbouwing van de door Van der Stoel ervaren ondernemerslobby. Veel waarschijnlijker lijkt het dat Van der Stoel doelde op de druk die op hem werd uitgeoefend door ambtenaren van binnen zijn departement die telkens aandrongen op wijziging van het beleid teneinde - met een opschuiving van standpunt - de Arabische landen gunstig te stemmen (zie 2.2.4.1). Hoewel een deel van deze ambtenaren het Nederlandse belang. identificeerde met de belangen van enkele grote ondernemingen, waren zij vooral beducht dat Nederland uit de pas zou lopen bij de overige Europese partners. Zij tracht-

289. Interview met Van der Beugel op 19 november 1982.

290. Interview met Metzemaekers op 2 juni 1982.

291. Interview met Basoski op 27 augustus 1982.

292. Brief van Van Doorn aan auteur van 16 september 1982.

293. Interview met Van der Beugel op 19 november 1982. Deze Adviescommissie uit het bedrijfsleven is inmiddels opgeheven, Intermagazine, november 1989, p. 65.

294. Interview met Basoski op 27 augustus 1982 en brief van Basoski aan autenr van 11 maart 1983.

295. Interview met Van der Stoel door Van Traa in: Gortzak, 1978, pp. 85-86. De woorden zijn van Van Traa; Van der Stoel sprak hem echter niet tegen. 
ten vooral een geïsoleerd Nederlands optreden te voorkomen en zochten meer aansluiting bij de opvattingen van andere Europese partners. Maar daarmee kan nog niet van een 'ondernemerslobby' gericht op een beleidswijziging worden gesproken. Een direct waarneembare beïnvloedingspoging van de zijde van het bedrijfsleven op het beleid in deze kwestie van de regering hebben we niet kunnen vaststellen.

De opvattingen aan de zijde van, of in ieder geval een deel van, het bedrijfsleven werden indertijd naar voren gebracht in enkele artikelen van Van Iersel, toen adjunctsecretaris van het Nederlands Christelijk Werkgeversverbond (NCW). Hij zou vanaf 1978 in de Tweede Kamer zitten voor het CDA.

In het tijdschrift 'Politiek perspectief" van het Centrum voor Staatkundige Vorming, dat is het wetenschappelijk instituut van de KVP, verscheen in november en december een artikel van Van Iersel waarin het Nederlandse Midden-Oostenbeleid werd veroordeeld. Volgens hem verdisconteerde de regering in haar buitenlandse politiek niet voldoende de nationale belangen en was de Midden-Oostenpolitiek een eigen leven gaan leiden, 'sterk geïnspireerd door sympathieën en ressentimenten in de publieke opinie en geheel los gezien van belangen die een bepaalde rol zouden gaan spelen". Nederland zou "meer oog moeten hebben voor de belangen van het bedrijfsleven en meer rekening moeten houden met de EG-partners'. Nederland had daarin gefaald, aangezien 'Nederland alleen politieke interesse had voor het veiligstellen van de positie van Israël'. Dat bleek onder meer uit Nederlands veto op de EPS-bijeenkomst over het Brits-Frans mandaat (zie 2.2.1.3).

Er werd toen volgens Van Iersel geen verband gelegd 'tussen de Nederlandse MiddenOostenpolitiek en de voor ons land wezenlijke oliebelangen'. Zijns inziens was een heroriëntatie van de Nederlandse EG-politiek noodzakelijk en daarmee werd een begin gemaakt toen Nederland zich op 6 november bij een gemeenschappelijk standpunt aansloot (zie 2.2.1.7) 296 .

In december 1973 schreef Van Tersel zowel in het orgaan van de NCW, De Werkgever, als in NRC-Handelsblad opnieuw dat Nederland zijn beleid moest afstemmen op dat van de partners. De oliecrisis had Nederland gedwongen de realiteit te erkennen, 'dat onze onafhankelijke positie aan steeds meer beperkende voorwaarden is gebonden' ${ }^{297}$.

Ook later herhaalde Van Iersel dat volgens hem de afweging veel te eenzijdig voor Israël was. Weliswaar hadden de werkgevers geen politieke opvattingen, maar zij deelden wel zijn mening dat te weinig rekening werd gehouden met de zakelijke belan gen ${ }^{298}$. Eenmaal gekozen in het parlement zou Van Iersel zich aansluiten bij de parlementaire Euro-Arabische dialoog. Hij wilde in de Nederlandse politiek de volgens hem te eenzijdige pro-Israëllijn, proberen om te buigen.

Tenslotte kan vermeld worden dat het Centraal Orgaan tijdens de oliecrisis heeft getracht een onderdeel van het buitenlands beleid, te weten de ontwikkelingssamenwerking, te wijzigen met het doel Egypte, Syrië en Soedan als concentratielanden voor ontwikkelingshulp op te nemen. Zowel indirect via het ministerie van Economische Zaken als in direct contact met de minister voor Ontwikkelingssamenwerking werd op

296. Van Iersel, 1973, pp. 14-20.

297. NRC-Handelsblad 7-12-1973; zie ook De Werkgever no. 26 wan 20 december 1973, p. 685 en NRC-Handelsblad van 12-12-1973.

298. Interview met Van Iersel op 21 maart 1983. 
deze opening naar de Arabische wereld aangedrongen. Hoewel Pronk wel geïrriteerd raakte door dit herhaalde verzoek - hij wilde niet de indruk wekken dat criteria voor het concentratielandenbeleid op verzoek wan het bedrijfsleven werden ontwikkeld - beslool hij in 1975 Soedan en Noord-Jemen als algemeen concentratieland en Egypte als bijzonder concentratieland aan te wijzen. Ofschoon Syrië werd afgewezen en Noord-Jemen als armste Arabisch land werd toegevoegd, heeft het bedrijfsleven wel het beoogde resultaat bereikt ${ }^{299}$.

\section{Vakbeweging}

Aan het begin van de Oktoberoorlog verklaarden de drie Nederlandse vakcentrales zich solidair met Israël en veroordeelden zij de aanval van de Arabische staten op Israël. Zij stuurden daartoe gezamenlijk op 8 oktober 1973 - NVV, NKV, CNV - een telegram aan de Israëlische vakbeweging, Histadrut.

In november 1973 bracht een NVV-delegatie een, tevoren gepland, bezoek aan Israël. De kunstenaarsbond van het NVV bemiddelde bij het sturen van Nederlandse kunstenaars naar Israëlische ziekenhuizen in deze periode. Een actie om in 1973 net als in 1967 over te werken en het daarmee verdiende loon aan Israël af te staan, werd niet overwogen $^{300}$.

Op de solidariteitsbetuiging van de vakcentrales werd door een aantal leden van het NVV kritisch gereageerd. Zij verweten de vakcentrales in een open brief van 25 oktober zich eenzijdig achter Israël op te stellen ${ }^{301}$. Het overlegorgaan van het NVV antwoordde hen dat het geen politieke uitspraak had willen doen. Door het ontbreken van contacten met bevriende organisaties in de Arabische wereld, was de 'sympathie waarin medeleven met alle slachtoffers van de oorlogshandelingen tot uiting werd gebracht" naar de Israëlische vakcentrale gestuurd ${ }^{302}$. De briefschrijvers waren niet tevreden gesteld met dit antwoord en verweten de leiding van de vakcentrale medeverantwoordelijk te zijn voor het Arabisch olie-embargo tegen Nederland ${ }^{303}$. In het algemeen kan gesteld worden dat de Nederlandse vakbeweging zich aan het begin van de Oktoberoorlog pro-Israëlisch opstelde maar verder geen activiteiten heeft ontplooid tot beïnvloeding van het Nederlandse beleid.

\section{Oliemaatschappijen}

Het onderwerp van deze studie rechtvaardigt afzonderlijke aandacht voor de rol van de oliemaatschappijen. De president-directeur van de Koninklijke Shell/Groep, Wagner,

299. Interviews met Basoski op 27 augustus 1982 en met Pronk op 17 maart 1982.

300. Brief wan Van Laar, medewerker Internationale Zaken van de FNV, aan auteur van 111 januari 1983.

301. Nieuwsbrief Palestina Konitee (2e), novemberdecember 1973, no. 1, pp. 12-13; Het Schoolblad - orgaan van de $A B O P$ - $(8 e)$, no. 39 van 25 oktober 1973 p. 714 , no. 40 van 1 november 1973 p. 730 en no. 41 van 6 november 1973 , p. 759 .

302. Nieuwsbrief Palestina Komitee (2e), januari-februari 1974, no.2, p. 27.

303. Ibidem pp. 28-30. 
heeft verzekerd dat men weliswaar 'heel goed kan stellen dat het volstrekt legitiem was woor Shell, gezien de enorme moeilijkheden waarin het concern toen verkeerde, om de Nederlandse regering te bewegen zich wat meer pro-Arabisch op te stellen. Maar dat is niet gebeurd" ${ }^{304}$. Kort na de instelling van het olie-embargo verklaarde de president-directeur op 4 november publiekelijk dat alle landen in principe hetzelfde percentage olie minder zouden ontwangen ${ }^{305}$. Eerder heb ik vermeld (zie 2.2.1.7) dat deze verklaring met name bij de Britten in slechte aarde viel. Nederland, dat baat vond bij de evenredige toewijzing van de olietoevoer ${ }^{306}$, heeft de positie van de oliemaatschappijen ook verdedigd tijdens de top van medio december in Kopenhagen. Dat was tegen de zin van de Fransen en Italianen, die al sinds 1959 ijverden voor een gemeenschappelijke protectionistische marktordening waarin de Franse en Italiaanse staatsoliemaatschappijen een groter marktaandeel. zouden kunnen verwerven ten koste van de gevestigde oliemaatschappijen ${ }^{307}$.

Tijdens de top werd Nederland wel als 'the voice of Shell' gezien ${ }^{308}$. Tussen oliemaatschappijen en de rijksoverheid vond tijdens de oliecrisis zeer frequent overleg plaats over de olieleveranties; de directeur van Shell Nederland stelt in dit verband dat de negen of tien oliemaatschappijen vrijwel dagelijks nauw contact met het ministerie van Economische Zaken hadden ${ }^{309}$. Op het hoogste niveau vonden gesprekken plaats tussen Wagner en Den Uyl op 7 en 11 november (volgens Den Uyls agenda), maar ook deze bleven beperkt tot Shells bijdrage aan een voortgaande olietoevoer naar Nederland ${ }^{310}$. Volgens Wagner was het beleid van de Koninklijke/Shell Groep 'erop gericht de verplichtingen zo goed en zo fair mogelijk na te komen en politieke druk of uitspraken te vermijden. De internationale situatie was uiterst delicaat en de verantwoordelijkheden van het bedrijf zo veelzijdig, terwijl wij de lange termijn nooit uit het oog verliezen, dat elke andere gedragslijn grotere bezwaren leek te hebben' ${ }^{\prime \prime \prime}$. De Shell heeft getracht haar positie veilig te stellen. Daartoe heeft het "alle "instructies" van de regeringen van de olie-exporterende landen nauwgezet opgevolgd' ${ }^{3 / 2}$ en tevens 'aan de regeringen van olie-importerende landen medegedeeld op welke wijze wij zouden trachten aan onze verplichtingen op het gebied van de voorziening te voldoen' ${ }^{313}$.

304. Brief van Wagner aan auteur van 29 november 1983.

305. Stobaugh, 1975, pp 189, 191. Televisje-interview met Wagner.

306. Interview met Den Uyl voor de radio 'Den Hang vandlag' (NOS) op 1 februari 1974; uit: Beleid Beschouwd no. 2685 , p. 6 .

307. Van Ginkel, 1978 , p. 53 .

308. Pefarson, 1979, p. 126.

309. Vaz Nunez op 29 januari 1974 voor de radionubriek Echo (KRO); uit: Beleid Beschouwd no. 2685, p. 6 .

310. Brief van Den Uyl aan auteur van 28 februari 1984 .

311. Brief wan Wagner aan auteur van 29 november 1983 .

312. Brief van Wagner aan auteur van 29 november 1983.

313. Brief van Wagner aan auteur van 13 januari 1984 .

In een radio-interview op 13 juli 1990 wees Wagner op dit onderzoek en de correspondentie tussen hem en mij. Aanvankelijk had ik geschreven - de Volkskrant, 5-11-1983 - dat wanuit de Koninklijke/Shell bij de Nederlandse regering op een beleidswijziging in pro-Arabische richting was aangedrongen. Nader onderzoek bracht an het licht dat een dergelijke beînwloedingspoging niel was geschied. Deze onjuuste beschuldiging van mij. greep hem hevig aan: 'Daar slaap je niet van, dat 
Door een verschuiving in de aanvoer van olie uit niet-Arabische olieproducerende landen kon het beleid van 'gelijke monniken, gelijke kappen' worden uitgevoerd. Bij het verleggen van de aanvoer van olie door de grote oliemaatschappijen was ook het ministerie van Buitenlandse Zaken betrokken. Van daaruit werden besprekingen gevoerd met de niet-Arabische, olieproducerende landen als Iran, Nigeria en Venezuela. Daarnaast vond in het begin wan de oliecrisis (op 22 oktober) een gesprek plaats tussen Van der Stoel en een vertegenwoordiger van de Koninklijke/Shell Groep waarbij ambtenaren van de ministeries van Economische Zaken en Buitenlandse Zaken aanwezig waren. De dag tevoren had Irak het aandeel van Shell in de Basrah Petroleum Company genationaliseerd en op 21 oktober werd door de Arabische Liga aan achttien Arabische staten verzocht een olie-embargo tegen Nederland in te stellen. Wellicht heeft de regering in deze twee gebeurtenissen aanleiding gezien op 23 oktober een verklaring over het Midden-Oostenconflict te publiceren met het doel het Nederlandse standpunt toe te lichten en misverstanden uit de weg te ruimen. Deze verklaring werd ook via de diplomatieke posten in de Arabische hoofdsteden verspreid. Inhoudelijk bevatte deze verklaring geen nieuwe elementen, maar zij vormde een herhaling van het Nederlandse standpunt over het Midden-Oosten zoals dat in september reeds was opgenomen in de Memorie van Toelichting bij de Begroting van Buitenlandse Zaken voor $1974^{314}$. Dit onderzoek leidde niet tot de conclusie dat de Koninklijke/Shell Groep heeft getracht het Nederlands buitenlands beleid ten aanzien van het Midden-Oosten gedurende de olie-crisis te beïnvloeden.

\subsubsection{Media}

In de Nederlandse massamedia wordt zeer veel aandacht besteed aan de gebeurtenissen in het Midden-Oosten. Uit een inhoudsanalyse van een aantal Nederlandse kranten door de Werkgroep Massacommunicatie van de Rijksuniversiteit Utrecht bleek dat na de berichten over West-Europese landen de buitenlandse berichtgeving over het MiddenOosten op de tweede plaats kwam ${ }^{315}$.

Zeer veel discussie vond plaats over de inhoud van de berichtgeving: een discussie die hoog kon oplopen en zelfs eens tot voor de Nederlandse rechter werd uitgevoch-

313. $(\rightarrow)$

Wreet an je".

Wagner vond het standpunt van de Nederlandse regering, die zich achter Israël opstelde volkomen $_{n}$ juist.

In het radio-interview bevestigde hij de Britse en Franse angst. Na zijn TV-interview op 4 december 1973 stond in een Britse krant: 'Britisch oil diverted to Holland'. Indertijd heeft hij zijn standpunt van "gelijke monniken-gellijke kappen" in Parijs tegenover de Franse president Pompidou herhaalld. VPRO-radio, Het Gebouw, marathon-interview met G.A. Wagner op 13 juli 1990.

314. Verklaring wan 23 oktober 1973, Keesings Historisch Archief, 1973, pp. 737-738.

315. Werkgroep Massaconmunicatie RUU, Utrecht, 1981, p. 146, tabel 5.7.2. Twalf dagen uit het voorjaar van 1977 werden geselecteerd voor deze kwantitatieve inhoudsanalyse waarbij het aantal items, de plaatsruimte in de vorm van kolombreedte en de tijdsduur van de uitzending werden
gemeten. 
ten $^{\text {116. }}$. Een kritisch oordeel over Israël betekent voor de én een vorm van selectieve verontwaardiging en komt daarentegen volgens een ander voort uit de traditionele vriendschapsband met Israël waardoor aan Israel hogere verwachtingen worden gesteld dan aan zijn buurlanden.

Vertroebeld wordt de discussie wanneer het 'schuldcomplex" van de Europeanen over de Shoa erbiij wordt gehaald, van waaruit de cén meent dat Israëls fouten worden benadrukt en de ander dat het lot van de Palestijnen wordt veronachtzaamd.

Dat kritiek op het Israëlische beleid mogelijk moet zijn, is nu in Nederland geen onderwerp van discussie meer. Het is eerder opvallend dat pas na 1973 een grotere openheid ontstond voor verschillende meningen. In april 1973 was het nog gewaagd een uitzending te wijden aan de vraag 'Kritiek op Israël, mag dat?' 317 . "Tot aan het begin van de jaren zeventig was het nagenoeg taboe in Nederland enige kritiek op Israël te uiten. Degenen die dat well deden of meer begrip vroegen voor de Arabische of Palestijnse zaak, werden als verdacht aangezien ${ }^{318}$. Vanuit dit tijdsbeeld is het niet verwonderlijk dat de opinie in de Nederlandse dag- en weekbladen in 1973 nog overwegend pro-Israël was. Gedurende de Oktoberoorlog stonden de media aan de kant van Israël en ook na de instelling van het Arabisch ollie-embargo tegen Nederland kwam daarin nauwelijks wijziging ${ }^{319}$. Aan het Nederlandse beleid ten aanzien van het Midden-Oosten werd tijdens de Oktoberoorlog weinig aandacht besteed, maar dat veranderde na de instelling van het olie-embargo. In het bijzonder werd toen verschillend gedacht over de vraag of de Nederlandse regering vanwege haar gedrag het olie-embargo had veroorzaakt. Op het beleid en de werkwijze van de minister van Buitenlandse Zaken, Van der Stoel, werd eind oktober door enkele kranten felle kritiek geuit.

Voor meer inzicht in deze kritiek op het beleid is een kwalitatieve inhoudsanalyse uitgevoerd onder Nederlandse dagbladen ${ }^{320}$. Daarbij heb ik een onderscheid gemaakt in twee perioden namelijk de kritiek van eind oktober na de instelling van het olleembargo en de kritiek begin november na de ondertekening van de EG-verklaring van 6 november.

Deze kwalitatieve inhoudsanalyse betreft de hoofdredactionele commentaren. De selectie is voornamelijk gebaseerd op knipsels van de Rijksvoorlichtingsdienst die werden gepubliceerd in Beleid Beschouwd ${ }^{321}$. Deze commentaren van de provinciale en landelijke dagbladen zijn per uitspraak geanalyseerd.

De eerste periode - 24 oktober tot 6 november - bevatte de reacties op de instelling van het Arabisch olie-embargo en eindigt met de ondertekening van de gemeenschappelijke EG-verklaring van 6 november. Voor de inhoudsanalyse werden de categorieën: contra-

316. Kort geding wan De Volkskrant tegen Hiltermann, die dit dagblad ervan beticht had 'antisemitisch; althans anti-Isrä̈l' te zijn.

317. Zaterdag Informatie, VARA radio van 28 april 1973.

318. Zie onder meer het artikel van Joris, L., 1981, pp. 24-33.

319. De uitzonderingen waren zeldzzaam, zoals het Algemeen Dagblad van 29-10-1973 en NRC-Handelsblad van 7-11-1973. Zie tabel in 2.2.4.4. voor contra-Israël standpunt.

320. Zie voor literatuur omtrent inhoudsanalyse onder meer: Holsti, O.R. 1969: Content Analysis for the Social Sciences and Humanities, Reading, Addison Wesly Publishing Company; Krippendorff, K. 1980: Content Analysys, An Introduction to its Methodology, Beverly Hills, Sage Publications.

321. Beleid Beschourwd no. 2604 van 31 oktober 1973, no. 2616 van 13 november 1973 en no. 2624 van 19 november 1973 . 


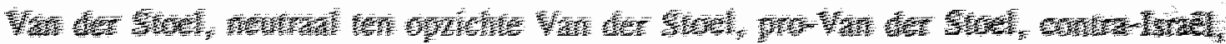

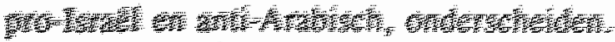

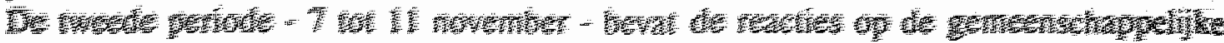

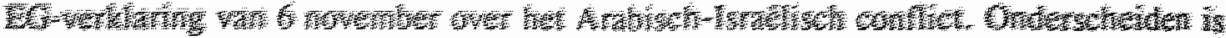

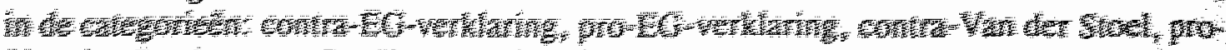

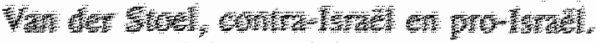

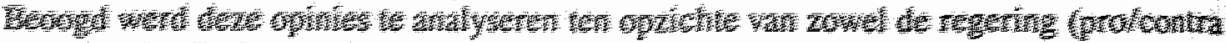

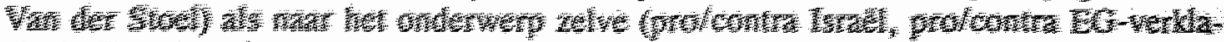

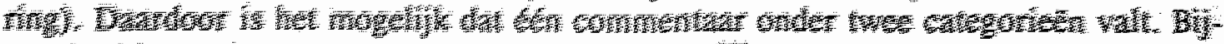

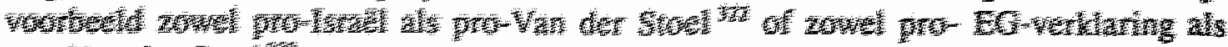

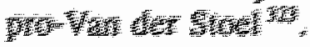

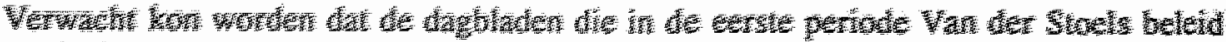

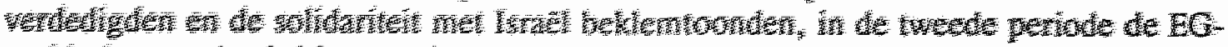

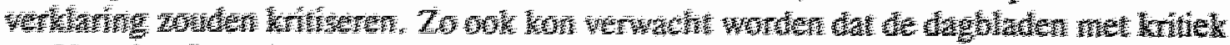

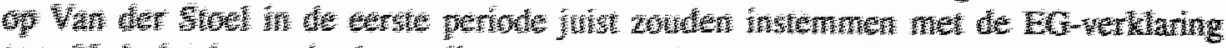

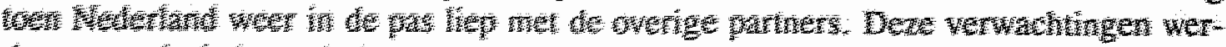

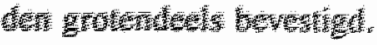

322. Leeuwarder Courant van 26-10-1973, 29-10-1973 en 5-11-1973.

323. NRC-Handelsblad, 9-11-1973. 


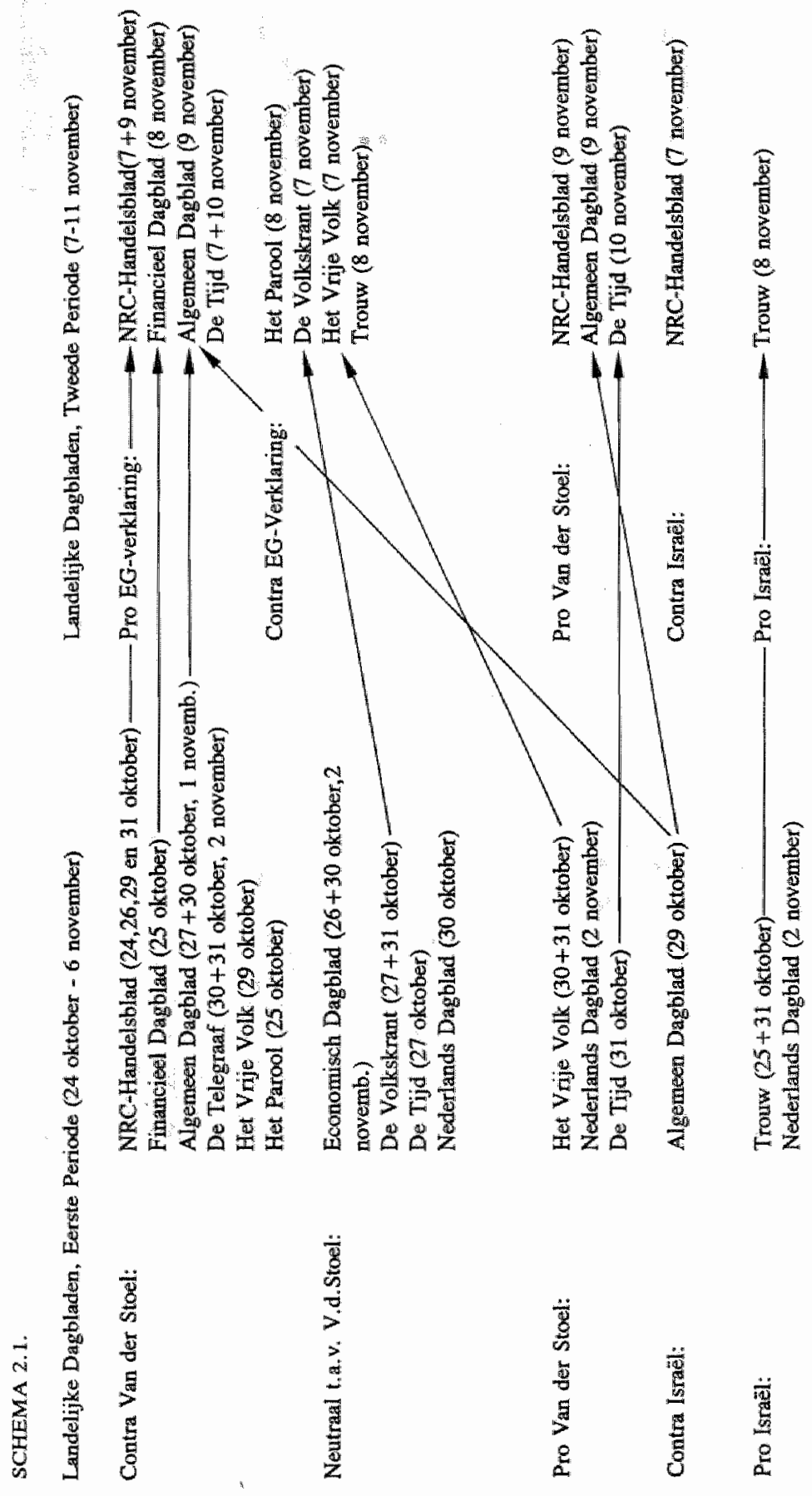




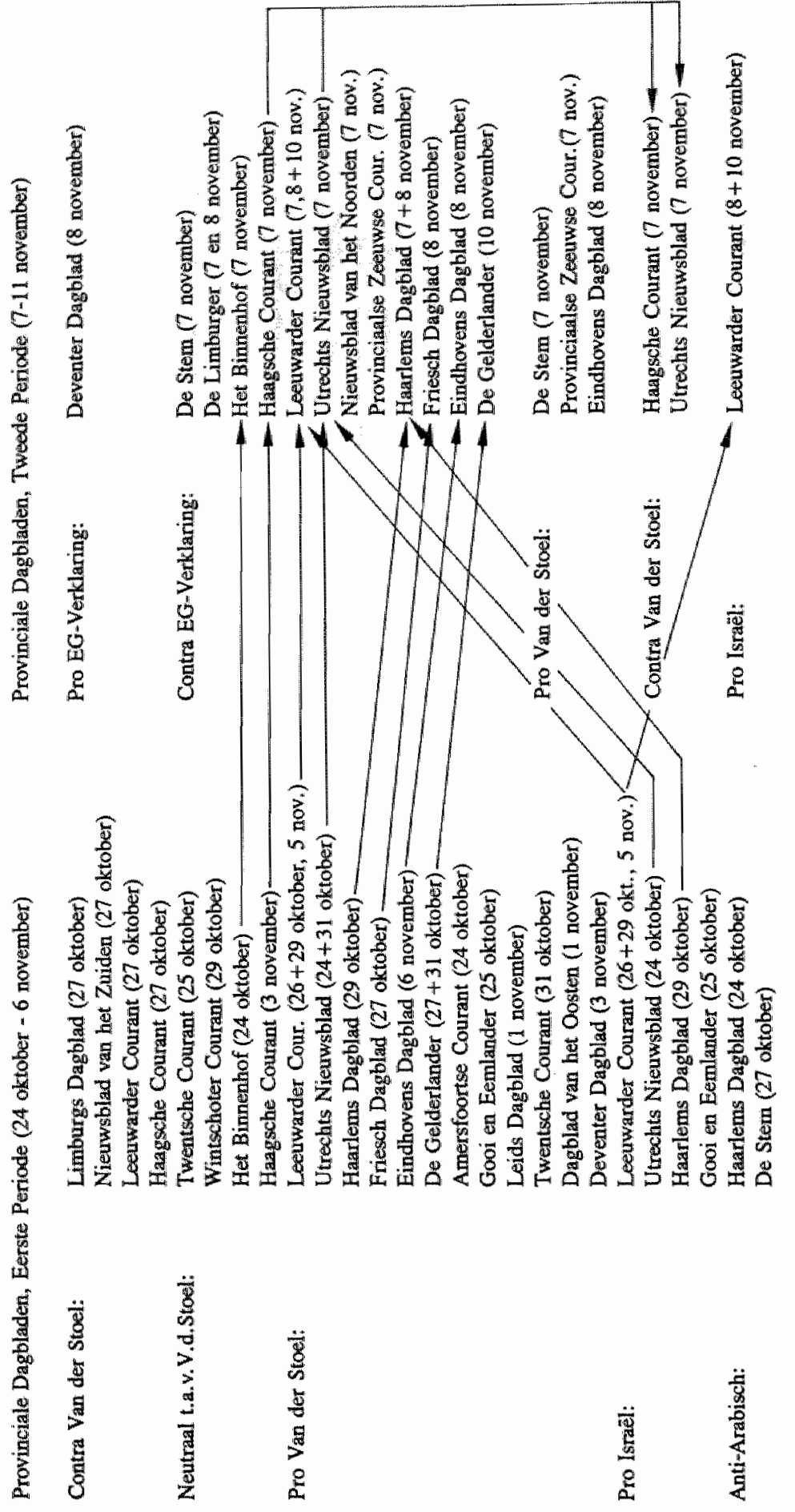


Enkele voorbeelden wan witspraken uit de hoofdredactionele commentaren op grond wasrvan bovenstaande categorisering heeft plastsgevonden zijn:

Contra Van der Stoel:

Neutraal t.o.v. V.d. Stoel:

Pro Van der Stoel:

Contra Israël:

Pro Israël:

Anti Arabisch:

Pro EG-Verklaring:

Contra EG-Verklaring:
Oliedom, zedemmeesterij, dilettantisme begint zich te wreken, diplomatieks blunder, politiek van de achterban verving diplomatie, deconfiture.

Niet cen diplomatieke blunder maar belang Rotterdam, regering reageart laconiek.

Fabel dat Luns het beter zou hebben gedaan, niet de schuld van Van der Stoel, Van der Stoel als alibi; Van der Stoel kon moeilijk anders, verstandig dat Van der Stoel van eerder beleid terugkwam.

Israell"s maximalistisch standpunt, Nederland moet alles op alles zetten om en suelle opheffing te bereiken.

Resolutie 242 als ondeelbaar, beter solidariteit met levende dan met dode joden, niet er uitt praten maar de oliecrisis uitzitten.

Deze olietirannie is politiek, economisch en strategisch bar ongezond; een sfeer van chantage en intimidatie.

Hypotheken afgelost, op misstappen uit verleden teruggekomen, realistische richting, Arabische landen paaten zonder Israël in de steek te laten.

Knieval voor chantage, economisch München, gesmeerde diplomatie, atanbetaling met toegift voor chantage, onsmakelijke vertoning, sluier wan Israël sympathie afgerukt.

Interessant is achteraf te constateren dat de kritiek in de eerste periode op Van der Stoel - ook wel als "hetze tegen Van der Stoel" omschreven - in de herinnering van de betrokkenen is blijven hangen. Uit de hierboven weergegeven tabel blijkt dat deze kritiek slechts afkomstig was van een deel van de Nederlandse pers en dat het grootste deel van de provinciale dagbladen deze kritiek niet deelde.

Het vertekende beeld bij politici is gebaseerd op landelijke dagbladen als De Telegraaf, het Algemeen Dagblad, NRC-Handelsblad, Het Parool, het Financieel Dagblad en het Vrije Volk van eind oktober. Deze kritiek heeft dus zeker indruk gemaakt op de politici, maar dat wil nog niet zeggen dat zij daardoor ook zouden zijn beïnvloed. Dat laatste lijkt niet het geval te zijn. Politici maakten namelijk eerder gebruik van de geluiden uit de pers om hun eigen opinie te sterken dan dat de kritiek tot een verandering in hun mening leidde.

Zo bracht Kruisinga van de oppositie de hem welgevallige kritiek uit de pers op het beleid van Van der Stoel in het parlement naar voren.. Anderzijds verweten socialistische politici de 'rechtse" pers Israël zo snel te hebben laten vallen. Dit werd de laatste groepering vergemakkelijkt, omdat bijvoorbeeld de socialistische politici Dankert, Ter Beek en Van Thijn door de hoofdredactie van NRC-Handelsblad tezamen met Van der Stoel verantwoordelijk werden gesteld voor het olie-embargo ${ }^{324}$. We constateren dat politici door de media eerder in hun mening werden gesterkt dan dat deze tot een wijziging in hun opinie leidden. 
De felle kritiek uit de eerste periode had Van der Stoel nauwelijks 'geraakt' daar deze - volgens hem - afkomstig was van de oppositie en de daarmee verwante media. Daarentegen voelde hij zich wel 'geraakt' door de kritiek uit de tweede periode op hem door L. de Jong naar aanleiding van zijn ondertekening van de EG-verklaring; hij kwam daar in nagenoeg elk interview ower deze periode op terug ${ }^{325}$. Ook binnen de Tweede Kav merfracties van de ARP en de PvdA werd aandacht besteed aan de interviews met buitenlanddeskundigen als Van "t Veer ${ }^{326}$ en Van der Beugel en Heldring ${ }^{327}$. Hun afkeuring van de EG-verklaring versterkte de twijfell inzake de wijsheid van deze beslissing bij deze regeringsgezinde fracties ${ }^{328}$.

Naast de hierboven gestelde vraag over de invloed van de media op de politici is een andere vraag: welke waarde moet worden toegekend aan de in de media naar voren gebrachte opinies? Moet daar een zelfstandige betekenis aan worden toegekend als zijnde de opinies van een aantal hoofdredacteuren op dat moment, of kwam daarin ook de openbare mening in Nederland van dat moment in tot uiting? Met andere woorden, de vraag is: zijn zij te beschouwen als 'actor' of als 'resource'? Aantjes kiest duidelijk voor het eerste wanneer hij stelt 'Geweldig moment in de Nederlandse politiek want Nederland heeft echt niet gewankeld, ook al die aanvallen van De Telegraaf, wat toch altijd grote invloed heeft, we hadden natuurlijk ook echt wel het Nederlandse volk achter ons' ${ }^{329}$. De publieke opinie in Nederland wordt in de volgende paragraaf behandeld. De daar gepresenteerde cijfers ondersteunen Aantjes' stelling.

\subsubsection{Publieke opinie}

Voor enig inzicht in de publieke opinie en met name bij een vergelijking in de tijd of met andere landen, is voor de beoordeling van de resultaten de vraagstelling in de enquête van belang. Zelfs bij een enquête op hetzelfde tijdstip en onder dezelfde populatie kunnen de resultaten aanzienlijk verschillen als gevolg van een andere vraagstelling. Zo werd in de eerste week van november 1973 de Nederlandse bevolking tweemaal ondervraagd. In het eerste geval werd aan de respondenten gevraagd of zij zich 'neutraal' voelden in het conflict tussen Israël en de Arabische staten of dat zij partij kozen en vervolgens of zij aan de kant van Israël of aan de kant van de Arabische staten stonden. Het resultaat was dat een krappe meerderheid zich neutraal voelde. In het tweede geval werd louter gevraagd of de persoonlijke voorkeur naar Israël of naar de Arabische staten uitging, zonder dat de categorie 'neutraal' in de vraagstelling was opgenomen. Nu stond een ruime meerderheid achter Israël.

325. Interviews met Van der Stoel door Van Traa in: Gortzak, 1985, p. 85; en met de Volkskrant 30-101982 en met auteur dezes op 17 november 1982.

326. VARA, 6 november 1973.

327. NOS, 11 nowember 1973 .

328. Verslag ARP-fractie van 13 november 1973, PvdA-fractie F 406 notitie Dankert van 10 januari 1974.

329. Interview met Aanties op 28 december 1982. 
Tabel 2.3

\begin{tabular}{|l|c|l|c|}
\hline \multicolumn{2}{|l|}{ Publieke opinies november 1973} \\
\begin{tabular}{|l|l|} 
november 1973 (eerste vraagstelling) \\
(NIPO, no. 1603, 11 dec. 1973, \\
N=1017)
\end{tabular} & $\begin{array}{l}\text { november 1973 (tweede vraagstelling) } \\
\text { (AVRO's Televizier nov. 1973) }\end{array}$ \\
\cline { 1 - 2 } Pro Israël & $40 \%$ & Pro Israël & $72 \%$ \\
\hline Pro Arabische staten & $1 \%$ & Pro Arabische staten & $4 \%$ \\
\hline Geen mening & $8 \%$ & & $24 \%$ \\
\hline neutraal & $51 \%$ & Geen voorkeur & \\
\hline
\end{tabular}

Bij het wegvallen van de categorie 'neutraal' verdeelden deze respondenten zich niet gelijkelijk over de beide partijen, maar kozen zij cerder voor Israël (zie tabel 2.3). Een toename van de 'neutralen' ging ten koste van de Israël-aanhangers (zie tabel).

Wanneer de resultaten uitgesplitst worden naar kiesgedrag, dan blijkt de sympathie voor Israël onder het grootste deel van de ARP-kiezers, terwijl vooral de KVP-kiezers zich 'neutraal' opstellen. Dit verschil heeft te maken met godsdienstige gezindte. In het nationaal verkiezingsonderzoek werd door politicologen naar de relatie tussen godsdienstige gezindte en kiesgedrag gevraagd. Zowel in 1967 als in 1972 was $98 \%$ van de KVP-stemmers rooms-katholiek. Van de ARP-kiezers was in $196761 \%$ en in $197266 \%$ gereformeerd. Kortom, de KVP-kiezers bestonden nagenoeg volledig uit rooms-katholieken en bij de ARP-kiezers was de aanhang circa tweederde van gereformeerde hui$\mathrm{ze}^{330}$. Generalisaties over 'de' rooms-katholieken versus 'de' gereformeerden zijn echter niet mogelijk, want van alle rooms-katholieken koos in $196767 \%$ en in 1972 $38 \%$ voor de KVP en van alle gereformeerden koos in $196782 \%$ en in $197256 \%$ voor de ARP ${ }^{331}$. Eerder werd aangetoond (zie 1.4.1) dat op grond van enquêteresultaten nadien wel generalisaties mogelijk waren.

330. De Bruyn, Foppen, Hoogerwerf, 1972, pp. 30-35.

331. Ibidem, p. 32; De Bruyn, 1972, p. 42. 
Tabel 2.4

\begin{tabular}{|c|c|c|c|c|c|c|c|}
\hline \multicolumn{8}{|c|}{ Publieke opinie, drocember 1969} \\
\hline & ARP & $D^{1} 66$ & $\mathrm{CHU}$ & PudA & VND & KVP & Allen: \\
\hline Pro Israel & 74 & 64 & 61 & 56 & 66 & 39 & 51 \\
\hline $\begin{array}{l}\text { Pro } \\
\text { Arabstat. }\end{array}$ & - & 1 & 2 & 1 & 3 & 1 & 1 \\
\hline Neutranl & 6 & 26 & 18 & 24 & 17 & 38 & 27 \\
\hline $\begin{array}{l}\text { Geen ant- } \\
\text { woord }\end{array}$ & 20 & 9 & 19 & 19 & 14 & 22 & 21 \\
\hline
\end{tabular}

Bron: NIPO no. 1330 wan 28 januari $1970, N=918$

Tabel 2.5

\begin{tabular}{|l|r|r|r|r|r|r|r|r|r|}
\hline \multicolumn{1}{|c|}{ Publieke opinie, januari 1973} \\
\hline & DS'70 & ARP & D'66 & CHU & PvdA & VVD & PPR & KVP & Allen \\
\hline Pro Israël & 61 & 53 & 50 & 41 & 39 & 41 & 45 & 28 & 36 \\
\hline $\begin{array}{l}\text { Pro } \\
\text { Arab stat. }\end{array}$ & -- & -- & -- & - & 1 & 1 & 2 & 1 & 1 \\
\hline Neutraal & 32 & 46 & 50 & 57 & 58 & 56 & 49 & 66 & 59 \\
\hline $\begin{array}{l}\text { Geen ant- } \\
\text { woord }\end{array}$ & 7 & 1 & -- & 2 & 2 & 2 & 4 & 5 & 4 \\
\hline
\end{tabular}

Bron: NIPO no. 1546 van 15 februari $1973, \mathrm{~N}=1042$

Tabel 2.6

\begin{tabular}{|c|c|c|c|c|c|c|c|}
\hline \multicolumn{8}{|c|}{ Publieke opinie, noveniber 1974} \\
\hline & ARP & $\mathrm{CHU}$ & PvdA & VVD & PPR & KVP & Allen \\
\hline Pro Israêl & 65 & 63 & 33 & 50 & 26 & 29 & 37 \\
\hline $\begin{array}{l}\text { Pro } \\
\text { Arab. stut. }\end{array}$ & - & 3 & 4 & 1 & 5 & 3 & 3 \\
\hline Neutraal & 35 & 33 & 60 & 44 & 68 & 68 & 56 \\
\hline $\begin{array}{l}\text { Geen ant- } \\
\text { woord }\end{array}$ & - & $\rrbracket$ & 3 & 5 & $\cdots$ & $\mathbb{1}$ & 4 \\
\hline
\end{tabular}

Bron: NIPO no. 1679 van 17 december $1974, N=834$

Al is het aantal responenten dat zich voor Israël uitsprak, in de loop der tijd afgenomen, niettemin bestond in 1973 nog overwegend een pro-Israël houding in de publieke opinie. 
Dat was in andere Westeuropese landen eveneens het geval. Zo sympathiseerde in oktober 1973 in de Duitse Bondsrepubliek 57\% en in het Verenigd Koninkrijk $47 \%$ met Israë ${ }^{332}$. Zie bijlage 4 .

Verwacht had kunnen worden dat de sympathie voor Israël na oktober 1973 in Nederland sterk zou afnemen. Deze afname zou veroorzaakt zijn door het beëindigen van de oorlogssituatie in het gebied als gevolg waarvan meer mensen zich eerder 'neutraal' opstellen. Een toename van degenen 'zonder voorkeur' had verwacht kunnen worden, omdiat na afloop van de oorlogshandelingen over het algemeen een partij kiezen afneemt ten gunste van de categorie 'neutraal'. Bovendien had de sympathie voor Israël tijdens de oorlog Nederland in moeilijkheden gebracht en lag een verminderde sympathie op een later tijdstip voor de hand. Het Arabische olie-embargo zou, volgens de veronderstelling, deze tendens van afnemende sympathie voor Israël versterken. Dat blijkt echter niet het geval te zijn.

In een deel van de pers en ook in het parlement waren kritische geluiden over de $\mathrm{Ne}$ derlandse houding ten gunste van Israël te horen. Onder het Nederlandse publiek, inmiddels geconfronteerd met autoloze zondagen en sombere economische vooruitzichten, ontwikkelde zich een interessante reactie op deze gebeurtenissen. Opvallend daarbij is dat de voor de hand liggende verschuiving zich niet heeft voorgedaan: de sympathie voor Israël bleef nagenoeg constant.

De afgenomen sympathie voor de Arabische staten - van $6 \%$ naar $4 \%$ - zou verklaard kunnen worden uit een reactie onder de Nederlandse bevolking op de tegen Nederland gerichte Arabische maatregelen.

Tabel 2.7

\begin{tabular}{|l|c|c|}
\hline Publieke Opinie, oktober 1973 en november 1973 \\
\hline & oktober 1973 & november 1973 \\
\hline pro Israël & $73 \%$ & $72 \%$ \\
\hline pro Arabische staten & $6 \%$ & $4 \%$ \\
\hline geen voorkeur & $21 \%$ & $24 \%$ \\
\hline
\end{tabular}

Bron: Avro's Televizier van 5 november 1973

Over de houding van de respondenten ten aanzien van de Nederlandse regering bleek een ruime meerderheid van de ondervraagden - $59 \%$ - de Nederlandse regering (mede)verantwoordelijk te stellen voor de olieproblemen, waarbij met name de kiezers van D'66, VVD en KVP waren oververtegenwoordigd. De Nederlandse regering werd als medeschuldige aangewezen door $70 \%$ van de D'66-kiezers (wellicht verband houdende met Imkamps reactie), 69\% van de VVD-, 68\% van de KVP-, 58\% van de PPR-, $54 \%$ van de PvdA-, $54 \%$ wan de CHU-en $50 \%$ van de ARP-kiezers ${ }^{333}$. We

332. Resultaten publieke opinie-onderzoek bij Baschwitz Instituut, Amsterdam; de Boer, 1987.

333. $\mathrm{NIPO}$ no. 1604 van 11 december $1973, \mathrm{~N}=992$. 
zien hier enige overeenkomst met enkele 'contra-Van der Stoel' reacties in de landelijke pers. Daarnaast weerspiegelden deze cijfers zowel de houding tegenover het kabinetDen Uyl als de houding ten aanzien van het Arabisch-Israëlisch conflict.

Naar de houding ten aanzien van het Arabisch conflict werden medio december opnieuw enkele vragen gesteld. Zo vond nog steeds $61 \%$ tegenover $15 \%$ het terecht dat nat het uitbreken vam de Oktoberoorlog veel mensen tot steun aan Israël opriepen ${ }^{334}$. Daarnaast werd naar de toekomstige rol van Nederland in het conflict gevraagd.

Tabel 2.8

\begin{tabular}{|c|c|c|}
\hline \multicolumn{3}{|l|}{ Publieke opinie, december 1973} \\
\hline \multicolumn{3}{|l|}{ Houding van Nederland ten opzichte van Israël: } \\
\hline door dik en dun steunen & $26 \%$ & \multirow{2}{*}{$40 \%$} \\
\hline steunen zonder daar bekendheid aan te geven & $14 \%$ & \\
\hline neutraal trachten te worden & \multicolumn{2}{|c|}{$26 \%$} \\
\hline het Israëlisch standpunt kritisch bekijken & \multicolumn{2}{|c|}{$21 \%$} \\
\hline Israël niet meer te steunen & \multicolumn{2}{|c|}{$5 \%$} \\
\hline weet niet & \multicolumn{2}{|c|}{$8 \%$} \\
\hline \multicolumn{3}{|c|}{ Houding van Nederland ten opzichte van de Arabische landen: } \\
\hline de Arabische zaak verdient onze steun & \multicolumn{2}{|c|}{$2 \%$} \\
\hline meer aandacht voor de Arabische zaak is noodzakelijk & \multicolumn{2}{|c|}{$29 \%$} \\
\hline neutraal standpunt is gewenst & \multicolumn{2}{|c|}{$30 \%$} \\
\hline Arabische eisen met argwaan bekijken & \multicolumn{2}{|c|}{$13 \%$} \\
\hline miet tegemoet komen aan Arabische eisen & \multicolumn{2}{|c|}{$18 \%$} \\
\hline weet niet & \multicolumn{2}{|c|}{$8 \%$} \\
\hline
\end{tabular}

Brom: NSS no. 5209 van december $\$ 973, \mathrm{~N}=612$.

Vanwege de verschillende antwoordcategorieën zijn de beide kwesties waarnaar gevraagd is, niet zonder meer te vergelijken. Zo kunnen we bij kruising van de antwoorden bijvoorbeeld constateren dat van degenen - in totaal $29 \%$ - die meer aandacht voor

334. NSS no. 5209 , p. 5. Marktonderzoek inzake thet Midden-Oasten, vitgewoerd door NV v/h Nederlandse Stichting voor Statistiek (NSS) in opdracht van Novum BV, Haarlem, december 1973, ter beschikking gesteld door de redactie van Panorama, $\mathrm{N}=612$. 
de Arabische zaak noodzakelijk vonden, niettemin $38 \%$ van mening was dat Nederland Israel diende te steunen en slechts $3 \%$ deze steun wenste te beëindigen ${ }^{33 s}$.

Ongeveer dertig procent was van mening dat een neutraal standpunt van Nederland ten aanzien van de Arabische landen gewenst was en dat Nederland ten opzichte van Israel neutraal moest trachten te worden. Bij een andere vraagstelling een maand eerder was maar liefst $64 \%$ van mening dat de Nederlandse regering in conflict tussen Israël en de Arabische staten neutraal zou moeten blijven (Israël steunen 26\%, Arabische landen steunen $1 \%$, neutraal blijven $64 \%$, geen antwoord $9 \%{ }^{336}$ ).

Het verschil in de resultaten van beide enquêtes wordt mijns inziens niet zozeer veroorzaakt door de tijd, maar door de vraagstelling waarbij de impliciete veronderstelling verschilde (Nederland is wel of niet neutraal) en door het opnemen van meer antwoordcategorieën in de vragen van december.

Tenslotte kan uit het bovenstaande worden geconcludeerd dat weliswaar een meerderheid van de Nederlandse bevolking in 1973 bij een expliciete vraagstelling voor een neutrale houding opteerde en van mening was dat Nederland ook neutraal diende te blijven, maar tegelijkertijd geen beleidsverandering in een meer pro-Arabissche richting voorstond. Wanneer de keuze voor een neutraal standpunt aan de respondenten niet werd aangereikt; koos een zeer ruime meerderheid voor een pro-Israël houding. De eerste drie regeringsbeslissingen van oktober 1973, gericht op het handhaven van de solidariteit met Israël, konden dan ook op steun rekenen onder de Nederlandse bevolking. We doelen dan op de houding van het massapubliek zoals dat in de opiniepeiling tot uiting kwam. De overwegend pro-Israëlische houding onder het aandachtige publiek, de opinieleiders en de buitenlandse politieke elite heb ik eerder behandeld in dit hoofdstuk $^{337}$.

\subsection{Internationale politiek}

Nadat in de vorige paragraaf de totstandkoming van het Nederlands buitenlands beleid ten aanzien van het Arabisch-Israëlisch conflict en de energiecrisis is behandeld, zullen we ons nu richten op het internationale politieke besluitvormingsproces in de Europese Gemeenschap over deze kwestie. In het vierde kwartaal van 1973 heeft een opmerkelijke verschuiving wan de Nederlandse positie in de relatie tot haar Europese partners plaatsgevonden. Geconstateerd kan worden dat Nederland zich medio oktober 1973 in de EG in een geïsoleerde positie bevond. Het Nederlandse standpunt vond binnen deze kring geen gehoor. Nederlarid verzette zich tegen de Franse wensen en gaf daaraan concreet gestalte door zich uit te spreken tegen een mandaat aan de beide permanente

335. De kruistabel van degenen die kozen woor 'meer aandacht voor do Arabische zaak is noodzakelijk" uit de vraag naar de houding van Nederland ten opzichte van de Arabische landen met de vraag naar de houding van Nederland ten opzichte van Israël geeft de volgende uitkonst: door dik en dun steunen $22 \%$, steunen zonder daar bekendheid an te geven $16 \%$, neutraal trachten te worden $20 \%$, het Israëlisch standpunt kritisch bekijken $39 \%$, Israël niet meer steunen 3\%. Uit NSS no, 5209, p. 7.

336. NIPO no. 1603, 11 december $1973 \mathrm{~N}=1017$.

337. Zie voor onderscheild natr niveaus in de openbare mening: Everts, 1981 pp. 307-310 en 1.2.3. 
leden van de Veiligheidsraad om aldaar namens de Negen het woord te voeren. Nadat Nederland vervolgens aan een Arabisch olie-embargo werd onderworpen, weigerden de leden van de EG Nederland bij te staan en het principe van de gemeenschappelijke markt ten aanzien van de olievoorziening in stand te houden. Doelbewust werd het geisoleerde Nederland op dit punt gediscrimineerd. Deze houding werd gehandhaafd ook nadat Nederland begin november enigszins toegaf door een gemeenschappelijke standpuntbepaling ten aanzien van het Arabisch-Israëlisch conflict niet langer tegen te houden. De Franse overwinning die bleek uit de gemeenschappelijke zes november verklaring, beoogd als een begin van een Europees Midden-Oostenbeleid, onafhankelijk van de door de VS in gang gezette 'shuttle diplomacy', was echter van korte duur ${ }^{338}$. Een vervolg op deze verklaring zou pas vier jaar later (juni 1977) tot stand komen.

De Europeanen behaalden geen resultaten in het Midden-Oosten, terwijl de VS wel troepenscheidingsovereenkomsten wist te bewerkstelligen. Aan de voorgenomen internationale vredesconferentie te Genève mochten de Europeanen niet deelnemen. Op het terrein van de energievoorziening werd de Amerikaanse suprematie aanvaard door de leden van de EG met uitzondering van de Fransen. Gemeenschappelijke maatregelen ten behoeve van de olievoorziening konden binnen de kring van de EG niet tot stand komen. Zelfs het voorstel tot een studie naar een oplossing van deze problematiek werd door de Fransen en Britten gedwarsboomd. Op Amerikaans initiatief bleek daarentegen de 'westelijke wereld" wel in staat te zijn een organisatie, de IEA, op te richten, die zich onder meer ten doel stelde de gevolgen van een olie-embargo van één van haar leden in de toekomst te ondervangen. Het Franse verzet bleek bij de Europese partners weinig bijval te krijgen en op de conferentie in februari 1974 werd de geïsoleerde Franse positie voor eenieder duidelijk. Ook de voorzitter van de EG koos op dat moment voor de Amerikaanse lijn.

Nederland bevond zich weer in een meer comfortabele positie. Op het terrein van de buitenlandse politiek had Nederland zich geschaard onder de overige partners door de aanvaarding van een gemeenschappelijke stellingname van de EG. Op het terrein vam de energievoorziening was Nederland niet langer kwetsbaar door de gemeenschappelijke machtsvorming van de olieverbruikende landen tegenover de olieproducerende landen. Frankrijk had zijn hand overspeeld in het vierde kwartaal van 1973. Nederland was van een geïsoleerde positie terechtgekomen in een comfortabele positie, waarin het voor de toekomst ook op steun en solidariteit van de overige EG-partners kon rekenen.

Binnen de Negen zou Nederland nog wel een meer pro-Israëlisch standpunt blijven innemen dan de overige partners, maar de gevolgen op politiek en economisch terrein van dat standpunt zouden Nederland minder raken, daar het zich niet langer in een kwetsbare positie bevond.

Bovendien was het resultaat dat de Atlantische band niet verder werd verzwakt en de Europese 'Alleingang' niet werd voortgezet.

338. Met 'shuttle diplomacy' wordt gedoeld op de bemiddelingspogingen van de Amerikaanse minister van Buitenlandse Zaken, Kissinger, tie in het Midden-Oosten tussen de verschillende hoofdsteden. wloog en ook vanuit het vliegtuig bemiddelde en witeindelijk de troepenscheidingsakkoorden wist te realiseren. 
Het evenwicht in de Nederlandse buitenlandse politiek van de Europese en de Atlantische bindingen was niet al te sterk verstoord en gold nog steeds als een belangrijk uitgangspunt en doel van het Nederlands buitenlands beleid ${ }^{339}$.

De vraag dringt zich nu op of het herstel van de Nederlandse positie louter te danken is aan de invloed van derden - Nederland als speelbal in de internationale politiek - of dat Nederiand met eigen activiteiten dat herstel heeft bewerkstelligd - Nederland met een eigen rol in de internationale politiek.

\subsubsection{Oktober 1973}

In mei 1971 was onder Frans voorzitterschap een gemeenschappelijk standpunt over het conflict in het Midden-Oosten door de lidstaten van de Europese Gemeenschap in het kader van de Europese Politieke Samenwerking geformuleerd. In dit 'Schuman document' werd de inhoud van resolutie 242 onderschreven en de daaruit voortvloeiende VN-vredesmissie van de Zweed Jarring ondersteund. Het Europese voorstel ging echter verder dan deze internationaal voorgestane zienswijze, door aan te dringen op zowel de vorming van gedemilitariseerde zones langs de grenzen van 1967 als de internationalisatie van het oude deel van Jeruzalem. Bovendien zou aan de Palestijnse vluchtelingen de keus moeten worden geboden tussen terugkeer of compensatie ${ }^{340}$. Volgens de Duitse deelnemer in het Comité Politique ontstond de indruk dat: "die EG Staaten wollten eine eigene Verhandlungsinitiative ergreifen und auf Israel in der Territorialfrage Druck ausüben" ${ }^{341}$. Deze verkilaring werd niet gepubliceerd vanwege zowel Nederlandse bezwaren als Duitse en Italiaanse reserves ${ }^{342}$. Het Nederlandse verzet zou weliswaar iets sterker zijn geweest dan dat van de Duitsers en de Italianen ${ }^{343}$ en volgens kranteberichten en Algerijnse bronnen zou Nederland de primaire verantwoordelijkheid voor het niet publiceren dragen ${ }^{344}$.

Aan de andere kant zwakte de Duitse minister van Buitenlandse Zaken op bezoek in Israël de betekenis van het gemeenschappelijk standpunt af door het slechts een 'werkdocument' te noemen. De Fransen waren hierdoor teleurgesteld en behoorlijk geïrriteerd $^{345}$. Pas op 6 november 1973 zou de eerste gemeenschappelijke Europese verklaring over het Midden-Oosten worden gepubliceerd, een verklaring die volgens de Duitse vertegenwoordiger veel leek ('spiegelte sich entsprechend') op de gemeenschappelijke positie uit 1971. Eerder hebben we geconstateerd (zie 2.2.1.7) dat er onder Luns' opvolger Schmelzer enige invloed vanuit de EPS op het Nederlandse stemgedrag in de

339. Zive werder Scheffer, 1988.

340. Die Welt van 12-7-1971, 14-7-1971 en 16-7-1971, Le Soir 15-7-1971, zie ook Greilsammer, 1981. p. 88; Greilsammer and Weiler, 1984, p. 33; Artner, 1980, p. 430-431.

341. Van Well, 1976, p. 120.

342. Ifestos, $1987, \mathrm{p} .420$.

343. Ifestos' onderscheid tussen "objections' en 'reservations" is gebaseerd op B. Khader (ed.); l'Europe et le conflit Israëlo-Arabe, bilan d'une décennie (1973-1982) in: Cooperation Euro-Arabe, vol, 3, Universite Catholique de Louvain, 1982, p. 186, in: Ifestos, 1987, p. 531.

344. "Ce faisant, la Hollande a purement et simplement torpillé la première tentative serrieuse de l'Europe tendant à contribuer la definition d"une solution au Proche Orient", Balta, 1974, p. 15; NRC 2111-1970 en 15-5-1971, angehaald in Schreiner, 1978, p. 42.

345. Van Well, 1976, p. 120 en Greilsammer, 1981 , p. 89. 
VN uitging inzake de eerbiediging wan de rechten van de Palestijnen ${ }^{346}$. De directeurgeneraal internationale samenwerking had op deze stellingname geen invloed kunnen uitoefenen maar over het algemeen werd door Nederland ook in de $\mathrm{VN}$ in de periode 1972-1973 nog wel partij voor Israël gekozen. Zo werden bijvoorbeeld in de Algemene Vergadering van de VN op 13 december 1972 de rechten van de Palestijnen nader ingevuld in resolutie 2963 onder E. Daarin werd gesteld, dat deze onvervreembare rechten gericht zijn op zelfbeschikking. Bij deze resolutie onthielden Frankrijk en de latere EG-leden lerland en het Verenigd Koninkrijk zich van stemming, de overige EGleden stemden tegen ${ }^{347}$. De Arabische regeringen veroordeelden achteraf Nederlands stemgedrag ten tijde van de jaarvergadering van de UNESCO van november 1973, de Commissie voor de Rechten van de Mens in het voorjaar van 1972, de vergadering van de WHO van mei 1973 en de vergadering van de ITU uit oktober $1973^{348}$.

De Nederlandse houding uit 1972 in de Commissie voor de Rechten van de Mens ten aanzien van het Arabisch-Israëlisch conflict wordt nu beschreven. Tijdens de zitting van de Commissie voor de Rechten van de Mens te New York werd in maart 1972 door Egypte mede namens Libanon, Tanzanië, India en Pakistan een resolutie over de rechten van de mens in bezette gebieden ingediend. Ook de Nederlandse delegatie vond dat de Vierde Geneefse Conventie ter bescherming van de bewoners van de bezette gebieden moest worden uitgevoerd. De Nederlandse vertegenwoordiger, Van Boven, keerde zich tegen 'iedere poging een parallel te trekken tussen nazi-Duitsland en Israël', zoa]s Libanon deed. Voor Nederland was de operatieve paragraaf 7 waarin de schending door Israël van de Vierde Geneefse Conventie als oorlogsmisdrijf werd opgevat, onaanvaardbaar. Van Boven verlangde afzonderlijke stemming over deze paragraaf - 12 voor, 8 tegen (onder meer het Verenigd Koninkrijk, Nederland, Italië en de Verenigde Staten) en 10 onthoudingen (Frankrijk) - en vervolgens werd de resolutie met steun van Frankrijk aangenomen. De vier tegenstemmers waren toen Guatamala, Nederland, de Verenigde Staten en Zaïre.

De Syrische waarnemer bij deze vergadering leverde kritiek op de Nederlandse interventie, aangezien daarin resolutie 242 van de Veiligheidsraad als basis voor een oplossing ter sprake was gebracht. Nederland verzette zich tevergeefs tegen een Libanese motie om, in afwijking van de procedureregels, op de dag van indiening van de ontwerpresolutie daarover te stermmen. Kortom, een markeerbare Nederlandse positie waarbij Nederland zich keerde tegen de wensen van Egypte, Syrië en Libanon door in 1972 een tegenstem uit te brengen, terwijl het zich in 1971 bij dezelfde resolutie - overigens zonder de operatieve paragraaf over 'oorlogmisdrijven' - van stemming had onthouden ${ }^{349}$.

Van Boven had indertijd een tamelijk grote vrijheid van handelen. Hij stelde zelf zijn toespraak op en gaf aan hoe hij woorstelde te stemmen; dit werd door Den Haag goedgekeurd. Over het algemeen werd het optreden van de Nederlandse delegatie inzake het

346. Resolutie 2949 (XXVII) in de AV van de VN op 8 december 1972, UN Yearbook 1972, p. 180,

347. UN Yearlook 1972, p. 207.

348. Balta, 1974, p. 15 .

349. Verslag over de achtentwintigste zitting wan de Commissie der Verenigde Naties voor de Rechten wan de Mens - New York, 6 maart - 7 april 1972, pp. 13-14, 66-69. 
Midden-Oosten sterker vanuit Den Haag bepaald dan inzake andere internationaal politieke kwesties. De vrijheid van handelen van de Nederlandse gedelegeerden is in de loop der tijd verminderd. Vreemd genoeg werd in het 'Arabisch dossier' niet gerept over de Nederlandse houding in de Commissie voor de Rechten van de Mens in 1972. Op het departement van Buiterlandse Zaken werd van Arabische zijde in 1973 ten tijde van het olie-embargo wel aan Nederlands optreden in 1972 gerefereerd.

In het 'Arabisch dossier' werd Nederland echter verweten op de 29 ste zitting van de Commissie voor de Rechten van de Mens in 1973 te Geneve tegen de resolutie te hebben gestend waarin de schending van de Rechten van de Mens in de bezette gebieden werd veroordeeld ${ }^{350}$. De beschuldiging over 1973 blijkt ongegrond te zijn. $\mathrm{Ne}$ derland heeft zich in maart 1973 evenais alle andere Westeuropese staten van stemming onthouden en evenals alle andere Westeuropese staten gestemd tegen paragraaf 1 , waarin de schendingen van de Geneefse conventie als oorlogsmisdaden werden betiteld ${ }^{351}$.

In vergelijking met 1972 schoof Nederland op in 'pro-Arabische richting' en schoof Frankrijk op in de andere richting. In 1974 schoof Nederland met de andere lidstaten van de EG verder op aangezien het niet langer tegen de operatieve paragraaf - waarin de schendingen van de Vierde Geneefse conventie als oorlogsmisdaden werden bestempeld - stemde maar het zich van stemming onthield. De andere Westeuropese staten - Noorwegen en Oostenrijk - handhaafden wel hun standpunt van 1973. Zowel de Franse als de Nederlandse vertegenwoordiger - de laatste in een stemverklaring van Van Boven - distantieerden zich weliswaar van de term 'oorlogsmisdaden', maar brachten niet langer een tegenstem uit ${ }^{352}$.

Medio oktober 1973, bij de eerste bijeenkomst van de EPS sinds het uitbreken van de Oktoberoorlog, leek de mogelijkheid aanwezig te zijn de Franse wensen uit 1971 te realiseren. De eerder bestaande reserves aan Duitse en Italiaanse zijde bleken te zijn vervallen en de inmiddels tot de EG toegetreden Britten steunden de Fransen. Nederland daarentegen bleef aan zijn oude standpunt vasthouden en kon in de op consensus gebaseerde EPS-besluitvorming de overige landen dwarsbomen. Volgens sommigen werd Nederland nog wel gesteund door Denemarken ${ }^{353}$, maar internationaal kwam Nederlands verzet op de voorgrond. Een citaat uit het Arabisch dossier:

'le 13 octobre 1973, lors de la réunion du comité politique, à Copenhague, la Hollande s'est opposée à une initiative plus constructive et plus élaborée des Neuf, envisagée cette fois en vue d"une action concertée. Selon le dossier, les Pays-Bas se sont également élevés contre une proposition tendant à donner mandat aux deux pays membres. permanents du Conseil de sécurité, la France et la Grande-Bretagne, pour présenter le.

350. Balta, 1974 , p. 15.

351. Verslag over de negenentwintigste zitting van de Commissie der Verenigde Naties voor de Rechten van de Mens, Geneve 26 februari - 6 april 1973, pp. 17-18 en 87-88.

352. Verslag over de dertigste zitting van de Commissie der Verenigde Naties voor de Rechten van de Mens, New York, 4 februari - 8 maart 1974, pp. 11-12,48-50; in 1975 vond geen aparte stemming plaats over de operatieve paragraff, owerigens was het verloop gelijk aan 1974 .

353. 'Holland and Denmark, as a mark of distrust, refused to allow Britain and France to speak for the EEC in the United Nations Security Council debates'. Sus, 1974, p. 78. 
point de vue de l'Europe, estiment que ni l'une ni l'autre n'étaient assez objectives $^{354}$.

Eerder heb ik Van der Stoels tegenwerping aangehaald dat er geen gemeenschappelijk standpunt bestond en dat hij zich daarom verzette tegen een blanco mandaat aan Frankrijk en thet Verenigd Koninkrijk (zie 2.2.1.3.).

In de (Manchester) Guardian, die zich baseerde op vooraanstaande ('highly qualified") diplomatieke bronnen, werd gesteld dat 'France and Italy privately informed Arab governments about Dutch reluctance to support a joint neutralist European stand on the Middle East ${ }^{355}$. Het is niet duidelijk of er op 13 oktober 1973 wel of niet een uitgewerkte standpuntbepaling op tafel lag.

Wel werd in de Arabische wereld verondersteld dat een uitgewerkt plan bestond, dat door Nederlands optreden niet werd aangenomen. Dit was voor de Arabische wereld temeer van belang daar zij hoge verwachtingen koesterde van een eigen Europees optreden ten gunste van hen, dat van invloed zou kunnen zijn op de afloop en de politieke gevolgen van de Oktoberoorlog. Enkele Europese regeringen konden baat vinden bij een geilsoleerde positie van Nederland. Dat stond dan ook te gebeuren.

\subsubsection{November 1973}

Op zaterdag 13 oktober werd het overleg van het Comite Politique in Kopenhagen beẻindigd met een korte verklaring. Deze verklaring was niet naar de zin van de Fransen, Italianen, Britten en de Arabische staten en was voor hen ontoereikend. Op dinsdag 16 oktober werd het olie-embargo tegen Nederland aan dle Nederlandse ambassadeur in Algiers bekendgemaakt, die dat meteen doorgaf aan het departement in Den Haag ${ }^{355}$. Op zondag 20 oktober zou pas de officiële bekendmaking van Algerijnse zijde volgen. Deze tweede week van de Oktoberoorlog was beslissend voor de uitkomst van de strijd in het Midden-Oosten. In het begin van de week was Egypte nog aan de winnende hand en weigerde het in te stemmen met een staakt-het-vuren ter plaatse waartoe Israël wel bereid was. In deze week kwam de VS Israël helpen met de opening van de wapenluchtbrug en het verlenen van noodhulp. Het Egyptische offensief halverwege deze week tot herovering van de Mitla- en Giddi-passen mislukte. De kansen op een Egyptische overwinning leken verkeken. Aan het eind van de week vloog Kissinger naar Moskou waar resolutie 338 werd ontworpen die de volgende morgen op 21 oktober door de Veiligheidsraad werd aanvaard. De aanwending van het economische machtsmiddel olie ten behoeve van een zo gunstig mogelijk politiek resultaat voor de Arabische wereld kwam nu van pas.

Ter voorkoming van de "overwinningsnederlaag" - waarmee ik bedoell dat de aanvankelijke Egyptische successen door latere Israëlische successen op het slagveld teniet gingen - kon met het 'oliewapen' druk worden uitgeoefend op de 'westelijke' wereld. Deze strategie kwam overeen met de opvatting van Saoedie-Arabië van eind augustus om zich slechts in te spannen voor aanwending van het oliewapen indien de oorlog lang

354. Balta, 1984 , p. 15 .

355. Sus, 1974 , p. 78.

356. Interview met Van Lynden op 13 september 1982. 
genoeg zou kunnen worden volgehouden (in tegenstelling tot 1967) opdat het oliewapen ook effectief zou zijn ${ }^{35 \%}$.

In de periode van 18 tot en met 21 oktober werden dan ook de maatregelen tot beperking van de olieproduktie en tot het olie-embargo tegen de VS officieel bekend gemaakt. Vervolgens kwam het clie-embargo tegen Nederland aan de beurt ${ }^{358}$.

Op 30 oktober vroeg de Nederlandse regering aan de Europese Commissie en de lidstatem "de consequenties van de produktie- en exportbeperkingen voor de gemeenschappelijke markt' op de Raadszitting van 5 en 6 november te bespreken ${ }^{359}$. Nederland stelde aldus de artikelen 30 tot 35 van het EEG-verdrag inzake het vrije verkeer van goederen aan de orde:

Frankrijk stelde daar tegenover dat zolang geen gemeenschappelijk energieprogramma bestond, het vrijmakingsproces van goederen onderworpen aan een staatsmonopolie langzamer diende te verlopen ${ }^{360}$. Duidelijk was dat Frankrijk zijn bevoorrechte positie als bevriend land niet in gevaar wilde brengen. Het Europees beraad werd onder zware druk gezet door het besluit van de OAPEC-ministers in Koeweit op 4 november de produktie onmiddellijk met $25 \%$ te verminderen. Door de Arabische verdeel- en heerspolitiek met de introductie van verschillende categorieën landen waar Europa gevoelig voor was, bleef de door Nederland gewenste Europese solidariteit uit. Op de inhoud en betekenis van de zes november verklaring heb ik eerder gewezen (zie 2.1.7). De verklaring werd als een Frans succes beschouwd. Maar ook de Britten waren zeer tevreden met deze verklaring. Zowel de Franse als de Britse minister van Buitenlandse Zaken meenden dat met deze verklaring een eerste stap werd gezet naar een belangrijke rol voor Europa in de internationale politiek ${ }^{36 !}$.

Algemeen werd aangenomen dat deze verklaring een Frans ontwerp was. Bij het debat over de begroting van Buitenlandse Zaken op 12 november 1973 in de Assemblée Nationale zei Jobert dat volgens de Duitse en Franse kranten deze verklaring een Frans initiatief was en volgens The Times een Engels initiatief. Op dat moment sprak hij zich niet verder uit ${ }^{362}$, maar in zijn memoires stelde hij dat het een Engels initiatief was en dat de Britten zich ook inspanden de resolutie uit te werken en aanvaard te krijgen ${ }^{363}$.

Al zullen de Duitsers en Nederlanders de verkJaring niet van harte hebben onderschreven, ze waren zich wel voldoende bewust van de realiteit om er mee in te stemmen, aldus Jobert die vervolgens de Nederlanders verwijt, maatregelen - zoals de autoloze zondag - als 'pure façade' te nemen en er behagen in te scheppen de rol van slachtoffer te spelen ${ }^{364}$. In ieder geval bestaat er geen aanwijzing dat Nederland op de zitting

357. Heykal, 1975 , p. 268

358. Voor een overzicht van de Arabische maatregelen ter beperking van de olie-export, zie bijlage 6.

359. Tweede Kamer, 1973-1974, no. 12.600 nir. 14, Nota van de minister van Butenlandse Zaken betreffende recente ontwikkelingen in het Midden-Oosten, p. 2 .

360. Sus, 1974 , p. 78.

361. Europe, 7-11-1973 aangehaald door Ifestos, 1987, p. 427.

362. J.O. Assemblede Nationale 1973, p. 5596.

363. Jobert, 1974 , p. 270 en Jobert, 1976 p. 343.

364. Jobert, 1974, p. 271. 
van de ministers in Brussel nog heeft tegengestribbeld. Ook zonder de Engelse druk van Douglas- Home op Van der Stoel, vlak voor het begin van de bijeenkomst, zou Nederland deze verklaring wel hebben aanvaard. De beslissing daarover werd de dag tevoren in Den Haag genomen (zie 2.2.1.6).

Interessant blijft de vraag of de in het vooruitzicht gestelde 'packagedeal' met de economische verklaring in de middag, die volgens Davignon in thet Comite Politique was overeengekomen, mede de Nederlandse aanvaarding heeft bewerkstelligd. Enerzijds zou elk Nederlands beroep op Europese solidariteit zeker gefaald hebben, indien Nederland in Brusssel dwars had gelegen. Bovendien zou Nederland dan niet meer kunnen volhouden dat het olie-embargo vooral Europa via de haven van Rotterdam beoogde te treffen. Van der Stoel haastte zich dan ook dezelfde dag te verklaren dat 'the hostility shown by these nations (the Arab countries) towards the Netherlands could not be based on any concrete factor ${ }^{365}$. Om deze redenen was Nederland welhaast genoodzaakt de politieke verklaring te ondersteunen. Anderzijds weten we nu dat Nederland pas op een laat moment * de zondag van vier november - op basis van de informatie uit het beraad van het Comité Politique door Van Lynden gepresenteerd, besloot de verklaring te aanwaarden. Het door Davignon geschetste beeld moet welhaast bij de besluitvorming in Den Haag betrokken zijn en voor Nederland was dat een aantrekkelijk vooruitzicht. Zoals eerder gesteld (zie 2.2.1.7) lag het in de bedoeling dat de politieke verklaring over het Arabisch-Israëlisch conflict gepaard zou gaan met een gezamenlijke reactie op het 'oliewapen' waaruit de solidariteit van de Gemeenschap met de Nederlandse positie zou blijken.

Bovendien verklaarden de Duitsers en de Denen vlak voor de EPS-bijeenkomst nog 'that they are in principle to bring Community solidarity fully into play" ${ }^{366}$. Opvallend is dat geen van de door mij ondervraagde Nederlanders op dit vooruitzicht van de beoogde solidariteit inzake energie heeft gewezen. Wellicht is het nogal pijnlijk deze Nederlandse misrekening naar voren te brengen, te meer indien Nederland's instemming met de EG-verklaring was ingegeven door de daarmee gepaard gaande verwachtte solidariteit inzake de energievoorziening (zie 2.2.1.7). Het zou aan het Nederlandse beeld van 'standvastigheid' wellicht afbreuk doen. Overigens bleek geen der ministers op de bijeenkomst nog enige moeite te doen voor Nederland op te komen. De angst onder de ministers won het in dit opzicht van de meer communautaire instelling, voor solidariteit binnen de gemeenschap, van hun topambtenaren. Deze directeuren-generaal politieke zaken hadden immers, kort voor de bijeenkomst van de ministers, ingestemd met een verklaring over de olievoorziening in de Gemeenschap (zie 2.2.1.7).

De Nederlandse topambtenaar, Van Lynden, die deelnam aan het Comité Politique, was echter wel gelukkig met het resultaat, daar Nederland door de gemeenschappelijke politieke stellingname ten aanzien van het Arabisch-Israëlisch conflict niet langer was geïsoleerd. Hij kon zich nadien weer meer geaccepteerd voelen onder zijn collegass in de EPS en voor hem was daarmee aan de moeilijkste periode - van 15 oktober tot 6 november - een einde gekomen. Ook de Belgische directeur-generaal stelde 'dat in het leven van een directeur-generaal (Politieke Zaken) de prioriteit ging naar het slagen van

365. Europe, 7-11-1973, 1393.

366. Europe, 5/6-11-1973, 1392. 
de EPS. De prioriteit om de Europese Politieke Samenwerking te doen slagen ging ten koste van de nationale posities en een duidelijk aparte rol in de $\mathrm{VN}^{*}{ }^{35}$. Op deze verschuiving heb ik eerder gewezen (zie 2.2.3.1).

Nederland bleef desondanks in een zwakke positie. Voor de Nederlandse regering waren de problemen, na aanvaardig san de zes november verklaring, allesbehalve opgelost. Een gemeenschappelijke reactie op de Arabische oliemaatregelen was niet tot stand gekomen, waardoor de Europese solidariteit op het gebied van de olieleveranties uitbleef en Nederland geïsoleerd bleef.

We kunnen concluderen dat met de zes november verklaring het doel van de EPS gericht op een gemeenschappelijke positie in het buitenlands beleid ten opzichte van landen buiten de Gemeenschap was bereikt, maar dat tegelijkertijd het hoofddoel van de Europese Gemeenschap gericht op Europese samenwerking en integratie was mislukt ondat geen oplossing werd gevonden voor de betrekkingen binnen de Gemeenschap. Interessant is dat al bij de eerste EPS-verklaring deze tegenstelling duidelijk was. Deze tegenstelling zou ook later de aandacht trekken waarbij het succes van de EPS als alternatief en antwoord is te zien op stagnatie in de Europese Gemeenschap.

\subsubsection{December 1973}

Davignon herinnert zich grote ontevredenheid over het falen van de vergadering van 6 november. Vooral de Duitsers waren ontevreden en hun ontevredenheid richtte zich in het bijzonder op Frankrijk, dat een bereikbare gemeenschapspositie niet had aanvaard ${ }^{368}$. Voor Nederland was nu de mogelijkheid aanwezig deze ontevredenheid te benutten om de lidstaten van de EG alsnog tot solidariteit met Nederland te bewegen. Op de Energie Raad van 3 en 4 december en de top van 14 en 15 december zou de olievoorziening opnieuw op de agenda staan. Premier Den Uyl heeft in november en december enkele malen met bondskanselier Brandt telefonisch overlegd en aangedrongen op steun voor het Nederlandse standpunt. Brandt had daar wel begrip voor, maar was ook heel voorzichtig met het oog op de eigen olievoorziening. Op de top te Kopenhagen 'tendeerde Brandt toch geleidelijk om het Nederlandse standpunt steun te geven' ${ }^{369}$. Eerder had Brandt op 26 november op bezoek in Parijs tegenover Pompidou verklaard dat "de Europese opbouw alleen kan geschieden onder het teken van solidariteit...en niemand van ons heeft het recht om de ander met zijn zorgen te laten zitten'. "Door verzwakking wan een land te aanvaarden, zouden wij in werkelijkheid de Gemeenschap zelf en via haar, elk van haar leden verzwakken. Indien wij op dit gebied niet verenigd blijven, zullen wij geen blijvende resultaten op andere gebieden boeken" ${ }^{370}$.

Pompidou reageerde daarop met de stelling dat de solidariteit niet louter op de olievoorziening moest slaan, maar op de totale energiepolitiek. Inzake de kernenergie wilde Frankrijk een uraniumverrijkingsindustrie die gebaseerd was op het zogenaamde gasdif-

367. Interview met Davignon op 22 juni $198 \%$.

368. Interview met Davignon, 22 juni 1987.

369. Interview met Den Uyll op 26 februari 1987.

370. NRC-Handelsblad, 27-11-1973, zie ook Europe van 28-11-1973, 1408 en voor International Herald Tribune van 27-11-1973 in Van Ginkel, 1978, p. 98 en eerder interview met Brandt in NRC-Handelsbliad, 24-11-1973. 
fusieprocedé. De Britten, Duitsers en Nederlanders stelden daar het ultracentrifugeproject tegenover ${ }^{371}$.

In Le Monde werd op dat moment Nederland opnieuw verweten dat het op 13 oktober 'zijn veto heeft uitgesproken over een voorstell dat ten doel had om Frankrijk en Engeland - als permanente leden van de Veiligheidsraad - het Europese standpunt over de Israëlisch-Arabische oorlog te laten vertolken' ${ }^{372}$. In het hoofdredactioneel commentaar van Le Monde van 28 november 1973 werd gesteld:

'L'archarnement des pays arabes envers la Hollandle a ses raisons. Jusqu'à la guerre d'octobre, les PaysBas ont été l'un des rares pays européens à soutenir indéfectiblement, sans réserve ni muance, l'Etat juif, Tant dans less organisations internationales, qu'au sein de la Communauté europétenne, les Hollandais sé sont toujours retrouvés, et parfois seuls, aux cötés d"Israel.

Selon les pays arabes, et cest la sans doute le reproche le plus grave, les Pays-Bas se seraient toujours opposés toute initiative européenne dans la recherche d'une solution au Proche-Orient, estimant qu'elle ne pourrait être que contraire aux intérêts d'Israël. C'est ainsi que lors de la réunion du comitê politique des Neuf, tenu le 13 octobre a Copenhague, ills avaient rejeté une proposition tendant a mandater la France et la Grande-Bretagne, en tant que membres da Conseil de sécuritê, pour présenter le point de vue de l'Europe. Le représentant néerlandais aurait jugé que ces deux pays n'étaient pas suffisamment objectifs pour parler au nom des Neuf.

Ces divergences entre la Hollande et deux de ses partenaires de la Communauté ćclairent les difficultes que les Neuf éprouvent actuellement a manifester leur solidarité envers les Pays-Bas dans la crise pétrolière'.

Deze krant sloot hiermee aan bij het Franse regeringsstandpunt dat ervan uitging dat de oorzaken van dle olieproblematiek uitsluitend te wijten waren aan het Arabisch-Israëlisch geschil. Frankrijk bleef zich evenals het Verenigd Koninkrijk verzetten tegen een evenredige verdeling van het olietekort. Volgens Van Ginkel daarentegen vond de grote meerderheid van de burgers in alle Europese landen van de Gemeenschap economische saamhorigheid juist vanzelfsprekend ${ }^{373}$. In onder meer het Britse, Belgische en Duitse parlement werd dan ook voor solidariteit met Nederland en voor een gemeenschappelijke oplossing gepleit ${ }^{374}$.

371. NRC-Handelsblad 27-11-1973, Jobert, 1976 p. 349, Van Ginkel, 1978, pp. $54-55$ en 58.

372. Le Monde 28-11-1.973.

373. Van Ginkel, 1978, p. 95 die zich zonder bronvermelding op publieke opinie-onderzoeken baseert: Volgens een opiniepeiling in l'Express van $12-11-1973$ is $65 \%$ van de Fransen van mening dat Europese solidariteit ten gunste van Nederland moet werken "zelfs als Frankrijk daarbij risico"s loopt, wit NRC-Handelsblad, 12-11-1973; NRC-Handelsblad, 7-12-1973 meldt dat in september 1973 dus nog voor de oliecrisis de volgende vrang werd gesteld: "Als een land van de EG ernstige economische moeilijkheden krijgt, moeten de andere landen dan bulp bieden?' Positief werd deze vraag beantwoord door $98 \%$ uit Italiè, $92 \%$ uit de BRD en Luxemburg, $90 \%$ uit België, Nederland en Frankrijk, $89 \%$ uit Ierland, $71 \%$ uit Denemarken en $68 \%$ uit het Verenigd Koninkrijk.

374. House of Conmons op 31 oktober 1973, p. 269 en op 27 november 1973, p. 296 door Labrour afgevaardigden Orbach en Shore; Kamer van Volkswertegenwoordigers op 27 november 1973, p. 437 en p. 450 door de afgevaardigden De Croo (PVV) en De Keersmaekers (CVP); volgens Het Parool, 6-11-1973 zouden op 5 november 1973 zestig leden van het Lagerhuis uit zowel de Conservatievo- als Labourhoek vergeefs getracht hebben een motie voor daadwerkelijke steun aan Nederland in behandeling te krijgen; resolutie op CDU-congres te Bonn van 8 november 1973 wit NRCHandelsblad, 9-11-1973. 
De olieministers van Algerije en Saoedi-Arabie, op rondreis door Europa, lieten daarop de Europeanen niet in het ongewisse en dreigden te zullen optreden als de Gemeensehap haar solidariteit op het gebied van de oliedistributie zou tonen ${ }^{375}$. De Engelsen en Fransen waren toch al niet van plan daartoe stappen te ondernemen en verhinderden bijwoorbeeld op 3 december het voornemen van de Europese Commissie een Europees crisisplan op de agenda te plaatsen. Vervolgens mislukten op dezelfde dag de bijeenkomsten van de raad van ministers van Buitenlandse Zaken en van Financiën, omdat de oliecrisis alle vooruitgang blokkeerde. Met name de Duitsers blokkeerden nu de besluitvorming op andere terreinen, waardoor Nederland in een meer comfortabele positie kwam dan voorheen, daar het nu geen veto hoefde uit te spreken ${ }^{376}$.

De Engelsen en Fransen herinnerden bijvoorbeeld op de bijeenkomst van ministers van Buitenlandse Zaken op 20 november 1973 de Nederlanders nog eens aan hun veto van 13 oktober en betoogden dat, indien Nederland toen solidair geweest zou zijn, het onder de EG-paraplu had kunnen schuilen ${ }^{377}$.

De politieke tegenstellingen binnen Europa, in het bijzonder de houding van de Britten en Fransen tegenover de Nederlanders, waren scherp op dat moment. Bij dergelijke politieke verhoudingen ligt het niet voor de hand dat juridisch ingrijpen een oplossing zal kunnen brengen. Er bestaan geen aanwijzingen dat Nederland een juridische procedure heeft overwogen. Een Belgische topdiplomaat verklaarde evenwel kort voor de EPS-bijeenkomst van 20 november te Kopenhagen aan een Nederlandse journalist dat het niet-toepassen van de solidariteit een spectaculaire beslissing zou zijn en voegde daaraan toe dat leden die zich niet solidair tonen wegens schending van het Verdrag van Rome - onderlinge exportverboden - door het Hof van Justitie in Luxemburg veroordeeld zouden kunnen worden ${ }^{378}$. Er bestond echter nog geen jurisprudentie over de interpretatie van de artikelen 30 en 36 van het EEG-verdrag over het vrije verkeer van goederen ${ }^{379}$. Ook werd wel duidelijk dat bezoeken van Den Uyl en Van der Stoel aan Heath en Pompidou hen niet tot een verandering in hun standpunten hadden bewogen. Nederland zou sterker zijn eigen machtsmiddelen moeten benutten om zijn EG-partners te overreden dan wel naar alternatieve mogelijkheden buiten de EG moeten zoeken.

Vanuit universitaire kring werd een alternatief samenwerkingsverband buiten de EG woorgesteld. Deze 'noordelijke ring' zou dan moeten bestaan uit de Duitse Bondsrepubliek, Nederland, de Scandinavische landen en ook België en zich met steun van de Verenigde Staten richten op de samenwerking ${ }^{380}$. Dit alternatief voor het vastgelopen EPS-overleg sloeg volgens Helldring wel aan bij sommige ambtenaren op het departement ${ }^{38 t}$. Zij namen echter niet deel aan de besluitvorming in deze kwestie en het idee

375. Europe, 1-12-1973, 1411 .

376. NRC-Handelsblad, 4-12-1973.

377. NRC-Handelsblad, 20-11-1973.

378. NRC-Handelsblad, 20-11-1973.

379. Dassonville arrest van 11 juli 1974 , zaak $8 / 74$.

380. Degenkamp, J.Th., 1974: Politiek medicijn voor ziek Europa, in: De Volkskrant, Open Forum, januari 1974. Degenkamp, J.Th, 1974: Het "koele' Europa, een onmogelijk alternatief?" in:" NRCHandellsblad, februari 1974. Zie Heldring, 1975, p. 5.

381. Brief van Heldring aan auteur van 9 december 1982. 
werd noch door de hoge beleidsambtenaren noch door de minister als serieus alternatief in het besluitvormingsproces betrokken ${ }^{382}$.

Daarentegen werd het Amerikaanse aanbod om Nederland van olie te voorzien wel serieus in het besluitwormingsproces betrokken. Gezien de toegenomen spanning tussen de VS en Europa in deze periode over deze kwestie, kon dat als alternatief voor het uitblijven van solidariteit van de EG worden beschouwd. De Amerikaanse steun werd voorlopig door de Nederlandse regering in beraad gehouden, hetgeen de Nederlandse positie in het EG-overleg heeft versterkt. Dit alternatief kon nu achter de hand worden gehouden en als optie worden aangewend om daarmee de Europese partners onder druk te zetten ten behoeve van de Nederlandse wensen. Deze waren gericht op het in stand houden van de gemeenschappelijke markt. Tevens wilde Nederland voorkomen dat de Amerikaanse vredesmissie vanuit Europa zou kunnen worden gedwarsboomd. De Amerikanen waren zich bewust wan deze Nederlandse positie en zij hadden belang bij een zo sterk mogelijke positie van Nederland binnen de EG. In ieder geval kwam het herhaaide Amerikaanse aanbod voor steun aan Nederland op het juiste moment gezien de politieke agenda van de Europeanen. Op 6 november 's ochtends - de dag van het EPS-overleg in Brussel - kreeg Van der Stoel van de Amerikaanse minister van Defensie Schlesinger het bericht dat de VS Nederland niet in de steek zou laten wat betreft de olievoorziening ${ }^{383}$. Op 21 november 1973 - de dag na het mislukte EPS-overleg in Kopenhagen - verklaarde de Amerikaanse minister van Buitenlandse Zaken Kissinger op een persconferentie dat de Amerikaanse regering serieus bestudeerde in hoeverre zij] Nederland kon thelpen ${ }^{334}$. Op 9 december 1973 - enkele dagen na de mislukte EGRaden van ministers te Brussel en nog voor de Europese top te Kopenhagen - vond een gesprek tussen Kissinger en Van der Stoel plaats. Kissinger zou in dat gesprek zijn waardering voor het Nederlandse standpunt over het Midden-Oosten hebben geuit en Van der Stoel hebben aangeraden niet voor Arabische druk te capituleren. Door de Nederlandse opstelling inzake het conflict in het Midden-Oosten verdween het wantrouwen van Kissinger in de "linkse" Nederlandse minister van Buitenlandse Zaken ${ }^{385}$. Bekend werd gemaakt dat de Amerikaanse onderminister voor oliezaken, Donaldson,

382. Interview met Vau Lynden, Meijer en Van der Stoel op respectievelijk 13 september 1982, 15 oktober 1982 en 17 november 1982 .

383. Interview met Van der Stoel op 11 februari 1977. NRC-Handelsblad, 7-11-1973.

384. NRC-Handelsblad 22-11-1973, zie ook Heldring: Nederland tussen Negen en Amerika, in: NRCHandelsblad 27-11-1973, Kissinger had waardering voor het verantwoorde Nederlandse beleid tijdens de Oktoberoorlog mar ook kritiek op Nederland vanwege de ondertekening van de 6 novernber verklaring.

385. Vrij Nederland, 23-12-1989, artikel van Jan Fred van Wijnen: Max van der Stoel ${ }_{\text {" de stille profeet }}$ die in Griekenland en Tsjechoslowakije wordt geěerd. Van der Stoel: 'Ik proefde zijin (Kissingers) wantrouwen: wat is dat woon linkse dweper?' Later sloeg Kissinger om, en wel "als een blad aan de boom". "Tijdens de Yom Kippoeroorlog was Nederland niet gebogen voor de Arabische oliechantage, met de autoloze zondag als gevolg. Van der Stoel: 'Kissinger verachtte de Europeanen ondat zo als de dood waren voor het oliewapen. In zijn ogen toonde alleen Nederland karakter.' Nederland werd uitgenodigd om het debat op de Washington energis conferentie (11 februari 1974) te openen en bij de eerstvolgende Navo-mimisterraad werd Van der Stoel ontvangen als eerste in de rij vam. Europese ministers die bij Kissinger op het traditionale spreekuur kwamen. 
nar Den Haag zou komen ${ }^{386}$. De dag na de Europese top in Kopenhagen arriveerde Donaldson in Nederland voor gesprekken met Den Uyl en Lubbers ${ }^{387}$.

We hebben kunnen constateren dat Nederland gedurende november en december in toenemende mate steun kreeg binnen de EG van de Duitse Bondsrepubliek en buiten de EG van de Verenigde Staten. Daarnaast bood de VS, met Kissingers voorstel op 12 december voor de oprichting van een 'consumersgroup', het westen een alternatieve oplossing voor de energiepolitiek. Dit alternatief sprak ook de Britten aan die weliswaar primair hun olievoorziening veilig wilden stellen en - ondanks meningsverschil met de Amerikanen over de politieke oplossing van het Arabisch-Israëlisch conflict - zich toch niet te sterk van de Amerikanen wilden verwreemden. De Fransen kwamen daardoor hoe langer hoe meer geïsoleerd te staan. Ook de verwachting dat zij na de zes november verklaring via 'Europa' weer een belangrijke politieke rol in de internationale politiek zouden kunnen spelen, kwam niet uit.

Eind november maakte Douglas-Home nog duidelijk dat Frankrijk en het Verenigd Koninkrijk alls permanente leden van de Veiligheidsraad en als woordvoerders van de Negen met een gemeenschappelijke politiek voor het Midden-Oosten aan de Geneefse vredesbesprekingen wilden deelnemen ${ }^{388}$.

Op 12 december werd bericht dat de Negen zich voorlopig afzijdig zouden houden bij de vredesbesprekingen in Genève ${ }^{389}$. Ook het Verenigd Koninkrijk en Frankrijk zouden uiteindelijk niet voor deelname aan deze Geneefse vredesbesprekingen worden uitgenodigd. Bovendien had Nederland zijn positie nog enigszins versterkt door te dreigen de eigen energie-bron - het aardgas - niet langer onbeperkt uit te voeren. In november werd door PvdA-Kamerleden de vraag gesteld of het mogelijk was de export van aardgas naar het buitenland stop te zetten - wat vooral België, Frankrijk, WestDuitsland en Italië als belangrijkste afnemers zou treffen - indien de Europese solidariteit uitbleef en de situatie met betrekking tot de olievoorziening zou verslechteren ${ }^{390}$. Volgens Lubbers was dat slechts op grond van overmacht mogelijk vanwege de bestaande contracten ${ }^{391}$. Ook bij de behandeling van de begroting van Economische Zaken drong Van der Hek bij de regering aan op het trekken van de consequenties ten aanzien van de in- en uitvoer van olie, olieprodukten en aardgas als de EG-markt niet functioneerde ${ }^{392}$.

Lubbers stemde daarmee in door te verklaren dat 'de regering niet zal schuwen de aardgasexporten naar de EG-partners te beperken wanneer er wat ons land betreft een ongelijke energieverdeling dreigt te ontstaan. Ieder zal begrijpen dat ons aardgas in de

386. NRC-Handelsblad, 10-12-1973. Volgens Associated Press zou Nederland de Amerikanen tijdens de Oktoberoorlog transitfaciliteiten voor hun wapentransporten natr Israẻl hebben gegeven, makar vanuit Den Hagg werd dat bericht ontkend.

387. NRC-Handelsblad, 17-12-1973.

388. NRC-Handelsblad, 27-11-1973.

389. Europe, 13-12-1973, 1419.

390. Tweede Kamer, zitting 1973-1974, Aanhangsel vragg no. 504 van Epema-Brugma, Van der Hek en Dankert op 6 november 1973, p. 1009.

391. Tbidem, antwoord Lubbers op 30 november 1973 .

392. NRC-Handelsblad, 15-11-1973. 
huidige situatie een zeer kostbaar goed is ${ }^{393}$. Deze mededeling drong ook door in de buitenlandse pers ${ }^{394}$.

Achteraf wond Den Uyl dat de overweging de uitvoer van aardgas te beperken geen grote rol had gespeeld ${ }^{395}$. In een gesprek met de fractieleiding van ARP en KVP had de premier deze mogelijkheid wel geopperd maar hij wilde eerst de resultaten van de top in Kopenhagen afwachten ${ }^{396}$. Een Nederlands beroep op een gemeenschappelijk beleid stond voorop.

In Kopenhagen werd echter nog niet besloten een gezamenlijk energiebeleid te ontwikkelen. Wel werd in een korte energie-paragraaf die als bijlage van de algemene verklaring van de Deense voorzitter werd gepresenteerd, aan de Commissie - na een studie gevraagd voorstellen in te dienen voor een gemeenschappelijke energiemarkt. Volgens Van den Bergh - in een notitie voor de PvdA-fractie - was dat een soort 'verbale energie solidariteit'. De top nam eigenlijk nog geen beslissingen en schoof de besluitvorming over de energie op de lange baan. De westerse aanpak die door Kissinger werd voorgesteld, bleef wel tot de mogelijkheden behoren.

De 'grote drie' Brandt, Pompidou en Heath bereikten dus weinig op deze eerste Europese top, maar wel werd een halt toegeroepen aan de voornamelijk door Frankrijk gepropageerde toenadering tot de Arabische wereld en de verslechterde verhouding met de VS. Nog steeds probeerden de Fransen en Britten hun gepriviligieerde positie in de Arabische wereld te versterken door na afloop de Arabieren te laten weten dat de Duitse Bondsrepubliek en Nederland zich hadden verzet tegen aanvaarding van een voor Israel veel scherpere verklaring over het Midden-Oosten. In de verworpen tekst werd Israël gevraagd zich dankbaar te tonen voor de Arabische bereidwilligheid in Genève te gaam onderhandelen ${ }^{397}$. Den Uyl heeft op de top 'heel hard gevochten' voor het Nederlandse standpunt:

1. ten aanzien van Israël;

2. voor het feit dat de EG-llanden Nederland moesten steunen in zijn bedreigde positie vanwege het afsnijden van de olietoevoer;

3. dat Europa één lijn moest trekken tegenover de olieleverende landen ${ }^{398}$.

Hij heeft achteraf gezien wel resultaat bereikt ${ }^{399}$.

Van den Bergh wees op het belangrijk politiek en diplomatiek succes van de Nederlandse regering die zich aanvankelijk in een volstrekt geïsoleerde positie bevond en er uiteindelijk in slaagde de Fransen en Engelsen te confronteren met een gemeenschappe-

393. NRC-Handelsbiad, 16-11-1973.

394. International Herald Tribune, 21-11-1973 onder de kop 'The Hague says it may cut North Sea gas exports" in: Van Ginkel, 1978 , p. 98.

395. Interview mat Den Uyl op 26 februari 1987.

396. Archief ARP Tweede Kamerfractie, 11 december 1973.

397. NRC-Handelsblad, 19-12-1973.

398. Interview met Den Uyl op 26 februari 1987.

399. Na afloop was hij miet echt tevreden (Europe, 22-12-1973, 14.26) en zei 'het is meer dan ik had durven hopen, maar minder dan ik wilde' (NRC-Handelsblad, 17-12-1973). 
lijk front van Nederland, Duitsland, Belgiē, Denemarken, Ierland en Italië: landen waarin democratisch-socialisten belangrijke posities innamen ${ }^{400}$.

\subsection{Februari 1974}

Na afloop van de top in Kopenhagen zouden we ons het volgende hoofdredactioneel commentaar kunnen indenken:

"Ook de regeringsleiders kunnen geen ijzer met handen breken. Dat is op de jongste topeonferentie van de Europese Gemeenschap opnieuw gebleken, speciaal ten aanzien van het zo belangrijke vraagstuk van de energiepolitiek. Aan de details wan een gemeenschappelijk intern energiebeleid - dat nu door de communautaire instellingen moet worden witgewerkt - zijn zij helemaal niet toegekomen. Toch zou bet te ver galan daarom de top op dit punt als werkelijk mislukt te beschouwen. De formuleringen van het slotcommuniqué boden nog voldoende ruimte voor manoeuwres, die tot bevredigende regelingen zullen kunnen leiden'.

Maar nee, dit commentaar werd een jaar later na afloop van de top in Parijs van december 1974 gepubliceerd $^{401}$. Hieruit blijkt dat in 1974 binnen de Europese Gemeenschap niets werd bereikt voor een gemeenschappelijk energiebeleid. De positieve openingen op de top in Kopenhagen 1973 werden al binnen een week ongedaan gemaakt, doordat de Britten op 18 december 1973 de eerste aanzet tot een gemeenschappelijk beleid al met een veto torpedeerden toen zij op een ander terrein - forse verhoging van het fonds voor de regionale ontwikkeling - hun zin niet kregen. De Amerikanen besloten vervolgens niet alleen de Europese Gemeenschap als zodanig maar ook de - grotere - lidstaten van de Europese Gemeenschap afzonderlijk voor een energieconferentie in Washington uit te nodigen.

De uitnodiging van 9 januari 1974 vloeide voort uit de door Kissinger op 12 november gelanceerde voorstellen. Kissinger hoopte dat de landen van de EG ditmaal niet met eén vertegenwoordiger namens de EG op de uitnodiging zouden ingaan. Dat kwam uit en vervolgens werden ook de andere lidstaten (België, Denemarken, Ierland en Luxemburg) uitgenodigd. Voor Kissinger was de conferentie een 'test of the proposition that the world has become truly interdependent, and that isolation and selfish approaches must be destructive for all concerned ${ }^{402}$. Daarmee zette hij zich af tegen het aangaan van bilaterale overeenkomsten tussen olieproducenten en consumenten. Bovendien misbruikte Frankrijk - in de visie van Kissinger - het energievraagstuk om zich met een Europese identiteit onder Franse leiding te kunnen afzetten tegen de VS. Ook de EuroArabische dialoog en het Europese alternatief voor het Midden-Oosten waren in zijn ogen gericht tegen de Amerikaanse diplomatie. Bovendien zouden de consumentenlanden bij de door Jobert voorgestane conferentie van de Verenigde Naties verdeeld worden door de keuze van de communistische landen en de Derde Wereld voor de OPEC, waaruit de Verenigde Staten geïsoleerd tevoorschijn zouden komen ${ }^{403}$.

400. Notitie H. van den Bergh: Analyse van de Gemeenschap na de topconferentie 1973, Partij van de Arbeid, F 434 .

401. Keesings Historisch Archief 1974, p. 802, gebaseerd op NRC-Handelsblad, 11-12-1974.

402. Kissinger, 1982, p. 901.

403. Kissinger, 1982, pp. 848, 901-903, 905. 
Kissingers vrees dat bij een keuze woor een gemeenschappelijke Europese positie de Fransen door gebruikmaking van hun veto-recht binnen de EG de resultaten van de conferentie konden bepalen, bleek niet ongegrond. De positie van Frankrijk in de EG was tot eind december sterk geweest: het had een leidende rol gespeeld. Voorafgaand aan de Washingtonconferentie bleek echter de steun van de lidstaten van de EG aan de Fransen minder te worden. Gesteld voor de keuze tussen de Franse en de Amerikaanse visie, werd uiteindelijk voor de laatste gekozen.

Het Franse isolement betekende dat aan de eigen 'Europese rol' een einde kwam en aansluiting bij het Amerikaanse beleid werd gevonden. De ontwikkeling daartoe wordt hier kort aangegeven.

Op de EPS-vergadering van 15 januari mochten de Europeanen op Frans aandringen het initiatief van de VS niet verwelkomen ${ }^{404}$. Op 5 februari bepaalde de Raad van ministers de instructies woor de conferentie, waaruit bleek dat elke confrontatie met de olieproducerende landen moest worden vermeden en dat de EG daarentegen contacten met de olieproducerende landen moest aanknopen ${ }^{405}$. Voor de Fransen was de EuroArabische dialoog daarvoor de arangewezen weg. Zij waren absolute tegenstanders van een geïnstitutionaliseerde samenwerking van de 13 olieconsumerende landen. De Fransen kregen in zoverre hun zin dat hun opvattingen in het mandaat van 5 februari voor de EG-delegatie naar de Washington conferentie werd verwoord ${ }^{406}$. Vervolgens besloot de Franse ministerraad op 6 februari 1974 dat Jobert toch naar Washington zou gaan, waarmee aan de wens van de overige ministers van Buitenlandse Zaken van de EG tegemoet werd gekomen ${ }^{407}$.

Eenmaal in Washington bleken de andere Europeanen nog bevreesd dat de Fransen uit de Gemeenschap zouden weglopen. Zij drongen aan op consensus, maar toonden zich nog voor de opening van de conferentie niet enthousiast over het Brusselse mandaat. Kissinger wist zich te verzekeren van de steun van Scheel (voorzitter van de $\mathbb{E G}$ ), Ortoli (voorzitter van de Europese Commissie), Douglas-Home (minister van Buitenlandse Zaken van het Verenigd Koninkrijk) en vooral van Schmidt, de Duitse minister van Financiên die de Duitse delegatie leidde ${ }^{408}$. Volgens Jobert had Kissinger de Acht onder zware druk gezet ${ }^{40 \%}$. Met deze steun was Kissinger niet langer beducht voor een mislukking van de conferentie maar vreesde hij wel een uitkomst met 'halve maatregelen".

Op de conferentie bleek Jobert echter iedereen tegen zich in het harnas te jagen. In een interview na afloop zei Jobert dat hij de conferentie had willen laten mislukken ${ }^{410}$. De Acht bleken nu niet langer bereid de Fransen in hun verzet tegen een verbruikersorganisatie te steunen. De Franse minister vond dat zijn collega's zich lieten schofferen

404. Europe, 17 januari 1974, 1437.

405. Europe, 6 februsi 1974, 1451.

406. Keesings Historisch Archief, 21 juni 1974, pp. 389-390.

407. Jobert, 1974. p. 286-287.

408. Kissinger, 1982, pp. 907-909.

409. Jobert, 1974. p. 287.

410. Interview, in: The Times van 15 februari 1974, in: Roggen, 1979, pp. 56-57. 
en zich uiterst dociel gedroegen, terwijl alleen Frankrijk zich onafhankelijk opstelde ${ }^{411}$. De Fransen tenslotte verwierpen de operationele paragrafen in de slotverklaring. Het Internationaal Energie Agentschap zou later, zonder de Franse deelname worden opgericht.

Na vier maanden werd solidariteit tussen de geinndustrialiseerde democratieën op het terrein van de energievoorziening bereikt. Nederland heeft daar van meet af aan naar gestreefd en heeft daaraan bijgedragen door consequent voor een gemeenschappelijke Europese aanpak te pleiten. Daarmee heeft het de Europeanen niet van zich vervreemd maar juist het Franse isolement - weliswaar in een laat stadium - mede bewerkstelligd. Tevens werd de politieke suprematie van de VS op dit punt aanvaard en ook dat sloot mooi aan bij de Atlantische instelling van Nederland. Bovenal werd met de instelling van het Internationaal Energie Agentschap een kwetsbare positie van Nederland op het terrein van de olievoorziening voor de toekomst vermeden (zie 2.2).

\subsection{Het Internationaal Energie Agentschap}

Op de Washington-conferentie was besloten een coördinatiegroep van hoge ambtenaren in te stellen die ondermeer 'een systeem voor toewijzing van olievoorraden in tijden van nood en ernstige tekorten' zouden opzetten ${ }^{412}$. Deze groep kwam veelvuldig bijeen ${ }^{413}$ onder voorzitterschap van de Belg Davignon, met als resultaat het ontwerp van een overeenkomst. Dit Internationaal Energie Programma (IEP) zou worden uitgevoerd door het Internationaal Energie Agentschap (IEA) dat werd ondergebracht bij het secretariaat van de Organisatie voor Economische Samenwerking en Ontwikkeling (OESO) in Parijs.

Het voor dit onderzoek meest interessante onderdeel van dit programma is het gedetailleerde crisismechanisme voor tijdelijke olieschaarste. De basisprincipes die ten grondslag liggen aan het verdelingsmechanisme staan in de artikelen $7 \mathrm{t} / \mathrm{m} 71$ van de Overeenkomst inzake een Internationaal Energieprogramma ${ }^{414}$. Deze overeenkomst van 18 november 1974 stelt onder meer de verplichting tot het aanhouden van een noodvoorraad voor 90 dagen (art. 2) en het.opstellen van een programma van noodmaatregelen ter beperking van de vraag (art. 5) om een energietekort tot $7 \%$ zelf te kunnen opvangen. Bij een tekort van meer dan $7 \%$ van een of enkele landen treedt het verdeelschema in werking; met andere woorden de tekorten boven de $7 \%$ worden door de groep verdeeld naar rato van de consumptie van elk land (art. 8) ${ }^{415}$.

Het bijzondere van deze overeenkomst schuilt in de automatische inwerkingtreding van het verdeelschema nadat het secretariaat van het Internationaal Energie Agentschap een vermindering van $7 \%$ heeft vastgesteld. Daar is dan geen afzonderlijk politiek besluit van de Raad van Bestuur in het IEA voor nodig (art. 19).

411. Johert, 1976, p. 378-379.

412. Punten 16 en 9 van het slotconmuniqué, Keesings Historisch Archief 21 juni 1974, p. 390-391.

413. 25 februari, 13-14 maart, 3-4 april, 3-4 mei, 17-18 juni, 8-9 juli, 29-31 juli, 19-20 septenber, 4 en 22-24 oktober 1974. Keesings Historisch Archief, 1974 pp. 391, 564, 806-807.

414. Tractatenblad 1975, 47; opgenomen in Wet voorraadvorming aardolieprodukten van 21 oktober 1976. Staatsblad 569 .

415. Memorie van Toelichting, p. 12, Tweede Kamer, zitting 1974-1975, 13515 no. 3. 
Slechts een gekwalificeerde meerderheid van de Raad van Bestuur - bestaande uit de ministers of hun afgevaardigden van de deelnemende landen - kan uitdrukkelijk besluiten het verdeelschema niet in werking te laten treden. Indien het tekort van een of enkele leden meer dan $7 \%$ bedraagt, terwijl het totale IEA tekort beneden de $7 \%$ blijf;; is voor een dergelijk besliuit een gekwalificeerde meerderheid van 51 van de in totaal 60 algemene stemgewichten vereist. Alle twintig deelnemende landen hebben elk drie algemene stemgewichten. Dat betekent dat Nederland met de steun van drie landen (bijvoorbeeld Canada, Nieuw Zeeland en Luxemburg) een dergelijk negatief besluit zoui kunnen voorkomen (art. 19 en art. $61 \mathrm{a}$ en 62$)^{416}$.

Hoewel dit crisisprogramma niet volmaakt is - zo zal het crisismechanisme falen bij een groot tekort van $25 \%$ voor de totale IEA-groep gedurende een lange periode ${ }^{417}$. heeft het wel de kwetsbaarheid voor een olie-embargo tegen éen of enkele leden van de IEA-groep sterk gereduceerd.

Niet alleen bleek de Europese Gemeenschap in 1973 niet in staat tot een dergelijke solidariteit op het terrein van de energievoorziening, maar ook de naderhand genomen besiluiten van de EG blijven achter bij het door het IEA in het leven geroepen mechanisme. De EG heeft wel maatregelen genomen ter vermindering van het verbruik; zij heeft ook een verplichting tot voorraadvorming ingesteld, voorts is zij begonnen met de opzet van een systeem van crisisbeheersingsmaatregelen waaronder wel een verdeling van aardolieproduktie maar niet een regeling voor de verdeling van olie valt ${ }^{418}$. Het ontbreken van het automatisch verdelingsmechanisme wordt als belangrijkste verschil tussen de regelingen van de EEG en die van het IEA gezien ${ }^{419}$.

Alle EG-lidstaten met uitzondering van Frankrijk hebben zich aangesloten bij het IEA. Door gebrek aan overeenstemming is de EG niet toegetreden tot het IEA maar de Europese Commissie is daarin wel als waarnemer vertegenwoordigd. In feite volgt de Gemeenschap het initiatief van de IEA in belangrijke mate ${ }^{420}$ alhoewel de crisismaatregelen van het IEA strikter zijn ${ }^{42\rfloor}$.

Zoals gesteld vormt het crisismechanisme de kern van het Internationaal Energie Programma. Dit crisismechanisme is een uiting van de solidariteitsgedachte binnen de westerse wereld ten aanzien van de olievoorziening. De besluitvorming ten aanzien van de inwerkingtreding van dit crisismechanisme is bijzonder en geeft aan het Internationaal Energie Agentschap in feite een supra-nationaal karakter. Het Internationaal Energie Agentschap is ook de enige internationale organisatie waar de Verenigde Staten bij is aangesloten zonder over het veto-recht te beschikken. Dat laatste kostte de VS wel moeite maar was een conditio sine qua non voor de oprichting van het IEA ${ }^{422}$.

Ondanks de bredere doelstelling van het Internationaal Energie Programma was dit toch vooral gericht op het ongedaan maken van de zojuist verworven machtspositie van de

416. Zie ook: Van der Meulen, 1982, pp. 111-112; Barents, 1977, pp. 236-240.

417. Roggen, 1979, p. 88-89.

418. Wijland-Spek, 1980, pp. 686-694.

419. Asscher, 1980, p. 685 .

420. Kapteyn en VerLoren van Themaat, 1987 , p. 525.

421. De Clerq, 1979, pp. 345-347.

422. Interview met Davignon op 22 juni 1987. 
olieproducerende landen. Dit stond niet alleen haaks op de Franse oogmerken maar ook op de aanspraken van de Derde Wereld voor een Nieuwe Internationale Economische Orde. Deze andere visie op de internationale economische betrekkingen met een sterkere positie van de grondstoffen uit de Derde Wereld stond ook centraal op de zesde bijzondere zitting van de Algemene Vergadering van de Verenigde Naties in april - mei $1974^{423}$. Ook de Nederlandse minister van Ontwikkelingssamenwerking, Pronk, voelde meer voor een brede aanpak van 'wereldwijde afspraken waarbij alle consumenten en producenten zijn betrokken'. Eerder werd gesteld (zie 2.2.3) dat Pronk wel begreep dat de oprichting van het Internationaal Energie Agentschap ook specifiek in het belang van Nederland was. Hij accepteerde daarom Nederlands' toetreding tot het Internationaal Energie Agentschap ${ }^{424}$. Nederland was immers door zijn Europese partners in de steek gelaten en het primaire doel was een kwetsbare positie in de toekomst ten aanzien van de olieleveranties te voorkomen. Het Internationaal Energie Agentschap slaagde waar de Europese Gemeenschap had gefaald.

De Nieuwe Internationale Economische Orde die in 1974 nog wel verbaal door de Westerse landen werd onderschreven, mede dankzij de Nederlandse rol van 'bruggenbouwer' op de zesde bijzondere zitting van de Algemene Vergadering van de VN, is nog altijd niet verwezenlijkt. De in de ogen van de Derde Wereld positieve rol van Nederland tijdens deze VN-conferentie die vooral door Algerije was geinitieerd, heeft een aantal Derde Wereld landen ertoe gebracht bij de Arabische olieproducerende landen te pleiten voor opheffing van het specifieke tegen Nederland gerichte olie-embargo. Minister Pronk legde achteraf een verband tussen het Nederlandse beleid inzake ontwikkelingssamenwerking en de opheffing van het olie-embargo: 'Bij de olieboycot in 1973 zijn we geholpen door onder andere Algerije, waarmee we inmiddels goede contacten hadden opgebouwd. De Algerijnen namen zelf het initiatief. We hoefden niet naar hen toe. Ze oefenden druk uit op de Arabische landen om de boycot te verzachten, want Nederland was geen rechts en conservatief land en kon dat met harde gegevens staven" ${ }^{\text {" } 25 .}$.

Uiteindelijk heeft Algerije op 2 juni 1974 als eerste het olie-embargo tegen Nederland opgeheven. Een causaal verband tussen Nederlands rol op de zesde Bijzondere Zitting van de Algemene Vergadering van de Verenigde Naties in april 1974 en de Algerijnse opheffing van het olie-embargo van juni 1974 is echter twijfelachtig. Veeleer moet aan het directe Algerijnse belang gedacht worden. Dit belang lag bij het afsluiten van associatieverdragen tussen de Europese Gemeenschap en de landen rond de Middellandse Zee. Nederland zou het afsluiten van die verdragen tegenhouden zolang het olieembargo voortduurde. Daarnaast blokkeerde Nederland het op gang komen van de Euro-Arabische dialoog. Frankrijk was aan Europese zijde de belangrijkste voorstander van deze dialoog, die gezien kan worden als tegenwicht van de door de VS gekozen weg naar machtsvorming van de consumentenlanden in het IEA. De Fransen wilden deze Euro-Arabische dialoog zo spoedig mogelijk op gang brengen en probeerden om

423. Verslag Ministerie van Buitenlandse Zaken, deel 106, Staatsuitgeverij, "s-Gravenhage 1974.

424. Interview met Pronk op 17 mart 1983 .

425. Interview in NRC-Handelsblad, 10-6-1989. 
die reden de Arabische landen te overreden het olie-embargo tegen Nederland op te hef. fen ${ }^{426}$.

Van Arabische zijde werd dit gehonoreerd. Bij de opheffing van het olie-embargo werd vermeld: ${ }^{\circ}$ Cette discrimination a été ressentie par les Européens qui en ont fait l'obstacle majeur à l'ouverture du dialogue euro-arabe et à la reprise des négociations d"accords d'association élargis avec les pays du bassin mediterannées" ${ }^{427}$.

De Duitse vertegenwoordiger in het Comité Politique ging nog een stap verder. Hij meende achteraf dat het voorstel van de Euro-Arabische dialoog was bedoeld om de opheffing van het olie-embargo tegen Nederland te bewerkstelligen ${ }^{428}$.

Op 10 juli 1974 beëindigden na Algerije ook de andere Arabische staten het olie-embargo tegen Nederland. De Euro-Arabische dialoog kon vervolgens op 31 juli met Algerije, Marokko en Tunesië aan Arabische zijde, beginnen ${ }^{429}$.

De Arabische olie-exporterende staten vonden zelf dat zij er niet in geslaagd waren hun politieke doeleinden door middel van het olie-embargo tegen Nederland te verwezen]jken. Zij verklaarden bij de opheffing van dit embargo dat Nederland was blijven vasthouden aan de zienswijze van Israẻl en dat het embargo alleen werd beëindigd vanwege de gewenste relatie tussen de Arabische naties en de Europese Gemeenschap ${ }^{430}$. De Saoedi-Arabische minister van oliezaken Ya'amani voegde daar aan toe, dat Europa nu maar moest proberen Nederland te overtuigen dat Israël zich uit alle Arabische gebieden moest terugtrekken ${ }^{431}$.

De directe druk met economische sancties vanuit de Arabische wereld tegen Nederland had er niet toe geleid Nederland tot een andere politieke opstelling te bewegen. De fakkel werd door de Arabische wereld overgedragen aan het Europa van de Negen en in het volgende hoofdstuk zullen we bezien of de EG met meer subtiele middelen in de periode 1974-1980 de Nederlandse opstelling kon beinvloeden.

\subsection{Conclusies en slotopmerkingen}

Kenmerkend voor het beleidsproces in de kwestie van het olie-embargo was de grote spanning tussen de externe - buitenlandse - druk en de interne - binnenlandse - druk op de regering. Het verdisconteren in het beleid van de interne druk had problemen veroorzaakt waarvan het olie-embargo en de geïsoleerde Nederlandse positie in de internationale politiek het gevolg waren. Het toegeven aan de externe druk zou op binnenlands verzet hebben gestuit. In zekere zin zou de regering daardoor de 'gevangene' hebben kunnen worden van beide soorten druk die als druk en tegendruk werden beschouwd. De druk was gericht op het verminderen van steun aan Israël en daarmee afstand nemen van het tot dusverre gevoerde pro-Israëlisch beleid. Het beeld van de 'gevangene' is

426. Zie voor uitvoerige beschouwing van deze Euro-Arabische dialoog in Simon, 1985; zie ook. Allen, 1982.

427. Maghreb-Machrek, no. 65,1974, p. 17.

428. Interview met Van Well op 30 januari 1990.

429. Maghreb-Machrek, no. 65,1974 , p. 7 .

430. The Arab. World, 11 juli 1974, p. 5,12 juli 1974 pp. 11 en 12.

431. Arab Report \& Record, 1-15 juni 1975, pp. 218, 229 en 241; deze laatste uitsprauk werd gedaan de dag na het Algerijmse besluit tot beẻindiging van het olie-embargo. 
echter niet juist omdat de regering het beleid ten aanzien van het Arabisch-Israëlisch conflict niet wenste te wijzigen. De interne druk die een continuiteit van het Nederlands beleid voorstond, werd zodoende een steun aan de regering in het verzet tegen de buitenlandse druk.

We kunnen nu de drie vragen uit de probleemstelling voor deze casus beantwoorden.

1. Het Nederlands buitenland beleid kwam tot stand onder invloed van de pro-Israël consensus in eigen land. De politieke actiegroepen waren actief in het mobiliseren van steun voor Israël. Andere groepen uit de niet-formele politieke elite - zoals politieke partijen en vakbeweging - sloten zich daarbij aan of zwegen (bijvoorbeeld het bedrijfsleven). De groepen die zich tegen steun aan Israël verzetten, bijvoorbeeld Nederlands Palestina Komitee en Pax Christi, vonden weinig gehoor bij de formele politieke elite. De formele politieke elite was betrokken bij de totstandkoming van de Nederlandse pro-Israëlische verklaring tijdens de Oktoberoorlog en gaf er zijn steun aan. Dat betekende manifeste invloed van het parlement, vanuit de vaste Kamercommissie voor Buitenlandse Zaken en de Tweede Kamer tijdens het debat over de begroting, op het beleid in oktober 1973.

$\mathrm{Na}$ de instelling van het olie-embargo werd behoedzaam en achter de schermen geopereerd. De eerdere steunbetuiging aan het Nederlands standpunt ten gunste van Israël werd in deze studie evenwel als anticiperende invloed beschouwd en als zodanig door de regering ervaren.

2. De Nederlandse rol in de internationale politiek was gericht op het doen beëindigen van het olie-embargo, zonder al te zeer toe te geven aan Arabische wensen met betrekking tot het eigen standpunt over het Arabisch-Israëlisch conflict. De Nederlandse pogingen om de Arabische olie-exporterende staten te bewegen het olieembargo tegen Nederland op te heffen, faalden. Binnen de Europese Politieke Samenwerking kwam Nederland geïsoleerd te staan. Dit isolement werd ook veroorzaakt door de Nederlandse weigering aan Frankrijk en het Verenigd Koninkrijk het gevraagde mandaat voor hun optreden in de Veiligheidsraad van de VN te verlenen. Dat was een beleid van onverzoenlijke aanpassing door Nederland. Het weerstand bieden aan de externe druk kon Nederland echter niet volhouden. Het gaf toe aan de externe druk met de ondertekening van de EG-verklaring van 6 november 1973. Nederland kreeg daar niets voor terug omdat het er niet in slaagde de solidariteit van de Europese partners op het terrein van de olievoorziening te verwerwen. Dit Nederlands beleid kwam over als een vorm van inschikkelijke aanpassing. Maar deze indruk behoeft enige correctie. Met een interpretatieve verklaring door Van der Stoel trachtte hij de EG-verklaring te doen aansluiten op het eerdere Nederlands buitenlands beleid. Dat duidt op een vorm van bewarende aanpassing. Voor het realiseren van de Nederlandse wensen in internationaal verband was de steun van de andere EPS-partners nodig. Het verwerven van die steun bleek een moeizaam proces te zijn. Na de Westduitse steun voor Nederland keerden uiteindelijk ook de andere Europese partners zich tegen de Fransen. Dat geschiedde in februari 1974 in Washington, toen de Amerikanen erin slaagden de Westerse olieverbruikende Janden te verenigen. Daar kwam Frankrijk geisoleerd te staan. Het aanwenden van eigen machtsmiddelen - afsiluiten van de gasexport werd overwo- 
gen - maakte geen indruk op de Europese partners. De steun van de VS op politiek terrein - te onderscheiden van de olietoevoer door de oliemaatschappijen op economisch terrein - bleek doorslaggevend te zijn voor de realisatie van de Nederlandse wensen.

3. Er bestond een duidelijke overeenstemming tussen het Nederlands buitenlands belleid en de Nederlandse inbreng in de internationale politiek. De aandrang verder toe te geven aan de Arabische wensen wees de Nederlandse minister van Buitenlandse Zaken ook af omdat daar geen binnenlandse steun voor bestond. Een afzonderlijke Nederlandse meer pro-Arabische verklaring - zie onder meer de kwestie-Thurkow - werd daarom niet uitgegeven. Bedenkingen tegen de beoogde machtsworming van de olieverbruikende staten door de oprichting van het Internationale Energie Agentschap, van onder meer Pronk, vonden evenmin gehoor. Het zoeken naar een evenwicht tussen de belangrijkste binnenlandse en buitenlandse wensen duidt op een beleid van bewarende aampassing. Deze bewarende aanpassing slaat op het Nederlands beleid dat leidde tot de oprichting van het IEA.

Nederland gaf niet toe aan de Arabische eisen tot beëindiging van het olie-embargo en continueerde zodoende een beleid van onverzoenlijke aanpassing op dat punt.

In dit hoofdstuk werden tien beslissingen onderzocht. In bijlage 20 zijn deze schematisch weergegeven. Alle beslissingen op én na werden door de directe besluitvormers - het Nederlandse kabinet - genomen. De uitzondering betreft de gemeenschappelijke EG-verklaring van 6 november 1973. Deze beslissing werd in het intergouvernementeel samenwerkingsverband - EPS - genomen zonder voorafgaande besluitvorming in thet Nederlandse kabinet daarover. Achteraf werd dit internationaal politieke standpunt als Nederlands buitenlands beleid gepresenteerd. Aan deze wijziging in de besluitvorming werd in dit hoofdstuk veel aandacht besteed. De consequenties van deze wijzigingen in de besluitvorming worden in de volgende hoofdstukken belicht. 
Eén van de belangrijkste gevolgen wan het olie-embargo uit 1973 was dat Nederland aan zijn Midden-Oostenbeleid gestalte zou gaan geven binnen het kader van de Europese Politieke Samenwerking. Deze procedurele wijziging zou tot een verandering van standpunt leiden. De Nederlandse stellingname verschoof gedurende de periode 19741980. Ook Licklider concludeerde dat het Nederiandse beleid ten aanzien van het Arabisch-Israëlisch conflict zich niet onder de druk van het Arabisch oliewapen wijzigde, maar well nadien in pro-Arabische richting opschoof ${ }^{\text {. }}$.

In dit hoofdstuk zullen deze veranderingen in kaart worden gebracht; het hoofdstuk is derhalve tamelijk inventariserend van aard. De resultaten van het internationaal politieke proces met name in EPS-verband worden hier belicht. De reactie daarop in het binnenland door ondermeer het parlement wordt onderzocht. Tevens wordt aangegeven dat zich ook in de Nederlandse politiek een wijziging van standpunt voltrok ten aanzien van thet Arabisch-Israëlisch conflict. Daarvoor worden de verkiezingsprogramma's van de Nederlandse politieke partijen onderling en ook per partij in de tijd vergeleken. De publieke opinie-cijfers en de activiteiten van actiegroepen komen eveneens aan de orde. De nadruk in dit hoofdstuk ligt niet op het buitenlands politiek proces maar op het internationaal politiek proces. In het bijzonder staat daarbij de vraag centraal welke rol Nederland daarin heeft vervuld. Werd bijvoorbeeld de pro-Israëlische reputatie van Nederland ook binnen EPS-verband waargemaakt? Voor een beantwoording van die vraag wordt in dit hoofdstuk de Nederlandse inbreng tamelijk gedetailleerd beschreven en het succes van de beïnvloedingspogingen geanalyseerd (3.1.2.4).

\subsection{Internationale Politiek}

$\mathrm{Na}$ de verklaringen over het Midden-Oosten in het vierde kwartaal van 1973 werden in 1974,1975 en 1976 geen nieuwe verklaringen vanuit het EPS-beraad uitgegeven. Deze opmerkelijke stilte had te maken met veranderingen binnen Europa en het internationale politieke krachteriveld van dat moment. De Amerikaanse suprematie en de bemiddelaarsrol van de Amerikaanse minister van Buitenlandse Zaken, Kissinger, werden door de partijen in het Midden-Oosten erkend en verwelkomd. Kissingers diplomatieke pogingen werden bekroond met troepenscheidingsakkoorden, eerst tussen Egypte en Israël (14 januari 1974) en later tussen Syrië en Israël (31 mei 1974). In september 1975 werd een veelomvattend 'deelakkoord' tussen Egypte en Israell gesloten dat niet alleen een troepenscheiding en verdere Israëlische terugtrekking inhield, maar ook politieke componenten bevatte, zoals het afzien van geweld. In feite werd op dat moment reeds een aanzet gegeven tot het 'vredesverdrag' tussen Israël en Egypte, dat op 26 maart 1979 zou worden getekend. Van Europese zijde werd aan deze Amerikaanse

1. Licklider, 1988 , p. 44 . 'The Dutch government made little or no significant policy change on the Arab-Israeli issue while the oil weapon was being applied. In the longer term, however, the Netherlands abandoned its semi-independent policy on the Middle East in favor of closer links with the European Commumity, did not act on the Arab boycott, and increasingly supported the Arab position vis-ât-vis the Palestinian issue'. 
rol onder de presidenten Nixon en Ford geen afbreuk gedaan. Van een eigen Europese rol werd afgezien.

De veranderde Europese opstelling had ook te maken met de regeringswisselingen in Europa. De 'grote Europese drie' uit 1973, Heath, Pompidou en Brandt zouden in 1974 wan het politieke toneel verdwijnen. Labour won de parlementsverkiezingen in het Verenigd Koninkrijk. De niewwe Britse minister van Buitenlandse Zaken, Callaghan, verklaarde in het Lagerhuis Kissingers vredesmissie niet in de weg te willen staan en reageerde om die reden zeer terughoudend op het op gang brengen van de Euro-Arabische dialoog ${ }^{2}$. In Duitsland werd de afgetreden Brandt opgevolgd door Schmidt die zeer gericht was op nauwe relaties met de VS en dat combineerde met een goede persoonlijke verstandhouding met Kissinger. Daarnaast versterkte Schmidt de band met Frankrijk, waarbij ook de goede persoonlijke relatie met Pompidou"s opvolger Giscard d'Estaing een rol speelde. Bij de Franse presidentsverkiezingen in 1980 zou Schmidt zelfs zijn voorkeur uitspreken voor Giscard d'Estaing boven de socialistische kandidaat Mitterrand. De VS hadden hun positie na de Oktoberoorlog bij beide partijen in het conflict aanzienlijk versterkt en konden nu op Israël druk uitoefenen om aan Arabische wensen tegemoet te komen. Europa werkeerde niet langer in een dergelijke positie en had in Israèl veel goede wil verspeeld.

De VS hadden echter wel met het verkrijgen van de Israëlische concessies over terugtrekking in 1975 ook aan vrijheid van handelen ingeboet. De VS waren gebonden aan hun belofte aan Israël dat zij niet met de PLO in contact zouden treden, voordat deze organisatie de VN-resoluties 242 en 338 inclusief Israëls bestaansrecht zou erkennen en van terreurdaden zou afzien. Aan deze voorwaarden werd pas voldaan in december 1988. Europa was op dat punt nilet gebonden en kon daardoor aansturen op een opwaardering van de PLO en op een nadere inwulling van de Palestijnse legitieme rechten die ook hun beslag zouden kunnen krijgen in een toevoeging dan wel herformulering van resolutie 242. In die resolutie was slechts sprake van het Palestijnse vluchtelingenwraagstuk. In de verklaringen vanuit het EPS-beraad zou in de periode 1977-1980 daarop de aandacht worden gericht. De beweegredenen aan Europese zijde voor een dergelijk optreden verschilden per staat: voor sommige was het beleid complementair aan het Amerikaanse optreden, voor andere was het een alternatief voor het Amerikaanse vredesproces. De verschillende opvattingen binnen Europa daarover worden behandeld.

Twee andere redenen voor het Europese stilzwijgen in 1976 - na het Egyptisch-Isralelisch Sinaï akkoord uit 1975 - waren de Amerikaanse presidentsverkiezingen van november 1976 en de Israëlische parlementsverkiezingen van mei 1977. Aan de nieuwe Amerikaanse president Carter zou gelegenheid voor een eigen beleid moeten worden geboden en de socialistische regeringsleiders wilden de verkiezingskansen voor de Israëlische Arbeiderspartij niet verkleinen. Dat laatste was althans volgens Den Uyl én belangrijke reden om eind 1976 onder het Nederlandse voorzitterschap van de EPS niet met een nieuwe verklaring over het Midden-Oosten naar buiten te treden ${ }^{3}$.

2. Parliamentary Debates a.w. vol. 870 c. 864, Europe 4/5-3-74, 1470 .

3. Interview met Den Uyl op 26 februari 1987. 
In juni 1977 werd te Londen door de Europese Raad een volgende stap gezet met een verklaring waarin aan het Palestijnse volk een eigen land (homeland) in het vooruitzicht werd gesteld. In juni 1980 erkende de Europese Raad te Venetië tenslotte het zelfbeschikkingsrecht voor het Palestijnse volk. Deze ontwikkeling binnen de EPS ten aanzien van het Arabisch-Israëlisch conflict van 'vluchtelingenprobleem" (1971) via "legitieme rechten voor de Palestijnen' (1973) en 'eigen land voor het Palestijnse volk' (1977) naar 'zelfbeschikkingsrecht voor het Palestijnse volk' (1980) werd meestal voorafgegaan door een gewijzigde opstelling van de EG-lidstaten in de Algemene Vergadering van de Verenigde Naties. De afstemming van het buitenlands beleid op de andere EG-lidstaten kreeg in de te New York afgelegde verklaringen gestalte en preludeerde op de hierboven vermelde gemeenschappelijke verklaringen in de periode 1974-1980.

In de volgende paragraaf zal de besluitvorming en standpuntenbepaling van de Europese Negen in de Algemene Vergadering van de Verenigde Naties worden behandeld, waarna meer in detail op de totstandkoming van de verklaringen in het EPS-verband zal worden ingegaan.

\subsubsection{Algemene Vergadering der Verenigde Naties}

In 1974 werd de Palestijnse kwestie voor het eerst als afzonderlijk punt op de agenda van de Algemene Vergadering gezet. Tijdens deze 29 ste vergadering werd onder Algerijns voorzitterschap de PLO als de vertegenwoordiger van het Palestijnse volk uitgenodigd aan het debat deel te nemen ${ }^{4}$.

In oktober 1974 wees de Arabische Topconferentie te Rabat de PLO als de enige vertegenwoordiger van het Palestijnse volk aan. Daarmee werden de Jordaanse aanspraken op de Westelijke Jordaanoever en de Israëlische beleidskeuze voor de Jordaanse optie van tafel geveegd. Bij de stemming over de uitnodiging aan de PLO in de Algemene Vergadering - 120 voor, 4 tegen en 20 onthoudingen - stemden drie EG lidstaten vór (Frankrijk, Ierland, Italië) en onthielden de andere zes lidstaten zich van stemining. Voor een overzicht van het stemgedrag van de lidstaten van de EG over de MiddenOostenkwestie in de periode 1974-1982 zie bijlage 7. De Nederlandse permanente vertegenwoordiger, Kaufmann, gaf in een stemverklaring op 14 oktober 1974 aan dat de stem van de Palestijnen in het debat moest worden gehoord maar dat deze resolutie cen politiek element bevatte (dè vertegenwoordiger) waarover de A.V. zich nog niet kon uitspreken. Het ministerie van Buitenlandse Zaken voegde daar in zijn verslag aan toe dat de PLO in de resolutie niet als 'enige' ('sole') vertegenwoordiger werd aangeduid. In die zin werd de uitspraak uit Rabat niet onderschreven. Aan de andlere kant rept deze resolutie over 'de' ('the') en niet 'een' ('a') vertegenwoordiger van het Palestijnse volk. Bovendien wordt hier het 'Palestijnse volk' naar voren gebracht terwijl tot dusverre over 'Palestijnen" werd gesproken. De benaming 'Palestinian people' in plaats van 'Palestinians' nam de Nederlandse permanente vertegenwoordiger over in een stemverklaring op 22 november 1974.

Taalkundige wijzigingen gaan inzake debatten over het Midden-Oosten vaak samen met verschuivingen in de politieke opstelling. Het verschil tussen 'de Palestijnen' en 'het

4. Resolutie $3210(X X I X)$. 
Palestijnse volk' lijkt niet groot, maar de aan volkeren toe te kennen rechten zijn anders dan de rechten voor groepen. Het is voor een goed begrip van de aan volkeren toe te kennen rechten nuttig aan het begrip 'zelfbeschikkingsrecht' aandacht te besteden.

In de belangrijkste $\mathrm{VN}$-verdragen over de Rechten van de Mens, de verdragen van New York uit 1966 (Internationaal Verdrag inzake burgerrechten en politieke rechten en het Internationaal Verdrag inzake economische, sociale en culturele rechten), werd in artikel 1 vastgesteld:

'Alle volkeren bezitten zelfbeschikkingsrecht. Uit hoofde van dit recht bepalen zij in alle vrijheid hun politieke status en streven zij vrijelijk hun economische, sociale en culturele ontwikkeling na'. Dit recht van volkeren - en niet van 'groepen' - is verankerd in het internationale recht en wordt beschouwd als een voorwaarde voor de uitoefening van individuele rechten.

Op basis van de unaniem aanvaarde resolutie 2625 uit 1970 van de Algemene Vergadering van de VN - te weten de 'Verklaring inzake Beginselen van Internationaal Recht betreffende Vriendschappelijke Betrekkingen en Samenwerking tussen Staten' - kunnen drie vormen worden onderscheiden voor de uitvoering van dit recht op zelfbeschikking. Deze zijn:

1. Een souvereine en onafhankelijke staat;

2. Vrije associatie of integratie met een onafhankelijke staat;

3. Enige andere politieke status ${ }^{5}$.

Hoewel volgens de verdragen van New York de vorm van het uitvoering geven aan het recht op zelfbeschikking door de vrije keuze van het volk wordt bepaald, werd niet beoogd elke afscheidingsbeweging te honoreren. Buiten de koloniale context werden aan het recht op staatsvorming beperkingen opgelegd. Door de Algemene Vergadering van de VN werd het recht op zelfbeschikking buiten de koloniale context aan de inwoners van Zuid-Afrika en de Palestijnen toegekend.

Het is mogelijk een onderscheid te maken tussen enerzijds externe zelfbeschikking - enige vorm van staatsvorming door afscheiding, associatie of federatie - en anderzijds interne zelfbeschikking. Bij dit laatste wordt gedacht aan een eigen plaats binnen bestaande staatsverbanden in de vorm van autonomie of zelfbestuur ${ }^{6}$. Voor inzicht in het Palestijns-Israëlisch conflict is dit onderscheid relevant.

De Israëlische regering zou in de Camp Davidakkoorden het principe van autonomie of zelfbestuur voor de Palestijnen aanvaarden ${ }^{7}$. Daarnaast bleek Israel bereid tot het aanvaarden van een oplossing in de vorm van een federatie van de Palestijnen in Jor-

5. Het vijfde principe van deze verkllaring; zie ook Cassese, 1988, p. 134 die deze vorm onder het begrip externe zelfbeschikking rangschikt.

6. College Th. van Boven an de Rjjksuniversiteit Limburg op 25 april 1989.

7. Volgens twee Franso juristen worden in de Camp Davidakkoorden de uitwoering van het recht op zelfbeschikking beperkt' en thebben deze akkoorden geen betekenis (null and void) omdat het recht op zelfbeschikking deel uitmaakt wan het "jus cogens", aangehaald in Cassese, 1988, pp. 136-137; de voorstellen over autonomie in de Camp Davidakkoorden - hoe beperkt op zichzelf dan ook en was bovendien geen uitvoering an werd gegeven - passen echter wel binnen de begripsomschrijving van het 'interne zelfbeschikkingsrecht". 
daans staatswerband, de zogenaamde 'Jordaanse optie". De Palestijnen hebben steeds geijverd voor een souvereine en onafhankelijke staat. In deze onderzoeksperiode zou dat voor de PLO de vervanging van Israël door een Palestijnse staat moeten zijn. In de werklaring van Venetië werd in 1980 door de EG-lidstaten het recht op zelfbeschikking aan de Palestijnen toegekend. Tevens werd daarbij echter vastgehouden aan het voortbestaan van de staat Israël ${ }^{8}$.

Het PLO-Handvest verwierp zelfs expliciet het bestaan van het Joodse volk ${ }^{9}$. In resolutie 242 werd nog over Arabische viluchtelingen gesproken en in Israël werd lange tijd over vluchtelingen en niet over 'Palestijnen' gesproken ${ }^{10}$.

In resolutie 3236 werd door de Algemene Vergadering van de VN in 1974 het zelfbeschikkingsrecht voor het Palestijnse volk erkend waarbij Nederland zich met de andere EG-partners van stemming onthield. Voor de Nederlandse afgevaardigde ontbraken het bestaan en de rechten van de staat Israël in deze resolutie ${ }^{n}$. Deze onthouding ontmoette veel kritiek in de Tweede Kamer, die vond dat Nederland tegen deze resolutie had moeten stemmen. Van der Stoel verdedigde zich met het argument dat hij niet de indruk wilde wekken de politieke dimensie van het Palestijns probleem te ontkennen. Hij wilde Nederland niet afzonderen van de overige EG-lidstaten. Bij een Nederlandse tegenstem zou het net lijken alsof onthouding van de overige EG-partners een net niet instemmen betekende ${ }^{12}$.

Daarmee gaf Van der Stoel aan dat het Nederlandse gedrag vooral in relatie met de overige EG-partners moest worden bezien en niet zozeer in vergelijking met andere min of meer gelijkgerichte staten, zoals Noorwegen dat tegenstemde. De in het vorige hoofdstuk gesignaleerde wijziging dat Nederland na 1973 vooral niet wilde afwijken van zijn EPS-partners vindt hier een eerste bevestiging. Voor bijvoorbeeld Frankrijk gold dat minder. Het onthield zich dezelfde dag - 22 november 1974 - bij een stemming (resolutie 3237) waarin aan de PLO de waarnemersstatus in de Algemene Vergadering werd toegekend. Frankrijk verklaarde zich toen al voorstander van een vaderland voor de Palestijnen. De overige EG-staten zouden pas drie jaar later de Fransen volgen. In 1974 stemden de andere acht EG-lidstaten tegen het toekennen van de waarnemersstatus aan de PLO ${ }^{13}$. De instructie van Van der Stoel aan de Nederlandse permanente vertegenwoordiger bij de VN over het PLO-waarnemerschap hield in dat Nederland tegen de waarnemersstatus was, maar dat bij de stemming wel rekening moest worden gehouden met de opstelling van West-Duitsland. Op het moment van de stemming kreeg de

8. Zie ook Akehurst 1987, p. 297 die stelt dat "The General Assembly's extension of the right of selfdetermination to the Palestinians and the inhabitants of Sonth-Africa, coupled with its fallure to extend that right to other 'non-colonial' peoples, has increased rather than reduced the problem of double standards'.

9. In artikel 20 van het Palestijnse Nationale Handwest staat onder meer: "Evenzo zijn de Joden miet éc wolk met een onathankelijke persoonlijkheid'.

10. Israëls oud-premier Meïr noemde zichzelf bijvoorbeeld Palestijn en doelde daarmee op haar immigratie wan voor 1948 nar Palestina; in haar wisie paste geen Palestijnse politieke beweging. In een interview in The Sunday Times op 15 juni 1969 zou Meï gezegd hebben dat een Palestijins wolk miet bestond, maar plaatste dat wel in de context van 1948, Demandt, 1989, p. 56 en 73.

11. Stenwerklaring Kaufmann op 22 november 1974.

12. Handelingen Tweede Kamer, zitting 1974-1975, 27 nowember 1974, pp. 1582-1583.

13. Zie ook Soetendorp, 1982, pp. 152-157. 
permanente vertegenwoordiger geen contact met de minister ondat deze toen onderweg was van zujn huis naar het departement ${ }^{14}$.

Tijdens de 30ste Algemene Vergadering in 1975 bleek buj de stemmingen nog duidelijker dat de EPS-partners niet eensgezind optraden ten aanzien van het Arabisch-Israelisch conflict. Een driedeling kan worden gemaakt:

1. Frankrijk, Italie en Ierland gaven enige steun aan de Palestijnse wensen.

2. Nederland, Verenigd Koninkrijk, West-Duitsland steunden de Israëlische opvattingen.

3. De overige EG-landen namen een middenpositie in ${ }^{15}$.

Bij een resolutie uit 1975 waarin de PLO op voet van gelijkheid aan een internationale vredesconferentie zou moeten kunnen deelnemen en de PLO als de vertegenwoordiger van de Palestijnen werd beschouwd (resolutie 3375), stemde Nederland met de Britten en Duitsers tegen, terwijl de overige EG-lidstaten zich van stemming onthielden. Ook bij een resolutie waarin Kissingers "stap voor stap diplomatie" werd veroordeeld (3414) en bij de instelling van een commissie ter verwezenlijking van de Palestijnse rechten uit resolutie 3236 (3376) stemde Nederland met vijf EG-lidstaten tegen. Van de EG-landen onthielden alleen Frankrijk, Italië en Ierland zich van stemming ${ }^{116}$

Hoewel alle EG-staten tegen de beruchte resolutie stemden waarin zionisme met racisme werd gelijk gesteld, onthield Frankrijk als enige van de EG zich van stemming over een resolutie over het actie-programma waarin aan die resolutie werd gerefereerd; de overge EG-partners stemden tegen (resolutie $3419 \mathrm{c}$ ).

In 1974 berustte ten tijde van de Algemene Vergadering het voorzitterschap van de EPS bij Frankrijk en in 1975 bij Italie. Dat belette in 1974 de Fransen niet een afwijkend stemgedrag te tonen, terwijl in 1975 de Italiaanse afgevaardigde zich namens de EPS uitsprak voor een 'nationale identiteit' van het Palestijnse volk maar tegelijkertijd namens de eigen regering, overigens evenals de Fransen, opteerde voor een Palestijns vaderland.

In 1976 bekleedde Nederland tijdens de 31ste vergadering van de Algemene Vergadering het voorzitterschap van de EPS. De vergadering in 1975 had een grimmig karakter doordat werd aangestuurd op de verwijdering van Israël uit de VN. Het dieptepunt was de "zionisme $=$ racisme" resolutie. In 1976 waren met het oog op de presidentsverkiezingen in de VS (zie daarover de op Quandt gebaseerde cyclus in 1.3.2.1) van Amerikaanse zijde geen nieuwe vredesinitiatieven ontplooid. Dat gaf de Europeanen de mogelijkheid een rol in het Midden-Oosten te vervullen. De VS waren in de Veiligheidsraad bovendien, wat hun steun aan Israël betreft, in toenemende mate in een geisoleerde positie terechtgekomen. Aan Europese zijde bestonden ook aarzelingen (zie 3.1) om vlak voor de Amerikaanse en Israelische verkiezingen met een Europees initiatief voor de dag te komen. Weliswaar werd in 1976 nog geen afzonderlijke verklaring uitgegeven, maar de gewijzigde opvattingen over het Midden-Oostenvraagstuk kwamen ditmaal. wel naar buiten op de Algemene Vergadering. 'Van Nederlandse zijde is de samen-

14. College Kaufmann aan de Rijksuniversiteit Limburg op 28 januari 1986.

15. Zie ook Greilsammer, 1981, pp. 155-156.

16. Zie ook Soetendorp, 1982, pp. 157-160. 
werking der Negen zoveel mogelijk bevorderd om aldus met gebundelde krachten een constructieve bijdrage aan de werkzaamheden van de Algemene Vergadering te leveren', aldus Van der Stoel ${ }^{17}$.

De bijdragen van de Nederlandse minister op 28 september 1976 en de Nederlandse permanente vertegenwoordiger op 7 december 1976 aan het debat namens de Negen vormen de basis van de verklaring van de Europese Raad van juni 1977. Van der Stoell zei: 'a solution of the conflict in the Middle East will only be possible if the legitimate rights of the Palestinian people to give effective expression to its national identity is translated into fact' ${ }^{18}$. Kaufmann stelde 'that the exercise of the right of the Palestinian people to the effective expression of its national identity could involve a territorial base in the framework of a negotiated settlement' ${ }^{19}$. De oplossing van het Palestijnse probleem werd nu van beslissende betekenis - "revêt un poids déterminant" ${ }^{20}$ - voor de oplossing beschouwd waarbij voor de Palestijnse identiteit 'een territoriale basis moet worden gevonden' ${ }^{21}$.

Bij de afzonderlijke stemmingen bleken de lidstaten van de EG weer verdeeld te stemmen, waarbij anders dan in 1975 Denemarken zich ditmaal bij de meer pro-Israëlische groep van Nederlanders, Britten en Duitsers schaarde (resolutie 31/61). De meer proPalestijnse groep bleef bestaan uit Frankrijk, Italië en Ierland (resolutie 31/20) ${ }^{22}$.

\subsubsection{Europese Politieke Samenwerking}

In 1974, 1975 en 1976 werden vanuit de EPS geen verklaringen over het ArabischIsraelisch conflict gepubliceerd. De harmonisatie van standpunten werd. well voortgezet en in de Algemene Vergadering van de Verenigde Naties kon wel namens de Negen een standpunt worden geuit. Bij de stemmingen aldaar kwamen de onderlinge verschillen in standpunt aan het licht.

Tijdens de Europese Raad van juni 1977 werd een gemeenschappelijke verklaring vastgesteld. Deze wordt in de volgende paragraaf - 3.1.2.1 - behandeld. Vervolgens wordt de reactie aan Europese zijde op de Camp Davidakkoorden - 3.1.2.2 - beschreven. De harmonisatie van standpunten leidde in juni 1980 tijdens de Europese Raad tot de 'verklaring van Venetië'. Het betrof de meest uitgewerkte gemeenschappelijke stellingname die binnen de Europese Politieke Samenwerking over het conflict in het Midden-Oosten tot stand kwam. De inhoud en totstandkoming van deze verklaring van Venetië wordt beschreven in 3.1.2.3. Tenslotte zal de aandacht gericht worden

17. In zijn 'Ten Geleide' bij het verslag van de 31ste zitting van de Algemene Vergadering der VN, Ministerie van Buitenlandse Zaken, deel 117, 1977.

18. Van der Stoel op 28 september 1976.

19. Kaufmann op 7 december 1976 .

20. Kaufmann op 18 november 1976.

21. Van der Stoel op 3 februari 1977 in de Handelingen Tweede Kamer, zitting 1976-1977, p. 2956; met dit imperatief ging Van der Stoel een stapje verder; een voorgestelde wijziging naderhand van de Handelingen in 'zou kunnen' werd door de stenografische dienst geweigerd:

22. De totale EG-groep schoof iets op bij de resolutie over Israëlische compensatie aan Syrie vanwege de verwoesting van Kuneitra. Zij onthield zich dit jaar van stemming, terwijl zij het vorig jiar tegenstemde. 
- 3.1.2.4 - op de Nederlandse inbreng en het resultaat van deze Nederlandse inbreng op de gepubliceerde verklaringen over het Arabisch-Israëlisch conflict in EPS-verband.,

\subsubsection{Europese Raad van juni 1977}

In januari 1977 trad de nieuwe Amerikaanse regering van president Carter met Vance op Buitenlandse Zaken aan. Carter koerste begin 1977 aan op een hervatting van de Geneefse Conferentie en koos daarbij voor een allesomvattende overeenkomst over algemene principes. Hij nam daarbij afstand van de benaderingswijze van Kissinger, onder de presidenten Nixon en Ford, die voor kleine stappen had gekozen ${ }^{23}$.

In het eerste half jaar van 1977 bekleedde het Verenigd Koninkrijk het voorzitterschap van de EPS en reeds bij de eerste bijeenkomst van de ministers van Buitenlandse Zaken op 31 januari 1977 te Londen zou een verklaring over het Midden-Oosten worden opgesteld ${ }^{24}$. Het initiatief daartoe zou van de West-Duitsers zijn uitgegaan en inhoudelijk de Palestijnse kwestie betreffen ${ }^{25}$. Na afloop werd geen verklaring gepubliceerd. Wel was er overeenstemming bereikt en de pers maakte gewag van een geheime verklaring. Een geheime verklaring is in feite een contradictio in terminis; een verontruste Tweede Kamer voelde daarom minister Van der Stoel aan de tand. Hij verklaarde dat de lidstaten gebonden waren aan hetgeen in Londen was afgesproken maar gaf geen opheldering over wat was afgesproken ${ }^{26}$. Later werd 'het afgesprokene' als een werkdocument bestempeld dat zou dienen als basis voor een toekomstige publikatie ${ }^{27}$. Het afgesprokene lekte uit en het Egyptische dagblad Al Ahram publiceerde de tekst op 21 februari $1977^{28}$. Daarin stond dat Israël de rechten van het Palestijnse volk moest erkennen en dat deze rechten tot uitdrukking moesten komen in een 'nationale entiteit' ${ }^{29}$. Onderschreven werd de resolutie van de Algemene Vergadering van 9 december $1976^{30}$ waarin op een nieuwe vredesconferentie vóór maart 1977 werd aangedrongen. De belangrijkste verschuiving was dat nu niet meer zoals in 1976 over een Palestijnse identiteit maar over een Palestijnse entiteit werd gesproken. Een half jaar later zou de term entiteit worden vervangen door vaderland - 'homeland' - voor het Palestijnse volk. Deze laatste verschuiving werd vergemakkelijkt doordat Carter zich op 16 maart 1977 eveneens voor een 'homeland' voor de Palestjnse vluchtelingen uitsprak ${ }^{31}$.

In januari hadden de door socialisten gedomineerde regeringen van West-Duitsland, het Verenigd Koninkrijk en Nederland publikatie nog kunnen tegenhouden ${ }^{32}$, ondermeer op Amerikaans verzoek en waarschijnlijk ook met het oog op de Israëlische parlementsverkiezingen. Onverwachts bleek op 17 mei 1977 dat de socialistische regering voor het

23. Quandt, 1986, p. 40,

24. Het Parool, 29-1-1977.

25. Het Parool 29-1-1977, Haagsche Courant 31-1-1977, Lo Monde 2-2-1977.

26. Handelingen Tweede Kamer, zitting 1976-1977, pp. 2956-2966 van 3 februari 1977.

27. Europe, 23-3-77, 2161.

28. Le Monde, 23-2-1977: zie bijlage 8 .

29. Bevestiging door Greilsammer en Weiler 1984, p. 138.

30. Resolutie 31/62.

31. Quandt, 1986, p. 48.

32. Lo Monde, 2-2-1977. 
cerst niet meer over een meerderheid in het Israëlische parlement kon beschikken en een Likud regering onder leiding van Begin in het zadel kwam.

Inmiddels was bovendien het Amerikaanse standpunt over de Palestijnse kwestie opgeschoven. Carter beijverde zich voor het bijeenroepen van de Geneefse conferentie. Hij rekende erop daar concrete reselltaten te kunnen bereiken. Terughoudendheid aan Europese zijde om tot publikatie over te gaan was in juni 1977 niet meer nodig (zie bijlage 9).

\subsubsection{Europese reactie op Camp David}

President Carter wilde een actieve bijdrage leveren aan de oplossing van het ArabischIsraëlisch conflict. Een eerste teleurstelling was dat de meer genatigde socialistische Israelische leiders na mei 1977 niet meer in de Israellische regering zaten. Voor Carters adviseur Brezinski echter konden de VS Begins verkiezingsoverwinning ook benutten, omdat de Amerikaanse president nu meer druk op de Israëlische regering kon uitoefenen. Carter zou immers bij het uitoefenen van deze druk kunnen rekenen op steun van de Israëlische oppositie en de meerderheid van de Joodse gemeenschap in de VS.

De VS stuurden daarom aan op een spoedige bijeenroeping van de Geneefse vredesconferentie. Tezamen met de Sovjetunie - communiqué van 1 oktober 1977 - verstuurden de VS de uitnodigingen. Het probleem was echter dat zowel de Israëlische regering als de Egyptische president gekant waren tegen deze conferentie. Sadat gaf de voorkeur aan Kissingers benadering; hij was tegen de betrokkenheid van de Sovjetunie en tegen één Arabische delegatie waarin Syrië elke vooruitgang kon dwarsbomen. De Israëlische regering verzette zich met steun van het Amerikaanse congres en de Amerikaanse Joodse gemeenschap tegen de Russisch-Amerikaanse uitnodiging en Dayan wist Carter te bewegen de uitnodiging te herzien. Sadat was daarover ontstemd. Hij weigerde op de veranderde uitnodiging in te gaan en wilde liever direct met de Israëil's onderhandelen.

Op 9 november 1977 zei Sadat in het Egyptische parlement bereid te zijn in Jeruzalem met de Israëli's te praten. Begins uitnodiging van 15 november werd via Amerikaanse ambassadeurs aan Sadat overhandigd. Op 19 november vloog Sadat naar Israël. Een aantal barrières leek doorbroken maar het daarop volgende overleg verzandde. Het vertrouwen nam snel af en op 18 januari $1978 \mathrm{kwam}$ het Israëlisch-Egyptisch overleg tot een eind. De VS - die kort buiten spel hadden gestaan - werden nu door Sadat gevraagd met een compromis een doorbraak te bewerkstelligen. Volgens vice-president Mondale konden de VS succesvol zijn door druk uit te oefenen op twee van Begins kwetsbare punten: het nederzettingenbeleid en de interpretatie van resolutie 242 . Zowel de Israëlische oppositie als de binnenlandse publieke opinie in de VS waren namelijk tegen de door Begin voorgestane uitbreiding van het aantal nederzettingen en diens uitsluiting van de Westelijke Jordaanoever van teruggave. Helaas bleek voor Carter dat Begin juist op deze twee punten tot geen enkel compromis bereid was. Bovendien bleek Sadat minder geïnteresseerd te zijn in de Westelijke Jordaanoever en de Gazastrook. Hij richtte zich voornamelijk op de teruggave van de Sinaï. Carter zou in een politiek kwetsbare positie kunnen komen wanneer hij als meer 'pro-Arabisch' dan Sadat zou worden gezien. Vele bemiddelingspogingen van de VS leverden niets op en de situatie verslechterde toen na een Palestijnse aanslag de Israëlische invasie in maart 1978 in 
Libanon plaatsvond. Ook Carter achtte eind juli Sadats vredesinitiatief mislukt. Carter besliste, ondanks andersiluidende adwiezen, tegen een confrontatiepolitiek tegenover Begin. Uiteindelijk koos Carter voor het bijeenroepen van Egyptenaren en Israëli"s om te onderhandelen op zijn buitenverblijf te Camp David. Hij had daarvan hogere verwachtingen dan zijn adviseurs. De adviseurs van Carter meenden dat een algemene gezamenlijke verklaring het maximaal haalbare zou zijn, vooral gezien de Pallestijnse problematiek en de toekomst van de Westelijke Jordaanoever. Sadat verwachtte tevoren op de steun van Carter te kunnen rekenen en daardoor van Israël concessies te verkrijgen. Carter meende daarentegen dat Sadat eerder zou toegeven op het punt van de Westelijke Jordaanoever dan Begin. Zo werd vooral Sadat het mikpunt van concessies. Carter beoogde een geschreven Israëlisch-Egyptische overeenkomst en wist die uiteindelijk ook te bereiken. De inmiddels van verschillende kanten minutieus door Quandt, Carter, Kamel, Dayan en anderen - vanuit participerende observatie - beschreven Camp Davidonderhandelingen zijn interessant en leerzaam voor het beter begrijpen van zowel processen in de internationale politiek als voor de problematiek van het Midden-Oostenconflict. Voor deze studie telt alleen het resultaat. Onderzocht zal worden op welke wijze de EG en Nederland daarop gereageerd hebben. In het besluitvormingsproces waarin de Camp Davidakkoorden en het Egyptisch-Isrälisch vredesverdrag tot stand kwamen, heeft het Europa van de Negen geen enkele rol gespeeld. Geen der deelnemers aan de Camp Davidonderhandelingen heeft enige referentie aan de EG in zijn publikatie gegeven.

Direct na Sadats bezoek aan Jeruzalem reageerden de negen ministers van Buitenlandse Zaken positief op deze historische ontmoeting. De werkelijke wrede zou volgens hen echter tot stand moeten komen op basis van de beginselen die de Europese Raad op 29 juni 1977 had geformuleerd. In deze verklaring spraken de Negen 'de hoop uit dat het binnenkort mogelijk zal zijn de conferentie van Genève bijeen te roepen" ${ }^{33}$. Daarbij] werd voorbij gegaan aan Sadats beweegredenen, die gericht waren op directe onderhandelingen met de Israëli's. Weliswaar waren ook de Amerikanen geporteerd voor de Geneefse conferentie - ten onrechte stelt Ifestos dat deze verklaring haaks stond op de Amerikaanse benadering ${ }^{34}$ - en was Sadat wanneer de Palestijnen er ook bij betrokken zouden worden nog wel bereid naar Genève te gaan. Na de Israëlische druk op de VS van 5 oktober besloot Sadat echter tot zijn eigen doorbraak buiten Genève om ${ }^{35}$. Aan Europese zijde bestond daarvoor weinig begrip. Anders zouden de woorden 'comprehensive negotiations leading to a just and lasting overall settlement' niet zijn gebezigd in de EG-verklaring van 22 november 1977. Frankrijk meende dat met Sadats reis geen oplossing voor het Palestijnse probleem zou worden gevonden en had liever geen EPSverklaring uitgegeven. Weiler en Greilsammer halen 'commentatoren' aan die beweer-

33. Verklaring van 22 november 1977 , Brussel, Bull, EG 11 - 1977, no. 2.2.4.

34. Iffestos, 1987, p. 144.

35. In zijin autobiografie - In Search of identity - zwijgt Sadat (1977) over de oorzaak. Quandt (1986) meent dat niet het Amerikans-Russisch communiqué maar de gebeurtenissen daarna Sadat tot zijn beslissing hebben gebracht, zie pp. 124, 125, 131, 132 en 134 . 
den dat Amerikaanse druk heeft bewerkstelligd dat Sadats initiatief door de EPS toch werd verwelkomd ${ }^{36}$.

Nadat de weg van het 'Camp Davidproces' was ingeslagen die in feite tot het Egyptisch-Israëlisch vredesakkoord leidde, werd elke aansporing tot het bijeenroepen van de Geneefse conferentie en elke aamidrang tot een allesomvattende regeling ('comprehensive settlement') als een dwarsbomen van het door de VS op gang gebrachte vredesproces beschouwd. De Camp Davidakkoorden van 17 september 1978 en het Egyptisch-Israelisch vredesverdrag van 26 maart 1979, onder leiding van de Verenigde Staten tot stand gekomen, zetten de Westeuropese landen en de Sovjeturie buiten spel. Ze werden in de rest van de Arabische wereld - met uitzondering van Soedan en Oman - verworpen. Ook de Derde Wereld keerde zich tegen de overeenkomsten en bij stemmingen in de Verenigde Naties was de uitkomst van de stemming voorspelbaar ${ }^{37}$.

Zo werd in resolutie 34/70 door de Algemene Vergadering van de Verenigde Naties alle deelovereenkomsten en aparte verdragen veroordeeld. Dat geschiedde bij een overweldigende meerderheid van 102 tegen 17 bij 20 onthoudingen. Frankrijk onthield zich van stemming, de overige EG-lidstaten stemden tegen ${ }^{38}$. Resolutie $34 / 65 \mathrm{~B}$ was nog scherper gesteld. Alle deelakkoorden en aparte verdragen werden daarin sterk veroordeeld als zijnde een flagrante schending van de rechten van het Palestijnse volk en de beginselen van het Handvest. Bovendien werd in punt 4 van deze resolutie gesteld 'that the Camp. David accords and other agreements have no validity in so far as they purport to determine the future of the Palestinian people and of the Palestinian territories occupied by Israel since $1967^{, 39}$.

Aanvankelijk steunden de EG-lidstaten het Camp Davidproces. Direct na de ondertekening van de Camp Davidakkoorden reageerde de Duitse voorzitter van de EPS na afloop van een bijeenkomst van de ministers van Buitenlandse Zaken zelfs zeer enthousiast op het behaalde resultaat. De presidenten Carter en Sadat en premier Begin werden geprezen. Greilsammer en Weiler meenden dat het succes van Camp David de lidstaten van de EPS die het Amerikaans initiatief steunden, toestond 'to get their revenge' met deze verklaring ${ }^{40}$. Anderzijds werd het enthousiasme enigszins beteugeld doordat werd gehoopt op een 'comprehensive peace' waaraan alle betrokken partijen zoudlen meewer$\mathrm{ken}^{41}$. Hoewel Carter en Sadat hoopten dat met name Jordanië zich bij de akkoorden zou aansluiten, lag dat niet erg voor de hand ${ }^{42}$.

Op de dag van de ondertekening van het Egyptisch-Israellisch vredesverdrag - 26 maart 1979 - werd onder Frans voorzitterschap door de EG een gereserveerde reactie gegeven. Enerzijds werd geconstateerd 'dat het verdrag een correcte toepassing van de

36. Greilsammer and Weiler 1984, p. 140.

37. 102 voor, 17 tegen bij 20 onthoudingea.

38. Resolutie 34/70 van 6 december 1979; de Dominicaanse Republiek stemde tegen maar deelde achteraf het secretariat van de VN mee, dat het had willen woorstemmen. Yearbook of the United Nations 1979, pp. 375-377.

39. Met ruime meerderheid van 75 voor en 33 tegen bij 37 onthoudlingen werd dere resolutie annvaard. Frankrijk onthield zich weer van stemrning terwijl de overige EPS-partners tegenstemden. Resolutie. $34 / 65 \mathrm{~B}$ van 29 november 1979. Yearbook of the United Nations 1979, pp. 377-378.

40. Greilsammer, 1981 , p. 159; Greilsammer en Weiler, 1987, p. 42.

41. Verklaring van 19 september 1978 , Bull, E.G. 9-1978, no. 2.2.8.

42. Kamel, 1986, pp $365,376$. 
beginselen van deze resolutie - resolutie 242 - op de betrekkingen tussen Egypte en Israël vormt'. Nederland had voor deze passage geijverd; het was het uiterste dat de Fransen konden accepteren ${ }^{43}$.

Anderzijds werd het recht van het Palestijnse volk op een vaderland beklemtoond en werd opgemerkt dat een globale overeenkomst zou moeten volgen waaraan ook de vertegenwoordigers van het Palestijnse volk zouden deelnemen; tenslotte werd de Israelische nederzettingenpolitiek veroordeeld ${ }^{44}$.

Kort daarop volgde onder het Franse voorzitterschap een nieuwe verklaring die in vergelijking met de vorige nog wat sterker was aangezet. Na cen opsomming van de beginselen uit de verklaring van juni 1977 werd de Israëlische regering als een obstakel voor de vrede afgeschilderd. Deze kritiek betrof met name het nederzettingenbeleid en het bezet houden van gewelddadig veroverd grondgebied ${ }^{45}$. De vraag lijkt gewettigd of dit laatste kritiekpunt wel zo opportuun was op een moment dat Israell zich bereid had verklaard het grootste deel van de bezette gebieden te ontruimen. Bovendien waren de Europese wensen niet verenigbaar met de inhoud van de Camp Davidakkoorden, waarin werd geopteerd voor Palestijnse autonomie. De nog niet vastgelopen onderhandelingen over deze autonomie werden niet bevorderd door deze desiderata voor een vaderland voor het Palestijnse volk en het betrekken van de vertegenwoordigers van het Palestijnse volk bij een algemene regeling. In feite werd met deze verklaring afstand genomen van de Camp Davidbenadering waaraan niet meer werd gerefereerd, maar werd teruggegrepen op de Europese benadering uit $1977^{45}$.

Sicherman ziet deze verklaring als een poging van Carter om via West-Duitsland middels de EG de Israëli's tot meer vaart in de autonomie onderhandelingen te bewegen ${ }^{47}$. Dat lijkt niet erg waarschijnlijk gezien ondermeer Schmidts verwijt aan Carter waarin hij "claimed that Vance had failed to carry out a promise to amend resolution $242^{\prime}{ }^{49}$. Carter moest niet denken dat de BRD de 51ste staat van de VS was en dat liet Schmidt blijken in wat Carter noemde 'the most unpleasant exchange I ever had with a foreign leader during my four years in office ${ }^{49}$.

Daarnaast riep deze verklaring die gezamenlijk door Duitsers en Fransen was voorbereid, bij de Israëli's een totale afwijzing op ${ }^{50}$. De Europese standpuntbepaling toont juist een afwijzing van de Amerikaanse benadering en een verschuiving van de Acht naar het Franse standpunt. De door de Fransen voorgestane eigen Europese rol in het Midden-Oostenconflict zou vervolgens in de komende jaren verder ontwikkeld worden.

43. Interwiew met Rutten op 10 februari 1987.

44. Verklaring van 26 maart 1979, Bull, EG 3-1979, no. 2.2.74.

45. Verklaring van 18 juni 1979, Bull, EG, 6-1979, no. 2.2.59. Volgens Feldman, 1984, p. 172, zou

West-Duitsland bij deze verklaring ean leidende rol hebben vervuld.

46. Artner, 1980, p. 433.

47. Sicherman, 1980, pp. 852-853.

48. Vit Carters dagboek van 21 juni 1980 , in Carter, 1982, p. 537.

49. Carter, 1982, p. 538.

50. Greilsammer, 1981 , p. 161 . 


\subsubsection{De verklaring van Venetië}

Op de bijeenkomst van de Europese Raad, in juni 1980, waren de regeringsleiders en ministers van Buitenlandse Zaken het erover eens dat de stijgende spanningen in het Midden-Oosten een ernstig gevaar vormden. Dit maakte een algehele oplossing voor het Arabisch-Israëlisch conflict meer dan ooit dringend noodzakelijk. Er werd een verklaring opgesteld - de verklaring van Venetiê - waarin onder meer het zelfbeschikkingsrecht voor het Palestijnse volk werd erkend. Bovendien werd een "vredesmissie" naar het Midden-Oosten geëntameerd. Op grond van de resultaten van deze "vredesmissie" werd een Europees initiatief in het vooruitzicht gesteld. Dat zou het begin kunnen worden van een actieve en daadwerkelijke bemoeienis door de Europese Negen met het Arabisch-Israëlisch conflict. In deze paragraaf zal de totstandkoming van deze verklaring van Venetië worden beschreven. Tevens zal de Nederlandse inbreng in deze besluitvorming worden behandeld. Het vervolg op de verklaring van Venetië, te weten de Europese vredesmissie, komt in hoofdstuk vier aan de orde.

Op de 34ste Algemene Vergadering 1979 van de Verenigde Naties sprak de Ierse minister O'Kennedy namens de Negen. Hij zei dat de principes uit de Europese verklaring van juni 1977 moesten worden geaccepteerd door 'all those involved - including the Palestine Liberation Organization - as the basis for negotiation of a comprehensive settlement in which all the parties will play their full part'. Hij voegde daaraan toe dat the Palestinian people, who are entitled within the framework set by a peace settlement, to exercise their right to determine their own future as a people" ${ }^{51}$.

In deze toespraak, waarin volgens Van der Klaauw het Nederlandse standpunt volledig werd weergegeven, werd voor het eerst door de Negen de PLO met name genoemd als deelnemer aan het onderhandelingsproces. Bovendien werd hier in feite voor het eerst het zelfbeschikkingsrecht voor de Palestijnen erkend. Deze toespraak kan als de voorloper van de verklaring van Venetië worden beschouwd. In bijlagen 10 en 11 zijn beide teksten afgedrukt. Ondanks de vele beraadslagingen die nog zouden volgen voordat de verklaring van Venetiè werd vastgesteld, kan ik geen inhoudelijk verschil ontdekken tussen deze verklaring en de toespraak van de Ierse minister van Buitenlandse Zaken. Volgens de Nederlandse permanente vertegenwoordiger, Scheltema, vond in New York over deze toespraak geen overleg tussen de Negen plaats. De toespraak was als het ware 'voorgekookt' in de EPS ${ }^{52}$.

De PLO werd in de verklaring van Venetië nog niet erkend als de enige vertegenwoordiger van het Palestijnse volk maar zou wel bij de onderhandelingen moeten worden betrokken. Een niet onbelangrijke clausulering hierbij was dat alle partijen de 'Europese beginselen' bij het bereiken van een oplossing moeten naleven. Dat betekende dat de PLO het bestaansrecht van Israël en dat Israël het zelfbeschikkingsrecht voor het Palestijnse volk moest erkennen.

Deze wederzijdse erkenning was het voornaamste doel dat de Negen beoogden te bereiken met hun vredesmissies die op de verklaring van Venetië volgden. Het op gang brengen van deze vredesmissies was het belangrijkste nieuwe punt uit de verklaring van Venetiè en kan worden gezien als een eerste stap van een verbaal naar een daadwerke

51. Rede van 25 september 1979, zie bijlage 4, in: Verslag B.Z., deall 124, II, p. 32-33, 1980 .

52. Interview met Scheltema op 8 augustus 1989. 
lijk beleid. Het verschil is dat niet louter werd volstaan met de publikatie van verklaringen over het Arabisch-Israellisch conflict, maar dat de reacties van de betrokken partijen op het gemeenschappelijke Europese standpunt werden verzameld. Op grond van de reacties zou vervolgens de vorm van een eventueel Europees initiatief worden bepaald. Het was nog niet zeker of het ook tot een Europees initiatief zou komen. Op dat moment bleef de voorgenomen activiteit nog beperkt tot een 'fact-finding" missie.

Vervolgens doet de vraag zich voor hoe de Europese optie zich tot die van de Amerikanen verhield. De Europeanen, zo constateerden we in de vorige paragraaf, hadden steeds meer afstand genomen van de Camp Davidbenadering. Aan Camp David werd niet langer gerefereerd. Een allesomvattende regeling moest het uitgangspunt zijn. Bij de stemming in de Algemene Vergadering in 1979 over resoluties tegen Camp David hebben echter acht van de negen lidstaten tegengestemd, alleen Frankrijk onthield zich steeds van stemming ${ }^{53}$. Ifestos ziet in de schuivende stellingen over de periode 1974 1979 der Europeanen een bepaalde mate van 'creeping antagonism' ten opzichte van de Amerikaanse positie inzake het Midden-Oostenconflict ${ }^{54}$. Zo werden de Camp Davidakkoorden uit 1978 nog wel verwelkomd maar op het Egyptisch-Israëlisch vredesverdrag uit 1979 werd koel en afstandelijk gereageerd. Bovendien stelden de Europeanen met nadruk een 'allesomvattende vrede' voor, die in tegenspraak was met de strekking van het door de Amerikanen gesteunde vredesverdrag. Openlijke verwerping van Camp David vond niet plaats vanwege een beduchtheid de Amerikanen te zeer voor het hoofd te stoten. Deze beduchtheid vloeide voort uit de Westeuropese afhankelijkheid van de VS op het terrein wan veiligheid. Bovendien was een deel van de EPS-partners zich er terdege van bewust dat zij niet in staat waren de Amerikaanse bemiddelaarsrol in het Midden-Oostenconflict over te nemen.

Het is opvallend dat men zich in de EPS ten aanzien van het Midden-Oosten vooral bezighield met de reactie van de VS en dat veel minder werd stilgestaan bij de vraag naar de ontvankelijkheid van de Europese plannen bij de diverse partijen in het MiddenOostenconflict. Tekenend hiervoor is het antwoord van premier Van Agt op de vraag of hij tevreden was met de verklaring van Venetië; hij antwoordde dat hij dacht dat de verklaring voor de VS acceptabel zou zijn ${ }^{55}$. Allen en Smith trekken uit hun studie de conclusie dat 'the Middle East has come to serve as a testbed for some of the most fundamental of these uncertainties' waarbij ze met onzekerheden doelen op de rollen van de EG en de VS in het internationale systeem waarin de EG zich is gaan ontpoppen als een economische rivaal en potentiële politieke concurrent van de $\mathrm{VS}^{56}$.

Binnen de Negen bestond geen eensgezindheid ten aanzien van de gewenste relatie met de VS. Deze verschillen in opvatting, tezamen met de verschillende nationale oriëntaties van de Negen ten opzichte van het Midden-Oosten, bepaalden de inhoud van de gemeenschappelijke verklaringen over het Midden-Oosten. De nationale oriëntaties vonden

53. Resolutie $34 / 70$ (102 voor, 17 tegen, 20 onthoudingen) en resolutie $34 / 65$ B (75 voor, 33 tegen, 37 onthoudingen),

54. Ifestos, 1987 , p. 350 .

55. De Volkskrint, 14-6-1980.

56. Allen and Smith, 1984, p. 208-209. 
deels weer hun oorsprong in de politieke geschiedenis en hedendaags problematiek in de lidstaten van de Gemeenschap. Zo hebben de Duitsers vanwege hun geschiedenis zich niet alleen in de internationale politiek maar vooral in de kritiek op Israell terughoudend opgesteld. Anderzijds hebben de Duitsers als - toen nog - gedeelde natie het voortouw genomen in de erkenming van het zelfbeschikkingsrecht van de Palestijnen. Ook de relatie met de geallieerden en in het bijzonder de veiligheidsgarantie van de VS speelden, gezien Duitslands geografische ligging, een cruciale rol. Ook een actieve 'Ostpolitik' kon slechts gedijen bij instandhouding van goede relaties met het Westen. Anderzijds heeft de binding met Frankrijk weer tot een grotere afstand tot de VS geleid. De Britten met een traditioneel sterke Atlantische band hadden toch problemen met de sterke geinnolveerdheid van de VS in het door hen van oudsher grotendeels als 'hun Midden-Oostendomein' beschouwde gebied. De mogelijkheid om door middel van de EPS weer een grotere rol in de internationale politiek te kunnen spelen had ook de instemming van de Britse socialisten, die overigens huiverig stonden tegenover de EG. Van erkenning van de PLO waren de Britten daarentegen zeer afkerig, met het oog op de rol van de IRA in Noord-Ierland.

Wanneer we de Fransen en de Amerikanen als de tegenover elkaar staande krachten beschouwen inzake het Midden-Oosten in de periode 1973-1981, is met name de positie wan de andere twee grote Europese staten voor de uitkomst van een Europese stellingname van belang. De coalitie-vorming binnen de Negen verschilt per vraagstuk en deze verschilt bovendien per onderdeel binnen een vraagstuk. Nederlands rol daarbinnen zal in de volgende paragraaf worden behandeld. De hierboven kort geschetste posities van de Bondsrepubliek Duitsland en het Verenigd Koninkrijk leidden er ondermeer toe dat in de verklaring van Venetiê bijvoorbeeld de PLO niet als vertegenwoordiger van het Palestijnse volk werd erkend (Britse bezwaren) en dat het zelfbeschikkingsrecht voor het Palestijnse volk werd erkend (Duitse wensen).

Bezien wij nu meer gedetailleerd de totstandkoming van de verklaring van Venetië. In 1980, het laatste presidentiële jaar van Carter, werd de internationale positie van de VS verzwakt. Amerikaanse initiatieven voor een oplossing van het conflict in het MiddenOosten waren niet te werwachten, gezien de komende presidentsverkiezingen en door de crisis in Teheran waar Amerikaanse diplomaten werden gegijzeld. De VS waren gebonden aan het Camp Davidproces maar de autonomie-onderhandelingen zaten op dood spoor. De problemen rond de Perzische Golf en vooral de invasie van de Sovjetunie in Afghanistan maakten het Midden-Oosten minder stabiel. Met name de Britten wilden de gematigde Arabische landen daar binnen de Westerse invloedssfeer houden. De tweede energiecrisis van 1979-1980 versterkte aan Westere zijde deze laatste optie. Aan A rabische zijde werd ook meer waarde gehecht aan Europese betrokkenheid hetzij als een alternatief voor de twee grote mogendheden, hetzij als middel om via Europa de VS te kunnen beïnwloeden.

De Britten hoopten een islamitisch front van anti-Sovjet krachten te smeden maar kwamen na een rondreis door het Midden-Oosten van zowel de minister van Buitenlandse Zaken Carrington als de parlementaire commissie voor Buitenlandse Zaken tot de conclusie dat zulks alleen mogelijk was indien in de Palestijnse kwestie vooruitgang 
werd geboekt en ook de positie van Jeruzalem weer op de agenda werd geplaatst $t^{\text {st }}$. Carrington kondigde aan daarover een Europees initiatief te ontwikkelen ${ }^{58}$. Ook de Duitse Bondskanselier Schmidt en de Franse president Giscard d'Estaing kondigden aan met een ontwerp voor een Palestijnse staat en een voorstel over de rol van de PLO voor de dag te zullen komen ${ }^{59}$. Inmiddels was de PLO al opgewaardeerd door contacten van PLO-leider Khaddoumi met de Belgische minister van Buitenlandse Zaken, Simonet en de EG-Commissaris Cheysson.

Op 29 april 1980 werd na afloop van de Europese Raad te Luxemburg verklaard 'dat alleen cen allesomvattende rechtvaardige en duurzame regeling een werkelijke vrede kan brengen in het Nabije Oosten'. Aan de ministers van Buitenlandse Zaken werd de opdracht gegeven een rapport over de Europese rol daarin op de volgende zitting in Venetië voor te leggen ${ }^{60}$.

De Britten stelden voor resolutie 242 zo te wijzigen dat daarin de Palestijnse kwestie genoemd zou worden. Namens de EG zou dat in de Veiligheidsraad aan de orde gesteld dienen te worden ${ }^{61}$. De wijziging betrof volgens Artner de toevoeging van het Palestijnse zelfbeschikkingsrecht ${ }^{62}$. In het Lagerhuis zei de minister van Staat voor Buitenlandse Zaken en het Gemenebest, Hurd, dat 'to the principles of Security Council resolution 242 should be added the need to take full account of the legitimate rights of the Palestinian people, including their right to a homeland" ${ }^{33}$. De Amerikanen waren daar sterk tegen gekant. De Amerikaanse autonomie-onderhandelaar, Linowitz, probeerde op zijn reis door Europa tevergeefs de Fransen, Duitsers en Britten van dit voornemen af te houden ${ }^{64}$. Minister van Buitenlandse Zaken Muskie ondernam dezelfde poging op 13 mei 1980 . Hij trachtte toen tevens te voorkomen dat de Europeanen zich voor het betrekken van de PLO bij de onderhandelingen zouden uitspreken ${ }^{65}$.

De Britten gaven de moed niet op en trachtten Sadat voor hun standpunt te winnen ${ }^{66}$. Sadat waarschuwde de EG niet tegen de Camp Davidakkoorden te handelen. Hij zag weinig heil in een wijziging van $242^{67}$. De Egyptische onderminister van Buitenlandse Zaken, Boutros Ghali, en de Egyptische vice-president Mubarak zeiden echter een Europees initatief ter doorbreking van de impasse rond de autonomie-onderhandelingen te verwelkomen, al zou dat waarschijnlijk op hevig Amerikaans verzet stuiten ${ }^{68}$. Op 2 juni was de Franse minister van Buitenlandse Zaken, François-Poncet, aan de beurt

57. Ifestos, $1987 \mathrm{pp} .451$, 452, 454; Fifth report from the Foreign Affairs Commiltee Session 1979 and 1980. Afghanistan: the Soviet invasion and its consequences for British policy, London, 1980, pp. XVII en XXIX.

58. Trouw, 14-2-1980.

59. Trouw, 13-3-1980.

60. Verklaring van 29 april 1980. Bull, EG 4-1980; no. 1.1.15.

61. Parluamentary debates. Official report. House of Commons 1979-1980, 13-02-1980, 16-03-1980.

62. Artner, 1980, p. 435 baseert zich op de Financial Times, 13-2-1980.

63. House of Commons, 13 februari 1980, p. 978.

64. Trouw, 4-3-1980.

65. Department of State Bulletin, vol. 80 , July 1980 p. 6 .

66. Kimche, 1981 , p. 4-6.

67. International Herald Tribune, 30-5-1980.

68. De Volkskrant, 31-5-1980. 
on de Europese plannen aan zijn Amerikaanse collega Muskie uiteen te zetten ${ }^{69}$. Daarop reageerde Carter door te verklaren dat de VS dan in de Veiligheidsraad van het veto-recht gebruik zouden maken ${ }^{70}$. Kort daarop kon worden bericht dat de EG van een wijziging van resolutie 242 zou afzien ${ }^{71}$. In een interview op 13 juni en op een persconferentie van 14 juni verklaarde Carter dat de VS er kort geleden in geslaagd waren de Europese bondgenoten te weerhouden van hun aangekondigde voornemen om te proberen 242 te wijzigen ${ }^{72}$. In dit verband komt de West-Duitse minister van Buitenlandse Zaken niet erg geloofwaardig over met zijn verklaring dat de Gemeenschap niet van plan was een verandering van resolutie 242 voor te stellen ${ }^{73}$. Veeleer heeft het hevig Amerikaans verzet de Europeanen ertoe gebracht hun aanvankelijk plan niet door te zetten. Het voorstel zou in de Veiligheidsraad toch zijn gesneuveld.

Inmiddels was het Europese voorstel bijgesteld en mocht de Italiaanse minister van Buitenlandse Zaken dit in de VS aan Muskie tonen. Die had toen geen bezwaar meer ${ }^{74}$. Vervolgens konden ook de negen ministers van Buitenlandse Zaken met de ontwerp-verklaring instemmen ${ }^{75}$.

Na deze lange voorbereiding - vele voorbereidende vergaderingen van de ministers, het comitế politique en ambtelijke deskundigen worden nog vermeld - en nadat bovendien de angel uit de verklaring was gehaald, zou verwacht mogen worden dat de verklaring 'als hamerstuk' zou worden aangenomen. Dat bleek niet het geval te zijn.

Buiten het overleg, tijdens de lunches en diners, werd gedurende deze topconferentie van 12 en 13 juni in vier gremia overlegd. Zo vonden aparte onderhandelingen plaats tussen de regeringsleiders (twee bijeenkomsten), de ministers van Buitenlandse Zaken, de directeuren-generaal politieke zaken ('het Comité Politique') en de chefs van de afdelingen Midden-Oosten op experts-niveau. De laatsten vergaderden de hele nacht door ${ }^{76}$. Aan de conceptverklaring van voornamelijk Brits-Franse makelij viel volgens de Nederlandse DGPZ Reinink nog wel wat bij te schaven ${ }^{77}$. Tijdens de topconferenthe werd bekend dat de Fransen, die eerder een actieve Europese rol beoogden, over de aangebrachte verzwakking zo teleurgesteld raakten, dat ze halverwege aan de pers verklaarden aan publikatie van een dergelijke afgezwakte verklaring geen behoefte te hebben ${ }^{78}$.

69. NRC-Handelsblad 31-5-1980, Frankfurter Allgemeine Zeitung, 2-6-1980.

70. Agence Europe, $2 / 3$ juni $1980,2919$.

71. Agence Europe, 9110 juni $1980,2924$.

72. President Carter, Weekly Compilation of Presidential Documents, vol 16, no. 25,23 june 1980 , p. 1114 en Wireless Fille-Daily Press release of the United States" embassy in Brussels - Eur - 504, 15 june, p. 3; uit: Ifestos, 1987 , pp. 457 en 543

73. Agence Europe, 13 juni 1980, 2927.

74. Agence Europe, 7 en $9 / 10$ juni 1980,2923 en 2924 ; De Volkskrant, 9 en 11 juni 1980 ; Frankfurter Allgemeine Zeitung, 12 juni 1980 .

75. De Volkskriant, 11-6-1980.

76. Le Monde, 14-6-1980 en bevestigd door de daar aanwezige Nederlanders Reinink en Van Dam en de Duitser Fiedler interviews respectievelijk op 5 februari 1987, 3 september 1987 en 15 oktober 1987.

77. Interview met Reinink op 5 februtri 1987 .

78. Internationall Herald Tribune, 13-6-1980. 
Na publikatie reageerden enkele Arabische staten zoals Jordaniè en Saodi-Arabië tamelijk positief. De Egyptenaren reageerden zeer enthousiast en zagen in de verklaring een ondersteuning van het Egyptische beleid. De VS reageerden niet negatief. Zij zagen in de verklaring geen bedreiging voor het Camp Davidproces. De enigszins welwillende houding van de VS ten aanzien van de verklaring - wellicht ook ingegeven door de hoop dat daarmee enige beweging in de onverzoenlijke houding van de Israęli's inzake de autonomie-onderhandelingen kon worden bewerkstelligd - verontrustte de Israelische regering. Deze reageerde fel en makkte een vergelijking met de eerder in 1938 gegeven garanties aan Tsjechoslowakije nadat Sudetenland ook in naam van de zelfbeschikking was gestolen. De PLO verwierp de verklaring eveneens; aan geen van hun wensen - wijziging resolutie 242 , verwerping van de Camp Davidakkoorden en erkenning van de PLO als enige vertegenwoordiger - was tegemoetgekomen. In de visie van de PLO was Europa gezwicht voor Amerikaanse druk. De PLO had tevoren gehoopt dat de EG de VS zou kunnen beînvloeden; in hun ogen was het tegendeel geschied. Deze (te) hoge verwachtingen verklaren hun teleurstelling over deze verklaring, die in de rest van de wereld wèl als een versterking van de PLO en een uitbouw van de Palestijnse rechten werd beschouwd. Voor de tekst van de verklaring van Venetië zie bijlage 11 .

\subsubsection{Nederlandse bijdrage aan de besluitvorming in de EPS}

Welke rol vervulde Nederland in internationaal verband ten aanzien van het MiddenOostenconflict? De internationale politieke rol van Nederland in de EPS staat hier centraal. De Nederlandse inbreng bij de totstandkoming van de verklaringen in EPSverband over het Midden-Oosten in de periode 1977-1980 wordt in deze paragraaf behandeld.

Greilsammer stelt dat Nederland met Denenarken en Luxemburg de 'pôle pro-israélien' van de EG is gebleven, "mais les prises de position communes des Neuf leur sont précieuses pour prouver leur 'bonne volonté' aux pays arabes tout en ménageant leurs populations encore amicales envers Israel, 79 . Afgezien van de constatering dat Luxemburg tot dit groepje behoort, hetgeen niet blijkt uit de stemmingen in de VN maar waar Eban in zijn memoires wel toe neigt, wordt met bovenstaand citaat aangegeven dat Nederland de gemeenschappelijke stellingname van de Negen niet wilde tegenhouden. De indeling van Greilsammer komt overeen met de indeling vanuit participerende observatie van de Duitse vertegenwoordiger Fiedler die Denemarken met Nederland tegenover Frankrijk, Jerland en Griekenland plaatst waarbij de overige lidstaten zich in een middenpositie van het politiek spectrum bevinden ${ }^{80}$. Miles, de Britse vertegenwoordiger, voegt daar aan to dat Griekenland - in 1981 toegetreden tot de EG - vooral werd beïnloed door de radicale Arabieren en in die zin een uitzonderingspositie innam en bijvoorbeeld niet mér pro-Egyptisch of pro-Saoedisch was dan de anderen ${ }^{81}$.

79. Greilsamnzer, 1981 , p. 154 .

80. Interview met Fiedler op 15 oktober 1987.

81. Interview met Miles op 24 juni 1987. 
Volgens Reinink, de Nederlandse directeur-generaal politieke zaken, kon Nederland wel zijn invloed te gelde maken als het er zeker van was dat het medestanders - bijvoorbeeld Denemarken en de Bondsrepubliek Duitsland - had ${ }^{82}$. De visie van Rutten stemt overeen met die van zijn opvolger Reinink. Hij benadrukt eveneens de steun die Nederland van de Duitsers in het intorne beraad kreeg. Volgens hem speelden bovendien de Italianen altijd de Arabische kaart, waardoor het voor Nederland moeilijk was zich niet te isoleren. Isolement wilde Nederland immers voorkomen en het deed in EPS-verband dan ook steeds zijn uiterste best de aansluiting met de partners in de EPS te behouden, hetgeen zonder Duitse steun veel moeilijker zou zijn geweest ${ }^{83}$. Ook Van Dam, de Nederlandse vertegenwoordiger op expertsniveau, deelt deze opvatting en stelde dat Nederland wel degelijk een rol speelt binnen de EPS. Ten tijde van de verklaring van Venetië remde Nederland vooral af, tezamen met Denemarken, de Bondsrepubliek Duitsland en nog één of twee andere landen. Aan Nederlandse zijde werden volgens hem geen bewuste strategie en taktiek opgezet om anderen te winnen. De coalitievorming was een gevolg van het naar voren brengen van ieders eigen politiek geluid ${ }^{84}$. Ook Van der Klaauw legt de nadruk op de steun die hij van de Duitsers kreeg voor zijn standpunt waardoor hij succes kon behalen ${ }^{85}$. De Duitse positie is voor Nederland van belang waarbij het opvalt dat de Nederlanders deze positie dichter bij de hunne plaatsen dan de Duitsers doen. De Duitse beleidsambtenaar Fiedler situeert de eigen staat in een middenpositie en plaatst de Nederlanders en Denen aan de pro-Israël zijde ${ }^{86}$. De Duitse topambtenaar Van Well deelt daarentegen wel de mening van Van der Klaauw ${ }^{87}$. Den Uyl meende dat ook Brandt ondanks emotionele bindingen met Israël en gevoel voor het Nederlandse standpunt later toch meer naar Arabische gezichtspunten toegroei$\mathrm{de}^{88}$.

Nu worden enkele voorbeelden gegeven van de Nederlandse inbreng in het EPS-beraad. De zin uit de verklaring van juni 1977 (zie bijlage 9) ' $\mathrm{Zij}$ blijven vasthouden aan de opvatting dat al deze aspecten als een geheel moeten worden gezien' was volgens Rutten een Nederlandse bijdrage. Het betekende een waarborg voor Israël, aangezien de rechten van de Palestijnen werden beperkt door de eerbiediging van elke staat in de regio. Voor Nederland was dat een conditio sine qua non. De zin over 'een eigen land voor het Palestijnse volk" was een compromis en hiermee kon vooralsnog 'een Palestijnse staat" vermeden worden. Niet alleen de Fransen, ook de Britten maakten het de Nederlanders in dit geval moeilijk. Bovendien kostte het Rutten veel moeite om dit compromis door Den Haag aanvaard te krijgen ${ }^{89}$.

Bij de voorbereiding van de verklaringen van maart en juni 1979 vond de Nederlandse deelnemer in het Comité Politique de Fransen en Italianen tegenover zich. De Nederlan-

82. Interview met Reinink op 15 februari 1987

83. Interview met Rutten op 10 februari 1987.

84. Interview met Van Dam op 3 september 1987.

85. Interview met Van der Klaauw op 31 augustus 1989.

86. Interview met Fiedler op 15 oktober 1987.

87. Interview met Van Well op 30 januari 1990.

88. Interview met Den Uyl op 26 februari 1987.

89. Interview met Ruten op 10 fethruari 1987. 
der wenste een ondersteuning van de Camp Davidaanpak. De Belgen stonden meer aan de zijde van de Fransen en Italianen en ook de Duitsers wilden zich minder geprononceerd opstellen dan de Nederlanders. Nederland wilde evenwel de aansluiting niet missen en het maximaal bereikbare voor de Nederlanders was de zinsnede omtrent de constatering dat het Egyptisch-Israëlisch vredeswerdrag een correcte toepassing was van resolutie 242 (maart 1979, zie 3.1.2.2).

Bij deze onderhandelingen werden de instructies aan de Franse directeur-generaal niet door diens minister van Buitenlandse Zaken gegeven maar door president Giscard d'Estaing. De Quai d'Orsay werd gepasseerd door het Elysée en dat geeft aan welk belang de Fransen aan de EPS-verklaring gaven ${ }^{90}$. De Nederlandse diplomatie, die sinds 1973 primair gericht was op het voorkomen van isolement, wilde daarom de aansluiting niet missen bij de EPS-partners. De gemeenschappelijke standpunten moesten nog wel binnenlands aanvaard kunnen worden. Bij deze spanning tussen binnenlandse en buitenlandse opvattingen werd Rutten geholpen door het beleid van Begin, dat in Nederland veel weerzin wekte. Rutten heeft zelf nooit veel gezien in de EG-verklaringen. Hij benadrukte de zeer geringe betekenis ervan. De EG had een groot potentieel drukmiddel op Israël. De Arabische staten wilden dat de EG druk op Israël zou uitoefenen met de handelsakkoorden. De Europese partners wilden echter geen economische sancties uitvaardigen ${ }^{9 t}$.

Ter voorbereiding van de verklaring van Venetië kwamen op 28 en 29 mei in Rome de experts - dat is de werkgroep Midden-Oosten van de EPS - bijeen. Daar kwamen de Italianen en de Fransen met een nieuw element. Dit betrof met name de rol van de PLO en het Franse voorstel voor een Palestijnse staat. De Fransman wist dat dit voorstel niet haalbaar was en rekende erop dat de Nederlander Van Dam het idee zou 'afschieten'. Deze wachtte echter af en toen de Italiaanse voorzitter concludeerde dat dit voorstel aanvaardbaar was, kwamen de West-Duitser en de Belg daarentegen in het geweer. De 'zwarte piet' werd aldus naar de West-Duitsers en Belgen gespeeld maar aangezien in de pers berichten verschenen dat Nederland zich had verzet, kreeg de Nederlandse minister Van der Klaauw een half jaar later in Syrië toch de schuld in de schoenen geschoven.

Het Comité Politique kwam op 4 juni in Rome bijeen. De bespreking ging vooral over het karakter van de verklaring en over de relatie van de verklaring tot de Camp Davidbenadering. In deze bijeenkomst werd besloten verder af te zien van een voorstel tot wijziging van resolutie 242 . Tevoren had de Britse vertegenwoordiger op 8 mei 1980 in de werkgroep Midden-Oosten nog de volgende, (in vergelijking met Hurd's eerdere toelichting in het Britse Lagerhuis een afgezwakte versie, zie 3.1.2.3) formulering naar voren gebracht: 'The foreign Ministers are in principle for a new Security Council Resolution to provide a new basis for the peace efforts'. Een Westduits-Nederlands amendement:" 'to consider the possibility' haalde het toen niet.

De Fransen wensten op 4 juni in het Comite Politique geen verwijzing naar Camp David; de verklaring van Venetië zou in hun ogen juist als een alternatief voor Camp

90. Interviow met Rutten op 10 februari 1987.

91. Interview met Rutten op 10 februari 1987. 
David moeten worden gepresenteerd. De Engelsen stonden een neutrale verwijzing naar Camp David voor ${ }^{92}$. Anderen wensten dat 'Venetië' parallel zou lopen aan Camp David. De Duitsers beschouwden de derde alinea uit de verklaring van Venetië als een brug naar Camp David. Pas tijdens de top werd deze tekst, na Frans verzet, aanvaard ${ }^{93}$. Het is dan wel een smal bruggetje geworden door de zeer indirekte verwijzing naar Camp David via de verwijzing naar de verklaringen van 19 september 1978 en 26 maart 1979.

Omtrent het karakter van de verklaring verschilden de deelnemers van het Comite Politique van mening. Vanuit de Arabische wereld werd er bij de deelnemers op aangedrongen met een plan te komen. De Fransen wensten de verklaring als een Europees initatief te beschouwen. Andere deelnemers waaronder Nederland wilden niet zo ver gaan en zagen in de verklaring van Venetië een mogelijkheid om het nemen van een initiatief te bestuderen. Dat betekende in feite een voorstel tot een initiatief. Dit is eén van de voorbeelden waarin Frankrijk 'sneller' wilde gaan dan de anderen maar uiteindelijk zijn zin niet kreeg. Voor Nederland was dit een zwaarwegend probleem. Het dilemma was dat de EPS-verklaringen vaak in tegenspraak waren met het Amerikaans buitenlands beleid. Nederland trachtte dat dilemma te ondervangen - zo stelt Soetendorp terecht vast - door de retoriek van de EG te steunen, maar zich te verzetten tegen elke Europese actie die het Camp Davidproces kon verstoren ${ }^{94}$. Een bevestiging van deze stelling kan worden gevonden in het gedrag van de Nederlandse minister van Buitenlandse Zaken tijdens de Europese Raad in Venetië, waar hij zich verzette tegen het direct activeren van dit Europees initiatief. 's Avonds kwamen de ministers van Buitenlandse Zaken bijeen om te vergaderen over de Franse wens dat Europa een initiatief zou nemen.

Van der Klaauw zei daarover: 'Daar heb ik me geweldig tegen verzet. lk vroeg welk initiatief, ja dat zien we later wel werd er gezegd en daar had ik geen zin in, dan geef je een blanco kaart. Dan krijg je later een enorme druk, het zou de relatie met de Amerikanen verstoren die helemaal niet gebrand waren op een Europees initiatief. Daar zijn we die avond niet uitgekomen. De volgende ochtend in de Raad - en dat was niet gebruikelijk daar als minister van Buitenlandse Zaken een uiteenzetting te geven maar Dries van Agt die wist daar helemaal niets vanaf en liet dat aan mij over - heb ik daar een hele tijd over gediscussieerd met Giscard die uiteindelijk met het compromis kwam van 'éventuelle', en daar kon ik vrede mee hebben. Wat mij betreft hadl er helemaal niets in gehoeven maar met een eventueel initiatief kon ik leven' ${ }^{95}$.

De reden van Van der Klaauw's verzet was niet alleen de relatie met de VS maar vooral de vrees 'dat dan de Fransen met een plan zouden kunnen komen waarmee ik het niet eens zou kunnen zijn. Als je zegt er komt een initiatief dan moet het er komen en ben je bezig een blanco kaart weg te geven' ${ }^{96}$. Opvallend is dat de voornaamste beweegreden van Nederland dezelfde is als in oktober 1973, toen het ook weigerde een blanco cheque af te geven en daarom de Britten en Fransen geen open mandaat voor hun optre-

92. Interview met Van Dam op 3 september 1987.

93. Interview met Fiedler op 15 oktober 1987.

94. Soetendorp, 1984, pp. 44-45; Licklider, 1988 , p. 42.

95. Interview met Van der Klaauw op $\mathbf{3 1}$ augustus 1989.

96. Interview met Vap der Klaauw op 31 augustus 1989, 
den in de Veiligheidsraad gaf. Evenals in 1973 stond Nederland in 1980 alleen en kreeg het geen steun wan andere EPS-partners. Zij vonden dat Van der Klaauw overdreef en reageerden op zijn verzet in de trant van 'kom nou Chris, dat zien we dan wel'. Giscard d'Estaing had een machtige positie op dat moment ${ }^{\text {g7 }}$.

Verschil van mening bleef bestaan over het betrekken van de PLO bij de onderhandelingen (zie bijlage 11 , paragraaf 7 ). Uiteindelijk hebben de regeringsleiders op de tweede bijeenkomst de knoop moeten doorhakken omtrent de rol wan de PLO. De Britten wilden niet verder gaan dan een aanvaarding van de betrokkenheid van de PLO; zij gebruikten daarvoor de term 'association'. De Fransen en Ieren waren daar tegen en wensten de deelname van de PLO te verwoorden met 'participation'. Voor de Nederlanders maakte het weinig verschil ${ }^{98}$.

De erkenning wan het Palestijnse zelfbeschikkingsrecht was binnen de Negen geen bron van conflict meer (zie bijlage 11, paragraaf 6). De Duitsers claimden het zelfbeschikkingsrecht als hun bijdrage aan de verklaring (reeds in 1974 werd door de Duitse permanente vertegenwoordiger op de Algemene Vergadering van de VN het zelfbeschikkingsrecht van de Palestijnen naar voren gebracht). Wel werd opnieuw door de Fransen getracht 'de Palestijnse staat' in Venetië ingang te doen vinden. Uiteindelijk heeft een overgrote meerderheid van Duitsers, Denen, Luxemburgers, Belgen en Nederlanders zich verzet tegen erkenning van het recht op een Palestijnse staat. Waarschijnlijk heeft Thatcher zich tijdens de laatste bijeenkomst van regeringsleiders in Venetië bij de meerderheid aangesloten, aangezien zij in het Lagerhuis expliciet weigerde aan te nemen dat het zelfbeschikkingsrecht in een eigen staat zou uitmonden. De Britse ambtenaren en ministers waren daar veel minder uitgesproken over.

\subsection{Buitenlandse politiek}

In dit onderdeel wordt het buitenlands politieke proces in Nederland ten aanzien van het Midden-Oosten behandeld. Behandeld wordt slechts dat deel van het beleid dat relevant is voor het optreden van Nederland in internationaal verband in de periode 1974-1980. In de volgende paragraaf komt de reactie van het Nederlandse parlement op Nederlands optreden in internationaal verband aan de orde. Tevens worden de wensen van het parlement inzake het te voeren beleid belicht. In hoeverre de regering met deze wensen rekening heeft gehouden in zijn optreden in internationaal verband (de effectiviteit van deze anticiperende invloed) komt in de conclusie aan de orde.

\subsubsection{Regering en parlement}

Het parlement volgde het Nederlandse optreden in de VN nauwgezet en kritisch. Direct na de stemming in 1974 in New York over resoluties 3236 en 3237. werd op verzoek van het Kamerlid Aantjes (ARP) een interpellatie-debat in de Tweede Kamer gehouden. Het werd een uitgebreid debat waarin bijna alle fracties de Nederlandse onthouding over resolutie 3236 - over het zelfbeschikkingsrecht voor het Palestijnse volk - van 22 no-

97. Interview met Van der Klaauw op 31 augustus 1989

98. Interview met Van Dam op 3 september 1987. 
yember 1974 kritiseerden en aan een Nederlandse tegenstem de voorkeur zouden hebben gegeven. Slechts de PPR was het eens met de Nederlandse onthouding; de PSP had liever gezien dat Nederland had voorgestemd ${ }^{99}$.

Dit debat was interessant, omdat nu kort na de oliecrisis het Nederlands beleid ten aanzien van het Arabisch-Israëlisch conflict werd ontvouwd. Daarnaast was het debat van belang vanwege het antwoord van de regering, waarin over de implementatie van het Nederlands buitenlands beleid in de internationale politiek uitleg werd gegeven. Onthullend was daarin dat de Nederlandse positie-keuze werd bepaald door het gedrag van de overige acht partners, waarbij het Nederlands vertrouwen in een gemeenschappelijk optreden op het laatste moment werd beschaamd door het geïsoleerde Franse optreden. Afgesproken was dat de Negen zich van stemming zouden onthouden over resolutie 3236 en tegen 3237 - toekenning van de waarnemersstatus aan de PLO - zouden stemmen. De Nederlandse onthouding over 3236 kon als een concessie aan de meerderheid in de Negen worden gezien. 'Pas op het allerlaatste moment is gebleken, toen er geen mogelijkheid was op het punt van de Nederlandse stembepaling op de eerste resolutie nog verandering aan te brengen, dat Frankrijk t.a.v. de tweede resolutie de solidariteit van de Negen had verbroken', aldus Van der Stoel ${ }^{100}$. Aantjes trok de conclusie 'Frankrijk heeft ons beduveld' ${ }^{101}$ en ook Van Mierlo (D'66) kwam tot de slotsom dat 'wij natuurlijk gewoon zijn bedonderd. Als Frankrijk het op het laatste moment eens eventjes anders ritselt dan het ons eigenlijk heeft gesuggereerd, dan mogen wij dat zo zeggen" ${ }^{102}$. Deze situatie vertoont veel gelijkenis met die op 6 november 1973 waarin Frankrijk, nadat een gemeenschappelijke politieke verklaring tot stand was gekomen, weigerde met een gemeenschappelijke energieverklaring in te sternmen (zie 2.2.1.7).

De minister noemde ter verdediging van het Nederlandse stemgedrag twee argumenten. Hij wees een tegenstem af, omdat die 'zou kunnen worden uitgelegd als een stem tegen de gedachte aan cen nationale identiteit van de Palestijnen" ${ }^{103}$ en omdat 'onze vrees was dat, als enkele landen of eén land zou hebben tegengestemd, de onthouding van de andere landen meer het karakter zou hebben gekregen van het net niet met de resolutie eens zijn' ${ }^{104}$. Volgens Van der Stoel werd aan de onthouding van de Negen nu een andere betekenis gegeven dankzij het - ook door Nederland onderschreven - gemeenschappelijke optreden. Hij overtuigde met deze argumentatie de Kamer, die een tegenstem met een stemverklaring ten gunste van de Palestijnse aspiraties prefereerde, niet. Ook de - door de Kamer gewaardeerde - stemverklaring van de Nederlandse permanente vertegenwoordiger, Kaufmann, kon wolgens de overgrote meerderheid van de Kamer 'logischerwijze slechts leiden tot tegenstemmen' ${ }^{105}$. Niet alleen ontbrak de verwijzing naar resolutie 242 van de Veiligheidsraad met Israëls recht tot voortbestaan, hetgeen in

99. Handelingen Tweede Kamer, zitting 1974-1975, 27 november 1974, pp. 1585 en 1587.

100. Tbidem p. 1584.

101. Tbidlem p. 1584.

102. Ibidem p. 1590.

103. Ibidem p. 1582.

104. Ibidem p. 1583.

105. Aantjes, ibidem p. 1582, Dankert (PvdA) ibiden p. 1584, Van Amelswoort (KVP) ibidem 1588, Van Mierlo ibidem p. 1589. 
Kaufmanns stemverklaring naar voren werd gebracht, maar daarnaast meenden Dankert en Van Mierlo dat Nederland ook stelling had moeten nemen tegen de operatieve paragraaf over het zelfbeschikkingsrecht van de Palestijnen in geheel Palestina en het onbeperkte recht op terugkeer van de Palestijnen ${ }^{106}$ "De minister zei deze bezwaren te delen maar maakte niet duidelijk waarom daarvan geen gewag was gemaakt en stelde slechts dat dit 'niet duidelijk wit de verf was gekomen omdat de resolutie in z'n geheel in stemming werd gebracht' ${ }^{10 \%}$. Van der Stoel keerde zich in de Kamer tegen een principiële Nederlandse standpuntbepaling en vond "dat men als land alleen veel minder gewicht in de schaal legt dan de Negen bij elkaar. Uitgaande van het gegeven, dat een meerderheid zich van stemming zal onthouden, kan men proberen de Negen zover mogelijk te krijgen in het onderstrepen van essentiële elementen, waaruit een voor het Midden-Oostenconflict aanvaardbare oplossing zou moeten bestaan" 108 . Daarop reageerde het Kamerlid De Brauw (DS'70): 'De minister bakent zijn beslissing telkens af, en cadreert haar als het ware in de EEG' ${ }^{109}$. In de Algemene Vergadering van 1974 werd zodoende reeds duidelijk dat de oliecrisis uit 1973 had geleid tot een beperking van de vrijheid van handelen van Nederland in de internationale politiek, waarbij de grenzen werden bepaald door de meerderheid in de Negen.

Op 12 november 1975 lichtte Van der Stoel de Nederlandse stem tegen de resoluties 3375 en 3376 in de Algemene Vergadering op verzoek van enkele Tweede Kamerleden toe. Met name de tweede resolutie beoogde volgens hem 'niets anders dan de grond voor te bereiden voor de beknotting van Israëls rechten als lid van de Verenigde Naties' ${ }^{110}$. Met onmiskenbaar ongenoegen tekende hij daarbij aan 'dat Frankrijk, Italië en Ierland zich meenden te moeten onthouden' "I"!.

De PLO mocht niet als dé vertegenwoordiger van de Palestijnen beschouwd worden - hetgeen in resolutie 3375 werd gesteld - en van erkenning van de PLO - door het PSPKameriid Van der Spek voorgesteld - kon geen sprake zijn, zolang deze organisatie het voortbestaan van Israël achter veilige en erkende grenzen niet had aanvaard. Hij voegde daaraan toe dat 'de nationale identiteil van het Palestijnse volk vorm en gestalte zal moeten krijgen" "12. Het Kamerlid van de PvdA Ter Beek vroeg daarop wat nog het gemeenschappelijke in het beleid van de Negen was, nu Frankrijk en Italië zich in de Algemene Vergadering voor een 'homeland' (eigen land) voor de Palestijnen hadden uitgesproken ${ }^{113}$.

De KVP plaatste zich buiten de meerderheid in het parlement door te stellen 'dat er een Palestijnse staat moet komen' ${ }^{114}$. De minister gaf zijn steun, in navolging van onder meer Van Mierlo en Ter Beek, aan het Egyptisch-Israëlische interim akkoord dat als

106. Ibidem pp. $1584,1589$.

107. Ibidem p. 1592 .

108. Ibidem p. 1590.

109. Ibidem p. 1590.

110. Handelingen Tweede Kamer, zitting 1975-1976, 12 november 1975, p. 1042.

111. Ibidem p. 1042 .

112. Tbidem p. 1042 .

113. Ibidem p. 1056 .

114. Ibidem p. 1059 . 
een moedige stap voorwaarts in de richting van een vrede in het Midden-Oosten' werd gekenschetst ${ }^{115}$.

Kortom de minister steunde het Amerikaanse vredesproces en had geen behoefte aan een nieuwe EG-verklaring ${ }^{116}$.

In januari 1977 werd door de negen ministers van Buitenlandse Zaken te Londen een geheime verklaring opgesteld. De Tweede Kamer was daarover ontstemd ${ }^{117}$. Volgens de minister stond in deze verklaring inhoudelijk niets nieuws en was ze te beschouwen als een samenvatting van de verklaring van 6 november 1973 en de door de Nederlandse permanente vertegenwoordiger Kaufmann op 7 en 9 december 1976 in de Algemene Vergadering gehouden redevoering ${ }^{118}$.

Oppositieleider Wiegel (VVD) vroeg zich dan ook af waarom die verklaring niet kon worden bekendgemaakt ${ }^{119}$. Ook Dankert (PvdA) vond de procedure uitermate vreemd en zeil 'het ergste is dat de mogelijkheid voor de Kamer om verklaringen of afgesproken standpunten, die toch internationaal politiek gaan functioneren te controleren, verdwenen is" ${ }^{120}$.

Terlouw (D'66) voegde daaraan toe dat 'zo'n handelwijze vermoedens wekt en tot geruchten leidt' ${ }^{121}$. Minister Van der Stoel antwoordde dat er onderlinge overeenstemming over de verklaring was en dat de Negen aan de inhoud daarvan gebonden waren ${ }^{122}$. De verklaring werd volgens Van der Stoel niet gepubliceerd, omdat er zich nieuwe ontwikkelingen zouden kunnen voordoen op grond van de reizen van Waldheim (secretaris-generaal van de Verenigde naties) en Vance (minister van Buitenlandse Zaken van de Verenigde Staten) naar het Midden-Oosten ${ }^{123}$. Het parlement verzette zich echter nauwelijks tegen deze uitholling van zijn bevoegdheden. Aan de andere kant paste het regeringsbeleid wel bij de door de meerderheid van het parlement voorgestane lijn dat het Amerikaanse beleid vanuit Europa niet doorkruist mocht worden. Het Kamerlid Bakker (CPN) was het meest geprononceerd toen hij stelde 'tegen iedere inmenging te zijn van de kant van de EEG, van de Negen of wel de EPS. Er is nog niets goeds uit voortgekomen' ${ }^{124}$.

Het is mogelijk aan de visie van het parlement over het voorgestane beleid ten aanzien van het Midden-Oosten ten tijde van de verklaring van Venetië meer aandacht te besteden, daar kort voor en kort na de openbaarmaking van deze verklaring hieraan parlementaire beraadslagingen waren gewijd. Inmiddels was Van der Stoel als minister van Buitenlandse Zaken opgevolgd door Van der Klaauw uit het kabinet-Van Agt I (zie bijlage $17 \mathrm{~B})$.

115. Jbidem p. 1072 .

116. Zive ook ibidem p. 1043.

117. In de pers verschenen berichten dat een verklaring in Londen was opgesteld waurvan de inhoud onbekend bleef.

118. Handelingen Tweede Kamer 1976-1977, 3 februari 1977, p. 2956.

119. Ibidem p. 2957.

120. Ibidem p. 2960.

121. Ibidem p. 2963.

122. Ibidem p. 2963 .

123. Thidem p. 2963-2964.

124. Ibidem p. 2961. 
Een deel van de discussie richtte zich op de rol en positie van de PLO. Het Tweede Kamerlid Abma (SGP) beschouwde de PLO als het 'paard van Troje' ${ }^{2}$ en het Eerste Kamerlid Broeksz (PvdA) koos voor de Nederlandse variant, te weten het "Turfschip van Bredal" 126.

Contacten met de PLO in de vorm van onderhandelingen werden 'zonder voorafgaande zeer uitdrukkelijke gedragsveranderingen van de $\mathrm{PLO}$ als onaanvaardbaar gezien ${ }^{2}$ Ook minister Van der Klaauw wenste geen contacten met deze organisatie aan te gaan op grond van de "volledige onacceptabele" doelstellingen van deze organisatie ${ }^{128}$. De minister verduidelijkte verwolgens dat er geen politieke of diplomatieke contacten mochten plaatsvinden en dat PLO-functionarissen zelfs niet door ambtenaren op hel departement ontvangen mochten worden. De minister had deze zienswijze ook naar voren gebracht in een uitvoerige gedachtenwisseling met vertegenwoordigers van de Joodse gemeenschap in Nederland. In de Eerste Kamer betreurde hij dat een PLOfunctionaris wel op zijn departement was ontwangen ${ }^{129}$. Zelf wilde hij woorlopig ook geen Pallestijnen op het departement ontvangen, want zo zei hij aan de overzijde van het Binnenhof: 'dan zou ik misschien gevoelens kwetsen die ik helemaal niet wil kwetsen' 130 . In tweede termijn zei Van der Klaauw "Willen wij ooit de PLO als een volwaardige partner kunnen accepteren in het vredesproces, dan zal het Handvest moeten worden gewijzigd" ${ }^{31}$. Aan deze Nederlandse voorwaarde werd in de verklaring van Venetië - zoals we hebben kunnen constateren - niet voldaan, hoewel de betrokkenheid wan de PLO bij de onderhandeling wel enigszins geclausuleerd werd.

De door Nederland gewenste relatie met de VS werd door Van der Klaauw nog vóor de verklaring van Venetië als volgt aangegeven: 'Verder ben ik van mening dat ieder initiatief van de Negen, gericht op een bespoediging van het vredesproces in het Midden-Oosten slechts zinvol kan zijn in harmonie met de Verenigde Staten. De Negen zullen bij activiteiten zich niet moeten keren tegen de ene staat die als enige zeer directe invloed kan uitoefenen in Israël en Egypte en naar ik hoop ook elders. Dus geen eigen gang van de Negen, die tot een botsing met de Verenigde Staten zou kunnen leiden' ${ }^{132}$. Voor de vaste Commissie voor Buitenlandse Zaken verklaarde Van der Klaauw eveneens op 11 juni 1980 dat "Europa wat betreft het Midden-Oosten uitsluitend initiatieven moet nemen in goed overleg met de VS* ${ }^{33}$. In zijn beschouwing naderhand gaf Van der Klaauw aan dat hij in de bijeenkomst van de ministers van Buitenlandse Zaken in Venetie daarop ook zijn activiteit had gericht; hij vertelde de Eerste Kamer: 'Voor Nederland was van belang - die lijn heb ik althans gevolgd - dat in ieder geval voorkomen werd dat het tot een breuk tussen de VS en Europa zou komen. De

125. Handelingen Tweede Kamer, zitting 1979-1980, 24 juni 1980, p. 5616.

126. Handelingen Eerste Kamer, zitting $1979-1980,27$ mei 1980 , p. 758 en 28 mei 1980, p. 790 .

127. Handelingen Eerste Kamer zitting $1979-1980,27$ mei 1980, p. 761, Van Hulst CDA.

128. Rede Van der Klatww weergegeven in Trouw 30-4-1980 en aangehaald in de Handelingen Eerste Kamer, zitting 1979-1980, 27 mei 1980, p. 773.

129. Handelingen Eerste Kamer, zitting 1979-1980, 28 mei 1980, p. 782 .

130. Handelingen Tweede Kamer, zitting 1979-1980, 24 juni 1980, p. 5653.

131. Handelingen Eersie Kamer, zitting 1979-1980, 28 mei 1980, p. 802.

132. Handelingen Eerste Kamer, zitting 1979-1980, 28 mei 1980, p. 781.

133. Tweede Kamer, zitting 1979-1980, 16250 nr. 4, p. 6. 
VS zijn uiteindelijk de werkelijke machtsfactor en kunnen dat ook zijn in deze crisis. Europa kan zijn goede diensten aanbieden, maar kan nimmer, door zijn structuir ook, optreden als een soort makelaar tussen de verschillende partijen' ${ }^{134}$. Ook in de Tweede Kamer zeil Van der Klaatiw: 'Ons beleid is er voortdurend op gericht geweest om niet van de Verenigde Staten af te dwalen. Iedereen die de internationale politiek kent begrijpt waarom Camp David niet met zoveel woorden is genoemd. Toch is de relatie met de Camp Davidonderhandelingen behouden. De Verenigde Staten zijn uiteindelijk essentieel voor het bereiken van resultaten in het Midden-Oosten. Zij zijn dat veel meer dan Europa' ${ }^{135}$. Dat Van der Klaauw geen vertrouwen had in een Europese bijdrage in de onderhandelingen kwam naar voren toen hij zei: 'Voor elke zin die Europa zou willen uitspreken zou het een uur moeten debatteren' ${ }^{136}$.

De minister vond de verklaring van Venetië redelijk en evenwichtig en werd in zijn oordeel met name door Brinkhorst van $D^{\prime} 66$ in de Tweede Kamer gesteund ${ }^{137}$. De partijgenoot van de minister, Bolkestein van de VVD, vond de verklaring daarentegen teleurstellend en onevenwichtig. Teleurstellend omdat het vredesproces tussen Egypte en Israël niet werd verwelkomd en onevenwichtig omdat voorbij werd gegaan aan het door El Fatah begin juni te Beiroet opgestelde programma waarin El Fatah zich ten doel stelde 'Palestina volledig te bevrijden en de zionistische identiteit, politiek, economisch, militair, cultureel en ideologisch te vernietigen'. Met de verklaring van Venetië speelde de Europese Raad zijns inziens de strategieên van de PLO in de kaart en werd de vrees van de Israëli's bevestigd ${ }^{138}$.

Brinkhorst juichte een Europese rol in het vredesproces toe: 'Europa dient een rol te spelen bij een vredesregeling in het Midden-Oosten' ${ }^{139}$, terwijl Bolkestein zijn bedoelingen tot uiting bracht in een motie waarin de regering werd verzocht 'alleen dan met een dergelijk initiatief akkoord te gaan indien het is ontstaan na tijdig en goed overleg met de regering van de Verenigde Staten" ${ }^{140}$. Deze motie werd door de Tweede Kamer aanvaard met de tegenstem van de PPR, PSP, CPN ${ }^{141}$ en kan gezien worden als een ondersteuning van het door de Nederlandse regering voorgestane beleid. Voor Nederland zou een eventueel Europees initiatief geen doorkruising van het Amerikaans Camp Davidproees mogen zijn; de Europese partners verschilden daarover eehter van mening ${ }^{142}$.

De minister deelde de bezwaren van Bolkestein wel, maar vond het 'belangrijk dat de Negen op één لijn zijn blijwen zitten en dat er geen splitsing is ontstaan' ${ }^{143}$. In de tweede termijn verklaarde hij zelfs Bolkesteins bezwaren tegen een globale benadering

134. Handelingen Eerste Kamer, zitting 1979-1980, 18 juni 1980, p. 1001.

135. Handelingen Tweede Kamer, zitting 1979-1980, 24 juni 1980, p. 5652.

1136. Dbidlem p. 5652 .

137. Handelingen Tweede Kamer, zitting 1979-1980, 24 juni 1980, pp. 5652, 5659 .

138. Ibidem p. 5610.

139. Tbidem p. 5611 .

140. Handelingen Tweede Kamer, zitting 1979-1980, $16249 \mathrm{nr} .6,24$ jun 1980, p. 5654.

141. Handelingen Tweede Kamer, zitting 1979-1980, 26 juni 1980, p. 5820.

142. Ten onrechte doet Soetendorp het voorkomen alsof hierover eensgezindheid binnen de Negen bestond; Soetendorp, 1983, 255.

143. Handelingen Tweede Kamer, zitting 1.979-1980, 24 juinj 1980, p. 5652. 
te delen ${ }^{144}$. (Bolkestein vertaalde 'comprehensive settlement" minder gelukkig mot 'globale benadering', de term 'allesomvattende regeling" lijkt me juister). Interessant is de kritiek van Bolkestein op dit Europese stokpaardje temeer daar de minister van Buitenlandse Zaken die kritiek deelde. 'Een globale benadering is een recept woor mislukking, om de eenvoudige reden dat die benadering onderhevig is aan het veto van de meest radicale onderhandelingspartner. Er is dus geen alternatief voor een stap-voorstap benadering", aldus Bolkestein ${ }^{145}$.

Eerder werd gewezen op het verschil in opvattingen omtrent het karakter van de verkda. ring van Venetië (zie 3.1.2.4). In antwoord op een vraag van het Kamerlid Mommersteeg (CDA) benadrukte Van der Klaauw dat de Negen miet tot een initiatief hadden besloten. In Venetië was slechts afgesproken met alle partijen contact op te nemen en hun standpunten te horen ${ }^{146}$. Uit het Kamerdebat werd duidelijk dat Nederland zich in Venetië heeft verzet tegen het voornemen direct met een Europees initatief te starten. De minister zei: 'Er is heel lang over gesproken om het [initiatief FG] conditioneel te maken op de sonderingen. Het besluit erover moet nog worden genomen. Dat is een van de punten waarvoor ik mij sterk heb gemaakt. In de considerans wordt een Europees initiatief in het vooruitzicht gesteld. Dat is in iets te sterke bewoordingen gesteld wat de verklaring van de Europese Raad betreft' 147

\subsubsection{Politieke partijen}

In het eerste onderdeel van dit hoofdstuk - 3.1. - is de opschuiving van standpunten ten aanzien van het Arabisch-Israëlisch conflict in internationaal verband behandeld. In de vorige paragraaf - 3.2.1. - werd de reactie van parlementaire zijde beschreven.

Ook in het binnenland vond gedurende de periode 1974-1980 een opschuiving van standpunten plaats. Deze zal in deze paragraaf worden geïnventariseerd op basis van de verkiezingsprogramma's van de Nederlandse politieke partijen voor de Tweede Kamerverkiezingen van 1977 en 1981. Daarnaast worden deze standpunten van de politieke partijen vergeleken met de in internationaal verband ook door Nederland onderschreven standpunten. Deze vergelijking maakt het mogelijk te achterhalen of Nederlands interna* tionaal optreden, dat werd gekenmerkt door een remmende invloed op verandering van het Midden-Oostenbeleid in EPS-verband, ook in het binnenland op instemming kon rekenen ${ }^{148}$.

CDA: In het eerste gemeenschappelijke verkiezingsprogramma van KVP, CHU en ARP uit 1977 stond: 'Een oplossing van het Midden-Oostenconflict vereist, dat Israël en zijn Arabische buurlanden kunnen bestaan binnen veilige en erkende grenzen, dat territoriale

144. Ibidem p. 5660.

145. Ibidem p. 5654

146. Ibidem, pp. 5653, 5659.

147. Ibidem p. 5663.

148. Uit de werkiezingsprogramma's voor de Tweede Kamerverkiezimgen van 1977 en 1981 kunnen de partijstandpunten over het Midden-Oosten worden achterhåld. Lipschits, 1977, 1981. In 1977 werd het partijstandpunt toegelicht in brieven aan de Werkgroep Israël in: Nabij, speciaal no. 4 , april 1977. In 1981 werden partijstandpunten toegelicht, Naftaniel 1981. 
bezettingen worden beëindigd en dat de positie der Palestijnen in staatkundige vorm wordt geregeld'. Dit standpunt kwam overeen met de stellingname van de Negen van dat moment, dat wil zeggen na de Algemene Vergadering van 1976 - 'daadwerkelijke uiting aan hun nationale identiteit' - en nog voor de EG-verklaring van juni 1977 waarin voor een 'vaderland voor het Palestijnse volk' werd gekozen.

Het CDA-standpunt verschilde aanmerkelijk van het KVP-fractie- standpunt uit 1975, waarin werd gekozen voor een Palestijnse staat. Al in 1970 had het KVP-partijbestuur geopteerd voor een Palestijnse staat in Cis-Jordanie ${ }^{149}$.

In 1981, nadat in Europees verband het recht op een vaderland en zelfbeschikkingsrecht voor de Palestijnen was aanvaard, bleef het CDA vasthouden aan het standpunt uit 1977. Het CDA beperkte zich tot de passage dat 'de staatkundige rechten van de Palestijnen moeten worden verzekerd'.

Daarnaast was het opvallend dat in het CDA-verkiezingsprogramma niet werd gerept over de Europese vredesmissie maar wèl over "het vervolg op de Camp Davidaccoorden waarin de Palestijnen moeten worden betrokken'. In de toelichting op dit program werd daarentegen in de CIDI-enquête door het CDA wel gewezen op de 'activiteiten van de Europese Tien, die convergerend zullen moeten zijn met die van de Verenigde Staten'. Het CDA vervolgde: 'Uiteindelijk zal staatsvorming in enigerlei vorm door het Palestijnse volk niet uitgesloten dienen te zijn.' Deze toelichting ging verder dan het programma uit 1981 maar minder ver dan het KVP-standpunt uit 1970. Ook uit de toelichting bleek dat door het CDA een onafhankelijke Europese rol werd afgewezen en dat samenwerking met de VS de voorkeur verdiende.

De invloed van de protestants-christelijke achterban op het CDA-program lijkt - bij een vergelijking van de standpunten van ARP, CHU en KVP van vroeger - doorslaggevend te zijn geweest.

PvdA: Het PvdA standpunt in 1977 werd in eén zin verwoord: 'Nederland bevordert het totstandkomen van vrede in het Midden-Oosten door het steunen van initiatieven in VNverband, welke kunnen leiden tot de oprichting van een Palestijnse staat naast Israël'. Aan deze uitspraak was een uitgebreide discussie binnen de PvdA voorafgegaan. Met de keuze voor een Palestijnse staat liep de PvdA enigszins vooruit op de stellingname van de Negen. In de toelichting werd aan de EG een politieke rol van beperkte aard toegekend en stelde de PvdA 'dat het niet zinvol lijkt de rol van de supermogendheden te doorkruisen.'

In 1981 werd opnieuw voor 'de totstandkoming van een zelfstandige Palestijnse staat' gepleit en werd gekozen voor 'wederzijdse erkenning van de PLO en Isräll' in onderhandelingen waaraan ook de PLO deelneemt. De PwdA ging hierin verder dan de Negen in de verklaring van Venetië waarin weliswaar eveneens de betrokkenheid van de PLO bij onderhandelingen werd aanvaard, doch deze verklaring bevalte geen uitspraak over het doel, te weten de wederzijdse erkenning van de PLO en Israël. In de toelichting werd door de PudA een erkenning van de PLO als enige vertegenwoordiger van het Palestijnse volk nog afgewezen. De PvdA zweeg omtrent een onafhankelijke Europese

149. Rapport KVP partijbestuur: Het Conflict in het Midden-Oosten, 1970. Onder Cis-Jordaniê wordt de Westelijke Jordaanover verstaan, terwijl Trans-Jordanie het huidige Jordanië onwvat. 
rol en sloot een Camp Davidbenadering niet uit. De PvdA-opvatting paste binnen de beleidslijn zoals de Negen die waren overeengekomen en hoewel de PvdA in 1981 nie meer expliciet - zoals in 1977 - een oplossing in VN-verband voorstond, sprak zij zich evenmin uit voor een onafhankelijke Europese rol. Zowel in 1977 als in 1981 werd het Midden-Oostenconflict in het verkiezingsprogramma van de PvdA onder de paragraaf over de Verenigde Naties behandeld.

VVD: In het verkiezingsprogramma voor 1977 besteedde de VVD geen aandacht aan het Midden-Oosten. In een toelichting werd 'de rol van de EEG-landen als positief ervaren' en de uitspraak van de Negen over de politieke rechten van de Palestijnen, te realisenen in de vorm van een 'territoriale basis," onderschreven. De VVD steunde het beleid op dat onderdeel van de regering (het kabinet Den Uyl) expliciet in de toelichting."

In 1981 werden in het verkiezingsprogramma "de verlangens van het Palestijnse volk naar zelfbestuur' ondersehreven. Daarmee koos de VVD voor de Camp Davidbenadering waarin over "autonomie" werd gesproken en week zij af van het standpunt van de Negen over 'zelfbeschikking' in de verklaring van Venetië. Omtrent de gewenste internationale rol van Nederland stelde het verkiezingsprogramma van de VVD: 'Ons land bevordert met betrekking tot het Midden-Oosten een gemeenschappelijk beleid van de Europese Gemeenschap, dat totstandkomt na diepgaand overleg met de Verenigde Staten" 150 . In de toelichting werd aangegeven dat Amerikaanse initiatieven door de EPS niet mochten worden doorkruist. Het positieve oordeel over de Europese rol uit 1977 ontbrak in 1981. De betrokkenheid van de VS werd in 1981 onderstreept en in de toelichting werd tevens voor de Camp Davidbenadering gekozen.

D'66: In het verkiezingsprogramma van 1977 werd door D'66 niet expliciet op het Midden-Oostenvraagstuk ingegaan. In de toelichting werd het recht van het Pallestijnse volk op een eigen staat erkend en diende Nederland 'contacten met de PLO niet langer uit de weg te gaan'. De andere 'grotere' politieke partijen deelden deze opvatting niet. Hoewel D'66 'diepgaande inmenging' van derden niet wenste, koos deze partij wel voor een Europese rol, immers: 'Het belangrijkste middel dat Nederland ter beschikking. heeft om bij te dragen tot een oplossing van het conflict is de gemeenschappelijke politiek die de Negen in deze woeren :..."

In het verkiezingsprogramma van 1981 werd het standpunt uit 1977 over het recht van de Palestijnen op een eigen staat en het 'niet uit de weg gaan' van politieke contacten door de regering met de PLO herhald. In dit verkiezingsprogramma sloot D'66 aan bij de verkllaring van Venetië met het standpunt dat de PLO niet buiten het onderhandelingsproces mocht worden gelaten. In de CIDI*enquête werd bevestigend geantwoord op de vraag of Nederland de PLO als enige vertegenwoordiger van het Palestijnse volk diende te erkennen. Daarover ontstond vervolgens enig rumoer. Een voorkeur voor de Nederlandse rol in het kader van de EEG werd - evenals in 1977 - 'het meest effectief genoemd.

150. De tekst bij Lipschits, 1981 , p. 44 verschilt: 'Ons land bevordert dat het beleid van de Europese Gemeenschap met betrekking tot het Midden-Oosten aansiwit bij dat van de Verenigde Staten". 
Na bespreking van de grotere politieke partijen zullen we nu korter de kleinere politieke partijen de revue laten passeren.

"Klein rechts': Het uitgangspunt van SGP, GPV en RPF kwam in het werkiezingsprogramma van deze laatste partij voor 1981 het duidelijkst naar voren waar werd gesteld: 'Ook al mag men de huidige staat. Israël niet vereenzelvigen met het bondswolk, toch leert de Bijbel dat God 'om der Vaderen wil' met Israël speciale bemoeienis blijft houden' ${ }^{151}$. Met als politieke gevolgtrekking 'Nederland zal Israël als volk en als natie, niet ten onrechte een Godswonder genoemd, elke steun en sympathie moeten geven die mogelijk is' ${ }^{\prime 152}$. Deze drie partijen verzetten zich tegen deelname van de PLO aan het vredesoverleg en keerden zich op dat punt tegen de verklaring van Venetie ${ }^{153}$. De RPF stelde expliciet in bet programma - de andere twee in de toelichting eveneens - dat Nederland binnen de EG zijn invloed moest aanwenden voor steun aan de Camp Davidakkoorden. Op én punt nam het GPV binnen 'klein-rechts" een uitzonderingspositie in, daar deze partij al voor de verkiezingen van 1977 stelde dat "de vorming van een afzonderlijke staat voor de Palestijnen in het huidige bezette gebied kan worden bevorderd'; in 1981 behoorde Israël van het GPV 'het recht van de Palestijmen op een eigen staat te erkennen'. DS'70 tenslotte wenste vooral het Camp Davidproces te steunen en was gekant tegen contacten met de PLO.

'Klein links': Binnen 'klein-links' werd verschillend gedacht over het Midden-Oosten. Op basis van de verkiezingsprogramma's kan een tweedeling tussen PSP en PPR enerzijds en CPN'en EVP anderzijds worden gemaakt. De PSP verzette zich in feite nog tegen het delingsplan van 1947 en vond dat 'de zionistische struktuur de blijvende onderdrukking van de Palestijnse Arabieren inhield' en erkende slechts een 'zelfbeschikkingsrecht van de Isrälische Joden dat behoud van sociaal-culturele identiteit omvatte'. Volgens de PSP 'moet in alle gevallen vermeden worden dat opnieuw een staat onstaat waarin het mogelijk blijft om een rascistische (sic! ${ }^{154}$ ) en onderdrukkende politiek te voeren als in de huidige staat Isräl' .

De PPR ging niet zo ver als de PSP, die het bestaansrecht van Israël afwees, maar was evenmin gelukkig met 'een exclusief Joodse staat'. Beide opteerden in hun verkiezingsprogramma uit 1977 al voor een Palestijnse staat, maar deze moest volgens de PPR wel naast Israël ontstaan en kon voor de PSP ook wel een binationale staat worden. De Nederlandse regering zou volgens de PSP in 1977 de PLO als enige en wettige vertegenwoordiger moeten erkennen. In 1981 sprak de PPR zich daar ook voor uit.

De CPN besteedde geen aandacht aan het Midden-Oosten in de verkiezingsprogramma's voor 1977 en 1981. In een toelichting werd het recht op bestaan en de veiligheid van de staal Israël centraal gesteld.

De EVP tenslotte stelde in 1981 voorzichtig 'voorzover Nederland invloed kan uitoefenen' dat een regeling gebaseerd moet zijn op 'erkenning van het bestaansrecht van de

151. Lipschits, 1981, p. 365 .

I52. Ibidem p. 366.

153. Lipschits, 1981, pp. 209, 184, 366.

154. Spelfout met opzet owergenomen; warschijnlijk wordt er fascistisch en racistisch bedoeld. 
staat Israel zowel als erkenning van het recht op zelfbeschikking van het Palestijnse volk: 155 .

Over de houding van de politieke partijen ten aanzien van het Europese vredesinitiatief stelde het CIDI ten tijde van de Kamerverkiezingen in 1986 een vraag ${ }^{156}$. Ondanks: de enigszins suggestieve bewoordingen (de vraag luidde: 'Acht uw partij de verklaring van Venetie uit 1980, waarin o.m. gesteld wordt dat de PLO betrokken moet worden bij vredesonderhandelingen nog steeds een geschikt uitgangspunt voor de Europese Midden-Oostenpolitiek?') bleek uit de antwoorden dat de PvdA, D'66, PSP, CPN, PPR, EVP achter de verklaring van Venetie stonden. Het CDA stond tamelijk positief en de VVD tamelijk negatief tegenover dit Europese streven. De overige partijen SGP, RPF en GPV waren ertegen, De antwoorden van de politieke partijen uit 1986 komen overeen met de bevindingen uit de vergelijking van de programma's der politieke partijen in deze studie.

VVD, SGP, RPF wilden minder ver gaan dan reeds in EPS-verband was overeengekomen. EVP en CDA hadden een nagenoeg overeenkomstig standpunt als in EPS-verband werd gerealiseerd. PvdA en D'66 gingen iets verder omtrent de positie van de PLO dan de EPS-verklaringen. GPV en PPR gingen verder dan het EPS-standpunt, omdat zij voor cen Palestijnse staat naast Israël kozen, terwijl voor de PSP deze Palestijnse staat ook in plaats van Israël mocht ontstaan. Weliswaar waren de Nederlandse politieke partijen in hun posities ten aanzien van het Midden-Oosten niet gepolariseerd, toch begon zich ook op dit terrein een tweedeling tussen 'links' en 'rechts' te voltrekken, die op veel andere terreinen in opinies ten aanzien van het buitenlands beleid reeds gebruikellijk was.

\subsubsection{Departementen}

Het buitenlands beleid ten aanzien van het Midden-Oosten in de periode 1974-1980 dat in dit hoofdstuk werd besproken, werd voornamelijk voorbereid op het departement van Buitenlandse Zaken. De directeur-generaal politieke zaken en de ambtenaren van de onder hem ressorterende Directie Afrika en Midden-Oosten waren bij de voorbereiding de belangrijkste deelnemers. De in het vorige hoofdstuk aangegeven overheveling van VN-forum naar EPS-beraad betekende tevens de afkalvende betrokkenheid van de directie internationale organisaties vanuit het directoraat-generaal internationale samenwerking op dit terrein. Van de topambtenaren werd aan de directeur-generaal internationale samenwerking niet langer een belangrijke rol in het besluitvormingsproces toegekend. De ambtelijke voorbereiding was in handen van de directeur-generaal politieke zaken.

In verband met de bijeenkomsten van de Europese Raad was op politiek niveau ook de minister-president bij de besluitvorming betrokken. Zijn departement - het ministerie van Algemene Zaken - was echter niet betrokken bij de ambtelijke voorbereiding van

155. Lipschits, 1981 , p. 149.

156. R.M. Naftaniel, Kamerverkiezingen "86, standpunten over het Midden-Oosten, CIDI informatie, (12) no. 3, mei 1986. 
de Europese Raad. De voorbereiding vond plaats vanuit het ministerie van Buitenlandse Zaken. Ambtenaren van het ministerie van Algemene Zaken hadden daar geen bemoeienis mee ${ }^{157}$.

De toegenomen Nederlandse export naar de Arabische wereld - de 'petrodollars' veroorzaakte een grotere belangstelling van het departement van Economische Zaken voor het Nederlandse Midden-Oostenbeleid. Deze belangstelling was voornamelijk gericht op het voorkomen van schade voor de exportmogelijkheden. Zolang Nederland in de pas bleef lopen met de Europese partners, was er weinig gevaar te duchten. Toch bleef de vrees voor een kwetsbare positie bestaan, met name in de periode 1979/1980 tijdens de zogenaamde tweede oliecrisis, die onder meer werd veroorzaakt door de Iraanse revolutie ${ }^{158}$ en het begin van de oorlog tussen Iran en Irak ${ }^{159}$. In een interview met Trouw op 31 mei 1979 dreigde bijvoorbeeld Arafat met maatregelen tegen Nederland, indien het beleid niet evenwichtiger zou worden. Sedert 1974 hadden Van der Stoel en Van der Klaauw telkenmale verklaard dat het Nederlandse beleid ten aanzien van het Midden-Oosten evenwichtig - 'evenhanded' - was, maar het zou volgens Arafat 'evenwichtiger' moeten worden, daar Nederland volgens hem 'binnen de EG het slechtste standpunt inneemt tegenover de Palestijnse rechten'. Zijns inziens werd de vooruitgang binnen de EG naar 'praktische stappen ten behoeve van de Palestijnse rechten" waar Frankrijk en Italië naar streefden door Nederland gedwarsboomd ${ }^{460}$. Arafats voorstel tot verbreking van de diplomatieke betrekkingen en een boycot van de Nederlandse commerciële en oliebelangen werd evenwel door de Arabische ministers van Buitenlandse Zaken en Financiēn niet aanvaard ${ }^{161}$.

Zolang aan het Nederlands beleid binnen de EG gestalte werd gegeven, was de interdepartementale invloed niet manifest. Anders werd de situatie toen Nederland als enig Westeuropees land een beslissing moest nemen over de verplaatsing van zijn ambassade van Jeruzalem naar Tel Aviv in de zomer van $1980^{162}$. In dit geval kon Nederland niet terugvallen op een gemeenschappelijke stellingname van zijn EG-partners. Op grond van een vraag van het Kamerlid Mommersteeg (CDA) over de Nederlandse belangen in de Arabische wereld werd door de plaatsvervangend directeur-generaal voor de Buitenlandse Economische Betrekkingen vanuit het departement van Economische Zaken een notitie aan de Kamer gestuurd. Deze notitie passeerde niet minister Van Aardenne. De opsteller, de heer Huibregtse, deelde de auteur van deze studie mee deze notitie 'in een moment van verstandsverbijstering' te hebben opgesteld en rechtstreeks aan de griffie van de Tweede Kamer te hebben verstuurd ${ }^{163}$. Minister Van Aardenne wenste louter ministeriële verantwoordelijkheid te aanvaarden voor de statistische gegevens uit deze notitie. Niet alleen de minister van Economische Zaken maar ook zijn

157. Informatie uit telefoongesprek op 3 augustus 1989 met J.P.M.H. Merkelbach wan het ministerie van Algemene Zaken, kabinet van de minister-president

158. Odell in NRC-Handelsblad, 8-8-1990.

159. Le Monde, dossiers et documents, no. 121, april 1985.

160. Trouw, 31-5-1979; Nieuwsnet, 2-6-1979.

161. Troun, 31-5-1979.

162. Van de Westeuropese landen was alleen de Nederlandse ambassade in Jeruzalem gevestigd.

163. Telefoongesprek met J.W.A. Huibregtse op 18 april 1983. 
collega van Buitenlandse Zaken voelde zich gepasseerd, zo bleek uit het Kamerdebat ${ }^{164}$. Zeer overtrokken werd de Nederlandse kwetsbaarheid voor de olievoorziening in deze notitie ten tonele gevoerd. De spectaculaire groei van de export-orders naar met name Saoedi-Arabië en Irak werd beklemtoond evenals de beoogde samenwerkingsovereenkomsten met Irak, Saoedi-Arabië, Koeweit en de Verenigde Arabische Emiraten ${ }^{165}$.

De notitie kon worden gelezen als een pleidooi voor verplaatsing van de Nederlandse ambassade van Jeruzalem naar Tel Aviv ten behoeve wan de Nederlandse handels- en betalingsbalans en de werkgelegenheid, zo concludeerde ik eerder ${ }^{166}$. Het departement van Economische Zaken vertolkte daarmee de opvattingen van zijn clientële, het bedrijfsleven, dat op grond van zijn eigen belangen duidelijk pro-Arabisch georiënteerd was, volgens een ingewijde uit deze kring ${ }^{167}$.

Bij de ambassadekwestie zagen we dat de minister van Buitenlandse Zaken zich gepasseerd voelde door de minister van Economische Zaken ${ }^{168}$. Te zelfdertijd werd de minister van Buitenlandse Zaken ook gepasseerd door zijn eigen departementsambtenaren. Op 2 september 1980 zou namelijk in de Tweede Kamer de stemning plaatsvinden over een motie waarin de regering werd verzocht het besluit tot verplaatsing van de ambassade op te schorten. Maar voordat het parlement kon stemmen, bleek dat op $\mathbb{1}$ september 1980 de Nederlandse ambassade in Israël reeds was verplaatst ${ }^{169}$. Deze actie wals buiten medeweten van de minister geschied, die zijn verontschuldigingen aanbod en achteraf zijn ambtenaren terecht heeft gewezen ${ }^{170}$. De Tweede Kamer kon nog slechts unaniem een motie aanvaarden waarin geconstateerd werd dat hiermee inbreuk was gepleegd op de goede verhouding tussen de Kamer en de regering ${ }^{171}$.

Ook in New York, zo bleek mij bij dit onderzoek, werd de parlementaire behandeling niet afgewacht, want op 29 augustus 1980 schreef de Nederlandse permanente vertegenwoordiger bij de VN, Scheltema, aan de secretaris-generaal van de VN dat de Nederlandse regering 'decided to transfer the Royal Netherlands embassy in Israel from West Jerusalem to Tel Aviv" "72. Ook buiten medeweten van de minister was in mei 1980 de PLO-vertegenwoordiger Sartawi door de chef van de directie Afrika en MiddenOosten, N. van Dijl, op het departement ontvangen hetgeen de minister in de Eerste Kamer betreurde. De greep van de minister op zijn ambtenaren was blijkbaar nogal

164. Handelingen Tweede Kamer, zitting 1979-1980, 28 augustus 1980, p. 5966.

165. "Notitie inzake de kwestie Oost-Jeruzalem in relatie tot de Nederlandse economische belangen in de Arabische wereld' van 22 augustus 1980; zie ook: Trouw, 27-8-1980 en De Volkskrant 27 en 28-8-1980, Interview met De Grooth op 24 maart 1983.

166. Grünfold, 1984, p. 125.

167. Interview met Van der Beugel op 19 november 1982.

168. Handelingen Tweede Kamer, zitting 1979-1980, 28 augustus 1980, p. 5966.

169. Handelingen Tweede Kamer, zitting 1979-1980, Motie wan Rossum 16.300 no. 5, 2 september 1980 pp. $6007,6008,6020,6021$.

170. Interview met Van Rossum op 16 maart 1983.

171. Tweede Kamer, zitting 1979-1980, tweede motie-Van Rossum 16.300 no, 6.

172. Brief van Scheltema aan de secretaris-generaal, S. 14.144, zie ook: Yearbook of the United Nations 1980, pp. 399-405 en Repott of the Secretary General under Security Council resolution 478 (1980) van 11 noverniber $1980, S / 14.248$. 
gering. Dat betekent echter niet dat er een "Palestijnse lobby" binnen het departement zou zijim ontstaan ${ }^{173}$.

\subsubsection{De niet-formele politieke elite}

\subsubsection{Actiegroepen}

In hoofdstuk 1 - 1.4.2.2. - werden enkele politieke actiegroepen besproken die het Nederlands buitenlands beleid ten aanzien van het Midden-Oosten trachtten te beïnvloeden. Deze actiegroepen ontplooiden in de periode 1974-1980 veel activiteiten, voornamelijk gericht op het informeren en uitdragen van hun standpunten in de Nederlandse samenleving. De niet-formele politieke elite richtte zich op de publieke opinie op massaniveau. De wijze waarop dat geschiedde is mede afhankelijk van de toegang van de betreffende groep tot de geïnteresseerden. Het CIDI bijvoorbeeld dat van de vier actiegroepen - CIDI, NPK, WI, NZB - het gemakkelijkst toegang tot de media had, gaf daaraan prioriteit. Volgens Naftaniel - de directeur van het CIDI - zijn de media in eerste instantie opinie-bepalend omdat de parlementariërs gevoelig zijn voor de pers ${ }^{174}$. Het CIDI had ook contact met nagenoeg alle politieke partijen - uitgezonderd de Centrum Partij en PSP - in en buiten het parlement. Ook rechtstreekse contacten met de regering waren voor het CIDI mogelijk. De contacten met de ambtenaren op Buitenlandse Zaken werden door het CIDI grotendeels overgelaten aan de Israëlische ambassade ${ }^{175}$. De andere actiegroepen konden niet bogen op rechtstreekse contacten met de formele politieke elite en de directe besluitvormers.

De politieke opstelling van het NPK verhinderde een grote mate van ontvankelijkheid. Het NPK liet het 'lobbywerk' grotendeels over aan Rabbani, intertijd honorair consul voor Koeweit ${ }^{\Perp 76}$. Deze had voornamelijk contact met fractiewoordvoerders op het terrein van Buitenlandse Zaken en Defensie van CDA, PvdA en D'66 en met de ambtenaren op Buitenlandse Zaken en de Nederlandse ambassadeurs in de Arabische wereld ${ }^{177}$.

Het ICN en de WI waren beperkt in hun contacten die voornamelijk respectievelijk klein rechts en de PvdA omvatten.

De NZB had wel contact met de directe besluitvormers; zowel de minister van Buitenlandse Zaken als de ambtenaren van het ministerie van Buitenlandse Zaken reageerden meestal positief op een verzoek tot overleg. Voor de overheid waren de joodse kerkgenootschappen. de vertegenwoordigers van de Joodse gemeenschap in Nederland ${ }^{178}$. De NZB adviseerde hen en was meestal aanwezig bij de ontmoetingen van de joodse kerkgenootschappen met de directe besluitvormers. Aangezien de Nederlandse regering het beleid ten aanzien van het Midden-Oosten grotendeels afstemde op de grootste

173. Reformatorisch Dagblad, 3-9-1980.

174. Interview met Naftaniel op 21 september 1982.

175. Ibidem.

176. Interview met Hendriks op 11 februari 1983.

177. Interview met Metzemaekers op 2 juni 1982.

178. Brief van het Nederlands-Israëlietisch Kerkgenootschap aan auteur wan 28 september 1981. Voor Frankrijk geldt dit eweneens. Eytan, 1986, p. 171. 
gemene deler van de EG, achtte de NZB hun invloed gering ${ }^{179}$. Een succes op binnenlands terrein - Arabische boycotmaatregelen, subsidie NPK, ambtelijke contacteit met PLO - was daardoor eerder mogelijk dan op het terrein van de internationale politiek. Bovendien speelde de "tijdsfactor" daarbij een belangrijke rol. Eerder werd beschreven - 1.1. - dat het buitenlands beleidsproces niet langer voorafgaat aan het internationale politieke proces. Dat had gevolgen voor de effectiviteit van de binnenlandse beinvloedingspogingen. Zo stelde Wajsberg: "je kan pas reageren als thet al gebeurd is. Dat heeft geen zin. Je zou van tevoren moeten kunnen reageren en naar Buitenlandse Zaken stappen. Dat was mogelijk bij de dreigende uitstoting van Israël ait de UNESCO en WHO, maar meestal hoor je het pas achteraf. Ook de Israëlische ambassade verstrekt die informatie niet vooraf" ${ }^{\prime 180}$.

Inzake de in het vorige deel - 3.1 - behandelde EPS-verklaringen werden dan ook geen beirnvloedingspogingen vooraf ondernomen. Dat nam niet weg dat de opvattingen van de actiegroepen over de aan de orde zijnde kwesties wel tevoren werden geuit. Zo drong het NPK aan op erkenning van de PLO. De WI had een voorkeur voor een 'twee-staten' oplossing en was voorstander van een erkenning van het zelfbeschikkingsrecht van de Palestijnen. De NZB en het CIDI hadden zich verzet tegen contacten door ambtenaren en minister met de PLO. Zij voerden daartoe overleg met de minister van Buitenlandse Zaken en zijn ambtenaren op 18 december 1979 en 12 mei 1980. De proIsraëlisehe organisaties juichten het Egyptisch-Israëlisch vredesverdrag toe. De WI vierde de ondertekening van dat verdrag met een demonstratieve bijeenkomst op de Dam te Amsterdam onder de leus 'Shalom en Salaam gaan tesaem' "181.

Het in EPS-verband bereikte resultaat stemt het meest overeen met de standpunten van de WI. Dat betekent dat het uitgangspunt van de WI dat in 1973 nog omstreden was, in 1980 aanvaard werd en tot uiting kwam in het Nederlands buitenlands beleid. Overigens wil dat niet zeggen dat aan de WI hiermee een succesvolle beïnvloedingspoging moet worden toegeschreven. Het resultaat had immers minder te maken met directe binnenlandse beïnvloedingspogingen dan met de internationale politieke verhoudingen in EPS-verband ${ }^{182}$.

\subsubsection{Kerken}

Na 1974 kan een verschuiving van standpunt door de kerken in Nederland ten aanzien van het conflict in het Midden-Oosten worden geconstateerd. Vórr 1974 overheerste bij de Raad van Kerken in Nederland de solidariteit met het bedreigde Israël ${ }^{183}$. In een verklaring van 11 december 1974 reageerde de Raad van Kerken nog verontrust op de

179. Interview met Boers op 6 april en op 6 juli 1982.

180. Interview met Wajsberg op 24 maart 1982.

181. De auteur wan deze studie hield op 27-3-1979 de toespraak aldaar. Jaarverslag NIK 1980, pp. 20 22.

182. Zie ook jaarverslag WI uit 1982 en de Volkskrant 6-8-1982 waarin werd gesteld dat de doelstellingen - de erkenning van het zelfbeschikkingsrecht van de Pallestijnen nast de noodzaak van veilige grenzen voor Israell - van de linksgeoriënteerde werkgroep in Nederland well voldoende lijkt te zijn. aangeslagen, inaar politiek te weinig respons heeft gekregen in Isnael.

183. Snoek 1983, p. 100 . 
steun aan de PLO in de Algemene Vergadering van de VN en in de UNESCO. Het bestaansrecht van Israël stond voorop - vergelijk ook de felle reactie van 12 november 1975 op de 'racisme-zionisme' resolutie van de Algemene Vergadering van de VN maar daarnaast stelde hij voor het eerst dat Israell het recht op een staatkundig bestaan van de Palestijnse Arabieren most erkennen ${ }^{184}$.

De Wereldraad wan Kerken was de Nederlandse Raad daarin voorgegaan toen hij, in augustus 1969, blijkens een verklaring van het Centraal Comite in Canterbury, opkwam voor de legitieme rechten van het Palestijnse volk. In september 1970 werd bijvoorbeeld een PLO-functionaris door de secretaris-generaal van de Wereldraad in Geneve ontvangen ${ }^{185}$. Tijdens de vijfde Assemblee van de Wereldraad te Nairobi in november en december 1975 werd in een verklaring onder meer het zelfbeschikkingsrecht van het Palestijnse volk erkend en tevens vastgesteld dat 'wederzijdse erkenning door de partijen niet gezien moet worden als een voorwaarde voor, maar veeleer als een resultaat van onderhandeling' ${ }^{186}$. Deze benadering werd en wordt nog steeds door Israël verworpen - als zijnde in strijd met de paragraaf over erkenning van Israël uit resolutie 242 en door de PLO voorgestaan. Israël beschouwde resolutie 242 als én geheel en eiste erkenning als voorwaarde vooraf d.w.z. het was niet bereid te onderhandelen zonder voorafgaande erkenning. De PLO wilde deze laatste 'troefkaart' niet bij voorbaat uitspelen. Erkenning van Israël zou eventueel een resultaat van de onderhandelingen kunnen zijn.

Vier jaar later - in 1979 - volgde de Raad van Kerken in Nederland pas de Wereldraad met een verklaring waarin eveneens wederzijdse erkenning als voorwaarde vooraf werd afgewezen. In deze 'verklaring van de Raad van Kerken betreffende het conflict in het Midden-Oosten' stond onder punt vier 'Het recht van de Palestijnen op zelfbeschikking en op een staatkundig bestaan dient eveneens onverkort erkend te worden' ${ }^{187}$.

Deze door de sectie internationale zaken van de Raad van Kerken ontworpen verklaring ontmoette kritiek binnen de kerken. Zo deelde bijvoorbeeld het moderamen van de Generale Synode van de Gereformeerde Kerken in Nederland mee dat het op advies van deputaten Kerk en Israël 'het niet raadzaam achtte de verklaring op dit moment - zonder meer - naar de gemeenten te sturen' ${ }^{188}$. De in 1974 opgerichte werkgroep 'De Kerk en het Joodse volk', die ressorteent onder de sectie geloofsvragen van de Raad van Kerken, bereidde een andere verklaring voor ${ }^{189}$.

184. Ibidem p. 102.

185. Snoek 1983 , pp. $88-89$

186. Tbidem p. 93.

187. Brief aan de leden - kerken van de Raad wan Kerken in Nederland vam 17 oktober 1979 met verklaring van 10 oktober 1979 - (Sectie Internationale Zaken 103/79, in de Engelse tekst werd "statkundig bestaan' met 'political existence' en 'onverkort' met 'without restrictions' vertaald (Sectie Internationale Zaken 129/79).

188. Citaat aangehaald door Snoek, 1983, p. 103.

189. Brief van Th. Fossen, secretaris van de Werkgroep 'De Kerk en het Joodse volk" wan 10 maart 1982 aan de auteur. 
Op 25 mei 1981 werd deze "verklaring van de Raad van Kerken betreffende het hard nekkige antisemitisme bestemd voor christenen en kerken in Nederland" aanvaard 190. De beide afgevaardigden van de Remonstrantse Broederschap stemden tegen. $Z$ ij vonden dat bestrijding van het antisemitisme zich niet mocht toespitsen op vragen rond de houding jegens de staat Israël. Daamaast wonden zij dat 'een erkenning van de historische en godsdienstige verbondenheid tussen christendom en jodendom echter nog niet betekent dat de staat Israèl vanuit een theologisch gefundeerd solidariteitsbeginsel beoordeeld zou moeten worden' 19 . In de verklaring werd grote terughoudendheid bepleit in de kritiek op Israẻl en aangedrongen om bij de te uiten kritiek "de diepe en blijvende solidariteit met de joden' en 'de verbondenheid met Israel' ${ }^{192}$ naar voren te hallen.

Over de vraag in hoeverre verbondenheid met het Joodse volk door christenen ook moest leiden tot solidariteit met Israël, werd binnen de kerken verschillend gedacht. In Nes Amin - een christelike "kibbutz" in Israël - werd "getuigenis afgelegd van de christelijke solidariteit met het zionistische streven" ${ }^{193}$. Bijvoorbeeld tijdens Kerstmis: in 1974 spoorde zij kerken en christenen in Nederland aan er bij de Nederlandse regering en wolksvertegenwoordiging op aan te dringen om 'het langzaam afglijden naar een anti-Israelische houding te verlaten' ${ }^{194}$. Aan de andere zijde van het spectrum stond het Vaticaan dat weigerde Istael te erkennen. Ook het Nederlands Episcopaat beperkte zich tot een uitspraak over 'het verlangen van het Joodse volk naar een eigen tehuis' ${ }^{195}$.

Van directe beinvloedingspogingen vanuit de kerken op het Nederlands buitenlands beleid was nauwelijks sprake. Hun activiteiten beperkten zich grotendeels tegen het misbruik van doopbewijzen voor de 'niet-jood verklaringen'; met misbruik van doopbewijzen werd gedoeld op het tegemoetkomen aan de Arabische boycotmaatregelen waarbij van werkgevers een verklaring werd geeist waarin stond dat zij of de uitgezonden medewerker christelijk, dat wil zeggen niet-joods was ${ }^{196}$.

In de standpuntbepaling liep de Wereldraad van Kerken voorop in de erkenning van de Palestijnse rechten en onderschreef hij bijvoorbeeld eerder de legitieme rechten van de Palestijnen en hun zelfbeschikkingsrecht dan Nederland in internationaal verband deed ${ }^{197}$. De Raad van Kerken in Nederland volgde pas na geruime tijd de Wereldraad en liep op het punt van het Palestijnse zelfbeschikkingsrecht de Nederlandse regering. evenmin voor de voeten. Hun verklaring uit 1979 veroorzaakte veel opschudding binnen

190. Sectie Internationale Zaken 7I/81.

191. Kuiper, E.J., Remonstrants lid van de Raad van Kerken, in: Tijd en Taak, augustus 1981, no. 15 angehanld door Blaauw, 1983, pp. 114-115.

192. Punten 3d en 30 wit verklaring wan 1981.

193. Schoon, 1976, p. 20.

194. Vdidlem p. 27.

195. De Tijd, 11-5-1974, Interview van A. Kuiper met Th.C. de Kruijf als voorzitter van de Katholieke Raad woor Israël.

196. Brief van het moderamen van de Generale Synode van de Gereformeerde Kerken in Nederland van 3 november 1981 aan de auteur. Een discussie in eigen kring heeft wel plaatsgewonden.

197. Onder de achterban van de Wereldrad van Kerken bevond zich ook de christelijke kerken in helk Midden-Oosten en veel Pulestijnen waren christelijk, zoals onder meer de radicale Habash van thet Volksfront voor de bevrijoling van Palestina. 
de kerken ${ }^{198}$ en de verklaring uit 1981 corrigeerde die zelfs enigszins terwijl de $\mathrm{Ne}$ derlandse regering in de internationale politiek inmiddels het Palestijnse zelfbeschikkingsrecht onderschreef. Kortom, de Raad van Kerken in Nederland heeft een terughoudende positie ten aanzien van het Arabisch-Israëlisch conflict ingenomen en zo bezien de Nederlandse regering eerder geremd dan gestimuleerd tot het in internationaal verband innemen van een positie, die wel eens ten koste zou kunnen gaan van de verbondenheid met Israël.

De drie joodse kerkgenootschappen hebben zich in de periode 1974-1980 een aantal malen tot de minister-president en de minister van Buitenlandse Zaken gericht over het Nederlands beleid ten opzichte van het Midden-Oosten. De nagenoeg elk jaar ondernomen beïnvloedingspogingen over de Arabische boycotmaatregelen en de subsidie voor het Palestina Komitee van de NCO waren volgens het Nederlands-Israëlietisch Kerkgenootschap wel succesvol ${ }^{199}$. Deze blijven hier verder buiten beschouwing, omdat dit voornamelijk binnenlands beleid betreft en geen directe relatie heeft met het Nederlands optreden in de internationale politiek ${ }^{200}$.

Het Nederlands optreden in internationaal verband werd kritisch gevolgd door de joodse kerkgenootschappen. Over een mogelijke erkenning van de PLO door de Algemene Vergadering van de VN in 1974 werd door de drie joodse kerkgenootschappen en de $\mathrm{NZB}$ op 3 oktober 1974 een brief aan de minister van Buitenlandse Zaken geschreven, waarin deze werd verzocht zich met kracht tegen erkenning van de PLO te verzetten. Op 14 oktober 1974 volgde daarover een gesprek met de staatssecretaris van Buitenlandse Zaken, Kooijmans. De Nederlandse stemonthouding over deze resoluties - 3210, 3236 - veroorzaakte diepe teleurstelling bij de joodse kerkgenootschappen die dat op 25 november 1974 lieten weten in een brief aan de fractievoorzitters in de Eerste en Tweede Kamer ${ }^{201}$. Het Nederlandse parlement, met uitzondering van de PPR en PSP, deelde de bezwaren van de joodse kerkgenootschappen (zie 3.2.1). Op 24 september 1976 hebben de drie joodse kerkgenootschappen en de NZB in overleg met het CIDI in een brief aan de minister van Buitenlandse Zaken, Van der Stoel, hun bezorgdheid geuit over de politisering in de gespecialiseerde organisaties van de VN. Zij wezen daarin op de positie van Israël in de UNESCO, de WHO en de ILO. De minister antwoordde de politisering van geval tot geval te willen beoordelen. Zijns inziens was binnen UNESCO wel enig succes geboekt door de toelating van Israël tot de Europese regio ${ }^{202}$.

Naar aanleiding van de Algemene Vergadering van de VN in 1976, werden de voorzitters van de drie joodse kerkgenootschappen, de NZB en de directeur van het CIDI op 12 januari 1977 door de minister-president, Den Uyl, en de minister van Buitenlandse Zaken, Van der Stoel, ontvangen. De bewindslieden verklaarden dat het Nederlandse standpunt ten opzichte van Israël niet weżenlijk was veranderd ${ }^{203}$.

198. Interview met Zijerveld op 30 juni 1982.

199. Brief van de voorzitter en secretaris van de Permanente Commissie tot de Algemene Zaken van het Nederlands-Istaëlietisch Kerkgenootschap aan auteur van 28 september 1981.

200. Zie voor de NCO-subsidie bij paragrat 1.4.2.2.

201. Jaarverslag NIK over 1974, pp. 26-27.

202. Jaarverslag NIK over 1976, pp. 23-24.

203. Jaarverslag NIK over 1977, pp. 21-22. 
De verontrusting van Joodse zijde nam in de loop van 1977 toe door onder meer de EG-verklaringen van 29 juni 1977 (zie 3.1.2.1) en het niet langer noemen van de VNresoluties 242 en 338 in de Memorie van Toelichting op de begroting van Buitenlandse Zaken voor $1978^{204}$. De drie joodse kerkgenootschappen en de NZB schreven een brief aan minister Van der Stoel, die hen vervolgens uitnodigde voor een gesprek. In dat gesprek deelde Van der Stoel mee dat zijn beleid over de afgelopen vier en half jaar onder meer gericht was op het voortzetten van de traditionele vriendschap met Israel, 'zulks in overeenstemming met de warme en hechte gevoelens van vriendschap die het Nederlandse volk in overgrote meerderheid voor het Israëlische volk koestert'. Hij voegde daaraan toe dat Nederland juist als vriend van Israël het recht had kritiek op Israël uit te oefenen, 'ja het was zelfs een vriendenplicht dit te doen' ${ }^{205}$.

Uit deze toelichting komt naar voren dat de minister in zijn beleid rekening hield met de pro-Israëlische consensus in de Nederlandse samenleving. Tevens is zijn uitspraak een illustratie van hetgeen eerder werd gesteld (zie 1.4) dat Nederland vanwege zijn hechte relaties met Israël en juist ten behoeve van Israël soms genoopt is kritisch op het Israëlische beleid te reageren. Door het NIK werd geconstateerd dat het Nederlandse beleid was gewijzigd ${ }^{206}$. Om enige invloed te kunnen uitoefenen op de Europese politiek ten aanzien van het Midden-Oosten werd besloten nauwer samen te werken tussen de Joodse Gemeenschappen in de EG-landen en gezamenlijk op te treden. Bovendien zou worden getracht een eigen kantoor in Brussel te openen ${ }^{207}$.

Over de uitwoering van de motie-Brinkhorst ${ }^{208}$ - inhoudende het verzoek aan de regering om feitelijke contacten met de PLO, die mede gericht dienden te zijn op wijziging van het PLO-Handvest, niet langer uit de weg te gaan - vond een gesprek met minister Van der Klaauw plaats. Aan dat gesprek op 18 december 1979 werd deelgenomen door vertegenwoordigers van de drie joodse kerkgenootschappen, de NZB en het CIDI. Volgens de minister zou eerst het PLO-Handvest gewijzigd moeten worden, voordat officieel met de PLO werd gesproken ${ }^{209}$. Desalniettemin werd op 26 maart 1980 een PLO functionaris, Sartawi, op het ministerie ontvangen en liet de minister in een interview in Trouw van 3 april 1980 doorschemeren dat het PLO-Handvest niet zo letterlijk moest worden genomen ${ }^{210}$. De drie joodse kerkgenootschappen en de NZB lieten in een telegram aan de minister weten, geschokt te zijn. De minister nodigde hen opnieuw uit voor een gesprek op 12 meil 1980 en zei hun dat PLO-functionarissen niet meer op het departement zouden worden ontvangen (zie ook 3.2.1 waarin hij dezelfde toezegging in de Eerste Kamer deed). Tenslotte hebben de drie joodse kerkgenootschappen in een

204. In de Memorie van Toelichting op de begroting wan Buitenlandse Zaken voor 1979 werden beide VN-resoluties weer vermeld.

205. Jaarverslag NIK over 1977, pp. 22-24.

206. Jaarverslag NIK over 1979, pp. 24-25.

207. Jaarverslag NIK over 1977, p. 6. Deze Europese sectie van het World Jewish Congress had op 1 maart 1981 een gesprek met minister Van der Klaauw. Zij gaven uiting aan hun ongerustheid over het 'plan van Luxemburg', zie daarover 4.1.1.1; Van Houten, Kopuit, 1981, pp i 171-173.

208. Handelingen Tweede Kamer, zitting 1979-1980, 20 november 1979, pp. 1325 en 1326; motie no. 15.800-V, nr. 24.

209. NIK jaarverslag over 1980, pp. 19-20. Van den Houten en Kopuit, 1981, pp. 153-156.

210. NIK, jaarwerslag over 1980 , p. 21 ; naar aanleiding van een Kamervraag daarover verklaarde de minister de journalist op dat punt niet te hebben tegengesproken. 
telegram aan de minister-president erop aangedrongen niet toe te geven aan de Arabische eisen inzake de plaats van de ambassade in Israel ${ }^{2 n}$.

Uit de hier gepresenteerde voorbeelden blijkt dat de drie joodse kerkgenootschappen - deel uitmakend van de niet-formele politieke elite - over het Nederlands beleid ten aanzien van het Arabisch-Israëlisch conflict rechtstreeks contact hadden met de directe besluitvormers. Het contact met parlementariërs werd door hen grotendeels toevertrouwd aan het CIDI, in welks bestuur zij vertegenwoordigd waren. Wel vonden kort na de gesprekken tussen de joodse kerkgenootschappen en de minister in 1974, 1977 en 1980 over deze gespreksonderwerpen Kamerdebatten plaats. Een grote mate van ontvankelijkheid voor de wensen en zorgen bij de joodse kerkgenootschappen bij ministers en Kamerleden kwam daarbij naar voren.

\subsubsection{Bedrijfsleven}

Volgens de voorzitter van het overlegorgaan met het bedrijfsleven was het hele bedrijfleven pro-Arabisch met het oog op de eigen belangen in de Arabische wereld ${ }^{212}$. Van een lobby door het bedrijfsleven was volgens hem geen sprake. Wel werden ambtenaren individueel benaderd en vonden lunches met Kamerleden plaats. Als er werd opgetreden geschiedde dat gezamenlijk via het Centraal Orgaan ${ }^{213}$. Ook de directeur van het Centraal Orgaan van het bedrijfsleven, Basoski, benadrukte de terughoudendheid aan de zijde van de werkgevers. Deze terughoudendheid kwam voort uit de gevoeligheid ten aanzien van het Midden-Oostenconflict in de Nederlandse samenleving. Ook de werkgeversorganisaties hadden leden met pro-Israëlische gevoelens ${ }^{214}$.

Het bedrijfsleven was voorstander van de 'inbedding' van het Nederlandse MiddenOostenbeleid in EPS-verband. Een kwetsbare handelspositie voor het Nederlandse bedrijfsleven kon daarmee worden voorkomen. Beduchtheid voor een kwetsbare handelspositie kwam vooral tot uiting in het voldoen aan de eisen inzake de Arabische boycot tegen Israël. Daarnaast heeft bijvoorbeeld Philips de NOS verzocht de documentaire 'De dood van een Arabische prinses' niet uit te zenden. Saoedi-Arabië had met economische sancties gedreigd bij uitzending van deze film. Philips vreesde dat daarcoor de telecommunicatieorder in Saoedie-Arabië van vier miljard gulden met werk voor vierduizend mensen gevaar zou lopen ${ }^{215}$. Ook bij de kwestie over de verplaatsing van de Nederlandse ambassade in Israël, waarbij eveneens met Arabische economische sancties werd gedreigd, heeft niet het VNO maar hebben indlividuele bedrijven de minister op hun belangen gewezen ${ }^{216}$. Volgens het Kamerlid. Bakker (CPN) was druk van het bedrijfsleven ook niet nodig omdat de ambtenaren van het departement van

211. NIK, jaarwerslag over 1980 , pp. 23-24.

212. Interview met Van der Beugell op 19 november 1982.

213. Ibidem.

214. Interview met Basoski op 27 augustus 1982.

215. Discussie vond plaats in AVRO's: Televizier op 14 april 1980 tussern de vice-president wan de Raad van Bestuur van Philips, Dekker, en de hoofdredacteur van het Parool, Sandberg. Tekst aan auteur gestuurd door Philips Press Department.

216. Haagsche Courant 18-8-1980, NRC-Handelsblad 18-8-1980, NIW 22-8-1980. 
Economische Zaken, die een rapport aan de Kamer opstelden, al 'volstrekt op het standpunt van het bedrijfsleven stonden" 217 .

Kortom, beïnvloeding van het bedrijfsleven vond eerder plaats over het Nederlands buitenlands beleid op het bilaterale terrein dan inzake Nederlands optreden in internationaal verband. De 'beschermfunctie' van de EPS - zie 1.3.2.1 - omvatte cok de belangen van het Nederlandse bedrijfslewen.

\subsubsection{Media}

De Nederlandse media bleven in de periode $1974-1980$ veel aandacht schenken aan de gebeurtenissen in het Midden-Oosten. Eerder zijn de resultaten van het Utrechtse krantenonderzoek gepresenteerd (zie 2.2.4.4), waaruit bleek dat na berichtgeving omtrent Westeuropese landen de informatie over het Midden-Oosten op de tweede plaats kwam. Meer correspondenten dan vóór 1973 berichtten vanuit de Arabische wereld en nagenoeg alle media hadden eigen correspondenten in Israël. Gevolg van dat laatste was de zeer grote aandacht voor Israëlische gebeurtenissen in Nederland. De correspondenten in Israẽl wisselden nauwelijks - Rob Simons, Salomon Bouman, Eddo Rosenthal, Marcel Kupferschmidt, Joop Meyer, Inez Polak, Willy Werkman, Jaap van Wesel, James Dorsey - en naast deze correspondenten verschenen bij enkele dagbladen redacteuren die zich grotendeels met het Midden-Oosten bezighielden. Daardoor werd naast de rapportage ook meer aandacht aan de analyse van het conflict besteed. Toch kwam daarin ook veelvuldig de normatieve invulling van de journalist tot uiting zoals 'een oplossing van het conflict is niet denkbaar zonder .......' en - dat is een ernstige tekortkoming - soms een verkeerde beoordeling van de situatie. Zo werden de Likud-verkiezingsoverwinningen van 1977 en 1981 niet verwacht. Bij de lezers werd eerder de verwachting gewekt dat de Arbeiderspartij aan de macht zou blijven of zou terugkeren. Deels was de hoop dan vaak de vader van de gedachte, maar ook de journalistieke contacten binnen het Israëlisch establishment van voornamelijk Ashkenazische afkomst veroorzaakten een verkeerde beoordeling. Ook Israëlische journalisten en opinie-peilers maakten dezelfde misrekening; het meten van opinies in Israël - met wisselende migratie-golven, opkomst van een nieuwe in Israël geboren generatie, enkele gesloten streng religieuze gemeenschappen en verschillend verwerkte oorlogservaringen - is een nog hachelijker zaak dan in West-Europa.

Ondanks de overvloed aan informatie en aanzetten tot analyse heb ik niet de indruk gekregen dat de media een rol spelen in het proces van beinnvloeding van het buitenlands beleid anders dan op de indirecte wijze als informatiedragers. Voorstellen tot een Nederlandse opstelling in EPS-verband bleven achterwege en ook nadat bijvoorbeeld een EPS-verklaring was gepubliceerd, werd daaraan nog nauwelijks commentaar gewijd. In het vorige hoofdstuk zagen we dat de kranten uitgebreid commentaar gaven op de verklaring van 6 november 1973 (zie 2.3.5.4); hoewel enkele kranten nog wel aandacht schonken aan de verklaring van juni 1977, werd aan de daaropvolgende verklaringen weinig aandacht besteed en geen commentaar gegeven. Voorzover uit de berichtge-

217. Handelingen Tweede Kamer, zitting 1979-1980, 28 agustus 1980, p. 5960. 
wing een houding kan worden afgeleid stemde die over het algemeen in met het bereikte resultaat.

De geringe aandacht aan deze op internationaal niveau tot stand gekomen standpunten in de EPS over het Arabisch-Israëlisch conflict is opvallend gezien de overvloedige informatie uit Israel, over het conflict en het gegeven dat elke opinie van een Nederlands politicus over het Midden-Oosten breed werd uitgemeten ${ }^{218}$.

Enkele uitzonderingen daargelaten ${ }^{219}$ schonk de pers dus nauwelijks aandacht aan de EG-verklaringen over het Midden-Oosten. De EG-verklaringen stonden niet centraal in de politieke discussie in Nederland over het Midden-Oosten. De aandacht in de media voor uitspraken van Nederlandse politici over het Arabische-Israëlisch conflict stonden in schril contrast met de aandacht voor de EG-verklaringen over het conflict. En dat terwijl de EG-verklaringen het Nederlands buitenlands beleid terzake weergaf, hetgeen niet het geval was bij de uitspraken van Nederlandse partijpolitici.

\subsubsection{Publieke opinie}

Ten aanzien van de publieke opinie kunnen enkele opinie-onderzoeken onder de Nederlandse bevolking over het Midden-Oostenconflict over de periode 1974-1980 worden gepresenteerd.

In april 1977 werden in opdracht van de Werkgroep Israël door het NIPO zes vragen aan 1127 Nederlanders van 18 jaar en ouder voorgelegd ${ }^{220}$ (tabel 3.1 tot en met 3.5).

218. In bijlage 12 staat een niet-volledig overzicht van de gandacht die de media in 1979 hebben geschonken aan enkele uitspraken van Nederlandse politici.

219. Trouw, 2-8-1979 reageerde op de EG-verklaring wan 26-3-1979 en Trouw, 16-6-1979 gaf een woorbeschouwing voor de EPS bijeenkomst waaruit de EG-verklaring van 18-6-1979 voortwloeide en in NRC-Handelsblad, 21-7-1979 reageerde Naftaniel van het CIDI op de beide Europese verklaringen.

220. De antwoord-alternatieven werden daarbij aan de respondenten gegeven. Opinie-onderzoek over Israêl en bet Midden-Oosten, F-702 (week 10), rapporten vain 24 maart 1977, 1 april 1977 en 19 april 1977. 
Tabel 3.1.

\begin{tabular}{|l|r|r|r|r|r|r|r|r|}
\hline \begin{tabular}{l} 
Publieke opinie over Israël, de Arabische landen en de Palestijnen (in \%), 1977 \\
\hline $\begin{array}{l}\text { Naar welke van de betrok- } \\
\text { ken partijen gaat Uw sympa- } \\
\text { thie uit: }\end{array}$
\end{tabular} Allen & $\begin{array}{l}\text { SGP } \\
\text { GPV } \\
\text { RKPN }\end{array}$ & CDA & VVD & PvdA & D'66 & PPR & $\begin{array}{l}\text { PSP } \\
\text { CPN }\end{array}$ \\
\hline Israël & 49 & 67 & 59 & 54 & 47 & 55 & 56 & 33 \\
\hline de Arabische landen & 2 & - & - & 1 & 3 & 3 & 5 & 6 \\
\hline de Palestijnen & 4 & - & 3 & 3 & 5 & 3 & 22 & 30 \\
\hline alle partijen & 9 & 10 & 7 & 8 & 12 & 16 & 8 & \\
\hline geen van de partijen & 12 & 10 & 7 & 12 & 13 & 8 & - & 32 \\
\hline geen oordeel & 25 & 14 & 23 & 22 & 20 & 16 & 9 & \\
\hline
\end{tabular}

Geslacht, leeftijd en politieke interesse in het conflict bleken niet van invloed op de getoonde 'sympathie'.

Tabel 3.2.

\begin{tabular}{|l|r|r|r|r|r|r|r|r|}
\hline Publieke opinie over de door Israẽl veroverde gebieden (in \%), 1977 \\
\hline & Allen & $\begin{array}{l}\text { SGP } \\
\text { GPV } \\
\text { RKPN }\end{array}$ & CDA & VVD & PvdA & D*66 & PPR & $\begin{array}{l}\text { PSP } \\
\text { CPN }\end{array}$ \\
\hline $\begin{array}{l}\text { Onvoorwaardelijk } \\
\text { afstand doen }\end{array}$ & 4 & - & 2 & 4 & 5 & 4 & 16 & 16 \\
\hline $\begin{array}{l}\text { Afstand doen na afsluiten } \\
\text { vredesakkoord }\end{array}$ & 21 & 10 & 21 & 20 & 24 & 26 & 42 & 42 \\
\hline $\begin{array}{l}\text { Afstand doen met grens- } \\
\text { correcties voor Israëls veilig- } \\
\text { heid }\end{array}$ & 34 & 35 & 39 & 43 & 32 & 53 & 28 & 23 \\
\hline $\begin{array}{l}\text { Geen afstand doen, ook niet } \\
\text { na vredesakkoord }\end{array}$ & 7 & 16 & 9 & 8 & 5 & 3 & -15 \\
\hline Geen antwoord & 34 & 40 & 28 & 25 & 33 & 15 & 15 & 20 \\
\hline
\end{tabular}


Tabel 3.3

Publieke opinie over de positie van de Palestijnen (in \%), 1977

\begin{tabular}{|l|r|l|r|r|r|r|r|r|}
\hline & Allen & $\begin{array}{l}\text { SGP } \\
\text { GPV } \\
\text { RKPN }\end{array}$ & CDA & VVD & PvdA & D'66 $^{\prime}$ & PPR & $\begin{array}{l}\text { PSP } \\
\text { CPN }\end{array}$ \\
\hline $\begin{array}{l}\text { Opgenomen worden door } \\
\text { Arabische landen }\end{array}$ & 16 & 10 & 20 & 20 & 14 & 9 & 31 & 14 \\
\hline $\begin{array}{l}\text { Een onafhankelijke staat } \\
\text { naast Israël }\end{array}$ & 43 & 44 & 41 & 47 & 50 & 63 & 55 & 60 \\
\hline Andere oplossing & 2 & 8 & 2 & 1 & 2 & 3 & -1 & \\
\hline Geen antwoord & 39 & 39 & 37 & 32 & 34 & 25 & 15 & 26 \\
\hline
\end{tabular}

Tabel 3.4.

Relatie sympathie met de door Israël veroverde gebieden (in \%), 1977

\begin{tabular}{|l|r|r|r|r|r|l|r|}
\hline & Allen & Israël & $\begin{array}{l}\text { Arabi- } \\
\text { sche } \\
\text { landen }\end{array}$ & $\begin{array}{l}\text { Pales- } \\
\text { tijnen }\end{array}$ & $\begin{array}{l}\text { Alle } \\
\text { Partijen }\end{array}$ & $\begin{array}{l}\text { Geen } \\
\text { van de } \\
\text { partijen }\end{array}$ & $\begin{array}{l}\text { Geen } \\
\text { antwoord }\end{array}$ \\
\hline $\begin{array}{l}\text { Onvoorwaardelijk } \\
\text { afstand doen }\end{array}$ & 4 & 3 & 23 & 23 & 5 & 6 & 2 \\
\hline $\begin{array}{l}\text { Afstand doen na } \\
\text { afsluiten vredesak- } \\
\text { koord }\end{array}$ & 21 & 21 & 39 & 42 & 49 & 20 & 7 \\
\hline $\begin{array}{l}\text { Afstand met } \\
\text { grenscorrecties } \\
\text { voor Israëls veilig- } \\
\text { heid }\end{array}$ & 34 & 50 & 21 & 28 & 30 & 21 & 11 \\
\hline $\begin{array}{l}\text { Geen afstand } \\
\text { doen, ook niet na } \\
\text { vredesakkoord }\end{array}$ & 7 & 11 & 4 & 2 & 2 & 5 & \\
\hline \begin{tabular}{l} 
Geen antwoord \\
\hline
\end{tabular} & 34 & 14 & 13 & 5 & 14 & 48 & 78 \\
\hline
\end{tabular}


Tabel 3.5

\begin{tabular}{|l|r|r|r|r|l|l|r|}
\hline \multicolumn{2}{|l|}{ Relatie sympathie met de oplossing voor de Palestijnen (in \%), 1977} \\
\hline & Allen & Israel & $\begin{array}{l}\text { Arabi- } \\
\text { sche } \\
\text { landen }\end{array}$ & $\begin{array}{l}\text { Palles- } \\
\text { tijnen }\end{array}$ & $\begin{array}{l}\text { Alle } \\
\text { Partijen }\end{array}$ & $\begin{array}{l}\text { Geen } \\
\text { van de } \\
\text { partijen }\end{array}$ & $\begin{array}{l}\text { Geen ant- } \\
\text { woord }\end{array}$ \\
\hline $\begin{array}{l}\text { Opgenomen } \\
\text { worden door } \\
\text { Arabische landen }\end{array}$ & 16 & 22 & 56 & 8 & 19 & 15 & \\
\hline $\begin{array}{l}\text { Een onafhankelijke } \\
\text { staat naast Israël }\end{array}$ & 43 & 51 & 27 & 78 & 69 & 35 & 18 \\
\hline Andere oplossing & 2 & 4 & - & 6 & 1 & 11 & \\
\hline Geen antwoord & 39 & 23 & 17 & 8 & 11 & 49 & 80 \\
\hline
\end{tabular}

Uit de tabellen 3.2 en 3.3 blijkt dat ongeveer tweederde wel een mening had over de toekomst van de bezette gebieden en de oplossing van de Palestijnse kwestie. De meerclerheid koos voor een 'twee-staten' oplossing en koos inzake de bezette gebieden overeenkomstig resolutie 242 - land in ruil voor vrede - en schaarde zich daarmee achter het Nederlandse regeringsbeleid. Andere oplossingen vonden weinig onthal en werden nog het meest door aanhangers van 'klein-rechts' - geen afstand doen - , en door aanhangers van 'klein-links" - onvoorwaardelijk afstand doen - naar voren gebracht.

Uit de tabellen 3.4 en 3.5 kan meer inzicht worden verkregen in de houding van de met verschillende groepen sympathiserende Nederlanders ten aanzien van de beide vraagstukken (i.c. de bezette gebieden en de Palestijnse kwestie). Een genuanceerd oordeel komt daaruit naar boven. Slechts $11 \%$ van de Israël-aanhangers vond dat Israël alle bezette gebieden moet behouden. Degenen die sympathiseerden met de Arabische landen, Palestijnen of alle partijen, spraken zich sterker uit voor opgave na het bereiken van een vredesakkoord en de Israël-aanhangers kozen vaker voor opgave met inbegrip van grenscorrecties ten behoeve van Israëls veiligheid. Degenen die sympathiseerden met Israël, de Palestijnen of alle partijen, waren ook het meest geporteerd voor een 'twee-staten" oplossing. Uit tabel 3.5 komt ook het verschil naar voren tussen degenen die met de Arabische landen en degenen die met de Palestijnen sympathiseren. Ten onrechte werden beide groepen wel eens over eén kam geschoren, terwijl uit de tabel blijkt dat $78 \%$ van degenen die met de Palestijnen sympathiseerden voor de 'tweestaten' oplossing koos en dat slechts $27 \%$ van degenen die met de Arabische landen sympatiseerden dezelfde keuze maakte. Opgemerkt kan worden dat ten tijde van deze enquête de PLO en bijwoorbeeld het Nederlands Palestina Komitee nog niet voor een 'twee-staten' oplossing hadden gekozen, maar voor één staat Palestina in het hele gebied opteerden. Zij verschilden op inhoudelijke gronden van mening met deze Nederlanders die met de Palestijnen sympathiseerden. Enige voorzichtigheid bij de interpretatie van deze gegevens is vanwege de kleine aantallen als gevolg van de uitsplitsing in de tabel 
wel geboden. Het percentage van $4 \%$ van degenen die met de Palestijnen sympathiseerden in 1977 (tabel 3.1) komt anderzijds wel overeen met de $4 \%$ die in 1979 aan de kant van de PLO stond (tabel 3.6).

Eind 1979 werd door het NIPO aan 1301 Nederlanders gevraagd (tabel 3.6 en 3.7) of zij aan de kant van Israël, van de PLO of neutraal stonden.

Tabel 3.6

\begin{tabular}{|c|c|}
\hline \multicolumn{2}{|c|}{ Publieke opinie over Israël en de PLO (in \%), 1979} \\
\hline Israël & $25 \%$ \\
\hline PLO & $4 \%$ \\
\hline Neutraal & $62 \%$ \\
\hline Geen antwoord & $9 \%$ \\
\hline
\end{tabular}

Tevens werd gevraagd "Is iemand die de PLO en/of de Palestijnen steunt dan ook een antisemiet, of alleen maar iemand die tegenstander is van dingen die de staat Israël doet?"

Tabel 3.7

Relatie sympathie PLO en Palestijnen met antisemitisme (in \%), 1979

\begin{tabular}{|c|c|}
\hline Antisemiet & $9 \%$ \\
\hline Alleen tegenstander van Israël & $55 \%$ \\
\hline Allebei & $19 \%$ \\
\hline Geen antwoord & $17 \%$ \\
\hline
\end{tabular}

Voor $28 \%$ van de Nederlanders zijn degenen die de PLO en/of de Palestijnen steunen antisemitisch ${ }^{221}$.

De indruk ontstaat dat dit negatieve waardeoordeel in 1979 vooral betrekking had op het beeld van de PLO en niet de steun aan de Palestijnen betrof. In 1979 had immers $32 \%$ veel sympathie voor de Palestijnen en kon slechts $8 \%$ geen sympathie opbrengen. Een verdeling naar aanhangers van de vier grote politieke partijen volgt in tabel $3.8^{222}$.

221. Nipo, 1979 week 44, No. 1301, Vaneker en Everts 1984 p. 10.

222. Elsevier-Nipo enquête uit Elseviers Magazine, 8 september 1979 , p. 15 en Elseviers Magazine, 10 juli 1982 , p. 8 . 
Tabel 3.8

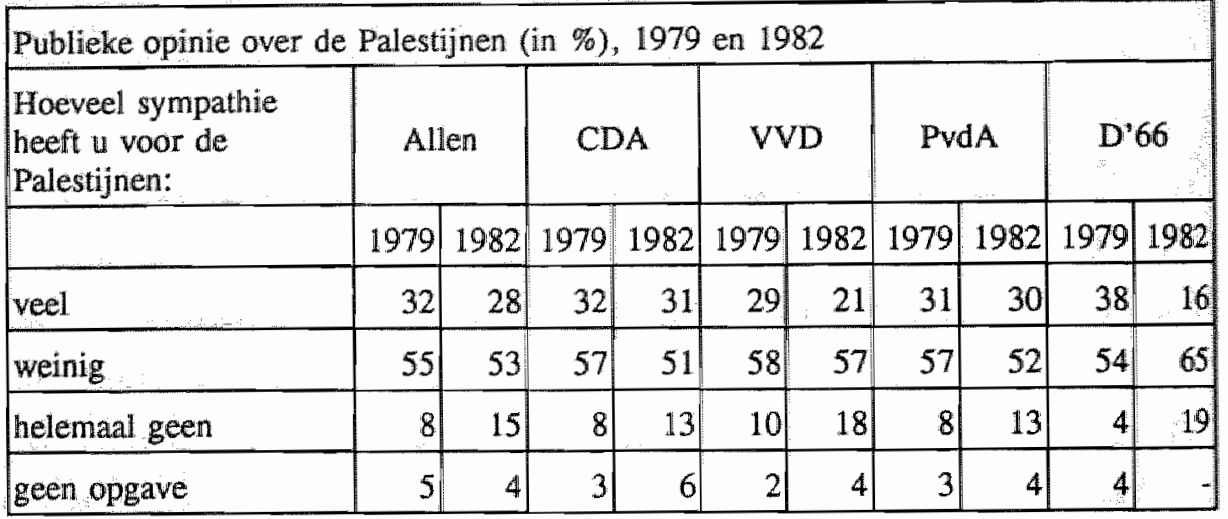

Bij dezellfide vraagstelling naar sympathie voor Israel ontstaat het volgende beeld.

Tabel 3.9

\begin{tabular}{|c|c|c|c|c|c|c|c|c|c|c|}
\hline \multicolumn{11}{|c|}{ Publieke opinie over Israël (in \%), 1979 en 1982} \\
\hline \multirow{2}{*}{$\begin{array}{l}\text { Haeveel sympathie } \\
\text { heeft U voor Israël: }\end{array}$} & \multicolumn{2}{|c|}{ Allen } & \multicolumn{2}{|c|}{$\mathrm{CDA}$} & \multicolumn{2}{|c|}{ VVD } & \multicolumn{2}{|c|}{ PvdA } & \multicolumn{2}{|c|}{$D^{\prime} 66$} \\
\hline & 1979 & 1982 & 1979 & 1982 & 1979 & 1982 & 1979 & 1982 & 1979 & 1982 \\
\hline veel & 57 & 41 & 65 & 53 & 68 & 50 & 47 & 30 & 56 & 32 \\
\hline weinig & 36 & 45 & 33 & 37 & 28 & 43 & 45 & 48 & 39 & 65 \\
\hline helemaal geen & 3 & 12 & 1 & 7 & 2 & 5 & 5 & 18 & 2 & 3 \\
\hline geen antwoord & 3 & 3 & 1 & 4 & 2 & 2 & 3 & 4 & 3 & - \\
\hline
\end{tabular}

De enquete uit 1982 werd gehouden na de Israëlische inval in Libanon waarvoor $73 \%$ weinig of helemaal geen begrip had. De sympathie voor Israël begon te tanen, waarbij het opvalt dat de sympathie voor de Palestijnen eveneens afnam ${ }^{223}$.

Het beeld van de publieke opinie in Nederland is gecompliceerd. Enerzijds roept 'Israël' positieve gevoelens op, anderzijds wordt het Israëlische beleid grotendeels afgekeurd. Deze afkeuring werd sterker na de regeringswisseling van 1977 in Israël. Het Likudbeleid stond haaks op het door de meerderheid van de Nederlanders en ook door de meerderheid van de Israël-aanhangers voorgestane beleid, zoals uit de hier gepresenteerde gegevens blijkt.

Een ondersteuning van deze stelling komt ook naar voren uit een enquête uit 1983, waaruit blijkt dat onder de staten waar Nederlanders bewondering voor hebben Israël het hoogst scoort, terwijl Israël eveneens hoog scoort onder de staten waarvan het

223. Elsevier-Nipo enquâte uit Elseviers Magazine, 8 september 1979 , p. 15 en Elsewiers Magazine, 10 juli 1982 , p. 9. 
buitenlands beleid door de Nederianders als slecht wordt gekwalificeerd (op de vierde plaats na de Sovjetunie, Suriname en de VS) ${ }^{224}$.

Het positieve beeld over Israël zou ook kunnen zijn veroorzaakt door het hoge vijandbeeld dat Nederlanders ten aanzien van de Arabische wereld toonden ${ }^{225}$.

In het algemeen kan worden gesteld dat een pro-Israëlische stemming op het niveau van het massapubliek in de periode 1975-1980 aanwezig was. Overigens verschilde de Nederlandse bevolking daarin niet sterk van de bevolking van enkele andere Westeuropese staten (zie bijlage 4).

\subsection{Conclusies en slotopmerkingen}

Na de ervaring van het olie-embargo van 1973 wilde Nederland voor de toekomst een kwetsbare positie voorkomen. Het zocht bescherming door middel van de gemeenschappelijke verklaringen in EPS-verband. In de EPS was de invloed van de Fransen groot. Nederland probeerde hen zoveel mogelijk te matigen. De Nederlandse beinnloeding richtte zich op het zoveel mogelijk steun verlenen aan Israël en het zo min mogelijk vervreemden van de Amerikaanse benadering ten aanzien van het Midden-Oosten. Geringe steun van de andere Europese partners voor de Nederlandse inbreng leidde ertoe dat de Nederlandse beïnvloedingspogingen weinig succesvol waren. Het gevolg was een toegeven aan de buitenlandse druk, te typeren als een inschikkelijke aanpassing van het Nederlands beleid in de periode 1974-1980. Dat stuitte niet op groot verzet in eigen land, omdat - naast het voorkomen wan kwetsbaarheid zoals tijdens het olie-embargo uit 1973 - dit EPS-beleid binnenlands wel aanvaard werd. Dat kwam omdat de binnenlandse pro-Israëlische consensus afnam. In Nederland ontstond een grotere verdeeldheid in opvattingen over het Arabisch-Israëlisch conflict. In de publieke opinie werd meer begrip getoond voor de Palestijnse kwestie. De politieke partijen schoven in hun verkiezingsprogramma's ook op in hun opvattingen. Pro-Israelische groepen waren actief in het naar voren brengen van hun opinie, daarentegen wees het bedrijfsleven op zijn belangen in de Arabische wereld. Deze grotere verdeeldheid in eigen land verschafte de regering meer vrijheid van handelen. Kritiek vanuit het parlement op het Nederlands optreden in de internationale politiek werd na 1975 eveneens minder. Enige anticiperende invloed van het parlement op de regering bleef bestaan en ondersteunde de terughoudende Nederlandse opstelling in de EPS evenals de steun aan Israël en de VS. Directe invloed door het parlement op het mede door Nederland ingenomen internationale politieke standpunt bleef achterwege. De besluitvorming was grotendeels in handen van de topambtenaar - de directeur-generaal politieke zaken - van het departement van Buitenlandse Zaken (zie 3.2.2.). Als gevolg van de in het vorige hoofdstuk

224. NIPO: Pro of anti-Amerikanisne, mei 1983, No. 1204, uit: Vaneker en Everts, 1984, p. 165.

225. De Arabische olielanden werden in 1979 na de Sovjetunie het meest genoemd yan de landen die nu $-16,0 \%$ - of in de toekomst - 19,7\% - de belangrijkste militaire bedreiging voor ons land vormen. Ook in 1980 werden de Arabische olielanden na de Sovjetunie het meest genoend - 24,0\% - van de landen welke momenteel voor Nederland een militaire bedreiging vormen.

Beide enquêtes over het vijandbeeld in Nederiand werden uitgevoerd door het NIPO in december $1979-N=763$ - en in februari $1980-N=1150$ - in opdracht van het Studiecentrum voor vredesvraagstukken van de K.U. Nijmegen. Vaneker en Everts, 1984, pp. 115 em 120. 
ontvouwde verschuiving van de besluitvorming over het conflict in het Midden-Oosten van de VN naar de EPS, werd deze topambtenaar niet langer gecorrigeerd of lastig gevallen door een andere topambtenaar: de directeur-generaal internationale samenwerking. De minister van Buitenlandse Zaken leunde in zijn beleid sterk op deze directeurgeneraal politieke zaken, voor wie een goede samenwerking met zijn Europese collega's, in het comité politique van de EPS, van groot belang was. Ook daardoor lag een beleid van inschikkelijke aanpassing voor de hand.

In bijlage 21 wordt de besluitvorming over de verklaring van Venetië schematisch weergegeven. Daaruit blijkt dat dit gemeenschappelijk standpunt in de internationale politiek pas achteraf aan het parlement werd voorgelegd. Zelfs de critici in het parlement konden de minister slechts steunen met een uitspraak dat het Amerikaanse beleid ten aanzien van het Midden-Oosten niet doorkruist mocht worden. In het interne EPSberaad had de minister daar ook voor geijverd en kon hij op een beperkt succes in deze kwestie bogen. In die zin bestond er wel degelijk een relatie tussen de Nederlandse inbreng in de internationale politiek en het Nederlands buitenlands beleid. Hiermee zijn de drie vragen uit de probleemstelling beantwoord aan de hand van de gegevens uit dit hoofdstuk.

In dit hoofdstuk werd naar voren gebracht dat in januari 1977 in de door socialisten gedomineerde kabinetten binnen de EG enige aarzeling bestond een 'Israël-onvriendelij$\mathrm{ke}^{t}$ verklaring aan te nemen. Op dat moment bestond de Israëlische regering nog uit socialisten. Dat werpt de vraag op of met socialisten aan de macht eerder een 'Israëlvriendelijk' beleid wordt gevoerd. Vier EPS-verklaringen worden, voor de beantwoording van de vraag, in verband gebracht met de positie wan socialisten in de regeringen van de EG-lidstaten.

Tabel 3.10

\begin{tabular}{|l|r|r|r|r|}
\hline Positie van socialisten in de regeringen van de EG-lidstaten, $1973-1981$ \\
\hline in kabinet & 1973 & 1977 & 1980 & 1981 \\
\hline als minister van Buitenlandse Zaken & 6 & 6 & 4 & 7 \\
\hline als premier & 2 & 4 & 1 & 4 \\
\hline
\end{tabular}

Bron: tabel is gebaseerd op gegewens uit bijlage 17 .

De verklaringen uit 1977 en 1980 werden door de Europese Raad aanvaard. Daarorn is de positie van de premier van belang. De verklaringen uit 1973 en 1981 werden door de ministers van Buitenlandse Zaken aangenomen. Om de vraag bevestigend te beantwoorden zou de verklaring uit 1977 gunstiger voor Israël moeten zijn dan de verklaring uit 1980. Bovendien zou de verklaring uit 1981 gunstiger voor Israël moeten zijn dan de verklaring uit 1973. Dat klopt omdat de verklaring uit 1981 (die in het volgende hoofdstuk wordt behandeld) waarin Europese participatie in de MFO werd goedgekeurd, voor Israël gunstig was. Hiermee werd het Israêlisch-Egyptisch vredesverdrag ondersteund. De verklaring van Venetiẻ uit 1980, waarin stond dat de PLO onder bepaalde 
woorwaarden bij de onderhandelingen moest worden betrokken, werd door Israël volledig afgewezen. Van de vier verklaringen riep deze de sterkste oppositie in Israël op. De verklaringen uit 1973 - legitieme rechten voor de Palestijnen - en 1977 - een Palestijns thuisland - lagen tussen beide uitersten in. Voorzichtigheid is echter geboden voor deze generalisatie omdat andere oorzakelijke factoren van invloed kunnen zijn (er is geen ceteris paribus constructie mogelijk) en vanwege zowell de houding van de Griekse socialisten ${ }^{226}$ als de beperkte numerieke gegevens waarop deze bewering is gebaseerd. 
- $\quad \vdots$

\%

-

$\therefore$ 


\section{Hoofdstuk 4. Israëlisch-Egyptisch vredesverdrag en de MFO}

\subsection{Internationale politiek}

In het vorige hoofdstuk werd het Europese voomemen behandeld om een eigen rol te gaan spelen in het Arabisch-Israëlisch conflict. Dit voornemen werd gepresenteerd in de verklaring van Venetiè. Voor de uitvoering werden in 1980 en 1981 besprekingen gevoerd met de bij het conflict betrokken partijen. Deze Europese 'vredesmissie' stond in het tweede halfjaar van 1980 onder leiding van de Luxemburger Thom, in het eerste halfjaar van 1981 onder leiding van de Nederlander Van der Klaauw terwijl in het tweede halfjaar van 1981 de Brit Carrington aan het hoofd stond. In deze periode bekleedden namelijk respectievelijk Luxemburg, Nederland en het Verenigd Koninkrijk het voorzitterschap van de EG en de EPS. De eerste twee ministers van Buitenlandse Zaken behoorden tot een liberale politieke partij en de laatste tot een conservatieve. Het Egyptisch-Israëlisch vredesverdrag uit 1979 voorzag in een vredesmacht (peacekeeping force) die na de Israëlische terugtrekking uit de Sinaï als buffer tussen de Egyptische en Israëlische legereenheden zou kunnen optreden. Volgens het bij het verdrag behorende tijdschema zou de laatste fase van de Israëlische terugtrekking in april 1982 plaatsvinden. De volledige uitvoering van het vredeswerdrag was echter afhankelijk van de totstandkoming van deze vredesmacht.

Een VN vredesmacht werd door oppositie in de Veiligheidsraad niet gerealiseerd (zie 4.1.2.1). Vervolgens werd, door de VS en de beide partijen, een vredesmacht buiten VN-verband gecreëerd. Dat was de Multinational Force and Observers (MFO). De VS hoopten dat ook Europese staten uit de EG aan deze vredesmacht zouden gaan deelnemen. Europese participatie zou belangrijke politieke ondersteuning voor hun beleid ten aanzien van het Midden-Oosten betekenen. Binding van de Europeanen aan de benadering door de VS zou verwijdering tussen de Atlantische partners over het Arabisch-Israëlisch conflict een halt toeroepen.

In dit hoofdstuk wordt de besluitvorming in de EPS over deelname aan de MFO behandeld. Daarbij zal ik betogen dat de Europese vredesmissie mislukte en in feite niet eens echt van de grond kwam. De Europese deelname aan de Multinational Force and Observers (MFO) was niet zozeer de oorzaak van deze mislukking, maar bezegelde de mislukking en vormde er de erkenning van. De MFO, weliswaar gering van omvang en inmiddels nagenoeg vergeten, heeft weinig publiciteit gekregen en was nauwelijks onderwerp van politieke controverse in Nederland. Desalniettemin bleef dankzij deze MFO het Israëlisch-Egyptisch vredesverdrag in stand en werd door middel van Europese participatie aan deze MFO het vredesproces van de VS voor het eerst sinds 1973 daadwerkelijk door de EG ondersteund.

Mijns inziens was en is deze MFO dan ook van groot politiek gewicht. Dat is de reden waarom ik aan deze vredesmacht, die buiten $\mathrm{VN}$-verband goed functioneert, uitgebreid aandacht besteed. Nederland heeft bovendien op een cruciaal moment bijgedragen aan de totstandkoming van de MFO. De bijdrage van Nederland was slechts mogelijk door twee belangrijke gebeurtenissen in deze periode, namelijk de overwinning in die Franse presidentsverkiezingen van mei 1981 van de socialist Mitterrand en de moord op de 
Egyptische president Sadat op 6 oktober 1981. Deze twee gebeurtenissen droegen bij aan het mislukken van een eigen Europese rol in het Arabisch-Israëlisch conflict.

\subsubsection{Europese Politieke Samenwerking op de vlucht}

\subsubsection{Missie Thorn}

Paragraaf elf van de verklaring van Venetië bevatte de opdracht voor de te entameren vredesmissie van de Negen. Hij luidde: 'De Negen hebben besloten de nodige contacten te leggen met alle betrokken partijen. Deze contacten hebben tot doel informatie in te winnen over de verschillende partijen ten aanzien van de beginselen die in deze verklaring zijn uiteengezet en, in het licht van de resultaten van dit overleg, de vorm te bepalen van een eventueel initiatief hunnerzijds' ${ }^{1}$.

Deze opdracht bedoelde geen bemiddeling of conciliatie en was evenmin gericht op het doen van voorstellen, maar was een 'fact-finding' missie. Het was een begrensde 'factfinding" missie daar reacties op de eerder vastgestelde principes van de verklaring van Venetië bij de partijen werden gepeild. Deze begrenzing betekende dat er geen ruimte leek te bestaan voor het afwijken of afwijzen van de eerder vastgestelde beginselen. Daar Israël deze beginselen volledig afwees en dat ook aan Thorn tijdens zijn bezoeken aan Israël begin augustus en eind september 1980 liet blijken, ontbrak van meet af aan het vertrouwen bij één van de partijen. De reacties uit de Arabische wereld en vanuit de PLO waren gunstiger voor Thorn en hoewel hij zich aanvankelijk gereserveerd opstelde ten aanzien van een mogelijk succes, werd hij daar later optimistischer over. Zo verklaarde Thorn op 23 september 1980 in de Algemene Vergadering van de Verenigde Naties dat het Camp Davidproces niet de gewenste resultaten had opgeleverd en dat nu meer dan ooit alleen een allesomvattende regeling een rechtvaardige en duurzame vrede kon brengen ${ }^{2}$.

De Franse minister van Buitenlandse Zaken, François-Poncet, was zeer tevreden over deze eerste vredesmissie en verklaarde op 12 november 1980 de missie Thorn als een succes te beschouwen. In deze verklaring voor het Franse parlement benadrukte hij die Franse invloed op dit Europees initiatief. Hij zei: 'En ce qui concerne le Proche-Orient, c'est à travers l'Europe que la France exerce en ce moment son action. Vous en connaissez les êtappes: L'adoption de la déclaration de Venise, le succès de la mission europeenne de Monsieur Thorn et maintenant l'effort entrepris par les Neuf pour approfondir et préciser les dispositions essentielles d'un règlement de paix. Je n'ai pas besoin de rappeler ici la part que la France a prise à ces initiatives. Le retentissement qu'elles ont eu au Proche-Orient nous fait un devoir, à nous comme à nos partenaires européens, de poursuivre la voie où nous sommes engagés' 3 .

De uitwerking waarop François-Poncet doelde, vond plaats op het niveau van deskundigen. Uiteindelijk zou het plan van de deskundigen - een rapport van dertig pagina"s -

1. Bull. EG juni 1980 , no. 1.1.6.

2. 'More than ever true that only a comprehensive settlement can bring about a just and lasting peace in the Middle East" Bull. EG september 1980, no. 3.4.1.

3. Journal officiel de la République Française, Debats parlementaires, Assemblée Nationale 1980, p. 3773; cursivering auteur. 
door de Europese Raad op 1 en 2 december moeten worden goedgekeurd. Het was bedoeld geheim te blijven, maar lekte uit naar de pers. Het Belgische blad Le Soir van 27 december $1980 \mathrm{kwam}$ als eerste met de inhoud en het Amerikaanse persbureau Associated Press bracht twee maanden later, op 27 februari 1981, het volledige plan, dat op 1 en 2 december was goedgekeurd, naar buiten. De juistheid van de inhoud van dit plan zoals weergegeven in de pers, werd door diplomaten bevestigd ${ }^{4}$. De verklaring van de Europese Raad van 1 en 2 december 1980 somde alleen de hoofdstukken van het rapport - in feite een plan - op en gaf aan dat aan enkele met name genoemde beginselen op verscheidene manieren inhoud kon worden gegeven ${ }^{5}$. Aan Van der Klaauw werd vervolgens de opdracht gegeven daarover met de partijen in het MiddenOosten van gedachten te wisselen. De vermelde hoofdstukken omvatten:

1. ontruiming;

2. zelfbeschikking;

3. veiligheid in het Midden-Oosten;

4. Jeruzalem.

De Fransen en Britten waren in het bijzonder betrokken bij de inhoudelijke voorbereiding. Volgens Ifestos werden het eerste en derde hoofdstuk door Franse deskundigen en het tweede hoofdstuk door Britse experts voorbereid ${ }^{6}$.

ad 1. ontruiming. Binnen zes maanden à twee jaar moet Israël de bezette gebieden ontruimen. De Israëlische nederzettingen in de bezette gebieden moeten worden ontmanteld. Gedurende de overgangsperiode van Israëlische ontruiming moet een interim-bestuur worden ingesteld door

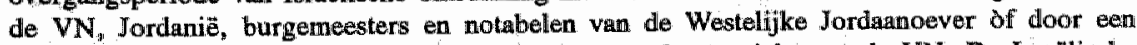
commissie van Israëli's, Jordaniērs en Palestijnen onder toezicht van de VN. De Israëlische terugtrekking moet gepaard gaan met een begin van het normaliseren door de Arabische regeringen van hun betrekkingen met Israël.

ad 2. zelfbeschikking. In een referendum kunnen de Palestijnen zich ten aanzien van de Westelijke Jondaanoever en de Gazastrook uitspreken, over drie opties" een onafhankelijke Pralestijnse staat of een federatie met Jordanië of een federatie met Jordaniè en Israël De vier miljoen Palestijnen kunnen aan de stemming deelmemen waarbij aan de stem van de 1,2 miljoen Palestijnenta van de Westelijke Jordaanoever en Gazastrook extra gewicht wordt toegekend.

ad 3. veiligheid. Internationale veiligheidsgaranties aan alle staten in het gebied. Instelling wan gedemilitariseerde zones aan beide zijden van de grens en controle door VN-troepen. De lidstaten wan de EG zijn bereid in deze. VN-wredesmacht te participeren.

ad 4. Jeruzalem. Inzake Jenuzalem wordt gekozen voor de internationalle status overeenkomstig bet VN-delingsplan uit 1947. Andere oplossingen worden niet uiltgesloten zoals verdeling van des stad met beheer yan de heilige platsen door de religieuze autoriteiten of een deling van de stad warbij de oude stad in Oost-Jeruzalem cen internationale status krijgt of onder een gemeenschappelijk bestuur komt te staan ?

4. International Herald Tribune 2-3-1981, Trouw 27-2-1981, Interview met Van Dam op 3 september 1987.

5. Bull. EG december 1980, no. 1.1.13.

6. Ifestos, 1987 , pp. $475-476$.

7. Deze weergave is gebaseerd op de berichtgeving in: Trouw; 27-2-1981. International Heralld Tribu ne, 2-3-1981 en Le Monde, 4-3-1981. 
Dit Europese plan werd besproken tijdens het overleg van Reagan en Haig met Thatcher en Carrington. Van Europese zijde werd toen beklemtoond dat het voorstel slechts een aanzet tot discussie zou vormen en niet gericht was op een doorkruising van de Camp Davidakkoorden. Volgens Begin zou het Europese plan het einde van de Joodse staat betekenen en vormde het plan derhalve een groot gevaar voor Israël ${ }^{8}$.

Mijns inziens was dit document wel degelijk een plan. In juni 1980 was het nog mogelijk van mening te verschillen over de aard van de verklaring van Venetië. Sommigen zagen daarin een initiatief, anderen slechts een voorstel tot een initiatief. De Fransen, die inmiddels een plan woor een vredesregeling voorstonden, kregen op de Europese Raad van december 1980 te Luxemburg hun zin. Er werd een plan goedgekeurd dat haaks stond op de Camp Davidbenadering. Slechts aan de Franse voorkeur voor een Palestijnse onafhankelijke staat werd nog niet volledig tegemoetgekomen.

Op 3 maart 1981 kondigden de Fransen aan over drie maanden een uitgewerkt voorstel

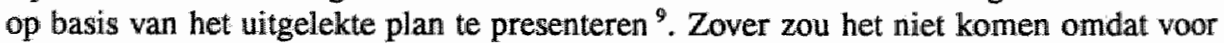
die tijd Giscard d'Estaing als president het veld moest ruimen voor Mitterrand.

Op het moment van bekendmaking - drie maanden na de goedkeuring - was het ook al enigszins achterhaald door onder meer de verkiezing in de VS van Reagan, met wie Thatcher een nauwe politieke binding voorstond.

Dit plan is het meest uitgewerkte werkstuk dat vanuit de Europese Politieke Samenwerking over het Midden-Oosten werd opgesteld. Het betekende tewens het hoogtepunt vanuit EPS-perspectief omdat vanuit de aanvankelijke afstemming van gemeenschappelijk buitenlands beleid de stap werd gezet naar gezamenlijke Europese diplomatie. Het betekende tevens de overgang van een 'communautê des vues' naar een 'communautế d'action'. Aan dit Europese plan is in de literatuur, in de Nederlandse pers en politiek weinig aandacht geschonken ${ }^{10}$.

De zwakte was dat het vanwege de totale verwerping door Israell niet uitgevoerd zou kunnen worden, terwijl het de EG aan machtsmiddelen ontbrak het plan aan Israël op te leggen. Daarnaast werd de zwakke interne basis van dit gemeenschappelijk beleid duidelijk aangetoond na de wisseling van de macht in Frankrijk. Mitterrand verwierp deze Europese aanpak op de Europese Raad van juni 1981 tot schrik van enkele Europeanen. Thatcher dacht toen dat Mitterrand de verklaring van Venetiē op de 'vuilnishoop der geschiedenis wilde werpen" ".

\subsubsection{Missie Van der Klaauw}

Greilsammer en Weiler meenden dat het Europees initiatief onder meer mislukte omdal Nederland in de eerste helft van 1981 het voorzitterschap bekleedde. Nederland, dat binnen de EG de grootste reserves had on de PLO bij het vredesproces te betrekken en nog als Israëls beste vriend binnen de Gemeenschap werd beschouwd, wilde 'to keep

8. Trouw, 5-3im1981.

9. Daily Report, Foreign Broadcast Information Service, Middlle East and Africa, (DR/FBIS/ME+A) 4 maart 1981.

10. If festos, 1987, pp. 475-476; Khader, 1984, p. 173; Greilsammer and Weiler, 1987, pp. 57-59.

11. Interview met Reinink op 5 februari 1987. 
as low a profille as possible" ${ }^{12}$. Van der Klaauw zei zelf ook niet met voorstellen te zullen komen daar 'its role is not to find answers but to try and spark off ideas which will make it easier to find these answers' ${ }^{13}$.

Na terugkeer van zijn reis naar Quatar en Koeweit zei Van der Klaauw: 'U kunt vragen wat voor zin dat heeft. Ik antwoord daarop dat het goed is om nauwkeurig uit te zoeken welke vragen er precies in het Midden-Oosten spelen". Hoge verwachtingen moest men niet hebben: 'Wij als Europa brengen geen vredesplan. Daartoe hebben we de mogelijkheid niet en het zou ook niet wenselijk zijn ermee te komen' aldus Van der Klaauw ${ }^{14}$. Bij hem ontbrak duidelijk de politieke wil daartoe.

Van der Klaaw vatte zijn opdracht - vastgesteld op de bijeenkomst van de ministers wan Buitenlandse Zaken op 20 januari 1981 - ook ruim op toen hij meedeelde 'over een grote mate van vrijheid te beschikken welke vragen hij kan stellen' ${ }^{15}$. Zijn missie was echter miet alleen gebaseerd op de verklaring van Venetië maar tevens op het rapport van Luxemburg. Hij heeft de verschillende elementen van het plan uit het rapport van Luxemburg naar voren gebracht en de reacties daarop geïnventariseerd. Een erkenning door de EG van de PLO, waarop door de Arabische wereld werd aangedrongen, wees hij af. Wel heeft hij tevergeefs getracht tot een wederzijdse erkenning van Israël en de PLO te komen.

Volgens Le Monde zou op de Europese Raad bepaald zijn dat Van der Klaauw zijn reizen niet zou maken om informatie in te winnen maar om voorstellen te doen. Volgens de Franse woordvoerder had Van der Klaauw de 'indications et orientations' los gemaakt van het rapport van de ministers van Buitenlandse Zaken ${ }^{16}$. Dat betekent dat Van der Klaauw voor zichzelf inderdaad vrijheid van handelen heeft geschapen door afstand te nemen van het rapport van Luxemburg.

De topambtenaren die Van der Klaauw begeleidden en zijn reizen uiterst grondig voorbereidden, beklemtoonden de grote activiteit en serieuze takkuitoefening van hun minister. Zo bezocht hij ook Oman, dat de betrekkingen met Egypte niet had verbroken, en landen in de periferie met cen Palestijnse gemeenschap als de Verenigde Arabische Emiraten ${ }^{17}$. Hij bezocht bijna alle Arabische staten en bracht ondermeer driemaal tussentijds verslag uit aan de Amerikaanse minister van Buitenlandse Zaken ${ }^{18}$.

De informatie uit de interviews komt overeen met de hier uit persberichten geconstrueerde weergave. Reinink stelde dat de Nederlanders tijdens de reizen steeds duidelijk

12. Greilsammer and Weiler 1982, p. 60; Greilsammer and Weiler, 1984, pp. 150-151; Ifestos, 1987, p. 477 en 478 .

13. Europe no. $3074,7-8$ febnuari 1981 in: Ifestos, 1987 p. 478 .

14. NRC-Handelsblad, 6-1-1981, cursivering auteur.

15. NRC-Handelsblad 21-2-1981.

16. Le Monde, 3-12-1980.

17. Intervilews met Reinink en Van Dam op respectievelijk 5 februari 1987 en 3 september 1987.

18. Uit: Jaarboek Buitenlandse Zaken 1980-1981, p. 106. Van der Klaauw had contact met de secretaris-generaal van de Arabische Liga (in Den Haag op 11 en 12 februari 1981 en later in Tunesie) Syrië, Irak en Jordanië (21-27 februari) Marokko en Tunesië (27-29 maart 1981); Libanon en de PLO (16-19 april); Egypte (24-28 april); Vaticaanstad (6 mei); Israël en religieuze leiders en Palestijnse notabelen en burgemeesters (10-13 mei); Saoedi-Arabie (15-17 mei); Algerije (22-24 mei); Koeweit, Bahrein, Quatar, Verenigde Arabische Emiraten en Oman (6-11 juni) en de Amerikaanse minister van Buitenlandse Zaken Haig ( 31 maart, 3 mei en 19 juni 1981). 
maakten dat de Negen niet met een plan kwamen maar dat het een 'fact-finding' missie was. Dat leidde well tot een zekere frustratie in de Arabische wereld. Daar werd immers meer van Europa verwacht. Sommige landen meenden dat het mogelijk zou zijn via Europa druk op de VS uit te oefenen. Dat laatste was niet de bedoeling van de Europeanen, aldus Reinink ${ }^{19}$. In deze teleurstelling school het gevaar dat een verwijdering tot de Arabische wereld kon ontstaan. Ter voorkoming daarvan werd getracht de EuroArabische dialoog weer te hervatten.

Zo ontstond de indruk dat de Europese vredesmissie toch wel sterk gericht was op het veiligstellen van de Europese economische belangen ten tijde van de tweede olie-crisis. Een botsing met de Arabische wereld kon worden vermeden, daar de actieve bellangstelling van de Negen voor de problematiek in de Arabische wereld werd gewaardeerd. De Europese vredesmissie zou tot een plan hebben kunnen leiden. Ten tijde van het Nederlandse voorzitterschap beperkten de Nederlanders zich tot het inventariseren van de antwoorden op grond waarvan het aan de Negen werd overgelaten ideeën te formuleren die een bijdrage konden leveren aan de oplossing van het conflict ${ }^{20}$.

Uitgangspunt voor Van der Klaauw was steeds dat hij het Amerikaanse beleid ten aanzien van het Midden-Oosten niet wilde doorkruisen. Hij wilde best de Amerikanen helpen, want hij vond dat de VS de enigen waren die wat konden doen en de enigen die werkelijk met Israël konden praten. Gedurende zijn voorzitterschap van de EG sprak Van der Klaauw drie keer met de Amerikaanse minister van Buitenlandse Zaken Haig en hij hield hem op de hoogte van zijn vredesmissie. Aanvankelijk waren de Amerikanen bang voor een Europees initiatief dat niet zou sporen met het hunne. Zij vreesden belemmerd te worden in hun optreden. Bovendien zou een Europees initiatief tot onenigheid tussen de VS en de Europeanen kunnen leiden. Bij het laatste gesprek van Van der Klaauw met Haig slaakte deze een zucht van verlichting. Logisch, volgens Van der Klaauw, 'want ik wou helemaal met hem meespelen' ${ }^{21}$. Een Europese lijn die niet op het Amerikaanse beleid zou aansluiten, zou immers vruchteloos zijn. De Nederlanders werden in deze opvatting gesteund door de Britten, Duitsers en Denen en zo ontstond ook geen isolement voor Nederland binnen de EPS ${ }^{22}$.

De nieuwe Amerikaanse president Reagan stond veel afwijzender dan Carter tegenower het Europese initiatief. De volledige afwijzing door zowel de VS als Israél 'seems to be the effective end of any illusions that the Community would have developed its initiative into a concrete peace initiative' aldus Ifestos ${ }^{23}$, waarbij hij ten aanzien van de Nederlandse rol opmerkt 'In fact, Dutch statements at a certain moment amounted to a unilateral playing down of Europe's role and purpose' ${ }^{24}$.

19. Interview met Reinink op 5 februari 1987.

20. Jaarboek Buitenlandse Zaken 1980-1981, p. 106. Het Jaarboek van Buitenlandse Zaken geeft de volgende omschrijving: 'Tijdens de missie is nagegaan of, en zo ja in hoeverre en op welke wijze, de Tien een bijdrage zouden kunnen leveren aan de totstandkoming van een klimat dat meer dain voorheen zich zou lenen voor onderhandelingen tussen de betrokken partijen gericht op een alomvat-
tende, duurzame en rechitvaardige vredesregeling".

21. Interview met Van der Klaauw op 31 augustus 1989.

22. Interview met Reinink op 5 februari 1987.

23. Ifestos; 1987, p. 480 .

24. Ifestos, 1987, p. 486 . 
Nederland heeft er in de rol van voorzitter van de EPS inderdaad toe bijgedragen dat het Europees initiatief niet verder werd ontwikkeld. Onder het Nederlandse voorzitterschap werd in feite 'een pas op de plaats gemaakt' waardoor de gelegenheid voor een impuls aan het Europese vredesinitiatief voorbij ging en door gebeurtenissen binnen en buiten de Gemeenschap ook niet zou terugkeren.

Van der Klaauw heeft zijn vredesmissie grondig en uitgebreid uitgevoerd. Hij bezocht niet alleen de direct betrokken partijen maar ook de staten in de periferie, zoals rond de Perzische Golf waar veel Palestijnen werkten. Hij stuurde een ambtelijke delegatie vooruit ${ }^{25}$. Zij overhandigden op ambtelijk niveau de vragen die in het gesprek met de minister zouden worden gesteld. Hij stelde vragen over bijvoorbeeld mogelijke demilitarisatie, economische levensvatbaarheid en de positie van de Palestijnen in de omringende Arabische staten. Kortom, hij vroeg zijn gastheren naar hun ideeën over de invulling en weigerde zelf plannen aan hen te presenteren. De Europese ideeèn lagen immers vast in de verklaring van Venetië. Deze omdraaiing - door niet langer Europese ideeën te ventileren maar de betrokken partijen naar hun zienswijzen te vragen - leidde tot uiterst verschillende benaderingen van de Arabische staten. Van der Klaauw bevestigde dat hij daarmee op de rem heeft getrapt: 'Ja, dat is een resultaat geweest en ook duidelijk een beleidskeuze van mijn kant omdat ik niet geloofde in een Europees initiatief'. Hij voegde daaraan toe dat voor Nederland zelf de missie goed was. 'Het verbeterde de relatie met de Arabische wereld en Nederland zal niet meer zo gauw door een Arabische olie-embargo worden getroffen' ${ }^{26}$.

Nederland heeft aldus zeer succesvol negatieve invloed uitgeoefend. Onder negatieve invloed wordt in deze studie verstaan het tegenhouden van veranderingen. Vooral de Fransen onder Giscard d'Estaing wensten dat Europa een actieve, eigen rol in het Midden-Oosten zou gaan vervullen. Dit zou een verandering inhouden van het tot dusverre gevoerde beleid. De Nederlanders hebben zich hiertegen verzet. Dat wil niet zeggen dat de Nederlandse invloed de reden ${ }^{27}$ is geweest voor het mislukken van het Europese vredesinitiatief. De gebeurtenissen in de eerste helft van 1981 - de verkíezing van president Mitterrand en van president Reagan, de herverkiezing van Begin en onenigheid in de Arabische wereld - maakten een succes voor een Europees vredesinitiatief onmogelijk.

De Europese Raad van 29 en 30 juni 1981 beperkte zich ten aanzien van het MiddenOosten tot het verzoek aan de ministers van Buitenlandse Zaken de verschillende opties en mogelijkheden te bestuderen, hetgeen voor de Britten die in de tweede helft van 1981 het voorzitterschap gingen bekleden een weinig inspirerende aansporing was. Toch was het Europees initiatief ook toen nog niet van de baan. Onder het Britse voorzitterschap zou blijken hoe moeilijk het was voor de Europeanen een andere koers ten aanzien van het Midden-Oosten in te slaan. Uiteindelijk zou pas de Europese participatie aan de MFO deze koerswending bezegelen. In paragraaf 4.2 .2 wordt de besluitvorming over deze participatie behandeld.

25. Die delegatie bestond wit de gepensioneerde oud-directeur generaall polutieke zaken, De Ramitz, de sous-chef wan de directie Afrika en Midden-Oosten, Van Arkel, en en oud-medewerker van het bureau Midden-Oosten die op de ambassade in Libanon werkte, Van Dam.

26. Interview met Van der Kleauw op 31 augustus 1989.

27. In de socilale wetemschappen aan te duiden als "voldoende voorwaturde". 
Lord Carrington stelde zich ten doel een wederzijdse erkenning van Israël en de PLO naderbij te brengen. Carrington, die eerder het Rhodesië-vraagstuk had helpen oplossen, meende in het Midden-Oosten op dezelfde wijze te werk te kunnen gaan: inzake Rhodesië had hij immers met 'terroristen' rond de tafel gezeten en van daaruit 'he argued repeatedly, why could it not work with Israel and the PLO' ${ }^{28}$. In zijn optimisme werd hij gesteund door de publikatie begin augustus van het plan-Fahd.

Dit plan van de Sabedische kroonprins bood voor de oplossing van het Arabisch-Israelisch conflict een opening uit de impasse doordat in de zevende paragraaf van dit plan het recht van alle staten in de regio om in vrede te leven werd erkend. Dat zou impliciet een erkenning van de staat Israël kunnen betekenen. Binnen de Europese Gemeenschap werd het plan-Fahd ook met de loupe bekeken op zoek naar mogelijkheden tot voortgang in het op de verklaring van Venetië berustende vredesproces van de EG. De Fransen voelden al niet meer voor een Europees initiatief. $\mathrm{Zij}$ gaven inmiddels, als gevolg wan het feit dat Mitterrand Giscard d'Estaing als president opvolgde, de voorkeur aan de Amerikaanse "stap-voor-stap" benadering die tijdens Camp David was toegepast en tot resultaat had geleid ${ }^{29}$. Bovendien hadden Carrington en Thatcher zelf eerder aan Haig en Reagan toegezegd het Camp Davidproces niet te zullen doorkruisen. Dat laatste weerhield de Britten er niet van de Europese benadering als een aanvulling van de Amerikaanse benadering te beschouwen.

Op grond van deze hier weergegeven uitgangspunten trachtte Carrington een gemeenschappelijke basis te vinden. Hij wilde met andere woorden het plan-Fahd, de verklaring van Venetië en het Camp Davidproces verenigen. Ook in de moord op president Sadat zag hij eerder een aansporing op zijn weg door te gaan dan daarvan terug te keren. De Britten meenden dat een regeling van het Palestijnse vraagstuk nu urgenter was geworden en de Camp Davidbenadering minder perspectief bood. Steun aan Egypte stond voor de westerse wereld voorop en ook de Europese ministers, die net terugkwamen van de begrafenis in Caïro, wilden op 13 oktober 1981 te Londen een bijdrage daartioe leveren.

De vraag deed zich voor waarmee Egypte het meest geholpen zou zijn. Sommigen gaven prioriteit aan het veiligstellen van het Egyptisch-Israëlisch vredesverdrag waardoor Israël ook het laatste deel van de Sinail voor 28 april 1982 zou ontruimen. Deze ontruiming zou plaatsvinden op 25 april 1982 nadat een vredesmacht was geformeerd waarvoor van enkele lidstaten van de EG een bijdrage was gevraagd. Anderen meenden dat met een voortgang van het vredesinitiatief en met name een wederzijdse erkenning van Israël en de PLO, Egypte uit zijn isolement in de Arabische wereld gehaald kon worden. Steun aan het Saoedische plan en afstemming daarop van het Europese vredesinitiatief zou daartoe een mogelijkheid zijn.

28. Corney, 1982, pp. $3-4$.

29. De 'stap-woor-stap" benadering is gericht op deeloplassingen en werd door Kissinger in 1973 en 1974 gevolgd. De andere benadering, de 'allesomvattende' benadering is gericht op gelijktijdige oplossing van alle onderdelen van het comflict. Aanvankelijk wenste Carter het conflict met een allesomvattende benadering op te lossen maar koos uiteindelijk voor een deeloplossing en boekte daarmee op Camp David succes. Hij bewerkstelligde het Egyptisch-Israelisch vredesverdrag. 
Hoe ideaal een combinatie van beide opties ook leek, in de realiteit was dat niet haalbaar. De Israëlische regering had namelijk het plan-Fahd en de verklaring van Venetiê categorisch verworpen. Bovendien besloot Israël de staten die achter deze voorstellen stonden, van deelname aan de MFO uit te sluiten. Pas nadat het plan-Fahd tijdens de Arabische topconferentie te $\mathrm{Fez}^{30}$ was verworpen, liet Carrington zijn plan vallen. Op dat moment was de Europese bijarrage aan de vredesmacht nog niet rond. De totstandkoming van deze vredesmacht en de Europese deelname daaraan wordt in de volgende paragraaf beschreven.

\subsubsection{Deelname aan de MFO}

\subsubsection{Geen VN-vredesmacht}

Van meet af aan waren de VN betrokken bij het Arabisch-Israelisch conflict. De totstandkoming van de staat Israël was mede te danken aan beslissingen in de VN. Relevant zijn de resoluties van de Algemene Vergadering van 1947 over het delingsplan van Palestina (resolutie 181) en van 1948 over de toelating van Israel als lid van de VN (resolutie 273).

De VN vervulden ook een rol in de handhaving van de bestanden na de vele oorlogen tussen Israël en zijn buren. Zij stelden vredesoperaties in die kunnen worden onderscheiden in waarnemersmissies en vredesmachten ${ }^{31}$.

Een waarnemersmissie bestaat uit neutrale waarnemers, die individueel of in klein teamverband werken. Hun taak beperkt zich tot rapportage. De eerste VN-waarnemersmissie was UNTSO - United Nations Truce Supervision Organization - in Egypte, Israël, Jordanië, Libanon en Syrië. Deze werd in 1948 opgericht om toezicht uit te oefenen op de wapenstilstandsakkoorden na de onafhankelijkheidsoorlog van 1948. De UNTSO functioneert nog steeds.

De vredesmachten bestaan uit militaire eenheden van verschillende staten. De militairen zijn licht bewapend. Zij vormen een militaire buffer tussen de strijdende partijen zolang een politieke oplossing nog niet is bereikt. Deze militaire eenheden staan onder gezag van de secretaris-generaal van de VN. Van de zeven vredesmachten die werden opgericht, waren er vier werkzaam in het Midden-Oosten. Drie van deze vredesmachten functioneren nog, waarvan twee in het Midden-Oosten ${ }^{32}$. In deze studie wordt aan de troepenmacht van de VN in het grensgebied tussen Israël en Egypte - UNEF I en II -

30. Op 25 november 1981.

31. Zeer veel literatuur is beschikbaar over de VN-vredesoperaties. Bijvoorbeeld LeRoy Bennett, 1984, PP. 144-168; Leurdijk 1986, pp. 14-24; Carter 1984, pp. 43-52..

32. De eerste vredesmacht was UNEF I (United Nations Emergency Fonce) tussen Egypte en IsraëI van 1956 tot 1967. Daarna vollgden ONUC (Opérations des Nations Unies au Congo) naar de Belgische Congo van 1960 tot 1964, UNSF (United Nations Security Force) naar West Nieuw Guinea van 1962 tot 1963, UNIFICYP (United Nations Force in Cyprus) naar Cyprus vanaf 1964, UNEF II (United Nations Emergency Force) tussen Egypte en Israël van 1973 tot 1979, UNDOF (United Nations Disengagement Observer Force) tussen Syrie en Israël vanaff 1974, en UNIFIL (United Nations Interim Force in Libanon) sedert 1978. 
werder aandacht besteed. Ook in de Camp Davidakkoorden werd een VN-vredesmacht in het vooruitzicht gesteld.

Op 17 september 1978 ondertekenden Sadat, Begin en Carter de Camp Davidakkoosden. Daarin stond: 'United Nations forces will be stationed .... and these forces will not be removed unless such removal is approwed by the Security Council of the United Nations with a unanimous vote of the five permanent members' ${ }^{33}$. Een herhaling van de situatie uit mei 1967, toen UNEF 1 door secretaris-generaal Oe Thant werd teruggetrokken, wilde men voorkomen. Ook was ditmaal gedacht aan garanties bij een eventuele terugtrekking. Maar deze VN-macht moest nog wel eerst geïnstalleerd worden. Met de omvangrijke kritiek op de Camp Davidakkoorden nam de twijfel aan de mogelijkheid deze binnen $\mathrm{VN}$-verband te realiseren toe.

In het Egyptisch-Israëlisch vredesverdrag van 26 maart 1979 werd in artikel IV lid 2 de volgende bepaling uit de Camp Dawidakkoorden opgenomen: 'The Parties agree to the stationing of United Nations personnel in areas described in Annex I. The Parties agree not to request withdrawal of the United Nations personnel and that these personnel will not be removed unless such removal is approved by the Security Council of the United Nations, with the affirmative vote of the five Permanent Members unless the Parties otherwise agree, ${ }^{34}$.

Op de dag van de ondertekening verstuurde Carter brieven aan Sadat en Begin waarin hij stelde dat de Veiligheidsraad van de VN de vredesmacht zou moeten instellen en dat hij zijn best zou doen zulks te realiseren. Mocht dat niet lukken, dan zou de president de noodzakelijke stappen ondernemen tot het instellen van een alternatieve multinationale macht ${ }^{35}$.

Op dat moment was de oprichting van een vredesmacht door de Algemene Vergadering van de Verenigde Naties vrijwel uitgesloten. Een zeer ruime meerderheid in de Algemene Vergadering had immers het Egyptisch-Israëlisch vredesverdrag afgewezen ${ }^{36}$. Instelling door de Veiligheidsraad lag evenmin voor de hand op grond van verzet van de Sovjetunie, die het vredesakkoord afwees. Wellicht zou een dergelijk voorstel niet alleen door een Russisch veto getroffen worden maar zou geen gekwalificeerde meerderheid binnen de Veiligheidsraad het voorstel hebben gesteund.

Toch was een continuering van UNEF II, de 'peace-keeping force' van de Verenigde Naties tussen Israël en Egypte, niet bij voorbaat kansloos, gezien het precedent uit 1975. Het toen afgesloten Interim Sinail-akkoord tussen Egypte en Israël werd immers uitgevoerd met inschakeling van de UNEF II troepenmacht. Maar in oktober 1978 - dat

33. Quandt, 1986 , p. 382 .

34. Quandt, 1986, p. 399.

35. Brief van Carter aan Sadat en Begin op 26 maart 1979: 'The United States believes the Trealy provision for permanent stationing of United Nations personnel in the designated limited force zone can and should be implemented by the United Nations Security Council. The Umited States will exert its utmost efforts to obtain the requisite action by the Security Council. If the Security Council fails to establish and maintain the arrangements called for in the Treaty, the President will be prepared to take those steps necessary to ensure the establishment and maintenance of an acceptable alternative multinational force", Quandt, 1986, p. 407.

36. Zie resoluties $34 / 65 \mathrm{~B}$ en $34 / 70$. 
wil zeggen na de Camp Davidakkoorden maar nog voor het Israëlisch-Egyptisch wredesakkoord - verklaarde de Sovjetunie uitdrukkelijk tegen een wijziging van het UNEF II mandaat te zijn en wilde zij het mandaat niet langer met een jaar maar met negen maanden tot 24 juli 1979 verlengen. Na de eerste gefaseerde Israëlische terugtrekking op 27 mei 1979 veranderde de positie van de UNEF II troepen niet.

Zowel Israël als Egypte haddeñ aan de secretaris-generaal hun voorkeur voor een verlenging van het mandaat doorgegeven maar anderen waren daartegen ${ }^{37}$. De Veiligheidsraad weigerde het mandaat te verlengen dat op 24 juli 1979 afliep ${ }^{38}$ en Waldheim deelde daarop aan de president van de Veiligheidsraad mee voor een ordelijke terugtrekking te zorgen ${ }^{39}$. Volgens Ra"anan had Carter na de Russische bezwaren de UNEF zonder meer laten vallen ${ }^{40}$.

De UNEF II kwam tot stand na de Oktoberoorlog.

Siekmann wekt de indruk verwonderd te zijn over de uitsluiting van de deelname aan deze vredesmacht van de permanente leden, maar gaat in zijn dissertatie voorbij aan de politieke situatie van dat moment toen de Sovjetunie dreigde te interveniëren met eigen troepen in het strijdgebied ${ }^{41}$. De VS wisten door middel van het nucleair alarm Sovjet-interventie te voorkomen. Het gevaar van een confrontatie tussen de vs en de Sovjetunie werd bezworen met de aanvaarding van resolutie 340 , waarin de permanente leden van de Veiligheidsraad werden uitgesloten van deelname aan UNEF II. Als 'buffermacht' heeft het de Israëlische en Egyptische troepen gescheiden: Maar deze 'peace-keeping force' werd niet toegestaan een bijdrage te leveren aan de instandhouding van de Israëlische-Egyptische vrede.

Volgens een publikatie van het Nederlandse ministerie van Buitenlandse Zaken deden de VS wel moeite UNEF II te continueren. De bewering van Ra'anan wordt daarin weerlegd met de mededeling dat de VS 'negen medestanders voor verlenging van het UNEF-mandaat in de Veiligheidsraad had weten te mobiliseren' ${ }^{42}$. Een veto van de Sovjetunie lag voor de hand maar de VS en de Sovjetunie bereikten een compromis waardoor UNEF II stilzwijgend - dat wil zeggen dat het niet op de agenda van de Veiligheidsraad kwam - werd opgeheven en de UNTSO-waarnemers toezicht zouden houden op de bestandslijnen in de Sinaï. Israël wees een definitieve vervanging van UNEF II door UNTSO-waarnemers af ${ }^{43}$. Hiermee kwam aan de goed functionerende UNEF II een einde.

37. $\$ / 13460$.

38. Op 19 juli 1979 weigerde de Veiligheidsraad het mandaat voor UNEFF II to verlengen. A34/584, s/13578.

39. $S / 13468$.

40. Ra'anan, 1980-1981, p. 17.

41. Siekmann, 1988, p. 91 .

42. Ministerie van Buitenlandse Zaken, no. 128, Ontwapening, Veiligheid, Vrede, Staatsuitgeverij 'sGravenhage 1982, p. 211. Navraag naar de bron van dit bericht op het ministerie van Buitenlandse Zaken leverde geen resultaat op

43. Ibidem pp. $211-212$. 
Wiet alleen Carter heeft weinig moeite gedaan de VN een rol te laten spelen bij de instandhouding van het vredesverdrag, ook zijn opvolger Reagan heeft zich nauweliks moeite getroost een. VN-vredesmacht tot stand te brengen. In ieder geval had Egypte wel een sterke voorkeur voor een VN-vredesmacht.

Het niet slagen van een vredesmacht in $\mathrm{VN}$-verband leidde ertoe dat een aantal landen waaronder de Scandinavische, geen bijdrage wilden leveren aan de $\mathrm{MFO}^{44}$. Bij andere landen, waaronder Nederland en Australië; bestonden grote aarzelingen aan een vredesmacht buiten $\mathrm{VN}$-verband bij te dragen. Het betekende bovendien een verdere ondergraving van de vredesbewarende taak van de $\mathrm{VN}$, waarvoor Perez de Cuellar in zijn jaarrapport ower 1982 aandacht vroeg ${ }^{45}$.

Door de Russische weigering het UNEF II mandaat te verlengen en de overheersende Amerikaanse rol in de alternatieve vredesmacht, werd het Arabisch-Israëlisch conflict meer in de Oost-West tegenstelling getrokken. De Amerikaanse militaire betrokkenheid kwam al aan het lïcht bij de eerste Israëlische terugtrekking uit een deel van de Sinai, toen de United States Sinai Field Mission (SFM) toezicht hield op de door Israel ontruimde gebieden en tevens de surveillancevluchten boven de Sinaï aan de VS werden toegestaan ${ }^{* 6}$. De SFM werd in januari 1976 geïnstalleerd en beëindigde haar taak op 25 april 1982 toen Israël zich uit de Sinaï terugtrok. De SFM was Amerikaans, maar werkte samen met de VN vredesmacht UNEF II. Na de opheffing van UNEF II en woor de komst van de MFO nam het taken van UNEF II over ${ }^{47}$.

De gebrekkige rol van de VN kwam voort uit de afwijzing door het merendeel van de leden van het Israëlisch-Egyptisch vredesverdrag. Bovendien was secretaris-generaal Waldheim niet geneigd een doorbraak te bewerkstelligen, omdat die zou kunnen stuiten op mogelijke oppositie van de Sovjetunie, die waarschijnlijk wel van zijn oorlogsverleden op de hoogte was. Bovendien zou Russisch werzet zijn kansen op herverkiezing verkleinen ${ }^{48}$. Mijns inziens is dit een gemiste kans; ik kom daar later op terug.

Op 22 maart $1981 \mathrm{kreeg}$ de Egyptische permanente vertegenwoordiger bij de VN van zijn minister van Buitenlandse Zaken de instructie met de secretaris-generaal en de permanente leden van de Veiligheidsraad contact op te nemen "in order to discuss the

44. Tabory vermeldlt de weigering van Finland, Denemarken en Noorwegen, Tabory, 1986, p. 21. Hoewel Noorwegen niet met een eigen contingent tot de deelnemende statem behoorde, heeft het wel de commandant met drie stafofficieren aan de MFO afgestaan, Tabory, 1986, p. 45.

45. Report of the Secretary-General on the work of the Organization, 1982, A/37/1 "I find such a trend disturbing because it demonstrates the difficulties the Security Council encounters in fullfilling its responsibilities as the primary organ for the maintenance of intematiomal peace and security in the prevailing political conditions".

46. De Sinä Field Mission werd in 1976 opgericht op grond van het Egyptisch-Israëlisch deelakkoord van 1 september 1975. Het bestond uit 200 Amerikaanse burgers die toen waren belast mett de electronische waarschuwingsstations bij de strategische Gidi en Mitla passen in de Sinaã. Tabory, 1986, p. 4-7.

47. De informatie van de warnemingsstations werd doorgegeven aan Israël, Egypte en de VN “ Rikhye, 1984, pp. 67-69.

48. Zie artikel van C. van Lotringen in NRC-Handesblad van 8-7-1987, waarin hij schrijft over aanwijzingen dat Waldheim door de Sovjetunie zou zijn gechanteerd en stelt: "Waldheim was verslaafd aan zjjn functie en wie verslaafd is, kan geen wuist maken tegen chantage en manipulatie'. 
possibility of forming a U.N. emergency force to supervise Israel's withdrawal from Sinai: ${ }^{49}$. Volgens de Egyptische onderminister van Buitenlandse Zaken zouden Egypte en de VS proberen de Veiligheidsraad bij de vorming wan een vredesmacht te betrekken ${ }^{50}$. De Israëli's verzetten zich daar niet tegen maar geloofden niet in een positief resultaat ${ }^{51}$.

De Egyptische minister van Buitenlandse Zaken besprak vervolgens een mogelijke VNrol met Waldheim ${ }^{52}$. $\mathrm{Na}$ overleg van de Egyptische regering met de eigen permanente wertegenwoordiger op 21 april $^{53}$ richtte deze laatste dezelfde dag een formeel verzoek aan de lerse voorzitter van de Veiligheidsraad. Een maand later antwoordde de Japanse voorzitter van de Veiligheidsraad dat hij op grond van individuele consultaties de conclusie trok dat de leden niet in staat waren aan het verzoek te voldoen ${ }^{54}$. Een debat binnen de Veiligheidsraad over de instelling van een vredesmacht schijnt niet te hebben plaatsgevonden. De volgende dag al, op 19 mei 1981, bereikten Egypte, Israël en de VS een principe-akkoord over de MFO. Egypte beschouwde de MFO als een tijdelijke oplossing tot een $\mathrm{VN}$-vredesmacht wel gevormd zou kunnen worden ${ }^{55}$.

Over het verzoek aan Australiè aan de MFO bij te dragen, werd in het Australiseh parlement gedebatteerd. De oppositie verklaarde in het parlement verbijsterd te zijn dat nauwelijks was gepoogd de VN erbij te betrekken ${ }^{56}$. De oppositie was tegen Australische deelname aan de MFO, zag evenmin de militaire noodzaak voor deze vredesmacht in en vroeg zich af waarom de Sinaï Field Mission niet kon worden gecontinueerd. In dit debat op 3 juni 1981 werd meegedeeld dat aan dertien landen inmiddels een verzoek tot een bijdrage was gedaan. Daaronder bevonden zich drie Europese landen, te weten België, Italië en Nederland ${ }^{57}$. In Nederland was daarover toen nog niets bekend gemaakt.

Na de kritiek van de binnenlandse oppositie ondernam de Australische minister van Buitenlandse Zaken een poging de VN erbij te betrekken. Tijdens een ontmoeting in juli zei Waldheim dat VN-bemoeienis slechts zin had wanneer de Sovjetunie kenbaar zou maken dat zij haar veto niet zou gebruiken ${ }^{58}$.

Dat vormt een bevestiging van mijn eerdere stelling dat Waldheim ook weinig moeite deed een $\mathrm{VN}$-vredesmacht van de grond te krijgen.

49. DR/FBIS/ME + A, 24 maart 1981 .

50. 28 maart 1981, Keesings Historisch Archief 23-10-1981, p. 703.

51. DR/FBIS/ME + A, 2 april 1981 .

52. DR/FBIS/ME + A, 9 april 1981 .

53. DR/FBIS/ME + A, 22 april 1981 .

54. Brief van 18 mei 1981: "that the individual consultations I have taken lead to the conclusions that the members of the Security Council are unable, for various reasons, to reach the necessary agreet ment on the proposal contained therein' werd gepubliceerd in Australiẻ, House of Representatives, Parliamentary Debates, 26 mei 1981, p. 2538.

55. Keesings Historisch Archief, 23 oktober 1981, p. 703.

56. House of Representatives, Parliamentary Debates 1981, pp. 2540-2546.

57. House of Representatives, Parliamentary Debates, 1981 pp. 2987-2995.

58. House of Representatives, Parliamentary Debates, 19 augustus 1981, p. 394. 
Op 23 juni bereikten de Egyptische, Israëlische en Amerikaanse onderhandelaars in Cairo overeenstemming over de tekst van het akkoord over de $\mathrm{MFO}^{59}$. Een maand later werd te Londen het protocol tussen de drie opgesteld (17 juli 1981) dat op 3 augustus 1981 in Washington werd getekend ${ }^{60}$.

\subsubsection{Participatie in de MFO}

De vooruitzichten voor een vredesmacht waren eind september 1981 niet gunstig. Twee en een half jaar na het Egyptisch-Israëlisch vredesverdrag en een half jaar voor de volledige ontruiming door Israël van de Sinaï was er nog weinig bereikt. Een VNvredesmacht werd niet voor mogelijk gehouden, hoewel de inspanning daartoe minimaal was en in feite beperkt bleef tot eén formeel verzoek van Egypte.

Op Israellisch verzoek en tenslotte met instemming van Egypte, bleken de VS bereid te zijn het merendeel van de manschappen voor de vredesmacht te leveren. Daarmee was de vredesmacht nog niet multinationaal en een brede ondersteuning van het EgyptischIsraëlisch vredesverdrag werd met name door Egypte en de VS gewenst. Zij deden hun best en benaderden meer dan 25 staten ${ }^{61}$, zonder veel resultaat.

Slechts de Fiji-eilanden, Colombia en Uruguay hadden zich bereid verklaard een militaire bijdrage te leveren. Hoewel de VS dankbaar waren voor deze bijdrage van drie ontwikkelingslanden die van de VS een flinke financiële tegemoetkoming ontvingen, was daarmee het prestige van de MFO ondanks de diplomatieke inspanningen niet hoog. De Scandinavische landen vielen af daar deze niet bereid waren een vredesmacht buiten de VN te steunen. Staten die nog twijfelden, zoals Australië, Nieuw-Zeeland en Canada, stelden hun bijdrage onder meer afhankelijk van Europese participatie.

De steun van de lidstaten van de Europese Gemeenschap zou dus om een aantal redenen van het grootste belang zijn. Deze staten, met uitzondering van het nieuw toegetreden lid Griekenland, hadden diplomatieke betrekkingen met alle partijen. Het onderhouden van diplomatieke betrekkingen was één van de Israëlische voorwaarden, hoewel Israël bereid bleek enkele Afrikaanse landen, zoals Kenia en Ivoorkust, waarmee het geen diplomatieke relaties onderhield, te aanvaarden ${ }^{62}$. Egypte wees participatie van lidstaten van de Organisatie voor Afrikaanse Eenheid af. Egypte wenste geen bemiddelende rol te spelen tussen Israël en de Afrikaanse staten die de diplomatieke betrekkingen met Israell hadden verbroken.

Egypte legde zich erop toe de Scandinavische landen en de Latijns Amerikaanse landen bij de MFO te betrekken en had bij de laatste enig succes, ondanks de waarschuwingen en dreigingen van het Arabisch 'afwijzingsfront' dat hen van deelname trachtte af te houden ${ }^{63}$.

59. Middle East Journal, $(X X X V), 1981$, p. 597 en verklaring op 25 juni wan Amerikaanse ministerie van Buitenlandse Zaken; Department of State Bulletin, (81) 19 augustus 1981, no. 2053.

60. Tiubory, 1986, pp. 11-12.

61. In bijlage 13 staam de staten vermeld warmee Israell in 1981 diplomatieke betrekkingen onderhield. Tevens is angekruist welke van deze staten gevraagd zijn aan de MFO doel te nemen.

62. DR/FBIS/ME + A, 21 april 1981.

63. DR/FBIS/ME + A, 18 augustis 1981 . 
Van de benaderde Europese landen had Italiē, dat zowel door de VS als Egypte en Israel werd gevraagd, nog niet positief gereageerd. België toonde zich evenmin enthousiast. De Belgische minister van Buitenlandse Zaken verklaarde tegenover Egypte dat een officieel verzoek voor een bijdrage van de EG aan de MFO onderwerp van discussie zou worden ${ }^{64}$.

Nederland wees op voorhand een bijdrage af, daar Nederland reeds met 800 man in Unifil was vertegenwoordigd en een extra bijdrage fysiek onmogelijk zou zijn ${ }^{65}$. De Bondsrepubliek Duitsland zou op constitutionelle gronden geen militaire bijdrage kunnen geven en bovendien zou het veiligheidsgevoel van de Israëli's waarschijnlijk niet verhoogd worden met eenheden van het Duitse leger aan hun grenzen ${ }^{66}$. De Fransen werden in april 1981 door de Israëli's nog onaanvaardbaar gevonden op grond van het Franse Midden-Oostenbeleid ${ }^{67}$. In deze opvatting zou spoedig verandering komen na de Franse presidentsverkiezingen.

De Amerikanen hadden al in maart 1981 hun voorkeur voor het Verenigd Koninkrijk als mogelijke participant naar voren laten komen ${ }^{68}$. Het tot stand brengen van de Britse participatie zou, zoals later zal blijken, heel moeilijk worden. De kleinere landen Luxemburg en ferland werden waarschijnlijk mede op grond van hun geringe militaire potentieel niet benaderd. Bovendien hadden de Ieren zich vanwege interne Ierse problemen al in 1974 uit UNEF II teruggetrokken ${ }^{69}$. De Denen zullen waarschijnlijk op basis van de eerder naar voren gebrachte Scandinavische argumentatie - door Zweden verwoord $^{70}$ - niet bereid zijn geweest aan de MFO deel te nemen.

Weliswaar antwoordde de Amerikaanse minister van Buitenlandse Zaken op een persconferentie van 28 augustus 1981 dat hij zich niet kon indenken dat de VS een "big stick' zouden gebruiken voor deelname van andere landen ${ }^{71}$. Duidelijk werd toch dat de VS veel waarde hechtten aan Europese steun voor hun Midden-Oostenbenadering. Europese participatie aan de MFO zou hiervoor het uitgelezen middel zijn. De aandacht zou gericht worden op Frankrijk, Italië en het Verenigd Koninkrijk waar mogelijk nog een bijdrage van te verwachten was. Onverwachts zouden de Nederlanders zich bij dit gezelschap aansluiten.

64. DR/FBIS ME + A, 1 april 1981.

65. Mededeling op 15 juli 1981 an de auteur door Wildenburg, ministerie van Buitenlandse Zaken, directie perszaken en mieuwswoorzieming/woordvoering.

66. Fiedler moemde dat 'het psychologische probleem' en stelde verder dlat Duitse millitairen wel romd de Middellandse Zee, dat tot het N.AVO-gebied behoort, konden opereren maar op grond van artikel 87A van de Duitse Grondwet niet in de Sinaï of Perzische Golf, Interview met Fiedler op 15 oktober 1987.

67. DR/FBIS ME + A, 21 april 1981 .

68. Europe, no. 3180,28 maart 1981 .

69. Siekmanin, 1988, pp. 220-221.

70. DR/FBIS ME + A, 15 april 1981 .

71. Department of State Bulletin, (81), October 1981, nr. 2055, p. 20. 


\subsubsection{De vier Europese participanten in de MFO}

De moord op president Sadat van 6 oktober 1981 door Moslim fundamentalisten varn de Islamitische Jihad was een schok voor het Westen. Staatshoofden en regeringsleiders evenals ministers en oud-presidenten kwamen voor de begrafenis in Caïro bijeen.

De Amerikanen waren ruim vertegenwoordigd op de begrafenis met de oud-presidenten Ford, Nixon en Carter en de ministers Haig en Weinberger. Van Europese zijde waren onder meer de Franse en Italiaanse president, de Duitse bondskanselier en de Britse minister van Buitenlandse Zaken aanwezig. Nederland werd vertegenwoordigd door prins Claus en de nieuw aangetreden minister van Buitenlandse Zaken Van der Stoel ${ }^{72}$. Al deze buitenlandse vertegenwoordigers in een kleine ruimte bijeen, deed Van der Stoel denken aan een "Madame Tussaud" uit de jaren zeventig.

Gevreesd werd dat het Egyptisch-Israëlisch vredesverdrag nu gevaar liep. Volgens Van der Stoel moest nu eerst worden geprobeerd de vredesmacht tot stand te brengen daar anders het hele vredesverdrag op het spel kwam te $\operatorname{staan}^{73}$.

Vele gesprekken tussen de Westelijke leiders onderling en met de Egyptenaren en de Israëli's - onder meer vertegenwoordigd door Begin, Sharon, Burg en Shamir - vonden toen in Cairo plaats ${ }^{74}$. Een mogelijk gevolg van deze gesprekken is geweest dat bij Mubarak na afloop van een gesprek met Carrington de indruk gewekt werd dat in Europa enige bereidheid ontstond aan de MFO deel te nemen ${ }^{75}$. De betekenis en bewoording van deze toezegging blijft vaag.

Kort na de begrafenis van Sadat op 10 oktober, kwamen de ministers van Buitenlandse zaken van de EG-lidstaten op 13 oktober 1981 te Londen bijeen. Tijdens deze EPSbijeenkomst werd de politieke situatie in Egypte besproken (zie ook 4.1.1.3).

Hoewel de Negen eensgezind waren in hun steun aan Mubarak, bereikten de ministers van Buitenlandse Zaken geen overeenstemming over de beste weg daar naar toe. Enerzijds werd het Camp Davidproces op deze bijeenkomst te Londen als afgedaan beschouwd en het plan-Fahd als nieuwe impuls tot het Europese vredesinitiatief ge$z^{2 i e n}{ }^{76}$. Anderzijds werd, volgens de Italiaanse minister Colombo, tijdens deze ministerraad de mogelijkheid besproken dat Italië, Frankrijk en het Verenigd Koninkrijk aan de vredesmacht zouden meedoen ${ }^{7}$.

De Israëlische minister van Buitenlandse Zaken Shamir reageerde bezorgd en de Saoedische kranten verheugd op de Europese belangstelling voor het plan-Fahd.

De Egyptische onderminister van Buitenlandse Zaken, Boutros Ghali, zei dat Europese staten aan de MFO konden deelnemen en dat hij hoopte dat de EG nu eens ook daadwerkelijk zou optreden ${ }^{78}$.

72. Het Parool, 10-10-1981.

73. Interview met Van der Stoel op 11 februari 1987.

74. DR/FBIS ME + A, 13 oktober 1981.

75. The Times 13-10-1981; 'the Europeans want to be ready to help fill the breach, if required'.

76. The Guardian, 14-10-1981; DR/FBIS ME + A, 15 oktober 1981 .

77. Memorie van Toelichting op het Italiaanse wetsontwerp tot deelname aan de MFO in: Camera dei Deputati, Atti Parlementari, N. 3271 VIII Lesgislatura, Desegmi di Legge e Relazioni, Documenti, p. 1.

78. DR/FBIS ME + A, 15 oktober 1981 en 16 oktober 1981. 
De Negen bereikten op 13 oktober 1981 te Londen geen overeenstemming. Ook in de bijeenkomst van het Comite Politique op 23 oktober en in de bijeenkomst van de ministers van Buitenlandse Zaken op 26 en 27 oktober 1981 werd geen besluit over deelname aan de MFO genomen ${ }^{79}$. Maar kort daarna deelden de Fransen en Italianen mee een positief antwoord te zullen geven op een verzoek tot participatie van de VS, Israel en Egypte ${ }^{80}$.

De Italiaanse minister van Buitenlandse Zaken verklaarde op 27 oktober dat Italië bereid was deel te nemen, indien de andere EG-lidstaten daarmee instemden. Dit voorstel werd op 30 oktober 1981 door de Italiaanse ministerraad aanvaard ${ }^{81}$. Aan de secretarisgeneraal van de Arabische Liga verklaarde de Italiaanse minister dat Italiaanse deelname in overeenstemming was met de verklaring van Venetiê ${ }^{82}$. De Italiaanse beweegredenen kwamen tijdens de parlementaire behandeling tot uiting. De minister van Buitenlandse Zaken benadrukte de betekenis van de dood van president Sadat en het overleg tijdens diens begrafenis ${ }^{83}$. De Italiaanse premier meende dat Sadats dood de Europese besluitvorming over deelname aan de MFO had versneld ${ }^{84}$. De Italiaanse voorwaarde voor deelname - Europese instemming - werd verscherpt na het Italiaans-Britse overleg op 9 november van Thatcher met Spadolini en Carrington met Colombo in Londen. Inmiddels was bekend dat vier EG-lidstaten - Italië, Frankrijk, het Verenigd Koninkrijk en Nederland - overwogen een bijdrage aan de MFO te leveren. In Londen kwamen de Britten en Italianen overeen dat of alle vier Europese landen of geen enkele EG-lidstaat zou participeren ${ }^{85}$. Dat betekende een aanzienlijke complicatie vanwege de Britse aarzeling en het Israëlische voornemen de Britten te weren ${ }^{86}$.

Hoewel de Italianen als eerste van de vier zich officieel bereid verklaarden tot deelname, maakten zij de realisatie daarvan moeilijk door zowel de deelname te relateren aan de verklaring van Venetië als de Israëliërs te beletten én der Europese vier te weren. Bowendien wilden zij met hun bereidheid tot deelname, Israël de schuld in de schoenen te schuiven als de MFO niet tot stand zou komen. Althans, zij wensten Israël geen voorwendsel te geven zich niet uit de Sinaï terug te trekken. Israël zou zich bij uitblijven van een vredesmacht niet terugtrekken en daarmee zijn Camp Davidverplichtingen niet nakomen ${ }^{87}$.

79. Europe, no. 3237, 26/27 oktober 1981, Tabory, 1986 p. 23; Middle East Jcurnal met als bron de Washington Post (XXXVI) 1982, p. 66; Keesings Historisch Archief 30 april 1982, p. 276; Corriera della Sera 11-11-1981; Ifestos, 1987, p. 491.

80. Europe, no. 3238, 28 oktober 1981.

81. Middle East Journal (XXXVI) 1982, p. 67; The Guardian 31-10-1981; Corriera della Sera 31-101981.

82. Europe, no. 3240,31 oktober 1981.

83. Senato del Repubblica, 11-11-1981.

84. Corriera della Sera, 12-11-1981.

85. La Repubblica, 12-11-1981, 'O tutti o nessuno'.

86. De Britse houding zal ik nog behandelen.

87. Colombo in de Italiaanse Senaat op 11 november 1981 in: Tabory, 1986, p. 25 . 
De Fransen gaven medio oktober uiting aan hun bereidheid ${ }^{88}$, peilden vervolgens de

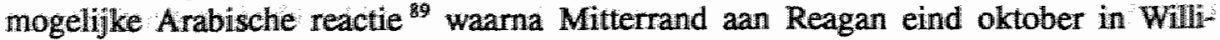
amsburg kon meedelen aan de MFO deel te zullen nemen alls Egypte en Israël dat wensten ${ }^{90}$.

De Franse minister van Buitenlandse Zaken ging vervolgens een stap verder door na de mislukte EPS-conferentie van 26 oktober te verklaren dat de EG inconsequent zout zijn als het niet aan de MFO bijdroeg. De EG had immers tot terugtrekking uit de Sinaii opgeroepen en kon het nu niet bij mooie woorden laten, anders reduceerde het zich zelf tot een 'praathuis' 91 .

De Britten waren niet gelukkig met deze Franse uitspraak die Carringtons reis naar Saoedi-Arabiè voor het Europese vredesinitiatief kon ondermijnen. Met het oog op deze reis hadden onder meer de Britten de besluitvorming over deelname aan de MFO op de EPS-bijeenkomst van 26 oktober kunnen uitstellen. Zoals gesteld in 4.1.1.3 beoogden de Britten namelijk met behulp wan het plan-Fahd het Europees vredesinitiatief nieuw leven in te blazen "2. Weliswaar hadden de Amerikanen ook tamelijk positief gereageerd op het plan-Fahd, hetgeen Israëls angst voor hun liquidatie in fasen (zoals Begin het plan-Fahd zag) vergrootte en hun wantrouwen ten aanzien van deelnemers met voor hen ongunstige bijbedoelingen versterkte. Een positief oordeel van de VS over het planFahd hield verband met het voornemen van de Amerikaanse regering aan Saoedi-Arabië toestellen voor zijn luchtmacht te leveren. Dankzij zeer forse druk van president Reagan op enkele senatoren werd eind oktober 1981 de verkoop van Awacs-toestellen aan Saoedi-Arabiễ goedgekeurd ${ }^{93}$. Wellicht heeft deze beslissing ertoe bijgedragen dat van Saoedische zijde de Amerikaanse pogingen niet werden gedwarsboomd om Europese participanten voor de MFO te vinden ${ }^{94}$.

De Britten wisten de woede van de Amerikanen en Israëli's op te wekken met de verklaring van Carrington in Riad dat het enige doel van de MFO de teruggave van Arabisch gebied aan de Arabieren was ${ }^{95}$.

De VS reageerden snel en fel. Haig belde Carrington op en ontbood tevens de Britse ambassadeur in de VS ${ }^{96}$. Haig zou in een stafbespreking medio december $1981 \mathrm{Car}-$

88. Op 19 olktober 1981, Tabory; 1986, p. 23.

89. Op 23 oktober 1981 benaderden ze de Sacedi"s en Algerijnen op de topconferentie te Cancun, DR/FBIS ME + A, 27 oktober 1981 .

90. Jerusalem Post, international edition weekeditie 25-31 oktober 1981.

91. Volgens The Guardian 27-10-1981 gebruikte Cheysson de term "talking shop" en volgens Europe, no. 3238, 28 oktober 1981; de termi "word machine".

92. Ook de Fransen hadden het plan-Fahd eerder verwelkomd. DR/FBIS ME + A, 29 september 1981.

93. Van Leeuwen, 1986 , p. 59 .

94. Grünfeld, 1987 , p. 268.

95. Carrington op 5 november 1981 in Riad "If the EEC did take part in the force, it would be on the basis of seeing the retum of Arab territory to the Arabs, and no other reason at all The Guardian, 9-11-1981.

96. Europe, no. 3244, 6 november 1981; The Guardian 7-11-1981; Middle East Journal (XXXVI) 1982, p. 217 , Haig "1984, p. 327: "A vigorous protest was sent to London over Carrington's remarks". 
rington voor 'duplicitous bastard' hebben uitgescholden ${ }^{97}$ en vroeg de Britten hun enthousiasme voor het plan-Fahd in te tomen ('to cool it'). De Amerikanen verdachten de Britten ervan de totstandkoming van de MFO opzettelijk te dwarsbomen. Een Amerikaanse hoge ambtenaar zei tegen de New York Times dat de Britten in een EG-verklaring een passage van de PLO wilden opnemen opdat Israël de Europese deelneming zou verwerpen ${ }^{98}$. Haig stelde in zijn memoires dat met name de Britten zich verzetten tegen deelname aan de MFO omdat zij zonodig de PLO in het vredesproces wilden betrekken ${ }^{99}$.

Ook Van der Stoel was ongerust over de Britse houding. Hij vermoedde dat Carringtons exercitie met het plan-Fahd voortkwam uit de Britse tegenzin in deelname aan de MFO. Mogelijk wilden de Britten niet openlijk weigeren deel te nemen maar de deelname zodanig conditioneren dat realisatie onzeker werd ${ }^{100}$. Deze visie is van belang voor de analyse van het succes van de Nederlandse bijdrage aan de totstandkoming van de Europese deelname aan de MFO. De Nederlandse rol wordt in 4.1.2.5 beschreven.

De bij de besluitworming betrokken Britse ambtenaar, Miles, erkent dat de Britten eigenlijk niet wilden meewerken aan de MFO. Een te sterk vastleggen op het Camp Davidproces zou, vanwege de oppositie uit de Arabische wereld, het Europees initiatief voor een allesomvattende vrede in het Midden-Oosten onmogelijk maken. Uiteindelijk vonden de Britten dat ze wel moesten meewerken. Niet alleen de dood van Sadat en de wens het vredesverdrag tot uitvoering te brengen speelden daarin een rol. Ook wensten de Britten Begin geen voorwendsel te verschaffen zich niet uit de Sinaï terug te trekken en bovendien wilden ze niet alleen de Amerikanen de last laten dragen voor een oplossing van het conflict. Een weigering te participeren in de MFO had bij de Amerikanen het gevoel versterkt dat Europa uitsluitend een criticus was en niet wilde meewerken, aldus Miles ${ }^{101}$.

De vrees aan Nederlandse kant over de Britse houding lijkt niet ongegrond te zijn geweest.

Medio november ontstond de situatie waarin Italië, Frankrijk, het Verenigd Koninkrijk en Nederland bereid waren aan de MFO deel te nemen, maar nog geen instemming daarvoor van de Grieken hadden verworven. Verder hadden ze onderling geen overeenstemming bereikt over het politieke kader waarbinnen de MFO-participatie kon plaatsvinden. Dat dit geen gemakkelijke opgave was, blijkt alleen al uit de frequentie van de beraadslagingen in de EPS over deze kwestie. Op het niveau van ministers werd op 13 en 14 oktober te Londen, op 26 en 27 oktober te Luxemburg, op 10, 16, 17 en 19

97. De term 'duplicitous bastard' wordt vermeld in Sicherman ${ }_{4} 1985$, p. 815; zijn bron was de Washington Post van 19 februari 1982 en werd aangehaald in Ismael, 1986, p. 130 en ook bevestigd in interview met Van der Stoel op 11 februari 1987.

98. NRC-Handelsblad, 9-11-1981.

99. Haig, 1984, p. 327: 'I had found European governments reluctant to participate in the Sinai force. The French less so because President Mitterrand wanted to reestablish a relationship with Israel, the British more so because Lord Carrington appesred to be devoted to the idlea of bringing the PLO into the peace process".

100. Interview met Van der Stoel op 11 februari 1987.

101. Interview met Miles op 24 juni 1987. 
november te Brussel vergaderd ${ }^{102}$. Daarnaast werd door de experts en de directeurengeneraal vergaderd. Bovendien werd zeer intensief en frequent op verschillende niveaus door de vier vergaderd. Dit leidde een aantal malen tot een ontwerp-tekst ${ }^{103}$.

Uiteindelijk kon op 23 november 1981 wel het besluit tot Europese deelname bekend worden gemaakt. Dat geschiedde door middel van zes verklaringen, namelijk eén gemeenschappelijke verklaring van de Tien, één gemeenschappelijke verklaring van de vier en vier afzonderlijke nationale verklaringen van de vier. Zo werd aan de doelstelling van de EPS, een harmonisatie van het buitenlands beleid van de Tien, nog enigszins voldaan.

\subsubsection{Besluiten inzake Europese participatie}

De Israëli's hadden de Europeanen eerder laten weten dat zij louter op basis van het Egyptisch-Israëlisch vredesverdrag met Carters brief aan Sadat en Begin en het protocol van de MFO konden participeren ${ }^{104}$. Tevens herhaalden de Israëli's enkele malen dat noch het plan-Fahd noch de verklaring van Venetië een basis mocht vormen voor deelname ${ }^{105}$.

Voortdurend overleg met de VS volgde opdat een verklaring kon worden uitgegeven die ook Israëls instemming zou kunnen krijgen. Resultaat was dat eerst door de VS op uitstel en het zoeken naar een compromis werd aangedrongen ${ }^{106}$. Vervolgens werd binnen de Tien wel een gemeenschappelijke noemer gevonden, maar daar verzette Israël zich - via de VS - tegen. Daarop werd een compromis ontworpen dat onaanvaardbaar bleek voor de Grieken ${ }^{10}$.

Op 18 november 1981 verklaarde de Britse onderminister van Buitenlandse Zaken, Hurd, in het parlement dat de vier nog geen overeenstemming hadden bereikt en dat de Britse regering nog geen besluit omtrent deelname had genomen ${ }^{108}$. Nog steeds werd getracht een gemeenschappelijke basis te vinden waarmee ook de VS konden instemmen

102. Bull EG 1981 , no. 10 en 11.

103. De Girieken verzetten zich tegen een gemeenschappelijke tekst ondanks een verwijzing daarin naar het zelfbeschikkingsrecht wan de Palestijnen (op 2 november, Le Monde, 7-11-1981, Europe 2/3-111981/3241). Een andere tekst waarin een passage over de PLO was opgenomen stuitte op verzet wan Israël en de VS (NRC-Handelsblad 9-11-1981, The Guardian 18-11-1981). Schrapping van deze passage leiddle tot een voor de VS aanwaardbare tekst die door de vier aan Israël zouden zijn gepresenterd (De Volkskrant 13-11-1981, Tabory 1986, p. 28). Maar deze veranderingen in de tekst werden door de Grieken afgewezen, terwijl de Nederlanders zich verzetten tegen een aparte verklaring waarin het Palestijns zelfbeschikkingsrecht en de betrekkingen met de PLO zouden zijn opgenomen (The Guardian, 18-11-1981). Vervolgens blewen de Grieken zich verzetten tegen afzonderlijike verklaringen van de vier (NRC-Handelsblad 18-11-1981, Haagsche Courant 18-11-1981).

104. Op 8 nowember 1981, Tabory, 1986, p. 27.

105. Agence Europe, no. 3244 en 3247 van $9 / 10$ en 11 november 1981, NRC-Handelsblad 5-11-1981, NRC-Handelblad 9-11-1981, Trouw 10-11-1981, De Volkskrant 12-11-1981.

106. Tabory, 1986, p. 28, NRC-Handelsblad 9-11-1981.

107. The Guardian, 18-11-1981, NRC-Handelsblad 18-11-1981, Europe van 18-11-1981, no. 3251.

108. House of Commons, Parliamentary Debates 1981/1982, p. 266-267. 
en die verenigbaar was met het Midden-Oostenbeleid van de EG zoals dat in de verklaring van Venetie was uiteengezet ${ }^{109}$.

Op zondag 22 november werd tenslotte het besluit tot deelname aan de Israelische en Egyptische regering overhandigd. De VS hadden tevoren met deze verklaring ingestemd en de Amerikaanse ambassadeur in Israël, Lewis, deed dezelfde zondag een dringend beroep op de Israëlische regering de Europese deelneming te aanvaarden ${ }^{110}$. Op donderdag 26 november 1981 deelde premier Begin mee de ministerraadsvergadering van 29 november te zullen adviseren een veto over de Europese deelname uit te spreken ${ }^{111}$. Op 26 november vertrok op Amerikaans verzoek de Israëlische minister van Buitenlandse Zaken, Shamir, voor spoedoverleg naar Washington. Daar spraken Haig en Shamir op vrijdag 27 november maar liefst zeven en een half uur met elkaar. Haig wist Shamir te overreden om op 29 november nog geen besluit te nemen en Haig zou met de vier nader beraad voeren.

De gemeenschappelijke verklaring van de vier is in bijlage 14 opgenomen.

Tabory ziet deze verklaring als een diplomatieke overwinning van Israël. De verklaring van Venetië werd niet vermeld en ook de Britse visie dat de MFO slechts zou toezien op de Israëlische terugtrekking ontbreekt ${ }^{112}$. Hoewel een verwijzing naar Camp David eveneens ontbreekt zou impliciet een aanvaarding daarvan, uit de deelname aan de MFO die daaruit voortkomt, kunnen worden gelezen ${ }^{133}$.

Deze voor Israël gunstige wending werd teniet gedaan door de vier nationale identieke verklaringen. Daarin werd enkele malen gesteld dat het doel een alomvattende vrede was. Tevens werd expliciet afstand genomen van de Camp Davidakkoorden en bovendien werd gesteld dat deelname juist voortvloeide uit de verklaring wan Venetië (zie bijlage 15). Niet alleen het zelfbeschikkingsrecht van de Palestijnen, maar ook de betrokkenheid van de PLO werden vermeld. Daarnaast werd expliciet de preambule van resolutie 242 aangehaald - de ontoelaatbaarheid van het verwerven van grondgebied door oorlog - een opvatting die de regering-Begin verwierp en niet van toepassing verklaarde voor de overige bezette gebieden. Tijdens de Camp Davidonderhandelingen was voor de Israëli's zelfs het verwijzen naar deze preambule bijna een breekpunt en slaagde Begin erin deze verwijzing te schrappen ${ }^{114}$.

Nog verder verwijderd van het Israëlisch-Egyptisch vredesverdrag was de EG-verklaring van de Tien. Deze verklaring bestond uit eén zin: 'De Tien zijn van mening dat het besluit van Frankrijk, Italië, Nederland en het Verenigd Koninkrijk deel te nemen in de Multinationale Vredesmacht in de Sinaĩ beantwoordt aan de veelvuldig door de lidstaten van de Gemeenschap uitgesproken wens iedere vooruitgang te vergemakkelijken in de richting van een alomvattende vredesregeling op basis van de wederzijdse

109. House of Commons, Parliamentary Debates 1981/1982, pp. 283-285.

110. NRC-Handelsblad 23-11-1981, DR/FBIS ME + A, 23 nowember 1981.

111. NRC-Handelsblad 26-11-1981; The Guardian 27-11-1981; Agence Europe no. 3257 van 26-111981 ; DR/FBIS ME + A, 25 november 1981.

112. Tabory, 1986, p. 29.

13. Tabory, 1986, $\mathrm{p}_{\mathrm{n}} 30$.

114. Quandt, 1986, pp. 243-246 en 256 . 
aanvaarding van het recht op bestaan en veiligheid van alle staten en van de noodzaak voor het Palestijnse volk om zijn recht op zelfbeschikking volledig uit te oefenen' ${ }^{\text {ins }}$. Zo zien we drie verschillende verklaringen en dat wekt de indruk van een "driedubbele tong' van de EG.

De eerste verklaring was gericht tot de drie betrokken partijen - Israël, Egypte en de VS - en sloeg nog het meest op het eigenlijke doel van de MFO, terwijl zij de deelnemers niet bond aan een bepaalde oplossing van het Midden-Oostenconflict.

De tweede verklaring was gericht tot het nationale gehoor van de vier deelnemers. Deze verkllaring gaf enerzijds steun aan het Egyptisch-Israëlisch vredesverdrag, maar beschouwde de deelname tegelijkertijd als de voortzetting van het beleid dat met de ver* klaring van Venetië was ingezet. De nationale regeringen hadden zich eerder gebonden aan de verklaring van Venetië en wilden daar geen afstand van nemen.

De derde verklaring was het maximum waarmee de Tien konden instemmen en had hoegenaamd niets van doen met het doel van de MFO. Deze gaf als politieke basis voor deelname een combinatie van passages uit de verklaring van Venetië en uit het planFahd. Dat laatste was niet verwonderlijk gezien de eerder ontwouwde Britse benadering die beide plannen met elkaar trachtte te verenigen en waaraan gedurende het Britse voorzitterschap - tevergeefs - door onder meer de Midden-Oostenexperts van de EG werd gewerkt ${ }^{116}$.

Juist omdat gescheiden verklaringen voor verschillend publiek werden afgegeven, kan men op grond van de eerste verklaring concluderen dat Europese deelname niet gepaard ging met het uitoefenen van politieke druk op Israël voor een aanvaarding van de Europese zienswijze. In een verduidelijking aan de VS onderstreepten de vier dat door te stellen dat 'they have attached no political conditions, linked to Venice or otherwise, to their participation'. Bovendien namen ze nu eerdere ongerustheid bij Israël weg door te stellen dat de MFO ook was bedoeld om de vrije scheepvaart door de Straat van Tiran overeenkomstig artikel $V$ van het vredesverdrag te verzekeren ${ }^{117}$. Deze verzekering ontbrak volgens de Israëli's in punt 1 van de eerste verklaring.

115. Tweede Kamer, zitting 1981-1982, 17.197 no. 1, p. 3.

116. DR/FBIS ME + A, 26 oktober 1981" Summary of World Broadcasts IV, The Middle East and Africa, Second Series ME/6816-6916, London 1981, 21 september 1981.

117. Verduidelijking van 26 november 1981; Europe no. 3264, 5 december 1981; Tabory, 1986, p. 33. 
Sichema 4.1

communicatie omtrent Europese participatie aan de MFO

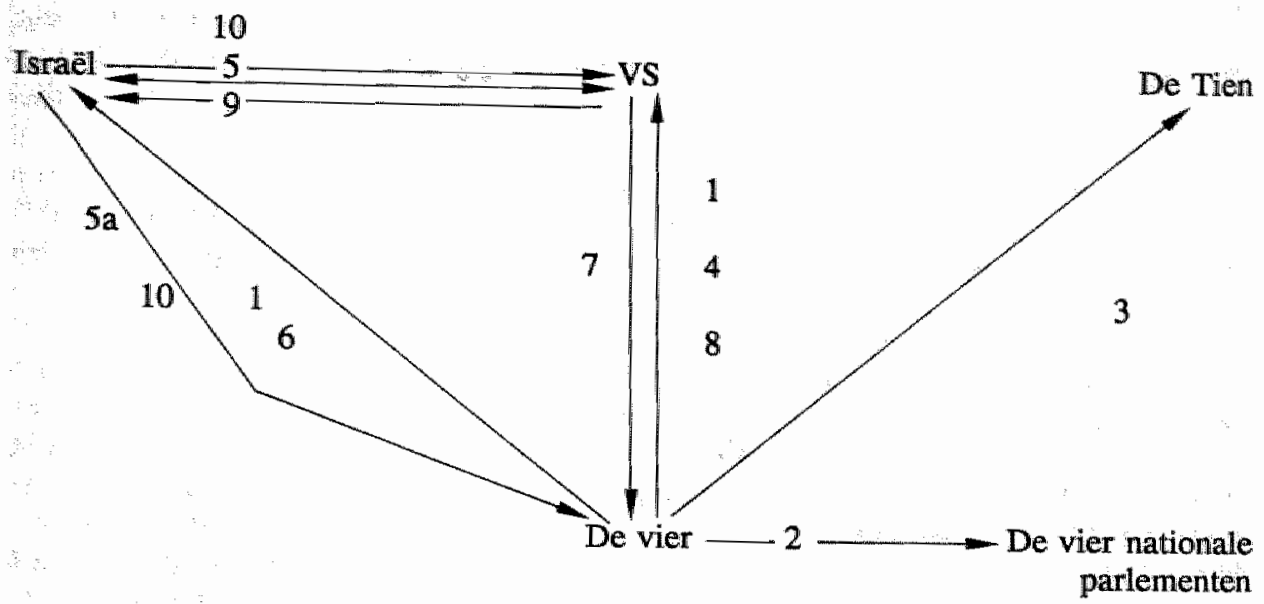

De nummers in bovenstaand schema hebben betrekking op het volgende:

1. de gemeenschappelijke verkdaring (23-11-1981)

2. de nationale verklaring (23-11-1981

3. de EG verklaring (23-11-1981)

4. de verduidelijking (26-11-1981)

5. de gemeenschappelijke Israëlisch-Amerikaanse verklaring (3-12-1981)

5a. brief van Israël aan de vier (3-12-1981)

6. antwoord van de vier (13-1-1982)

7. bericht van Haig aan de vier over Israëlische aarzeling (omstreeks 22-1-1982)

8. brief van de vier aan Haig omtrent achterwege laten politieke voorwaarden aan deelneming (24-1-1982)

9. brief van Haig aan Israël (28-1-1982)

10. Israëlisch besluit tot goedkeuring Europese deelneming (31-1-1982).

In een gemeenschappelijke Israëlisch-Amerikaanse verklaring van 3 december 1981 gingen beide partijen ervan uit dat deelname aan de MFO alleen gebaseerd kon zijn op het vredesverdrag, het protocol van 3 augustus 1981 en de brieven van Carter van 26 maart 1979. Afwijking of enig voorbehoud ter zake zou niet worden toegestaan ${ }^{138}$.

Dat was tevens de strekking van de brief van de Israëlische minister Shamir die hij op 3 december 1981 aan de vier schreef en waarop hij antwoord verwachtte. De Israeli's namen geen genoegen met slechts een stilzwijgende aanvaarding zoals Pijpers berichtte ${ }^{189}$. Shamir verzocht de vier deelnemende landen de gemeenschappelijke Ameri-

118. Tabory, 1986, pp. 33-34.

119. Pijpers, 1984, p. 215, en Pijpers, 1990, p. 156" 
kaans-Israëlische verklaring inzake de voorwaarde voor deelname te onderschrijven ${ }^{120}$.

De VS hebben de Israêli's waarschijnlijk doen afzien van hun voornemen de Europeanen expliciet afstand te laten nemen van de beginselen van de verklaring van Venetiè die in de nationale verklaringen nog eens naar voren kwamen. De VS verklaarden wel de Israëlische zorg te begrijpen over de nationale verklaringen waarin de vier hun beslissing tot deelname aan hun eigen achterban ('own legislatures and publics') verklaarden.

Pas op 13 januari 1982 kregen de Israëli's antwoord van de vier. Zij verwezen naar hun eerder ingenomen standpunt, maar erkenden dat de functie van de MFO was als gedefinieerd in 'the relevant Egyptian-Israeli agreements' en het protocol en 'no more and no less' ${ }^{121}$.

De Israëli's bleven argwanend. De vier schreven vervolgens aan Haig dat zij hun brief van 13 januari niet meer wilden wijzigen, maar dat zij geen politieke voorwaarden aan hun deelname verbonden. Haig berichtte daarop Shamir eind januari dat de vier heus wel te vertrouwen waren en geen verborgen oogmerk hadden. In zijn publikatie vatte Haig de houding van de Europeanen als volgt samen: 'Meanwhile, the European participants in MFO, seemingly aware at last of the stakes in the aftermath of Sadat's murder, decided to join without preconditions. The Israelis and the Arabs understood, as we all did, that European participation in the force implied European support of Camp David. The commitment of troops and national honor meant more than any words'. 122

Uiteindelijk keurde het Israëlische kabinet op 31 januari 1981 de Europese deeiname goed op basis van de brief van de vier aan Haig en de brief van Haig aan de Israëlische regering.

Opvallend is dat de Europese deelname op basis van informatie uit de VS (no. 8 en 9 uit schema) door Israël werd aanvaard en niet uit hetgeen de rechtstreekse communicatie (no. 1 en 6 uit schema) opleverde. Israël bleef als basis voor deelname vasthouden aan het Camp Davidproces en de Nederlandse regering argumenteerde de deelname tegenover het parlement met een beroep op de verklaring van Venetië. Naar aanleiding van een vraag van het Kamerlid Schaper (D'66) bevestigde Van der Stoel dat de deelname was gebaseerd op een "agreement tot disagree' ${ }^{123}$. De vier bonden zich daarentegen aan participatie op basis van de drie openbare verklaringen (no. 1, 2 en 3). Het Nederlandse parlement gaf ook op basis van deze verklaringen steun aan de Nederlandse participatie.

\subsubsection{Nederlandse inbreng bij Europese participatie}

In deze paragraaf zal ik nader ingaan op de Nederlandse rol bij de totstandkoming van Europese deelneming aan de MFO. Wat waren de Nederlandse motieven om plotseling aan de MFO deel te nemen nadat eerdere verzoeken tot deelneming waren afgewezen? Welke voorwaarden stelde Nederland aan deelneming? Op welke wijze zou Nederland

120. Tweede Kamer, zitting 1981-1982, 17.197 nr. 5, p. 3.

121. Tweede Kamer, zitting 1981-1982, 17.197 nr. 5, p. 3; Tabory, 1986, p. 35.

122. Haig, 1984, p. 328.

123. Tweede Kamer, zitting 1981-1982, 17.197, nr. 7, pp. 4 en 6. 
de Europese deelname aan de MFO hebben kunnen bevorderen? Hoe werd door de Europese partners de Nederlandse houding beschouwd? Hoe zag de Nederlandse regering de politieke basis voor deelname en hoe werd met name de verhouding tussen enerzijds deelname en anderzijds de verklaring van Venetiè en het plan-Fahd aan Nederlandse zijde beschouwd? Op deze vragen zal ik in deze paragraaf een antwoord geven. Vervolgens zullen het overleg en het debat tussen regering en parlement ter zake aan bod komen voor meer inzicht in de binnenlandse politieke steun aan de regering in deze kwestie.

Reeds in 1979 werd Nederland gepolst voor deelname aan de MFO. Door de Amerikaanse ambassade werd de directeur-generaal politieke zaken, Rutten, naar de Nederlandse bereidheid gevraagd. Bij Buitenlandse Zaken bestonden twijfels omtrent de structuur en het functioneren van een op te richten MFO. Andere bezwaren tegen deelname werden op het departement van Defensie geuit. Daar Nederland al deelnam aan Unifil en tevens benaderd was voor een VN-macht in Namibië, zou deelname aan MFO te veel worden. Derhalve wees men op dat departement deelname af ${ }^{124}$.

In 1980 werd Nederland opnieuw door de Amerikanen benaderd. Ditmaal - op 10 juni 1980 - op een lager ambtelijk niveau bij de directie internationale organisaties. Van ambtelijke zijde werd de Amerikanen te verstaan gegeven dat Nederland wel deelneemt aan internationale operaties binnen VN-verband, maar dat zou bij MFO niet het geval zijn ${ }^{125}$.

In het voorjaar van 1981 benaderde de Amerikaanse Ambassaderaad een ambtenaar van de directie Afrika en Midden-Oosten voor het beschikbaar stellen van een patrouilleboot aan de MFO; er is toen geen Nederlandse reactie gegeven ${ }^{126}$. Uit het archief van de directie Afrika en Midden-Oosten blijkt geen officieel verzoek te zijn ontvangen voor deelname aan de MFO. Op verzoek van de directeur-generaal politieke zaken werd door de directie Afrika en Midden-Oosten op 15 oktober 1981 een memo opgesteld omtrent de inhoud van hun archief over de MFO. Toen bleek dat tot die datum nog niets aan Nederlandse zijde was gebeurd ${ }^{12}$.

Dankzij dit memo kennen we het tijdstip waarop de ambtelijke top geinteresseerd raakte in deelname aan de MFO.

Het initiatief kwam evenwel niet vanuit de ambtelijke top maar van minister Van der Stoel. De directeur-generaal politieke zaken Reinink, werd tot zijn verbazing door Van der Stoel tijdens het EPS-beraad gevraagd de zitting van de drie mogelijke participanten - het Verenigd Koninkrijk, Frankrijk en Italië - die separaat bijeenkwamen, bij te wonen. Zodoende werd de Nederlandse actieve belangstelling voor deelname aan de MFO getoond. Reinink benadrukte dat hij tevoren niet door andere ambassadeurs was benaderd en dat Van der Stoel vóór de bijeenkomst te Londen er met hem evenmin een

124. Interview met Rutten op 10 februari 1987.

125. Interview mel Reinink op 5 februari 1987.

126. Interview met Serry op 3 september 1987.

127. Tbidem. 
woord over had gewisseld ${ }^{128}$. Aannemelijk is dat deze bijeenkomst op 13 en 14 oktober 1981 te Londen plaatsvond ${ }^{129}$.

Kort na Sadats begrafenis was Van der Stoel geporteerd geraakt voor de totstandkoming van de vredesmacht, opdat het vredesverdrag niet op het spel zou komen te staan. Van der Stoel kreeg de indruk dat hij met zijn opvatting dichter bij de Amerikanen stond dan bij de Europese partners. Hij was bevreesd dat vanwege de aarzelingen aan Europese zijde, de Europese deelname niet gerealiseerd zou worden. Een belangrijke drijfveer voor hem was dat Nederland een positieve rol kon vervullen bij het 'ontwarren van de knopen' tussen de VS en Europa.

Volgens Van der Stoel heeft Reinink 'telkens al het mogelijke gedaan om compromisformules te vinden en om de brug naar de Amerikanen te slaan'. Over het MiddenOostenconflict was de verstandhouding van de Amerikanen met de Nederlanders beter dan met de Britten. Op grond daarvan heeft Nederland, hoewel de Britten het voorzitterschap van de EPS bekleedden, de rol van bemiddelaar tussen de VS en de EG kunnen vervullen.

Van der Stoel benadrukte dat de voornaamste 'kopzorg' van hem en Reinink was dit Europees-Amerikaanse probleem op te lossen. Dat lukte. Van der Stoel concludeerde achteraf dat 'het Nederlandse aandeel uiteindelijk bij de totstandkoming niet onaanzienlijk is geweest" ${ }^{30}$. Deze visie werd gedeeld door de betrokken Britse ambtenaar ${ }^{131}$.

Nederlandse deelname paste in het beleid dat ook door zijn voorganger, Van der Klaauw, ten aanzien van het Midden-Oosten was gevolgd: geen doorkruising van het Amerikaanse beleid en naww overleg met de VS bij het zoeken naar een oplossing van het Midden-Oostenconflict.

Daarnaast speelde een andere factor een grote rol bij de Nederlandse deelname. Het NAVO dubbelbesluit van 12 november 1979 was in de Nederlandse samenleving zeer omstreden ${ }^{132}$. De massale demonstratie van 21 november 1981 in Amsterdam gaf uiting aan het brede verzet tegen plaatsing van nucleaire wapens voor de middellange afstand (kruisvluchtwapens) op Nederlandse bodem. Deze kwestie speelde ook een belangrijke rol bij de Tweede Kamerverkiezingen in 1981, vooral in de verkiezingsprogramma's van de politieke partijen. De PvdA had zich uitgesproken tegen plaatsing en makakte na de verkiezingen met het CDA en D'66 deel uit van het kabinet-Van Agt II. De in september aangetreden PvdA-minister van Buitenlandse Zaken, Van der Stoel,

128. Interview met Reimink op 5 februari 1987.

129. NRC-Handelsblad 22-10-1981.

130. Interview met Van der Stoel op 11 februari 1987.

131. Interview mett Miles op 24 juni 1981.

132. Het NAVO-dubbelbesluit was het besluit 'tot invoering in West-Europa van 464 kruisvluchtwapens en 108 Pershing-2 raketten en tegelijk onderhandelingen aan te bieden om te komen tot wederzijdse beperking van deze en soortgelijke wapens aan Sovjet-kant. Van Staden, A, Het gelijk vam de NAVO: achtergronden van het 'dubbelbesluit", pp. 232-251, in: Van der Beugel E.H. e.a. Te beginnen bij Nederland, Opstellen over oorlog en vrede, G.A. van Oorschot, Amsterdain 1983, p. 233. 
maakte al tijdens de begrafenis van Sadat een afspraak om over deze kwestie met zijn Amerikaanse ambtsgenoot te spreken ${ }^{133}$.

De Nederlands-Amerikaanse relatie was in deze periode bovendien gespannen vanwege de bezwaren van de PvdA tegen de Spaanse toetreding tol de NAVO ${ }^{134}$. Weliswaar is het niet juist dat de ministers van Defensie Weinberger en Van Mierlo zouden hebben afgesproken dat in ruil voor Nederlandse deelname aan de MFO, de VS Nederland zouden toestaan het besluit tot plaatsing van kruisvluchtwapens uit te stellen ${ }^{135}$. Anderzijds is het wel zo dat het Amerikaanse vertrouwen in het Nederlandse beleid met name bij Haig en Eagleburger groter werd op grond van de Nederlandse houding inzake de MFO. Een dergelijk positief effect ten aanzien van de Amerikaans-Nederlandse relatie kwam Van der Stoel wel goed uit. Volgens Van der Stoel werden de Nederlandse bemiddelingspogingen door de Amerikanen gewaardeerd ${ }^{136}$. Hij voegt daaraan toe: "dat was ook niet weg in een tijd waar toch met name als gevolg van de dubbelbesluitkwestie de Amerikaans-Nederlandse betrekkingen onder spanning stonden' ${ }^{137}$.

Ook Van Mierlo beklemtoonde dat de Nederlandse deelname aan de MFO door de VS als een constructieve daad werd beschouwd. Nederland zou eerst de VS gepolst hebben over zijn bereidheid aan de MFO deel te nemen en de VS hebben aangeboden de helpende hand te bieden bij het oplossen van de politieke problemen ${ }^{138}$ "

Daarnaast was voor Van Mierlo participatie van Nederland gewenst om greep te houden op de Midden-Oostenproblematiek en speelden twee overwegingen op het terrein van defensie een rol. Zo zou deelname aan een vredesmacht een rechtvaardiging voor het instandhouden van een defensie-apparaat zijn en kon operationele ervaring worden opgedaan. De legerleiding was echter minder enthousiast dan Van Mierlo. Zij vreesde een verzwakking van de NAVO-inspanning omdat specialisten daaraan nu onttrokken zouden worden voor de MFO ${ }^{139}$.

Kortom, er bestonden bezwaren op ambtelijk niveau zowel bij Defensie - verzwakking van de NAVO-inspanning - als bij Buitenlandse Zaken en in het bijzonder bij de directie internationale organisaties - de structuur van de MFO buiten VN-verband - maar aangezien beide ministers politiek eensgezind waren, werd daar niet verder aan getornd. Andere departementen, zoals Economische Zaken (waar het directoraat-generaal van de Buitenlandse Economische Betrekkingen onder viel,) werden niet bij de besluitvorming

133. Hagsche Courant, 24-10-1981.

134. De moord op de IKON-journalisten in El Salvador vond plats op 17 matrt 1982, dus toen de besluitworming over de MFO al had plaatsgevonden. Naar ammleiding van deze moord werden - als protest-kruisen geplaatst voor het Amerikaanse consulaat-generaal te Amsterdam. Volgens de Nederlandse ambassadeur in Washington, J.H. Lubbers, veroorzaakte dat het dieptepunt in de Nederlands-Amerikaanse relatie en kon deelname aan de MFO 'well een beetje als wisselgeld gebruikt worden". Interview met Lubbers op 6 mast 1987.

135. Zie daarover Europa van Morgen, 28-10-1981 en werd ontkend door zowel Van Mierlo, Van der Stoel als Reinink in de interviews op 2 april 1987, 11 februari 1987 en 5 februari 1987; zie ook Pijpers, 1984, p. 219.

136. Pijpers, 1984 p. 223 baseert zich op interview van Van der Stoel in NRC-Handelsblad, 20-1-1983; Pijpers, 1990, p. 166.

137. Interview met Van der Stoel op 11 februari 1987.

138. Interview met Van Mierlo op 2 april 1987.

139. Interview met Van Mierlo op 2 april 1987. 
betrokken. Slechts het departement van Financiën moest zijn toestemming voor deze beslissing gegeven. Tenslotte werd het besluit zonder problemen door de ministerraad aanvaard.

Op 22 oktober 1981 maakte de regering haar voornemen bekend aan de MFO deel te nemen. $\mathrm{Zij}$ stelde daarbij vier voorwaarden:

1. de tien landen van de Europese Gemeenschap zouden het Nederlandse voomemen moeten ondersteunen;

2. naast Nederland zouden nog ten minste twee à drie Europese landen aan de MFO moeten deelnemen;

3. met de MFO zou overeenstemming moeten worden bereikt over de juridische en praktische aspecten van de deelname;

4. het Nederlandse parlement moest met de deelname instemmen ${ }^{140}$.

Van der Stoel had zich in een vroegtijdig stadium al van de parlementaire steun verzekerd door instemming te vragen van de fractievoorzitters van de vier grootste politieke partijen. Hij kreeg die steun. Het telefoongesprek tussen Van der Stoel en de VVD-fractievoorzitter Wiegel werd het kortste dat hij ooit met hem had gevoerd. Wiegel antwoordde: 'je gaat je gang maar' en legde vervolgens de hoorn op de haak. Gezien de zwakke politieke positie van het kabinet-Van Agt II was deze steun van het grootste belang ${ }^{141}$.

De eerste twee voorwaarden kwamen voort uit de vrees een kwetsbare positie als in 1973 nog eens mee te maken. Nederland wilde wel binnen de EG een actieve en sturende rol vervullen in de richting van Europese deelname aan de MFO, maar wilde voor alles voorkomen binnen de EG opnieuw geïsoleerd te raken. Uit de boot vallen zou Arabische maatregelen tegen Nederland vergemakkelijken en Nederland was - in de woorden van Van der Stoel - 'inderdaad wel zo voorzichtig dat het niet zo ver wilde gaan als enige - en klein - Europees land aan de MFO deel te nemen'.

Het is van belang te constateren dat Nederland zich vanwege zijn voornemen in het centrum van de besluitvorming binnen de EG bevond. Met name voor de Britten en Grieken was een verwijzing naar de verklaring van Venetië een conditio sine qua non voor hun instemming. Het compromis werd bereikt omdat tegelijk met de korte gemeenschappelijke verklaring, de verklaring van Venetië in de nationale verklaring van de vier werd vermeld ${ }^{142}$. Overigens meent Reinink dat de nationale verklaring voor de Tien niet aanvaardbaar zou zijn. Hij heeft met zijn drie buitenlandse collega's deze verklaring opgesteld. Dat was een moeilijke opdracht en bezorgde hem veel 'hoofdpijn'. Met de concept-verklaring op zak gingen Van der Stoel en Reinink op 3 november 1981 naar de VS. Tijdens het gesprek bleek Haig enige bedenkingen tegen de concept-verklaring te hebben ${ }^{143}$. Vervolgens werd het concept weer veranderd. Doel was daarbij

140. Tweede Kamer, zitting 1981-1982, $17.197 \mathrm{nr} .5$; p. 1.

141. Toespraak Van der Stoel, Rijksuniversiteit Leiden, op 23 maart 1989.

142. Interview met Van der Stoel op 11 februari 1987.

143. Niet geheel juist lichtte Van der Stoel de Tweede Kamer in toen hij zei: 'Ik zou het niet zo willen formuleren dat de VS bezwaren hebben tegen de woorgenomen verklaring wan de Europese Gemeenschappen', Handelingen Tweede Kamer, zitting 1981-1982, 11 november 1981, p. 274. 
een verklaring op te stellen die op niet al te groot verzet van Israel zou stuiten zonder bepaalde 'Europese' beginselen op te geven ${ }^{144}$.

Israel werd duidelijk gemaakt het de Europeanen niet te moeilijk te maken. Zo hoefde voor Nederland Israel de verklaring van Venetiè niet te onderschrijven, maar kon Israel niet van de Europeanen verlangen de verklaring van Venetie in te slikken ${ }^{145}$.Israel stuurde daar aanvankelijk wel op aan, maar bond toch enigszins in. Voor Reinink was het op 3 december 1981, op grond van de Amerikaams-Israëlische verklaring, duidelijk dat de Europese deelname ook door Israël zou worden geaccepteerd ${ }^{146}$ "Het was toen een "let us agree to disagree", waarbij de Europeanen de Israëli"s eind november ook tegemoet waren gekomen door geen enkele politieke voorwaarde aan deelname te verbinden.

Nederland heeft de Europese deelname over de MFO niet alleen bevorderd door nauwe samenwerking met de VS over deze kwestie, maar zich bovendien ingespannen de Griekse bezwaren weg te nemen. Nederland heeft ook een bijdrage geleverd aan de inhoud van de verklaring.

Tweemaal heeft Van der Stoel de Grieken apart over deze kwestie benaderd, énmaal schriftelijk en eenmaal mondeling tijdens zijn bezoek aan Athene op 7 november $1981^{147}$. De Griekse bezwaren waren zo sterk dat binnen de EPS de mogelijkheid besproken is dat Griekenland buiten de gezamenlijke opstelling zou blijven ${ }^{148}$. De Nederlanders en Italianen waren meer op de Griekse instemming gebrand dan de Britten en Fransen ${ }^{149}$, daar zij stewn voor deelname van de Tien verlangden. De Grieken $z a-$ gen deelname aan de MFO als uitvloeisel van Camp David en als cen breuk met de verklaring van Venetie.. De discussie met de Grieken ging 'uiterst moeizaam en tergend langzaam" ${ }^{150}$, terwijl zij alleen bij de totstandkoming van de gemeenschappelijke verKlaring betrokken werden ${ }^{151}$.

Voor de Britten was niet belangrijk of er inconsistentie met Camp David ontstond, maar wel of deelname in overeenstemming was met de verklaring van Venetië ${ }^{52}$. Dat laatste was in de visie van de vier het geval en volgens hen vloeide deelname ook voort uit paragraaf vijf van de verklaring van Venetie. In deze paragraaf hadden zij de bereidheid uitgesproken ter plaatse mee te werken aan garanties voor een algehele vredesregeling van de Verenigde Naties. Mijns inziens is dat een nogal ver verwijderd en gekunsteld verband. In ieder geval meenden de vier dat deelname aan de MFO overeenstemde met die beginselen van de verklaring van Venetie en brachten dat in hun nationale verkarin-

143. $\rightarrow$

Het belangrijkste onderwerp van dit gesprek betrof de plaatsing van raketten woor de middellange afstand.

144. Interview met Reinink op 5 februari 1987.

145. Interview met Van der Stoel in Het Parool 23-12-1981 en NRC-Handelsblad 18-11-1981.

146i. Interview met Reinink op 5 februari 1987.

147. NRC-Handelsblad 9-11-1981; Handelingen Tweede Kamer, zitting 1981-1982, 11 november 1981, p. 274 .

148. Interview met Reinink op 5 febnuari 1987.

149. Interview met Miles op 24 juni 1987.

150. Interview met Reinink op 5 februari 1987

151. Interview met Fiedler op 15 oktober 1987.

152. Intterview met Miles op 24 juni 1981. 
gen naar voren. Zo werd instemming voor deelname van de Tien verkregen en werd de deelname ook door de meerderheid van het Nederlandse parlement gesteund. In de volgende paragraaf zal ik deze parlementaire steun behandelen.

De deelname aan de MFO stond haaks op de verklaring van Venetië. Mijns inziens stierf deze verklaring hiermee een 'vroege dood'. Van belang is de constatering dat de Franse en Nederlandse besluitvormers niet langer achter de verklaring van Venetie en haar betekenis voor het vredesproces stonden. Eerder werd aangetoond dat ook Van der Stoels voorganger, Van der Klaauw, zeer sceptisch stond tegenover de verklaring van Venetiè. De Franse presidentsverkiezing veroorzaakte de. Franse koerswijziging.

Zo verklaarde de Franse minister van Buitenlandse Zaken, Cheysson, op 7 december 1981 in Israël: 'Il n'y aura pas, tant que nous serons au gouvernement, de projet européen ou d'initiative européenne ${ }^{153}$. Hij vond de verklaring van Venetië een vergissing ${ }^{154}$. Interessant is in dat verband dat aan nieuwe leden van de EG gevraagd wordt het 'acquis politique' althans de hoofdlijn van het gevoerde buitenlands beleid van de EPS te onderschrijven. Daarentegen blijken de leden van de EG na een regeringswisseling daar wel vanaf te kunnen wijken. De verandering in de opstelling van de Franse regering, nadat Mitterrand als president Giscard d'Estaing was opgevolgd, is hiervan een duidelijk voorbeeld.

Ook de Nederlandse minister van Buitenlandse Zaken verklaarde in een interview de op grond van de verklaring van Venetië uitgevoerde missies van Thorn en Van der Klaauw als een soort 'boedelbeschrijving' te zien ${ }^{155}$. In een ander interview stelde Van der Stoel: 'Een Europees initiatief voor het Midden-Oosten zie ik in de nabije toekomst niet. Daar is geen ruimte voor. We hebben de taak en de plicht zaken op tafel te leggen die een oplossing kunnen bevorderen. Ik wil ook niet spreken van een Europees initiatief, waar mijn voorganger Van der Klaauw, als EG-voorzitter, een half jaar mee bezig is geweest. Ik zou het een boedelbeschrijving willen noemen' ${ }^{356}$. De minister weet achteraf niet meer waarom hij de term boedelbeschrijving heeft gebruikt ${ }^{157}$ maar het wekt de indruk dat hij het Europese initiatief als achterhaald beschouwde.

De Nederlandse minister van Defensie, Van Mierlo, zei in retro-perspectief: 'De Europese deelname aan de MFO stond haaks op de beginselen uit de verklaring van Venetië. Sindsdien is het met het Europese Midden-Oostenbeleid dan ook snel achteruitgegaan. Het hoogtepunt was de verklaring van Venetië, maar ook dat hoogtepunt is nooit verder gekomen dan het verbale stadium, 158 .

Waarschijnlijk is het goed geweest voor de Nederlandse deelname aan de MFO dat deze ontboezemingen niet indertijd naar voren werden gebracht want dan zou de parlementaire steun tot de VVD en klein rechts beperkt zijn gebleven.

153. Politique étrangere, décembre 1981 , p. 160.

154. Agence Europe, 9-12-1981.

155. Interview met Van der Stoel door Hijmans in Het Parool, 23-12-1981.

156. De Volkskrant, 31-12-1981.

157. Interview met Van der Stoel op 11 februari 1987.

158. Interview met Van Mierlo op 2 sprill 1987. 


\subsection{Buitenlandse politiek}

\subsubsection{Parlement}

De minister van Buitenlandse Zaken had zich nog voor hij het voornemen tot deelname aan de MFO bekendmaakte, van de steun van de meerderheid van het parlement verzekerd. Daartoe had hij vertrouwelijk de fractie-voorzitters van CDA, PvdA, VVD en D'66 geraadpleegd evenals twee oud-ministers van Defensie en Buitenlandse Zaken. Vervolgens werden eveneens vertrouwelijk de vaste Kamercommissies voor Buitenlandse Zaken en Defensie geraadpleegd. Pas nadat de regering officieel te kennen gaf aan de MFO deel te nemen, werden de vergaderingen met de Kamercommissies openbaar gemaakt. De kleine fracties GPV, PPR en SGP hadden wel enige kritiek dat zij aanvankelijk gepasseerd waren ${ }^{159}$ maar voor het overige waren zij;, evenals de andere fracties, zeer te spreken over de nauwe samenwerking tussen regering en parlement over deze kwestie.

De motie-Van Es - Waltmans waarin de regering werd verzocht van deelneming af te zien, werd alleen gesteund door PSP, PPR en CPN. De motie-Schaper c.s. die door de drie buitenland-specialisten van de regeringscoalitie werd ingediend en waarin de regeringsbeslissing inclusief de politieke context werd onderschreven, kreeg slechts de tegenstem van de PSP. Er was vrijwel algehele consensus in de Tweede Kamer over deze tot dusverre unieke beslissing op grond waarvan 105 militairen buiten Nederlands grondgebied en eveneens buiten NAVO en VN-kader werden uitgezonden. Alleen het PSP-Kamerlid Van Es noemde hen 'huurlingen' ${ }^{160}$. Overigens werd het handhaven van de vrede tussen Egypte en Israël beschouwd als een bescherming van de belangen van de Nederlandse staat ${ }^{161}$.

Ondanks deze eenstemmigheid viel er wel werschil van mening te constateren tuissen de diverse fracties over de politieke context van de deelname. Andere kwesties zoals financiering, aantal en taak van de militairen, de mogelijke gedwongen uitzending van militairen, de volkenrechtelijke aard van de MFO en de gevolgen voor de Nederlandse NAVO-inspanning laat ik hier verder buiten beschouwing.

Binnen het parlement kunnen drie stromingen worden onderscheiden die samenvallen met 'links', 'midden' en 'rechts' van het politieke spectrum. In het vorige hoofdstuk werd opgemerkt dat een 'links-rechts' verdeling voor de meeste vraagstukken in de buitenlandse politiek gold, maar dat het Midden-Oostenvraagstuk daarop een uitzondering vormde. Verschil van politieke standpunten daarover deed zich vooral binnen de politieke partijen voor. Met het op de voorgrond treden van de Palestijnse kwestie en vooral na de politieke machtswisseling binnen Israël in 1977, ebden deze verschillen binnen fracties weg en kwamen verschillen tussen fracties meer naar voren. Kortom de 'links-rechts dimensie" werd ook beslissend voor de standpuntbepaling ten aanzien van het Nederlandse Midden-Oostenbeleid. In die zin vormde het Nederlands Midden-Oos-

159. Handelingen Tweede Kamer, zitting 1981-1982, 11 nowember, p. 273 en 24 februari 1982, pp. 2327 en 2340; Aanhangsel Tweede Kamer, zitting 1981-1982, p. 471.

160. Handielingen Tweedle Xamer, zitting 1981-1982, 24 februari 1982, p. 2325.

161. Artikel 195 oude Grondwet, art. 98.1 Grondwet 1983. 
tenbeleid nu meer een weerspiegeling van de totstandkoming van het gehele Nederlands buitenlands beleid.

De drie stromingen ten aanzien van deelname aan de MFO waren:

Links: zij wezen deelname af omdat de MFO gebaseerd was op de Camp Davidakkoorden en de 'Pax Americana van het Midden-Oosten'. De geringe aandacht voor het Palestijnse recht op zelfbeschikking en de overheersende rol van de VS waren voor de PSP, PPR en CPN de voornaamste reden om de Nederlandse deelname aan de MFO af te wijzen.

Midden: zij die de Camp Davidakkoorden als onvoldoende voor de Palestijnse rechten afwezen en aan het Europese beleid van de verklaring van Venetië wilden vasthouden. Zij hielden vast aan het streven naar een allesomvattende regeling maar erkenden dat als een einddoel te zien. Om die reden vonden zij het Egyptisch-Israëlisch vredesverdrag een positieve stap die los kon worden gezien wan het overige deel van de Camp Davidakkoorden. Deze positieve eerste stap wilden CDA, PvdA en D'66 ondersteunen met Nederlandse deelname aan de MFO.

Rechts: zij die de verklaring van Venetië kritiseerden en vooral de VS in de Camp Davidbenadering steunden en realistischer vonden. De VVD, SGP, GPV en RPF wilden het Egyptisch-Israëlisch vredesverdrag steunen en vonden dat het Europese initiatief het Camp Davidproces al te veel had gehinderd ${ }^{162}$. Steun voor de Nederlandse deelname aan de MFO vloeide uit hun benadering voort.

In feite heeft nagenoeg de hele Kamer, met uitzondering van de PSP, de politieke visie van de 'midden' groepering onderschreven door aanvaarding van de motie-Schaper. Weliswaar werd hun visie in afgezwakte vorm in de motie-Schaper gepresenteerd - 'deelname aan de Sinaï-vredesmacht doet geen afbreuk aan het in EPS-verband ontwikkelde beleid ten aanzien van het Midden-Oostenconflict, zoals dat onder andere in de verklaring van Venetie gestalte heeft gekregen" 163 - maar dat neemt niet weg dat een meerderheid van de Tweede Kamer de deelname aan de MFO niet zag of wilde zien als een ombuiging van het tot dusverre gevoerde Europese Midden-Oostenbeleid. Met andere woorden, vasthouden aan de gevoerde beleidslijn en daarmee miskennen van de ombuiging die had plaatsgevonden, vergroot de aanvaarding door het nationale parlement. Het - zogeheten - voortzetten van bestaand beleid was een belangrijke voorwaarde voor het succesvol aanvaarden van deze deelname aan de MFO.

\subsubsection{Groepen in de samenleving}

Over de binnenlandse beïnvloeding van de Nederlandse deelname aan de MFO kan ik bijzonder kort zijn: deze heeft nauwelijks plaatsgevonden. Het beleid werd door de regering geïnitieerd en door de politieke elite gesteund. In het land vond weinig discussie over de Nederlandse deelname ten principale plaats. Het is opvallend dat deze deelname ook op weinigen indruk heeft gemaakt en dat zij zich deze kwestie achteraf

162. Motie 17.100 V nr. 50, Handlelingen Tweede Kamer, zitting 1981-1982, 10 februari 1982, p. 1965 en 16 februari 1982 , p. 2051.

163. Handelingen Twoede Kamer, zitting 1981-1982, 10 februari 1982, p. 1963. 
nog maar met moeite kunnen herinneren. Het verschil met andere kwesties over het Nederlandse Midden-Oostenbeleid valt op zoals de deelname aan Unifil, de positie van de PLO of, op binnenlands terrein, de positie van het Nederlands Palestina Konnitee en de subsidiêring van door hem geëntameerde projecten. Bij deze laatste kwesties konden de emoties hoog oplopen en waren politieke partijen, kerken en actiegroepen actief in beinwloedingspogingen. Ook de pers besteedde aan deze kwesties meer aandacht dan aan de deelname aan de MFO. Deze werd sober verslagen. De pers besteedde meer aandacht aan de Britse of Israëlische houding ten aanzien van de MFO, dan aan de Nederlandse beleidskeuze terzake.

Zo bezien was de Nederlandse deelname aan de MFO niet controversieel. Bovendien leek Nederlandse deelname de Nederlandse economische belangen niet te schaden. De besluitvorming bleef beperkt tot de buitenland-politieke sector waarmee het departement van Economische Zaken en het bedrijfsleven zich niet inlieten. In de troonrede van 1978 werd reeds uitgesproken positief gereageerd op het resultaat van de Camp Davidonderhandelingen. In de overige troonredes in de periode 1974-1982 - met uitzondering van een korte vermelding in 1974 - werd aan het Midden-Oostenconflict geen aandacht geschonken ${ }^{164}$. In een publieke opinie onderzoek eind maart 1981 werd geconstateerd dat bijna $80 \%$ van de Nederlanders op de hoogte was van de ondertekening wan het Egyptisch-Israëlisch vredesverdrag. Volgens een ruime meerderheid was dat gunstig voor Egypte, Israël en de wereldvrede, terwijl eenderde van de respondenten geen mening had ${ }^{165}$.

De pro-Israëlische groepen waren wel gelukkig met de Nederlandse deelname aan de MFO, al waarschuwde de directeur van het CIDI, Naftaniel, dat deelname niet gepaard mocht gaan met druk op Israel om het plan-Fahd te aanvaarden en dat gegarandeerd zou moeten worden dat alleen Israël en Egypte tezamen terugtrekking van de MFO zouden kunnen vorderen ${ }^{1665}$.

Slechts het Palestina Komitee ondernam met de Palestijnse Vereniging en de Bond voor Dienstplichtigen een beïnloedingspoging om van deelname af te zien. Zij richtten het comité 'Geen soldaten naar de Sinai' op. Enkele groepjes (de jongeren in de PvdA en

164. Keesings Historisch Archief, 29 september 1978, p. 611 .

165. NIPO, no. $7913(\mathrm{~N}=1458)$ in: Vaneker en Everts, 1984 , p. 8.

\begin{tabular}{|l|r|r|r|}
\hline Vredesverdrag is & gunstig & ongunstig & weet niet \\
\hline voor Egypte & $56,1 \%$ & $11,9 \%$ & $32,2 \%$ \\
\hline voor Israel & $56,4 \%$ & $12,1 \%$ & $31,5 \%$ \\
\hline voor andere landen in Midden-Oosten & $36,1 \%$ & $21,5 \%$ & $42,4 \%$ \\
\hline voor de Palestijnen & $28,0 \%$ & $28,5 \%$ & $43,5 \%$ \\
\hline en voor de Wereldvrede & $57,8 \%$ & $9,7 \%$ & $32,6 \%$ \\
\hline
\end{tabular}

166. Het Parool, 10-11-1981. 
PSP, de Vereniging van Dienstweigeraars, het Komitee van Marokkaanse Arbeiders in Nederland, de Turkse Arbeiderswereniging, de Internationale Kommunistenbond, de jongerengroep Rebel, het El Salvadorcomité in Tilburg, het Ierlandcomité, de X-Y Beweging, De Vereniging van Wereldwinkels) steunden hen. Namens hen stuurden 43 dienstplichtige militairen een brief aan minister Van Mierlo tegen deelname ${ }^{16}$. De vereniging van dienstplichtige militairen gaf geen steun aan deze actie. In het parlement werd de zienswijze tegen deelname slechts door de PSP ondersteund.

Deze niet controversiele kabinetsbeslissing had bovendien de bescherming vanuit de EG. De koerswijziging voltrok zich in stilte. Niettemin werd nu voor het eerst door Nederland een daadwerkelijke bijdrage geleverd, niet in woorden maar met de uitzending van 105 militairen ter ondersteuning van de Egyptisch-Israëlische vrede.

\subsection{Conclusie over Nederland en de MFO}

We hebben kunnen constateren dat het besluit van de Nederlandse deelneming werd gepresenteerd als voortvloeiend uit de verklaring van Venetië en mede daarom met overgrote meerderheid in het parlement werd aanvaard. De in de verklaring van Venetië in het vooruitzicht gestelde troepenmacht was bedoeld als een soort 'garantiesysteem' voor het naderbij brengen van een algehele oplossing. Met andere woorden, de troepen zouden worden geïnstalleerd om een vredesregeling te bevorderen, die dan nog niet was bereikt. De MFO daarentegen werd geïnstalleerd als uitvloeisel van een vredesverdrag ${ }^{168}$. Van der Stoel gaf het Kamerlid Bollkestein indertijd gelijk door te stellen 'dat men de MFO op zichzelf niet als een onderdeel van een garantiesysteem kan zien' ${ }^{169}$. De MFO zou immers niet de schendingen van het vredesverdrag bestrijden en evenmin militaire operaties uitvoeren ter verwijdering van strijdkrachten uit het gebied ${ }^{170}$. Als vorm van Europese participatie in een garantiesysteem dat bij de verklaring van Venetië werd beoogd, voldoet de MFO niet.

Carrington hield in feite vast aari de strekking van de betreffende passage uit de verklaring van Venetië, toen hij verklaarde dat de MFO zou toezien op de terugtrekking van de Israëlische troepen. Dat wekte de woede op van de Israëli's, omdat daardoor aan de MFO een geheel andere functie werd toegekend dan hun voor ogen stond. Uiteindelijk werd de Israëlische positie aanvaard, aangezien door de vier verklaard werd dat de MFO 'uitsluitend bestaat met als doel de vrede in de Sinaï te handhaven na de Israëlische terugtrekking' 171.

Dit strijdpunt speelt nog steeds. De PLO wenst eerst VN-troepen op te ontruimen bezette gebieden om vervolgens tot een politieke oplossing te komen. Dit vormt één van

167. NRC-Handelsblad, 24-2-1982.

168. Normaliter haindhaven vredesmachten de stabiliteit in een gebied opdat partijen een vredesovereenkomst kunnen sluiten. Volgens Rilkhye lijkt de MFO op een vredesmacht maar speelt het vooral een roll in het scheppen wan vertrouwen tussen Egypte en Israël, Rikhye 1984, pp. 73 en 222. De term voor vredesmachten is wechter 'peace-keeping forces' en niet "peace-making' of 'peace-promoting forces'.

169. Handelingen, Tweede Kamer, zitting 1981-1982, 24 februari 1982, p. 2345.

170. Ibidem $p .2343$.

171. Tweede Kamer, zitting $1981-1982,17.197$ nr. $1_{*}$ p. 2. 
de geschilpunten met Israël over de te houden verkiezingen op de Westelijke Jordaanoever en in de Gazastrook.

Opvallend is dat de regering na het Kamerdebat de deelneming aan de MFO bijna vitsluitend in verband bracht met de Egyptisch-Israëlische vrede. In de toelichtende nota bij de overeenkomst met de MFO die op 2/4 maart 1982 tot stand kwam ${ }^{172}$, gaf de regering de volgende argumentatie voor haar deelname: 'Gezien het feit dat Nederland het vredesverdrag tussen Israël en Egypte destijds heeft verwelkomd als een eerste stap op weg naar de totstandkoming van een alomvattende vredesregeling, kan iedere bijdrage tot de voltooiing en consolidering van het vredesproces tussen Israël en Egypte worden geacht in overeenstemming te zijn met een beleid dat zich een dergelijke vredesregeling ten doel stelt ${ }^{173}$. Met de ondersteuning van het vredesproces tussen Israel en Egypte werden zelfs de belangen van de Nederlandse staat behartigd. Voor uitzending moest namelijk een grondwettelijke basis aanwezig zijn en die werd gevonden in het artikel 195 Grondwet (artikel 98 lid 1 Grondwet 1983). 'Het meewerken aan het voorkomen van een conflict elders in de wereld dat gevolgen zou hebben voor Nederland; kan gerekend worden tot de belangen van de staat waarop artikel 195 het oog heeft" ${ }^{174}$.

Het is niet duidelijk wat onder 'de belangen van de staat' ter bescherming waarvan een krijgsmacht volgens artikel 98 Grondwet bestaat, moet worden verstaan ${ }^{175}$. Deze hebben niet alleen betrekking op het eigen grondgebied ${ }^{176}$. De defensieplicht uit artikel 97 Grondwet beperkt zich 'tot handhaving van de onafhankelijkheid van het Rijk en tot verdediging van zijn grondgebied'. De vraag is dan of dienstplichtigen kunnen worden uitgezonden als de onafhankelijkheid van Nederland of de verdediging van zijn grondgebied er niet mee gemoeid zijn. Bij het Kamerdebat over Unifil meende de minister van Defensie dat uitzending ten behoeve van VN-vredesacties tot de belangen van de staat kan worden gerekend. Langemeijer stelde dat daarmee 'elke actie waar ook ter wereld via Nederland internationale banden of economische of politieke belangen op de een of andere wijze bestempeld kan worden tot Nederlands staatsbelang' ${ }^{17}$.

In het Kamerdebat over participatie in de MFO zei de minister van Defensie, Van Mierlo, met gevoel voor humor dat de uitmonstering van de MFO-militairen op zichzelf al bijdroeg tot een interpretatie van artikel 195 Grondwet dat de belangen van de Nederlandse staat in het geding zijn: zij dragen namelijk een oranje shawl en een oranje baret ${ }^{178}$.

172. De cwereenkonst was in de vorm wan de totstandgekomen briefwisseling tussen de regering wan het Koninkrijk der Nederlanden en de Multinationale Vredesmacht (MFO) inzake de Nederlandse deelname aan de MFO in de Sinaï, met bijlagen (Trb. 1982, 61 en 69); Tweede Kamer, zilting $1982-1983,17.691$, nr. 1 , p. 1 .

173. Tweede Kamer, zitting 1982-1983, $17.691 \mathrm{nr} .1$, p. 2 .

174. Tweede Kamer, zitting 1982-1983, 17.961 nr. 1, p. 5 .

175. Kortmann, 1980 , p. 366.

176. Behandeling Grondwetsherziening: Tweede Kamer 1978-1979, 15.467, nrs. 1-6, zie wok Akkermans, 1987, pp. 821-825.

177. Langemeijer, 1981, p. 518 .

178. Handelingen Tweede Kamer, zitting 1981-1982, 24 februari 1982, p. 2347. 
De Raad van State stelde de Nederlandse deelname principieel aan de orde met de vraag aan de regering te motiveren:

1. dat door deelname de bellangen van de staat worden gediend;

2. dat er sprake is van buitengewone omstandigheden in de zin van artikel 33, eerste lid, sub c van de Dienstplichtwet en

3. of deze deelname die op verzoek van derden en tezamen met derden dan nog wel geootloofd en wenselijk is ${ }^{179}$.

De Raad van State was het in zijn advies eens met de ruime uitleg van de regering van artikel 195 maar had kritiek op de toegevoegde beperking - 'dat gevolgen zou hebben voor Nederland' - door de regering. Dat zou maar tot discussie leiden 'zonder dat zulks aan een wezenlijke normering bijdraagt". Immers, ieder conflict in de wereld kan gevolgen hebben voor Nederland ${ }^{180}$. De regering was het naderhand met de visie van de Raad van State eens en vond 'deze toevoeging inderdaad weinig gelukkig' ${ }^{181}$. In feite werd daardoor voor een ruime ongeclausuleerde uitleg van artikel 195 gekozen.

Het tweede punt had de regering nodig om eventueel dienstplichtigen ook onvrijwillig uit te zenden. Een Koninklijk Besluit van 27 februari 1982 regelde dat, maar zou pas in werking treden als de regering deze machtiging nodig had ${ }^{182}$. De Raad van State vond met de regering dat het begrip 'buitengewone omstandigheden' ook betrekking kon hebben 'op de omstandigheden, welke verband houden met de plaats waar de inzet van de dienstplichtigen wordt overwogen' ${ }^{183}$; kortom op grond van de buitengewone omstandigheden in de Sinaï konden Nederlandse dienstplichtige soldaten verplicht worden daar te dienen om de belangen van de Nederlandse staat te behartigen. Mijns inziens een wel zeer vergaande stap. Tevens een unieke stap daar Nederland - anders dan bijvoorbeeld in de NAVO of de VN - geen partij was in deze volkenrechtelijke organisatie, de MFO.

In antwoord op de derde vraag van de Raad van State herhaalde de regering haar voorkeur voor deelname in $\mathrm{VN}$-verband. $\mathrm{Zij}$ was niet gelukkig met de deelname van Uruguay, waar de mensenrechten werden geschonden. Tevens deelde de regering mee dat de directeur-generaal van de MFO wel volkenrechtelijke status had en bevoegd was overeenkomsten aan te gaan ${ }^{184}$. De MFO was opgericht naar volkenrechtelijke regels bij verdrag tussen Egypte en Israël en was volgens Siekmann daarmee een vredesmacht 'sui generis' aangezien 'de partijen die haar in het leven hebben geroepen tegelijkertijd als gastland fungeren" ${ }^{185}$. De MFO leek veel op de vredesmachten die onder de hoede van de VN functioneerden ${ }^{186}$. Maar de MFO kon niet - wegens de bezwaren tegen het Egyptisch-Israëlisch vredesverdrag - door de Verenigde Naties worden opgericht. Dat werd door Nederland betreurd.

179. Tweede Kamer, zilting 1982-1983, 17.691, A, pp. 1-2.

180. Tweede Kamer, zitting 198.2-1983, 17.691, A, p. 1.

181. Tweede Kamer, zitting $1982-1983,17.691$, B, p. 4.

182. Tweede Kamer, zitting 1982-1983, 17.691, nr. 1 , p. 5 .

183. Tweode Kamer, zitting 1982-1983, 17.691, A, p. 2.

184. Tweede Kamer, zitting 1982-1983, 17.691, B, p. 4 .

185. Siekmann, 1982 , p. 667 .

186. Zie daartoe in het bijzonder Pelcovits, 1984; Tabory, 1986; en Siekmann, 1982, pp. 660-667. 
De Nederlandse minister-president en tijdelijk tevens minister van Buitenlandse Zaken, Van Agt, verklaarde voor de Algemene Vergadering van de Verenigde Naties, welke waarde Nederland desalniettemin aan de MFO hechtte: "Van tijd tot tijd, meneer de voorzitter, hebben bijzondere omstandigheden landen ertoe gebracht over te gaan tot vredesoperaties buiten het kader der Verenigde Naties. Dit kan tot enige bezorgdheid aanleiding geven. Aan het handhaven van vrede en stabiliteit moet echter soms de voorrang worden gegeven boven overwegingen van institutionele aard" ${ }^{187}$. Daarom cook hebben verschillende Nederlandse regeringen ingestemd met een verlenging van de Nederlandse deelname na 25 april 1984 tot 25 april $1986^{158}, 24$ april $1988^{189}$ met een uitbreiding tot 117 militairen ${ }^{190}$ en wederom met een verlenging tot 24 april $1990^{191}$.

De verlenging van de Nederlandse deelname aan de MFO van 1990 tot 1992 werd niet eens meer aan de Kamer voorgelegd. Volstaan werd ditmaal met een notitie van Buitenlandse Zaken aan de ministerraad van 9 februari 1990 waarin deze verlenging was vastgelegd ${ }^{192}$.

Het doel van Nederlandse deelname was een bijdrage te leveren aan de verdere verbetering in de betrekkingen tussen Egypte en Israël en een inhoudsvolle bijdrage te leveren aan het vredesproces ${ }^{193}$. Van der Stoel verklaarde in 1982 aan het slot van het debat in de Kamer: 'Het meedoen aan de vredesmacht is in mijn oordeel vredesbeleid in de beste zin des woords" ${ }^{194}$. Hij vond achteraf dat de Nederlandse deelname en de totstandkoming van de MFO één van de beste dingen waren die tot stand zijn gekomen tijdens zijn tweede ambtsperiode ${ }^{195}$.

De vraag doet zich voor hoe belangrijk de Nederlandse en Europese deelname aan de MFO waren voor de totstandkoming van deze vredesmacht. Zou Israël zich anders niet uit de Sinaï hebben teruggetrokken en daarmee de Israëlisch-Egyptische vrede op het spel hebben gezet?

Door de besluitwormers aan Europese zijde werd deze causale relatie herhaaldelijk naar voren gebracht. Deze was voor de Nederlandse minister van Buitenlandse Zaken één der belangrijkste beweegredenen zich sterk te maken voor de totstandkoming van een Europese bijdrage. Deze beeldvorming heeft grotendeels hun handelen bepaald en is alleen al daarom relevant. Met name de Italiaanse, Britse en Nederlandse perceptie daarvan heb ik in de voorafgaande paragrafen behandeld. Deze perceptie vond haar voedingsbodem in de beoordeling van het als onverzoenlijk omschreven beleid van de regering-Begin, met name na diens tweede verkiezingsoverwinning in 1981, toen de

187. Rede van 29 september 1982, Ministerie van Buitenlandse Zaken, deel 130, p. 369.

188. Tweede Kamer, zitting 1982-1983, 17.197 mr. 14; 18.100 , V en X, nr. 109.

189. Tweede Kamer, zitting 1982-1983, $17.197 \mathrm{nr} .15$.

190. Tweede Kamer, zitting 1982-1983, 17.197, nr. 16.

191. Tweede Kamer, zitting 1982-1983, 17.197, mr. 17.

192. Telefonische informatie van Braam DAM/MO aan auteur op 12 juli 1990.

193. Tweede Kamer, zitting 1982-1983, 17.197, nr. 15, p. 2 en 17.197 no. 17, p. 10.

194. Handelingen Tweede Kamer, zitting 1981-1982, 24 februari 1982, p. 2353.

195. Interview met Van der Stael op 11 februari 1987. 
meer gematigden de Israëlische regering verlieten. Maar, zo kan men zich afvragen, stemt deze beeldvorming ook overeen met de realiteit?

In de eerste plaats kan op het aandeel van de troepenleverende landen worden gewezen. Voordat de Europese belissing was genomen hadden de Fiji eilanden (500 mensen), Colombia (500 mensen), Uruguay (75 mensen) en de VS (1175 mensen) zich al aant deelneming gebonden. Zij leverden tezamen 2225 soldaten terwijl de totale MFO uit iets minder dan 2650 soldaten zou gaan bestaan. Kortom de bijdrage van $84 \%$ van de soldaten voor de totale MFO was reeds verzekerd. Australië (109 mensen) en NieuwZeeland ( 35 mensen) stelden hun deelname afhankelijk van de Europese beslissing. De BG-lidstaten Italië (90), Frankrijk (42), Verenigd Koninkrijk (35) en Nederland (105) leveren tezamen slechts 272 soldaten ${ }^{19 \%}$.

Ook zonder de Europese bijdrage en de daarvan afhankelijke deelname van Australiể en Nieuw-Zeeland kan van enige geografische speiding - Noord-Amerika, Zuid-Amerika en Oceanië - worden gesproken. De militaire bijdrage vanuit Europa was beperkt en de meer specialistische taken zouden wellicht ook door Amerikaanse soldaten kunnen worden uitgevoerd.

De Nederlandse en Europese deelname was zo bezien vanuit militair oogpunt niet noodzakelijk. Met andere woorden, de vredesmacht zou ook zonder Europese bijdrage tot stand kunnen zijn gekomen en de Israëli's zouden zich hebben kunnen terugtrekken uit de Sinaï. De politieke vraag of dit ook zonder Europese bijdrage zou zijn geschied is moeilijker te beantwoorden. Naar alle waarschijnlijkheid zou dat afhangen van de Amerikaanse houding tegenover Israël op dit punt. Zoals eerder uiteengezet was de Europese bijdrage voor de VS erg belangrijk. De Amerikanen hebben Israël bewogen de Europese deelneming niet af te wijzen. Een Israëllische afwijzing, nadat de VS met de Europese deelneming en politieke verklaring hadden ingestemd, zou tot IsraëlischAmerikaanse spanning hebben kunnen leiden, waardoor de Israëli's zich wel eens niet uit de Sinaï zouden hebben kunnen terugtrekken. De toenmalige Amerikaanse ambassadeur in Israël, Lewis, beschreef in 1988 de vrees aan Amerikaanse zijde dat Israël zich uiteindelijk niet zou terugtrekken ${ }^{197}$.

Kortom, bij deze kwestie ging het erom de steun van de Europese Tien te verwerven en tevens een voor de VS aanvaardbare politieke verklaring te ontwerpen. Het onderwerp was het Midden-Oostenconflict maar het ging in feite om de verhoudingen binnen de EG en om de Atlantische relatie. Het gepresenteerde communicatie-schema in paragraaf 4.1.2.4. geeft ook aan dat voor de Israëlische beslissing slechts de AmerikaansIsraëlische communicatie en relatie telden en dat de Europeanen zich op grond van andere boodschappen gebonden achtten.

196. Tabory, 1986, pp. 39-47. Noourwegen behoorde niet tot de deelnemende staten maar leverde well de commandant met drie stafofficieren voor de vredesmacht.

197. Lewis in Quandt 1988 , p. 236 'Washington was determined to ensure full implementation of peace with Egypt in April 1982. To thwart the suspected designis of Sharon and others to prevent final Israeli withdrawal, the Reagan administration had to restore a personal rapport with Begin, and with Sharon for that matter. Haig travelled to Jerusalem in mid-January to do so'. De Israellische annexatie van de Golan en als gevolg daarwan de Amerikaanse opschorting van het negentien dagen daarvoor getekende Amerikanns-Israelisch akkoord over strategische samenwerking had de wederzjjdse verhouding verslechterd. 
De parallel met de eerdere casus ligt voor de hand. Evenals bij de kwestie van het olieembargo en de verklaring van Venetiẻ staan de verschillen van opvattingen tussen de EG-partners op de voorgrond en speelt de Amerikaans-Europese relatie daarbij een belangrijke rol. Op zichzelf is dat vanzelfsprekend, omdat het gaat om beslissingen binnen het EPS-kader en de betekenis van de Europese buitenlandse politieke samenwerking aan de orde is. Dat kan leiden tot een afzetten tegen de dominante rol van de VS op het internationale politieke terrein. Inzake het Midden-Oostenvraagstuk komen de hierboven genoemde tegenstellingen samen; binnen de EPS wordt verschillend over het Arabisch-Israëlisch conflict gedacht en tevens bestaat er verschil tussen de visie van de VS en het gemeenschappelijk standpunt van de EG-lidstaten over de oplossing van het Midden-Oostenconflict. Het is dan ook waarschijnlijk bevorderlijk voor de ontwikkeling van de EPS geweest dat het Midden-Oostenconflict in dat beraad zo centraal heef gestaan. Met andere woorden bij verschil van visie tussen de VS en de EPS-partners konden deze laatsten zich profileren.

Een kritische reactie door de VS op de ingenomen standpunten in de EPS betekende op z"n minst dat de EG-stellingname werd opgemerkt. Datzelfde geldt voor de reacties vanuit Israël en de Arabische wereld op gemeenschappelijke EPS-standpunten. De EPS had zich kenbaar kunnen maken. Aan de andere kant heeft dat kenbaar maken niet geleid tot daadwerkelijke invloed op de partijen in het conflict. Noch Israël noch de Arabische landen of de PLO heeft op grond van het EPS-beleid een standpunt ingenomen dat een oplossing van het conflict bevorderde. Eerder zijn er aanwijzingen van het tegendeel, dat wil zeggen dat partijen op grond van het Europese standpunt hun positie eerder verhardden. Ook heeft de EPS niet kunnen bijdragen aan enige bemiddeling tussen de direct betrokken partijen en de VS niet tot een ander standpunt kunnen bewegen. Op dat punt is de uitspraak van Van den Broek interessant toen hij verklaarde wel jaloers te zijn op Zweden dat de PLO wist te bewegen zich zodanig uit te spreken dat deze voor de VS een aanvaardbare gesprekspartner werd ${ }^{198}$. Wat Zweden in decenber 1988 lukte, hebben de EG-lidstaten ondanks de vele pogingen daartoe in EPSverband niet bereikt.

\subsection{Conclusies en slotopmerkingen}

De invloed van binnenlandse groeperingen op de Nederlandse beslissing tot participatie in de MFO was nihil. De beslissing kon wel bogen op binnenlandse consensus. Minister Van der Stoel wist zich te verzekeren van de steun van de grote fracties in het parlement. Met deze beslissing werd een consistent beleid gevolgd. De regering stelde zich ten doel de Israellische veiligheid te verzekeren, het Amerikaanse Midden-Oostenbeleid niet te doorkruisen en een kwetsbare positie voor Nederland te vermijden. Deze drie doeleinden werden nu bereikt.

In de voorafgaande periode behaalde Nederland geen succes in zijn pogingen het EPSbeleid naar de Nederlandse voorkeur om te buigen. Het kon slechts aan de rem hangen en zodoende enige 'vooruitgang' in de ontwikkeling naar een Europese rol in het Midden-Oostenconflict blokkeren. In dit hoofdstuk werd beschreven op welke wijze minister

198. NRC-Handelsblad, 22-12-1988. 
Van der Klaauw erin slaagde in zijn rol van voorzitter van de EG, aan de Nederlandse doeleinden vorm te gewen. Mede dankzij ontwikkelingen in de internationale politiek kon Van der Stoel deze lijn voortzetten.

Nederland leverde een belangrijke bijdrage aan de totstandkoming van de Europese participatie in de MFO. Het EPS-beleid ten aanzien van het Midden-Oosten wijzigde als gevolg daarvan van koers. Het Amerikaanse Midden-Oostenbeleid werd daadwerkelijk ondersteund. De uitgesproken voorkeur van parlement en regering voor nauwe samenwerking met de VS inzake het Midden-Oostenconflict werd gerealiseerd. Een zeer belangrijke overweging van de regering voor participatie in de MFO was dat hierdoor de gespannen relatie tussen Nederland en de VS - als gevolg van de kwestie over plaatsing van kruisvluchtwapens - kon worden verbeterd. Tevens werd daarmee de veiligheid van Egypte en Israël gediend zonder dat Nederland in een kwetsbare positie terecht kwam. De instemming door de Europese partners met deze beslissing bood Nederland bescherming. De regering kon de wensen uit eigen land met de wensen uit het buitenland in overeenstemming brengen. Dat duidt op een beleid van bewarende aanpassing in deze kwestie. 


\section{Hoofdstuk 5. Conclusies}

Deze studie behandelt de totstandkoming van het Nederlandse beleid ten aanzien van het Arabisch-Israëlisch conflict. Het politieke proces staat daarbij centraal. Een onderscheid is gemaakt tussen het buiterlands politieke proces en het internationaal politieke proces. Ten aanzien van dat laatste is onderzocht welke rol Nederland in het - vanuit Nederlands gezichtspunt voor het onderwerp van deze studie - belangrijkste Europese intergouvernementele samenwerkingsverband, te weten de Europese Politieke Samenwerking (EPS), heeft vervuld. In deze studie zijn de effecten van dat internationale politieke overleg op de betrokken partijen in het Arabisch-Israëlisch conflict niet onderzocht. De studie beperkte zich tot een beschrijving van de totstandkoming van het Nederlands buitenlands beleid en de Nederlandse rol in de internationale politiek ten aanzien van het Arabisch-Israëlisch conflict. De Nederlandse activiteiten uit de periode 1973-1982 zijn onderzocht. Nederland stelde zich in deze periode ten doel het voortbestaan van Israël binnen veilige en erkende grenzen te verwezenlijken. De studie begint met de vrees van de Nederlandse regering uit 1973 dat Israël tijdens de Oktoberoorlog overrompeld zou worden. Het Nederlandse beleid beoogde dat te voorkomen. De studie eindigt met de ondersteuning in 1982 van het eerste vredesverdrag uit 1979 tussen Israël en éên van zijn buurlanden, Egypte. Voor Israëls voortbestaan was dat een mijlpaal in het Arabisch-Israëlisch conflict. Nederland heeft bijgedragen aan de bestendiging van de Egyptisch-Israëlische vrede.

In de gekozen optiek staan Nederland en tot op zekere hoogte Europa centraal. Het schriftelijke bronnenmateriaal bestaande uit secundaire literatuur, beschikbare archieven, kranten en parlementaire verslagen, werd aangevuld en ingekleurd met informatie uit interviews met voornamelijk Nederlandse, direct en indirect betrokken, besluitvormers. De keuze van de geïnterviewden is bepaald door de doelstelling van dit onderzoek, te weten inzicht te verschaffen in de twee onderscheiden politieke processen. Daarbij richtte de aandacht zich op degenen die invloed wilden vitoefenen en op degenen op wie de invloed was gericht. Voor het buitenlandse politieke proces waren dat enerzijds binnenlandse groeperingen zoals politieke partijen, actiegroepen, kerken en het bedrijfsleven en anderzijds parlementariërs, ambtenaren en bewindslieden. Voor het internationale proces waren dat bewindslieden, ambtenaren en diplomaten van respectievelijk Nederland en zijn EPS-partners. Slechts in beperkte mate is het mij gelukt interviews met vertegenwoordigers uit andere EG-lidstaten af te nemen. De Nederland-centrische benadering werd daardoor versterkt. Dit bergt het risico in zich van een overwaardering van de Nederlandse rol. Getracht is dat risico te verkleinen door een uitgebreide bestudering van literatuur en parlementaire verslagen uit de andere EG-lidstaten. Wel waren beide ministers van Buitenlandse Zaken uit de bestudeerde periode en alle topambtenaren van Nederlandse zijde, die direct betrokken waren bij het internationaal politieke proces, bereid tot een uitgebreid interview. Hier kan worden gewezen op de constatering door Van Staden, over een enquête onder de buitenlandse politieke elite van Nederland, dat topambtenaren over het algemeen tamelijk pessimistisch zijn over de Neder- 
landse invloed in de internationale politiek ${ }^{1}$. Voorts constateerde Roschar dat topambtenaren zichzelf minder vaak veel invloed bij de totstandkoming van het buitenlands beleid toekennen dan zij andere deelelites toeschrijven ${ }^{2}$. De vrees bestond dat de $\mathrm{Ne}$ derlandse rol in het internationaal politiek proces werd overgewaardeerd, omdat voomamelijk Nederlandse deelnemers aan het internationaal politieke beraad zijn geïnterviewd. Vanwege de pessimistische perceptie van de Nederlandse topambtenaren over zowel hun eigen invloed als de Nederlandse invloed, is het goed mogelijk dat deze vertekening - in casu overwaardering - niet plaatsvond.

De vraagstelling van dit onderzoek betreft, zoals gezegd, de totstandkoming van het Nederlands buitenlands beleid en de Nederlandse rol in de internationale politiek; Daartoe is de (binnenlandse) beinvloeding van het Nederlands buitenlands beleid en de inbreng van het Nederlandse standpunt in het internationale politieke overleg onderzocht. Eén hiervan afgeleide vraagstelling is de vraag naar de relatie tussen binnenlandse beinvloeding en internationaal optreden: in hoeverre bevorderen of belemmeren activiteiten van binnenlandse groeperingen de effectiviteit van het Nederlands optreden in internationaal verband? Het antwoord op deze vraag is zowel maatschappelijk als theoretisch relevant.

De maatschappelijke relevantie schuilt erin dat regeringen veelal afwijzend staan tegen binnenlandse inmenging in hun buitenlands beleid, ondat zulks een effectief internationaal optreden zou hinderen. Inzicht in de bovengenoemde relatie zou een nieuw licht kunnen werpen op de kansen op democratisering van het buitenlands beleid.

De theoretische relevantie betreft de vraag of de regering een op aanpassing aan de externe omgeving gericht beleid voert dan wel een beleid op tegemoetkoming aan de wensen uit het binnenland en buitenland. Kortom, zonder buitenlands politiek standpunt kan van een eigen Nederlandse inbreng in de internationale politiek niet gesproken worden en wordt Nederland een speelbal van machtiger staten. De democratie - in de zin van het rekening houden met de standpunten van de eigen bevolking in het beleid wordt dan op ernstige wijze uitgehold. Democratie wordt in dat geval opgevat in de zin van methode of procedure. De vereiste van effectieve participatie van de burgers in de besluitvorming is dan van belang. Aan de hand van Dahl omschrijft Spoormans in zijn dissertatie democratie in deze vorm als volgt: 'Iedere burger moet op adequate en gelijke wijze in de gelegenheid zijn om kwesties op de agenda te plaatsen en om voorkeuren kenbaar te maken. Hebben burgers die gelegenheid niet, dan kunnen hun voorkeuren niet voldoende gekend en dus niet voldoende in de beschouwing opgenomen worden' ${ }^{3}$. Het Nederlandse beleid inzake het Arabisch-Isrälisch conflict kon rekenen op ruime belangstelling bij de bevolking. Over dit 'gevoelige' vraagstuk werden op ruime schaal standpunten en wensen vanuit de Nederlandse samenleving naar voren gebracht. Een positief verband tussen opvattingen in de eigen samenleving en de Nederlandse inbreng in internationaal verband is een maatstaf voor het democratische gehalte van een staat.

1. Van Staden, 1978, p. 73 .

2. Roschar, 1978, p. 153. Ellemers heeft kritiek geleverd op deze conclusie van Roschar omdat slechts de percepties van veronderstelde deelnemers an het buitenliands beleid werden onderzocht. Een beeld wan feitelijke invloeden op het beleid werd aldus niet werkregen. Ellemers, 1979, p. 107.

3. Spoormans, 1988, p. 8. 
Zelfs indien een dergelijke doorwerking een effectief internationaal optreden - in de ogen van de besluitvormers - zou belemmeren, dan moet toch al het mogelijke worden gedaan deze vanuit het binnenland afkomstige standpunten in de besluitvorming op internationaal niveau gestalte te geven, indien Nederland in de internationale politiek een substantiële rol wil spelen. Zonder eigen standpunt is in het geheel geen sprake meer van effectiviteit. Op basis van de in dit boek gepresenteerde analyse zal nu een antwoord worden gegeven op de vragen naar de totstandkoming van het buitenlandse beleid (5.1), de Nederlandse rol in de internationale politiek (5.2) en de relatie tussen het Nederlandse buitenlands politieke standpunt en Nederlands optreden in de internationale politiek (5.3).

\section{Het buitenlands politieke proces}

De conclusie van dit onderzoek is dat de opvattingen in de Nederlandse samenleving van invloed zijn geweest op de inhoud van het Nederlandse buitenlands beleid teir aanzien van het Arabisch-Israëlisch conflict. De Nederlandse besluitvormers waren ontvankelijk voor hetgeen in Nederland leefde over deze kwestie en hielden daar in het gevoerde beleid rekening mee. De invloed is echter moeilijk aantoonbaar, omdat deze meer was gericht op een voortzetting van het bestaande beleid dan op een radicale koerswijziging. Aangezien bovendien is gebleken dat opeenvolgende Nederlandse kabinetten geen wijziging van het beleid wensten, is van invloed in de zin van een gedragsverandering van de directe besluitvormers op grond van binnenlandse beïnloeding geen sprake geweest. Het beleid van de regering lag grotendeels in het verlengde van de opvattingen in de Nederlandse samenleving. De invloed was niet manifest aanwezig. Daarentegen bleek dat er wel anticiperende invloed was gedurende de periode 1973-1982. Op tal van plaatsen blijkt in deze studie hoezeer besluitvormers zich bewust waren van de binnenlandse opvattingen ter zake en hun beleid daarbij trachtten aan te sluiten. Deze latente invloed kan het best worden aangetoond wanneer de invloeden vanuit de externe omgeving van Nederland in de beschouwing worden betrokken. Vanuit het buitenland en in het bijzonder door de EPS-partners werd op een wijziging in het Nederlands standpunt aangedrongen; de terughoudendheid in de Nederlandse reactie daarop werd in deze studie verklaard uit de spanning tussen interne en externe invloeden op het beleid. De schoorvoetende wijze waarop Nederland instemde met een opwaardering van de Palestijnse kwestie - in de EPS-verklaringen van 1973, 1977 en 1980 - is daarvan een voorbeeld.

De spanning in het beleid tussen de interne en externe invloeden was het duidelijkst zichtbaar bij het olie-embargo in 1973. Ondanks druk vanuit de Arabische wereld en de EPS-partners heeft Nederland zijn beleid inzake het Arabisch-Israëliseh conflict destijds nauwelijks gewijzigd. De pro-Israëlische consensus in eigen land makkte een dergelijke standvastigheid mogelijk, ondanks de door de Arabische wereld tegen Nederland genomen economische maatregelen en het ontbreken van politieke en economische steun vanuit de Europese Gemeenschap.

De pro-Israëlische consensus rond de Oktoberoorlog werd gedragen door actiegroepen, vakbeweging, protestantse kerken en nagenoeg alle politieke partijen in het parlement. De regering gaf blijk van haar steun aan Israël in de verklaring van 8 oktober 1973. Deze steun kwam vervolgens in het beleid tot uiting in de bereidheid tot militair logis- 
tieke steunverlening aan Israël en in het veto inzake het Brits-Franse mandaat ${ }^{4}$. De economische gevolgen en het politieke isolement leidden tot ontevredenheid in de samenleving en het regeringsoptreden kreeg met name vanuit de oppositie in het parlement, een deel van de media en een deell van het ambtenarenapparaat kritiek te verduren. Het Nederlands beleid onderging vervolgens een wijziging, doordat Nederland ermee instemde het Midden-Oostenvraagstuk tot onderwerp van beraad en besluitvorming in de Europese Politieke Samenwerking te maken. Deze procedurele wijziging zou ook tot inhoudelijke wijziging van het standpunt over het Arabisch-Israëlisch conflict leiden. Ook de critici bleven in 1973 trouw aan het eerder ingenomen pro-Israëlische standpunt; in zoverre bleef de consensus bestaan.

In 1973 trachtte Nederland inzake zijn olievoorziening de steun van zijn EPS-partners te verwerven, hetgeen door Frans ingrijpen op het nippertje niet gelukte. Het vermijden van een kwetsbare positie voor Nederland in de toekomst werd sindsdien de leidraad voor het Nederlandse handelen. Deze doelstelling versterkte de Nederlandse gebondenheid aan het EPS-beraad.

Eén gevolg van de procedurele wijziging was dat het buitenlands politieke proces niet langer vooraf ging aan het internationaal politieke proces. Dat betekent dat eerst in het vertrouwelijke EPS-beraad een internationaal politiek standpunt werd ingenomen dat vervolgens door de betrokken staten tot buitenlands beleid werd verheven. Het parlement kon daarover nog slechts achteraf debatteren en in het uiterste geval eventueel het vertrouwen in de minister opzeggen. Afgezien van het gegeven dat in Nederland bijna nooit ${ }^{5}$ een minister of kabinet over een buitenlandse politieke kwestie ten val wordt gebracht, is dat in dit geval extra moeilijk daar de minister zich kan verschuilen achter de Negen, Tien of anno 1990 de Twaalf. De EPS verschaft een 'paraplu-functie'; een paraplu voor de minister als bescherming tegen een regen van binnenlandse kritiek. Daarmee nemen ook de kansen op binnenlandse beïnvloeding af.

Tevens is geconstateerd dat internationale organen een 'bescherm-functie' voor Nederland konden uitoefenen. De Nederlandse belangen werden door deelname in de EPS beschermd tegen mogelijke bedreigingen van buiten de EG. Een kwetsbare positie, als tijdens het olie-embargo, werd voorkomen. Inboeting van de eigen zienswijze door zich te scharen achter een gemeenschappelijk standpunt leidde tot een verminderde kwetsbaarheid voor Nederland. Het innemen van een gemeenschappelijk standpunt is een vereiste voor de 'bescherm-functie'. Zo verviel deze bescherming bij de kwestie over de verplaatsing van de Nederlandse ambassade in Israël in 1980, toen Nederland zwichtte voor de dreigingen uit de Arabische wereld. Inzake de olievoorziening aan Nederland kon in 1973 geen gemeenschappelijk beleid ontwikkeld worden waardoor Nederland zich in een kwetsbare positie bevond. De politieke wil was toen bepalend voor de houding van de EPS-partners ten opzichte van Nederland. Qua taakstelling was de EG

4. Zie de eerste drie beslissingen 2.2.1.1, 2.2.1.2 en 2.2.1.3.

5. Nadat de Tweedle Kamer voor de tweede maal in verband met de Luxemburgse kwestie de begroting van Buitenlandise Zaken van minister Van Zuylen Van Nijevelt verwierp, trad het hele kabinet-Van Zuylen Van Nijevelt-Heemskerk Azn af op 4 juni 1868. Nadat de Eerste Kamer het NederlandsBelgisch werdrag had verworpen, trad minister Van Karnebeek op 1 aprill 1927 af. Tenslotte trad vanwege onenigheid in het kabinet ower de invoering van de neutronenbom de minister van Defensie, Krulisinga, op 3 maart 1978 af. 
in principe wel in staat een gemeenschappelijk energiebeleid te ontwikkelen en daarmee aan Nederland bescherming tegen bedreigingen van buiten de EG te bieden. Een nieuwe internationale organisatie werd opgericht, het Internationale Energie Agentschap, dat deze bescherming wel bood. Resumerend kan worden gesteld dat na 1973 de directe invloed van de binnenlandse groeperingen op de totstandkoming van het Nederlands buitenlands beleid gering was. Do vakbeweging heeft geen beïnvloedingspogingen meer ondernomen. Het bedrijfsleven vreesde niet langer dat zijn belangen werden geschaad zolang Nederland in de pas liep met de EPS-partners en zich achter het gemeenschappelijk standpunt schaarde. De media gaven opinies weer, maar vervulden geen direct beïnvloedende rol. De politieke partijen schoven in hun standpuntbepaling op en hun zienswijzen stemden grotendeels overeen met het gemeenschappelijke EPS-standpunt. Het parlement deelde in het algemeen de opvatting van de regering over het ArabischIsraëlisch conflict. Met name na 1977 nam de kritiek vanuit het parlement op het regeringsoptreden in internationale fora af. Het parlement gaf achteraf zijn goedkeuring over het door de Nederlandse regering gevoerde beleid. Daar waar het parlement wilde bijsturen, kon het rekenen op instemming van de regering. Een botsing tussen regering en parlement deed zich niet voor, temeer daar de oppositie ten tijde van het kabinet-Van Agt I zich veelal beter kon vinden in het gemeenschappelijke EPS-standpunt dan bijvoorbeeld de VVD die in deze periode (1977-1981) deel uitmaakte van de regering.

In deze studie werd de grote invloed van topambtenaren op de totstandkoming van het beleid aangetoond. De topambtenaren toonden zich in de interviews bescheiden over hun invloed op het beleid. De ministers gaven daarentegen aan sterk op hun inbreng te steunen. Een grote invloed wil nog niet zeggen dat de invloed ook van doorslaggevende betekenis voor het resultaat is geweest. Zo werd bij de besluitvorming uit 1973 aangetoond, dat bij verschil van mening tussen de topambtenaren de kwestie aan de minister werd voorgelegd die vervolgens besliste. De wedijver tussen twee eenheden binnen het departement - eerder aangeduid als bureaucratic politics - werkte vanuit democratisch oogpunt gunstig. Aan de politiek verantwoordelijk persoon, de minister, werd de keuze tussen alternatieven gegeven. Die alternatieven kwamen vooral voort uit de verschillende posities binnen het departement - éerder aangeduid als rolopvattingen - van de beide ambtenaren. Als gevolg van de besluitvorming uit 1973 werd het Midden-Oostenbeleid op internationaal niveau in de EPS behandeld. Daardoor werd de beleidsvoorbereiding in handen gelegd van één sector binnen het departement. De invloed op het beleid van de topambtenaar van deze sector - de directeur-generaal politieke zaken - nam derhalve toe. Deze topambtenaar is betrokken in het vooroverleg met zijn Europese collega's. Hij heeft in een vroegtijdig stadium van het besluitvormingsproces veel invloed. Vanwege zijn rolopvatting zal deze topambtenaar eerder dan een topambtenaar uit een andere sector binnen het departement, geneigd zijn met de inhoud van het binnen de EPS ontvouwde beleid in te stemmen. Bovendien werd de positie van deze topambtenaar - de directeur-generaal politieke zaken - versterkt door de reorganisatie binnen het ministerie, waardoor de directie politieke $\mathrm{VN}$-zaken onder hem kwam te ressorteren. 


\subsection{Het internationaal politieke proces}

De Nederlandse rol in het internationale overleg in het kader van de Europese Politielke Samenwerking werd door de Belgische directeur-generaal politieke zaken Davignon alls volgt onder woorden gebracht: 'Wij waren altijd een trait d'union tussen Nederland en de Fransen omdat wij altijd streefden naar een beslissing. Wij dachten dat het nemen van een beslissing belangrijker was dan onze positie tot het bittere eind te handhaven. Wij zijn meer geneigd een compromis naar woren te brengen en dat zo vlug mogelijk te doen. Onze Nederlandse collega's hielden hun been stijf. Onze kritiek was dat dat tot een vermindering van invloed leidde. Hun kritiek was dat wij geen stabiele partners waren omdat wij altijd bereid waren onze standpunten te veranderen'

Ook uit andere interviews komt de 'Frans-Nederlandse' tegenstelling gedurende het presidentschap van Pompidou en Giscard d'Estaing naar voren. De steun voor het Nederlandse standpunt van anderen in de EG bleef grotendeels beperkt tot de Denen en de Duitsers. De steun van de Duitsers was niet steeds aanwezig; zo heeft het Den Uyl weel moeite gekost in 1973 Brandt tot enige steun aan Nederland te bewegen? ${ }^{7}$ Duitse steun was voor de Nederlanders wel van groot belang voor het kunnen uitoefenen van invloed ${ }^{8}$. Toen bijwoorbeell Begin in een gesprek met Van der Klaauw fel uitviel tegen Schmidt, reageerde Van der Klaauw met de opmerking: 'als ik in Europa steum krijg dan is dat van de Duitsers' '. De Duitse topambtenaar Van Well bevestigde deze opvatting; een andere Duitse ambtenaar - Fiedler - was wat gereserveerder en plaatste Duitsland in een middenpositie tussen enerzijds de Fransen, Grieken en Ieren en anderzijds de Denen en Nederlanders 10.

De Britten steunden meestal de Franse positie. De Brits-Franse eensgezindheid kwam met name naar voren in 1973 en 1980 . Op het voor Nederland belangrijke punt betreffende de rol van de VS in het vredesproces kreeg Nederland echter ook enige steun van de Britten. Deze was echter niet zo sterk dat problemen over de participatie in de MFO uitbleven. Afgezien van de Grieken zorgden de Britten voor de grootste tegenwerking in de besluitvorming over de participatie in de MFO en het doen aanvaarden van de Europese deelname door de Israëli's. Met het aan de macht komen van president Mitterrand waren de Fransen bereid het onder Amerikaanse bemiddeling tot stand gekomen Israëlisch-Egyptisch vredesverdrag militair te ondersteunen.

De belangrijkste Nederlandse doelstellingen in de onderzochte periode werden met de deelname aan de MFO bereikt. Deze doelstellingen waren het zoveel mogelijk steun werlenen aan de veiligheid van Israël, het zo min mogelijk doorkruisen van het vredlesproces van de VS in het Midden-Oosten en het voorkomen van een kwetsbare positie woor Nederland. De laatste doelstelling werd gerealiseerd toen de EPS-partners hun goedkeuring hechtten aan het sturen van militairen naar de Sinaii. In het vierde hoofdstuk werd aangegeven dat Nederland op eigen initiatief een belangrijke rol heeft gespeeld in de besluitvorming over deze kwestie.

6. Interview met Davignon op 22 juni 1987.

7. Interview met Den Uyl op 26 februari 1987.

8. Interview met Reinink op 5 februari 1987.

9. Interview met Van der Klaanw op 31 augustus 1989.

10. Interview met respectievelijk Van Well op 31 januari 1990 en Fiedler op 15 oktober 1987. 
Tijdens de behandeling in de Tweede Kamer bleek dat de meerderheid van het Nederlandse parlement zozeer was gaan hechten aan het meest recente EPS-standpunt dat het daarvan geen afstand wilde nemen en deelname aan de MFO als een voortzetting van dat beleid beschouwde. De ministers hebben dat in het parlement niet tegengesproken. Zij erkenden achteraf dat deze beslissing toch wel als een breuk met de eerdere ambitieuze Europese vredesmissie kor worden aangemerkt ${ }^{11}$. Op grond van deze parlementaire behandeling kan gesteld worden dat de kansen op succesvolle realisatie van "nieuw" beleid groter zijn als bij het tot dusver gevoerde beleid wordt aangesloten. Dat zou betekenen dat degenen die veranderingen in beleid wensen tegen te houden, meer kans van slagen hebben dan degenen die het beleid wensen te veranderen.

Aangezien het EPS-beraad wordt gekenmerkt door consensusbesluitvorming, is de kans voor Nederland op succesvolle beïnvloeding van de besluitvorming in de Europese Politieke Samenwerking ten aanzien van het Israëlisch-Arabisch conflict niet gering. In principe kan én staat beleidswijziging voorkomen. Op grond van de hier gegeven analyse kan worden geconcludeerd dat Nederland succeswol is geweest in het tegenhouden van verdergaande veranderingen. Nederland heeft in EPS-verband de voortgang van een onafhankelijke en eigen rol voor Europa ten aanzien van het Midden-Oosten afgeremd. Deze invloedsuitoefening werd als 'negatieve invloed' omschreven. Veranderingen werden tegengehouden omwille van het niet doorkruisen en dwarsbomen van de rol van de VS in het Midden-Oosten. Vanzelfsprekend werd Nederland in deze rol door de VS gesteund. Dat bleek uit het aambod van de VS uit 1973 Nederland te helpen in zijn olievoorziening. Dat aanbod werd indertijd nog in beraad gehouden daar er hoop bestond op solidariteit van de Negen. Het bleek een ijdele hoop te zijn. Ook het dreigen van Nederlandse kant met economische sancties - afsluiting van aardgas naar EPSpartners - mocht niet baten. Het dreigement maakte weinig indruk op de Duitsers. De Verenigde Staten wisten uiteindelijk met hun initiatief tot oprichting van het Internationale Energie Agentschap de olievoorziening op de lange termijn veilig te stellen en verminderden daarmee de kwetsbaarheid van Nederland.

Een verdeeld Europa waarin Frankrijk zijn hand had overspeeld, maakte het mogelijk dat dit initiatief werd aanvaard. De verdeeldheid over het Arabisch-Israëlisch conflict bleef niettemin binnen de EPS voortduren. Dat bleek in de jaren 1974-1976 uit het verschillend stemgedrag van de EPS-partners in de Algemene Vergadering van de Verenigde Naties. De meer pro-Israelische Denen, Duitsers en Nederlanders werden in deze periode versterkt met de Britten waar Labour in de regering was gekomen. De Fransen en Italianen pleitten voor een Palestijns vaderland en zij wisten in juni 1977 de andere EPS-partners voor hun standpunt te winnen toen op de Europese topconferentie de formule over 'de behoefte aan een eigen land voor het Palestijnse volk' werd aanvaard. De door socialisten gedomineerde regeringen van West-Duitsland, het Verenigd Koninkrijk en Nederland hadden deze verklaring aanvankelijk kunnen tegenhouden. Nadat evenwel de Israẻlische socialisten de verkiezingen in mei 1977 hadden verloren en daarmee de regeringsmacht kwijt raakten en nadat bovendien president Carter zich in

11. Van Mierlo was daarin uitgesprokener dan Van der Stoel die weliswaar over een 'boedelbeschrijving" had gesproken maar dat achteraf niet zo'n gelukkige omschrijving vond. Interviews met Van Mierlo en met Van der Stoel op respectievelijk 2 april 1987 en 17 februari 1987. 
maart 1977 had uitgesproken voor een 'homeland' voor de Palestijnse vluchtelingen, konden ook West-Duitsland, het Verenigd Koninkrijk en Nederland met de formulering van bovengenoemde verklaring op de Europese topconferentie instemmen.

Bij het Camp Davidproces in 1978 stond Europa buiten spel. Een positieve reactie op Sadats reis naar Jeruzalem in 1977 wisten de Fransen in 1977 nog enkele dagen tegen te houden, maar onder het Duitse woorzitterschap werden in 1978 de Camp Davidakkoorden direct enthousiast begroet. Een jaar later was onder het Franse voorzitterschap de juichstemming weer voorbij. De Franse president mengde zich in de besluitvorming van het comité politique van de EPS. Het maximum dat de Nederlandse afgevaardigde in de wacht wist te slepen, was de zinsnede dat het Egyptisch-Israëlisch vredesverdrag als een correcte toepassing van resolutie 242 werd gezien. De kritiek op het Israellisch beleid werd in de EPS-verklaringen van 1979 heviger, maar de Nederlandse deelnemer was nu minder beducht voor binnenlandse onaanvaardbaarheid, omdat ook de kritiek in eigen land op het beleid van Begin was toegenomen.

Met de verklaring van Venetië in 1980 werd het meest - in vergelijking met alle hier onderzochte EPS-verklaringen - afstand genomen van Israël. Uit de gepresenteerde analyse wordt duidelijk dat Britten, Fransen, Duitsers en Italianen op dat moment tamelijk eensgezind in hun opvattingen waren. Bovendien was indertijd van de Amerikanen - verkiezingsjaar, echec van het gijzelingsdrama in Iran - geen initiatief te verwachten. Op zeer indirecte wijze werd nog - op Duits initiatief - aan Camp David gerefereerd, maar de overheersende gedachte was dat Europa een eigen en van de VS onafhankelijke rol in het Midden-Oosten had te vervullen.

Vanuit de Arabische wereld werd om een plan gevraagd. De Fransen wensten direct een initiatief. Besloten werd dat op basis van de uit te voeren vredesmissie een eventueel initiatief zou worden genomen. Het woord 'eventueel' werd ingelast tijdens het laatste overleg van regeringsleiders op aandrang van Van der Klaauw. Hij debatteerde daarover met Giscard d'Estaing. Deze gaf uiteindelijk toe terwijl de overigen zwegen; zij vonden het Nederlandse verzet wat overdreven ${ }^{12}$. Het Nederlandse verzet stoelde niet alleen op overwegingen om de VS niet te dwarsbomen, maar ook op de vrees een blanco cheque af te geven. Treffend is de overeenkomst van dit verzet in juni 1980 met het Nederlandse verzet uit oktober 1973, toen een veto werd uitgesproken over het BritsFranse verzoek om namens de Negen in de Veiligheidsraad te spreken. Ook dat verzet werd bepaald door de vrees van het uitschrijven van een blanco cheque. Toen de Nederlander Van der Klaauw de vredesmissie in 1981 mocht uitvoeren, kon hij in belangrijke mate de inhoud van het eventuele Europese initiatief bepalen. De Fransen waren er niet gelukkig mee dat juist Nederland - het land dat als meest pro-Israëlisch gold - in de eerste helft van 1981 het voorzitterschap bekleedde. Zij wantrouwden Van der Klaauws missie en hebben getracht zijn vrijheid van handelen te beperken. De Fransen vreesden dat onder leiding van Van der Klaauw het Europees initiatief inzake het Midden-Oosten niet zou worden bevorderd. Van der Klaauw geloofde inderdaad niet in een initiatief en wenste het Amerikaanse beleid ten aanzien van het Midden-Oosten niet te doorkruisen. Daarom heeft hij 'aan de rem getrokken' ${ }^{13}$. Interessant is dat hij zijn doel

12. Interwiew met Van der Klaauw op 31 augustus 1989.

13. Interview met Van der Klaauw op 31 augustus 1989. 
bereikte door de vredesmissie uitgebreid - hij bezocht ook Arabische landen in de periferie van het Arabisch-Israëlisch conflict - op te vatten, waarbij hij zijn gastheren naar de invulling van de verklaring van Venetiè vroeg. Uiterst verschillende benaderingen kwamen vooral te voorschijn waarop hij vervolgens verder inging ${ }^{14}$. Gesteld kan worden dat Nederland wel een steentje heeft bijgedragen aan het mislukken van het Europees initiatief, temeer daar het geschikte moment voor een Europese aanpak voorbij was als gevolg van ontwikkelingen - aantreden Mitterrand en Reagan, Falklandorisis, dood Sadat - in de internationale politieke constellatie.

Aan de Europese participatie in de MFO heeft Nederland een belangrijke bijdrage geleverd. Niet zozeer de Nederlandse participatie in de MFO, als wel de actieve Nederlandse rol in de besluitworming over Europese deelname is relevant. Met succes werd overeenstemming tussen de Europese partners gerealiseerd en tevens de kloof tussen de standpunten van de VS en de EPS overbrugd. In hoofdstuk vier werd geconstateerd dat de militaire inbreng van de vier Europese staten - Frankrijk, het Verenigd Koninkrijk Italiee en Nederland - niet noodzakelijk was voor het functioneren van de MFO. De politieke betekenis daarentegen was groot. De Amerikanen waren, meer nog dan de partijen in het conflict, gebrand op de Europese ondersteuning van het Egyptisch-Israelisch vredesverdrag. Nederland heeft daarbij een bemiddelaarsrol vervuld tussen enerzijds de vier en anderzijds de VS. Verbetering van de in 1981 gespannen NederlandsAmerikaanse relatie was één van de belangrijkste oogmerken voor de Nederlandse deelname.

Op basis van de in kaart gebrachte communicatie tussen Israël, de VS en de EG over deelname aan de MFO kan de conclusie worden getrokken dat Israël zich in zijn besluitvorming niet door de standpunten van de Europeanen maar door het standpunt van de Amerikanen liet leiden in zijn acceptatie vän Europese deelname aan de MFO. Nederland spande zich bij de MFO-kwestie in om steun van de EPS-partners te verwerven voor een standpunt dat aanvaardbaar was voor de VS. In dat opzicht past ook het Nederlandse optreden bij het beeld dat over het EPS-beleid ten aanzien van het Arabisch-Israëlisch conflict over de gehele periode werd gegeven: in naam had het betrekking op het Midden-Oosten maar in wezen betrof het de interne Europese verhoudingen en de Amerikaans-Europese verhouding. Het Midden-Oosten conflict vervulde een functie in de harmonisatie van standpunten van de EPS-partners en bevorderde de ontwikkeling van de EPS, omdat zij over het Midden-Oosten een eigen geluid in de internationale politiek liet horen dat veelal afweek van de VS en eerder op instemming kon rekenen in de internationale politiek ${ }^{15}$. De MFO kwestie betekende een ombuiging van het EPS-beleid. In 1979 werd in Europese kringen het Egyptisch-Israëlisch wredesverdrag tamelijk schamper ontvangen. In 1980 werd vervolgens getracht een eigen ambitieuze Europese rol te gaan vervullen. Daaraan kwam nu een einde met de daadwerkelijke ondersteuning van dat verdrag door middel van het sturen van eigen soldlaten naar de Sinaï.

14. Van Arabische kant hoorde Van der Klaauw naderhand dat de verklaring van Fez een rechtstreeks gewolg was van zijn vredesmissie. "Ik wheet niet of het waar is maar de Arabieren vertelden het me". Interview met Van der Klaauw op 31 augustus 1989.

15. Het isolement van de VS in de internationale politiek over het Arabisch-Israëlisch conflict blijkt onder meer uit het veelvuldig gebruikte Amerikaanse veto in de Veiligheidsraadi over deze kwestie. 
Voor Nederland constateren we een continuïteit in het beleid dat gericht was op de veiligheid van Israël. In 1973 werd militaire logistieke steun aan Israël overwogen, in 1982 vertrokken marechaussees uit Nederland naar de Sinaï ter beveiliging van de Israëlisch-Egyptische grens.

Het verschil is de reactie van de buitenwereld. Een tegen Nederland gericht olie-embargo werd niet herhaald. Door deelneming aan de Europese Politieke Samenwerking werd de acceptatie van de Nederlandse positie door de Arabische wereld bevorderd ${ }^{16}$. De EPS had voor Nederland daarmee een beschermfunctie. Daar Nederland niet langer in een kwetsbare positie verkeerde, kon een grote mate van continuïteit in het Nederlandse standpunt ten aanzien van het Arabisch-Israëlisch conflict worden gehandhaafd.

In de vorige paragraaf werd naar voren gebracht dat de EG Nederland deze beschermfunctie ten tijde van het olie-embargo niet bood. De toen opgerichte internationale organisatie, het IEA, bood deze bescherming wel. Inmiddels participeert de EG als waarnemer in het IEA en wordt door de EG het beleid van de IEA inzake de energievoorziening gevolgd:

In hoofdstuk vier werd de oprichting van een andere nieuwe internationale organisatie, de MFO, behandeld. Ook deze organisatie werd gecreëerd omdat de bestaande en in feite voor deze taak van vredeshandhaving geschikte organisatie, de VN, daartoe op dat moment niet in staat was. Binnen de VN ontbrak de politieke wil voor de oprichting van een vredesmacht tussen Egypte en Israël na de ondertekening van het EgyptischIsraëlisch vredesverdrag. De oorzaken die leidden tot de oprichting van deze twee nieuwe internationale organisaties, liepen dus parallel. Bestaande internationale organisaties beantwoordden niet aan de behoefte van dat moment, hetgeen een verzwakking inhield van beide internationale organisaties en twijfel opriep over het probleemoplossend vermogen van de EG en VN. De recente aanvaarding van Egypte door de Arabische wereld - op 23 meil 1989 werd Egypte weer toegelaten tot de Arabische Liga - en de toenadering van de Sovjetunie tot de Verenigde Naties bieden hoop op een overname van de MFO-taken door een VN-vredesmacht. Het vertrouwen van Israël in de VN zou daarmee kunnen toenemen, waardoor een directere bemoeienis van de VN met het conflict in het Midden-Oosten mogelijk zou kunnen worden ${ }^{17}$.

\subsection{Relatie buitenlands politieke en internationaal politieke proces}

Bij de totstandkoming van het buitenlands beleid spelen zowel interne als externe factoren een rol. De externe factoren kunnen direct en, door anticipatie, indirect van invloed zijn. De ten uitvoerlegging van het buitenlands beleid vindt plaats in het internationaal politieke proces. De mate waarin het buitenlands politieke standpunt in het interna-

16. De anvaanding van de Nederlandse bijdrage aan Unifil gaf daar ook al blijk van.

17. Op 31 mei 1990 werd het woorstel om een afvaardiging van de Veiligheidsraad een onderzoek te laten instellen in door Israêl bezet gebied nog door een Amerikaans veto getroffen, NRC Handelisblad 16-1990. Een speciale afgezant van de secretaris-generasll met hetzelfde doel werd dloor Israel aanvaard. NRC-Handelsblad, 22-6-1990. Zie ook de resoluties van de Veiligheidsraad 672 en 673. In deze lastste resolutie van 24-10-1990, werd de weigering van de Israëlische regering een onderzoekscommisie van de secretaris-generaal toe te laten, betreurd. S/RES/673 (1990). 
tionaal politieke proces tot uitdrukking kan worden gebracht is een indicatie voor het 'aanpassingsgedrag' van een staat. Voor de aanpassing van een samenleving aan zijn externe omgeving heeft Rosenau vier soorten gedrag onderscheiden: inschikkelijke aanpassing, onverzoenlijke aanpassing, bevorderlijke aanpassing en bewarende aanpassing. Dit onderscheid werd in hoofdstuk 1 uitgewerkt. Bij de onverzoenlijke aanpassing wordt de beslissing louter door interne factoren bepaald en bij de bewarende aanpassing door zowel inteme als externe factoren. De inschikkelijke aanpassing wordt gekenmerkt doordat het gedrag wordt bepaald door louter externe omgevingsfactoren. In het geval van bevorderlijke aanpassing wordt geen rekening gehouden met interne of externe invloeden en hebben de besluitvormers maximale vrijheid van handelen.

Het hanteerbaar maken van deze indeling is lastig. De druk vanuit het binnenland gaat vaak niet in eén richting; dat geldt eveneens voor de druk vanuit het buitenland. Naarmate de pluriformiteit in de druk op de regering toeneemt, neemt de vrijheid van handelen van de besluitvormers om naar eigen goeddunken te beslissen toe. Een beperking tot de hoofdstromen in deze beïnvloedingsprocessen biedt enige mogelijkheden tot een nadere analyse.

De kwestie van het olie-embargo is nog het meest duidelijk, omdat toen een eensgezinde binnenlandse publieke opinie bestond die zich verzette tegen druk uit het buitenland om het beleid in pro-Arabische zin te wijzigen. Aan de voorwaarden voor opheffing van het Arabische olie-embargo werd door de Nederlandse regering niet voldaan, hetgeen vanuit de Arabische wereld bij de opheffing van dat olie-embargo werd bevestigd. Er was sprake van een onverzoenlijke aanpassing, omdat prioriteit werd gegeven aan de wensen vanuit de eigen samenleving. De eerste drie regeringsbeslissingen werden gekenmerkt door een beleid van onverzoenlijke aanpassing; deze beslissingen hielden steun aan Israël in tijdens de Oktoberoorlog. De ondertekening van de EG-verklaring over het Midden-Oosten op 6 november 1973, werd als inschikkelijke aanpassing beschouwd. De verkregen solidariteit inzake de olievoorziening op de conferentie van Washington, betekende een verzoening van binnenlandse en buitenlandse verlangens; dit beleid werd omschreven als bewarende aanpassing (zie bijlage 20).

In de periode kort daarna ontstond in het parlement kritiek op het Nederlands stemgedrag in de Verenigde Naties. De regering verdedigde haar stellingname met een beroep op de opstelling der EPS-partners waarvan zij zich niet wilde verwijderen. De beslissing van de regering duidt op een inschikkelijke aanpassing. Het kamerlid Aantjes verwierp deze aanpak en zei tegen de regering. "Dare to stand alone", bewaar uw eer en karakter ${ }^{18}$.

Vervolgens brokkelde de pro-Israëlische stemming in Nederland enigszins af en werden minder beperkingen vanuit het binnenland aan het regeringsoptreden opgelegd. Zo veroorzaakte de verklaring van Venetië waarin onder meer - zij het geclausuleerd werd vastgelegd dat de PLO bij de onderhandelingen betrokken moest worden, geen storm van kritiek in Nederland. Kort tevoren had de minister in het parlement verklaard dat er geen politieke of diplomatieke contacten met PLO-functionarissen mochten plaatsvinden. Daags voor de Europese topconferentie op 11 juni 1980 verklaarde minister Van der Klaauw in het parlement dat Europa uitsluitend initiatieven moest nemen

18. Handelingen Tweede Kamer, zitting 1974-1975, 27 november 1974 , p. 1584 . 
in goed overleg met de Verenigde Staten. We hebben kunnen constateren dat de minister daar wel voor heeft geijverd maar amper resultaat heeft geboekt. Gezien de uitkomst van de besluitvorming omtrent de verklaring van Venetië wordt het Nederlands beleid als inschikkelijke aanpassing gekenschetst (zie bijlage 21). De Kamer deelde de politieke opvattingen van de minister in deze kwestie. Van een botsing tussen minister en parlement was dan ook geen sprake. Zelfs aan de ontevredenheid over de inhoud van de verklaring van Venetiè, die achteraf door de VVD-fractie werd geuit, werden geen consequenties verbonden. De parlementaire bevoegdheden beperkten zich tot de eigen minister, en ook het Europees parlement beschikte niet over enige controlerende bevoegdheid inzake het EPS-beleid. Het zogenaamde democratische 'gat' in Europa bepaalt in het hierboven geschetste geval de onmacht van het Nederlandse parlement ${ }^{19}$. De Karner steunde de minister in een motie waarin werd vastgelegd dat een Europees initiatief alleen na goed overleg met de VS mocht worden ontwikkeld. Aan deze wens vanuit de interne omgeving kon Van der Klaauw tijdens zijn vredesmissie tegemoet komen. Hij overlegde toen driemaal met zijn Amerikaanse ambtgenoot Haig. Ook Van der Klaauws opvolger Van der Stoell heeft aan de motie van de Kamer inhoud gegeven door in de MFO-kwestie met de VS te overleggen. Het resultaat, de Europese participatie in de MFO, duidt op het verzoenen van de interne en externe druk en kan als bewarende aanpassing worden gekarakteriseerd (zie bijlage 22). Deze wending in het EPS-beleid toont niet alleen dat bij de Nederlandse inbreng rekening werd gehouden met de in Nederland levende politieke opvattingen - zoals ook in de daaraan voorafgaande periode geschiedde - maar tevens dat deze inbreng tot resultaat leidde in het internationaal politieke overleg. De herkenbaarheid van de Nederlandse inbreng in de internationale politiek verhoogt het democratisch gehalte van het beleid.

Tenslotte kan de vraag worden gesteld of de Midden-Oostenkwestie uniek is of dat op basis van deze onderzoeksgegevens ook conclusies getrokken kunnen worden voor andere onderdelen van het Nederlands buitenlands beleid. De hier gebezigde onderzoeksmethode, waarbij onderscheiden wordt tussen het buitenlands politieke en internationaal politieke proces, $k a n$ ook op andere onderwerpen die op multilateraal niveau worden behandeld, worden toegepast ${ }^{20}$. Ook onderwerpen zoals Zuid-Afrika, Chili, Nicaragua, El Salvador, modernisering van kernwapens en meer in het algemeen de problematiek van de schendingen van mensenrechten en de ontwikkelingsproblematiek, leefden sterk onder grote delen van de bevolking ${ }^{21}$. Beïnvloedingspogingen van vele binnenlandse groeperingen hebben plaatsgevonden ten aanzien van deze onderdelen van het beleid, die in internationale organisaties onderwerp van beraad en besluitvorming werden ${ }^{22}$. Weliswaar verschilt de besluitvorming al naar gelang onderwerp en forum,

19. Onder "democratisch gat" wordt verstaan dat op die gebieden wasr een deel wan de wetgevende en controllerende bevoegdheden door de nationale parlementen zijo afgestaan aan de EG zonder dat daarvoor voorzieningen op Europees niveau zijn geschapen, een institutioneel vacuüm ontstaat. Hontelez en Van der Lek, 1989 , p. 355.

20. Voor vraagstukken op bilateraal niveau kan met een eenwoudiger methode - te weten een lichte uitbreiding van het buitenlands politieke proces - worden volstaan.

21. Zie bijwoorbeeld Everts (ed.), 1985 en Everts and Walraven (eds.), 1989.

22. Kwesties over Suriname; Indonesië en China betroffen daarentegen eerder bilateraal niveau. 
maar ook bij deze kwesties is de invloed van de EPS in toenemende mate merkbaar op de besluitvorming in New York, Wenen, Helsinki, Genève of welke plaats dan ook. De wrijheid van handelen van de Nederlandse regering werd beperkt doordat veelal eerst tussen de EPS-partners overeenstemming moest worden bereikt. Aangezien Nederland in de bovengenoemde kwesties valk een meer op verandering gericht beleid voorstond, werd het daarin geremd door EPS-partners die een terughoudend beleid voorstonden $^{23}$. In dat opzicht is de Nederlandse rol in deze kwesties een spiegelbeeld van zijn rol in de Midden-Oostenkwestie. De uitkomst van het internationaal politieke proces in de opgesomde reeks gevallen was meestal teleurstellend voor de binnenlandse actiegroepen, omdat nog minder werd bereikt dan op grond van de Nederlandse inbreng had kunnen worden verwacht.

In hoofdstuk 1 werden de resultaten aangehaald van het onderzoek van de interuniversitaire werkgroep 'Buitenlands beleid van Nederland' over buitenlandse politieke kwesties in de periode 1973-1982, die onderwerp van beraad waren in internationale fora en waarover in de meeste gevallen binnenlandse beinvloedingspogingen werden ondernomen ${ }^{24}$. Er werd geconstateerd dat alleen over de Midden-Oostenkwestie binnenlandse consensus bestaat voor het voeren van een beleid dat gericht is op het tegenhouden van veranderingen in de internationale politiek. Bij de andere voorbeelden van negatieve invloed in de studie van de interuniversitaire werkgroep 'Buitenlands beleid van Nederland' - verzet tegen modernisering van kernwapens en verzet tegen het tot standbrengen van een Nieuwe Internationale Informatie Orde - bestond geen binnenlandse consensus ${ }^{25}$. Uitsluitend Nederlandse voorstellen in het internationaal politieke proces die een verandering van beleid beoogden teweeg te brengen, konden rekenen op binnenlandse consensus; maar alleen inzake de Midden-Oostenkwestie ging dat niet op.

Tevens werd geconstateerd dat Nederlands internationale invloed duidelijk samenhangt met de binnenlandse consensus. Er was weliswaar consensus over de Midden-Oostenkwestie, maar dat leidde toch niet tot betere Nederlandse resultaten in de internationale politiek dan in andere kwesties (zie tabel 1.2). De binnenlandse consensus, tot uiting komend in het buitenlands politieke standpunt, die het draagvlak aangeeft van het door Nederland naar voren gebrachte standpunt in de internationale politiek, is van invloed op het resultaat van de pogingen tot beînvloeding van het internationale politieke proces. De kans op succes van Nederland is namelijk (zie 1.2.4) groter wanneer de Nederlandse voorstellen kunnen rekenen op binnenlandse consensus.

23. Zie voor: Zuid-Afrika, Kremers en Pijpers; Chili, Grünfeld; modernisering kernwapens, Soetendorp; mensenrechten, Baehr; ontwikkelingssamenwerking, Kremer en Van den Tempel in: Everts and Walraven (eds.) 1989.

24. Everts and Walraven (eds.) , 1989, pp. 323-340.

25. Bij de over de periode 1955-1970 onderzochte gevallen bestond ook consensus over het verzet tegen het. Fouchetplan en tegen de toegang van niet-kernwapenstaten tot het gebruik van kernwapens. De deellbeslissing over het opnemen van de wapenbeheersingscomponent in het NAVO dubbelbesluit over modernisering INF in Europa werd abusievelijk als een negatseve invloed vermeld (Everts and Walraven 1989, p. 326). Het moet een positieve invloed - doorvoeren wan een verandering - zijn waarin in Nederland consensus over bestond (telefonische bevestiging Soetendorp op 11-1-1980, zie colk Everts and Walraven (eds.), 1989, pp. 151 en 157). Enige voorzichtigheid met het omgewan met deze kwantitatieve gegevens is wel gewenst. 
Het tegenhouden van weranderingen in de internationale politiek door Nederland kwam in de periode 1970-1985 weinig voor. Met grote moeite kon in het interuniversitaire onderzoek één casus worden gevonden op het beleidsterrein van ontwikkelingssamenwerking, mensenrechten en internationale orde waarin Nederland een negatieve invloed heeft uitgeoefend ${ }^{26}$. Dat heeft te maken met de veranderingsgezindheid - een progressief land in de westelijke wereld - in het beleid wan Nederland. Daarnaast is het voor een land als Nederland - op grond van de Nederlandse positie in de wereld - niet mogelijk vaak 'nee' te zeggen. Te frequent 'nee' zeggen heeft volgens Van der Stoel tot gevolg dat de partners minder een boodschap hebben aan onze inbreng. Vaak is een 'negatieve invloed' gezien de krachtsverhoudingen onmogelijk, zoals de afwikkeling van de kwestie met Indonesie en Nieuw-Guinea heeft geleerd. Soms is het echter wel mogelijk 'nee' te zeggen en het is opvallend dat deze mogelijkheid zich in het bijzonder heeft voorgedaan in het Nederlandse Midden-Oostenbeleid. Zo kon Nederland het van start gaan van de Euro-Arabische dialoog tegenhouden zolang het olie-embargo niet werd opgeheven. De EPS-partners erkenden de redelijkheid van het Nederlands verzet tegen het tot stand brengen van de Euro-Arabische dialoog zolang Nederland door het olieembargo werd getroffen. Het Nederlandse veto in oktober 1973 tegen het verlangde Brits-Franse mandaat, om namens de Negen het woord te voeren in de Veiligheidsraad over het Arabisch-Israëlisch conflict, had volgens Van der Stoel louter te maken met het Nederlandse standpunt over het Midden-Oosten; het was niet gericht tegen een uitbreiding van het werkterrein van de EPS. Het kostte hem dan ook geen moeite zich een maand later bij een uitgewerkte Midden-Oostenverklaring aan te sluiten ${ }^{27}$. Een verklaring van de constatering dat inzake het Midden-Oosten soms wel een verandering kon worden tegengehouden, kan niet alleen gevonden worden in de houding van de partners. Naast het internationaal politieke proces dient het buitenlands politieke proces te worden betrokken voor een verklaring van het Nederlandse verzet in de Europese Politieke Samenwerking inzake een tegen Israël gericht standpunt. In deze studie werd aangetoond dat de binnenlandse consensus een belangrijke verklaring vormde voor het succesvol uitoefenen van negatieve invloed. Dat maakte het Nederlandse Midden-Oostenbeleid anders dan ander Nederlands buitenlands beleid.

26. Dat werd de casus over het tegengaan van een Nieuwe Internationale Informatie Orde in de UNES$\mathrm{CO}$.

27. Toespraak Van der Stoel, Rijksuniversiteit Leiden, op 23 maart 1989. 
Nederland en het Nabije Oosten: De Nederlandse rol in de internationale politiek ten aanzien van het Arabisch-Israëlisch conflict 1973-1982.

\section{SAMENVATTING}

In deze studie is het Nederlands buitenlands beleid en de rol van Nederland in de internationale politiek ten aanzien van het Arabisch-Israëlisch conflict over de periode 1973-1982 onderzocht.

Er is onderscheid gemaakt tussen twee verschillende besluitvormingsprocessen, namelijk het buitenlands politieke proces en het internationaal politieke proces. Het buitenlands politieke proces vindt plaats binnen de nationale samenleving. De vraag is daarbij welke invloed groepen in de samenleving op de totstandkoming van het Nederlands buitenlands beleid ten aanzien van het conflict in het Midden-Oosten hebben kunnen uitoefenen. Het internationaal politieke proces vindt plaats buiten de nationale samenleving en is in deze studie toegespitst op de besluitvorming op multilateraal niveau. Het intergouvernementele samenwerkingsverband van de Europese Politieke Samenwerking (EPS) van de lidstaten van de Europese Gemeenschap staat in deze studie centraal. De Nederlandse rol daarin is onderzocht door bestudering van de Nederlandse inbreng ("input') in het internationale politieke overleg en door het resultaat van dat overleg ("outcome') te vergelijken met de uitkomst van het Nederlands beleidsproces ('output'). De vraag is daarbij of Nederland zich louter heeft aan te passen aan de wensen van 'machtiger' bondgenoten of in staat is aan de eigen beleidswoorkeuren in dat internationale politieke overleg gestalte te geven.

Binnen de periode 1973-1982 werden drie kwesties onderzocht. Dat waren de besluitvorming in verband met:

- het Arabisch olie-embargo tegen Nederland uit 1973;

- de totstandkoming van een gemeenschappelijk internationaal politiek standpunt in EPS verband in de periode 1977-1981;

- de deelname aan een vredesmacht tussen Israël en Egypte, de MFO, in de periode 1981-1982.

Het voortbestaan van Israël binnen veilige en erkende grenzen was één van de hoofddoelstellingen van het Nederlands beleid. Met de Oktoberoorlog in 1973, zo werd gevreesd, kwam Israëls voortbestaan in gevaar. De Nederlandse regering was toen bereid Israël daadwerkelijk te steunen. Daarmee begint deze studie die eindigt met de ondersteuning van het Israëlisch-Egyptisch vredesverdrag. In 1982 is daaraan niet louter verbaal steun gegeven, maar werden Nederlandse militairen naar de vredesmacht MFO gestuurd. De hoofddoelstelling van veilige en erkende grenzen voor Israël, is aldus in belangrijke mate mede gerealiseerd door een actieve opstelling aan Nederlandse zijde.

Tijdens de Oktoberoorlog van 1973 stond Nederland aan de kant van Israell. Door actiegroepen waren demonstratieve bijeenkomsten georganiseerd waarin politici hun sympathie en steun voor Israël uitspraken. De regering publiceerde een pro-Israëlische verklaring die door het parlement met instemming is begroet. Binnen het kabinet werd zelfs de bereidheid uitgesproken, Israël ook met militaire middelen bij te staan. Daartoe 
zouden aan de Amerikanen faciliteiten voor tussenlandingen zijn aangeboden bij het vervoer van wapens van de VS naar Israël. Dit bleek later niet nodig te zijn. In internationaal verband sprak Nederland zijn veto uit tegen een Brits-Frans verzoek namens de EG in de Veiligheidsraad wan de Verenigde Naties het woord te voeren over het Arabisch-Israelisch conflict. Nederland was niet bereid hen 'carte blanche' te geven. Gezien de Brits-Franse opstelling indertijd hield deze Nederlandse actie steun voor Israël in. Nederland raakte daardoor geïsoleerd binnen de Europese Politieke Samentwerking. Vervolgens werd Nederland door het olie-embargo van de Arabische olieproducerende staten getroffen.

De vooruitzichten voor Nederland waren somber. Een tekort aan olie en een forse toename van de werkloosheid in Nederland lagen in het verschiet. Tevergeefs werd getracht de situatie te keren door aan de Arabische wereld duidelijk te maken, middels diplomatieke activiteiten, dat het olie-embargo op een misverstand zou berusten.

Getracht werd de solidariteit van de Europese partners te verwerven. Tijdens de bijeenkomst in het kader van de Europese Politieke Samenwerking van de ministers van Buitenlandse Zaken van 6 nowember 1973 zou 's ochtends een gemeenschappelijke politieke verklaring over het Arabisch-Israëlisch conflict en 's middags een economische verklaring over solidariteit tussen de Negen op het terrein van energie worden aanvaard. Dat beoogden althans de topambtenaren, maar uiteindelijk werd alleén de politieke verklaring aanvaard. Uit dankbaarheid voor de politieke verklaring besloten de Arabische olieproducerende staten van verdere reductie in de olie-aanvoer naar de EG-lidstaten af te zien, maar zij handhaafden het olie-embargo tegen Nederland.

De positie voor de regering werd nog moeilijker doordat naast kritiek uit het buitenland ook in het binnenland kritiek op de regering werd geuit. Sommigen vonden dat Nederland een afzonderlijk gebaar moest maken voor opheffing van het olie-embargo. Anderen meenden daarentegen dat Nederland met de aanvaarding van de EG-verklaring al te veel in Arabische richting was opgeschoven. Zij steunden op een voortdurende proIsraëlische consensus in eigen land.

De vrijheid van handelen voor de Nederlandse regering was beperkt. Kritiek vanuit regeringsgezinde parlementaire fracties op de EG-verklaring werd niet in de openbaarheid gebracht om de regering niet verder te verzwakken.

De regering bleef ijveren voor Europese solidariteit. Een herhaald Amerikaans aanbod tot hulp in de olievoorziening aan Nederland werd in beraad gehouden. Uiteindelijk hebben de VS wel de sleutel aangereikt voor een politieke oplossing van het energievraagstuk met de oprichting van het Internationaal Energie Agentschap. De Europese partners, met uitzondering van Frankrijk, traden toe tot deze nieuwe internationale organisatie. Het vermijden van een kwetsbare positie in de toekomst was - na de ervaring uit 1973 - een belangrijke doelstelling van het Nederlands buitenlands beleid ten aanzien van het Midden-Oostenconflict geworden.

De EPS vervulde in deze ook een functie omdat, met de gemeenschappelijke standpuntbepaling binnen dit samenwerkingsverband, individuele staten minder kwetsbaar werden voor pressie van buiten de EG vanwege het ingenomen standpunt. In deze studie is dat de 'beschermfunctie" van de EPS genoemd. Daarnaast vervulde de EPS een functie in de bescherming van de regeringen van de EG-lidstaten tegen een storm van binnenlandse kritiek. De regeringen konden zich verschuilen achter het gemeenschappelijk 
standpunt. Dat laatste is in deze studie met de term 'paraplufunctie' aangeduid. De overheveling van het uitdragen van het Nederlandse standpunt over het Midden-Oosten van de Verenigde Naties naar de Europese Politieke Samenwerking, was eén van de belangrijkste resultaten van de besluitvorming in 1973. Deze wijziging verliep niet zonder forse intradepartementele strijd.

Van belang was dat sedert 1973, de besluitvorming over de buitenlandse politiek niet langer voorafging aan de besluitvorming in de internationale politiek. Dat hield in dat de invloed op het beleid van groepen uit de samenleving en ook van het parlement afnam. Anderzijds is eveneens aangetoond dat de Nederlandse inbreng in dat internationale politieke overleg wel kon rekenen op binnenlandse steun. De Nederlandse deelnemers aan het internationaal politieke overleg, zo blijkt uit de interviews met de Nederlandse ministers van Buitenlandse Zaken en directeuren-generaal politieke zaken, hielden ook rekening met de verhoudingen in eigen land. Deze anticiperende invloed leidde ertoe dat Nederland in internationaal verband Israël bleef steunen en dat Nederland trachtte de diplomatieke activiteiten van de VS in het Midden-Oosten zo min mogelijk te dwarsbomen. Dat resulteerdle veelal in een Frans-Nederlandse tegenstelling binnen de EPS in de periode 1977-1981.

Nederland verzette zich met succes tegen een ambitieuze Europese vredesmissie in het Midden-Oosten. De uitgesproken voorkeur van parlement en regering voor nauwe samenwerking met de VS inzake het Midden-Oostenconflict werd gerealiseerd met de Europese participatie in de MFO. Nederland heeft in belangrijke mate bijgedragen aan de totstandkoming van deze Europese deelname. Het leverde tevens een militaire bijdrage. Aldus werd het Egyptisch-Israëlisch vredesverdrag daadwerkelijk gesteund met het sturen van eigen militairen. Een kwetsbare positie voor Nederland werd voorkomen vanwege de instemming van de Europese partners. Zij boden Nederland de bescherming die het in 1973 ontbeerde.

Geconcludeerd is dat met Europese participatie in de MFO de externe en interne druk werd verzoend. Het rekening houden met de in Nederland levende opvattingen bij de Nederlandse inbreng in de internationale politiek verhoogt het democratisch gehalte van het beleid. Bovendien kon daardoor de kans op succes van de door Nederland ondernomen beïnvloedingspogingen toenemen.

Over het algemeen konden slechts de op verandering gerichte Nederlandse voorstellen rekenen op binnenlandse consensus. Over de Midden-Oostenkwestie echter, werden door Nederland in de internationale politiek soms veranderingen tegengehouden. Deze Nederlandse opstelling werd binnenslands gesteund. In deze studie werd aangetoond dat de binnenlandse consensus een belangrijke verklaring vormde voor het succesvol uitoefenen van negatieve invloed. Dat maakte het Nederlandse Midden-Oostenbeleid anders dan ander Nederlands buitenlands beleid. 
The Netherlands and the Near East: the international political role of the Netherlands in the Arab-Israeli conflict 1973-1982.

\section{SUMMARY}

This study deals with Dutch foreign policy-making in connection with the role the Netherlands played in international politics regarding the Arab-Israeli conflict during the period 1973-1982. A distinction is made between two different decision-making processes: at the level of national policy and at the level of international politics. National foreign policy-making takes place within domestic society. The vital issue with respect to that process is the nature and extent of the influence which groups within the Dutch domestic community have been able to exert upon the shaping of Dutch foreign policy with respect to the conflict in the Middle-East. The process of making international politics takes place outside the sphere of the domestic community and is examined in this study by concentrating upon the decision-making process at the multi-lateral level. The inter-governmental co-operation by the member states of the European Community which takes place within the framework of the European Political Cooperation (EPC) is a main focus of the study. The role of the Netherlands in the EPC is examined by studying the input by the Netherlands into deliberations with respect to international politics, and then comparing the results of such deliberations - i.e. the outcome - with the output of foreign policy-making in the Netherlands (see diagram 1.3.).

Diagram 1.3.

International political process

State $\mathrm{A}$

International

Organization

State B

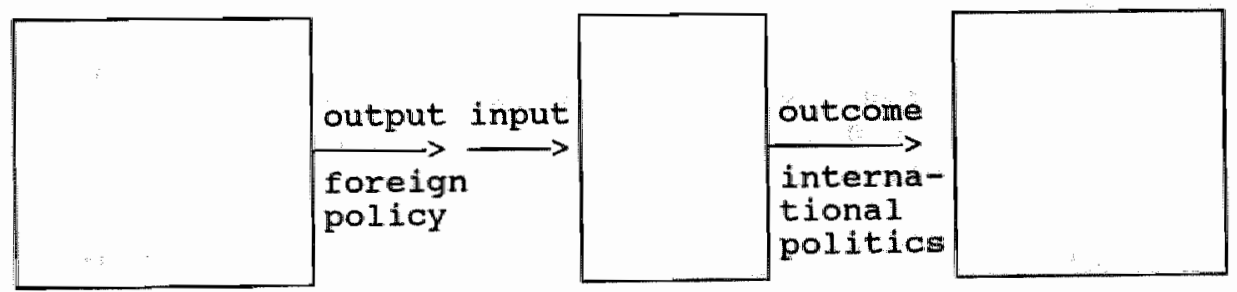

The key question that needs to be answered is whether the Netherlands cannot but conform to the wishes of more powerful partner states, or whether the Netherlands can achieve some of its own preferences and objectives in international policymaking.

To this end an analysis has been made of the decision-making process with regard to three issues which arose during the period 1973-1982:

- the Arab oil embargo against the Netherlands in 1973;

- the reaching of a common position within the framework of the EPC during the period 1977-1981; 
- the participation in the peacekeeping force in operation between Israel and Egypt (the MFO) in the period 1981-1982.

This study begins with the October-war of 1973 and ends with the express support given by the Netherlands to the Israeli-Egyptian peace-treaty. The continued existence of Israel within secure and recognised borders was one of the main objectives of the policy of the Netherlands. It was feared that the very survival of Israel was endangered by the October-war. The Dutch government was, at that time, prepared to actively support Israel. In its support for the Egyptian-Israeli peace-treaty, the Dutch stand was not only verbal but also of a substantial nature by sending troops to join the peacekeeping forces MFO. The Netherlands thus played a significant role in the realisation of the main policy objective: the achievement of secure and recognised borders for Israel.

During the October-war of 1973 the Netherlands was on the side of Israel. Demonstrations, at which politicians expressed their sympathy and support for Israel, were organised by pressure groups. The government issued a pro-Israeli statement which was greeted with approval by the Dutch parliament. Within the cabinet the willingness was even expressed to support Israel by military means. To that effect the Americans were offered landing-facilities for the purpose of transporting servicemen and arms from the United States to Israel. Eventually these facilities appeared to be unnecessary. At the international level the Netherlands expressed its veto against an Anglo-French request to represent the entire European Community (EC) in the Security Council of the United Nations in respect of the Israeli-Arab conflict. The Netherlands was not prepared to give them "carte blanche". Given the Anglo-French attitude at the time, this action by the Netherlands was considered as support for Israel. As a result the Netherlands became isolated within the European Political Cooperation. Subsequently, the Netherlands was affected by the oil embargo imposed by the Arab oil-producing states.

The prospects for the Netherlands were gloomy. A shortage of oil and a substantial increase in unemployment were to be feared as imminent dangers. Endeavours were made, in vain, to reverse the situation, by suggesting to the Arab world, by means of diplomatic activities, that the oil embargo was based upon a misunderstanding.

Furthermore, attempts were made to gain the solidarity of the European partners. For the gathering on 6th November 1973 of the ministers of foreign affairs, under the umbrella of the European Political Cooperation, it had been planned that there would be, in the morning, a common policy statement on the Arab-Israeli conflict and, in the afternoon $_{y}$ a statement on economic solidarity between the Nine Member States with regard to energy sharing. While this was the intention of the top officials, in the end only the policy statement was agreed upon by the ministers of foreign affairs. In appreciation of the policy statement, the Arab oil-producing states decided to abandon plans for further reductions in the export of oill to the EC Member States, but they maintained the embargo against the Netherlands. 
In addition to the criticism from abroad the government had also to deal with criticism at home, which made its position even more difficult. Some people felt that the Netherlands should make a special gesture to achieve a lifting of the oil embargo. Others considered, on the other hand, that, in agreeing upon the EC statement, the Netherlands had already gone too far in meeting Arab interests. The latter view was supported by a constant pro-Israel consensus within the country. For the Dutch government the freedom of manoeuvre was limited. To avoid a further weakening of the government, no criticism of the EC statement by pro-governmental parliamentary parties was expressed publicly.

The government continued to strive for European solidarity. A renewed American offer of help with the oil supplies to the Netherlands was kept under consideration. Finally, the United States found the key to a political solution to the energy question by the establishment of the International Energy Agency. The European partners, with the exception of France, joined this new international organization. The avoidance of a vulnerable position in the future had become, after the experience of 1973, an important objective of Dutch foreign policy with respect to the conflict in the Middle-East.

The EPC, too, fulfilled a function with respect to this last-mentioned objective in that the determination of a common position made individual states less vulnerable to pressure from outside the EC. In this study this phenomenon is called the "protective function' of the EPC. Additionally, EPC fulfilled a function by shielding the governments of the EC-Member States against a storm of domestic criticism. The governments could hide behind the common position. The latter phenomenon is called the 'umbrella function" in this study.

One of the most important results of the decision-making process in 1973 was that the Dutch position was no more primarily articulated at the level of the United Nations but rather made subject to the decisionmakers of the European Political Cooperation. This change did not occur wihout vigorous conflict within the ministry of foreign affairs. It was significant that, since 1973, decision-making in respect of foreign policy no longer preceded decision-making in the formation of international politics. This change meant that the influence exerted upon the policy by groups within the domestic community, as well as by parliament, decreased.

However, the study also reveals that the input by the Netherlands in the shaping of international politics could rely upon domestic support. The Dutch participants in the international decision-making process, as appears from interviews with the Dutch ministers of foreign affairs and their directors-general of political affairs, did take account of the prevailing political view in their own country. These views had an anticipating effect on the position taken by the Netherlands in the international decisionmaking process and resulted in the continued support of Israel by the Netherlands in the international sphere. Accordingly it was the Netherlands' policy not to hinder the diplomatic efforts of the United States in the Middle-East. This policy resulted, for the greater part, in differences of opinion between France and the Netherlands within the EPC during the period 1977-1981. 
The Netherlands successfully opposed an ambitious European peace-mission in the Middle-East. The expressed wish of parliament and the government for close co-operation with the United States on the Middle-East conflict was put into effect through European participation in the peace-keeping force. The Netherlands has, to a significant degree, contributed to securing this European participation. Furthermore, the Netherlands made a military contribution. Thus the Egyptian-Israeli peace treaty was given active support by the sending of Dutch troops. A potentially vulnerable position of the Netherlands was this time avoided because the consent of the European partners was secured. They then provided to the Netherlands the protection that was lacking in 1973.

This study concludes that, in consequence of European participation in the peacekeeping force, external and internal pressures were reconciled. The fact that in the Dutch input into the shaping of international policitics, prevailing views held in the Netherlands are taken into account, enhances the democratic character of policymaking. Furthermore, the chance of success of attempts by the Netherlands to exert influence in international politics can, in this way, be strenghtened.

In this study we distinguished between efforts to prevent "negative" developments on the one hand and to promote 'positive' developments on the other. As for other areas of foreign policy of the Netherlands, we came to the conclusion that those efforts of the Dutch government to promote 'positive' developments in international politics could count upon domestic consensus. It is therefore striking that only in the Middle East question, the Dutch efforts to prevent 'negative' developments enjoyed domestic support. In this study it is demonstrated that it was the domestic consensus on the ArabIsraeli conflict that mainly accounted for the successes in implementation of foreign policy in international politics, even when the government tried to prevent 'negative' developments. This feature distinguishes Dutch policy on the Middle East from other Dutch foreign policies. 


\section{BIJLAGE 1}

Schema van Rosenau's pretheorie

\begin{tabular}{|c|c|c|c|c|c|c|c|c|}
\hline \multirow{3}{*}{$\begin{array}{l}\text { geogratie + mate- } \\
\text { rielle bronnen } \\
\text { economische } \\
\text { status } \\
\text { Ftatus van politiek } \\
\text { systeem }\end{array}$} & \multicolumn{4}{|l|}{ groot land } & \multicolumn{4}{|l|}{ klein land } \\
\hline & \multicolumn{2}{|c|}{ ontwikkeld } & \multicolumn{2}{|c|}{ onderontwikkeld } & \multicolumn{2}{|c|}{ ontwikkeld } & \multicolumn{2}{|c|}{ onderontwikkeld } \\
\hline & $\begin{array}{l}\text { open } \\
\text { A }\end{array}$ & $\begin{array}{l}\text { geslloten } \\
\mathbb{B}\end{array}$ & $\begin{array}{l}\text { open } \\
\mathrm{C}\end{array}$ & $\begin{array}{l}\text { geslotien } \\
\mathrm{D}\end{array}$ & $\begin{array}{l}\text { open } \\
\mathrm{E}\end{array}$ & $\begin{array}{l}\text { gesloten } \\
\mathrm{F}\end{array}$ & open & $\begin{array}{l}\text { geslaten } \\
\mathrm{H}\end{array}$ \\
\hline \multirow{5}{*}{$\begin{array}{l}\text { rangorde wan de } \\
\text { variabelen }\end{array}$} & rol & $\mathrm{nol}$ & individu & individu & rol & rol & individu & individu \\
\hline & $\begin{array}{l}\text { samenlle- } \\
\text { ving }\end{array}$ & individu & rol & rol & system & systeem & systeem & systeem \\
\hline & regering & regering & $\begin{array}{l}\text { samenle- } \\
\text { ving }\end{array}$ & regering & $\begin{array}{l}\text { samenle- } \\
\text { ving }\end{array}$ & individu & rol & rol \\
\hline & systeem & systeern & systeem & systeem & regering & regering & $\begin{array}{l}\text { samenle- } \\
\text { ving }\end{array}$ & regering \\
\hline & individu & $\begin{array}{l}\text { samenle- } \\
\text { ving }\end{array}$ & regering & $\begin{array}{l}\text { samenle- } \\
\text { ving }\end{array}$ & individu & $\begin{array}{l}\text { samenile- } \\
\text { ving }\end{array}$ & regering & $\begin{array}{l}\text { samen- } \\
\text { leving }\end{array}$ \\
\hline bijwoorbeeld & $\begin{array}{l}\text { Verenig- } \\
\text { de Staten }\end{array}$ & $\begin{array}{l}\text { Sovjet } \\
\text { Unie: }\end{array}$ & India & $\begin{array}{l}\text { Volks- } \\
\text { republiek } \\
\text { China }\end{array}$ & $\begin{array}{l}\text { Neder- } \\
\text { land }\end{array}$ & $\begin{array}{l}\text { Tsjecho- } \\
\text { slowakije }\end{array}$ & Kenia & Ghana \\
\hline
\end{tabular}

Bron: Rosenau, 1966, p. 48.

De individu-variabelen omvatten al die persoonlijke aspecten van een besluitvormer - zijn waarden, talenten en belangrijke ervaringen - die hem onderscheiden van elke andere besluitvormer in zijn keuzen of gedrag inzake buitenlands beleid.

De rol-variabelen refereren aan de rollen die besluitvormers hebben te vervullen en die op zichzelf los staan van de individuele gesteldheid (de individu-variabelen) van de rolvervullers. Het doet er niet toe wie de rolvervullers zijn.

De regeringsvariabelen refereren aan die aspecten van een overheidsstructuur, welke de keuzen van het buitenlandse beleid door de besluitvormers beperken of vergroten. De samenlevingsvariabelen refereren aan groeperingen en de opvattingen van die groeperingen binnen een samenleving, voor zover ze niet tot de besluitvormers behoren. De systeemwariabelen omvatten alle niet-menselijke aspecten van de externe omgeving van een samenleving en alle in het buitenland plaatsvindende handelingen, welke de keuzen van haar besluitvormers bepalen of op andere wijze beînvioeden.

Bron: Rosenau, 1966, pp. $42-47$. 


\section{BIJLAGE 2}

\begin{tabular}{|l|l|l|l|l|}
\hline \multicolumn{3}{|l|}{ Schema van Rosenau's theorie van aanpassing } \\
\hline $\begin{array}{l}\text { Relatieve potentie } \\
\text { van variabelen }\end{array}$ & $\begin{array}{l}\text { Inschikkelijke } \\
\text { aanpassing }\end{array}$ & $\begin{array}{l}\text { Onverzoenl. } \\
\text { aanpassing }\end{array}$ & $\begin{array}{l}\text { Bevorderlijke } \\
\text { aanpassing }\end{array}$ & $\begin{array}{l}\text { Bewarende } \\
\text { aanpassing }\end{array}$ \\
\hline Hoog & systeem & samenleving & individu & $\begin{array}{l}\text { systeem } \\
\text { samenleving } \\
\text { regering }\end{array}$ \\
\hline Laag & $\begin{array}{l}\text { samenleving } \\
\text { individu } \\
\text { regering }\end{array}$ & $\begin{array}{l}\text { systeem } \\
\text { individu } \\
\text { regering }\end{array}$ & $\begin{array}{l}\text { systeem } \\
\text { samenleving } \\
\text { regering }\end{array}$ & individu \\
\hline
\end{tabular}

Bron: Rosenau 1980, p. 528 
BULAGE 3

\begin{tabular}{|c|c|c|c|c|c|}
\hline : & 1973 & 1977 & 1980 & 1982 & toename $\mathrm{X}$ \\
\hline Marolk ko & 89 & 262 & 220 & 263 & $296 \%$ \\
\hline Algerije & 190 & 395 & 528 & 639 & $336 \%$ \\
\hline Libivie: & 126 & 226 & 330 & 513 & $407 \%$ \\
\hline Souedan & 29 & 91. & 90 & 183 & $631 \%$ \\
\hline Tumesia: & 51 & 147 & 175 & 229 & 4495 \\
\hline Egypte & 108 & 323 & 424 & 896 & $830 \%$ \\
\hline Libanon & 93 & 110 & 144 & 200 & $215 \%$ \\
\hline Sympe & 41 & 124 & 230 & 242 & $590 \%$ \\
\hline Jordanië & 25 & 58 & 100 & 261 & $1,044 \%$ \\
\hline Irak & 49 & 242 & 496 & 781 & $1.594 \%$ \\
\hline Sacoedi-A rabië & 166 & 835 & 2.181 & 2.514 & $1.514 \%$ \\
\hline Koeweit & 68 & 196 & 204 & 318 & $468 \%$ \\
\hline Bahrein & 17 & 47 & 42 & 99 & $582 \%$ \\
\hline Katar & 18 & 53 & 58. & 115 & $639 \%$ \\
\hline Ver. Arabische Emiraten & 44 & 324 & 365 & 540 & $1.227 \%$ \\
\hline Oman. & 22 & 57 & 231 & 231 & $1.050 \%$ \\
\hline Zuid-Jemen & 8 & 54 & 98 & 98 & $1.225 \%$ \\
\hline Noord-Jemen & 18 & 57 & 155 & 155 & 861 g \\
\hline Totaal Arabische wereld & 1.162 & 3.601 & 5.868 & 8.277 & $712 \%$ \\
\hline Iran & 244 & 781 & 697 & 701 & $287 \%$ \\
\hline Lstäal & 305 & 387 & 311 & 459 & $150 \%$ \\
\hline Totaal Midden-Oosten & 1.711 & 4.769 & 6.876 & 9.437 & $551 \%$ \\
\hline Totale Nederlandse export & 66.857 & 107.195 & 148.860 & 176.851 & $265 \%$ \\
\hline M.O. in totaal & $2,6 \%$ & $4,5 \%$ & $4,6 \%$ & $5,3 \%$ & \\
\hline
\end{tabular}

$X=$ toename van 1973 tot 1983 (in percentages)

* De eerste vijf Arabische landen worden niet tot het Midden-Oosten gerekend.

Bron: CBS: Maandstatistiek van de buitenlandse handel per land jaargangen 24, 28, 31, 33. 
BIJLAGE 4

\begin{tabular}{|c|c|c|c|c|c|}
\hline & Israëli's & Arabieren & $\begin{array}{l}\text { Geen van } \\
\text { beide }\end{array}$ & Beide & $\begin{array}{l}\text { Geen } \\
\text { mening }\end{array}$ \\
\hline \multicolumn{6}{|c|}{ Publieke opinie 1973-1974 } \\
\hline \multicolumn{6}{|l|}{ Italië } \\
\hline augustus 1973 & 28 & 9 & 63 & & - \\
\hline oktober 1973 & 43 & 18 & 28 & & 11 \\
\hline \multicolumn{6}{|l|}{ BRD } \\
\hline april 1973 & 37 & 5 & 37 & & 21 \\
\hline oktober 1973 & 57 & 8 & 25 & & 10 \\
\hline november 1973 & 40 & 6 & 45 & & 8 \\
\hline december 1974 & 50 & 7 & 29 & & 14 \\
\hline \multicolumn{6}{|l|}{ Denemarken } \\
\hline januari 1974 & 37 & 7 & -- & & 56 \\
\hline \multicolumn{6}{|l|}{ Ver. Koninkrijk } \\
\hline april 1973 & 23. & 2 & 34 & 2 & 39 \\
\hline eind april 1973 & 34 & 7 & 35 & - & 24 \\
\hline meil 1973 & 30 & 5 & 35 & 3 & 27 \\
\hline oktober 1973 & 47 & 5 & 33 & - & 1.5 \\
\hline november 1973 & 43 & 7 & 31 & - & 19 \\
\hline december 1973 & 35 & 10 & 36 & - & 10 \\
\hline mei 1974 & 39 & 6 & 34 & - & 21 \\
\hline \multicolumn{6}{|c|}{ Vergelijking omstreeks november 1973} \\
\hline Nederland & 40 & 1 & 51 & - & 8 \\
\hline West-Duitsland & 40 & 6 & 45 & - & 8 \\
\hline Verenigd Koninkrijk & 43 & 7 & 31 & & 19 \\
\hline Italië & 43 & 18 & 28 & - & 11 \\
\hline Denemarken & 37 & 7 & -- & - & 56 \\
\hline
\end{tabular}




\begin{tabular}{|c|c|c|c|c|c|}
\hline & Israęli's & Arabieren & $\begin{array}{l}\text { Geen van } \\
\text { beide }\end{array}$ & Beide & $\begin{array}{l}\text { Geen } \\
\text { mening }\end{array}$ \\
\hline \multicolumn{6}{|l|}{ Publieke opinie $1975-1980$} \\
\hline \multicolumn{6}{|l|}{$B R D$} \\
\hline april 1978 & 44 & 7 & 33 & -1 & 16 \\
\hline \multicolumn{6}{|l|}{ Denemarken } \\
\hline maart 1978 & 28 & 8 & -1 & -1 & 64 \\
\hline april 1978 & 29 & 9 & -1 & I & 62 \\
\hline \multicolumn{6}{|l|}{ Verenigd Koninkrijk } \\
\hline juli 1975 & 33 & 8 & 31 & -1 & 28 \\
\hline april 1976 & 35 & 7 & 31 & 8 & 18 \\
\hline \multicolumn{6}{|l|}{ Vergelijking } \\
\hline Nederland (april 1977) & 49 & 6 & 12 & 9 & 25 \\
\hline West-Duitsland (april 1978) & 44 & 7 & 33 & -1 & 16 \\
\hline Denemarken (april 1978) & 29. & 9 & - & -1 & 62 \\
\hline Verenigd Koninkrijk (april 1976) & 35 & 7 & 31 & 81 & 18 \\
\hline \multicolumn{6}{|l|}{ Pubieke opinie 1981-1982 } \\
\hline \multicolumn{6}{|l|}{ BRD } \\
\hline mei 1981 & 24 & 16 & 41 & -1 & 19 \\
\hline \multicolumn{6}{|l|}{ Denemarken } \\
\hline mei 1981 & 25 & 10 & - & -1 & 65 \\
\hline juni 1981 & 25 & 12 & -1 & - & 63. \\
\hline augustus 1982 & 28 & 14 & -1 & -1 & 58 \\
\hline \multicolumn{6}{|l|}{ Verenigd Koninkrijk } \\
\hline augustus 1982 & 25 & $\begin{array}{r}16 \\
\text { (Pales } \\
\text { tijnen) }\end{array}$ & 38 & 2 & 19 \\
\hline \multicolumn{6}{|l|}{ Griekenland } \\
\hline maart/april 1985 & 8 & 59 & 25 & - & 8 \\
\hline
\end{tabular}

Bron: De Boer, 1987, pp. 88, 92, 93, 101, 104, 105, 106. 


\section{BULAGE 5}

De verklaring van zes november 1973

'De negen regeringen van de Europese Gemeenschap hebben hun gedachtenwisseling over de toestand in het Midden-Oosten voortgezet.

Erop wijzend dat onderstaande standpunten slechts een eerste bijdrage hunnerzijds tot het zoeken naar een globale oplossing voor het probleem vormen, zijn zij het volgende overeengekomen:

1. Zij dringen er krachtig op aan dat de strijdkrachten van beide partijen bij het conflict in het Midden-Oosten overeenkomstig de resoluties 339 en 340 van de Veiligheidsraad onmiddellijk dienen terug te keren tot stellingen die zij op 22 oktober bezetten. $\mathrm{Zij}$ geloven dat een terugkeer tot deze stellingen een oplossing van de andere dringende problemen betreffende de krijgsgevangenen en het derde Egyptische leger zal vergemakkelijken.

2. Zij hebben de vaste hoop dat er tengevolge van de aanneming door de Veiligheidsraad van zijn resolutie 338 van 22 oktober eindelijk onderhandelingen zullen kunnen worden geopend om een rechtvaardige en duurzame vrede in het MiddenOosten te herstellen op grond van resolutie 242 van de Veiligheidsraad in al haar onderdelen. Zij verklaren zich bereid alles te doen wat in hun vermogen ligt om hiertoe bij te dragen. $\mathrm{Zij}$ zijn van mening dat deze onderhandelingen in het kader van de Verenigde Naties moeten worden gevoerd. Zij herinneren eraan dat krachtens het Handvest de Veiligheidsraad de hoofdverantwoordelijkheid voor de vrede en de internationale veiligheid draagt. De Raad en de Secretaris-Generaal hebben een bijzondere rol te vervullen bij de totstandbrenging en de handhaving van de vrede overeenkomstig de resoluties van de Raad nrs. 242 en 338.

3. Zij zijn van mening dat een vredesovereenkomst met name op de volgende punten gebaseerd dient te zijn:

I. de ontoelaatbaarheid van de verwerving van grondgebied door middel van geweld;

II. de noodzaak voor Israël om de territoriale bezetting te beëindigen die het sinds het conflict van 1967 heeft gehandhaafd;

III. eerbiediging van de soevereiniteit, de territoriale integriteit en de onafhankelijkheid van elke staat in het geheel en hun recht om in vrede te leven binnen veilige en erkende grenzen;

IV. erkenning dat er bij de totstandbrenging van een rechtvaardige en duurzame vrede rekening dient te worden gehouden met de legitieme rechten van de Palestijnen. 
4. Zij herinneren eraan dat er voor de vredesregeling overeenkomstig resolutie nr. 242 internationale garanties moeten zijn.

$\mathrm{Zij}$ zijn van mening dat deze garanties zouden worden verstrekt door onder andere de zending van een vredesmacht naar de gedmilitariseerde zones zoals bedoeld in artikel $2 c$ van resolutie nr. 242 . Zij zijn het erover eens dat de garanties van primordiaal (fundamenteel) belang zijn om de algemene toestand in het Midden-Oosten te regelen overeenkomstig resolutie $\mathrm{nr} .242$ die door de Raad wordt verneld in resolutie nr. 338. Zij behouden zich het recht voor hierover voorstellen te doen.

5. Zij herinneren bij deze gelegenheid aan de velerlei banden die hen sederi lang met de landen aan de zuid- en oostkust van de Middellandse Zee verbinden. Zij bevestigen hierbij de verklaring van de Parijse Topconferentie van 21 oktober 1972 en brengen in herinnering dat de Gemeenschap vastbesloten is in het kader van een globale en evenwichtige benadering met deze landen te onderhandelen."

Bron: Bull. EG 10-9-1973, no. 2502. 


\section{BIJLAGE 6}

Overzicht Arabische maatregelen ter beperking van de olie-export

A) Oliesancties

\begin{tabular}{|l|r|r|r|r|r|r|r|r|r|}
\hline & Algerije & Koeweit & $\begin{array}{l}\text { Abu } \\
\text { Dhabi }\end{array}$ & Qatar & Onan & Libië & Bahrein & S.Arabue & Dubai \\
\hline Olieprod. beperking & $20 / 10$ & $21 / 10$ & & $18 / 10$ & & $18 / 10$ & $20 / 10$ & $18 / 10$ & \\
\hline Olie-embargo VS & $18 / 10$ & $21 / 10$ & $18 / 10$ & $21 / 10$ & & $19 / 10$ & $20 / 10$ & $20 / 10$ & $21 / 10$ \\
\hline olie-embargo NL & $20 / 10$ & $23 / 10$ & $24 / 10$ & $24 / 10$ & $25 / 10$ & $30 / 10$ & $30 / 10$ & $02 / 12$ & \\
\hline
\end{tabular}

B) Categorieën ollieconsumerende landen

1. Bevoorrechte landen:

Verenigd Koninkrijk, Islamitische en Afrikaanse staten, Spanje en Frankrijk.

2. Bevriende landen:

Frankrijk, Spanje, Verenigd Koninkrijk, Jordanië, Libanon, Malleisië, Pakistan, Tunesië, Egypte, India, alle Afrikaanse staten, Brazilië, Japan, de Philipijnen en Belgie.

3. 'Geboycotte" landen:"

VS, Canada, Bahamas, Trinidad, Nederlandse Antillen, Puerto Rico, Guam, Nederland, Zuid-Afrika, Zuid-Jemen, Portugal, Rhodesië.

4. Neutrale landen:

Alle overige landen en ook België en Japan tot 28 november 1973.

ad 1: Deze landen zouden alle voor binmenlands verbruik benodigde olie ontvangem. Deze categorie werd pas gecreëerd op de Arabische topconferentie van 26-28 november 1973.

ad 2: Deze landen zouden evenveel olie als in september 1973 of thet gemiddelde uit de periode januari-september 1973 blijven ontvangen.

ad 3: Voor deze vijandige landen gold een volledig embargo (Zuid-Jemen zou alleen door SacediArabiề en passant zijn meegenomen, volgens Van Ginkel zou ook Denemarken later onder een volledig embargo vallen, dit werd echter van Deense zijde ontkend (Van Ginkel, 1978, p. 90 zie ook Thune, 1984, p. 80 'only just avoided being placed alongside The Netherlands on the embargo list").

ad 4: Deze landen zouden maandelijks worden gekort met $5 \%$ met ingang van oktober 1973, op 4 november werd deze maatregel door de OAPEC verscherpt daar toen een korting van $25 \%$ werd vastgesteld op basis van het niveau van september en vervolgens maandelijks een $5 \%$ reductie daarenboven; senmalig werd op 18 november de $5 \%$ korting voor de mand december voor de EG-landen uit deze categorie niet geheven.

Bron: Paust and Blausteim, 1977, pp. 5-8 Arab Report and Record; 474 (Algerije 20/10) 478 (Koeweilt) 480 (Oman) 484 Sacedi-Arabie 28/10) 486 (Libië); Arab World 2/11: Radio Riad yesterdlay said that Saudi Arabia did suspend oil shipments to the Netherlands. This was in comment on a report that the Saudi Gowernment had merely warned the Dutch Government on its pro-Israel stance). 
C) Olieleveranties aan EG-lidstaten volgens Arabisch plan (als basis wordt het niveau van september 1973 genomen):

Frankrijk en het Verenigd Koninkrijk:

$100 \%$ tot eind november en daarna $100 \%$ of meer.

\section{Belgiē:}

tot 1 november $95 \%$, tot eind november $75 \%$ en daarna $100 \%$.

West-Duitsland, Luxemburg, Italië, Ierland, Denemarken:

tot 1 november $95 \%$ en tot 1 januari $75 \%$.

Nederland:

tot 1 november $95 \%$, daarna $0 \%$.

D) Werkelijk netto aanvoer ruwe olie in miljoen ton:

\begin{tabular}{|l|r|r|r|r|r|r|}
\hline & Okt. '73 & Nov. '73 & Dec. '73 & Jan. '74 & Febr. '74 & Mrt. '74 \\
\hline Frankrijk & 11,1 & 11,7 & 9,8 & 10,3 & 10,5 & 9,6 \\
\hline Duitsland & 12,8 & 11,9 & 11,2 & 10,5 & 9,3 & 10,1 \\
\hline Nederland & 6,5 & 6,4 & 3,5 & 5,3 & 4,7 & 5,5 \\
\hline
\end{tabular}

Bron: Mendershausen, 1976, p. 70; Tweede Kamer, zitting 1973-1974, no. 12.946, no. 1, p. 11, kwantitatieve beperkingen in de olie-aanwoer.

E) Aandeel van de Arabische olie-exporterende landen in de olievoorziening in 1973:

Italië: $79,9 \%$, Frankrijk: 76,8\%, België en Luxemburg: 72,8\%, West-Duitsland 71,7\%, Verenigd Koninkrijk: $70,7 \%$, Nederland: $68,1 \%$, Denemarken: $59,3 \%$, Denemarken: $59,3 \%$, lerland: 38,2 .

Bron: Maull, The Strategy of Avoidance: Europe's Middle East Policies after the Ootoberwar, p. 116 in Hurewitz (ed.): OHl, the Arab-Israel Dispute and the Industrial World, 1976, geciteerd in: Soetendorp 1983 , p. 140. 


\section{BULAGE 7}

Algemene Vergadering der Verenigde naties, stemgedrag van de EG

Dankzij de jaarlijkse schriftelijke vragen van het PPR Kamerlid Waltmans beschikken we over een gemakkelijk toegankelijk overzicht van het stemgedrag van de lidstaten der Europese Gemeenschap over resoluties in de VN; de resoluties over het ArabischIsraëlisch conflict, waarover door de EG-lidstaten niet eensgezind werd gestemd, worden hierbij tussen haakjes vermeld.

\begin{tabular}{|c|c|c|c|}
\hline Jaar & $\begin{array}{l}\text { Nederland anders } \\
\text { dan overige }\end{array}$ & \begin{tabular}{|l|}
$\begin{array}{l}\text { Eensge- } \\
\text { zinde EG }\end{array}$ \\
\end{tabular} & $\begin{array}{l}\text { Andere landen van de EG anders } \\
\text { dan Nederland en de meerderheid }\end{array}$ \\
\hline $1973(28 \mathrm{e}$ AV) 1) & 11 & 34 & 29 \\
\hline $1974(29 \mathrm{e} \mathrm{AV}) 2)$ & $7(3331 \mathrm{D})$ & 54 & $29(3210$ en 3237$)$ \\
\hline $1975(30 \mathrm{e} \mathrm{AV}) 3)$ & $10(3375)$ & 66 & $25(3376,3414,3419 \mathrm{C})$ \\
\hline 1976 (31e AV) 4) & $15(31 / 61)$ & 61 & $32(31 / 20)$ \\
\hline $1977(32 \mathrm{e}$ AV) 5) & 12 & 61 & $42(32 / 40 \mathrm{~B}, 32 / 40 \mathrm{~A})$ \\
\hline 1978 (33e AV) 6) & 12 & 82 & $48(33 / 28 \mathrm{~A}, \mathrm{~B}$ en $\mathrm{C} 33 / 13 \mathrm{E})$ \\
\hline 1979 (34e AV) 7) & 0 & 59 & $13(34 / 65 \mathrm{~A}, \mathrm{~B}$ en D $34 / 70)$ \\
\hline $1980(35 \mathrm{e} A V) 8)$ & 3 & 50 & $8(35 / 169 \mathrm{~A}$ en $\mathrm{B})$ \\
\hline 1981 (36e AV) 9) & 1 & 65 & $\begin{array}{c}28(36 / 27,36 / 87 \mathrm{~B}, 36 / 120 \mathrm{~A} \\
\mathrm{B}, \mathrm{C}, \mathrm{F}, 32 / 226 \mathrm{~A}, \mathrm{~B}, 36 \\
198,36 / 146 \mathrm{~B}, \mathrm{C}, \mathrm{G}, 36 / 147 \\
\mathrm{C} \text { en F, 36/70, 36/73, 173)* }\end{array}$ \\
\hline
\end{tabular}

Bron:

1) Tweede Kamer, zitting 1973-1974, Aanhangsel, p. 3561-3562a, no 1779

2) Tweede Kamer, zitting 1974-1975, Aanhangsel, p. 648-650, no 821

3) Tweede Kamer, zitting 1975-1976, Aanhangsel, p. 2299-2301, no 1155

4) Tweede Kamer, zitting 1976-1977, Aanhangsel, p. 1089-1091, no 545

5) Tweede Kamer, zilting 1977-1978, Aamhangsel, p. 1491-1494, no 741

6) Tweede Kamer, zitting 1978-1979, Aamhangsel, p. 2877-2880, no 1452

7) Twede Kamer, zitting 1979-1980, Aanhangsel, p. 1863-1865, no 950

8) Tweede Kamer, zitting 1980-1981, Aanhangsel, p. 2217-2218, no 1139

9) Tweede Kamer, zitting 1981-1982, Aanhangsel, p. 2013-2015, no 10780

* Bij al deze resoluties stemde alleen Griekenland voor; de andere negen lidstaten stemden gelijkgezind, d.w.z. tegen bij resolutie $36 / 120 \mathrm{~F}$ en $36 / 226 \mathrm{~A}$ en onthielden zich bij de overige resolluties. 


\section{BULAGE 8}

Werkdocument, 31 januari 1977 (Londen)

1. Les derniers développements au Proche-Orient présentent de sérieuses possibilités de négociation. Les pays de la C.E.E. expriment leur interêt pour un progrès rapide sur la voie d'une solution globale du conflit. Ils se rendent compte que la situation de 'ni guerre, ni paix" nuit sérieusement à la sécurité dans la région et dans le monde;

2. Les Neuf affirment la nécessité d'un accord de paix basé sur les résolutions 242 et $338 \mathrm{du}$ Conseil et sur les elements de leur communiqué du 6 novembre 1973, qui sont:

- Le rejet de l'occupation de territoires par la force;

- La nécessité qu'Israël cesse l'occupation qui se poursuit depuis la guerre de 1967 ;

- Le respect de la souveraineté, de la sauvegarde des territoires et de l'indépendence de chaque pays de la région ainsi que son droit a vivre en paix derrières des frontières sûres et reconnues;

- La reconnaissance des droits légitimes des Palestiniens lors de l'établissement d'une paix juste et durable;

3. Nous voulons réaffirmer que tous ces points doivent former un tout et qu'Israël, dans le cadre d'un règiement, doit être prêt à reconnaitre les droits du peuple palestinien. Nous estimons également que la partie arabe doit être prête à reconnaitre le droit d'Israël à vivre en paix derrière des frontières sûres et reconnues;

4. Pour ce qui est des droits des Palstiniens, les Neuf estiment que la solution du conflit du Proche-Orient ne sera pas possible que si se concrétise le droit du peuple palestinien à exprimer son entité nationale;

5. Les Neufs estiment que les négociations de paix visant un règlement global, juste et durable du conflit, doivent reprendre immédiatement.

Ils apprécient les efforts déployés à cet effet par le secrétaire des Nations Unies, confortement à la résolution de l'Assemblée Générale des Nations Unies du 9 décembre 1976. Ils estiment que les parties en cause, y compris le peuple palestinien, doivent entreprendre des consultations sous une forme convenable. Ils insistent auprès de toutes les parties pour qu'elles commencent au plus tôt des négociations réalistes et constructives;

6. Les pays de la C.E.E. sont disposếs à participer de façon concrète à un règlement au Proche-Orient. Ils restent également disposés à examiner la possibilité de participer aux garanties qui seraient nécessaïres pour assurer la sécurité de toutes les parties intéressés.'

Bron: Le Monde 23 februari 1977. 


\section{BULAGE 9}

Verklaring over het Midden-Oosten van 29 en 30 juni 1977 (Londen) (Europese Raad)

'1. Bij de huidige kritische siltuatie in het Midden-Oosten verheugen de Negen zich over alle pogingen die nu worden ondernomen om het tragische confliet aldaar te beëindigen. $\mathrm{Zij}$ beklemtonen dat zij spoedige en succesvolle onderhandelingen woor een rechtvaardige en duurzame vrede van vitaal belang achten.

Zij doen een beroep op alle betrokken partijen om met spoed te besluiten in een constructieve en realistische geest deel te nemen aan dergelijke onderhandelingen; juist op dit moment dienen alle partijen zich te onthouden van verklaringen of maatregelen die een belemmering kunnen vormen voor het streven naar vrede.

2. Herhaalde malen in het verleden, bijvoorbeeld in hun verklaringen van 6 november 1973, 28 september 1976 en 7 december 1976, hebben de Negen het standpunt gehuldigd dat een vredesregeling gebaseerd dient te zijn op de resoluties 242 en 338 van de Veiligheidsraad en op de volgende grondslagen:

- de ontoelaatbaarheid van het met geweld verwerven van gebied;

- de noodzaak dat Israël een einde maakt aan de territoriale bezetting waarin het volhardt sedert het conflict van 1967 ;

- eerbiediging van de souvereiniteit, territorale integriteit en onafhankelijkheid van elke staat in de regio en het recht op een vreedzaam bestaan binnen veilige en erkende grenzen;

- erkenning dat bij het tot stand komen van een rechtvaardige en duurzame vrede rekening moet worden gehouden met de legitieme rechten van de Palestijnen.

Zij blijven vasthouden aan de opvatting dat al deze aspecten als een geheel moeten worden gezien.

3. De Negen bevestigden hun overtuiging dat een oplossing voor het geschil in het Midden-Oosten slechts mogelijk is indien het legitieme recht van het Palestijnse volk om metterdaad uitdrukking te geven aan zijn nationale identiteit, wordt geconcretiseerd, waarbij rekening zou moeten worden gehouden met de behoefte aan een eigen land voor het Palestijnse volk. Zij zijn van oordeel dat de vertegenwoordigers van de partijen bij het conflict, met inbegrip van het Palestijnse volk, op een passende wijze, die in overleg tussen alle betrokken partijen moet worden vastgesteld, moeten deelnemen aan de onderhandelingen. In het kader van een algemene regeling moet Israël bereid zijn de legitieme rechten van het Palestijnse volk te erkennen; ook moet de Arabische partij bereid zijn het recht van Israël te erkennen om in vrede te leven binnen veilige en erkende grenzen. De veiligheid van de betrokken staten kan niet berusten op het met geweld verwerven van gebied, maar 
moet gebaseerd zijn op wederzijdse verbintenissen van alle betrokken partijen om tot vrede te komen, zulks met het oog op werkelijke vreedzame betrekkingen.

4. De Negen zijn van mening dat de vredesonderhandelingen met spoed moeten worden hervat met het oog op het bereiken en toepassen van een alomvattende, rechtvaardige en duurzame regeling van het conflict. Zij blijven bereid om in de mate die de partijen wensen bij te dragen tot het zoeken naar een regeling en tot de toepassing daarvan. Ook zijn zij bereid te overwegen een aandeel te nemen in garanties in het kader van de Verenigde Naties."

Bron: Bull. EG 6-1977, no. 2.2.3. 
Toespraak $\mathrm{O}^{\prime}$ Kennedy voor de Algemene Vergadering van de VN op 25 september 1979.

'The Nine continue to hope that it will be possible to achieve in the Middle East the just, lasting and comprehensive settlement to which this Assembly is overwhelmingly committed. They believe that such a settlement must be based on Security Council resolutions 242 (1967) and 338 (1973), applied in all their parts on all fronts. It must also be based on the principles set out by the Nine in their statement on June 1977 and on several occasions subsequently.

These principles are as follows: firstly, the inadmissibility of the acquisition of territory by force; secondly, the need for Israel to end the territorial occupation which it has maintained since the conflict of 1967; thirdly, respect for the sovereignty, territorial integrity and independence of all States in the area and their right to live in peace within secure and recognized boundaries; and fourthly, recognition that, in the establishment of a just and lasting peace, account must be taken of the legitimate rights of the Palestinians.

The Nine emphasize that it is essential that all parties to the negotiation of a settlement accept the right of all States in the area to live within secure and recognized boundaries with adequate guarantees. Equally, of course, it is essential that there be respect for the legitimate rights of the Palestinian people. These include the right to a homeland and the right, through its representatives, to play its full part in the negotiation of a comprehensive settlement.

Security Council resolutions 242 (1967) and 338 (1973), together with the principles I have mentioned, taken as a whole, set the essential framework for a peace settlement. In the view of the Nine it is necessary that they be accepted by all those involved including the Palestine Liberation Organization - as the basis for negotiation of a comprehensive settlement in which all the parties will play their full part.

Such a settlement would win the endorsement and support of the international community and would meet the legitimate rights and interests of all parties. This includes Israel, which is entitled to exist at peace within secure boundaries that are accepted and adequately guaranteed; and the Palestinian people, who are entitled within the framework set by a peace settlement, to exercise their right to determine their own future as a people.

The Nine recognize of course that such a settlement is not easy to achieve. But they believe it must be the continuing aim of the international community to promote it. They are convinced that such a comprehensive settlement would bring peace at last to the region; and they recall that they have already expressed their readiness to consider participating in guarantees in the framework of the United Nations.

The past year has seen some major developments to which the Nine, in view of their close connections with the region, are particularly sensitive. One of these was the signature last March of agreements between Egypt and Israel. In their declaration of 26 March last, the Nine stated their position on these agreements.

Since the signature of these agreements, which the Nine see as a correct application of the principles of resolution 242 (1967) as far as Egyptian-Israeli relations are concer- 
ned, there has been progress towards improved relations between Egypt and Israel and there have been withdrawals of Israeli forces in Sinai. The Nine note these recent developments and recall that one of the basic requirements of a comprehensive settlement is an end to the territorial occupation which Israel has maintained since the conflict of 1967. The Nine will continue to follow the situation closely and will seek in every way they can to advance the aim of a comprehensive and lasting peace settlement involving all parties and dealing with all of the fundamental issues I have mentioned. It follows that the Nine must view with the greatest regret any action or statement which aggravates the present situation or places an obstacle in the way of a peace settlement. Accordingly, they strongly deplore continued acts of violence by any of those involved. The Nine are opposed to the Israeli Government's policy of establishing settlements in occupied territories in contravention of international law; and they cannot accept claims by Israel to sovereignty over occupied territories, since this would be incompatible with resolution 242 (1967). The security of Israel, which the Nine consider essential; can be guaranteed, and the legitimate rights of the Palestinians given effect, within the framework of a comprehensive settlement.

The Nine are fully aware, too, of the importance of the question of Jersalem to all parties. They know that an acceptable solution to this problem will be vital to an overall settlement on the basis $I$ have indicated. They consider, in particular, that any agreements on the future status of Jerusalem should guarantee free access by all to the Holy Places; and they do not accept any unilateral moves which claim to change the status of the city.'

Bron: Ministerie van Buitenlandse Zaken, $34^{\circ}$ zitting van de Algemene Vergadering der Verenigde Naties, no. 124, deel II (Bijlagen), Staatsuitgeverij, "s-Gravenhage, 1980, pp. 32-33. 
Verklaring van Venetië van 13 juni 1980 (Europese Raad)

1. 'De Staatshoofden en Regeringsleiders en de Ministers van Buitenlandse Zaken hebben uitvoerig van gedlachten gewisseld over alle aspecten van de huidige toestand in het Midden-Oosten, met name over de stand van de onderhandelingen die voortvloeien uit de in maart 1979 tussen Egypte en Israël ondertekende akkoorden. Zij hebben geconstateerd dat de stijgende spanningen in dit gebied een ernstig gevaar vormen en een algehele oplossing voor het Israëlisch-Arabische conflict meer dan ooit dringend noodzakelijk maken.

2. De negen landen van de Europese Gemeenschap zijn van oordeel dat de traditionele banden en de gemeenschappelijke belangen die tussen Europea en het MiddenOosten bestaan, voor hen de verplichting meebrengen een bijzondere rol te spelen en thans een meer concrete bijdrage tot de vrede te leveren.

3. De negen landen van de Gemeenschap baseren zich in dit verband op de resoluties 242 en 338 van de Veiligheidsraad en op de herhaaldelijk door hen naar voren gebrachte standpunten, met name in hun verklaringen van 29 juni 1977,19 september 1978, en 26 maart en 18 juni 1979 alsmede in de rede die de Minister van Buitenlandse Zaken van Ierland namens hen op 25 september jongstleden heeft uitgesproken tijdens de 34e Algemene Vergadering van de Verenigde Naties.

4. Het ogenblik is gekomen om op de aldus omschreven basis de erkenning en tenuitvoerlegging van de beide universeel door de internationale gemeenschap aanvaarde beginselen te bevorderen: het bestaansrecht en het recht op veiligheid van alle Staten van het gebied, inclusief Israël, alsmede gerechtigheid voor alle volkeren, wat de erkenning van de legitieme rechten van het Palestijnse volk inhoudt.

5. Alle landen van het gebied hebben het recht om in vrede binnen veilige, erkende en gegarandeerde grenzen te leven. De garanties van de vredesregeling moeten door de Verenigde Naties worden versterkt op basis van een besluit van de Veiligheidsraad en eventueel op basis van andere onderling erkende procedures. De Negen verklaren zich bereid om ook ter plaatse in het kader van een algehele regeling mede te werken aan een stelsel van concrete en dwingende internationale garanties.

6. Voor het Palestijnse vraagstuk, dat geen gewoon vluchtelingenprobleem is, moet eindelijk een rechtvaardige oplossing worden gevonden. Het Palestijnse volk, dat zich ervan bewust is een eigen bestaan te hebben, moet in staat worden gesteld om via een passende procedure die in het kader van de algemene vredesregeling wordt. omschreven, zijn zelfbeschikkingsrecht volledig uit te oefenen.

7. Voor de tenuitvoerlegging van deze doelstellingen moeten alle betrokken partijen zich scharen achter en hun medewerking verlenen aan de vredesregeling die de 
Negen tot stand willen brengen op basis van de beginselen die in de bovengenoemde verklaringen zijn omschreven. Deze beginselen moeten worden nageleefd door alle betrokken partijen, dus ook door het Palestijnse volk en door de PLO die bij de onderhandelingen moet worden betrokken.

8. De Negen zijn zich bewust van de bijzonder belangrijke rol die de kwestie Jeruzalem speelt voor alle betrokken partijen. De Negen onderstrepen dat zij geen enkel unilateraal initiatief kunnen aanvaarden dat strekt tot wijziging van het statuut van Jeruzalem en dat ieder akkoord over het statuut van de stad voor allen het recht op vrije toegang tot de heilige plaatsen dient te garanderen.

9. De Negen memoreren dat Israël aan zijn sedert het conflict van 1967 gehandhaafde territoriale bezetting een einde dient te maken, zoals het voor een gedeelte van de Sinaï heeft gedaan. Zij zijn er vast van overtuigd dat de Israëlische nederzettingen een ernstige belemmering vormen voor het bereiken van vrede in het MiddenOosten. De Negen zijn van mening dat deze nederzettingen en de verandering van de bevolkingssamenstelling en van het onroerend bezit in de bezette Arabische gebieden in strijd zijn met het internationale recht.

10. De Negen zijn van mening dat, ten einde het geweld een halt toe te roepen, alleen het afzien van het gebruiken van en het dreigen met geweld door alle betrokken partijen een klimaat van vertrouwen in het gebied kan scheppen en een essentieel element vormt voor een algemene regeling van het conflict in het Midden-Oosten.

11. De Negen hebben besloten de nodige contacten te leggen met alle betrokken partijen. Deze contacten hebben tot doel informatie in te winnen over het standpunt van de verschillende partijen ten aanzien van de beginselen die in deze verklaring zijn uiteengezet en, in het licht van de resultaten van dit overleg, de vorm te bepalen van een eventueel initiatief hunnerzijds.'

Bron: Bull. EG 6-1980, no. 1.1.6. 


\section{BIJLAGE 12}

Aandacht in de media voor enkele uitspraken van Nederlandse politici in 1979

Reizen en uitspraken in 1979 van bijwoorbeeld Pronk. Pronk gaf te kennen een vooistander te zijn van het aanknopen van politieke contacten met de PLO (Amhemse Courant 4-1-1979, NCRV-radio Hier en Nu 4-1-1979, NRC-Handelsblad 6-1-1979, Haagsche Courant 6-1-1979, Groene Amsterdammer 10-1-1979, NIW 12-1-1979, IKON-radio De andere wereld van zondagmorgen 4-3-1979, NRC-Handelsblad 6-31979, NRC-Handelsblad 11-8-1979, De Telegraaf 13-8-1979, Haagsche Post 25-8-1979, Het Parool 14-8-1979).

Uitspraken van Scholten en Den Uyl veroorzaakten vele artikelen en commentaren. Scholten was een voorstander van subtiele contacten met de PLO. (Het Parool 6-6-1979 en 9-6-1979, NOS-radio Van onze redactie 15-6-1979, NIW 22-6-1979, VARA-radio Dingen van de Dag 28-7-1979, Het Binnenhof 31-7-1979, De Tellegraaf 31-7-1979, EOradio Tijdsein 1-8-1979).

Den Uyl was alleen bereid tot contacten met de PLO als die ten doel zouden hebben hen te bewegen Israël te erkennen en hun Handvest op dat punt te wijzigen. (NCRVradio Hier en Nu 4-2-1979, Haagsche Courant 5-7-1979, NOS-radio Met het oog op morgen 8-7-1979, NIW 13-7-1979, IKON-radio Andere wereld van zondagmorgen 227-1979, Trouw 25-7-1979, De Telegraaf 25-7-1979, NIW 3-8-1979).

In dezelfde periode werden de Kamerleden Bolkestein, Van der Stoel en Ter Beek ook vaak in de pers geïnterviewd of aangehaald. Voorts werd door de pers veel aandacht geschonken aan een mogelijke verandering in de opstelling van de PvdA.

(Vrij Nederland 14-7-1979, Het Parool 8-8-1979, VARA radio Dingen van de Dag 8-81979, NCRV-radio Hier en Nu 8-8-1979, De Telegraaf 10-8-1979, Algemeen Dagblad 10-8-1979, Leeuwarder Courant 10-8-1979, Tros T.V. Aktua 11-8-1979, Het Vrije Volk 11-8-1979, NIW 31-8-1979, NRC-Handelsblad 24-8-1979, Trouw 24-8-1979, Algemeen Dagblad 24-8-1979, Het Vrije Volk 29-8-1979, Amersfoortse Courant 18-81979, Het Parool 21-8-1979, Vrij Nederland 25-8-1979, NRC-Handelsblad 18-8-1979). De PvdA bracht in augustus 1979 een nieuw Midden-Oosten standpunt naar buiten; van tevoren waren de inhoud daarvan en de meningsverschillen binnen de Midden-Oostencommissie al veelvuldig uitgelekt naar de pers. 


\section{BIJLAGE 13}

Staten die in 1981 diplomatieke betrekkingen met Israël onderhielden en gevraagd zijn voor deelname aan de MFO

*Argentinië

*Australië

*Uruguay

*Italië

Usland

Ierland

El Salvador

*Ecuador

*Verenigde Staten

Bahamas

Bolivia

Burma

*België

Barbados

*Brazilië

*Verenigd Koninkrijk

* Guatemala

Jamaica

Bondsrepubliek Duitsland

Grenada

Dominica

Dominicaanse Republiek

*Denemarken

Zuid Afrika

Haïti

India

*Nederland

* Honduras

Zwitserland

Venezuela

Tonga

Trinidad en Tobago

Griekenland

Japan
Luxemburg

Lesotho

Malawi

*Mexico

Malta

Egypte

*Noorwegen

*Nieuw Zeeland

Nicaragua

* Nepal

Swaziland

Suriname

Westelijk Samoa

Portugal

Philipijnen

*Fiji

*Finland

*Panama

Papua-Nieuw Guinea

Paraguay

Peru

Chili

*Frankrijk

*Colombia

Costa Rica

Republiek van Korea

*Canada

Cyprus

Roemenië

*Zweden

Thailand

Turkije

*Singapore

* = de staten die gevraagd waren voor deelname aan de MFO 
Gemeenschappelijke verklaring van de vier inzake participatie MFO.

De gemeenschappelijke verklaring van de vier luidt als volgt:

'De regeringen van Frankrijk, Italië, Nederland en het Verenigd Koninkrijk hebben besloten, na hun partners in de Tien te hebben geraadpleegd en afhankelijk van hun constitutionele procedures en van overeenstemming over de praktische en juridische regelingen, in te gaan op het verzoek van de regeringen van Egypte, Israël en de Verenigde Staten, bij te dragen in de Multinational Force and Observers in de Sinaï.

De vier regeringen verklaren er bij hun deelname in de Multinational Force and Observers van uit te gaan dat:

1. de vredesmacht uitsluitend bestaat met als doel de vrede in de Sinaï te handhaven na de Israëlische terugtrekking. De macht vervult geen andere rol;

2. de vredesmacht in zijn huidige vorm wordt samengesteld bij ontstentenis van een VN-beslissing over een internationale vredesmacht en dat zijn positie opnieuw zal worden overwogen, mocht een dergelijke beslissing mogelijk worden;

3. deelname door de vier regeringen in de strijdmacht niet zal worden beschouwd als hen te committeren tot of uit te sluiten van deelname in zodanige andere internationalle vredeshandhavende regelingen als zijn of kunnen worden tot stand gebracht in de regio; en

4. deelname in de Multinational Force and Observers geen afbreuk doet aan hun algemeen beleid ten aanzien van andere aspecten van de problemen van het gebied.'

Bron: Tweede Kamer, zitting 1981-1982, 17.197, nr. 1, p. 2. 


\section{BIILAGE 15}

De nationale verklaring inzake participatie MFO.

'Dit besluit symboliseert de vastbeslotenheid van de regering een alomvattende vredesregeling op grond van onderhandelingen tussen de partijen te bereiken welke rechtvaardig zal zijn voor alle volkeren en veiligheid zal brengen voor alle staten in de regio. Zij verwelkomt het bereiken van vrede tussen Israël en Egypte als een eerste stap naar dat doel. Dienovereenkomstig verwelkomt zij de Israëlische terugtrekking uit de Sinaï als de eerste stap naar de verwezenlijking van de oproep tot terugtrekking, vervat in Veilligheidsraadresolutie 242 , welke met zoveel woorden het verwerven van grondgebied door oorlog ontoelaatbaar verklaart, en zij gelooft dat de internationale gemeenschap de plicht heeft de haar toekomende rol te spelen, zoals deze noodzakelijk is en met toestemming van de betrokken partijen, in vredesregelingen in het Midden-Oosten. $\mathrm{Z}_{\mathrm{ij}}$ is in principe bereid ook in dergelijke regelingen in andere gebieden welke momenteel bezet zijn, in het kader van een Israëlische terugtrekking deel te nemen. De regering beschouwt haar steun voor de regelingen die samenhangen met Israëls terugtrekking uit de Sinaï als geheel afzonderlijk en onafhankelijk van het resterende deel van het Camp David proces.

De regering daarenboven brengt haar krachtige steun voor de Egyptische regering en het Egyptische volk alsmede haar geloof in de noodzaak voor stabiliteit en continuiteit in Egypte tot uitdrukking. Het besluit van de regering deel te nemen in de Multinational Force and Observers in de Sinai vloeit voort uit het beleild zoals dit vermeld staat in de verklaring welke in juni 1980 te Venetië werd uitgegeven en in daaropvolgende verklaringen. Dringt dit beleid aan op garanties voor de veiligheid van de staat Israël, het legt evenzeer nadruk op rechtvaardigheid voor het Palestijnse volk en zijn recht op zelfbeschikking. Dit beleid houdt eveneens in dat de PLO betrokken moet worden in het proces leidende tot een alomvattende vrede.

De regering zegt toe de Multinational Force and Observers te ondersteunen. Zij herhaallt tevens dat zij, te zamen met de partners van de Tien, zal blijven werken aan het bereiken van een alomvattende vrede in het Midden-Oosten op alle wijzen welke in overeenstemming zijn met de beginselen welke zij aanhangt."

Bron: Tweede Kamer, zitting 1981-1982, no. 17.197, nr. 1, p. 2 . 
BIJLAGE 16

\begin{tabular}{|c|c|c|}
\hline \multicolumn{3}{|c|}{ Overleg regering-parlement over participatie in MFO } \\
\hline 1) 26 oktober 1981 & Kamervraag Schutte (schriftelijk) & $\begin{array}{l}\text { Aanhangsel, no. } 239 \text {, } \\
\text { p. } 471\end{array}$ \\
\hline 2) 29 oktober 1981 & $\begin{array}{l}\text { Kamercommissie B.Z. en Defen- } \\
\text { sie }\end{array}$ & $\begin{array}{l}\text { Geen verslag beschik- } \\
\text { baar (vertrouwelijk) }\end{array}$ \\
\hline 3) 11 november 1981 & $\begin{array}{l}\text { Kamervraag - mondeling - Walt- } \\
\text { mans e.a. }\end{array}$ & $\begin{array}{l}\text { Handelingen pp. } 273- \\
275,324\end{array}$ \\
\hline 4) 11 novernber 1981 & Kamercommissie B.Z. & $\begin{array}{l}\text { Geen verslag beschik- } \\
\text { baar (vertrouwelijk) }\end{array}$ \\
\hline 5) 17 november 1981 & $\begin{array}{l}\text { Antwoord Van der Stoel op } \\
\text { Kamervraag }\end{array}$ & $\begin{array}{l}\text { Aanhangsel no. } 239, p . \\
471\end{array}$ \\
\hline 6) 23 november 1981 & $\begin{array}{l}\text { Brief Van der Stoel aan Kamer } \\
\text { (tekst verklaring) }\end{array}$ & No. 17.197 nr. 1, pp. \\
\hline 7) 2 december 1981 & Kamercommissie B.Z. en Def. & $\begin{array}{l}\text { No. } 17.197 \text { nr. 2, pp. } \\
1-8\end{array}$ \\
\hline 8) 17 december 1981 & Kamercommissie B.Z. & $\begin{array}{l}\text { No. } 17.100 \text { Hoofdstuk } \\
\text { V, no. } 44 \text { pp.1-3 }\end{array}$ \\
\hline 9) 24 december 1981 & $\begin{array}{l}\text { Brief Van Mierlo aan Kamer- } \\
\text { commissie van Defensie }\end{array}$ & $\begin{array}{l}\text { No. } 17.197 \text { nr. 6, pp. } \\
\text { 6-7 }\end{array}$ \\
\hline 10) 18 januari 1982 & $\begin{array}{l}\text { Brief Van der Stoel en Van } \\
\text { Mierlo (tekst protocol) }\end{array}$ & No. 17.197 nr. 3 \\
\hline 11) 18 januari 1982 & $\begin{array}{l}\text { Brief Van der Stoel en Van } \\
\text { Mierlo aan kamer (briefwissel- } \\
\text { ling met Israël, vertrouwelijk) }\end{array}$ & No. 17.197 nr. 4 \\
\hline 12) 21 januari 1982 & Kamercommissie van Defensie & $\begin{array}{l}\text { No. } 17.197 \text { nr. 6, pp. } \\
1-3\end{array}$ \\
\hline 13) 10 februari 1982 & $\begin{array}{l}\text { Debat begroting B.Z. ook over } \\
\text { MFO }\end{array}$ & $\begin{array}{l}\text { Handelingen pp. } 1935- \\
1938 \text { en 1961-1965 }\end{array}$ \\
\hline 14) 10 februari 1982 & Motie Schaper c. s. & $\begin{array}{l}\text { No. } 17.100 \text { Hoofdstuk } \\
\text { V, no. } 49\end{array}$ \\
\hline 15) 11 februari 1982 & Kamercommissie van Defensie, & $\begin{array}{l}\text { No. } 17.197 \text { nr. 6, pp. } \\
4-5\end{array}$ \\
\hline 16) 12 februari 1982 & $\begin{array}{l}\text { Brief Van der Stoel en Van } \\
\text { Mierlo aan kamer (notitie over } \\
\text { deelname) }\end{array}$ & $\begin{array}{l}\text { No. } 17.197 \text { nr. 5, pp. } \\
1-8\end{array}$ \\
\hline 17) 16 februari 1982 & $\begin{array}{l}\text { Stemming moties begrotingsbe- } \\
\text { dat }\end{array}$ & $\begin{array}{l}\text { Handelingen pp. 2050- } \\
2051\end{array}$ \\
\hline 18) 18 februari 1982 & Kamercommissie B.Z. en Def. & $\begin{array}{l}\text { No. } 17.197 \text { nr. 7, pp. } \\
1-9\end{array}$ \\
\hline
\end{tabular}




\begin{tabular}{|c|c|c|}
\hline \multicolumn{3}{|c|}{ Overleg regering-parlement over participatie in MFO } \\
\hline 19) 23 februari 1982 & $\begin{array}{l}\text { Brief Van Mierlo aan Kamer } \\
\text { (antwoord op vragen) }\end{array}$ & No. 17.197 nr. 11 \\
\hline 20) 24 februari 1982 & $\begin{array}{l}\text { Debat Nederlandse deelname aan } \\
\text { MFO }\end{array}$ & $\begin{array}{l}\text { Handelingen pp. 2325- } \\
2355\end{array}$ \\
\hline 21) 24 februari 1982 & Motie Van Es en Waltmans & No. $17.197 \mathrm{nr} .8$ \\
\hline 22) 24 februari 1982 & Motie Waltmans en Van Es & No. 17.197 nr. 9 \\
\hline 23) 24 februari 1982 & Motie Ter Beek & No. 17.197 nr. 10 \\
\hline 24) 24 februari 1982 & Motie Schreuders & No. $17.197 \mathrm{nr} .12$ \\
\hline 25) 17 juni 1982 & $\begin{array}{l}\text { Brief Van Agt en Van Mierlo } \\
\text { aan Kamer }\end{array}$ & $\begin{array}{l}\text { No. } 17.197 \mathrm{nr} .13 \text {, pp. } \\
1-4\end{array}$ \\
\hline 26) 23 augustus 1982 & $\begin{array}{l}\text { Advies Raad van State aan Ko- } \\
\text { ningin }\end{array}$ & $\begin{array}{l}\text { No. } 17.691 \text { A-B, pp. 1- } \\
2\end{array}$ \\
\hline 27) 19 november 1982 & $\begin{array}{l}\text { Rapport Van den Broek en De } \\
\text { Ruiter aan koningin } \\
\end{array}$ & $\begin{array}{l}\text { No. } 17.691 \text { A-B, pp. 3- } \\
4\end{array}$ \\
\hline 28) 2 december 1982 & $\begin{array}{l}\text { Brief Van den Broek en De } \\
\text { Ruiter aan Kamer }\end{array}$ & $\begin{array}{l}\text { No. } 17.691 \mathrm{nr} .1, \mathrm{pp} . \\
1-8\end{array}$ \\
\hline 29) 22 februari 1984 & $\begin{array}{l}\text { Brief Van den Broek en De } \\
\text { Ruiter aan Kamer }\end{array}$ & $\begin{array}{l}\text { No. } 17.197 \text { nr. 1, pp. } \\
1-3\end{array}$ \\
\hline 30) 11 april 1984 & $\begin{array}{l}\text { Kamercommissie B.Z. en Defen- } \\
\text { sie }\end{array}$ & $\begin{array}{l}\text { No. } 18.100 \mathrm{~V} \text { en } \mathrm{X} \\
\text { no. } 109\end{array}$ \\
\hline 31) 4 maart 1986 & $\begin{array}{l}\text { Brief Van den Broek en De } \\
\text { Ruiter aan Kamer }\end{array}$ & No. 17.197 nr. 15 \\
\hline 32) 9 april 1986 & Brief De Ruiter aan Kamer & No. $17.197 \mathrm{nr} .16$ \\
\hline 33) 11 maart 1988 & $\begin{array}{l}\text { Brief Van den Broek en Van } \\
\text { Eekelen aan Kamer }\end{array}$ & No. 17.197 nr. 17 \\
\hline
\end{tabular}




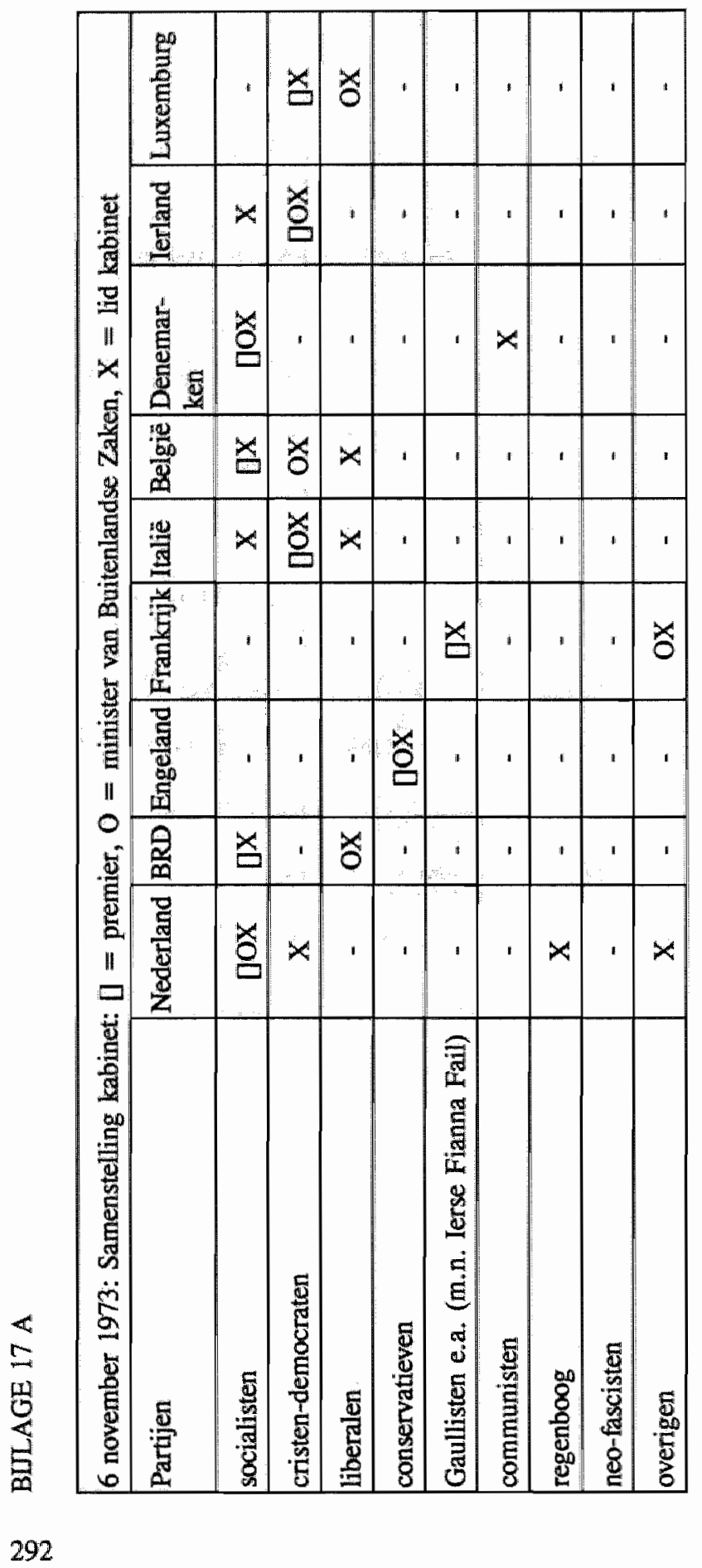




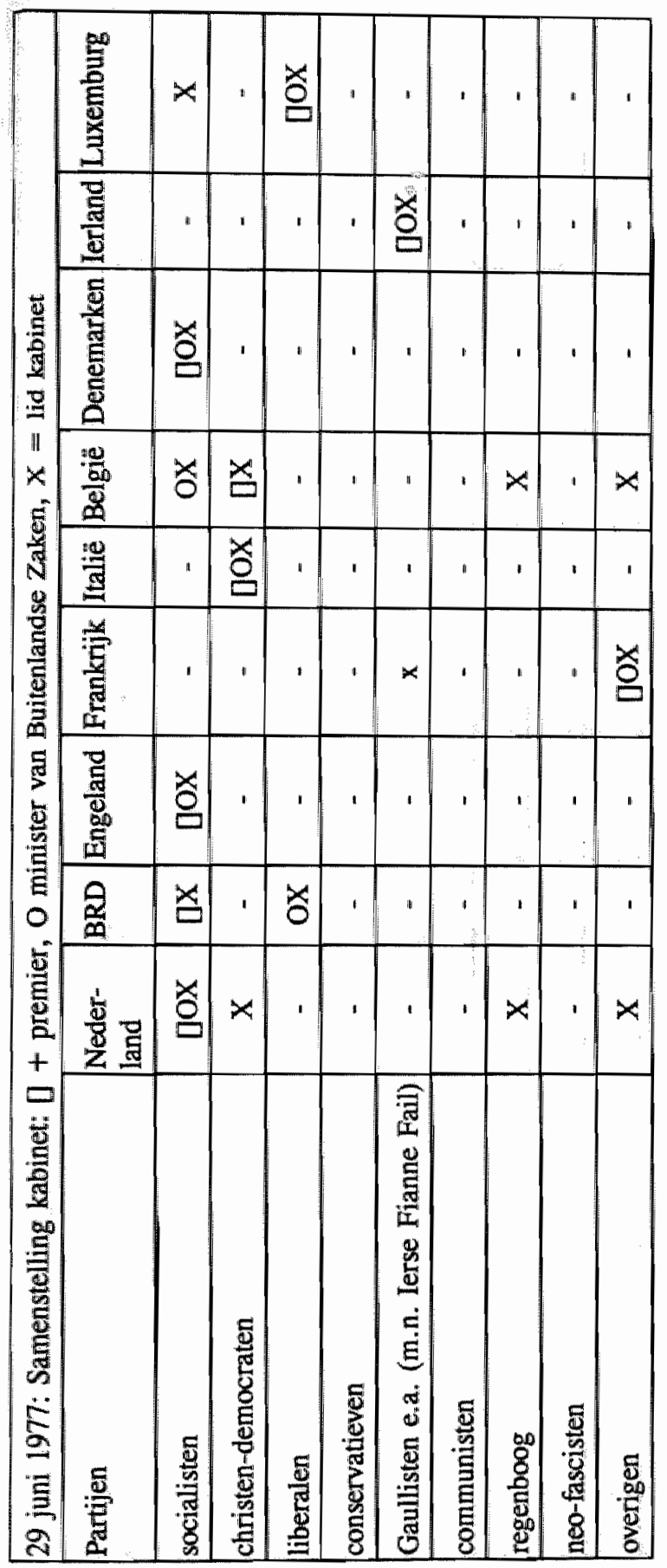




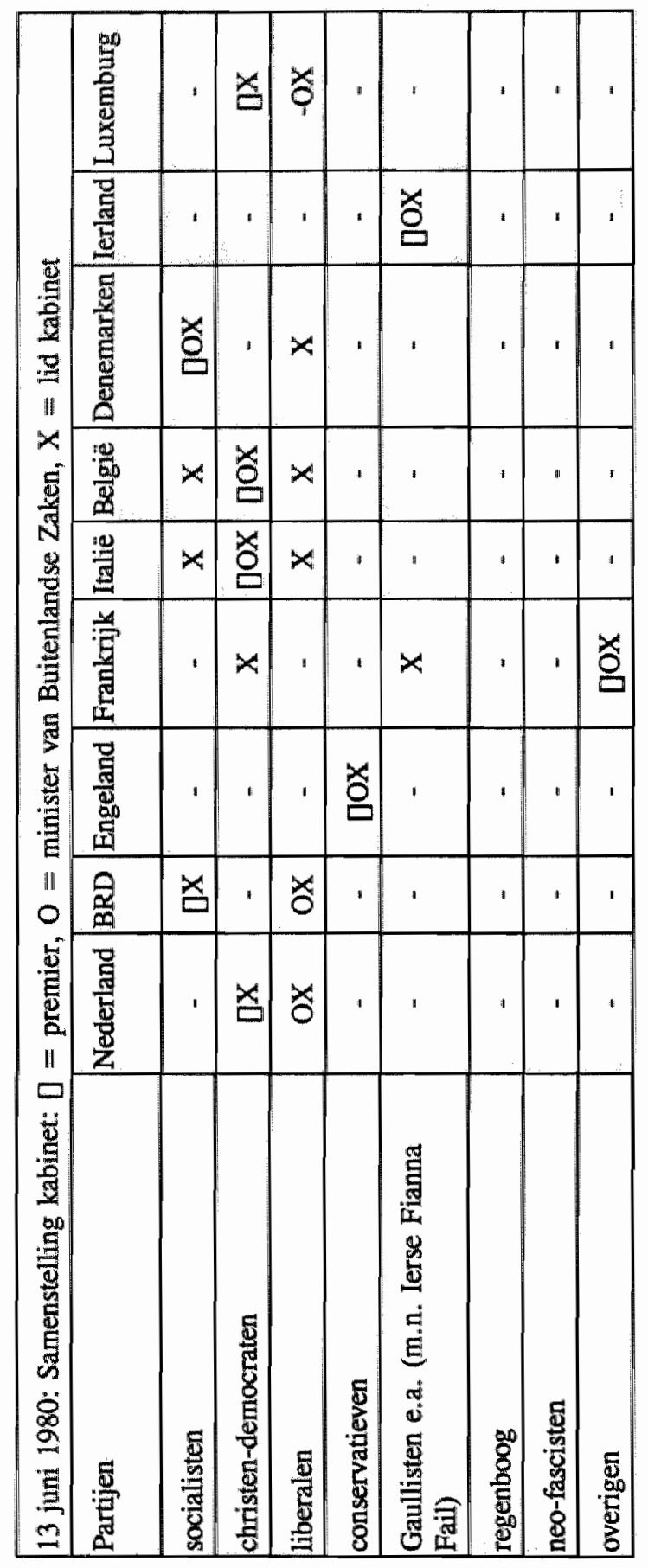




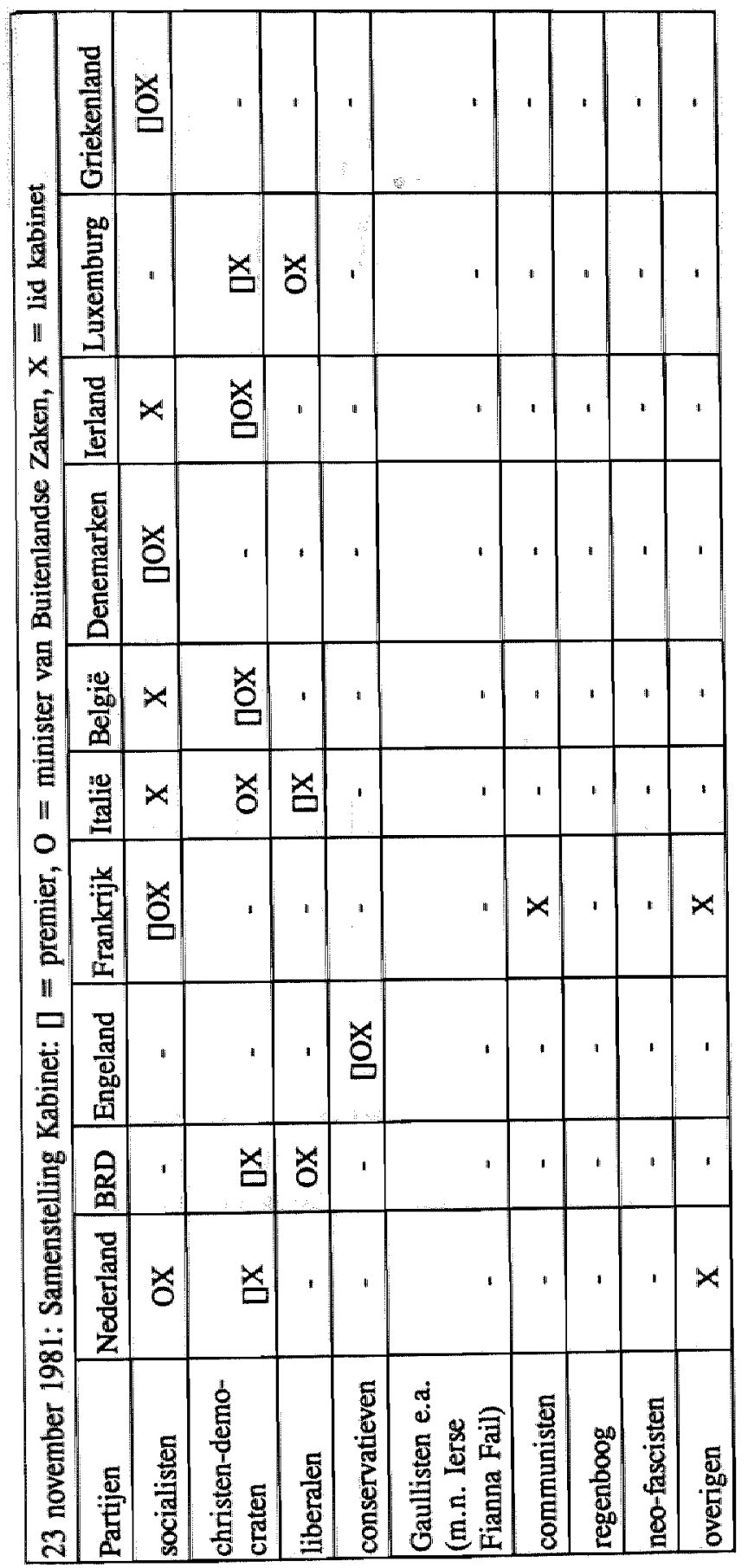




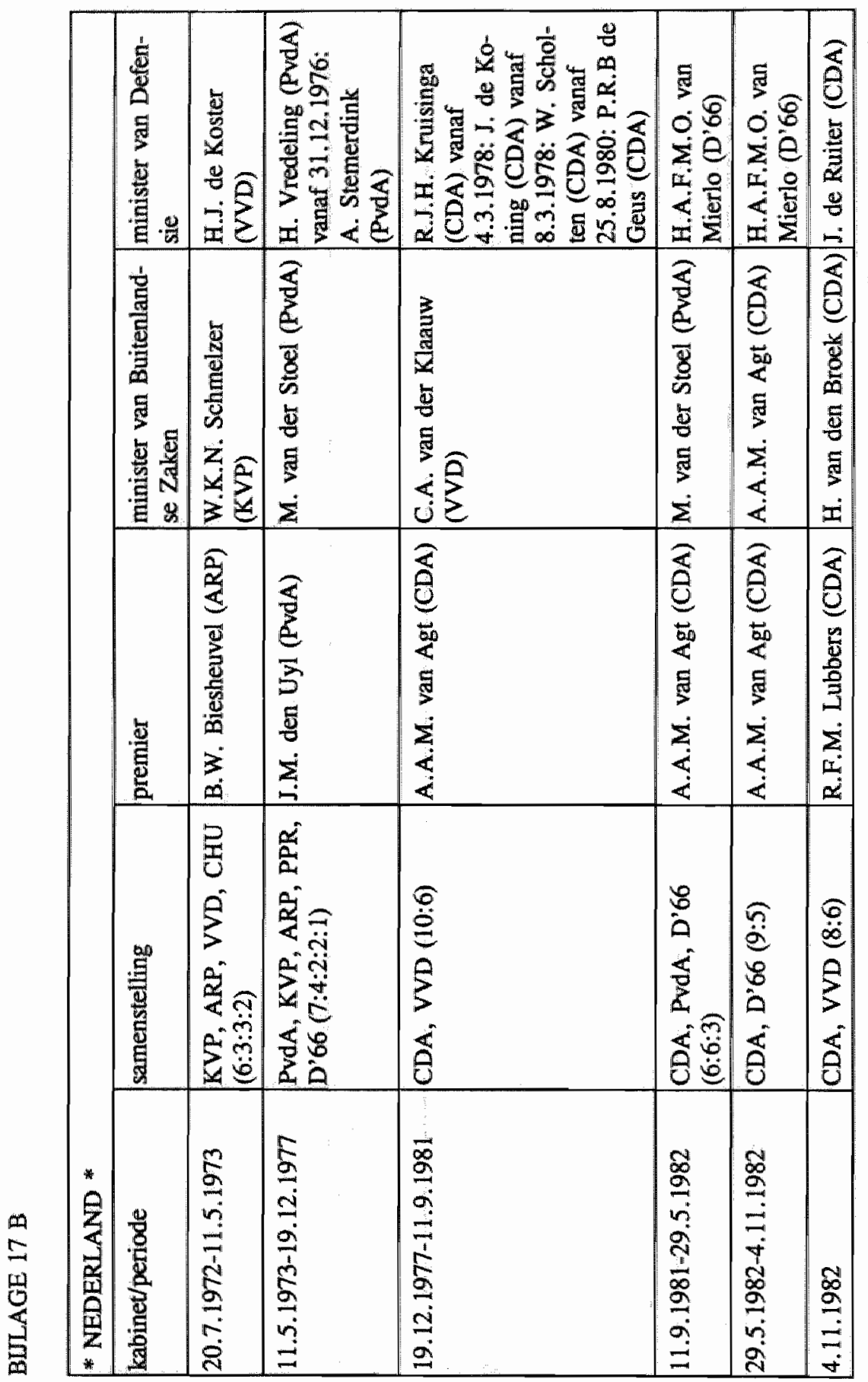




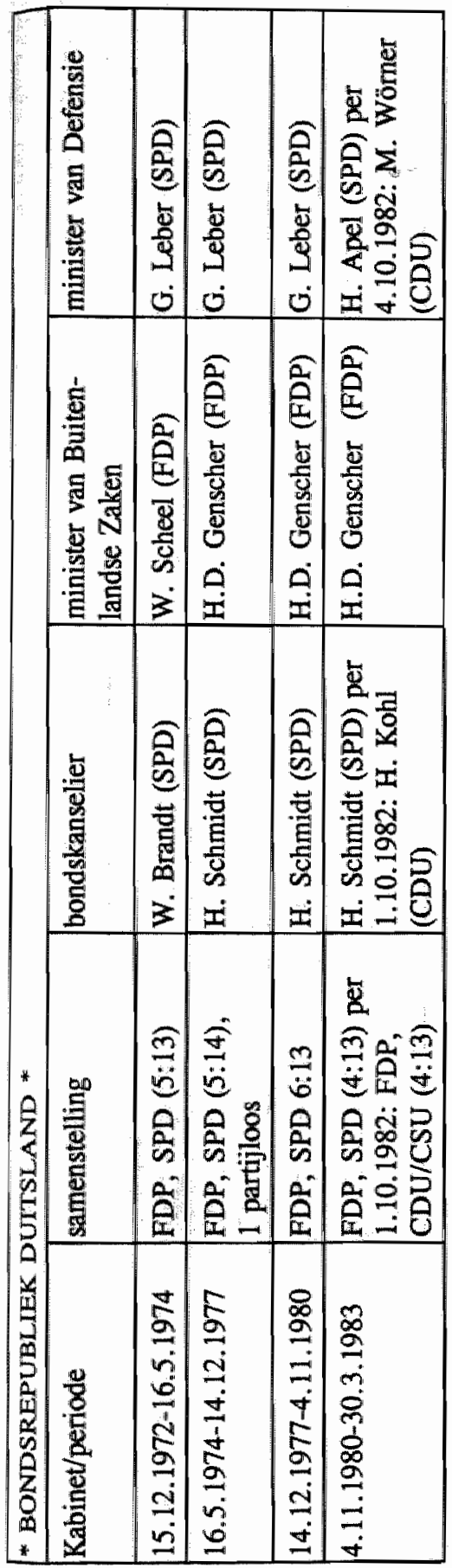

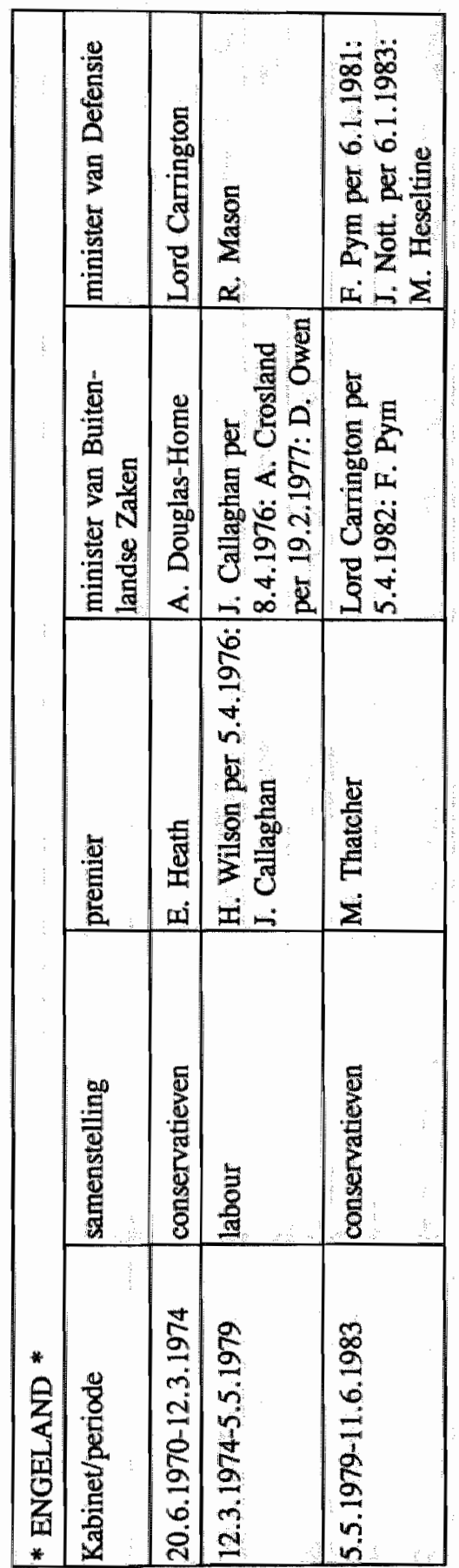




\begin{tabular}{|c|c|c|c|c|c|c|c|c|c|c|c|c|c|c|c|}
\hline & 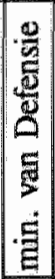 & 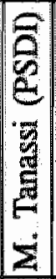 & $\begin{array}{l}8 \\
8 \\
8 \\
8 \\
8 \\
2\end{array}$ & $\begin{array}{l}0 \\
0 \\
\frac{E}{8} \\
\frac{8}{8} \\
\frac{8}{8} \\
0\end{array}$ & 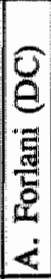 & 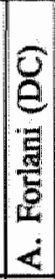 & 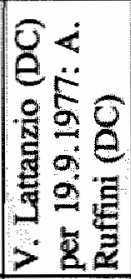 & $\begin{array}{l}0 \\
0 \\
2 \\
2 \\
2\end{array}$ & 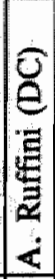 & 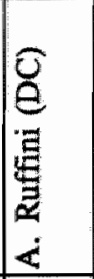 & $\begin{array}{c}0 \\
0 \\
0 \\
0 \\
0 \\
0 \\
0 \\
-3 \\
0 \\
\end{array}$ & $\begin{array}{l}0 \\
0 \\
0 \\
0 \\
0 \\
8 \\
3 \\
-3 \\
\end{array}$ & $\begin{array}{l}0 \\
0 \\
0 \\
0 \\
0 \\
0 \\
3 \\
3 \\
3\end{array}$ & 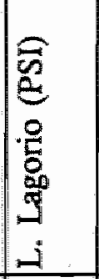 & 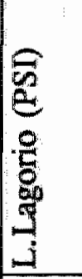 \\
\hline & 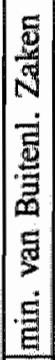 & $\begin{array}{l}0 \\
Q \\
\overline{8} \\
\frac{8}{2} \\
\frac{8}{0} \\
0\end{array}$ & $\frac{8}{0}$ & $\begin{array}{l}0 \\
0 \\
0 \\
0 \\
2 \\
2 \\
4\end{array}$ & $\begin{array}{l}0 \\
0 \\
8 \\
z \\
z \\
z\end{array}$ & $\begin{array}{l}8 \\
5 \\
8 \\
\vdots \\
\end{array}$ & $\begin{array}{l}0 \\
0 \\
3 \\
\frac{5}{6} \\
4\end{array}$ & 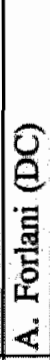 & 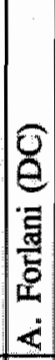 & 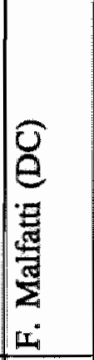 & 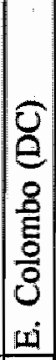 & $\begin{array}{l}0 \\
0 \\
0 \\
\frac{8}{0} \\
0 \\
\omega\end{array}$ & $\begin{array}{l}0 \\
0 \\
8 \\
8 \\
0 \\
0 \\
0 \\
\omega\end{array}$ & $\begin{array}{l}0 \\
0 \\
8 \\
\frac{8}{5} \\
\frac{0}{0} \\
1\end{array}$ & $\begin{array}{l}0 \\
\theta \\
0 \\
0 \\
0 \\
0 \\
0 \\
0 \\
\end{array}$ \\
\hline & 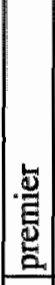 & $\begin{array}{l}0 \\
0 \\
\frac{E}{8} \\
\frac{5}{8} \\
\frac{3}{0} \\
0\end{array}$ & 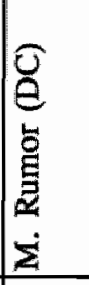 & 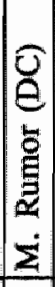 & 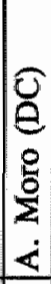 & $\begin{array}{l}0 \\
8 \\
8 \\
2 \\
\end{array}$ & 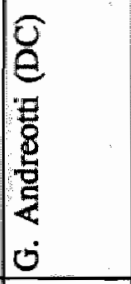 & 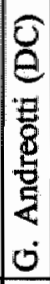 & $\begin{array}{l}0 \\
0 \\
8 \\
8 \\
\frac{5}{2} \\
0 \\
0\end{array}$ & $\begin{array}{l}0 \\
0 \\
8 \\
00 \\
0 \\
0 \\
0 \\
0\end{array}$ & $\begin{array}{l}0 \\
0 \\
0 \\
.0 \\
0 \\
0 \\
0 \\
x\end{array}$ & 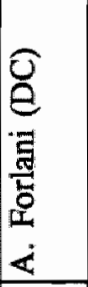 & 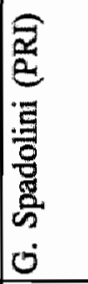 & 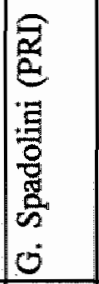 & 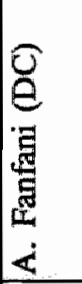 \\
\hline & 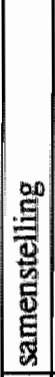 & 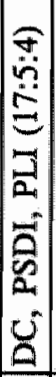 & 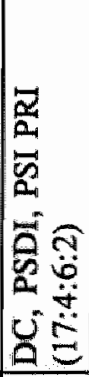 & 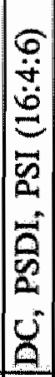 & 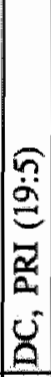 & Q & ๕ి & 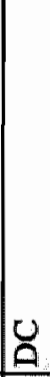 & 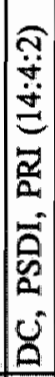 & 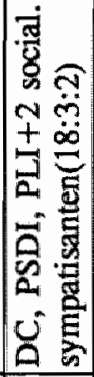 & 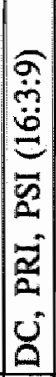 & 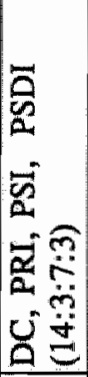 & 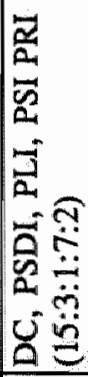 & 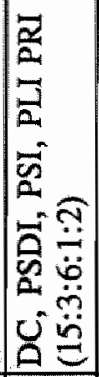 & 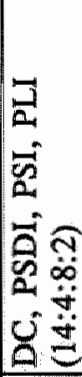 \\
\hline$\stackrel{*}{a}$ & $\left|\begin{array}{c}\frac{3}{8} \\
\frac{5}{8} \\
\frac{3}{3} \\
\frac{3}{3}\end{array}\right|$ & $\begin{array}{l}2 \\
2 \\
0 \\
0 \\
\infty \\
5 \\
0 \\
0 \\
0 \\
0\end{array}$ & $\begin{array}{l}\frac{\pi}{2} \\
\frac{2}{2} \\
\frac{2}{2} \\
\frac{5}{2} \\
\frac{2}{2}\end{array}$ & 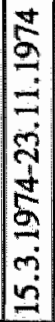 & $\begin{array}{l}5 \\
2 \\
\vdots \\
\vdots \\
\vdots \\
\vdots \\
5 \\
\vdots \\
\vdots \\
\vdots \\
2\end{array}$ & 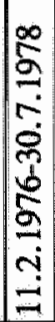 & 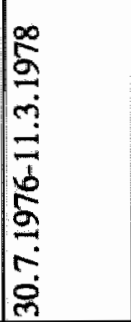 & 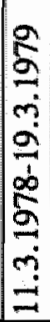 & 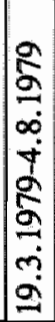 & 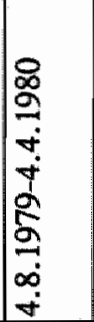 & 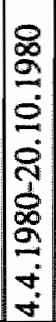 & 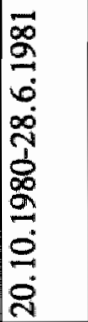 & 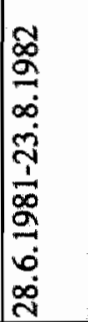 & 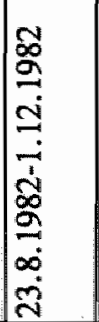 & 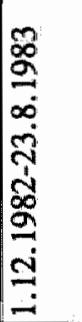 \\
\hline
\end{tabular}




\begin{tabular}{|c|c|c|c|c|c|c|c|c|c|}
\hline 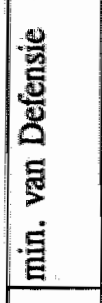 & 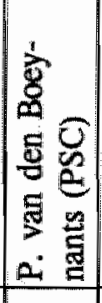 & 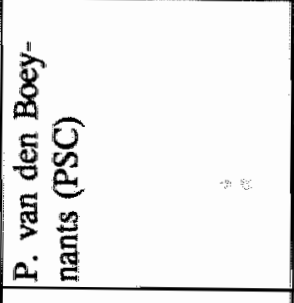 & 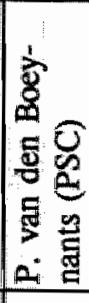 & 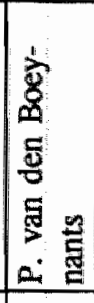 & 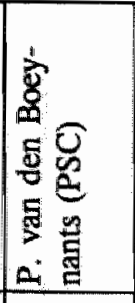 & 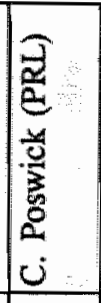 & 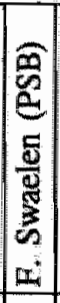 & 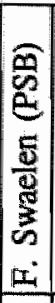 & 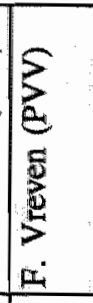 \\
\hline 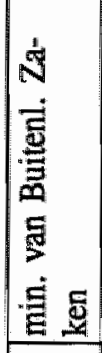 & 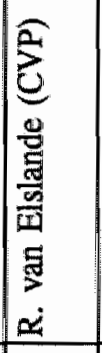 & 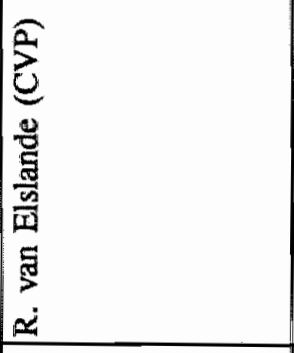 & 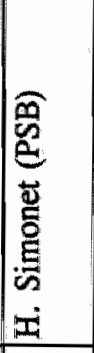 & 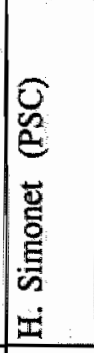 & 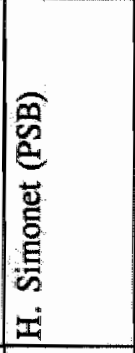 & 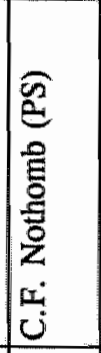 & 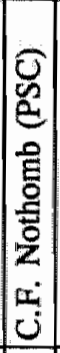 & 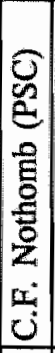 & 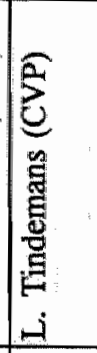 \\
\hline 总 & 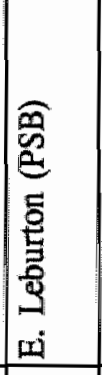 & 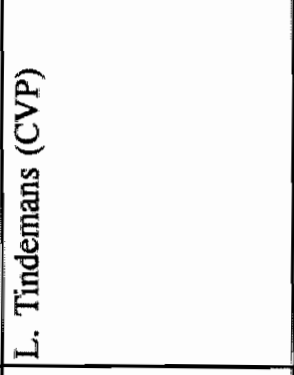 & 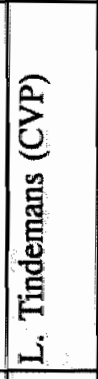 & 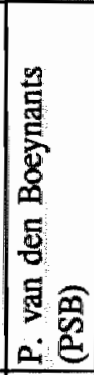 & 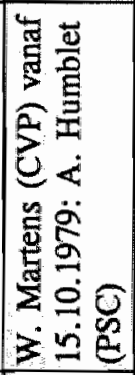 & 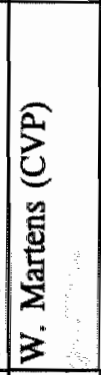 & 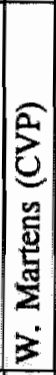 & 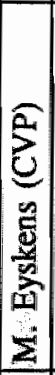 & 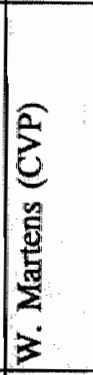 \\
\hline 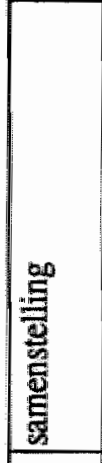 & 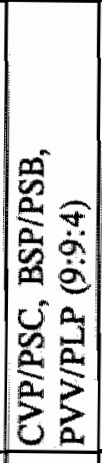 & 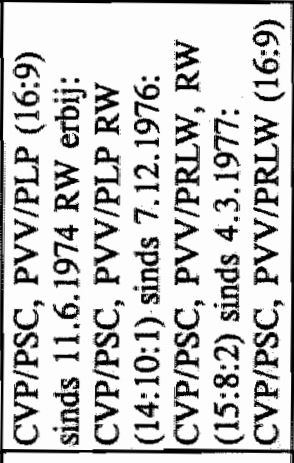 & 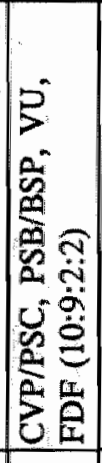 & 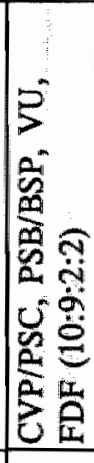 & 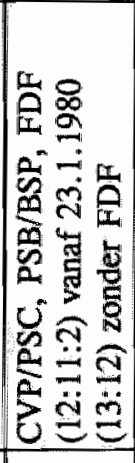 & 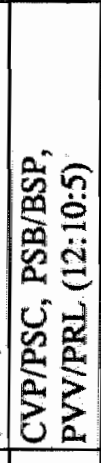 & 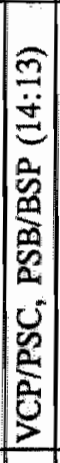 & 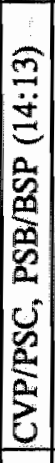 & 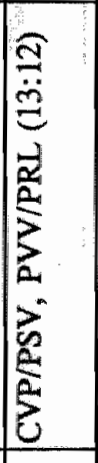 \\
\hline 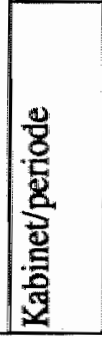 & 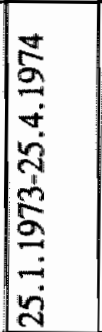 & 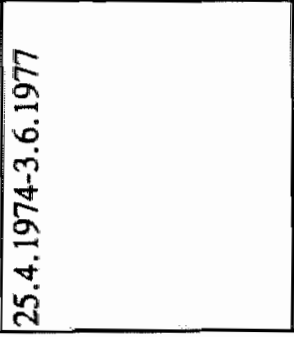 & 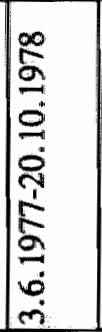 & 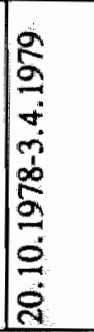 & 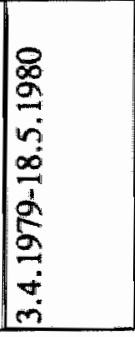 & 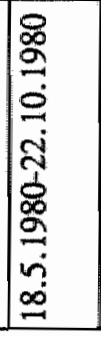 & 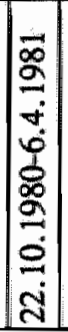 & 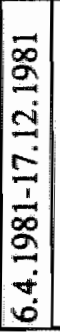 & 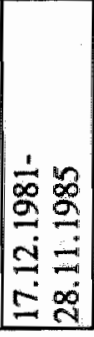 \\
\hline
\end{tabular}




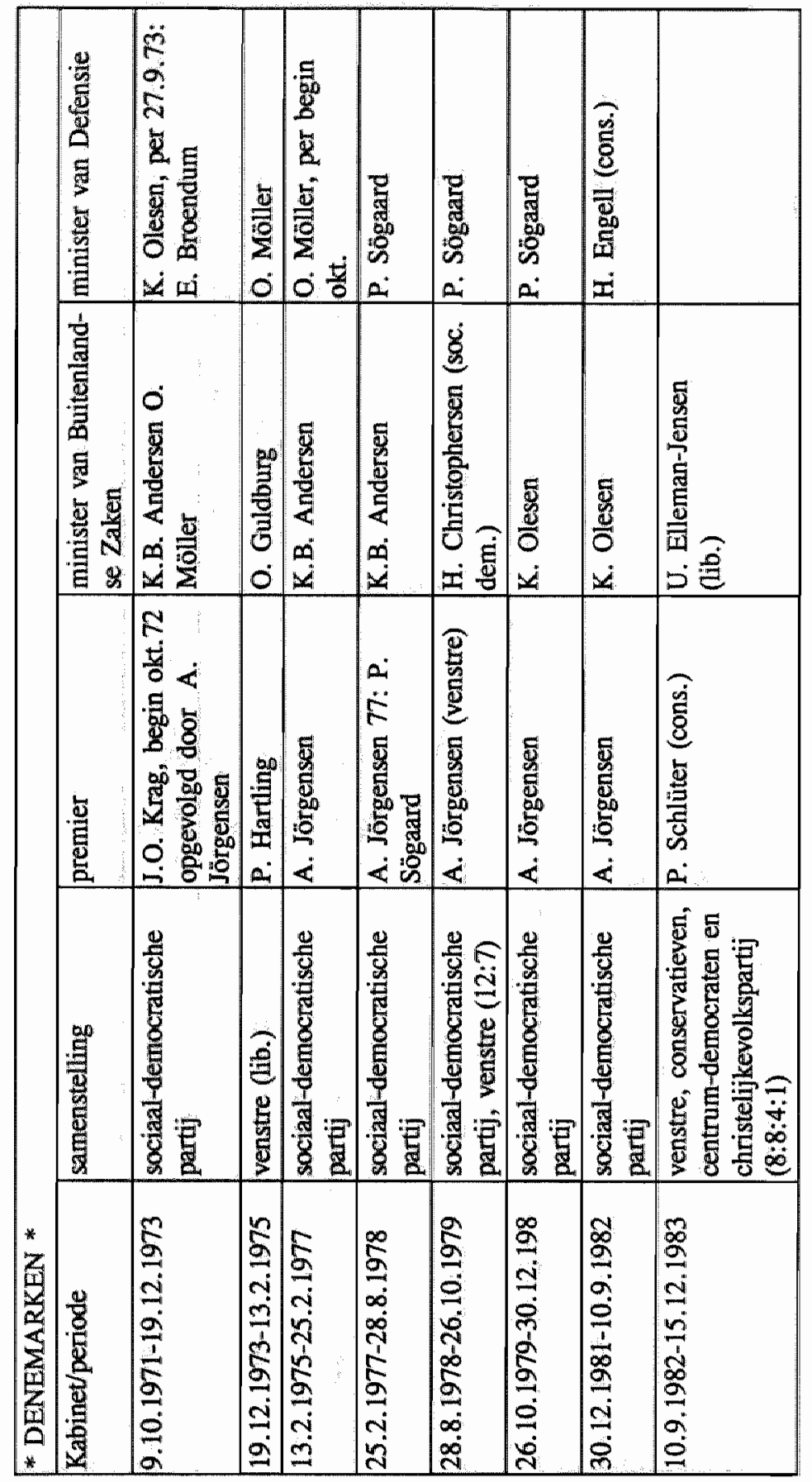




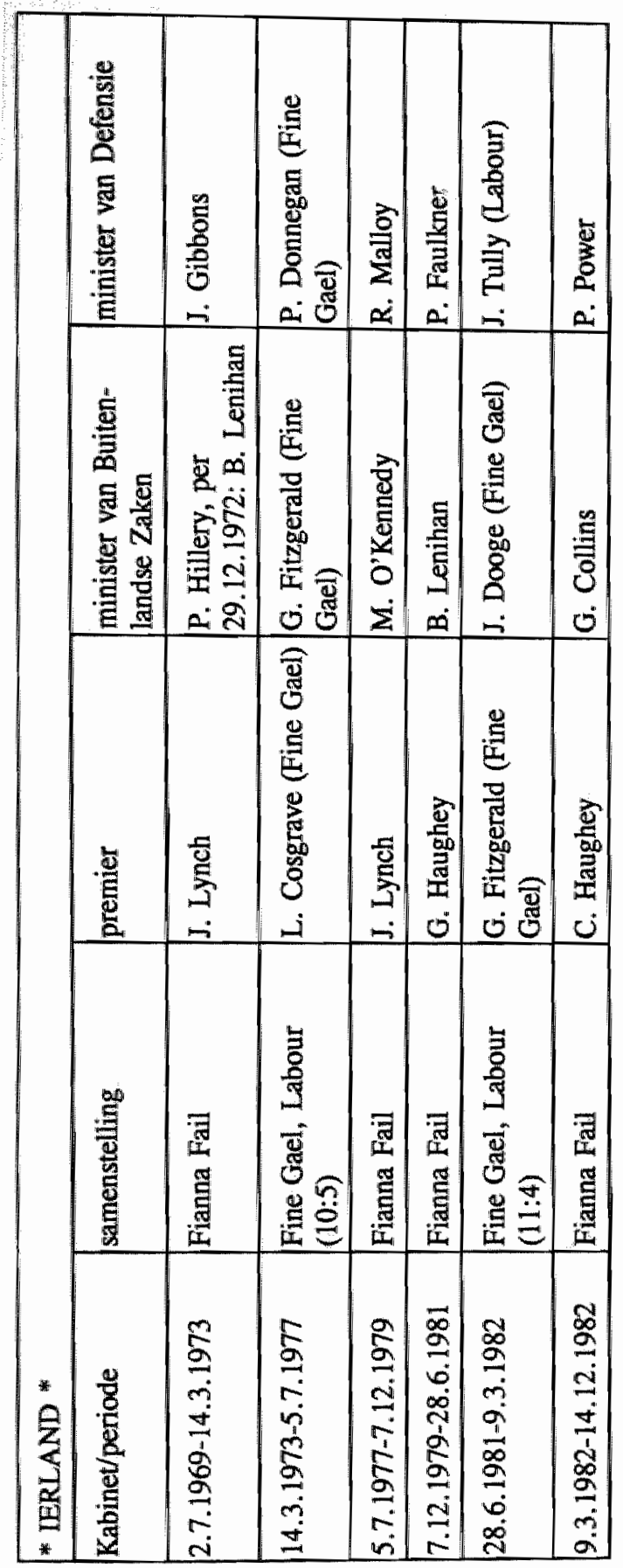




\begin{tabular}{|c|c|c|c|c|}
\hline & 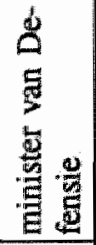 & 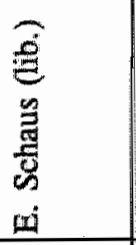 & 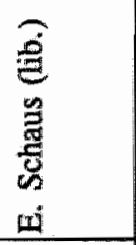 & 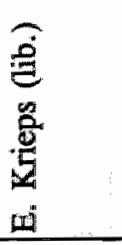 \\
\hline & 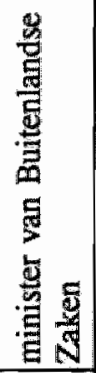 & 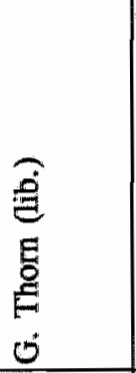 & 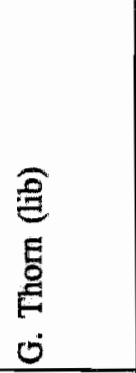 & 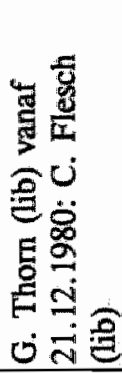 \\
\hline & $\begin{array}{l}\text { 点 } \\
\text { E } \\
\text { E. }\end{array}$ & 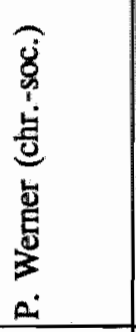 & $\begin{array}{l}\hat{\theta} \\
E \\
E \\
E \\
0\end{array}$ & 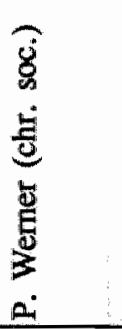 \\
\hline & 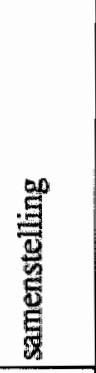 & 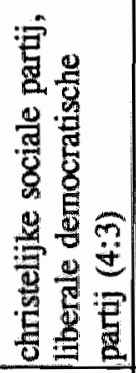 & 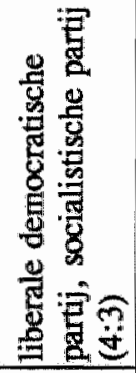 & 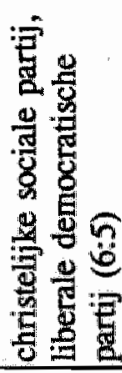 \\
\hline 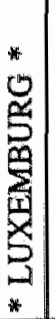 & 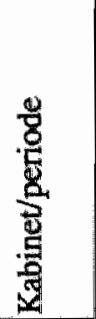 & 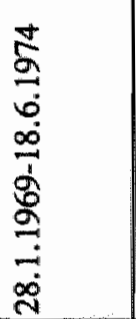 & $\begin{array}{l}\frac{9}{5} \\
2 \\
5 \\
\frac{6}{n} \\
\frac{1}{2} \\
\frac{5}{2} \\
0 \\
0 \\
0\end{array}$ & 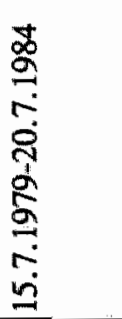 \\
\hline
\end{tabular}




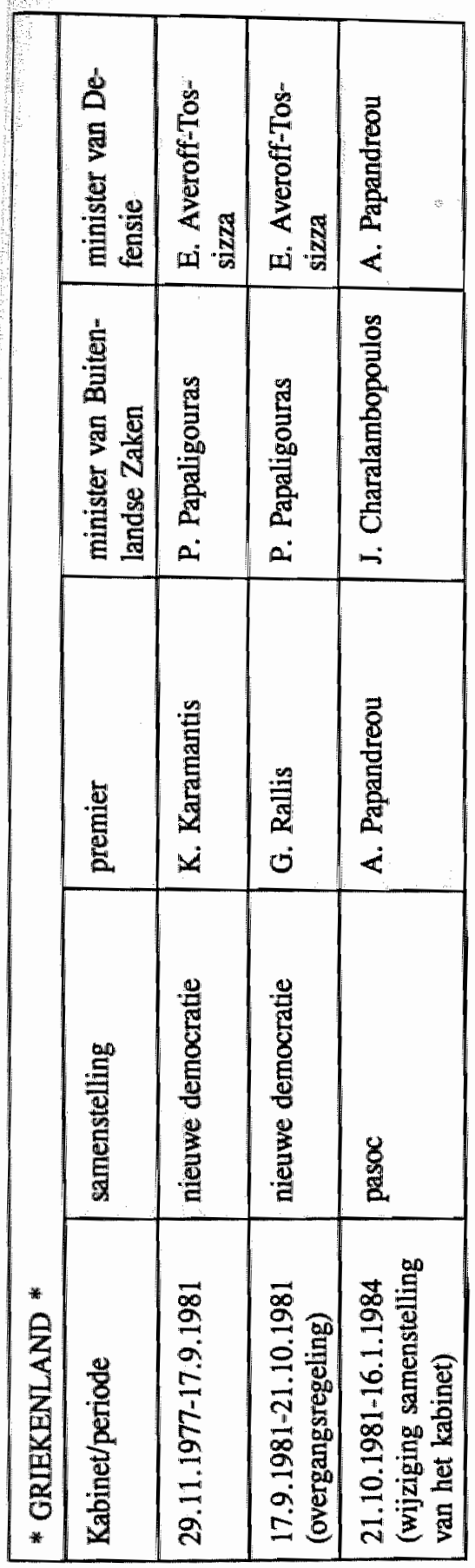




\begin{tabular}{|c|c|c|c|c|c|c|c|c|c|c|c|}
\hline 章 & & 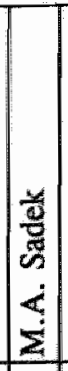 & 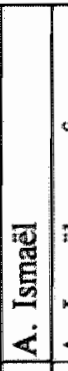 & 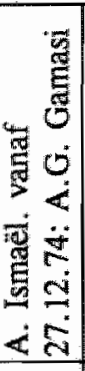 & 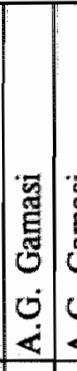 & 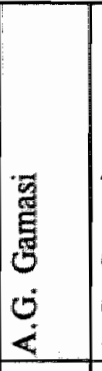 & 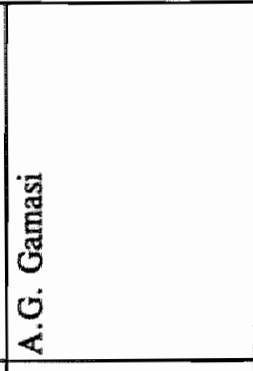 & 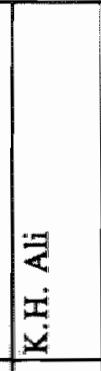 & 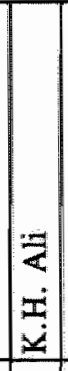 & 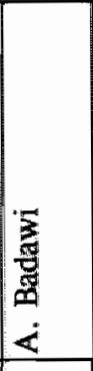 & 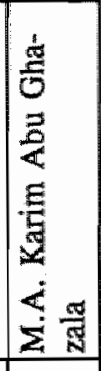 \\
\hline & 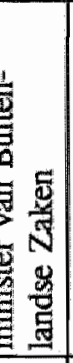 & 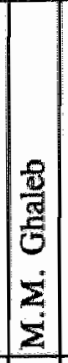 & 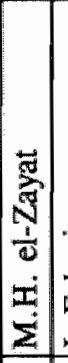 & 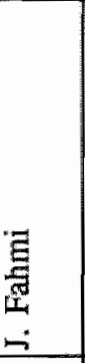 & 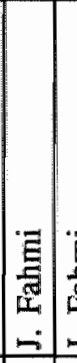 & 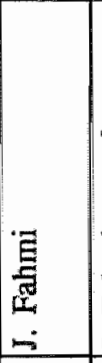 & 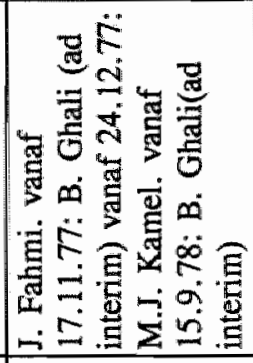 & 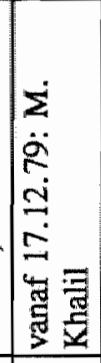 & $\mid \begin{array}{l}\mathbf{7} \\
\bar{z} \\
\Sigma\end{array}$ & 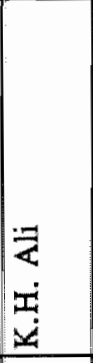 & 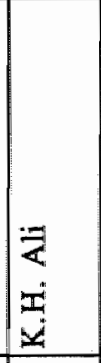 \\
\hline & & $\mid \begin{array}{l}0 \\
8 \\
0 \\
\dot{8} \\
<\end{array}$ & 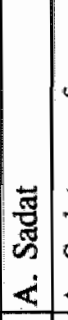 & 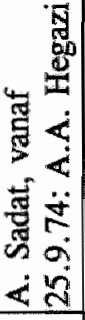 & 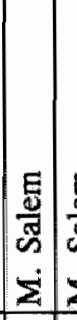 & 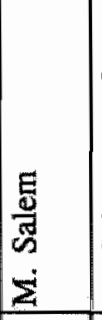 & 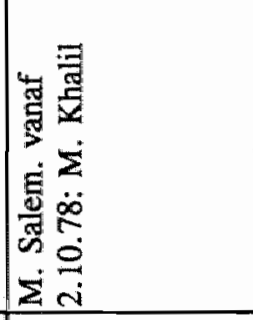 & $\begin{array}{l}\overline{7} \\
\text { 趇 } \\
\dot{\Sigma} \\
\end{array}$ & \begin{tabular}{|l}
$\mathbf{z}$ \\
$\frac{\mathbf{z}}{\mathbf{z}}$ \\
$\dot{\Sigma}$ \\
$\dot{\Sigma}$
\end{tabular} & 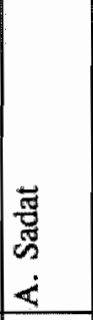 & 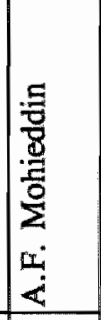 \\
\hline & $\underline{E}$ & 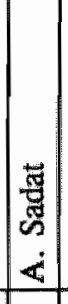 & 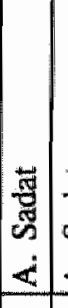 & 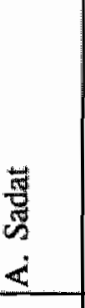 & 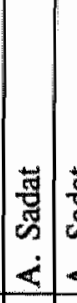 & \begin{tabular}{|l|} 
\\
矞 \\
$<$ \\
\end{tabular} & 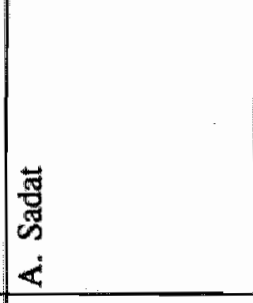 & 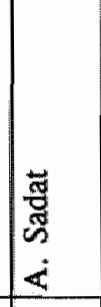 & 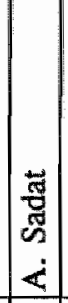 & 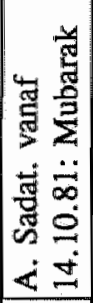 & 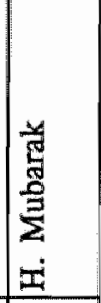 \\
\hline 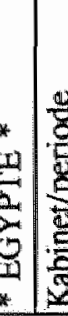 & . & 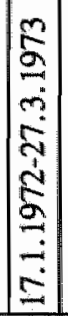 & 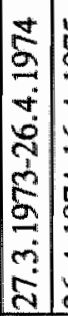 & 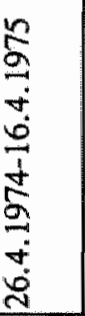 & 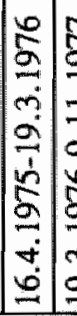 & 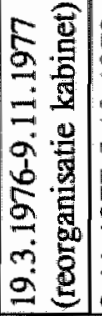 & 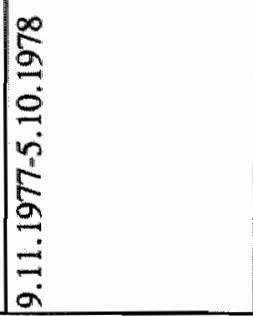 & 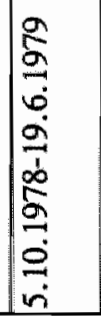 & 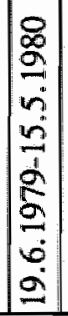 & 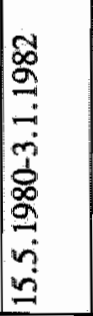 & 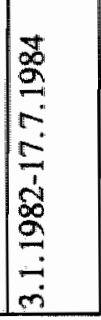 \\
\hline
\end{tabular}




\begin{tabular}{|c|c|c|c|c|c|}
\hline 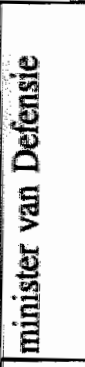 & 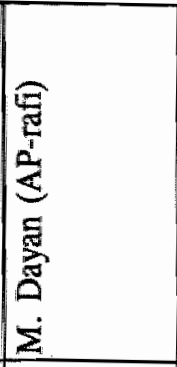 & 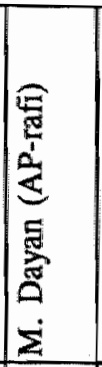 & 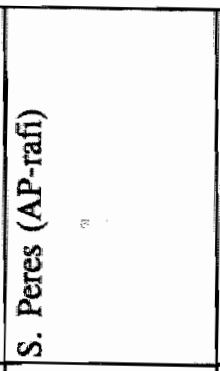 & 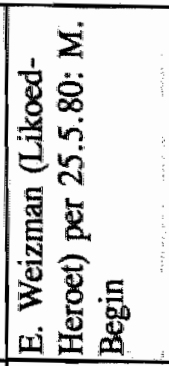 & 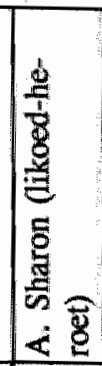 \\
\hline 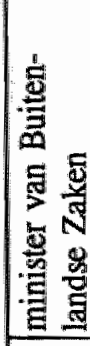 & 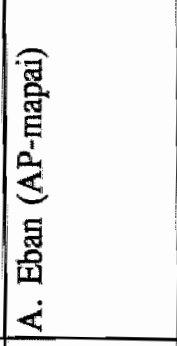 & 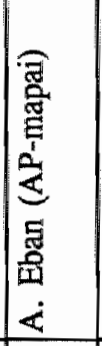 & 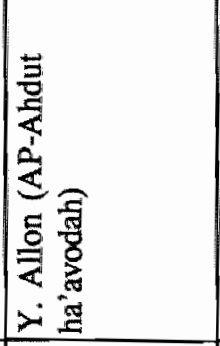 & 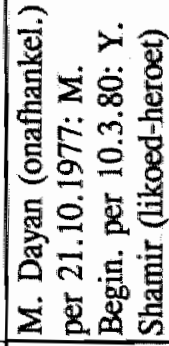 & 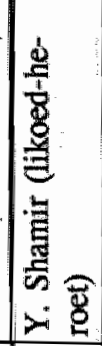 \\
\hline 㽞 & 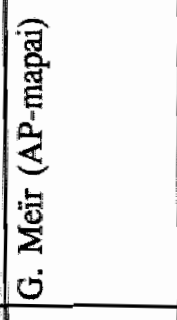 & 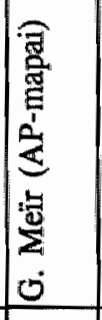 & 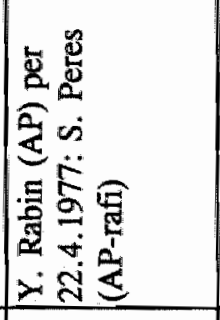 & 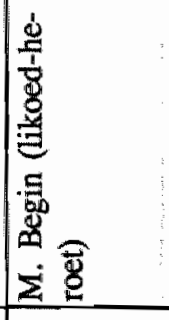 & 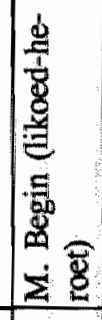 \\
\hline 兽 & 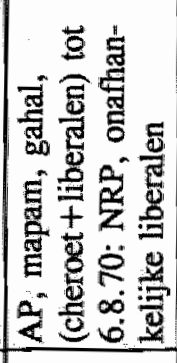 & 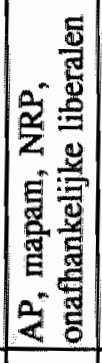 & 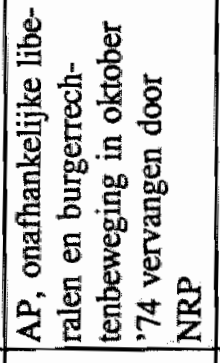 & 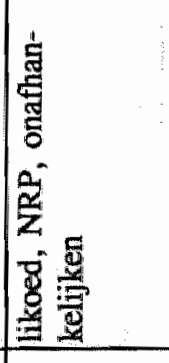 & 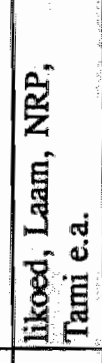 \\
\hline | & 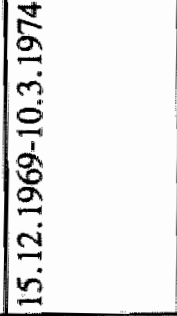 & $\mid$ & 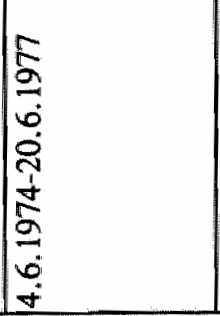 & $\mid \begin{array}{l}0 \\
0 \\
2 \\
0 \\
0 \\
0 \\
1 \\
5 \\
0 \\
0 \\
0 \\
0 \\
0 \\
\end{array}$ & 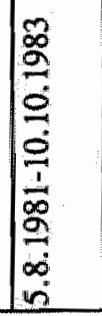 \\
\hline
\end{tabular}




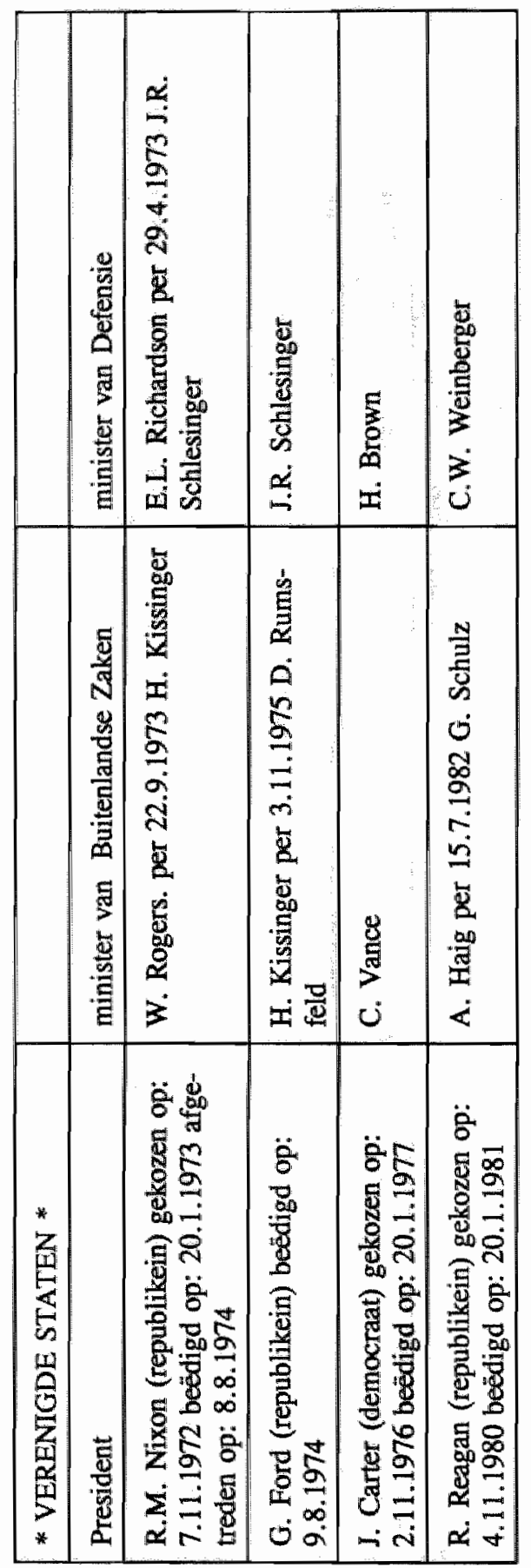




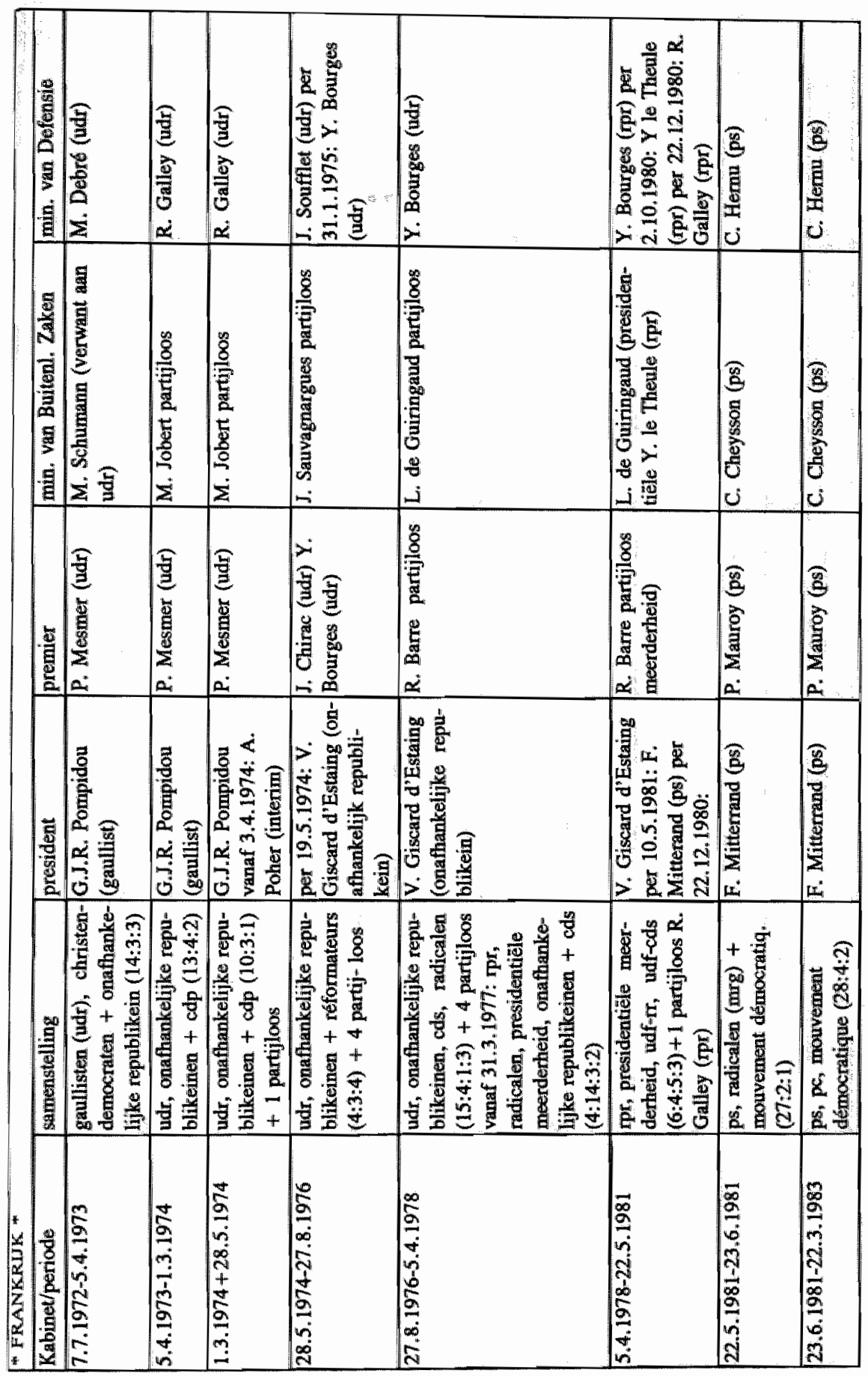




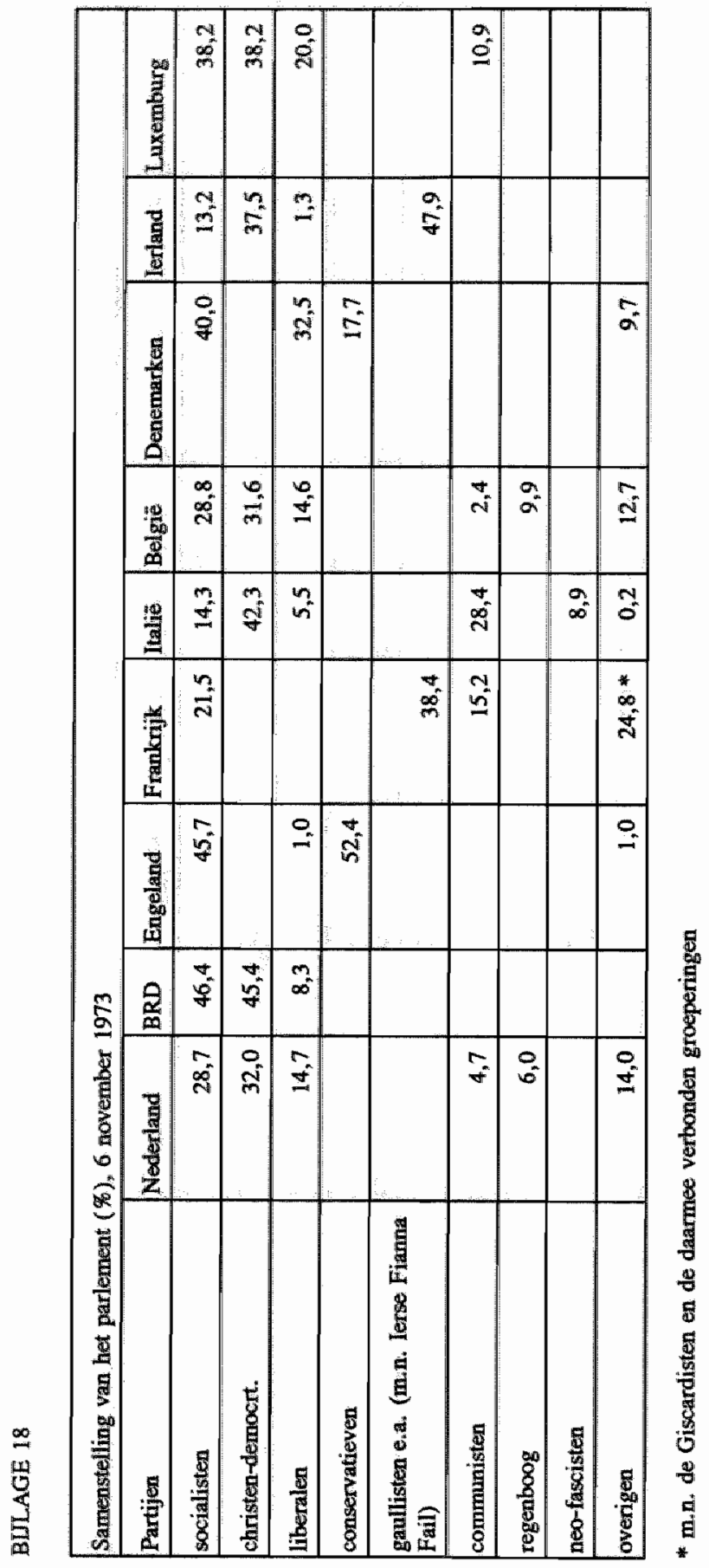




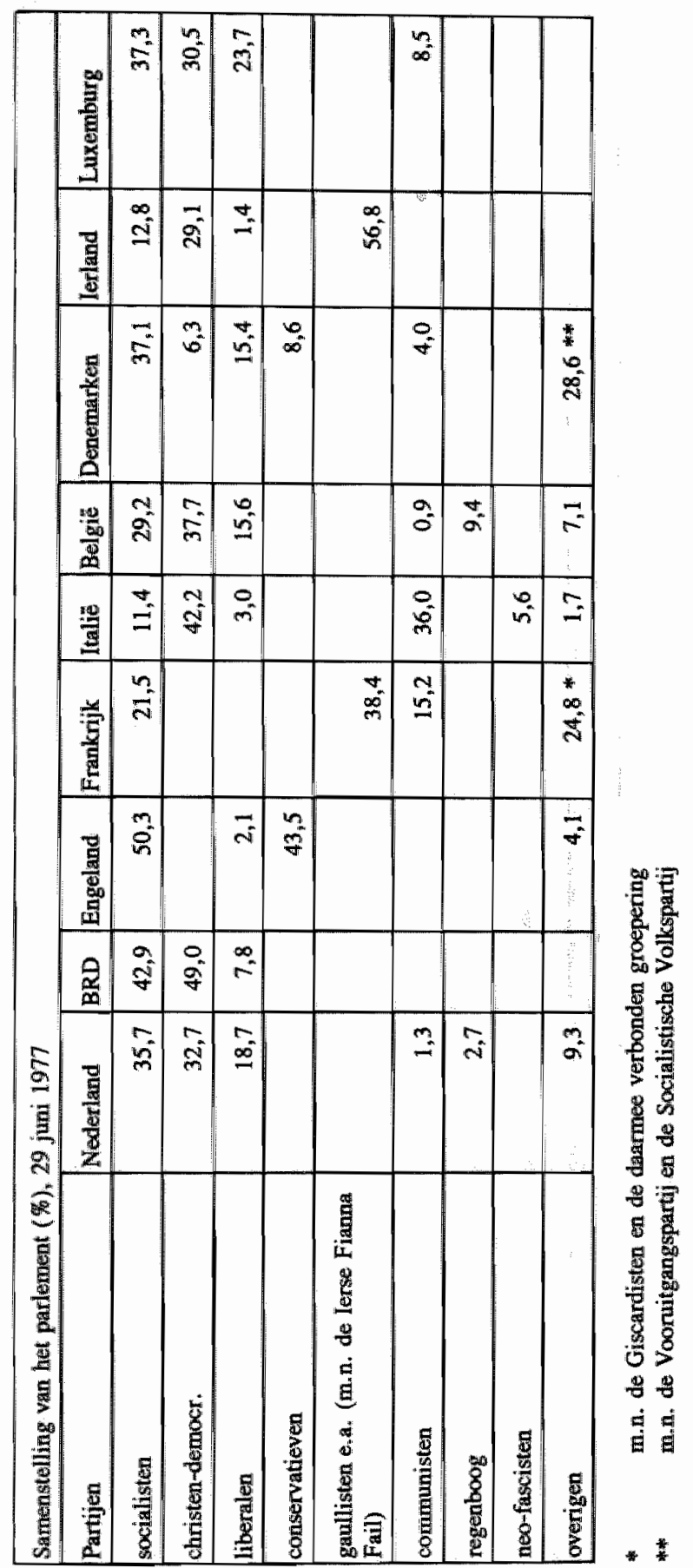




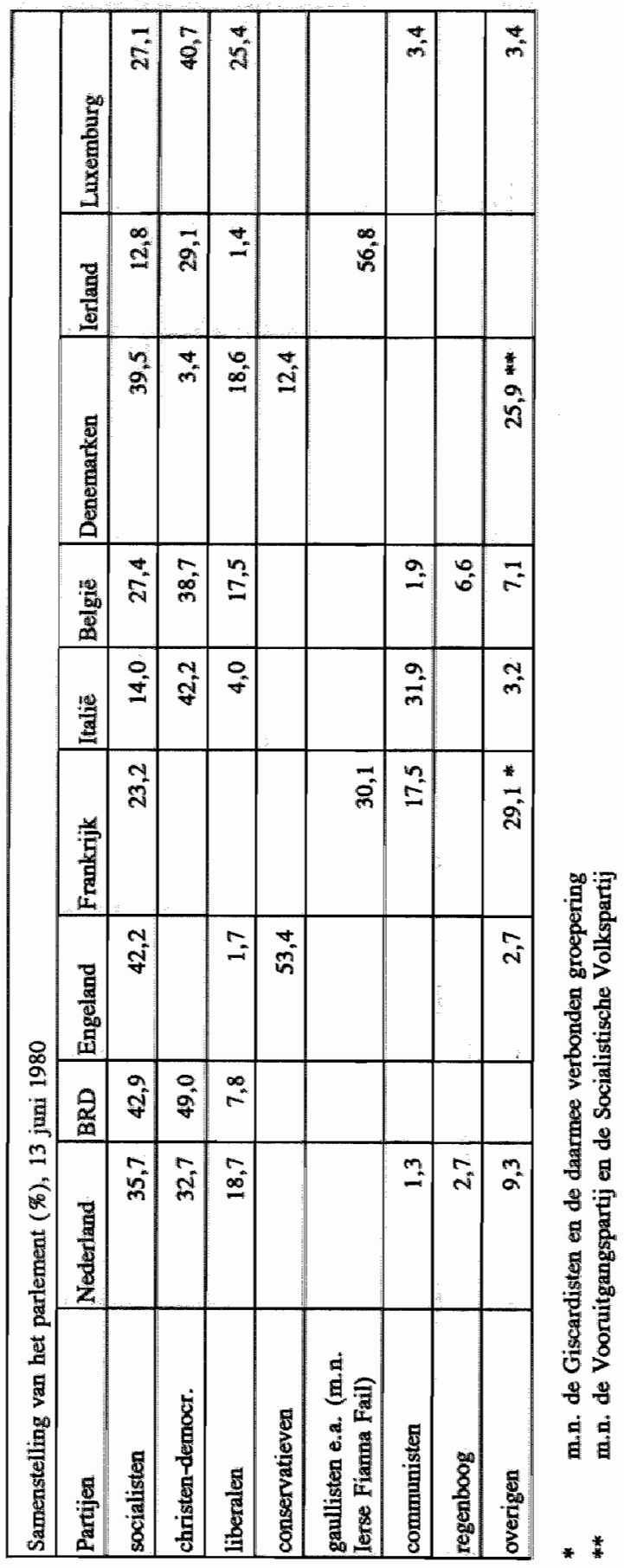




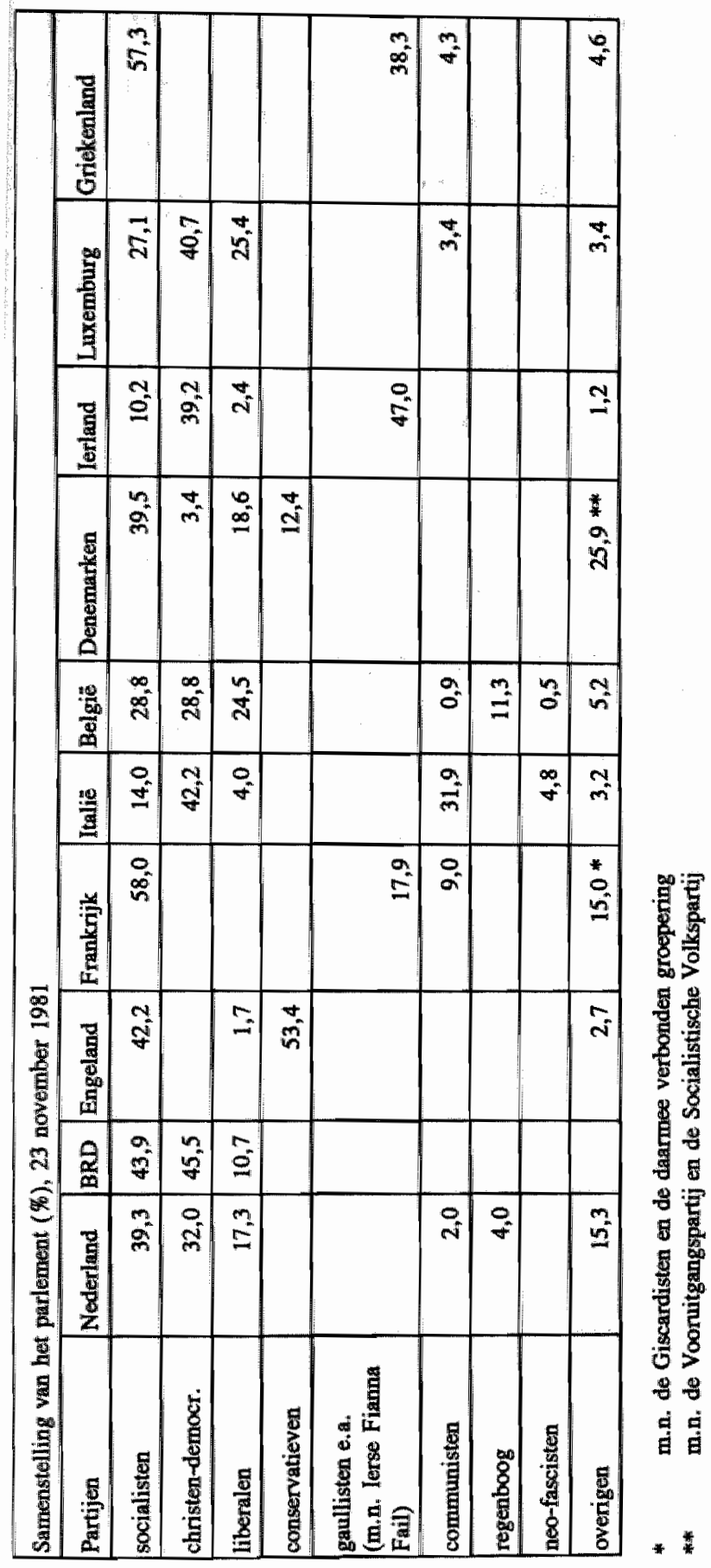


Bij het opstelling van de tabellen voor bijlage 17 A en B en 18 is gebruik gemaakt van de volgende bronnen:

Keesings historisch archief: geillustreerd dagboek van het hedendaagsch wereldgebeuren, Keesing-Amsterdam, de jaargangen 1970-1984.

A.J. Day, H.W. Degenhardt (eds.), Political Parties of the World, Longman Group Limited-Harlow, 2e druk, 1984.

Y. Simoni, Political dictionary of the Arab world, MacMillan Publishing Company-New York, Collier Macmillan Publishers-London, 1987.

Directoraat-Generaal Studiedienst van de Europese Gemeen schappen, Een parlement in volle ontwikkeling, het Europese parlement 1952-1988, 3e druk, Luxemburg, 1989.

P. Everts, G. Walraven (eds.), The Politics of persuation: implementation of foreign policy by the Netherlands, Gower-Aldershot, 1989.

A. K. Koekkoek, Partijleiders en Kabinetsformatie: een rechts vergelijkende studie over de rol van partijleiders bij de kabinetsformatie in Engeland, WestDuitsland, België en Nederland, Kluwer-Deventer, 1978.

The Statesman's yearbook: statistical and historical annual of the states of the world for the year 1974-1975, volume III (J. Paxton, ed.), Macmillan-London, 1974 .

A.S. Banks, W. Overstreet, Political handbook of the world 1981, Mc GrawHill Book Campany-New York, 1981.

Politiek jaarboek 1980, res. Publica, Belgisch Tijdschrift voor politieke wetenschappen, 1981, bundel XXIII nr. 2-3. 
overzicht van data gebeurtenissen

in 1973

6-10

$7-10$

$8-10$

8-10

8-10

9-10

$9+10-10$

$11,12+13-10$

$12-10$

13-10

13-10

$16-10$

$17-10$

$17-10$

$17-10$

17-10

20-10

21-10

21-10

22-10

$22-10$

23-10

23-10

24-10

$25-10$

$25-10$

$25-10$

$25-10$

26-10

$27-10$

28-10

30-10

$31-10$

$1-11$

2-11

4-11

4-11

4-11 start Oktoberoorlog

solidariteitsmanifestatie voor Israel in Amsterdam

Kamercommissie van Buitenlandse Zaken

militair logistieke hulp aan Israël overwogen

solidariteitsverklaring van vakbewegingen met Israël

regeringsverklaring over Midden-Oostenconflict

algemene beschouwingen Tweede Kamer

bijeenkomst comité politique in Kopenhagen

Nederlands veto in comité politique

verklaring van comité politique te Kopenhagen

solidariteitsmanifestatie voor Israël in Amsterdam

voornemen Algerijns olie-embargo tegen Nedierland bekend

onderhoud Arabische ambassadeurs met Van der Stoel

solidariteitsmanifestatie voor Palestijnen in Amsterdam

solidariteitsverklaring met Israël van bekende Nederlanders

maandelijkse reductie van olieproduktie met $5 \%$ door OAPEC

instelling olie-embargo van Algerijë tegen Nederland

verzoek Arabische Liga voor olie-embargo tegen Nederland

Irak nationaliseert aandeel Shell in de Basrah Petroleum Company

onderhoud directie Shell met Van der Stoel

resolutie 338 Veiligheidsraad

regeringsverklaring over Midden-Oostenconflict

olie-embargo van Koeweit

olie-embargo van Aboe Dhabi en Quatar

olie-embargo van Oman

alarmfase 3 voor strijdkrachten VS

resolutie 340 Veiligheidsraad

einde Oktoberoorlog

ultimatum van Saoedi-Arabie

onderhoud Saoedische ambassadeur met Van der Stoel

Nederlandse diplomaat naar Arabische Golfstaten

olie-embargo van Bahrein en Libië

Kamerdebat over olieverbruikbeperkende maatregelen

Saoedi-Arabië herhaalt waarschuwing

olie-embargo van Saoedi-Arabië

eerste 'autoloze' zondag

onderhoud van Van der Stoel met topambtenaren, toestemming tot gemeenschappelijke EG-verklaring

verklaring president-directeur Koninklijke/Shell over gelijke verdeling van olie 
reductie export olie met $25 \%$ door OAPEC

Brits dreigement aan Van der Stoel gemeenschappelijke verklaring van EG over Midden-Oosten te Brussel aanbod van Schlesinger voor Amerikaanse hulp aan Nederland onderhoud Den Uyl met president-directeur KoninklijkeShell onderhoud Den Uyl met president-directeur KoninklijkeShell Nederlands dreigement over beperking export van aardgas Nota van Van der Stoel over Midden-Oostenconflict Nederlandse diplomat naar Saoedi-Arabië OAPEC handhaaft olie-embargo tegen Nederland maar ziet af van $5 \%$ reductie in december voor andere EG-lidstaten

EPS-overleg van de ministers van Buitenlandse Zaken

Kissinger herhaalt aanbod VS tot hulp aan Nederland

Duitse steun voor Nederlandse positie onderhoud Lubbers met olieministers van Algerije en Saoedi-Arabië bijeenkomst energie-raad van EG voorlichter Buitenlandse Zaken op non-actief voorzitter Europese Commissie dreigt met aftreden onderhoud Van der Stoel met Kissinger Nederland herhaalt dreigement inzake export van aardgas toespraak Kissinger met voorstel tot olie-verbruikersorganisatie Europese Raad te Kopenhagen Amerikaanse onderminister voor oliezaken herhaalt aanbod tot hulp aan Nederland in gesprek met Den Uyl en Lubbers Britten torpederen gemeenschappelijk energiebeleid Geneefse vredesconferentie

uitnodiging van Nixon voor energieconferentie benzinedistributie in Nederland EPS-overleg Israëlisch-Egyptisch troepenscheidingsakkoord beëindiging benzinedistributie overleg ministers in EG over energieconferentie energieconferentie in Washington met verklaring Israëlisch-Syrisch troepenscheidingsakkoord opheffing olie-embargo tegen Nederland door Algerije algehele opheffing olie-embargo tegen Nederland begin van de Euro-Arabische dialoog oprichting IEA resolutie 3236 - zelfbeschikkingsrecht Palestijnse volk - in de VN aanvaard Tweede Kamerdebat over Nederlandse opstelling in de VN 
Israëlisch-Egyptisch deelakkoord

in 1976

verklaring Van der Stoel in de VN over nationale identiteit van het Palestijnse volk

ministers van Buitenlandse Zaken van de EG te Londen over MiddenOosten, werkdocument over Palestijnse entiteit Tweede Kamerdebat over EPS-bijeenkomst te Londen Carter spreek zich uit voor een eigen land voor de Palestijnse vluchtingen socialisten verliezen in Israëlische verkiezingen voor parlement verklaring van Europese Raad over Midden-Oosten te Londen Russisch-Amerikaanse verklaring voor Geneefse vredesconferentie Sadat naar Israël EG-verklaring te Brussel

in 1978

$17-9$

$19-9$

in 1979
Camp Davidakkoorden EG-verklaring te Bonn

Israëlisch-Egyptisch vredesverdrag

EG-verklaring te Parijs

EG-verklaring te Parijs

beëindiging UNEF II

toespraak Ierse minister O'Kennedy voor de VN

Britten overwegen een voorstel resolutie 242 te wijzigen Europese Raad in Luxemburg Amerikaanse minister Muskie verzet zich tegen wijziging resolutie 242 Eerste Kamerdebat over Midden-Oosten werkgroep Midden-Oosten van de EPS te Rome Carter kondigt aan dat de VS over een wijziging van resolutie 242 in de Veiligheidsraad een veto zal uitspreken comité politique van de EPS te Rome; geen wijziging 242 meer voorgesteld 
debat Tweede Kamercommissie voor Buitenlandse Zaken Europese Raad in Venetië met verklaring over Midden-Oosten Eerste Kamerdebat

$1+2-12$ Tweede Kamerdebat in 1981

$23+24-3$

$18-5$

$19-5$

$23-6$

$29+30-6$

3-8

6-10

10-10

$13+14-10$

22-10

26-10

3-11

23-11

23-11

25-11

26-11

27-11

3-12

3-12

$7-12$

in 1982
Europese Raad in Maastricht afwijzing VN vredesmacht voor de Sinaï principe-akkoord tussen de VS, Egypte en Israël over MFO overeenstemming tussen de VS, Egypte en Israël over MFO Europese Raad in Luxemburg ondertekening protocol MFO door Egypte, Israël en de VS Sadat vermoordt begrafenis Sadat EPS in Londen tussen ministers van Buitenlandse Zaken bekend wordt dat Nederland wil deelnemen aan MFO EG ministers van Buitenlandse Zaken over deelname MFO in Luxemburg overleg VS-Nederland regeringsverklaring over deelname MFO Europese verklaring over deelname MFO Arabische topconferentie te Fez verwerpt plan Fahd Begin wil Israëlische ministerraad adviseren Europese deelname over MFO af te wijzen

onderhoud Shamir met Haig over Europese deelname MFO Israëlisch-Amerikaanse verklaring over Europese deelname MFO brief van Shamir aan de vier Europese participanten Cheysson verklaart dat er geen Europees initiatief zal komen en dat de verklaring van Venetië een vergissing was

memorandum van de beoogde vier Europese participanten in de MFO aan Israël

brief van de beoogde vier Europese participanten in de MFO aan de vs

brief van Haig aan Shamir over Europese deelname MFO Israëlisch kabinet keurt Europese deelname van MFO goed Kamerdebat over Nederlandse deelname MFO Nederlandse deelname aan MFO door ministerraad goedgekeurd Kamerdebat over Nederlandse deelname MFO Europese Raad in Brussel. 
Israëlische terugtrekking uit de Sinaï voltooid. MFO begint aan haar taak

EG ministers van Buitenlandse Zaken te Luxemburg met verklaring over Israëlische overdracht van de Sinaï 


\section{BULAGE 20}

Olie-embargo

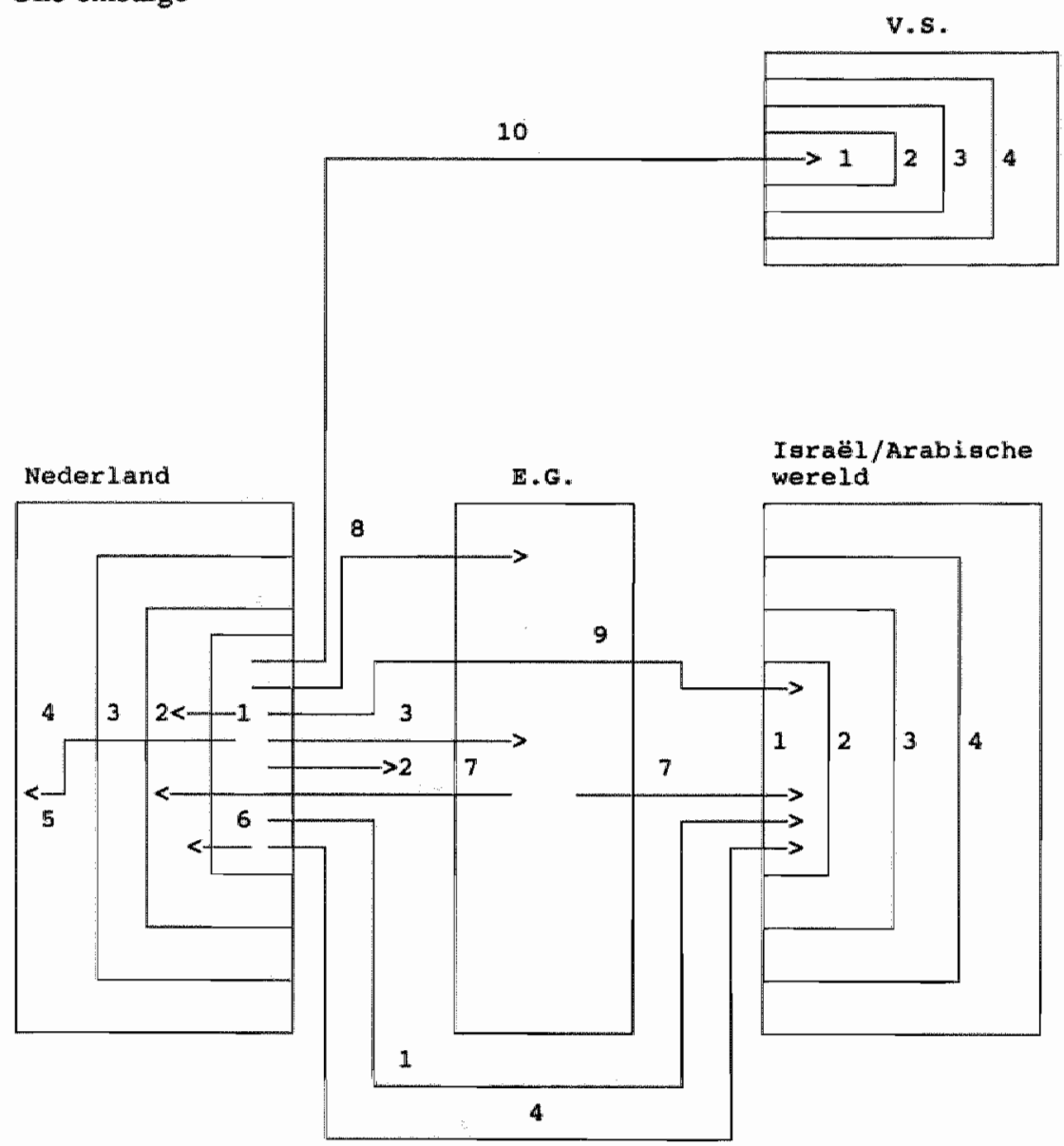


1. Het in overweging nemen van de mogelijkheid van Nederlandse militaire hulp aan Israël.

2. Verklaring van de Nederlandse regering over het Midden-Oostenconflict.

3. Nederlands veto op EPS-bijeenkomst over Brits-Frans mandaat.

4. Nederlandse diplomatie in de Arabische wereld.

5. Maatregelen ter beperking van binnenlands ollieverbruik.

6. Toestemming tot gemeenschappelijke EG-verklaring.

7. Instemming met gemeenschappelijke EG-verklaring Brussel.

8. Dreiging van afsluiten van aardgas naar EPS-partners.

9. Instemming met EG-verklaring Kopenhagen.

10. Instemming met verklaring conferentie van Washington.

Bij toepassing van het schema - bijlage 2 - van de aanpassingsbenadering op de tien beslissingen, blijkt dat de systeemvariabelen betrekkelijk weinig invloed hadden op de eerste drie beslissingen. Daarentegen hebben de systeemvariabelen bij de beslissingen 6 en 7 een zeer belangrijke rol vervuld. Bij de tiende beslissing waren zowel de systeemvariabelen als de maatschappelijke en rolvariabelen van belang.

De beslissingen die onder $4,5,8$ en 9 zijn behandeld lenen zich niet goed voor deze indeling. Bovenstaande komt erop neer dat Nederland aanvankelijk een beleid van onverzoenlijke aanpassing volgde, vervolgens een beleid van inschikkelijk aanpassing en tenslotte een beleid van aanpassende aanpassing.

\begin{tabular}{|l|l|l|l|l|l|l|}
\hline $\begin{array}{l}\text { Rangorde } \\
\text { van varia- } \\
\text { belen }\end{array}$ & \multicolumn{2}{|l|}{ Beslissingen } \\
\hline & 1 & 2 & 3 & 6 & 7 & 10 \\
\hline Hoog & $\begin{array}{l}\text { samenle- } \\
\text { ving } \\
\text { individu }\end{array}$ & $\begin{array}{l}\text { maatsch. } \\
\text { regering }\end{array}$ & $\begin{array}{l}\text { maatsch. } \\
\text { regering }\end{array}$ & $\begin{array}{l}\text { systeem } \\
\text { regering }\end{array}$ & systeem & $\begin{array}{l}\text { systeem } \\
\text { samenle- } \\
\text { ving }\end{array}$ \\
\hline Laag & $\begin{array}{l}\text { systeem } \\
\text { systeem }\end{array}$ & systeem & $\begin{array}{l}\text { samenle- } \\
\text { ving }\end{array}$ & $\begin{array}{l}\text { samenle- } \\
\text { ving }\end{array}$ & individu \\
\hline Resultaat & $\begin{array}{l}\text { onverzoen- } \\
\text { lijke } \\
\text { aanpassing }\end{array}$ & $\begin{array}{l}\text { onverzoen- } \\
\text { lijke } \\
\text { aanpassing }\end{array}$ & $\begin{array}{l}\text { onverzoen- } \\
\text { lijke } \\
\text { aanpassing }\end{array}$ & $\begin{array}{l}\text { inschikke- } \\
\text { lijke } \\
\text { aanpassing }\end{array}$ & $\begin{array}{l}\text { inschikke- } \\
\text { lijke } \\
\text { aanpassing }\end{array}$ & $\begin{array}{l}\text { bewarende } \\
\text { aanpassing }\end{array}$ \\
\hline
\end{tabular}




\section{BULAGE 21}

\section{Verklaring van Venetië}

Nederland

E.G.

İraë1/Arablache

wereld

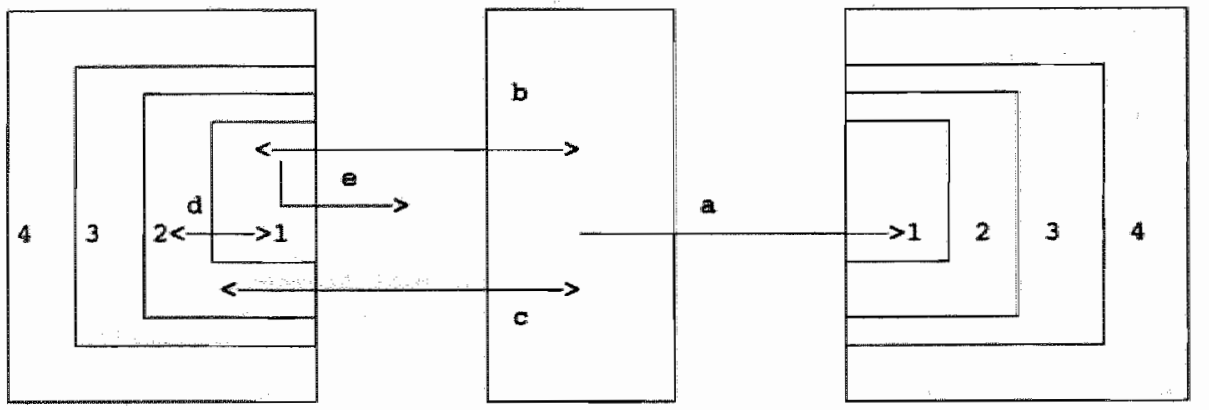

De Verklaring van Venetië was het gemeenschappelijke internationaal politieke standpunt over het Midden-Oosten; een 'outcome' van een internationaal politiek samenwerkingsverband naar derden (a). Er was enige Nederlandse inbreng bij de totstandkoming van deze verklaring van zowel de regering (b) (de directe besluitvormers) als de ambtenaren van Buitenlandse Zaken (c) (de formele politieke elite). Overleg tussen beide categorieën actoren over de totstandkoming van deze verklaring vond plaats (d). Het gemeenschappelijk standpunt in de internationale politiek werd vervolgens als Nederlands buitenlands beleid beschouwd (e).

Bij de beslissing tot instemming met de verklaring van Venetië speelden de systeemvariabelen een belangrijke rol. De regerings- en maatschappelijke variabelen waren minder belangrijk.

De instemming met de verklaring van Venetië kan als een beleid van inschikkelijke aanpassing van de regering worden beschouwd. 


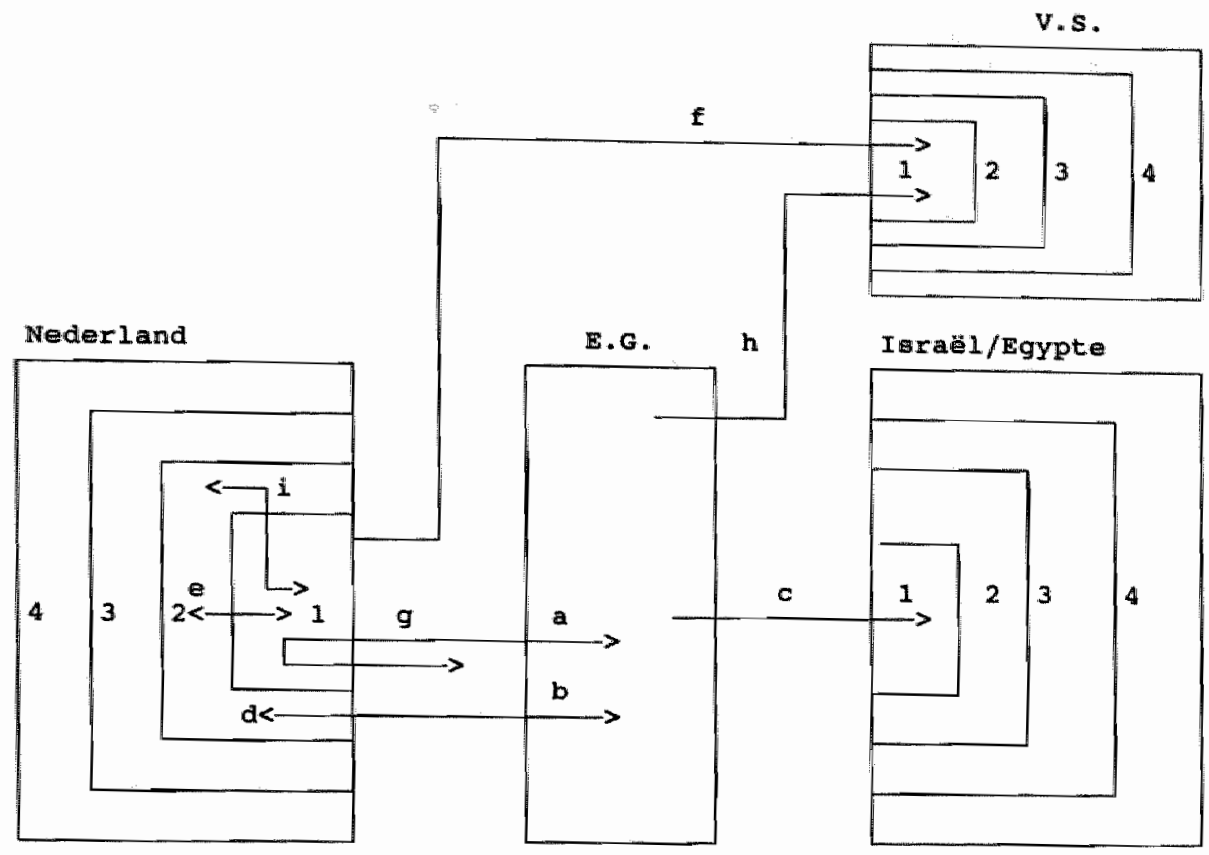

Nederland had een zelfstandige inbreng bij de besiuitvorming tot participatie in de MFO. De minister van Buitenlandse Zaken (a) en zijn ambtenaren (b) droegen tot deze beslissing bij. Het was nog geen buitenlands beleid van Nederland omdat ook nog geen overleg met het parlement, met uitzondering van enig vertrouwelijk beraad met enkele Kamerleden, had plaatsgevonden. In een gemeenschappelijk internationaal politiek standpunt werd de deelname aan de betrokkenen bekend gemaakt (c). Bij de totstandkoming werden de Nederlandse ambtenaren beïnvloed door de standpunten van hun collega's uit de EG (d). De Nederlandse ambtenaren van Buitenlandse Zaken voerden overleg met hun minister (e). Nederland trad in overleg met de regering van de VS over de tot stand te brengen inhoud van het gemeenschappelijke internationale standpunt (f). Het gemeenschappelijke politieke standpunt werd vervolgens Nederiands buitenlands beleid en de tevoren gemeenschappelijk vastgestelde (door vier van de Tien) bekendmaking, werd als 'nationale verklaring' naar buiten gebracht (g). Een verduidelijking vanuit de EG aan de VS volgde (h). Tenslotte werd na overleg met het parlement deze beslissing tot participatie in de MFO aanvaard (i).

Bij de beslissing tot deelname aan de MFO, waarbij de Europese partners deze participatie ondersteunden, waren zowel systeemvariabelen als maatschappelijke - en regeringsvariabelen van belang. Dat duidt op een beleid van bewarende aanpassing. 



\section{LIJST VAN ARCHIEVEN EN PERSDOCUMENTATIE}

Archieven:

PvdA bestuur, het Internationaal Instituut voor Sociale Geschiedenis, Amsterdam; het partijbureau, Amsterdam.

PvdA Tweede-Kamerfractie, Tweede Kamer, Den Haag.

ARP Tweede-Kamerfractie, bij de heer Aantjes, Utrecht.

KVP bestuur en Tweede-Kamerfractie, Katholiek Documentatie Centrum, Nijmegen.

CHU Tweede Kamerfractie, Tweede Kamer, Den Haag.

CDA bestuur, partijbureau, Den Haag.

PSP bestuur, partijbureau, Amsterdam.

PSP Tweede-Kamerfractie, Tweede Kamer, Den Haag.

Centrum voor Informatie en Documentatie Israël, Den Haag.

Nederlandse Zionisten Bond, Amsterdam.

Werkgroep Israël, Amsterdam.

Raad van Kerken, sectie International Zaken, Den Haag.

Keesings Historisch archief.

\section{Persidocumentatie:}

Europe, Agence Internationale d'information pour la presse.

Daily Reports of the Foreign Broadcast Information Service, Middle and East Africa. Pers Instituut, Universiteit van Amsterdam, Amsterdam.

Pers Documentatie, Vrije Universiteit, Amsterdam.

Centrum voor Informatie en Documentatie Israël, Den Haag.

Rijks Voorlichtings Dienst, Den Haag.

Het Parool, Amsterdam.

Vrij] Nederland, Amsterdam.

De Groene, Amsterdam.

Nieuw Israëlietisch Weekblad, Amsterdam.

Katholiek Documentatie Centrum, Nijmegen.

Bibliotheek Tweede Kamer, Den Haag.

Instituut voor het Moderne Nabije Oosten, Universiteit van Amsterdam; Amsterdam. Binnenlandse en buitenlandse dagbladen en weekbladen.

Publieke Opinie:

Baschwitz Instituut voor Massa Communicatie, Universiteit van Amsterdam, Amsterdam. 
Parlementaire verslagen:

Nederland: Handelingen Eerste en Tweede Kamer.

Frankrijk: Débats de l'Assemblée Nationale. Journal officiel de la république Française, Débats parlementaires Assemblée Nationale. Sénat, Comptes rendus des débats.

Bondsrepubliek Duitsland: Verhandlungen und Anlagen des Deutschen Bundestages.

Verenigd Koninkrijk: House of Commons, Foreign Affairs Committee. Parliamentary Debates, Official Report, House of Commons.

België: Annales Parlementaires de Belgique, Chambre des Représentants. Parlementaire Handelingen van België, Kamer van Volksvertegenwoordigers.

Italië: Camera dei Deputati, Atti Parlementari. Senato della Republica.

Australië: Parliamentary Debates House of Representatives, Commonwealth of Australia.

Verenigde Staten: House, Committee on foreign Affairs. House of Representatives. US Senate Committee on Foreign Relations.

Europees Parlement: Publikatieblad van de Europese Gemeenschappen, Handelingen van het Europees Parlement.

Jaarboeken e.d.:

Verenigde Naties: Ministerie van Buitenlandse Zaken, Verslagen over de zittingen van de Algemene Vergadering der Verenigde Naties. Official records of the General Assembly; Yearbook of the United Nations. Verslagen van de Commissie der Verenigde Naties voor de Rechten van de Mens.

Europese Gemeenschap: Bulletin van de Europese Gemeenschappen.

Ministerie van Buitenlandse Zaken, Department of State Bulletin. Jaarboek van het Departement van Buitenlandse Zaken, La politique étrangère de la France, Ministère des relations exterieurs, Textes et Documents.

International Institute for Strategic Studies: Strategic Survey, Military Balance. 
Lijst van geìnterviewden met functie en datum van interview

- Aantjes, W.

- Basoski, A.J.

- Beugel, E.H. van der

- Boers, A.

- Boon, R.

- Dam, N. van

- Davignon, E.

- Etty, T.

- Fiedler, H.

- Grooth, G.B. de

- Gualthérie van Weezel, J.S.L.

- Hendriks, A.

- Iersel, J.P. van

- Klaauw, C.A. van der fractievoorzitter in de Tweede Kamer van de ARP en CDA, op 28 december 1982.

directeur Centraal Orgaan voor de Economische Betrekkingen met het Buitenland, op 27 augustus 1982 .

voorzitter van het overlegorgaan met het bedrijfsleven, op 19 november 1982.

voorzitter van de Nederlandse Zionisten Bond, op 6 april en 6 juli 1982.

fractiemedewerker in de Tweede Kamer van de PSP, op 24 november 1982.

directie Afrika en Midden-Oosten, ministerie van Buitenlandse Zaken, op 3 september 1987.

direkteur-generaal politieke zaken, ministerie van Buitenlandse Zaken in Brussel, op 22 juni 1987.

beleidsmedewerker internationale zaken FNV, op 26 april 1982.

direkteur van de afdeling voor het Midden-Oosten, ministerie van Buitenlandse Zaken in Bonn, op 15 oktober 1987

direkteur-generaal Buitenlandse Economische Betrekkingen, ministerie van Economische Zaken, op 24 maart 1983.

lid Tweede Kamer voor het CDA, op 6 april 1983.

voorzitter van het Nederlands Palestina Komitee, op 11 februari 1983.

lid Tweede Kamer voor het CDA, op 21 maart 1983.

minister van Buitenlandse Zaken, op 31 augustus 1989. 
- Koster, H.J. de

- Lubbers, J.H.

- Lynden, D.W. van

- Meijer, J.

- Meijer, F.P.G. de

- Metzemaekers, L.A.V.

- Mierlo, H.A.F.M.O. van

- Miles, R.O.

- Mommersteeg, J.A.

- Naftaniel, R.M.

- Patijn, S.

- Portheine, F.

- Pronk, J.P.

- Reinink, K.W.

- Rossum, H. van

- Rutten, M.H.J.C. lid Tweede Kamer voor de VVD, op 31 december 1982.

ambassadeur in de Verenigde Staten, op 6 maart 1987.

direkteur-generaal politieke zaken, ministerie van Buitenlandse Zaken, op 13 september 1982.

direkteur-generaal internationale samenwerking, ministerie van Buitenlandse Zaken, op 15 oktober 1982.

studiesecretaris Katholieke Raad voor Israël, op 26 november 1981.

adviseur in politieke zaken van de honorair consul van Koeweit (M.S. Rabbani), op 2 juni 1982.

minister van Defensie, op 2 april 1987.

direkteur van de afdeling voor Noord-Afrika en de Arabische staten aan de Middellandse zee, ministerie van Buitenlandse Zaken in Londen, op 24 juni 1987.

lid Tweede Kamer voor het CDA, op 24 februari 1983.

direkteur van het Centrum voor Informatie en Documentatie Israël, op 21 september 1982.

lid Tweede Kamer voor de PvdA, op 7 december 1981.

lid Tweede Kamer voor de VVD, op 25 maart 1983. minister voor Ontwikkelingssamenwerking, op 17 maart 1983.

direkteur-generaal politieke zaken, ministerie van Buitenlandse Zaken, op 5 februari 1987.

lid Tweede Kamer voor de SGP, op 16 maart 1983. direkteur-generaal politieke zaken, ministerie van Buitenlandse Zaken, op 10 februari 1987. 
- Scheltema, $\mathbf{H}$.

- Serry, R.H.

- Stoel, M. van der

- Uyl, J.M. den

- Wajsberg, $\mathbf{H}$.

- Well, G. van

- Zijerveld, J.P.J. permanente vertegenwoordiger bij de Verenigde Naties, New York, op 8 augustus 1989.

hoofd van het bureau Midden-Oosten, ministerie van Buitenlandse Zaken, op 3 september 1987.

minister van Buitenlandse Zaken, op 17 november 1982 en 11 februari 1987.

minister-president, op 26 februari 1987.

voorzitter Werkgroep Israël, op 24 maart 1982.

direkteur-generaal politieke zaken ministerie van Buitenlandse Zaken in Bonn, op 30 januari 1990.

secretaris sectie internationale zaken van de Raad van Kerken, op 30 juni 1982

De interviews met Van Iersel en Gualthérie van Weezel werden door M.C. Groenendijk gehouden. Het interview met Pronk werd door G. Walraven en het interview met Van Mierlo door P.J. Knegtmans afgenomen. Bijna alle interviews staan op cassettebanden en van alle interviews zijn verslagen gemaakt. Deze berusten bij de auteur. 
Door onder meer de volgende personen werd uitgebreid commentaar gegeven op de tekst van dit proefschrift betreffende hun rol in het besluitvormingsproces:

Lubbers, R.F.M.

Lynden, D.W. van

Meijer, J.

Pronk, J.P.

Reinink, K.W.

Van der Stoel, $\mathbf{M}$.

Uyl, J.M. den

Wagner, G.A. minister van Economische Zaken, brief van 15 augustus 1990 .

directeur politieke zaken, brief van 3 augustus 1983.

directeur-generaal internationale samenwerking, brief van augustus 1983 .

minister voor Ontwikkelingssamenwerking, brief van 28 juli 1983.

directeur-generaal politieke zaken, brief van 7 januari 1988.

minister van Buitenlandse Zaken, brief van 1 september 1983 en 7 januari 1988.

minister-president, brief van 28 februari 1984 .

president-directeur Koninklijke/Shell groep, brieven van 29 november 1983, 13 januari 1984 en 5 april 1984. 
Aangehaalde literatuur

Abram, I.B.H.,

Agsteribbe, A.J.,

Akehurst, M.,

Akkermans, P.W.C.,

Allen, D, Rummel R. and Wessels, W.,

Allen, D.,

Allen D., en Smith, M.,

Allen, D. en Byme, P.,

Allen, D. en Pijpers, A. (eds.),

Allison G.T.,

Almond, G.A.,

Amerongen, J. van,
Joodse identiteit en multicultureel onderwijs, in:

Ter Herkenning, (12), 1984, no. 3 , pp. 78-85.

Antisemitisme, antizionisme. Het huidige antizionisme in Nederland, CIDI, Den Haag, 1977.

A modern introduction to international law, Unwinn Hyman, London, 1987.

De Grondwet, W.E.J. Tjeenk-Willink, Zwolle, 1987.

European political cooperation: towards a foreign policy for western Europe,

Butterworth scientific, London etc., 1982.

Political cooperation and the Euro-Arab dialoque, in: Allen, Rummel and Wessels, 1982, pp. 69-82.

Europe, the United States, and the Arab-Israeli conflict, in: Allen en Pijpers, 1984, pp. 187-210.

Multilateral decision-making and implementation: the case of the European Community, in:

Smith and Clark (eds.), 1985, pp. 123-141.

European foreign policy-making and the Arab-Israeli conflict, Martinus Nijhoff Publishers, Den Haag, 1984.

Essence of decision, Explaining the Cuban missile crisis,

Little Brown and Company, Boston, 1971.

The elites and foreign policy in:

Rosenau, 1967, pp. 268-272.

Recensie: Seidel, G., De ontkenning van de holocaust, in:

Transaktie, (18), 1989, no. 4, pp. 402-405. 
Andel, C.P. van,

Artner., S.J.,

Aschkenasy, Y.,

Asscher, M.,

Baehr, P.R.,

Baehr, P.R.,

Baehr, P.R. e.a.,

Bailey, S.D.,

Balta, P.,

Bank, J.,

Barents, R.,

Benthem, van van den Bergh, G.,
Jodenhaat en jodenangst. Over meer dan twintig eeuwen antisemitisme,

De Horstink, Amersfoort, 1984.

The Middle East: a chance for Europe? in:

International Affairs, (56), 1980, no. 3, pp. 420-442.

Heroriëntatie van de theologie, een voortgaand leerproces, openbaar afscheidscollege, Amsterdam, 1989.

Het Internationle Energie Agentschap; over samenwerking en solidariteit in:

Ars Aequi (29), 1980, no. 10, pp. 679-685.

De studie van de buitenlandse politiek; toegang tot de internationale betrekkingen (oratie),

Boom en zoon, Meppel, 1970.

Power and influence in international politics, in:

Meijers en Vierdag (eds.), 1977, pp. 1-20.

Elite en buitenlandse politiek in Nederland, Staatsuitgeverij, 's-Gravenhage, 1978.

The making of resolution 242,

Martinus Nijhoff Publishers, Dordrecht, Boston, Lancaster, 1985.

Le dossier Arabe les Pays-Bas, in:

Maghreb-Machrek no. 61, janvier-février 1974, pp. 1416.

Recentie: proefschrift Soetendorp 1982, in:

Bijdragen en Mededelingen betreffende de Geschiedenis der Nederlanden, (99), 1984, pp. 281-284.

Het Internationale Energie Agentschap, in:

VerLoren van Themaat, P., (hoofdred.), 1977, pp. 231277.

Dwang en bevrijding; essays en kritieken, Van Gennep, Amsterdam, 1972. 
Blaauw, J.W.H. e.a.,

Blaauw, J.W.H.,

Bleich, A.,

Boer, C. de,

Bonvicini, G.,

Boon, H.N.,

Bruyn, L.P.J. de,

Bruyn, L.P.J, de, Foppen, J. W., Hoogerwerf A.,

Carter, Jimmy,

Carter, Th,

Cassese, A.,

Chan, S.,

Claude, L.L.,
Geen plek om het hoofd neer te leggen, Israel en de Palestijnen,

Ten Have, Baam, 1983.

Verklaring over het antisemitisme, in:

Blaauw e.a., 1983, pp. 111-117.

Israël, de Palestijnen en de holocaust, in:

De Groene Amsterdammer, 4 mei 1988, pp. 12-13.

West European public opinion and the Palestine question, in:

Zureik and Moughrabi (eds.), 1987, pp. 85-142.

Mechanisms and procedures of EPC: more than traditional diplomacy, in:

Pijpers, Regelberger, Wessels (eds.), 1988, pp. 49-70.

Afscheidsaudiëntie. Studies over de diplomatieke praktijk,
A.D. Donker, Rotterdam, 1976.

Beleidsoriëntatie en partijkeus, in:

Acta Politica, (VII), 1972, no. 1, pp. 48-58.

De Nederlandse kiezers 1972 ,

Samson, Alphen aan de Rijn, 1973.

Keeping faith. Memoirs of a president, Bantam Books, Toronto, New York, London, Sydney 1982.

VN-vredesmachten van Kongo tot Libanon, in:

Internationale Spectator, (38), 1984, no. 1, pp. 43-52.

Internationall law in a divided world,

Oxford University Press, Oxford, 1988.

International relations in perspective, the pursuit of security, welfare and justice,

Macmillan Publishing Company, New York, 1984.

Swords into plowshares, The problems and progress of international organization, Random House, New York, 1971. 
Clerq, G. de,

Colijn, J. en Rusman, P.,

Corney, H.

Dajani, M.S.,

Dayan, M.,

Demant, P.,

Deutsch, K.W.,

Doel, H., van den en Lammers, H. (e.a.),

Dougherty, J.F. and Pfalzgraff, R.L.,

Easton, D.,

Eban, A.,

Eggen, A.Th.J., Van

der Eyk, C,

Niemöller, B.,
Energiecrisis en voorraadvorming, in:

Sociaal Economische Wetgeving, 1979, no. 5, pp. 336357.

Wapenleveranties-II: de leverantie van twee onderzeeboten aan Taiwan, Instituut voor Internationale Studiën Rijksuniversiteit Leiden, Leiden, 1984.

Britain and Israel: the Carrington era and after, in: Institute of Jewish Affairs Research Reports, 1982, no. 9, pp. 1-12.

Conflict and conflict resolution: political initiatives and formulas for peace in the Middle East, dissertatie, University of Texas, Austin, 1982.

Story of my life, an autobiography, William Morrow and Company, New York, 1976.

De Graven der Vaderen en de levens van de zonen: het Israëlisch-Joods vredeskamp tot 1983, in:

De Rooy en Van der Linde, (red.), 1989, pp. 48-75.

The analyses of international relations, Prentice-Hall, Englewood Cliffs, 1968 (1988).

Tien over Rood: Uitdaging van Nieuw Links aan de PvdA.,

Polak \& Van Gennep, Amsterdam, 1966.

Contending theories of international relations, Harper \& Row, New York, 1981.

A framework for political analysis, The University of Chicago Press, Chicago, 1979.

An autobiography, Random House, New York, 1977.

Kiezen in Nederland 1981, Acta Boek, Zoetermeer, 1988. 
Ellemers, J.E.,

Ellemers, J.E.,

Evangelista, M.,

Everts, Ph.P.,

Everts, Ph.P.,

Everts, Ph.P.,

Everts, Ph.P. (ed.),

Everts, Ph. P and Walraven, G. (eds.),

Eytan, F.,

Farrel, R.B. (ed.),

Feldman, L.G.,

Frankel, J.,
Een onderzoek naar bimnenlandse invloeden op het buitenlands beleid, in:

Transaktie, (8), 1979, no. 1, pp. 96-109.

Macht, in:

Rademaker, L. (red.), 1981, pp. 277-297 en 370-373.

Issue-area and foreign policy revisited, in:

International Organization (43), 1989, no. 1, pp. 147171.

Een onderzoek naar binnenlandse invloeden op het buitenlands beleid - een theoretische verantwoording in: Baehr, e.a., 1978, pp. 1-24.

"Wat vinden de mensen in het land"? Openbare mening en kernwapens, in:

Acta Politica (XVI), 3, 1981, pp. 305-354.

Public opinion, the churches and foreign policy; studies of domestic factors in the making of Dutch foreign policy, dissertatie, Instituut voor Internationale Studièn Rijksuniversiteit Leiden, Leiden, 1983.

Controversies at home: Domestic factors in the foreign policy of the Netherlands, Martinus Nijhoff Publishers, Dordrecht, 1985.

The politics of persuasion, implementation of foreign policy by the Netherlands, Gower Publishing Group, Aldershot, 1989.

David et Marianne, La France, les juifs et Israël, Alain Moreau, Parijs, 1986.

Approaches to comparative and international politics, North Western University Press, Evanston, 1966.

The special relationship between West Germany and Israel, Allen \& Unwin, Boston, 1984.

International relations in a changing world, Oxford University Press, Oxford 1977 (3e ed.), 1988, (4e ed.). 
Gainsborough, $\mathbf{J} . \mathbf{R}$,

Gans, M.H.,

Giebels, L.,

Gilboa, E.,

Ginkel, J. van,

Golan, M.,

Gortzak, W. (red.),

Greilsammer, I.,

Greilsammer, I. and Weiler, J.H.H.,

Greilsammer, I., and Weiler, J.H.H.,

Greilsammer, I., and Weiler, J.H.H. (eds.),

Grieves, F.L. (ed.),

Grosser, A.,
The Arab-Israeli Conflict; a politico-legal anallysis, Gower, Alderhot, 1986.

De Joden in Nederland (oratie), Universitaire pers, Leiden, 1976.

De zionistische beweging in Nederland 1899-1941 (dissertatie), Van Gorcum \& Co., Assen, 1975.

American public opinion toward Israel and the ArabIsraeli conflict, Lexinton Books, Massachusetts, Toronto, 1987.

Het Westen en de oliecrisis 1973-1974, Staatsuitgeverij, 's-Gravenhage, 1978.

Kissingers geheime diplomatie, Agathon, Bussum, 1976.

De kleine stappen van het kabinet-Den Uyl, Gesprekken met PvdA-bewindslieden, Kluwer, Deventer, 1978.

Israèl et l'Europe: une historie des relations entre la Communauté Européenne et l'Etat d'Israël, Centre de Recherches Euopéennes, Lausanne, 1981.

European political cooperation and the Palestinian-Israeli conflict: an Israeli perspective, in:

Allen and Pijpers, 1984, pp. 121-160.

Europe's Middle East Dilemma; The quest for a unified stance,

Westview Press, Boulder and London, 1987.

Europe and Israel, troubled neighbours, Walter de Gruyter, Berlin, New York, 1988.

Transnationalism on world politics and business, Pergamon Press, New York, 1979.

The Western alliance, European-American relations since 1945, Vintage Books, New York, 1982. 
Grünfeld, F.,

Grünfeld, F.,

Grünfeld, F. and Knegtmans, P.J.,

Hahn, H.J.,

Haig, jr. A.M.,

Heldring, J.L.,

Hermann, C.F. Kegley, C.W., Rosenau, J.N.,

Heykal, M.,

Hoadley S.J and Hasegawa, S.,

Holsti, K.J.,

Hommes, P.M., (red.).,

Hontelez, J. en Lek, B. van der,
Nederland en het Midden-Oosten. Het Arabisch olie-embargo 1973/1974. De verplaatsing van de Nederlandse ambassade in Israël, 1980,

Instituut voor Internationale Studiën, Rijksuniversiteit Leiden, Leiden, 1984.

Beînvloeding van het congres, in:

Internationale Spectator, (41), 1987, no. 5, pp. 267-268.

Europe and the Middle East conflict, in:

Everts and Walraven (eds.), 1989, pp. 189-202.

Continuity in the law of international organization, in:

Oesterreichische Zeitschrift für öffentliches Recht, (13), 1962, (H 3-4), pp. 167-239.

Caveat; Realism, Reagan and foreign policy, Macmillan Publishing Company, New York, 1984.

The impact of the energy crisis on Dutch policy and politics, Paper voor Western European study group, the Atlantic insitute, Parijs, 15-16 mei 1975.

New Directions in the study of foreign policy, Allen and Unwinn, Boston, 1987.

The road to ramadan, William Collins Sons \& Co, London, 1975.

Sino-Japanese relations 1950-1970: an application of the linkagemodel of international politics, in:

International Studies Quarterly, (15), 1971, no. 2., pp. 131-157.

International Politics: A Framework for analysis, Englewood Cliffs, Prentice-Hall Inc., New Jersey, 1972 (1988).

Nederland en de Europese eenwording, Martinus Nijhoff, Den Haag, 1980.

Het grote democratische gat in de Europese Gemeenschap, in:

Ars Aequi, (38), 1989, no. 5, pp. 349-357. 
Houten, $\mathbf{A}_{\text {., wan den }}$ en Kopuit, M.,

Houwaart, D.,

Iersel, J.P. van,

Ifestos, $P_{.}$,

Irwin G.A., Verhoef J., Wiebrens C.J.

(eindred.),

Ismael, T.Y.,

Jacobson, H.K.,

Jobert, M.,

Jobert, M.

Jong, L. de,

Joris, L.,

Kamel, M.I.,
Wij staan achter Israël, wij hebben achter Israël gestaan; de evenwichtige politiek wan Nederland, Amphora Books, Amstelveen, 1981.

Journalistieke verkenningen door Israël, Semper Agenda, Apeldoorn, 1973.

De energiecrisis en het Nederlandse EG-beleid, in: Politiek Perspectief, november-december 1973.

European Political Cooperation, Gower Publishing Group, Alderschot, 1987.

De Nederlandse kiezer " 77 , Voorschoten, 1977.

International relations of the contemparary Middle East. A study in world politics, Syracuse University Press, (z.p.) 1986.

Networks of interdependence. International organizations and the global political system,

Alfred A. Knopf, New York, 1984.

Mémoires d'avenir, Grasset, Paris, 1974

1'Autre regard, Grasset, Paris, 1976.

Het Koninkrijk der Nederlanden in de Tweede Wereldoorlog,

Deel 8, Gevangenen en gedeporteerden, band 2, Martinus Nijhoff, 's-Gravenhage, 1979.

De Palestina lobby, in:

De Haagse Post, 14 februari 1981, pp. 24-33.

The Camp David Accords, KPI, London, 1986. 
Kapteyn, P.J.G.

VerLoren van The-

maat; $\mathbf{P .}$,

Karns, M.P. en

Mingst, K.A.,

Khader B.,

Kimche, J.,

Kissinger, H.A., in:

Kissinger, $H_{\text {. }}$,

Kleerekoper, S.,

Kopuit, M, (red.),

Kortmann, C.A.J.M.,

Kuyper, P.J.,

Kuypers, G.,

Langemeyer, F.F.,

Laqueur, W.,
Inleiding tot het recht van de Europese Gemeenschappen,

Kluwer, Deventer, 1987.

International organizations and foreign policy; influence and instrumentality, in:

Hermann, Kegley, Rosenau (eds.), 1978, pp. 454-474.

Europe and the Arab-Israeli conflict 1973-1983,

an Arab perspective, in:

Allen and Pijpers, 1984, pp. 161-186.

Carrington's Caviare, in:

Midstream (XXVIII), 1981, no. 6, pp. 4-6.

American foreign policy, pp. 11-52,

Weidenfeld \& Nicolson, 1969.

Years of Upheaval,

Weidenfeld \& Nicolson Lid, London, 1982.

Het antisemitisme en zijn randverschijnselen,

Van Loghum Slaterus, Deventer, 1970.

Mijn Israël,

JiN. Voorhoeve, Den Haag, 1982.

De verdediging in de nieuwe Grondwet, in:

Militair Rechtelijk Tijdschrift, juni 1980 , no. 6, pp. 361-166.

Erkenning: politiek in het wolkenrecht en volkenrecht in de politiek, in:

Internationale Spectator, (XXVIII), 1974, no. 17, pp.

587-594.

Grondbegrippen van politiek, Het Spectrum BV, Utrecht/Antwerpen, 1973.

De voorgestelde wijziging van art. 33 van de Dienstplichtwet, in:

Militair Rechtelijk Tijdschrift, (74), 1981, pp. 513-521.

Confrontation, The Middle East war and world politics, Abacus, London, 1974. 
Leeuwen, M. van,

LeRoy Bennett, A.,

Leurdijk, D.A.,

Leurdijk, J.H.,

Lewis, S.W,

Licklider, R.,

Lijphart, A.,

Lipschits, I.,

Lipschits, I.,

Lynden, D.W. van,

Maghroori, R. and Gorman, S.M.

Meïr, G.,
Lobby's in actie, achtergronden bij het Amerikaanse

Midden-Oosten beleid,

Nederlands Instituut voor Internationale Betrekkingen

'Clingendael', 's-Gravenhage, 1986.

International organizations, principles and issues, Prentice Hall, Englewood Cliffs, 1984 (1988).

VN-vredemachten, macht of onmacht? in:

Maatschappij en krijgsmacht, (8), no. 6, 1986.

De analyse van de wereldsamenleving, in:

Soctendorp/Van Staden (red.), 1987, pp. 37-64.

The United States and Israel: constancy and change, in: Quandt, 1988, pp. 217-257.

Political power and the Arab oil weapon: the experience of five industrial nations, University of California Press, Berkeley, 1988.

Paradigmata in de leer der internationale betrekkingen (oratie),

J.H. De Bussy, Amsterdam, 1969.

Honderd jaar NIW. Het Nieuw Israëlietisch Weekblad, 1865-1965,

Polak \& Van Gennep, Amsterdam, 1966.

Verkiezingsprogramma's: verkiezingen voor de Tweede Kamer der Staten-Generaal 1977, 1981, Staatsuitgeverij, Den Haag, 1977 en 1981.

Perspectieven voor de Europese politieke samenwerking, in:

International Spectator, (XXVI), no. 17, pp. 16511667.

The Yom-Kippur War: a case study in crisis decisionmaking in American foreign policy, University Press of America, Washington, 1981.

My life,

Dell, New York, 1976. 
Mendershausen, $\mathbf{H}_{\text {, }}$

Meulen, J.W. van der,

Meijers, $H_{.}$, and

Vierdag, E.W. (eds.),

Morgenthau, H.J.,

Naftaniel, R.M.,

De Nederlandse kiezers in 1967,

$\mathrm{Oz}, \mathrm{A}$,

Paust, J.J. and Blaustein, A.P.,

Pearson, F.S.,

Pelcovits, N.A.,

Pijpers, A.E.,

Pijpers, A.,
Coping with the oil crisis; French and German experiences;

The John Hopkins university Press, Baltimore, 1976.

Het Westen en zijn olievoorziening,

Staatsuitgeverij, 's-Gravenhage, 1982.

Essays on international law and relations in honour of A.J.P. Tammes,

Sijthoff, Leiden, 1977.

Politics among nations, The struggle for power and peace,

Alfred A. Knopf, New York, 1985.

Verkiezingen ' 81 , standpunten over het Midden-Oosten, CIDI, Den Haag, 1981.

Sociaal Wetenschappelijk Instituut van de Vrije Universiteit Amsterdam, Agon Elsevier, Amsterdam, Brussel, 1967.

Hier en daar in Israël, verslag van een reis, Veen, Utrecht/Antwerpen, 1984.

The Arab oilweapon, Dobbs Ferry, 1977.

Netherlands foreign policy and the 1973-1974 oil embargo: the effects of transnationalism, in:

Grieves, 1979, pp. 114-138.

Peacekeeping on Arab-Israeli fronts, lessons form the Sinai and Lebanon, Westview Press, Boulder, London, 1984.

De binnenlandse bronnen van de buitenlandse politiek: stagnerende theorievorming, in:

Acta Politica, (XIV), 1979, no. 3, pp. 379-404.

European participation in the Sinai peace-keeping force (MFO), in:

Allen and Pijpers, 1984, pp. 211-223. 
Pilpers, A, Regelsberger, E. and Wessels, W. (eds.),

Pijpers, A.,

Pijpers, A.E.,

Pogany, I.S.,

Praag, H. van, Zwi

Werblowsky, R.J.,

Presser, J.,

Quandt, W.B.,

Quandt, W.B.

Quandt, W.B., (ed.),

Ra'anan, G.,

Rademaker, L. (red.),

Raeymaeker, O.,

Regelsberger, E.,
European political cooperation in the $1980^{\prime} \mathrm{s}$ : a common foreign policy for Western Europe?

Nijhoff, Dordrecht, 1988, pp. 143-165.

The Twelve out-of-area: a civilian power in an uncivil world?, in: Pijpers, Regelsberger and Wessels, 1988, pp. $143-165$.

The vicissitudes of European Political Cooperation; Towards a Realist interpretation of the EC's collective diplomacy, dissertatie Rijksuniversiteit Leiden, 22 mei 1990.

The Security Council and the Arab-Israeli conflict, Gower Publishing Company, Aldershot, 1984.

Antisemitisme antizionisme, De Haan, Bussum, 1969.

Ondergang. De vervolging en verdelging van het Nederlandse Jodendom 1940-1945, Staatsuitgeverij, Martinus Nijhoff, 's-Gravenhage, 1965.

Decade of decisions: American policy toward the ArabIsraeli conflict 1967-1976,

University of California Press, Berkeley, Los Angeles and London, 1977.

Camp David peacemaking and politics, The Brookings Institution, Washington D.C., 1986.

The Middle East, Ten years after Camp David, The Brookings Institution, Washington D.C., 1988.

United States credibility: the Carter Administration, in: Middle Fast Review (13), no. 2, 1980-1981, pp. 16-21

Sociologische grondbegrippen I: Theorie en analyse, Het Spectrum, Utrecht/Antwerpen, 1981.

België en de Israëlisch-Arabische conflicten 1948-1978, University Press, Leuven, 1979.

EPC in the 1980's: reaching another plateau? in:

Pijpers, Regelsberger, Wessels (eds.), 1988, pp. 3-48. 
Renkema, I.,

Ribbelink, O.M.,

Roggen, P.,

Rolef, S.H. (ed.),

Rooy, P. de, en Linde, $C$ van der (red.),

Roschar, F.M.,

Rosenau, J.N.,

Rosenau, J.N.,

Rosenau, J.N., (ed.),

Rosenau, J.N., (ed.),

Rosenau, J.N.,

Rosenau, J.N.,
Schrijfwijzer,

SDU Uitgeverij, Den Haag, 1989.

Opvolging van internationale organisaties van Volkenbond-Verenigde Naties tot ALALC-ALADI, dissertatie Universiteit van Amsterdam, Amsterdam, 1988.

Die Internationale Energie Agentur, Energiepolitiek und wirtschaftiche Sicherheit, Deutsche Gesellschaft für Auswärtige Politiek E.V., Bonn, 1979.

Political dictionary of the state of Israel, Macmillan Publishing Company, New York, 1987.

Op zoek naar stabiliteit in de Oriënt, SDU Uitgeverij, 's-Gravenhage/Universiteit van Amsterdam, Amsterdam, 1989.

Een structureel model van de Nederlandse buitenlandspolitieke elite, in:

Baehr, 1978, pp. 169-196.

Pre-theories and theories of foreign policy in:

Farrel, 1966, pp. 27-92.

Domestic sources of foreign policy,

The Free Press, New York, 1967.

International politics and foreign policy; a reader in research and theory,

The Free Press, New York/Collier-Macmillan Limited, London 1961, 1969 (rev. ed.). (Rosenau 1969a).

Linkage politics; Essays on the convergence of national and international systems, The Free Press, New York, 1969, Collier-Macmillan Limited, London, 1969 (Rosenau 1969b).

Toward the study of national-international linkages, in: Rosenau (ed.), 1969b, pp. 44-63.

Theorizing across systems: linkage politics revisited, in: Wilkenfeld, 1973, pp. 25-56. 
Rosenau, J.N.,

Rosenau, J.N.,

Rosenthal, U. en

Scholten, G.H.,

Rozemond, S.,

Rozemond, S.,

Russett, B., and Starr, H.,

Sadat, A. el-,

Sartre, J.P.,

Schaper, H.A.,

Scheffer, P.,

Schoutheete, Ph. de,

Schöffer, J.,

Schoon, S.,
The scientific study of foreign policy, Frances Pinter (Publishers) Ltd. London, 1980, Nichols Publishing Company, New York, 1980

The adaption of national societies: a theory of political behaviour and transformation, in:

Rosenaw, 1980, pp. 501-534.

Crisis en continuïteit. Economische Zaken, de oliecrisis en andere turbullenties, Samsom Uitgeverij, Alphen aan den Rijn, 1977.

Israëlische opties-vaagheid troef? in:

Internationale Spectator, (XXVII), 1983, no. 3, pp. 149152.

Nederland in West-Europa: een plaatsbepaling, Instituut Clingendaal, Den Haag, 1987.

World politics, the menu for choice, W.H. Freeman and Company, San Fransisco, 1981 (1989).

In search of identity, an autobiography, Harper \& Row, New York, 1978.

Anti-semitism \& Jew, Schocken Books, New York 1965, (oorspronkelijk: Réflexions sur la question Juive, 1946).

Nederland en het Midden-Oosten conflict, in: Internationale Spectator (XXIX), 1975, pp. 229-242.

Een tevreden natie, Nederland en het wederkerend geloof in de Europese status quo, Bert Bakker, Amsterdam, 1988.

La Cooperation Politique Européenne, Labor, Bruxelles, 1986.

recensie: proefschrift Soetendorp 1982, in:

Tijdschrift voor Geschiedenis, (97), 1984, pp. 658-659.

Nes Amin. Een christelijk experiment in Israël, Zomer en Keuning, Wageningen, 1976. 
Schreiner, K.M.,

Sheehan, E.R.F.,

Shihata, I.F.I.,

Shimoni, Y. and Levine, E. (eds.),

Shwadran, B.,

Sicherman, H.,

Sicherman, H.,

Siegler, H.,

Siekmann, R.C.R.,

Siekmann, R.C.R.,
Politieke samenwerking in Europa,

Staatsuitgeverij, 's-Gravenhage, 1978.

The Arabs, Israelis and Kissinger: A secret history of American diplomacy in the Middle East, Readers' Digest Press, New York, 1976.

Destination embargo of Arab oil: its legality under international law, in:

The American Journal of International. Law, (68), 1974, no. 4 , pp. 591-627.

Political dictionary of the Middle East in the 20th Century,

Quadrangle, The New York Times Book Company, New York, 1974.

Middle East Oil, Issues and Problems,

Schenkman Publishing Company, Cambridge, Massachusetts, 1977.

Politics of dependence: Western Europe and the ArabIsraeli conflict,in:

Orbis, (23), 1980, no. 4, pp. 845-857.

Europe's role in the Middle East: illusions and realities, in:

Orbis (28), 1985, no. 4 (winter), pp. 803-828.

Europäische politische Einigung II; Dokumentation von Vorschlägen und Stellungnahmen 1968-1973, Siegler \& Co., Bonn, Wien, Zürich, 1973.

De volkenrechtelijke toetsing van voorlichtingsprojecten over ontwikkelingssamenwerking vanwege hun subsidiering door de Nederlandse overheid, in: Internationale Spectator, (XXXVI), 1982, no. 6, pp. 330-340.

Volkenrechtelijke aspecten van de multinationale vredesmacht in de Sinaï, in:

Intemationale Spectator (XXXVI), 1982, no. 11, pp. 660-667. 
Siekmann, R.C.R.,

Simon, $T$.,

Singer, J.D.,

Smith, S.M.,

Smith, S. and Clark, M.,

Snoek, J.M.,

Soetendorp, R.B.,

Soetendorp, R.B.,

Soetendorp, R.B.

Soetendorp, R.B. en van Staden, A. (red.),

Sondermann, F.A.,
Juridische aspecten van de deelname met nationale contingenten a $\mathrm{V}$ VN-vredesmachten (Nederland en Unifili), dissertatie, T.M.C. Asser-Instituut, 's-Gravenhage, 1988.

Arabische rivitaliteit: de omwenteling van 1973-1974 en de Europese factor, Universiteit van Amsterdam, 1985, (ongepubliceerde doctoraalscriptie).

The level-of-analysis problem in international relations, in:

Rosenau, 1969a, pp. 20-29.

Foreign policy adaptation, Gower Publishing Company, Aldershot, 1981.

Policy implementation, Allen and Unwinn, London, 1985.

De Wereldraad van Kerken, Israel en de Palestijnen, in: Blaauw e.a., 1983, pp. 87-97.

Het Nederlandse beleid ten aanzien van het ArabischIsraëlisch conflict 1974-1977, dissertatie Rijksuniversiteit Groningen, Krips Repro, Meppel, 1982.

Pragmatisch of principieel, Het Nederlands beleid ten aanzien van het Arabisch-Israëlisch conflict, Martinus Nijhoff, Leiden, 1983.

The Netherlands, in:

Allen and Pijpers, 1984, pp. 37-54.

Internationale betrekkingen in perspectief, Het Spectrum, Utrecht, 1987.

The linkage between foreign policy and international politics, in:

Rosenau, 1961, pp. 8-17. 
Spoormans, H.,

Sprout, $H$. and

Sprout, M.,

Staden, A. van,

Stobaugh, R.B.,

Strategic Survey 1973,

Sus, I,

Tabory, M.,

Thune, C.,

Vaneker, Ch.J. and

Everts, Ph.P.,

Vedder, A.,

VerLoren van Themaat, P., (hoofdred.)
'Met uitsluiting van voorregt'; Het ontstaan van liberale democratie in Nederland, dissertatie Katholieke Universiteit Nijmegen, SUA, Amsterdam, 1988.

Man-milieu relationship hypotheses in the context of international politics,

Center of International Studies, Princeton, 1956.

Voorstellingen omtrent Nederlans invloed: hun samenhang met opvattingen over macht en beleidsvoorkeuren, in:

Baehr, 1978, pp. 69-93.

The Oil Companies in the crisis, in:

Daedulus (104), no. 4, 1975.

The International Institute for Strategic Studies, London, 1974.

Western Europe and the October war, in:

Journal of Palestine Studies (3), 1974, nr. 2, pp. 65-83.

The Multinational Force and Observers in the Sinai.

Organization, structure and function,

Westview Press, Boulder, London, 1986.

Denmark, in:

Allen and Pijpers, 1984, pp. 80-90.

Buitenlandse politiek in de Nederlandse publieke opinie Clingendael, Den Haag, 1984.

De Joden in Nederland na de Tweede Wereldoorlog. Een demografische analyse, Joachimstal, Amsterdam, 1961.

Serie studies over international economisch recht, deel I.2., organisaties en problemen op het gebied van internationale handel, T.M.C. Asser Instituut, H.D. Tjeenk Willink, A.W. Sijthof, 1977. 
Vermeulen, W.H.,

Voorhoeve, J.J.C.,

Voorhoeve, J.J.C.,

Voorhoeve, J.J.C.,

Walraven, G.,

Well, G. van,

Werkgroep Massacommunicatie Rijksuniversitet Utrecht,

Wiesel, E.,

Wijland-Spek, P.,

Wijnberg, S.,

Wilkenfeld, J.,
Nederland en de vaststelling van de Europese landbouwprijzen 1979-1981,

Instituut voor Internationale Studiễn, Rijksuniversiteit

Leiden, Leiden, 1984.

Internationale macht en interne autonomie; verkenning van de Nederlandse stiuatie, voorstudies en achtergronden van de Wetenschappelijke Raad voor het Regeringsbeleid, 's-Gravenhage, 1978.

De slinkende rol van Nederland, in:

Internationale Spectator, (XXXV), 1981, no. 2, pp. 6978.

Peace, profits and principles, a study of Dutch foreign policy, dissertatie, Martinus Nijhoff, Leiden, (1979, $1^{\circ}$ druk) 1985.

Arrangements for nuclear sharing in NATO: the Multilateral Planning Group, in:

Everts and Walraven, 1989, pp. 103-117.

Die Entwicklung einer gemeinsamen Nakost-Politik der Neun, in:

Europa-Archiv, (4), 1976, pp. 119-128.

Een wereld vol nieuws - inhoudsanalyses van de buitenlandse berichtgeving in een aantal kranten over de jaren $1979,1969,1959$ en 1949 ,

Utrecht, 1981.

Een jood vandaag,

Gooi en Sticht b.v., Hilversum, 1978.

Het aardoliebeleid van de EEG en de uitwerking daarvan in Nederland, in:

Ars Aequi 29 (1980) no. 18, pp. 686-694.

De Joden in Amsterdam, een studie over verandering in hun attitudes, proefschrift Universiteit van Amsterdam, Van Gorcum, Assen, 1967.

Conflict behavior and linkage politics,

David Mac Kay company, New York, 1973. 
Yaniv, A.,

Yearbook of the United Nations,

Zureik, E., and

Moughrabi, F. (eds.),
Dutch Middle East policy since 1973, in:

The Wiener Library Bulletin, (XX), 1977, no. $41 / 42$.

1967, (21), New York, 1969,; 1979, (33) New York, 1982, 1980 (34), New York, 1983.

Public opinion and the Palestine question, Croom Helm, London \& Sydney, 1987. 

PERSONENREGISTER (gebaseerd op de tekst en niet de noten)

Aantjes, W. 38, 82, 97, 98, 128, $176,177,257$

Aardenne, G.M.V., van 187

Abma, H.G. 180

Abram, I.B.H. 44

Agsteribbe, A.J. 44

Agt, A.A.M., van 98, 168, 175, $179,232,234,243,251$

Allen, D. 168

Andriessen, F.H.J.J. 82, 98

Arafat, Y. 187

Artner, S.J. 170

Baehr, P.R. 3, 9, 18

Bakker, M. 179, 195

Bar On, C. 66

Basoski, A.J. 195

Beek, A.L., ter 92, 93, 127, 178

Begin, M. 34, 50, 77, 163-165, $174,210,213,216,222$, $224-227,243,252,254$

Bergh, H., van den 67, 92-93, 146

Berkhouwer, C. 90, 114

Beugel, E.H., van der 97, 128

Beyen, K.H. 110

Biesheuvel, B.W. 114

Bleich, A. 38

Boertien, R. 77, 97

Bolkestein, F. 181, 182, 240

Boon, H.J. 111

Bos, C.A. 89

Boutros Ghali, B. 170,222

Bounian, S. 196

Boven, Th.C., van 136, 137

Brandt, W. 83, 85, 141, 146, $156,173,252$

Brauw, M.L., de $114,115,178$

Brecher, M. 58

Brinkhorst, L.J. 53, 56, 103, 181,194

Broeksz, J.B. 180

Brugman, J. 109

Burg, J. 222

Brezinski, Z. 163
Callaghan, J. 156

Caradon, $H$, 61

Carmiggelt, S. 115

Carrington, K.G. $169,170,207$, $210,214,215,222-225,240$

Carter, J.E. 5, 156, 162-166, $169,171,212,216-218,222$, 229,253

Cheysson, C. 170, 236

Claude, I.L. 25

Claus, Prins 222

Colombo, E. 26, 222, 223

Dahl, R.A. 248

Dam, N., van 173,174

Dankert, P. $77,92-94,111,114$, 127,179

Davignon, E. $26,71,75,105$, $140,141,149,252$

Dayan, M. 58, 59, 163, 164

Delfgaauw, B. 38

Diepenhorst, I.A. 115

Dijl, N., van 188

Dis, C.N., van 73

Doel, H., van den 93

Donaldson, W. $81,144,145$

Doorn, H.W., van 103

Dorsey, J. 196

Douglas-Home, A., sir 76, 145, 148

Drees, W. 114

Drenth, H.H. 94

Ducci, R. 70

Duisenberg, W.F. 112

Eagleburger, L.S. 233

Eban, A. 42, 43, 58, 172

Epema-Brugma, M. 93

Es, A., van 237

Everts, Ph.P. 16, 20

Feisal, Koning 73

Fiedler, H. 172-173, 252

Ford, G.R. 156, 162, 222

François-Poncet, J. 170, 208

Frank, A. 42

Franssen, H.M. 94 
Gaast-Bakker Schut, S., van der 92

Gaulle, $\mathrm{Ch}$., de 26

Gilboa, E. 43

Giscard d'Estaing, V. 156, 170, $174,176,210,213,214$, $236,252,254$

Gorkom, L.H.J.B., van 112

Gorman, S.M. 84

Goudsmit, A.M. 114

Greilsammer, 1. 29, 164-165, 172,210

Gruyters, J.P.A. 103

Gualthérie van Weezel, J.S.L. 116

Harmel, P.C.J.M. 26

Heath, E. 76, 83, 85, 143, 146, 156

Hek, A., van der 82, 93, 94, 145

Heldring, J.L. 128,143

Hendriks, A. 48

Herzberg, A. 42

Heykal, M. 58

Houwaart, D. 113

Huibregtse, J.W.A. 187

Hulst, J.W., van 89

Hulten, M.H.M.V., van 98

Hurd, D. 170, 174, 226

Iersel, J.P., van 119

Ifestos, P. 164, 168, 212

Imkamp, M.J.J.A. 95

Italianer, F. 104

Jacobson, H.K. $21,22,25$

Jarring, G. 135

Jobert, M. $69,75,83,86,139$, 147,148

Jong, L., de 97, 114, 128

Jong, P.J.S., de 114

Juliana, Koningin 73

Kamel, M.I. 164

Kaufmann, J. 157, 161, 177, 179

Keja, G.W. 90, 114

Khaddoumi, F. 170
Kissinger, H.A. 57, 59, 77, 81, $84-86,138,144,146-148$, $155,156,162$

Klaauw, C.A., wan der 28,51 , $53,56,167,173-176$, 179-182, 187, 194, 207, $209-213,232,236,246,252$, 254,258

Kloos, A.H. 115

Klompé, M.A.M. 115

Knoop, H. 91

Koning, J., de 48, 49

Kooijmans, P.H. 103, 193

Koster, H.J., de $67,89,90,98$, 105

Kreisky, B. 63

Kruisinga, R.J.H. 89, 97, 127

Kuiper, D.Th. 97, 114

Kun, J.L. van der 109,110

Kupferschmidt, M. 196

Langemeijer, F.F. 241

Leeuwen, J., van 97

Lewis, S.W. 227,244

Linowitz, S.M. 170

Lipschits, I. 55

Louw, A.A., van der 92

Lubbers, R.F.M. 32, 73, 82, $98-101,109,110,145$

Luns, J.M.A.H. $67,89,90,105$, $110,127,135$

Lynden, D.W., van 75, 103-109, 140

Maghroori, R. 57, 84

Meijer, J. 75, 104-109

Meir, G. 58, 65, 67, 99

Meyer, J. 196

Mierlo, H.A.F.M.O., van 87, $95,114,177,178,233,236$, 240,241

Miles, R.O. 172, 225

Mitterrand, G. 5, 156, 207, 210, $213,214,224,236,252,255$

Mommersteeg, J.A. 38, 66, 182, 187

Mondale, W. 163

Mubarak, H. 170, 222 
Muskie, E.S. 170,171

Naftaniel, R.M. 51, 189, 239

Nederhorst, G.M. 94

Nenni, P. 26

Neuman, H. 91

Nixon, R.M. $30,86,156,162$, 222

O'Kennedy, M. 167

Oe Thant 216

Ortoli, F. $81,84-86,148$

$\mathrm{Oz}$, A. 55

Peres, S. 91, 101

Perez de Cuellar, J. 218

Pijpers, A.E. 229

Polak, I. 196

Pompidou, G. $26,83,85,141$, $143,146,156,252$

Portheine, F. 90, 91, 100, 111

Pronk, J.P. 48, 81, 92, 102, $103,120,151,154$

Quandt, W.B. $29,160,164$

Ra'anan, G. 217

Rabbani, M.S. 89, 109, 189

Rabin, Y. 65

Reagan, R. 30, 210, 212-214, $218,224,255$

Regelberger, E. 28

Reinink, K.W. 171, 173, 212, $231,232,234,235$

Renardel de la Valette, P.A.E. 73

Riad, M. 90

Riel, $H$., van 111

Roethof, J.J. 94

Rood-de Boer, M. 92

Roolvink, B. 97

Rosenau, J.N. 11, 12, 102, 104, 257

Rosenthal, E. 196

Rozemond, S. 78

Russett, B. 15

Rutten, M.H.J.C. 173, 174, 231

Sadat, A., el 5, 58, 163-165. $170,208,214,216,222$, $223,225,226,230,233,255$

Salam, A., al 58, 63, 109
Samkalden, I. 114

Sartawi, I. 188, 194

Sartre, J.P. 42

Schaper, H.A. $230,237,238$

Scheel, W. 86, 148

Scheltema, H. 167, 188

Schiff, E.L. 103,109

Schlesinger, J. 66, 81, 144

Schmelzer, W.K.N. 78, 94, 105, 108,135

Schmidt, H. $148,156,166,170$, 252

Shamir, Y. 222, 227, 229, 230

Sharon, A. 222

Sheehan, E.R.F. 57

Sicherman, H. 166

Siekmann, R.C.R: 217,242

Simonet, H. 14, 170

Simons, R. 196

Singer, J.D. 11

Smith, M. 168

Snouck Hurgronje, C. 73

Soetendorp, A. 116

Soetendorp, R.B. $31,36,77$, 175

Someren-Downer, H.V., van 90, 115

Sondermann, F.A. 3, 9, 18

Spadolini, G. 223

Spek, A.G., van der 66, 178

Spoormans, H.C.G. 248

Staden, A., van 247

Starr, H. 15

Stee, A.P.J.M.M., van der 98

Steenkamp, P.A.J.M. 115

Stempels, A. 115

Stoel, M., vani der $5,31,56$, $64-66,68-69,73-81,83$, 87-90, 92, 94, 95, 97-103, $106-111,114,115,118,122$, $123-128,132,140,143,144$, $153,159,161,162,177-179$, $187,193,194,222,225$, $230-236,240,243,245,246$, 258,260

Tabory, M. 227 
Terlouw, J.C. 95,179

Thatcher, M. 176, 210, 214, 223

Thijn, E., van 92, 98, 111, 127

Thorn, G. 207, 208, 236

Thurkow, M. 80, 94, 98, 111, 154

Toom, W., den 67

Trip, F.H.P. 103

Uyl, J.M., den 31, 64-67, 70,

$73,79,82-85,88-93,97-99$,

$101,103,114,115,121$,

$132,141,143,145,146$,

$156,173,184,193,252$

Vance, C.R. $162,166,179$

Veer, $P_{\text {., }}$ wan 't 97,128

Voogd, J.J. 93

Voorhoeve, J.J.C. 10

Vredeling, H. $65,66,114$

Wagner, G.A. 76, 120, 121

Wajsberg, H. 190

Waldheim, K. 179, 217-219

Waltmans, H.J.G. 237

Weiler, J.H.H. 29, 164, 165, 210

Weinberger, C.W. 222, 233

Well, G., van 173,252

Werkman, W. 196

Wesel, J. van 196

Wiegel, H. 88, 179, 234

Wiesel, $\mathbb{E}_{\text {. }} 41$

Wijk, J.H., van 96

Wijnberg, S. 46

Wilson, H. 67

Wttewaal van Stoetwegen, C.B.I. 115

Ya'amani, A.Z. 58, 109, 152

Yaniv, A. 98 
aandachtige publiek 33,133 ACP-landen 27

actiegroepen $16,22,32,39,40$, $45-47,50,51,91,113,115$, $153,155,189,190,239$, $247,249,259$

Afrika $8,22,28,32,62,72,88$, $90,91,109,110,158,186$, $188,213,231,258,259$

Aktie Comité Israël $92,113,114$ Algerije 58, 61-63, 71, 72, 85, $100,109,143,151,152,211$ ambtenaren $16,17,27,66,69$, $79,100,102,104,111,112$, $114,118,122,143,149$, $176,180,186,187-190,195$, 247,251

analyse-niveau 10

antisemitisme $37,38,42-44,55$, 192, 201

antizionisme $37,38,55$

Arabische Liga $71,90,122,211$, 223,256

Argentiniê 27, 38

Arjos 115

Belgiê $58,82,110,112,142$, $143,145,147,174,219,221$ bewarende aanpassing 12-14, $153,154,246,257,258$ boycot $22,26,51,61,73,81$, $90,93,111,151,187,195$

Brazilië 61 bruggenbouwer 14,151 buitenlandse politieke elite 33 , 133,247

bureaucratic politics model 105

Camp David (akkoorden) 30, 77, $158,161,163-166,168,170$, $172,174,175,181,185$, $210,214,216,217,227$, $230,235,238,254$

Canada $86,150,220$

CDA $22,35,36,40,51,89,96$, $119,180,182,183,186$,
$187,189,198,199,202$, $232,237,238$

Centrum voor Informatie en Documentatie Israell (CIDI) $40,41,45,47,51,52,56$, $183,184,186,189,190$, $193-195,197,239$

Chili $88,258,259$

China 9,259

CHU $36,89,96,97,110,115$, $118,130,131,182,183$

CNV 120

College van Burgemeester en Wethouders van Amsterdam 49

Colombia 220,244

comité politique $26,27,69,75$, $108,135,137,138,140$, $142,152,171,173-175,204$, 223,254

Commissie voor de rechten van de mens 136,137

communauté d'action $27,28,210$ communaute d'information 27 communautế des vues 27,28 , 210

Conferentie over Veiligheid en Samenwerking in Europa (CVSE) 26, 28, 62 consensus $1,4,10,19-21,87$, $88,137,148,153,194,203$, $237,245,249,250,259,260$ CPN $48,56,89,179,181,185$, $186,195,198,199,237,238$ crisismechanisme $4,149,150$ daadwerkelijk beleid 5, 167 De kerk en het joodse volk 40 , 117,191

decentralisatie 21,22

deelname aan de MFO $6,18,19$, $207,215,219,222-225,227$, $229,231,233-239,241,243$, $252,253,255$

democratische controle 3,28 
Denemarken $26,27,85,137$,

$142,146,147,161,172$,

173,218

departement (ministerie) van

Buitenlandse Zaken $3,9,50$, $66,67,69,75,77,79,80$, $93,94,100,102-104,109$, $110,115,118,122,137$, $151,157,161,186,187$, $189,203,217,220,221,243$ departernent van Defensie 66, 231

departement (ministerie) van

Economische Zaken 17, 81, $100,118,119,121,187$, $188,195,239$

departementen $9,27,98,100$, $102,186,233$

directe besluitvormers 16,45 ,

$112,154,189,195,249$ directeur-generaal internationale samenwerking (dgis) 48, 49, $51,75,103,104,106-109$, $112,136,186,204$ directeur-generaal politieke zaken (dgpz) 27, 28, 69, 75, 103, $104,106-109,112,140,171$ directie internationale organisatie (dio) 105,106 DS'70 91, 97, 114, 115, 130, 178,185

Duitsland $13,53,82-84,86$, $136,145,147,156,159$, $160,162,166,169,173$, $221,252-254$ economische sancties $1,27,152$, $174,195,253$

Egypte 5, 6, 30, 57, 59-61, 68, $72,77,106,119,120,136$, $138,155,166,180,181$, $211,214,215-224,228,237$, $239-243,246,247,256$ erkenning $6,7,9,36,37,78$, $79,91,93,94,115,117$, $167,169,172,176,178$,
$183,185,186,190,191-193$, $207,211,214$

Euro-Arabische dialoog 86,119 , $147,148,151,152,156$, 212,260

Euro-Israëlische dialoog 38

Europees Parlement 27, 28, 97, 258

Europees vredesinitiatief 5,6 , 213,224

Europese akte 26

Europese Commissie 27, 74, 81, $82,85,139,143,148,150$

Europese Gemeenschap 1, 2, 22, $26,29,34,59,63,69,133$, $135,141,147,150-152,184$, $214,220,234,249$

Europese integratie 10, 14, 29 Europese Politieke Samenwerking (EPS) 2-8, 11, 14, 18, $25-30,60,63,64,69,70$, $75,79,104-109,112,119$, $135,137,140,141,143$, $144,148,153-157,159-162$, $164,165,167-169,172-176$, $179,182,184,186,190$, 195-197, 203, 204, 207, 208, $210,212,213,222,224-226$, $231,232,235,236,238$, $245-247,249-260$

Europese vredesmissie 5, 167, $183,207,212,253$

Evangelisch-Lutherse kerk 41 Falklandoorlog 27

Federatie van Jongeren Groepen in de PvdA 115

Fiji-eilanden 220

filosemitisme 38

financiële protocol met Israël 27

Finland 218

Folkertsma Stichting 41

formele politieke elite 16,17 , $32,38,39,47,48,112,113$, $115,153,189,195$ 
Frankrijk $4,13,24,26,53,58$, $61,68,70,71,75,82,85$, $86,103,107,108,110,134$, $136,137,138,139,141$, $142,145-151,153,156,157$, $159-161,164,165,168,169$, $172,175,177,178,187$, $189,210,221-223,225,227$, $231,244,253,255$

gemeenschappelijk optreden 6,7 , 27,177

genootschap Nederland-Israël 40 , 114 gereformeerden $36,39,116,129$ gevoeligheid $10,23,31,52,98$, $99,113,118,195$

Golfstaten 71

GPV $36,46,185,186,198$, $199,237,238$

Griekenland 5, 26, 88, 144, 172, $220,225,226,234,235,252$

Guatamala 136

Hervormde Raad 41, 117

Ierland $26,136,142,147,157$, $160,161,169,172,178,221$ India $60,77,81,136$

input 9,17

inschikkelijke aanpassing 12-14, $54,153,203,204,257,258$ Internationaal Energie Agentschap (IEA) 8, 24, 25, 134, $149-151,154,256$

Internationaal Verdrag inzake burgerrechten en politieke rechten 158

Internationaal Verdrag inzake economische, sociale en culturele rechten 158 internationale organisatie 4,8 , $18,24,25,105,150,251$, 256

Intifadah 7,35

Irak $6,62,72,73,110,122$, $187,188,211$

Iran $71-73,122,187,254$
Israël $1,4-7,27,30-69,72,74$, $75,77-80,83-97,99,102$, $105-111,113-120,122-133$, $135,136,138,142,145$, $146,152,153,155,156$, $158-160,162-164,166,167$, $169,173,174,178,180-183$, $185,186,188,190-205$, $208-212,214-221,223-230$, $235-237,239,240,241-247$, $250,252,254-257,260$ Israël Comité Nederland (ICN) $46,47,56,189$

Israël-Moderamina 40,49

Israëlisch-Egyptisch vredesverdrag $5,30,50,204,207$, $218,227,252$

Israëlische ambassadeur 56,57 , $65,66,90$

Italie $6,13,26,70,91,121$, $135,136,137,142,145$, $147,157,160,161,171$, $174,178,187,219,221-223$, $225,227,231,243,244,255$

Ivoorkust 220

Japan $58,59,84-86$

Jeruzalem $7,32,45,46,55,56$, $61,95,117,135,163,164$, $170,187,188,209,254$

Joden $32,38-48,57,63,91,96$, $114-116,127,159,185,192$ Joegoslavië 32 joodse kerkgenootschappen 17 , $45,47,113,116,189$, 193-195

Joodse gemeenschap $17,39,41$, $45,51,163,180,189$

Jordanië $61,91,165,172,183$, $209,211,215$

kabinet $1,16,17,34,37,48$, $54,66,70,73,75,79-81$, $88-90,93,97-99,101-103$, $132,154,179,184,187$, $204,230,232,234,250,251$ kabinet van Agt I 179, 251 kabinet van Agt II 232,234 
kabinet Cals-Vondeling 102

kabinet Den Uyl 88-90,97, 132

Katholieke Raad voor Israël 40 , $41,117,192$

Kenia 220

kerken 16, 39-41, 51, 113, 116, $117,190-193,239,247,249$

kerkeraad 51

Koeweit 25, 58, 71-73, 89, 109, $139,188,189,211$

kruisraketten 10

KVP $36,37,82,89,92,95,96$, $99,105,110,114-117,119$, $129-131,146,177,178,182$, 183

kwetsbaarheid $2,10,23,42,52$, $150,188,203,250,253$

kwetsbare positie $2,4,5,52$, $109,134,149,151,163$, $187,203,234,245,246$, $250-252,256$

Latijns-Amerika 28, 90

Libanon $6,7,27,34,35,42$, $43,72,136,164,202,211$, 213,215

Luxemburg $26,27,82,142$, $143,147,150,170,172$, $194,207,210,211,221,225$ macht $9,12,15,53,102,196$, $204,210,216,231,252$

Mali 60

Marokko 152, 211

massa-publiek $16,17,39$

massamedia 54,122

Medisch Komitee Palestina 49, 50

mensenrechten $88,242,258-260$

Multinational Force and Observers (MFO) 5, 6, 8, 18, 19 , $25,204,207,213,215$, $218-246,252,253,255,256$, 258

Namibië 231
Nationale Commissie en voorlichting en bewustwording en Ontwikkelingssamenwerking (NCO) 48-51, 193

Navo-beraad 84

NCW 118, 119

Nederlands Christelijk Werkgeversverbond $(\mathrm{NCW})$ 118, 119

Nederlands Hervormden 116 Nederlands-Israëlietisch Kerkgenootschap (NIK) 190, 193-195

Nederlands Palestina Komitee (NPK) 46-51, 189, 190

Nederlands veto $63,69,70,119$

Nederlandse Zionisten Bond (NZB) 17, 45-47, 56, 114, $189,190,193,194$

nederzettingenbeleid $34,35,163$, 166

negatieve invloed $15,19,21$, $213,253,259,260$

Nes Amin 192

niet-formele politieke elite 16 , $32,38,39,112,113,153$, 189,195

Nieuw Israëlietisch Weekblad (NIW) $49,55,56,66,97$, $114,116,195$

Nieuw-Zeeland 220,244

Nigeria $60,71,122$

NKV 120

Noord-Jemen 120

Noorwegen $86,137,159,218$, 244

NVV 52,120

OAPEC $61,71,75,102,139$

Oeganda 41,42

OESO $24,86,99,149$

Oktoberoorlog 1, 4, 6, 30, 47, $57,58,61,62,65-69,71$, $83,88,89,97,111,113-$ $-116,120,123,132,137$, $138,144,145,153,156$, $217,247,249,257$ 
olieconsumerende staten 58

oliemaatschappijen $76,93,100$, $117,120-122,154$

Oman $71,165,211$ ondernemer 17, 101

onverzoenlijke aanpassing 1,2-14, $153,154,257$

oorlog in Libanon 7

Oostenrijk 32, 137

opinieleiders $33,97,133$

outcome 17,18

output 9,17

overlegorgaan met het bedrijfsleven 118,195

Overlegorgaan tussen Joden en Christenen (OJEC) 39, 41, 51

Pakistan 136

Palestijnse Bevrijdingsorganisatie (PLO) 7, 17, 35, 40, 41, $47,48,50,51,93,115,116$, $156,157,159,160,167$, $169,170,172,174,176-178$, $180,181,183-186,188,190$, $191,193,194,200,201$, $204,208,210,211,214$, $225-227,239,240,245,258$

Palestijnse Nationale Raad 7

Palestijnse Rode Halve Maan 49, 50

Palestijnse Vrouwenunie 48 paraplufunctie 80

Pax Christi 40, 49, 115, 116, 153

Pentagon 57

plan-Fahd 214, 215, 222, $224-226,228,231,239$

politieke elite $16,17,32,33,38$, $39,47,48,112,113,115$,

$133,153,189,195,238,247$ politieke partijen $16,22,37,39$, $46,53,54,73,87,88,97$, $104,113,153,155,182$, $184-186,189,201,203,232$, $234,237,239,247,249,251$ Portugal $66,88,91$ positieve invloed $15,19,21,259$

potentiele of anticiperende invloed 15

PPR $36,48,89,96,103,113$, $130,131,177,181,185$, $186,193,198,199,237,238$ presidentiële cyclus 29

pro-Israëlische consensus 194, 203,249

PSDI 91

PSP $48,56,66,89,96,115$, $177,178,181,185,186$, $189,193,198,199,237$, 238,240

publieke opinie $30,32,34,38$, $39,48,51,69,88,94,99$, $104,112,113,119,128$, $130-132,142,155,163,189$, $197-199,201-203,239,257$

PvdA 22, 35-37, 48, 51, 53, 56, $66,67,77-81,89-95,97,99$, $103,111,114,115,118$, $128,130,131,145,146$, $177-180,183,184,186,189$, $198,199,202,232,233$, 237-239

Quatar 71-73, 211

Raad van Kerken 40, 41, 51, $117,190-193$

Raad van State $49,51,242$

rapport van Kopenhagen van 23

juli 197326

rapport van Londen van 13 oktober 198126

rapport van Luxemburg van 27 oktober 197026

regeringsverklaring van 9 oktober $197363,67-69,71,87-89$, $92,95-97,105,106$

relatie Nederland-Israël 31 Remonstrantse Broederschap 192 Rhodesië 214

rolopvatting 102, 104, 251

Rooms-Katholieken 36, 39, 116 , 129

RPF $46,185,186,238$ 
Saoedie-Arabiẽ 138, 195

Scandinavische landen 85,143 , 220

Shell $22,62,76,100,118$, $120-122$

Shoa $31,38,42,44,45,123$ socialisten $4,53,83,91,147$, $162,169,204,205,253$

Socialistische Internationale 67 , $83,91,99$

Soedan $85,119,120,165$

solidariteitscomité voor Joden in de Sovjetunie 114

Sovjetunie $24,57,60,61,68$, $84,108,163,165,169,203$, $216-219,256$

Spaanse $60,95,233$

staakt-het-vuren $57,59,68,71$, $106,107,138$

Syriè $6,30,57,61,68,72,106$, $119,120,136,155,161$, $163,174,211,215$

Taiwan 9

Tanzanië 136

Tel Aviv 46, 56, 187, 188

Tsjechoslowakije 144,172

Tunesië $52,85,110,152,211$

Tweede Wereldoorlog 25,31 , $32,38-41,45-47,49,55$, 104

Unef I en II $215-218,221$

UNESCO 62, 136, 190, 191, 193,260

Unifil $215,221,231,239,241$, 256

United Nations Truce Supervision Organisation (UNTSO) 215, 217

United States Sinaï Field Mission (SFM) 218

Universele Verklaring van de Rechten van de Mens 41

Uruguay $220,242,244$. vakbeweging $52,115,117,120$, $153,249,251$

Vaticaan 39,192
Veiligheidsraad (VR) 24, 25, 57, $59,60,62,68,70,74,107$, $108,134,136,138,142$, $145,153,160,170,171$, $176,177,207,216-219$, $254-256,260$

- resolutie 242 (1967) 57, 59-62, $68,74,77,78,94,95,97$, $106,127,135,136,156$, $159,163,166,170,171$, $172,174,177,191,200$, 227,254

- resolutie 338 (1973) 59, 138

- resolutie 340 (1973) 217

Venezuela 72,122

verbaal beleid 5

verbond van Liberaal-Religieuze Jodlen in Nederland 41

Verenigd Koninkrijk 5, 13, 24, $53,58,60-6168,70,71,76$, $85-86,107,121,131,134$, $136-139,142-143,145-148$, $153,156,160-162,169-170$, $173,175,176,207,209$, $212-214,221-225,227,231-$ $232,234-235,244,252-255$

Verenigde Arabische Emiraten $73,85,188,211$

Verenigde Naties (VN) 3, 8, 24$25,28,38,62,74,77-79$, $93-95,98,104-108,112$, $117,135-137,141,147,151$, $153,156,158-161,165,167$, $172,176,178-179,183,184$, $186,188,191,193,194$, $204,207-209,215,216$, $218-220,231,233,235,237$, $240-243,251,253,256-257$

- resolutie 181 (1947) 95, 215

- resolutie 273 (1948) 215

- resolutie 2625 (1970) 158

- resolutie 3210 (1974) 157

- resolutie 3236 (1974) 159, 160, 176,177

- resolutie 3237 (1974) 159

- resollutie 3375 (1975) 160,178 
- resolutie $3376(1975) \quad 160,178$

- resolutie 3414 (1975) 160

- resolutie 3419 c (1975) 160

- resolutie $31 / 20$ (1976) 161

- resolutie 31/61 (1976) 161

- resolutie 34/65B (1979) 165

- resolutie 34/70 (1979) 165,168

VN-delingsplan 117, 209

Verenigde Staten (VS) 4-6, 14,

$25,27-30,32,43,44,57$,

$59-61,65,66,68,76,77$,

$81-86,101,108,134,136$, $138,139,143-151,154-156$, $160,163-166,168-172,175$, $179-181,183,184,203,204$, $207,210-212,214,217-221$, $223-235,238,244-246,252-$ 255,258

vereniging voor Palestijnen in

Nederland 48

verklaring van 6 november 1973

$4,18,63,76,111,153,154$,

179,196

Verklaring van Venetië $5,6,18$, $19,159,161,166-169$,

$172-175,179-186,204,207$, $208,210,211,213-215,223$, $226-228,230,231,234-236$, $238,240,245,254,255,258$ VNO $100,118,195$

vredesmacht 5, 18, 24, 207, 209, $214-220,222,223,227,232$, $233,238,240-244,256$

vredesmissie $5,135,144,156$, $167,183,207,208,212$, $213,253-255,258$

Vrienden van Vrede $\mathbb{N u} 44,50$,

51

vrij evangelische kerken 40 VVD $35-37,48,50,88-90,96$, $100,105,111,114,115$, $118,130,131,179,181$, $184,186,198,199,202$, $234,236-238,251,258$ waarnemersmissies 215 wapenleveranties 57,66
Washington-conferentie 101-103, 149

werkgeversorganisatie 17,118

Werkgroep Israël (WI) 46, 47, $50,189,190$

West-Europa 54, 58, 59, 84, $117,196,232$

West-Europese Unie 26

WHO $62,136,167,190,193$

Wiardi Beckman Stichting 99

Zaïre 136

zelfbeschikkingsrecht $38,63,72$, $96,110,117,157-159,167$, $169,170,176,178,183$, $185,190-193,226,227$

Zesdaagse oorlog 6, 44, 78, 97

zionistische beweging $42,51,78$, 91

Zuid-Afrika $8,22,32,62,88$, $158,258,259$

Zweden 221, 245

Zwitserland 32 


\section{CURRICULUM VITAE.}

Fred Grünfeld werd op 21 juni 1949 te Aarle-Rixtel geboren. Hij volgde middelbaar onderwijs aan het Lorentzlyceum in Eindhoven en het Dr. Knippenbergcollege in Helmond en behaalde in 1968 het HBS-diploma. Hij studeerde politicologie aan de Vrije Universiteit te Amsterdam (1968-1975).

In 1975 volgde hij de post-academische leergang buitenlands beleid aan het Nederlands Genootschap voor Internationale Zaken te Den Haag.

Van 1976 tot 1981 was hij als wetenschappelijk medewerker verbonden aan de Stichting voor het bevolkingsonderzoek in de drooggelegde Zuiderzeepolders te Amsterdam. Hij verrichtte daar politicologisch, historisch en taalkundig onderzoek.

Van 1981 tot 1983 was hij als wetenschappelijk onderzoeker, in dienst van de Nederlandse organisatie voor zuiver-wetenschappelijk onderzoek, verbonden aan het Instituut voor Internationale Studiën van de Rijksuniversiteit Leiden. Hij voerde onderzoek uit naar de binnenlandse beïnvloeding van het Nederlands buitenlands beleid. In 1984 en 1985 doceerde hij over internationale organisaties aan de Webster University te Leiden. Sedert 1984 is hij verbonden aan de vakgroep Internationaal Recht van de faculteit der Rechtsgeleerdheid van de Rijksuniversiteit Limburg als universitair docent in de leer der internationale betrekkingen. 